
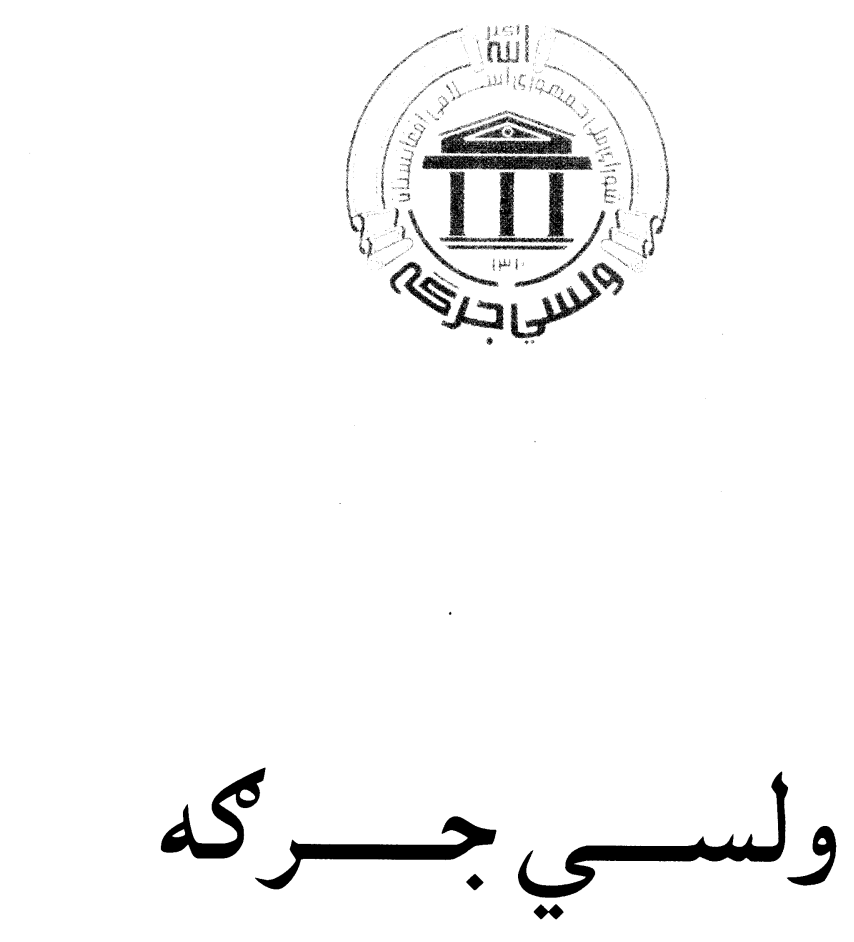

د ولسي جركي رسمي خيرونه

سال سوم تقنيني ولسي جركه شماره دوم 
Publication Organ of the Wolesi Jirga

Establishment Year: 2005

In charge:

Post Box:

Copies

Wolesi Jirga

5733 kabul Afghanistan

1000

Wj.records@yahoo.com

Wj.records@hotmail.com

http://www.parliament.af

0093752024667

Address: National Assembly of Afghanistan 

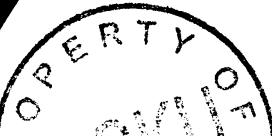

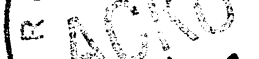

or 1

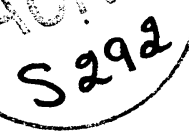

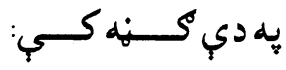

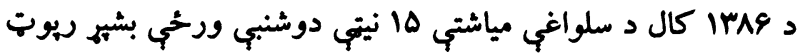

بحث روى يكك ماده قانون محصول حق العبور، بحث روى قانون انتخابات

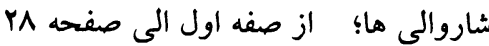

د I INA9 بحث روى قانون مبارزه عليه ارتشاء و فساد ادارى .

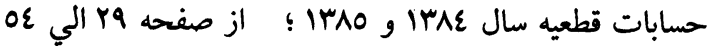

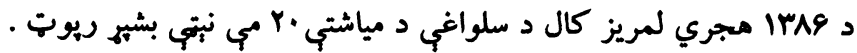

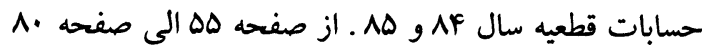

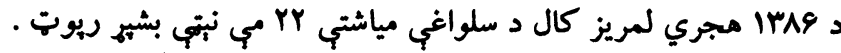

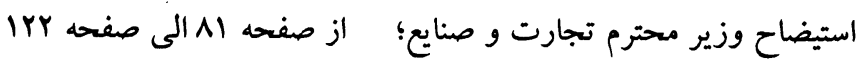

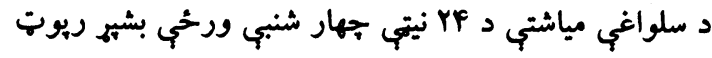

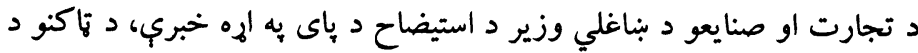

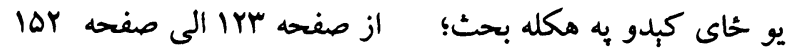

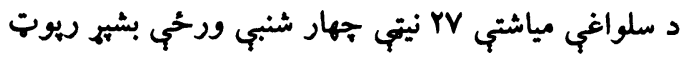

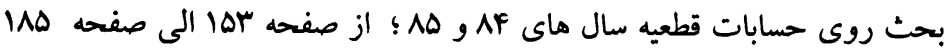




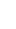

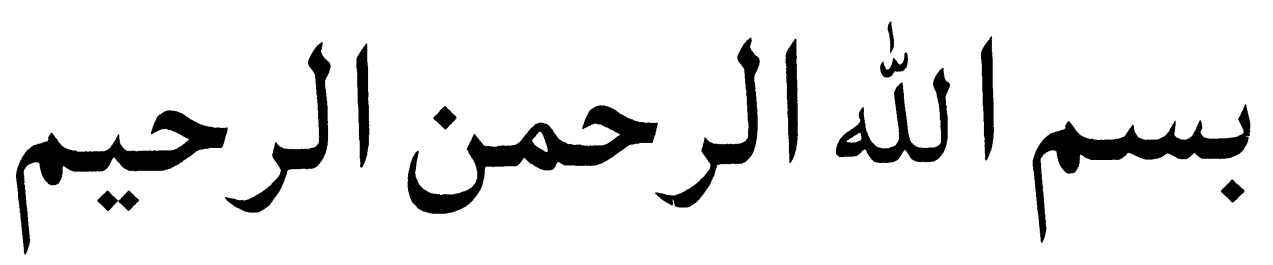


تر زره ختم شي شيكه جبي وروسته له هغه دوه درب ذهبر

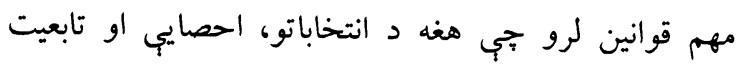

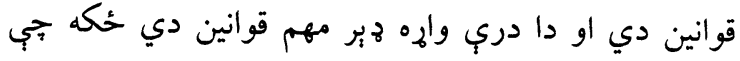

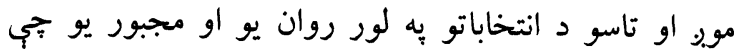

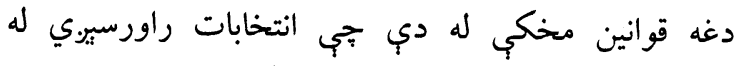
اساسي قانون سره سم دا بايد ختم شي، زه ده بيا هم منته كوم

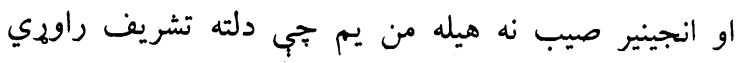
ترخو خيل بحث ته ادامه وركمو.

$$
\text { مير احمد جوينده: }
$$

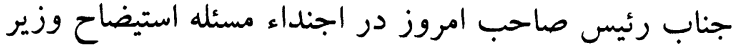

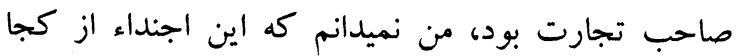
تغيير كرد؟

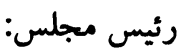
بلى جوينده صاحب تشكر ميكنم كه ياد كرديد و ضرور

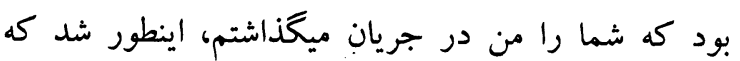

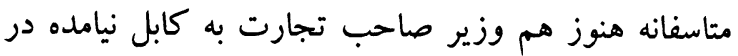

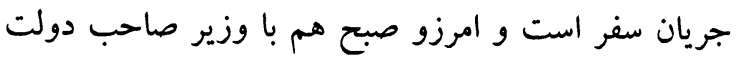
در امور بارلمانى كه تيلفونى تماس داشتيم در اجلاس

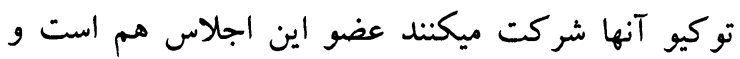

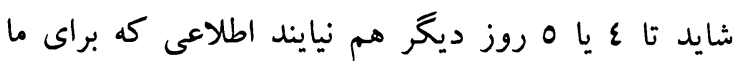

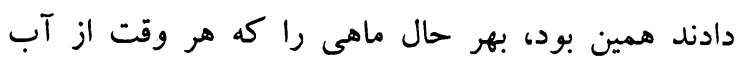
بَيرى تازه است هر وقت كه آمد به خير ما وشما هستيم رادي و همين اجلاس. قاضى محمد ايوب مهر:

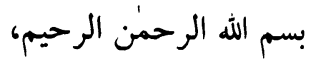
جناب رئيس صاحب! با اجازه شما، هيئ ادارى و و وكلاى الرى الرئ

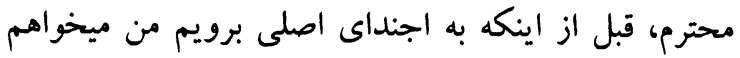

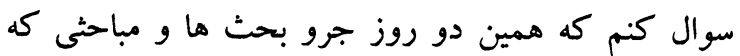

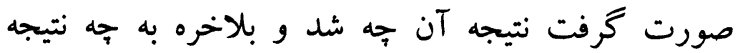
ميرسيم كه باز امروز آجندا قسم ديخر شد؟ ند انه

$$
\text { رئيس مجلس : }
$$
در اين مورد خواصى صاحب معلومات ميدهند.

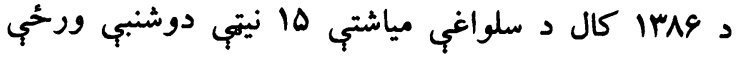

بشيه ريوت

|جنه| : - اجن

د حق العبور د محصول د قانون بر يوي مادي بحث، د بنارواليو د تاكنب بر قانون بحث، بحث

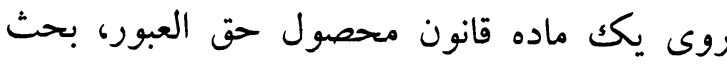
روى قانون انتخابات شاروالى ها ماهي د غونلهي منشى:

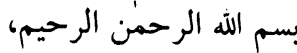

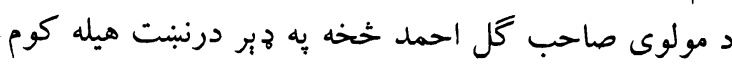

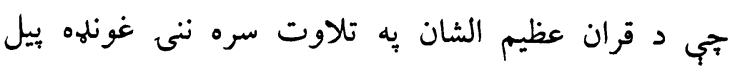
كرئ د مولوي كل احمد له خوا د سيبخلو آياتو تلاوت كيري

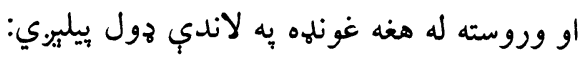
د غونلهي منشي:

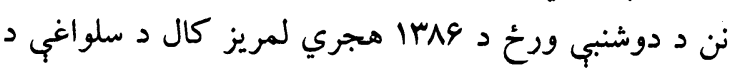

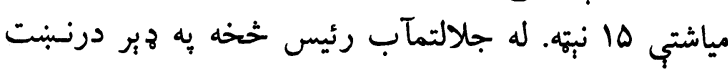

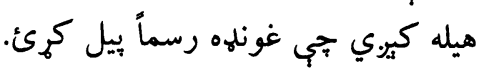
د غونلهي رئيس:

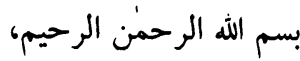

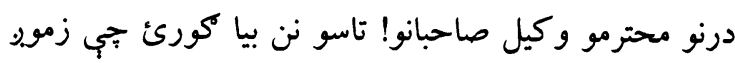

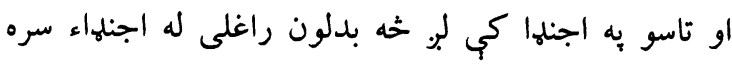

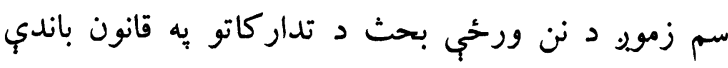

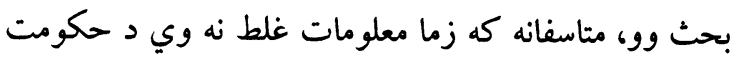

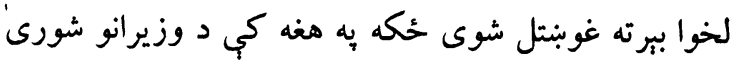

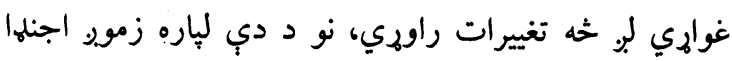

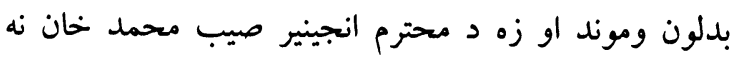

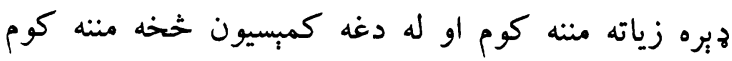

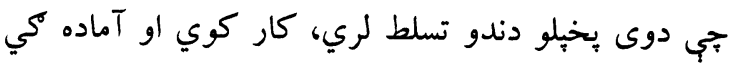

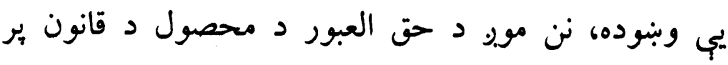

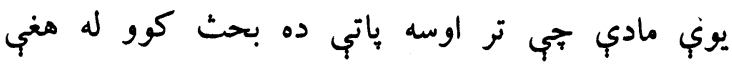

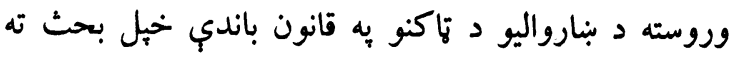

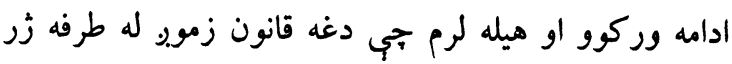




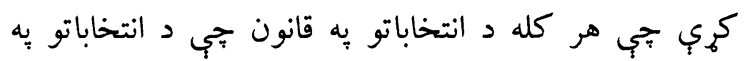
برخه كي د مور قانون حيثيت لري بحث وشو وروسته له

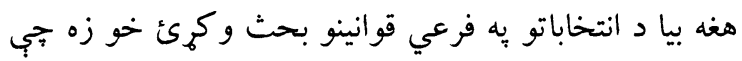

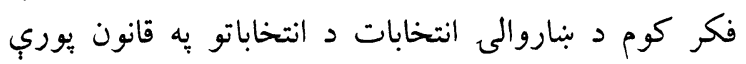

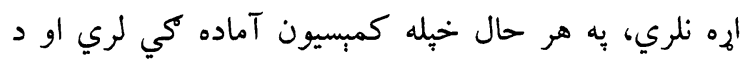

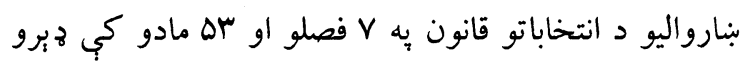

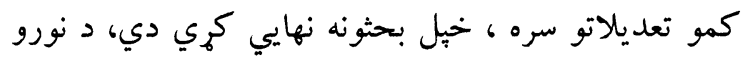

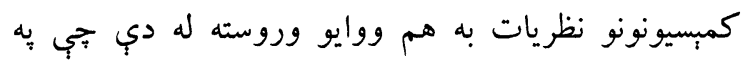

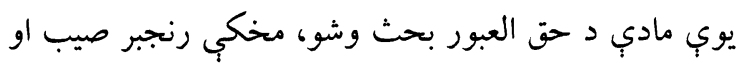

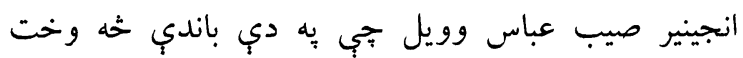
بحث شوى دى؟ ربنتيا هم هغه قانون جي وني 9 مياشتب

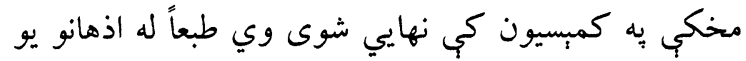

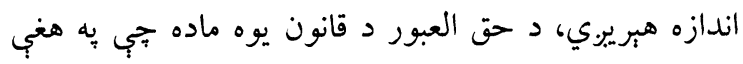

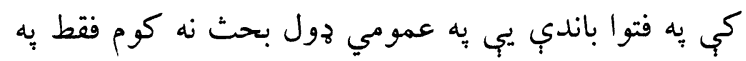

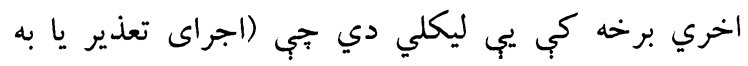

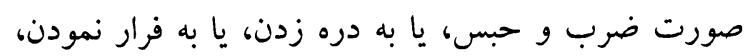

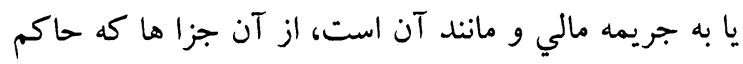

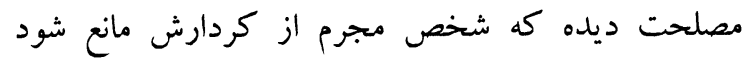

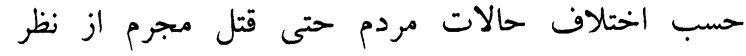
سياست مطابق احناف و مالكى ها هم مجاز است، وسلام)

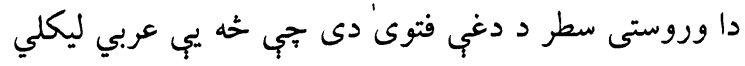

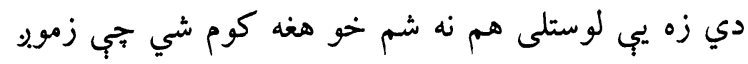

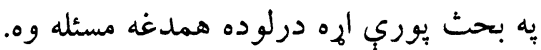

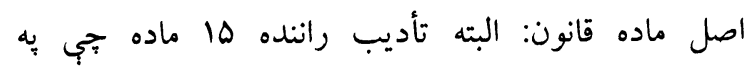

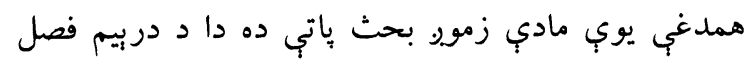

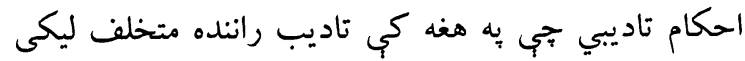

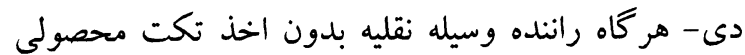
از دروازه خروجى شهر عبور نمايد علاوه بر بول مندرج

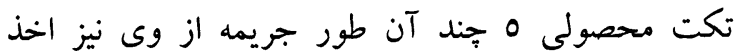
ميخر دد. دوهمه فقره: جريمه مندرج فقره يكك اين ماده يه رويت تكت مخصوصى كه شكل و محتواى آن از طرف وز وزارت ماليه مشخص ميشود اخذ ميخردد.

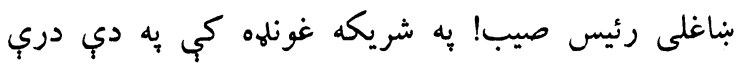

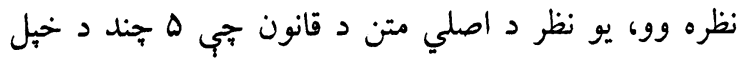

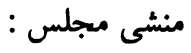

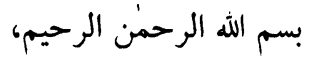

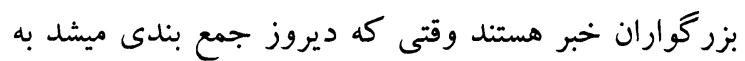

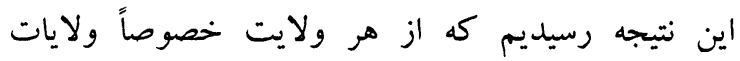
آسيب زده يكك يك وكيل وكيل محترم و با جمع كميسيون

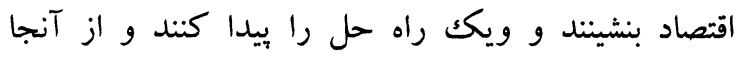

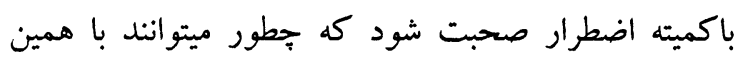

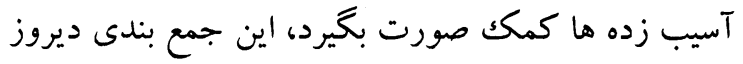

بود كه خودشان حضور داشتند.

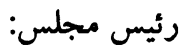

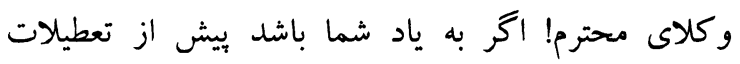

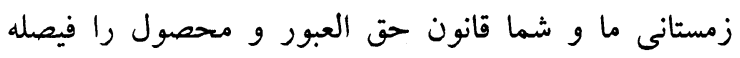
كرديم در يك مورد بحث جريمه بود كه آيا جريمه در اسلام است، نيست بين علماى كرامى كه در شورى هستئد

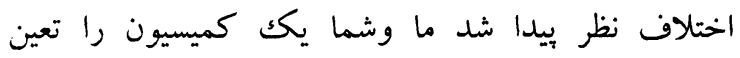

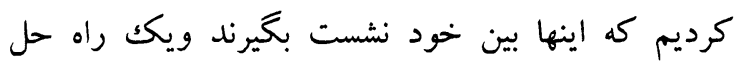
براى ما و شما بياورند، نشستى كه در بين اينها اعم از تشيع ما وتسنن ما هر دو نشست داشتند متاسفانه به نتيجه نرسيدند

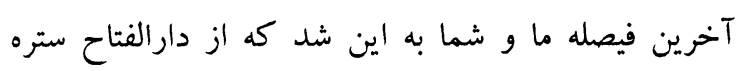

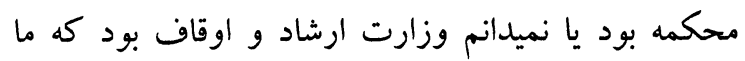

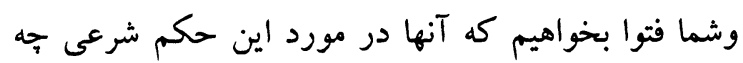

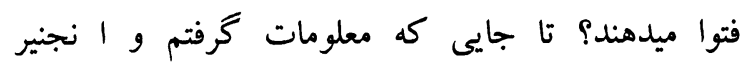
صاحب معلومات دادند فتواى شان رسيده است خوبست مئل كه انجنير صاحب از همين جا شروع كنيم. انجنير محمد خان:

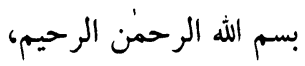

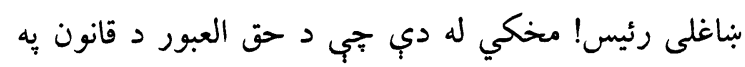

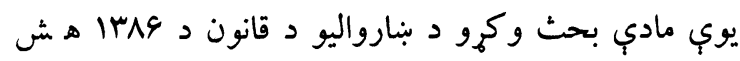

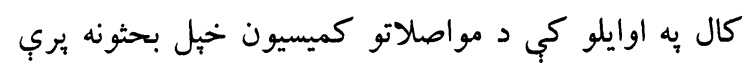

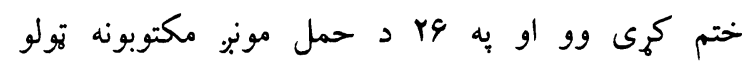

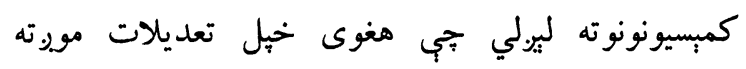

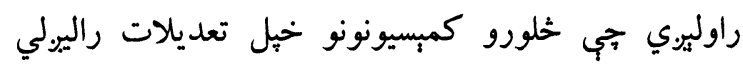
دي جبي د مخدره موادو ير ضد كمبسيون، طبعي منابعو او

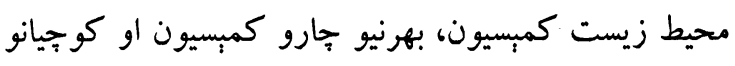
كمبسيون خو د بهرنيو جارو كمبسيون دا خبره داسي رد 
دلته راحي بايد به بِبتو يا دري زُبي وزُبارل شي ججي موبر

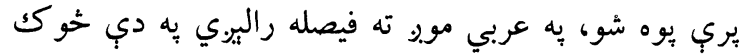

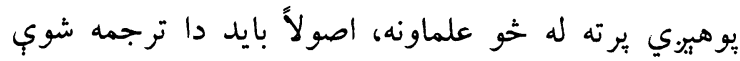
وى له هر مأخذهة هبي دا يبي راليرلبي بايد عربي متن يبي هم

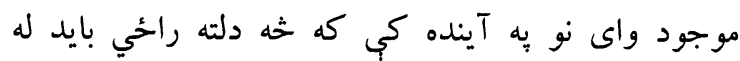
زَباري سره وي، منته.

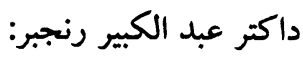

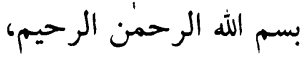
باعرض احترام به نماينده هاى محترم مردم در ارتباط همين المين

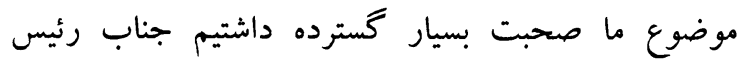
صاحب در همان وقتى كه ما روى موضوع حق العبور

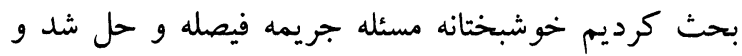

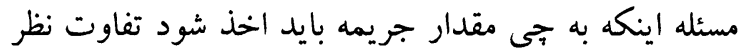

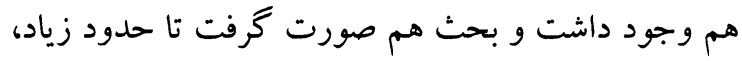

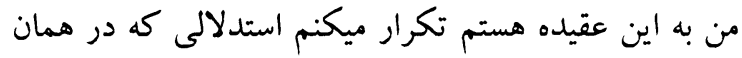

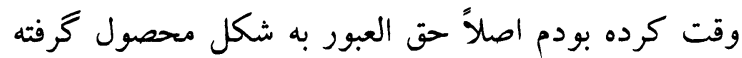
ميشود يكى از انواع است كه به عوايد دولت ميرود مثل اينكه ماليات هم جز عوايد دولت است است و محصولى هم

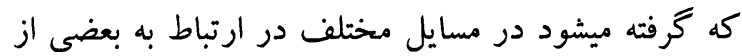

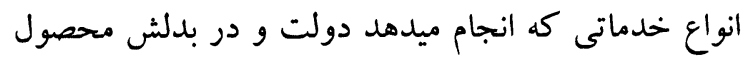
ميگيرد آنهم جز عوايد دولت است كه آخر ما هرقدر بيشتر

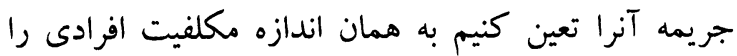

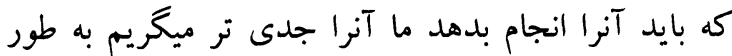

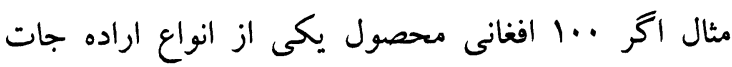

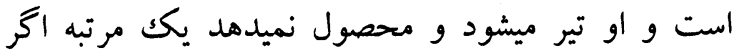

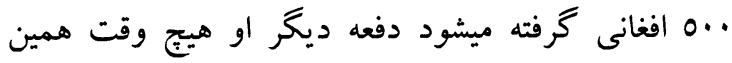

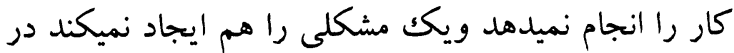

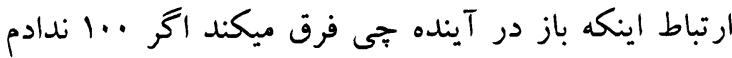

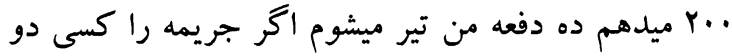

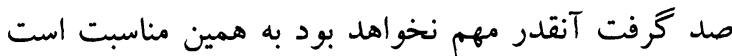

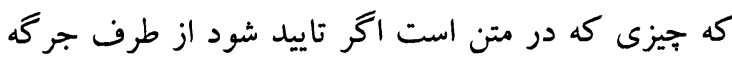

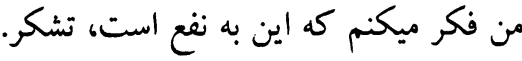
د غونلهي رئيس: بناغلى ميهنى صيب! دلته جي دا متن راغلى يو متن يب دي دي

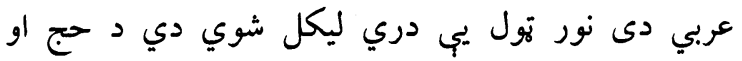

تكت وو د هغوى استدلال دا وو جبي د جريمب يا د جزا

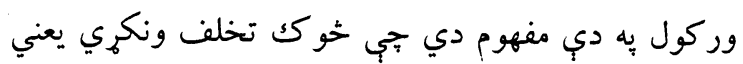

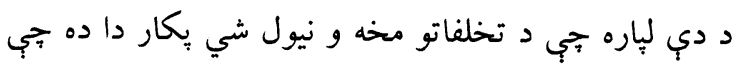

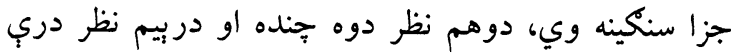

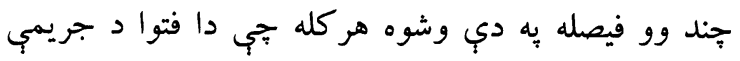

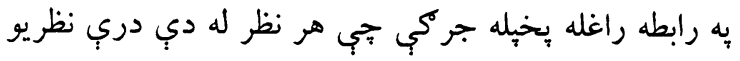
خخخه تائيد كم همغه زمور. فيصله ده.

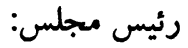
من يكك كمى توضيح ميدهم خدمت شئ شما و كلاى محترم مثل اينكه انجينير صاحب توضيح كردند، در مورد مان ماده 10 قانون حق العبور بحث ما و شما به همين نكته رسيد ريد كه

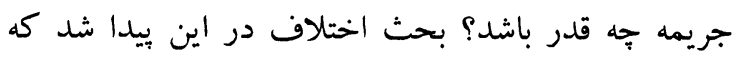

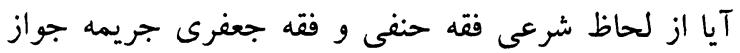

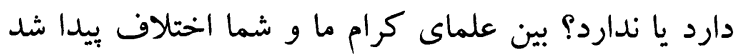
كميسيون تعين شد باز هم به نتيجه نرسيدند در نهايت

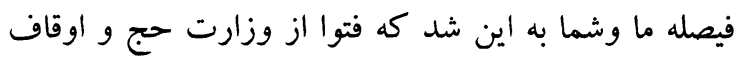
بخواهيم، فتوا خواسته شدكميسيون محترم كار كردند متن آند

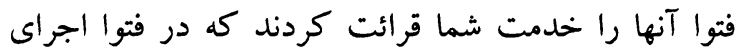

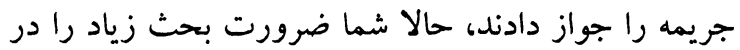
آن مورد نداريم جرا آخرين فيصلة را كه ما و و شما داشتيم اين بود كه هر فتواى كه از وزارت ارشاد و اوقاف آمد

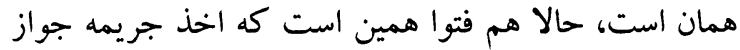

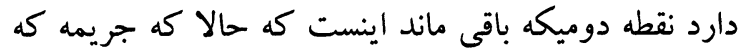
جواز دارد، بحئى را كه انجينير صاحب مطرح كردند كه

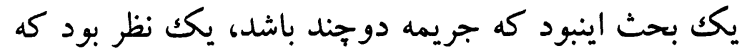

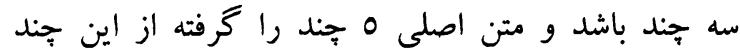

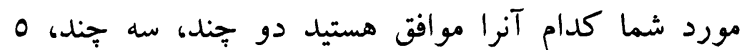
جند؟ خواصي صاحب موخذ فتوا را بخوانيد. عربي متن يب صحي نه لوستل كيب.ي.... غلام فاروق ميرنى :

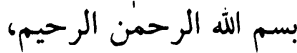
زه فكر كوم جي دا د افغانستان د ملت كور دي دي دلته بايد

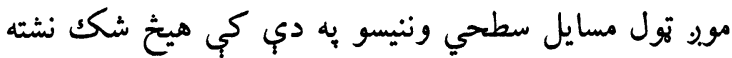

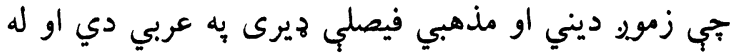

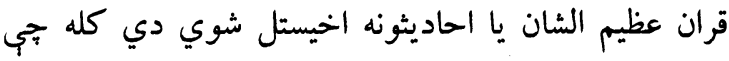


همراى كميسيون اقتصاد و مالى امروز نشست داشته باشند

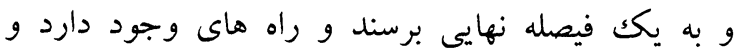

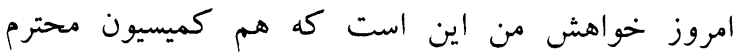

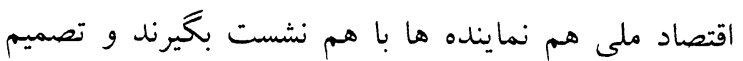

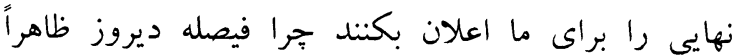

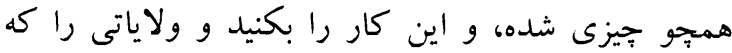

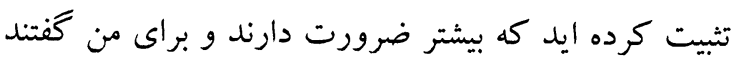

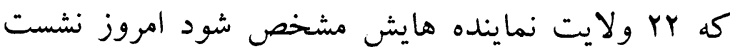

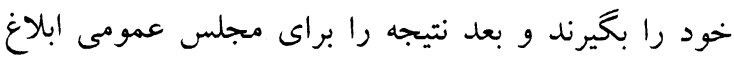

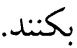

محمد داود سلطان زوى:

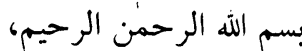
كميسيون اقتصاد ملى هم متشكل از يكى الرحك تعداد نماينده

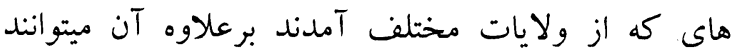

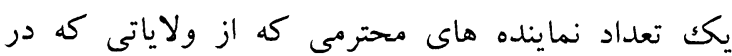

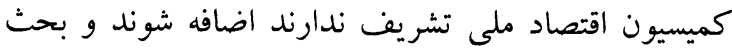

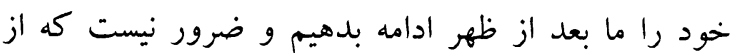
ولاياتى كه ما در كميسيون نماينده داريم قبلاً از آنها باز

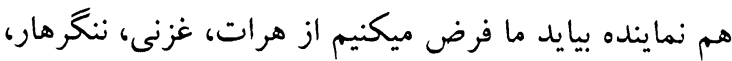
غور، بلخ وغيره نماينده هاى كه در داخل كميسيون دائ داريم

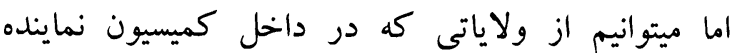
وجود ندارد بيايند ساعت دو بعد از ظهر و بحث نمايند. رئيس مجلس: ساعت Y بعد از ظهر كميسيون محترم اقتصاد ملى جلسه

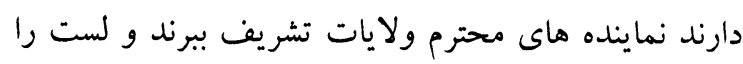
سلجوقى صاحب ميخو انند.

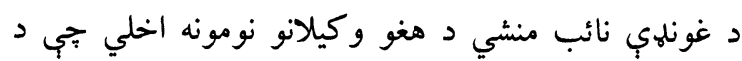

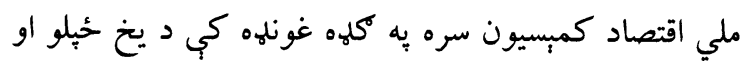

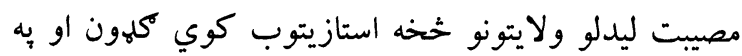
دي برخه كي د يادو شويو ستونزو به هكله تصميم نيسي..

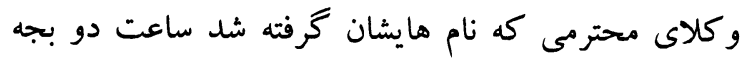
در كميسيون محترم اقتصاد ملى مجلس ميخيرند نتيجه را ما ماندان فردا براى ما وشما ابلاغ ميكنند.
اوقاف د وزارت لخوا، ستاسو فرموده بلكل سمه ده جبي

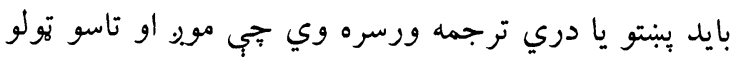

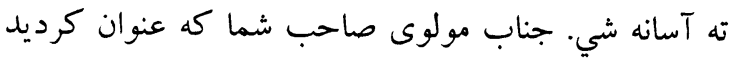

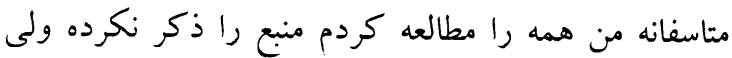

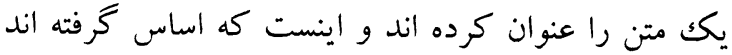

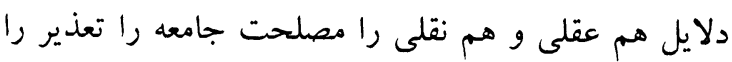

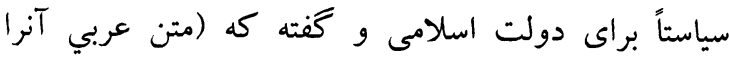
رئيس مجلس قرات مكيند مولوى دين محمد عظيمى:

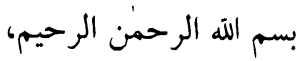
به اجازه جناب رئيس و و كلاى ملت نجيب الفيبا التغانستان

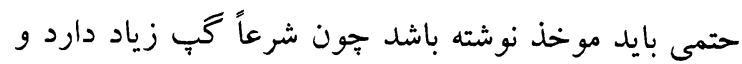

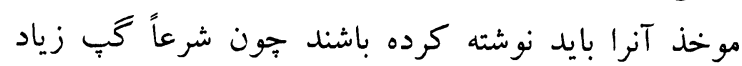

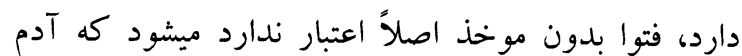

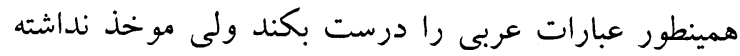

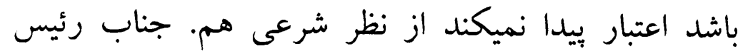

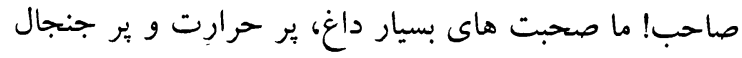

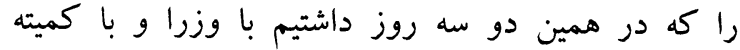
اضطرارى بلاخره نتيجه امروز جِّدر خاموش است و دو تمام مردم وقتى كه حالت اضطرارى است و مردم هم ميمرند يكك هزار تيلفون ميايد يك طرف مردم زياد خوش هستند

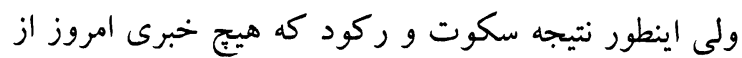

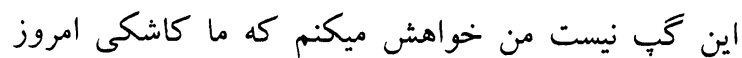
بالاى اين حرف بيشتر مينشستيم و نتيجه را امروز اعلان ميكرديم كه ما حهه كرديم بلاخره بعد از اين صحبت هاى

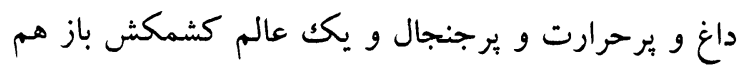

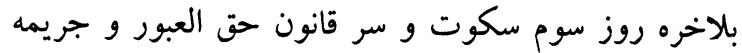
بحث ميكنم بالاخره اعتر اض داريم اين جه قسم ونم است؟ رئيس مجلس:

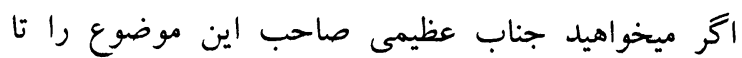

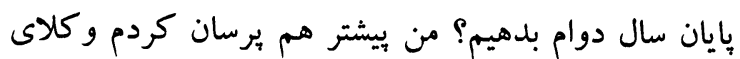
كه وقتتر تشريف آورده اند ياسينى صاحب تشريف ين ندارن

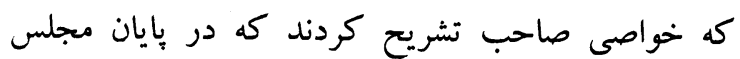
ديروز ظاهراً كميسيونى تشكيل شد متشكل احس از نمايند ولايتى آسيب بذير استند و بيشتر آسيب ديدند كه جمعاً 
فيصله رسيدند كه يكك كميسيون داير شود، تجربه ما از شهلا عطاء:

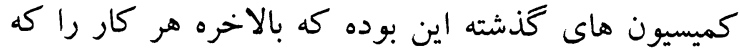
بخواهيم به نتجه نميرسد به كميسيون شما آنرا محول

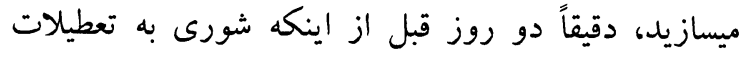

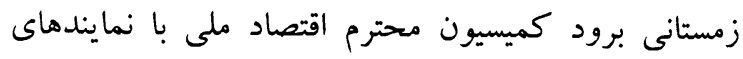
ولايات مختلف همين طور يكك مجلس را داشتند حالا من برون سر اين بحث نميكنيم كميسيون فيصله شده مجلس فيصله

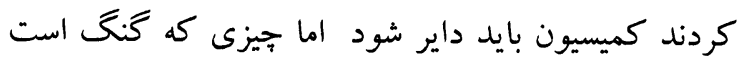
بيش وكيل صاحب ها ميكانيزم بعدى تعقيب اين موضوع

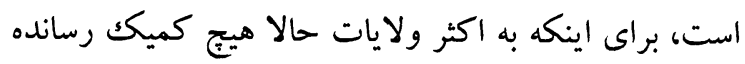

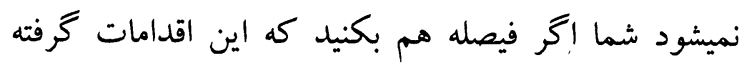

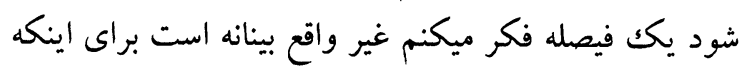

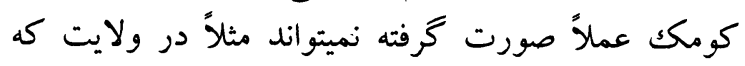

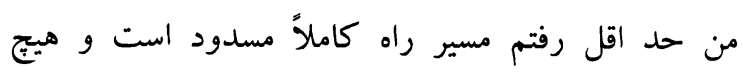

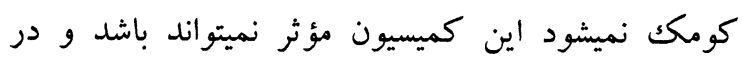

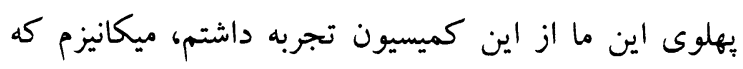

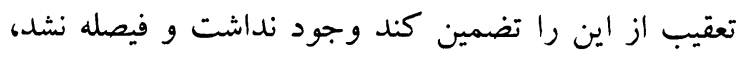
بيشنهادام اين است بعد از اين كه اين كميسيون مجلس تصنس

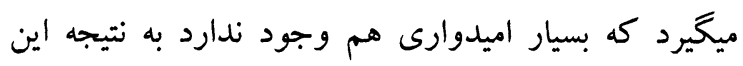
مجلس باز اگر رئيس صاحب كميسيون باسخ حالت اضطرار كه جناب استاد خليلى است و در بسيارى مواقع بسيار احساس مسئوليت هم دارند من كه تيلفونى همراى شان از بدخشان صحبت كرديم از تخار صحبت كرديم بسيار واقعاً شريك هستند در مسائل با انها اكر هيئت ادارى لخد يكك كسى با صلاحيت ترصحبت كنند كه اقدام عاجل جون ما با اين كميسيون مطرح كرديم كه سبسايدى در

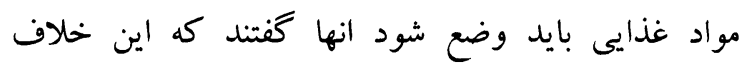

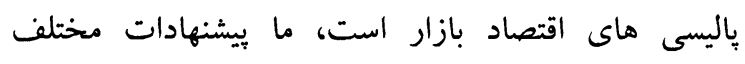

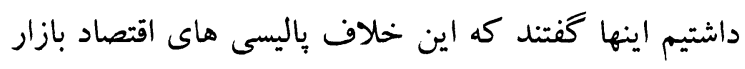
است يس راه حل بيدانشد، بيشنهاد من اين است كه خو

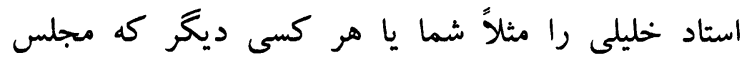
فيصله ميكند مجلس هم كرفته شود. رئيس مجلس: تشكر وكيل صاحب هاى محترم، انجنير صاحب محمد مد مدئ خان بيش ميرويم.

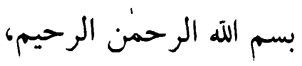

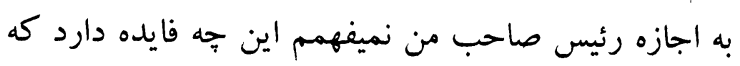

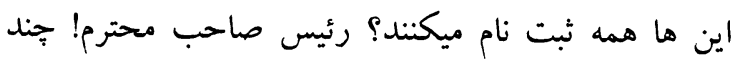

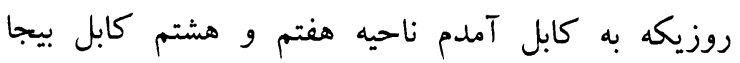

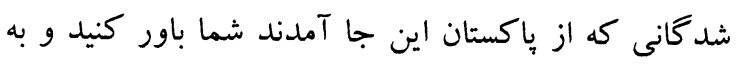

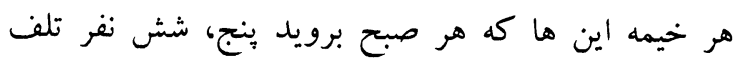

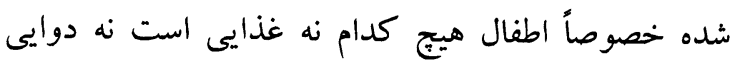

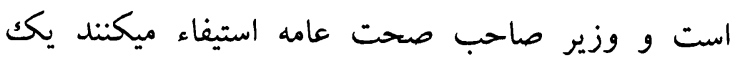
داكتر كه اين قدر حوصله ندارد او جطور ميتواند كه به به ماته

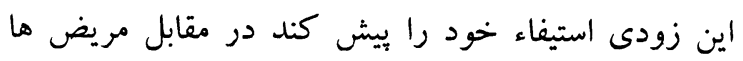

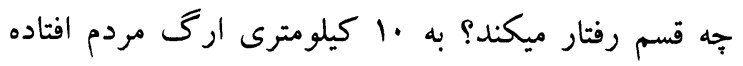

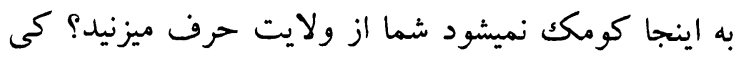
كومك ميكند؟ هميش دروغ است، جيزيكه اينها ميخفتند

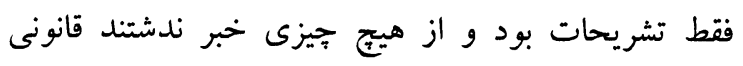

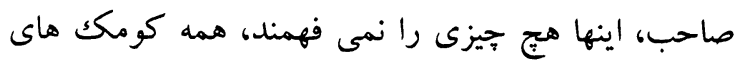

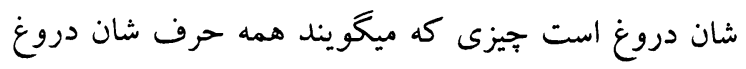

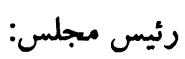

تشكر عطاء صاحب، وكيل صاحب ها محترم! امروز باز

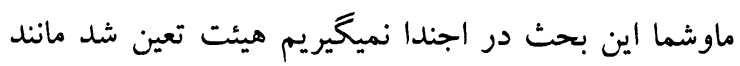

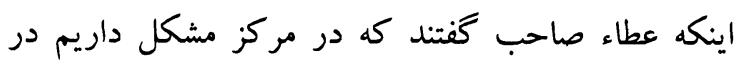

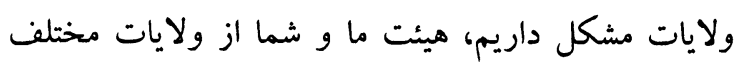

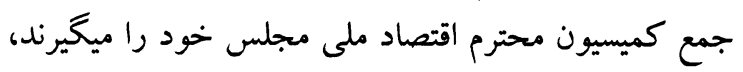

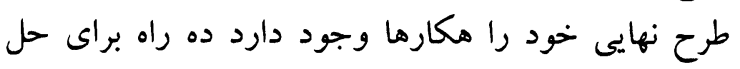

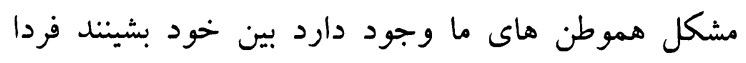

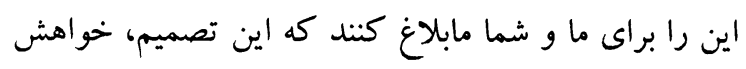

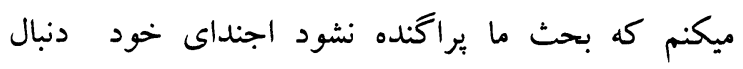
بكنيم، به هر حال يك كار بايد انجام بدهيم عطاء صاحب

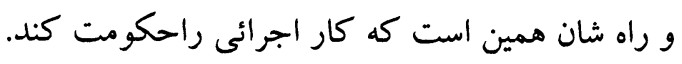

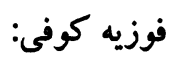
بسم الله الرحمن الرحيم، وزئ ديروز مجلس جمع مجلس به نحو بود كه بلاخره ما همه

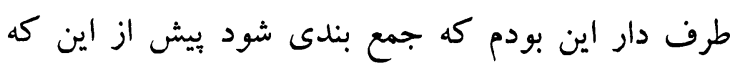

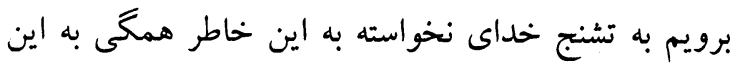


سرخ، تشر با اكثريت آراء ِينج جند تصويب شد، بيش ميرويم در قانون ديخر.

انجنير محمد خان:

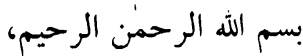

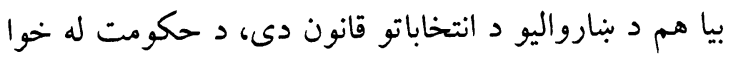

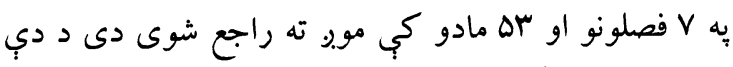

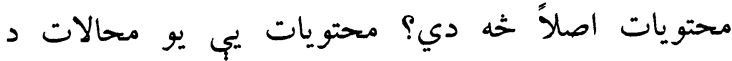

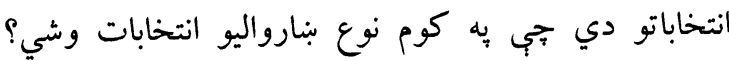

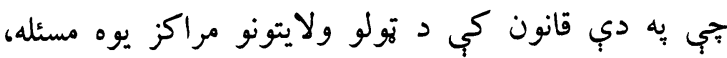
انشاله وكيل صاحبان خو متوجه دي، زه يو... رئيس مجلس: وقاضى زاده صاحب! جهه ميخويد شما؟ سر قانون انتخابات

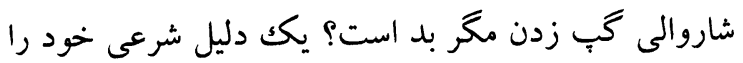

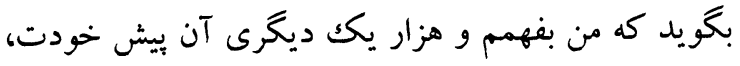
منظور تو همين بس ديروز است؟ به كدام زبان برايت

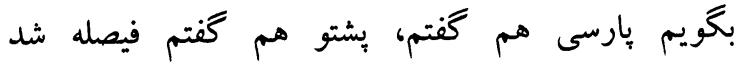

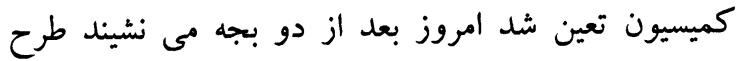

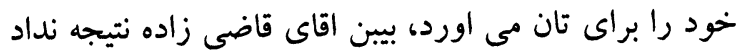

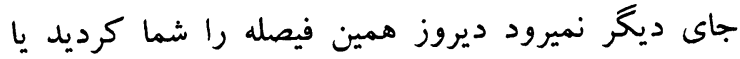

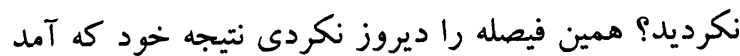
براى تان قانع نبود همان وقت استدلال كنيد كه به همين

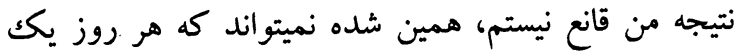

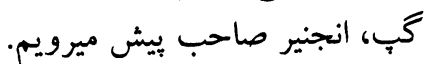
انجنير محمد خان: من يكك دفعه به وكيل صاحب ها در مجمان: ماندوع همين قانون

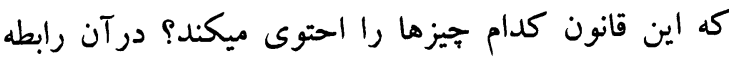

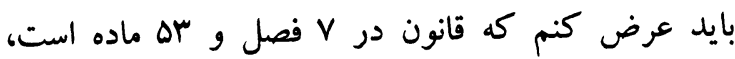

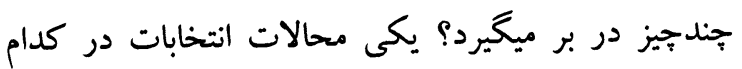
محلات انتخابات بايد شود؟ مر اكز تمام ولايات در بر دود دارد و بعضى ولسوالى ها كه شرايط شان ذكر كرده آن است و و در كل دشاروالى ها نيست كه در ان شاروالى هالى ها شاروالى نانى

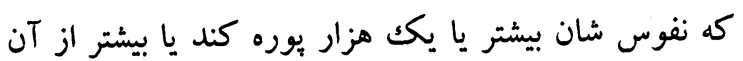

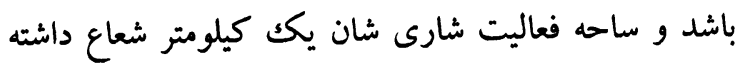
باشد و شاروالى هاى ولسوالى ها سرحدى ديخر شرايط انتخاب كنندگان انتخاب شونده گان وان است، ديخر همين
انجنير محمد خان: بسم الله الرحمن الرحيم،

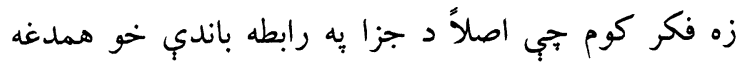

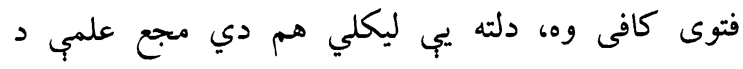
علماوو د وزارت حج او اوقاف دافتوى راليرلي ده او هغو

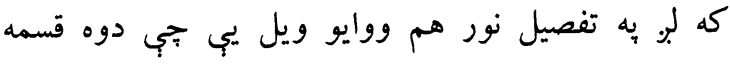

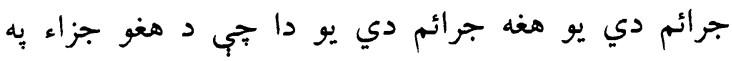

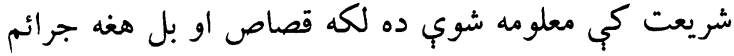

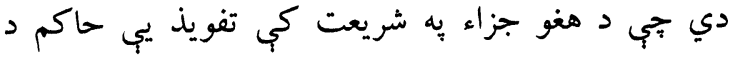

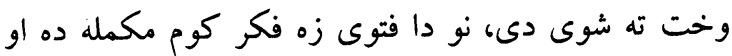

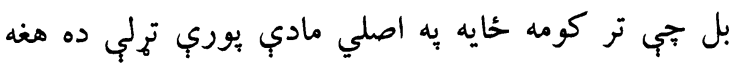

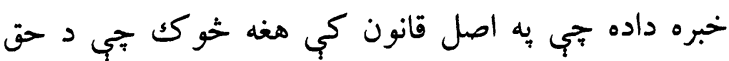

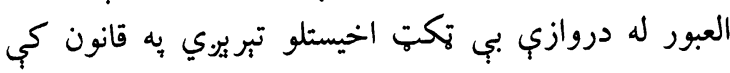

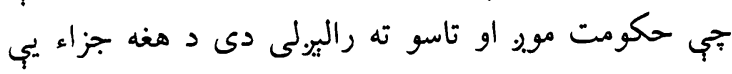

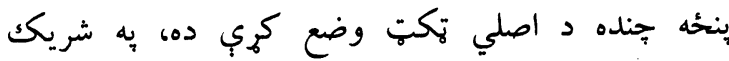

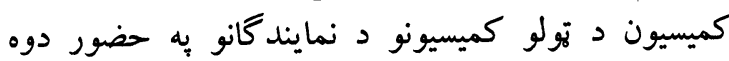

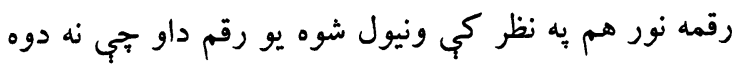

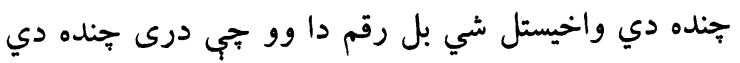

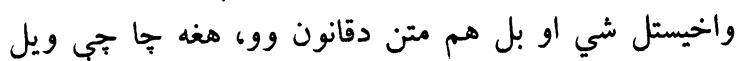

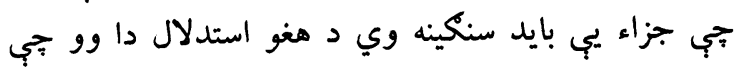

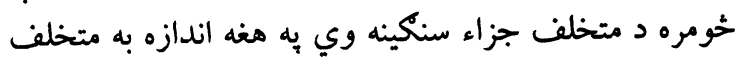

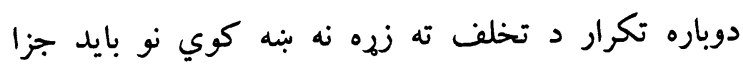

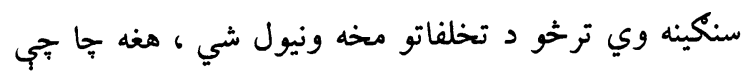

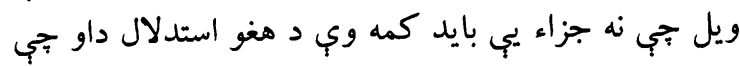

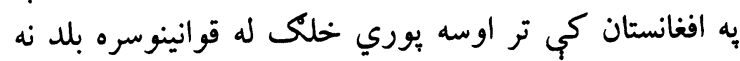

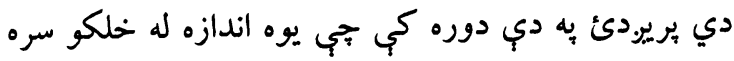

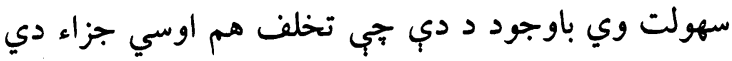
جيره سنكينه نه وي، د دوارو طرفو استدلال مويه امانت

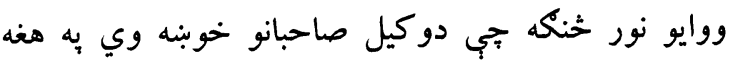
دي نظر وركري. رئيس مجلس: بلى وكيل صاحب ها مختصر ديخر حرا وقت تانئ مان را در

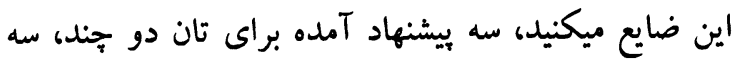

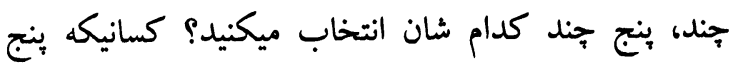
جند ميگويد كارت سبز و كسانيكه ميخويد نه كارت 


\section{رئيس مجلس:}

تشكر رنجبر صاحب، باز هم كه وكيل صاحب ها تصميم

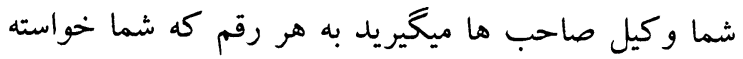

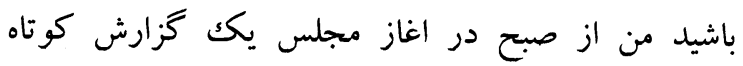

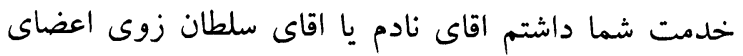

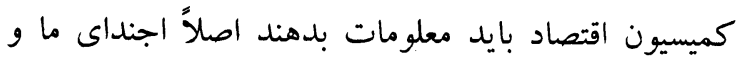
شما رنجبر صاحب قانون تداركات بود كه امروز سر قانون تدار كات در اجنداى قبلاً فيصله شده ما وشما ميبود ديروز

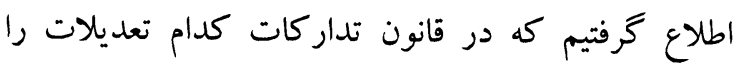
ظاهراً شورى وزراء يا بقيه در آن آن آوردند بس دئ تقاضاء

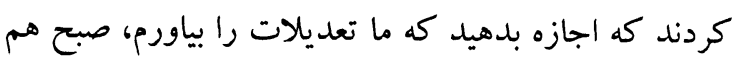

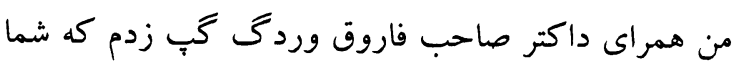

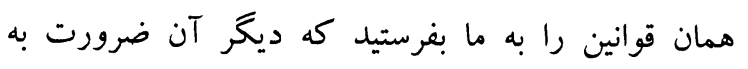

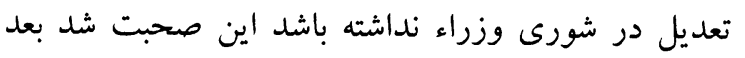

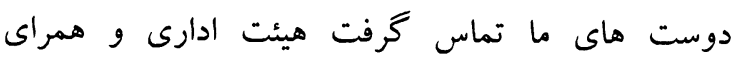

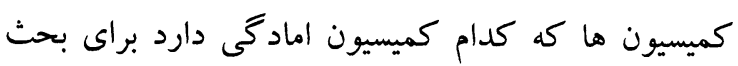

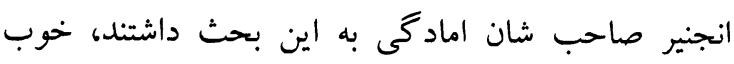

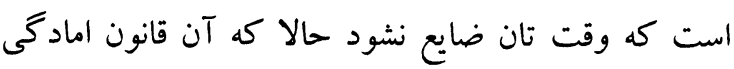

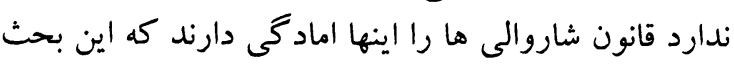
بحيريم شما وكيل صاحب ها موافق نباشيد شما صلاحيت

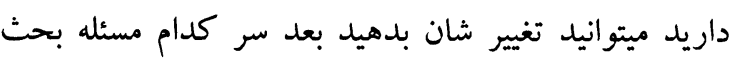

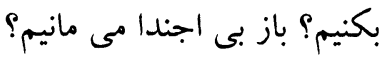

$$
\begin{aligned}
& \text { انجنير عباس نويان: } \\
& \text { بسم الله الرحمن الرحيم، عباس نويان: }
\end{aligned}
$$

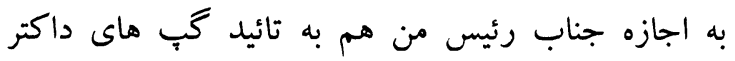

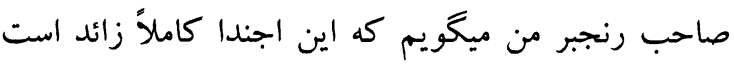

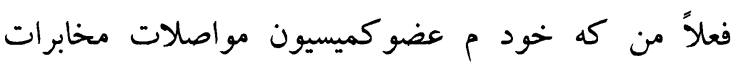

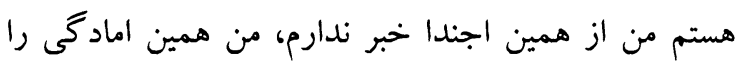

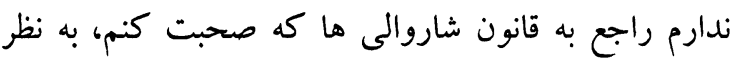

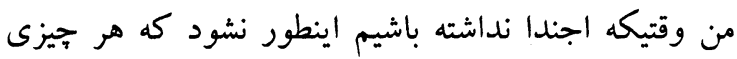

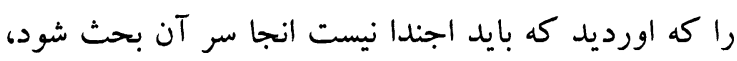
جنداى بسيار خوب و مهم اجنداى ديروز است كميسيون اقتصاد ملى را كه شما امروز شريكك ساختيد با تعداد از ماز

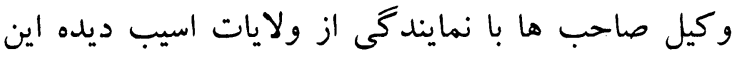

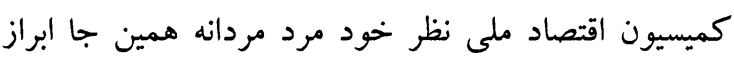

جيزى راكه دربر ميگيرد آن هيئت اجرائيه است كه

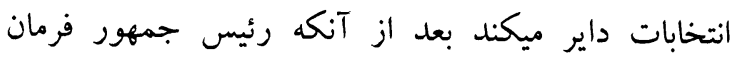

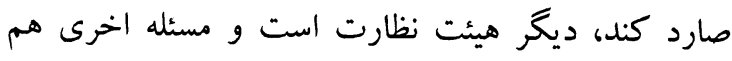

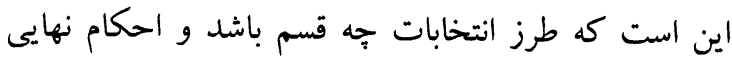

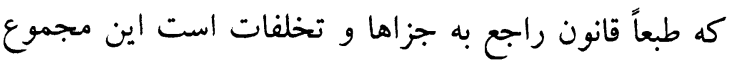
قانون است كه در V فصل و سه ماده است، رئيس صاحب!

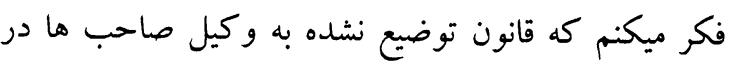

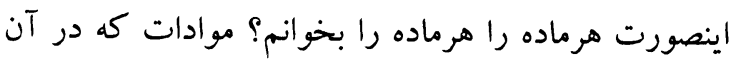
تعديل آمده بخوانم؟ ت مرماده روش ما و شما همين بود كه در مواد تعديل آمده، توزيع

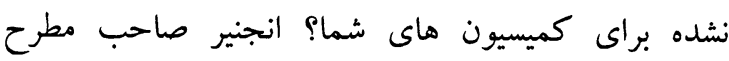
كردند كه در كميسيون ها قرائت شده خوانده شده.

$$
\text { داكتر عبد الكبير رنجبر: }
$$
با عرض سلام دوباره، جناب رئيس صاحب! اصلاً همين وندي موضوع قوانين وكار روى قوانين بسيار مهم است و بايد

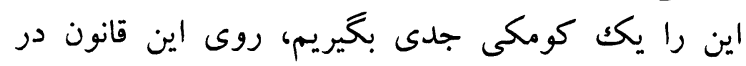

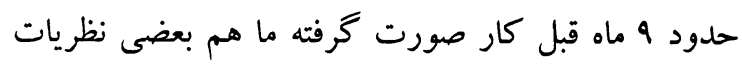

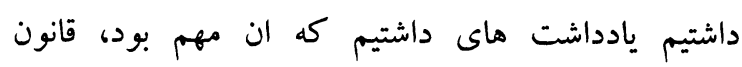

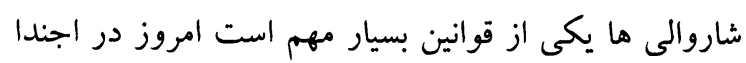

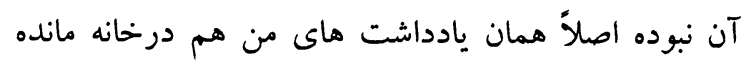

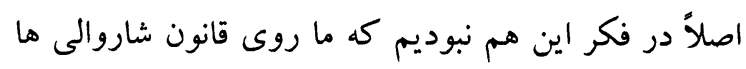

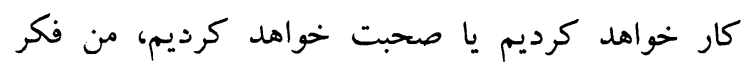
ميكنم كه اين به مصلحت نخواهد بود اكر من اين ران را فقط

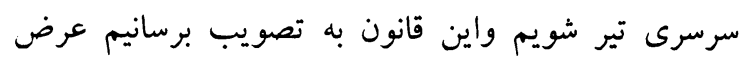

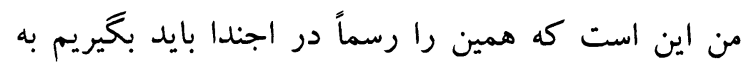
يكك روز ديگر كه همه مطلع باشند همه مجهز و مسلح

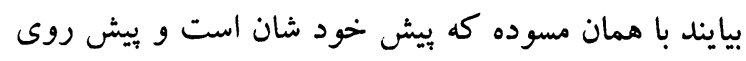

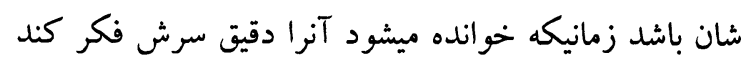
بايكك فكر خوب روى آن نظر بدهند كسانيكه ميخواهند

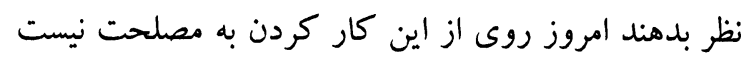

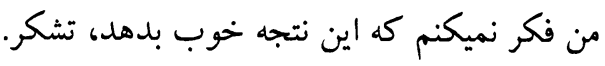


كميسيون باز يكك مرور ميكرديم يا كم از كم يادآورى

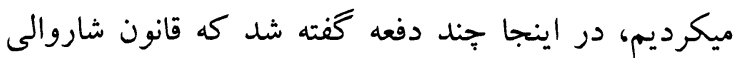

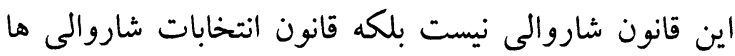

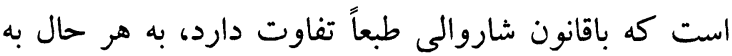
ارتباط فرموده انجنير صاحب عباس يا ديخر وكيل صاحب ساري هاى وقتيكه ديروز جلسه رخصت شد سلجوقى صاحي صاحب به به

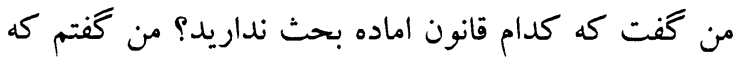

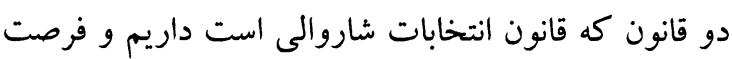
موقع اين نبود كه باز يا در كميسيون مطرح ميكرديم به فيه

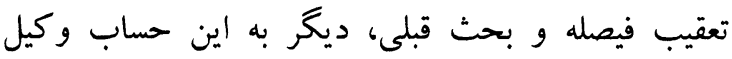
صاحب ها اينطور فكر نكند كه من هوايى اين مسئله را تير فير دئي

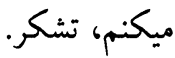

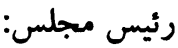
تشكر انجنير صاحب، بناءً وكيل صاحب هاى محترم از

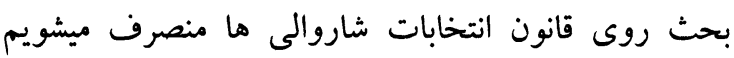
كه شما به وقت ضرورت داريد، ولى همان رقو كه كه انجنير صاحب محمد خان فرمودند شامل اجنداى تصويب شده وند

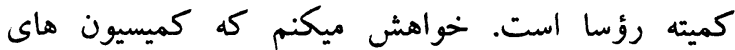

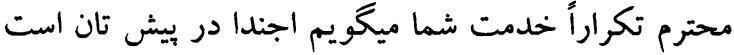

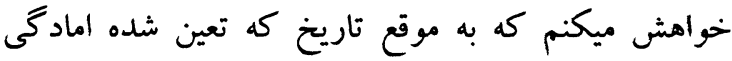

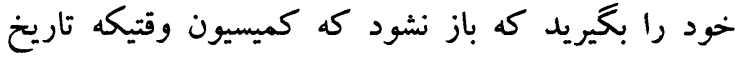
كارش ميرسد باز به ما تيلفون كنند كه هيئت ادارى ما بارد

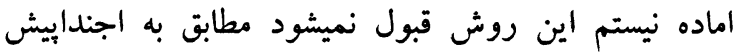

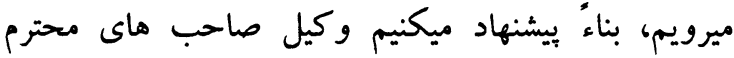
خدمت شما كه به ادامه صحب هاى را كه در اين دو روز كذشته داشتيم كه امروز صحبت خود دوام بدهيم نهام نتيجه نهايى را بخيريم، موافق هستيد به اين گَّب؟ موافق كارت

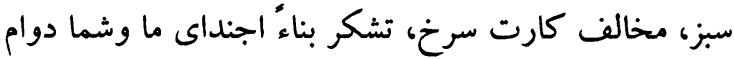

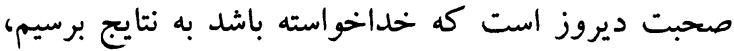
از انجنير محمدخان، داكتر صاحب فاطمه عزيز، كوهى صاحب از همكارى و امادگى شان اظهار سباس ميكنم

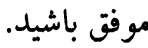

كرد توسط اقاى نادم، امروز هم همان كميسيون همان كميسيون اقتصاد است با همان نظرشان شما به اقاى ناديم

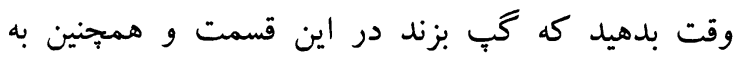

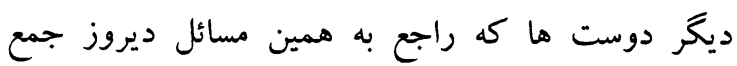
بندى شده بلى يكك كميسيون بسازيد همانطور كه خانم

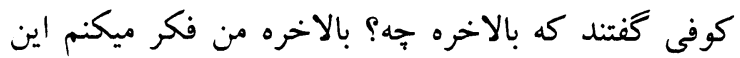

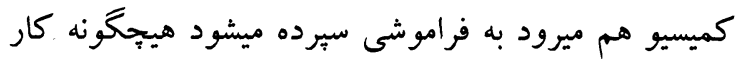

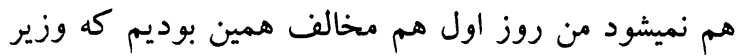

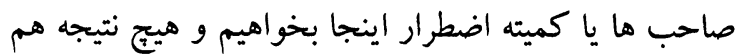
نميخيريم از آن، بهترين نتيجه اين است كه شورى محته

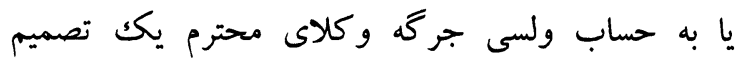

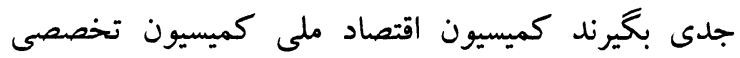

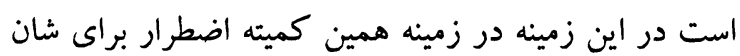

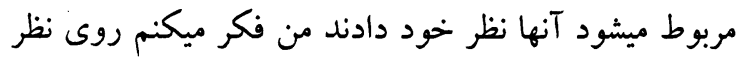
انها بحث شود يكك تصميم جدى تر گرفته شود. رئيس مجلس: - نها بحت وكيل صاحب هاى محترم قسميكه اقاى نويان مطرح

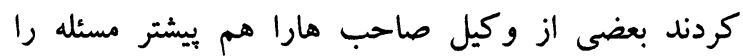

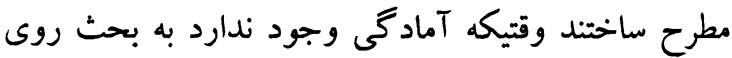

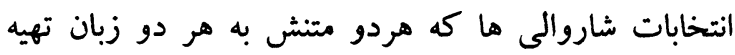
شود در اختيار كميسيون ها قرار بخيرد كمى به زمارد هان كار هار

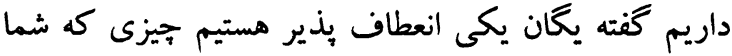

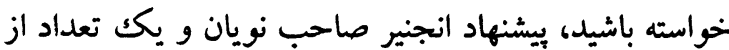
وكيل صاحب ها به اين است كه به ادامه مباحثات ديروز

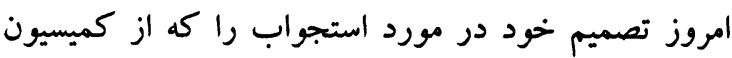
داشتيم نهايى بسازيم، موافق هستيد كه سر اين صحبت مورد

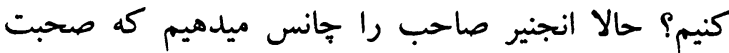
كنت بعد ناديم صاحب.

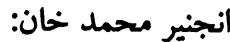

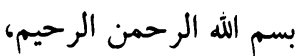
جناب رئيس صاحب! يا اعضاى كميسيون يا بقيه وكيل صاحب هاى اينطور فكر نكنند كه من انهارا در جريان

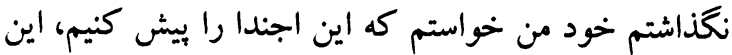
در اجنداى كه در كميته رؤسا رويش بحث شد مط مطابق همان اجندا نبوده كه من باز هم به تعقيب فيصله قبلى 
صاحب زراعت دايم سر اعمار و ارقام است ما به بار ها

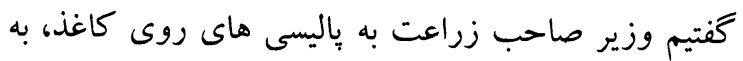
تيورى هاى كه شما ميخويد شكم مردم سير نميشود، بيايد يك كار عملى كنيم يك صند صندوق براى قرضه ايجاد ماد كنيم

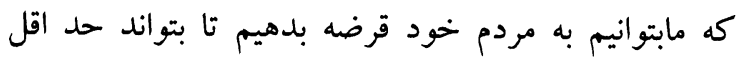

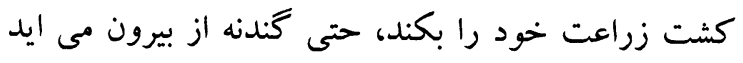

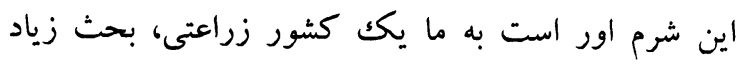

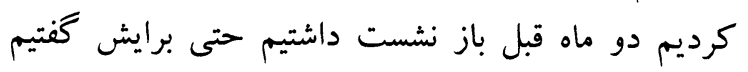

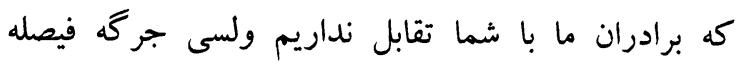
كرده كه با حكومت يكك جا براى رفع مشكل ما كار

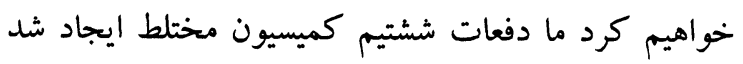

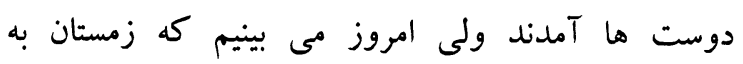

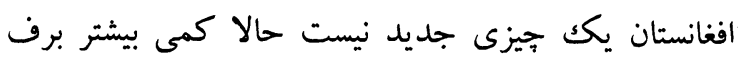

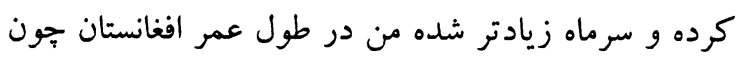

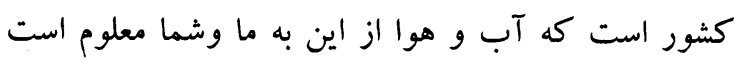

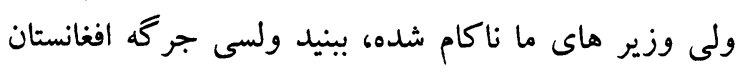

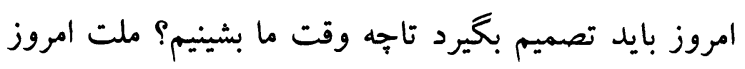

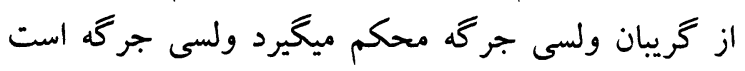

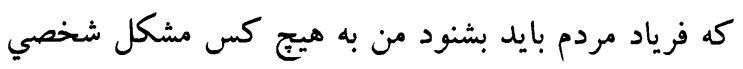

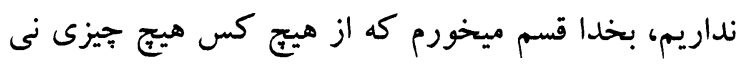

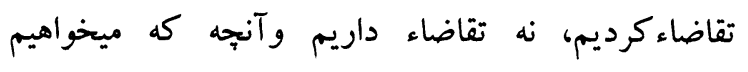

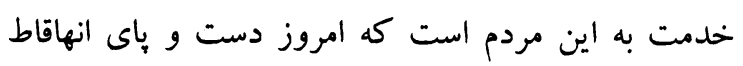

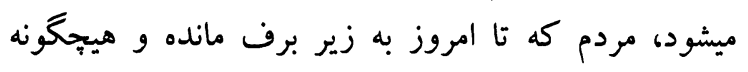

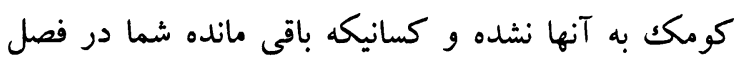
تابستان ببنيد جقدر بايد تلفات انسانى وحيوانى داشته باشيم از بيامد هاى اين، همين حالا تصميم به دست و كلاى ملت

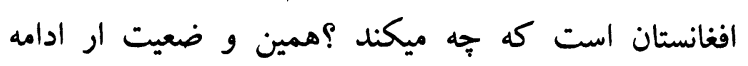
ميدهد با همين تشكل وهمين اعضاى كابينه كه ناكام هستند، من نميخويم كه تنها يكك وزير يا دو وزير ومين بينيد

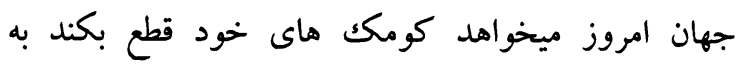
خاطريكه حكومت افغانستان نتوانسته تعهدات كه در لندان داشته در بن داشته به جامعه جهانى تعهد داده نتوانسته علت

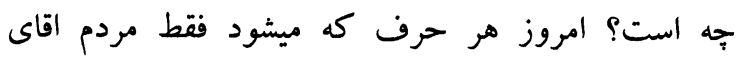

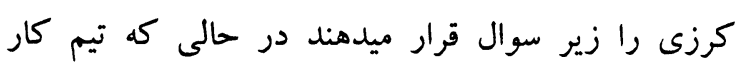
نميكند امروز ولسى جر گه زير سوال است درحاليكه قوه
عزيز احمد نادم: بسم الله الرحمن الرحيم، تمزئ.

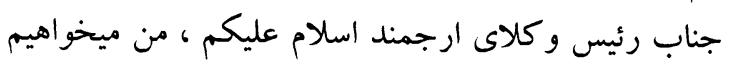

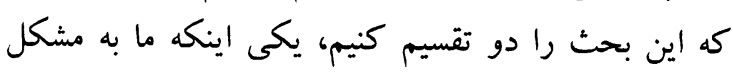

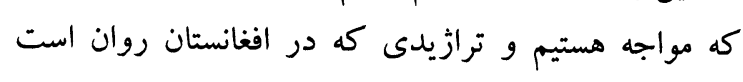

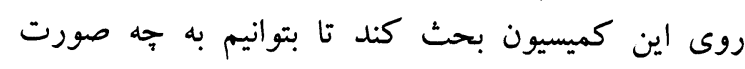

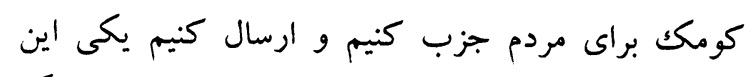
بحث است، بحث ديخر اين كه جهار ماه قبل ولسى جر كه به كميسيون اقتصاد ملى وظيفه سيرد كه در قسمت صعود

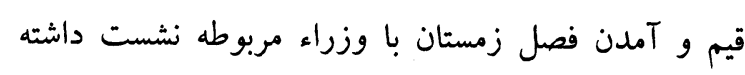

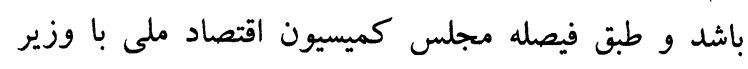

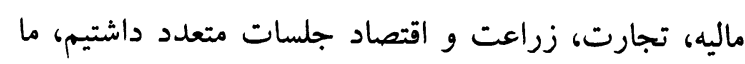

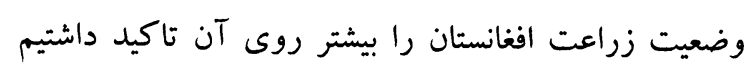

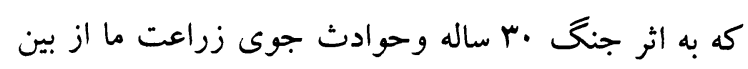
رفته، مردم ما گرسنه است، دهقان ما در شهر ها كار ميكند

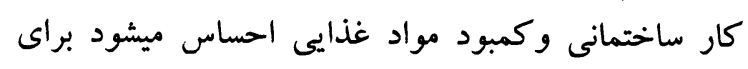

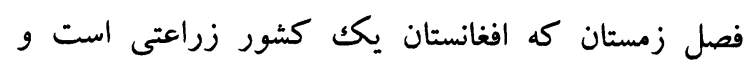
كوهستانى است و افغانستان راه هاى صعب العبور دارد افنان

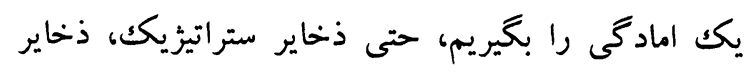

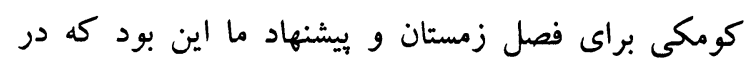

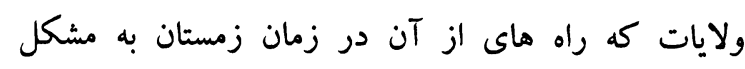

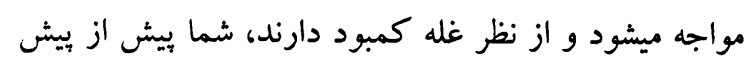

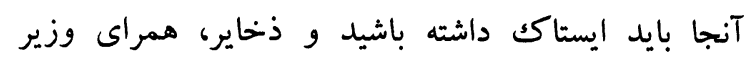
صاحب تجارت هم ما صحبت هاى متعدد داشتيم كه به

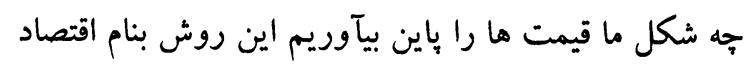

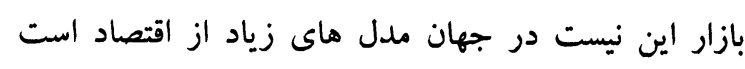
قوانين كمبود است قوانين را شما بسازيد، احتكار است،

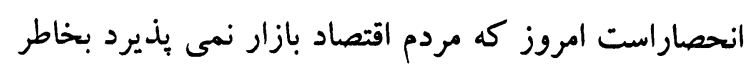
از اين است كه نفى ندارد براى مردم اين مدل در افغانستان

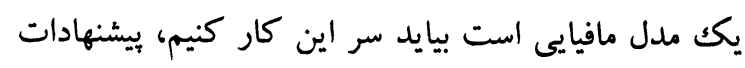

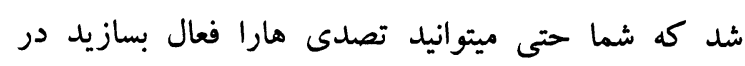

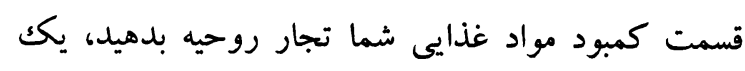

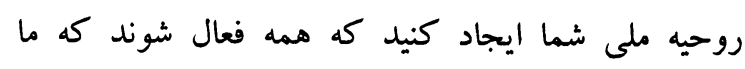
بتوانيم در زمستان مشكل نداشته باشيم، وعده شد هم همراى

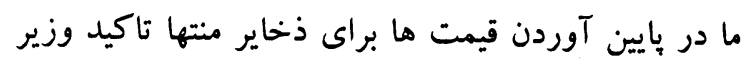




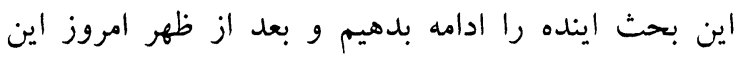

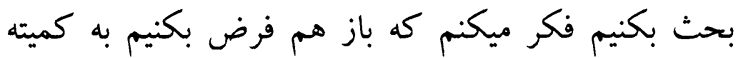

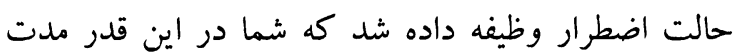

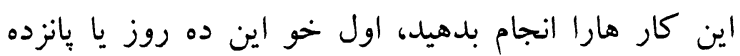

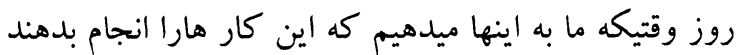

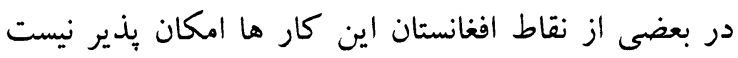

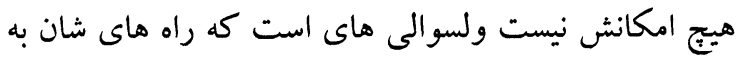

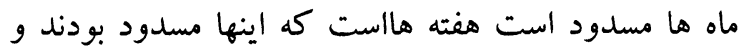

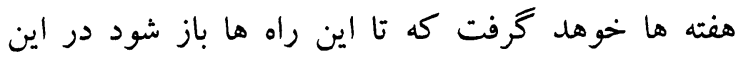
مدت جواب حيات از اين مردم كى ميدهد؟ انسان هاى هاى

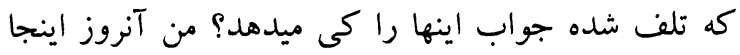
عرض كرديم كه اكر من وزير ميبودم استعفاء ميكردم و

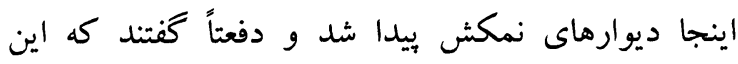
متوجه من بود، من متوجه همه قوه اجرائيه در اين مورد

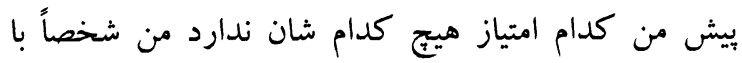

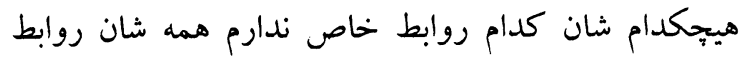

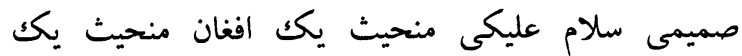

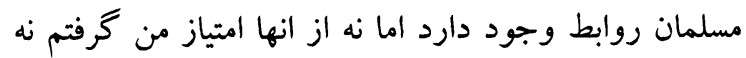

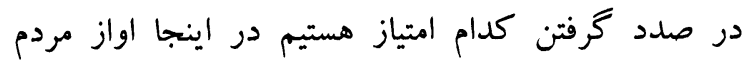
افغانستان بايد بلند شود جناب رئيس، من فكر ميكنم اكر امتر

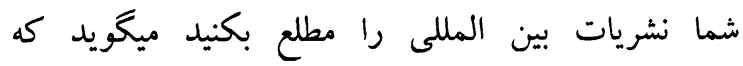

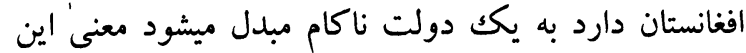
جه است جناب رئيس! دولت بارلمان افغانستان جز دولت

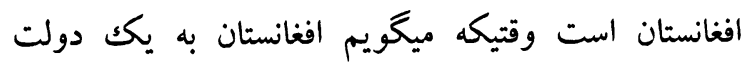
ناكام مبدل ميشود اينجا و كلاى كه با وزراء دوست هم

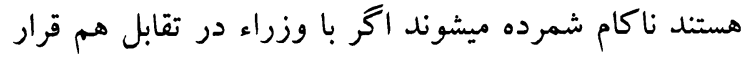

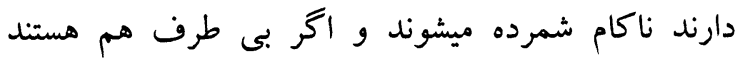

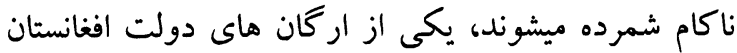

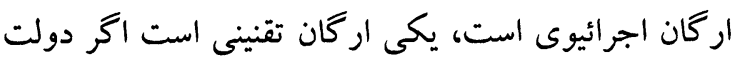

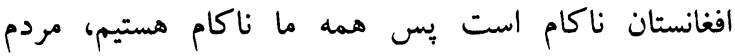

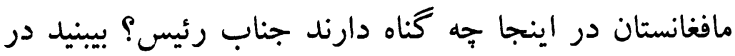

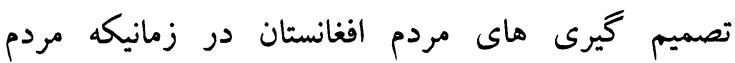
افغانستان در حالت قرار دارند كه هيج كس به به داد شان

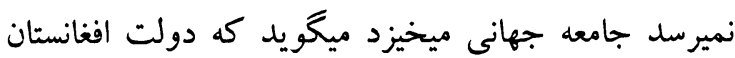

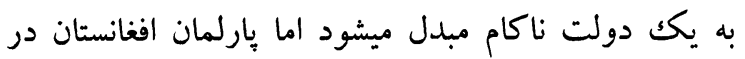

اجرائيه اينجا كمبود دارد مشكل دارد من اميد وار هستم

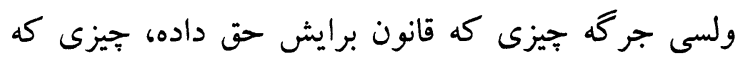

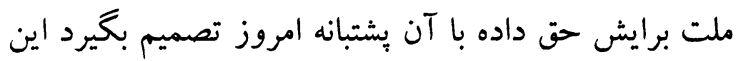

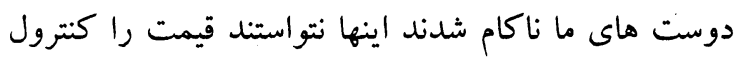

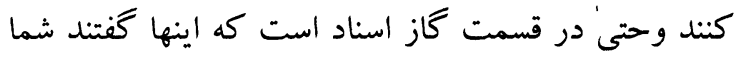

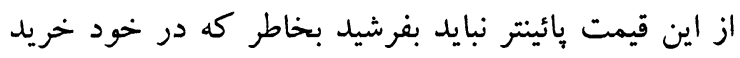

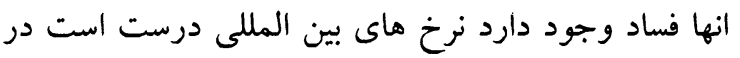

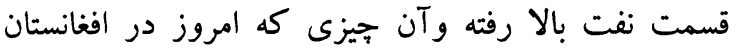
بنام مواد سوخت مصرف ميشود يترول و ديزل شما يكك

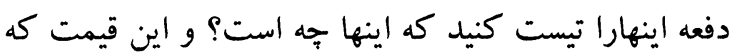

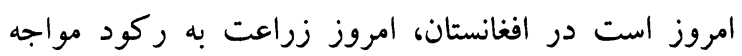

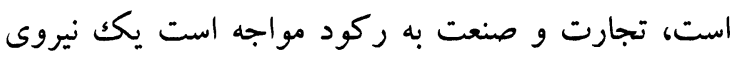

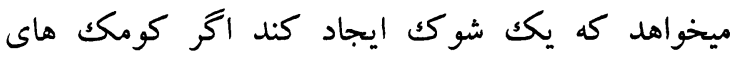

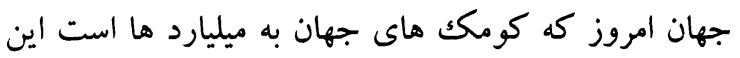
وضعيت ما است آر اين كومكك ها قطع شود به به دلايل

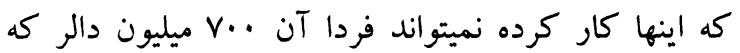

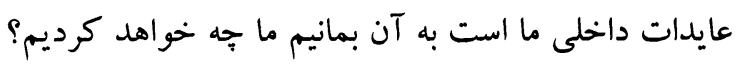

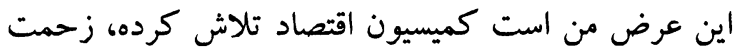
كشيده و آنجه وظيفه سيرده بود ولسى جر كَ آنه برايش انجام

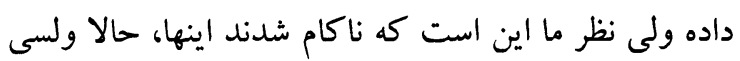
جر گه تصميم ميخيرد، تشكر. محمد داود سلطان زوى:

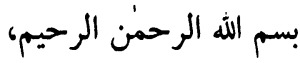

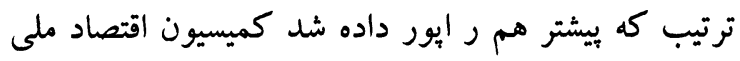

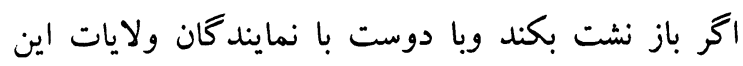

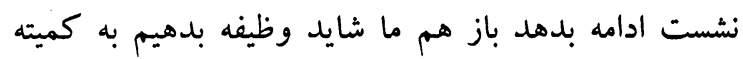

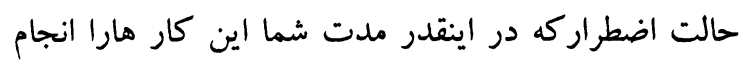

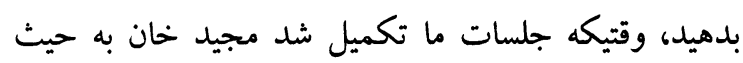

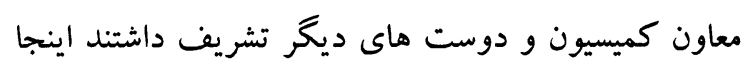
فيصله به عمل آمد كه بعد از صحبت هاى كه با وزراء

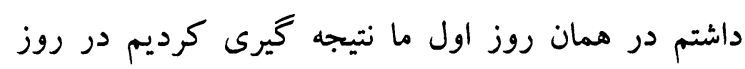

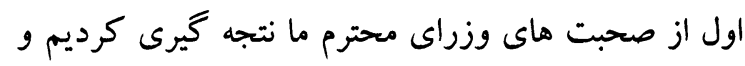

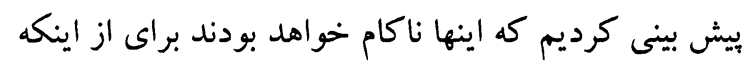

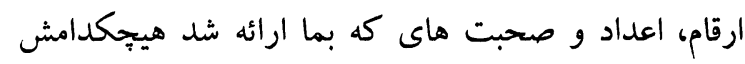

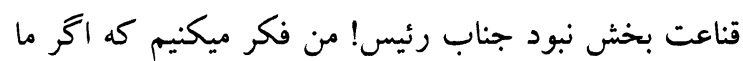


بنظرم، امروز ما فقط موضوع را مطرح ميكنم كه امروز

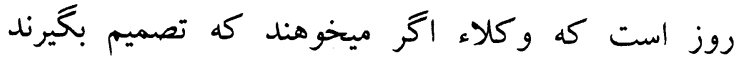
ميتو انند جلسه بخيرند بيشين صحبت بكنند و ميتواند همين

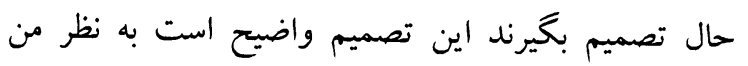

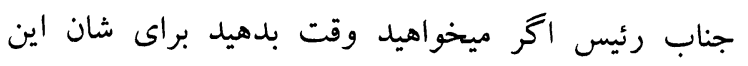

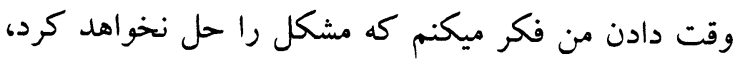

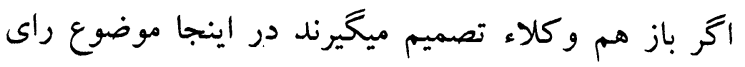

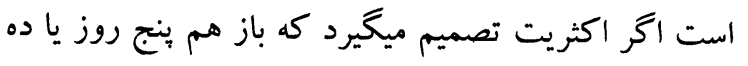
روز وقت ميدهيد و براى شان وظيفه ميدهيد كه همين كار

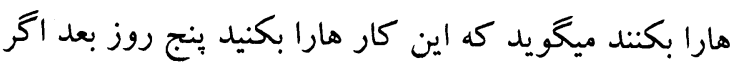

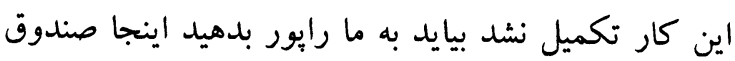

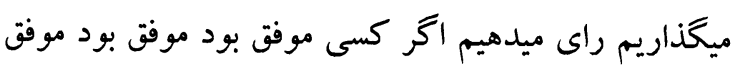

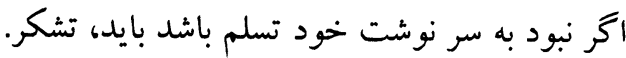

صالحه مهرزاد :

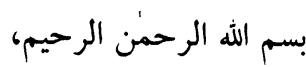

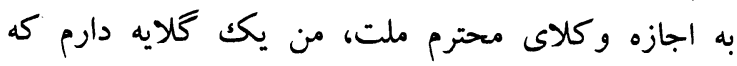

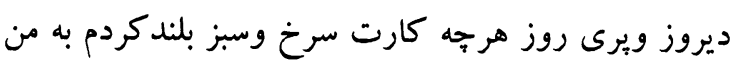

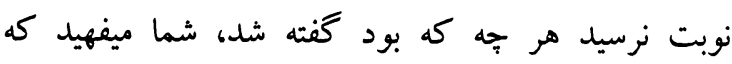
ولايت نيمروز در جاى قرار دارد كه درياى هلمند طغيان

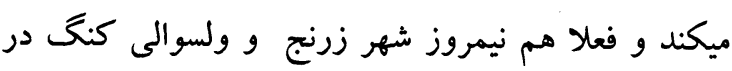

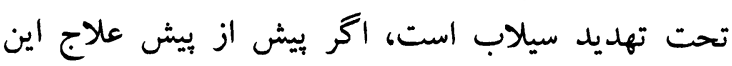

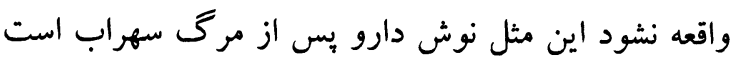

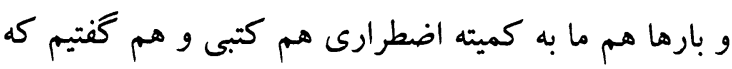

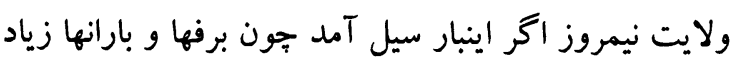

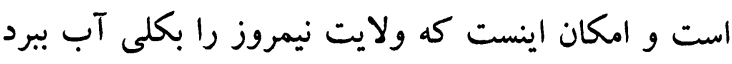

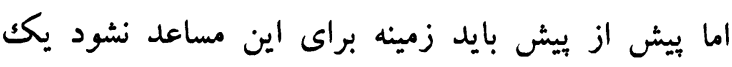

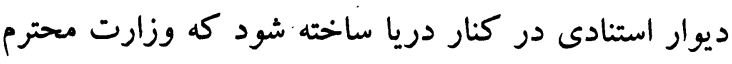

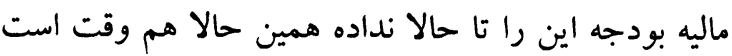
اكر اين ديوار ساخته شود و يا امكانات در دسترس مردم

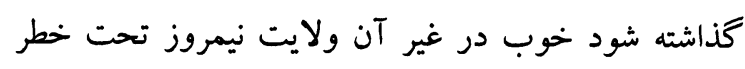

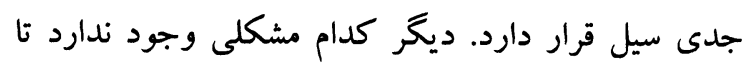
حالا تلفات از طرف برف و باران به مردم نرسيده منتها تنها

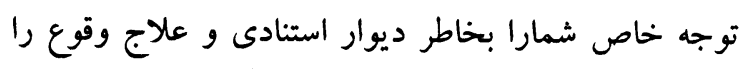
ييش از حادثه خواهان هستم.
كوشه بشيند و هيج تصميم نخيرد اين به نظر من شرم آنا

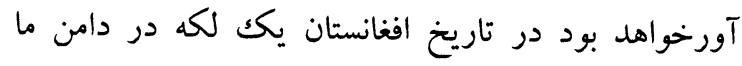

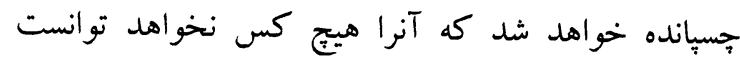
بِاكَ بكند جناب رئيس، من فكر ميكنم كه اكَر تصميم

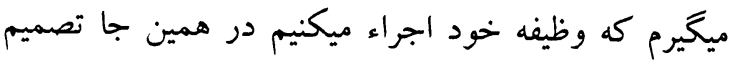

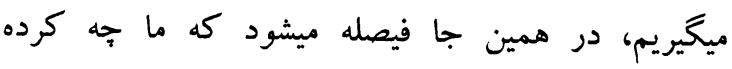

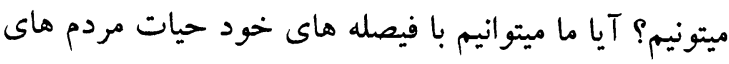
را كه از دست رفتند دوباره بدست بيآوريم؟ ايا ما ميتوانيم

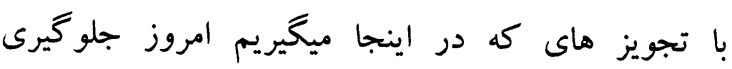

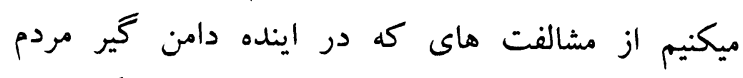

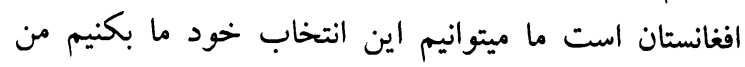

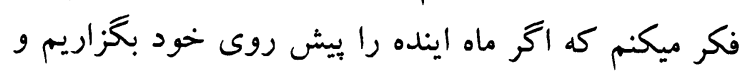

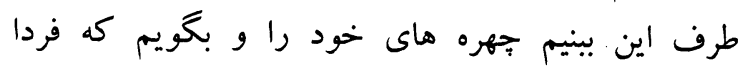

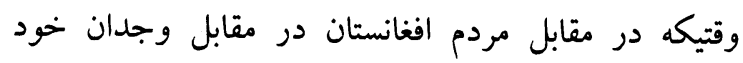

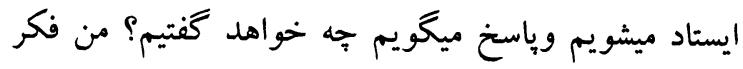
ميكنم كه وقتى اين رسيده كه قبل از اينكه جامعه جهانى

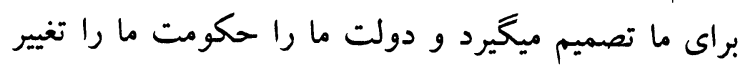

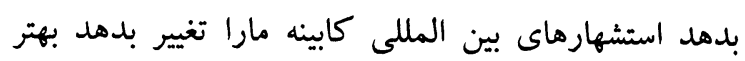

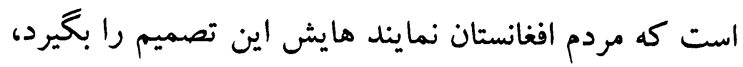
براى ما اشاره هاى بين المللى حتى ميرسد شما تصميم أماني

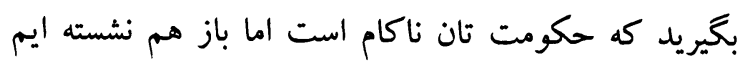

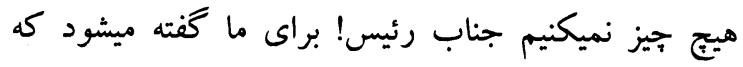

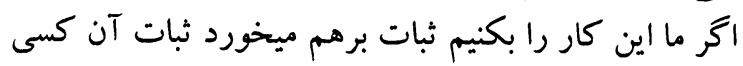

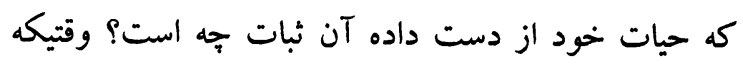
يكك انسان حيات خود از دست ميدهد مادر خود از دست

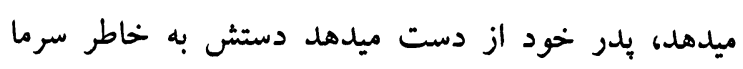

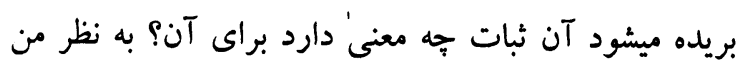

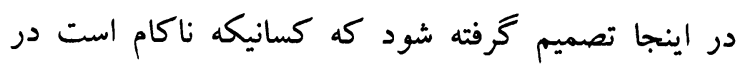

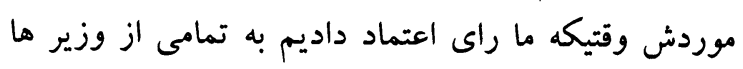

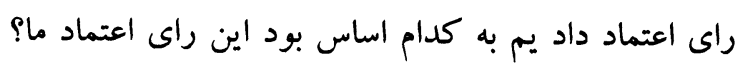
از خود سوال بكنيم ما به خاطر كاركرد راى اعتماد داديم

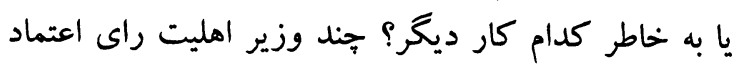
را داشت؟ من از وكلاء يرسان ميكنم اما جند نفرش راط راى

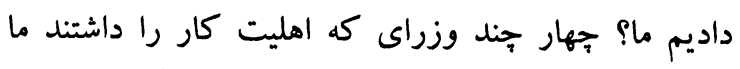

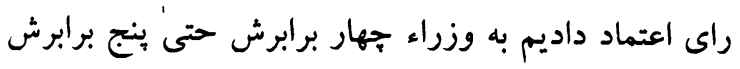


نداشتند و خواستم اين است كه البته به مشوره وكلاى

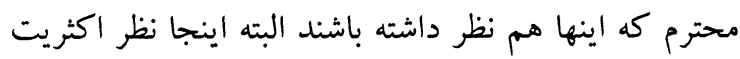
اقليت مطرح است مطلب من اينست كه براى اينها هم

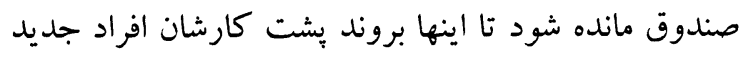

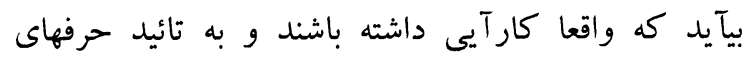
سلطان زوى صاحب ميكويم كه اين وطن قحط رجالى والى دانه

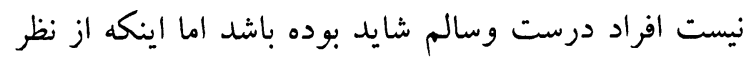

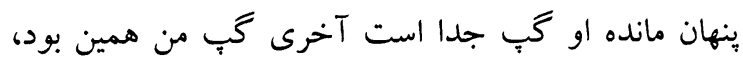
تشكر. داكتر رمضان بشردوست:

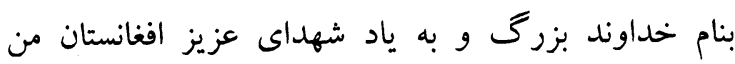

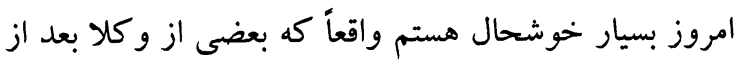

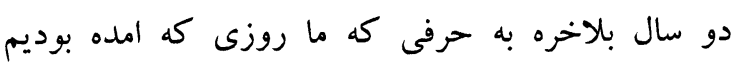
كفتيم امروز اينها توجه ميكنند، دوسال را ما ها هدر داديه ماته

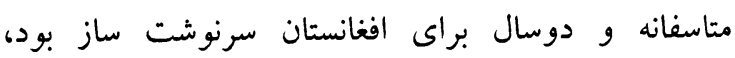

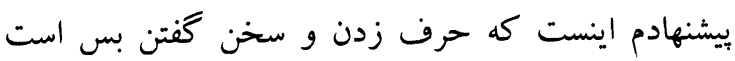

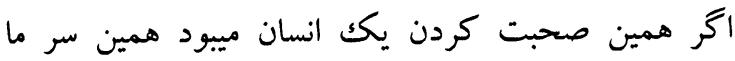
اعتراض ميكرد كه رهايمان كنيد بسيار از ما ما استفاده

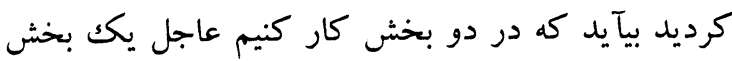

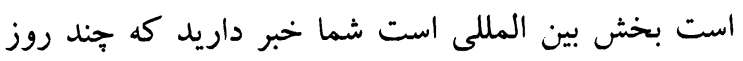
بعد كنفرانس توكيو داير ميشود بعد از آن اينها تماس بحس داس

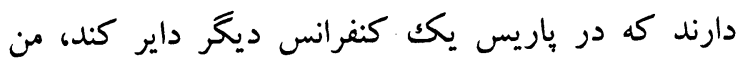

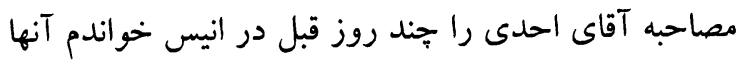

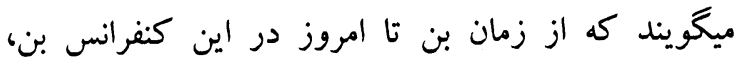
تو كيو، برلين و لندن جامعه جهانى براى ما جهان ميل ميليارد

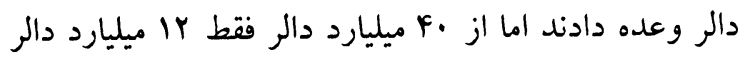

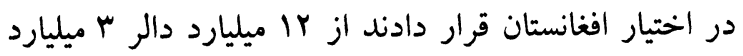
دالرش در اخيتار حكومت قرار داده شده وه ميلياردش در أنغار

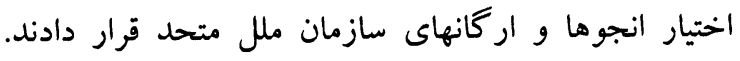

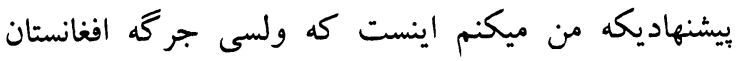
يكك فيصله جدى و قطعى بخيرد كه با هر كنفرانس ديخر

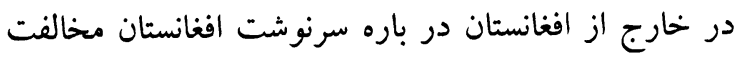

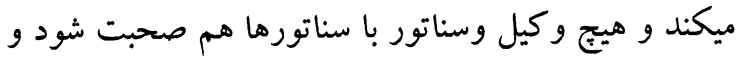

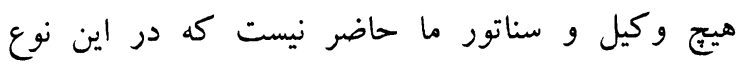
كنفرانس ها شركت كند، جָكر زدن در شانزه ليزه بـاريس،
رئيس مجلس:

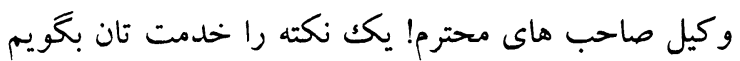

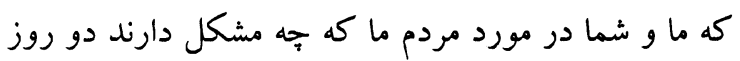

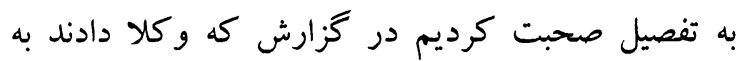

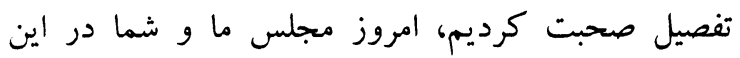
است كه جه بكنيم؟ راه حل را بخويم بحث متمر كز شود

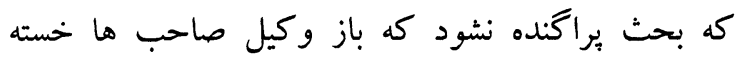
نشوند.

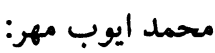

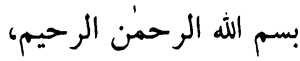
به اجازه رئيس صاحب، هئيت ادارى و و ساير و كلاى الهى

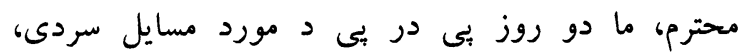

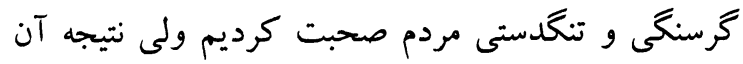

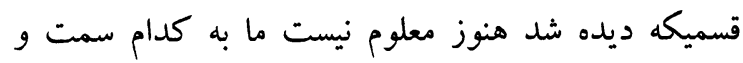

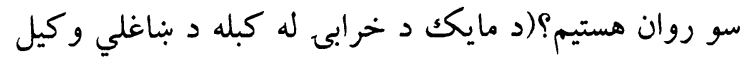

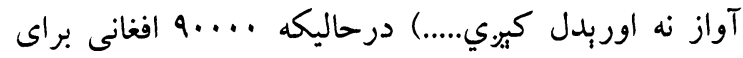

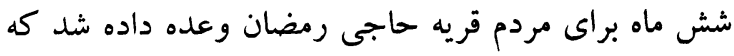

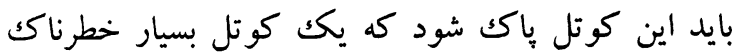

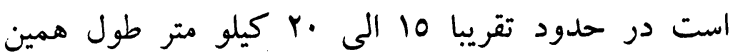

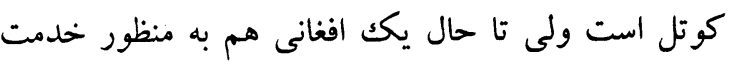

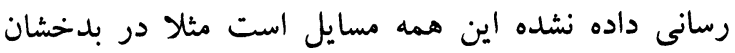

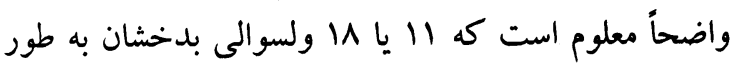

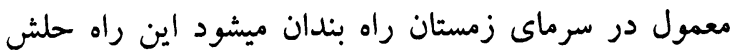

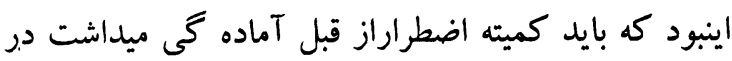
همان ولسوالى ها استوكك يا ذخيره ميداشتند در حاليكه الئه

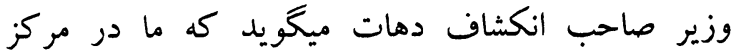

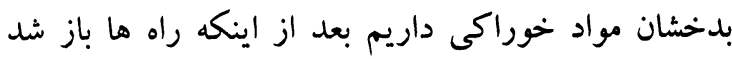

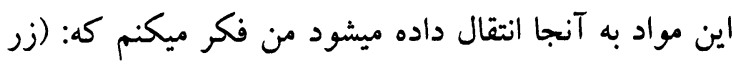

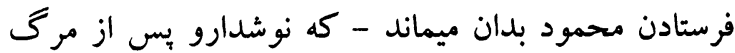

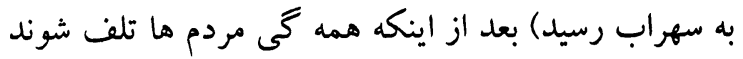

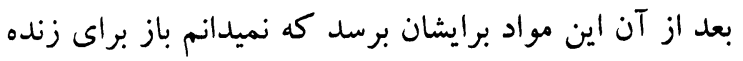

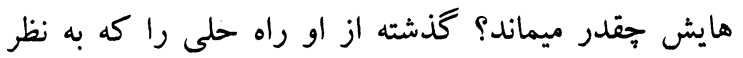

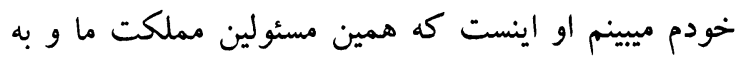
خصوص حكومت ما همه گیى قسميكه دوست هاى ديخر كَتند ناكام به نظر ميرسد اينها كارآيى درست فم فيك وسالم 
افراديكه اطراف اش راكرفته اند نجات ندهيم اين كشور به

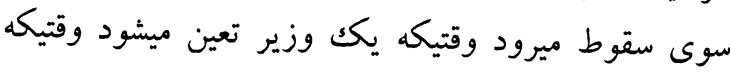

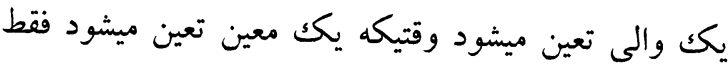

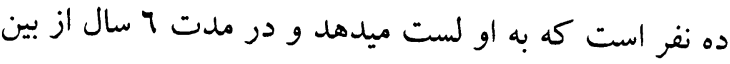

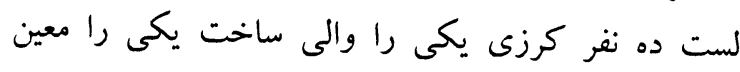

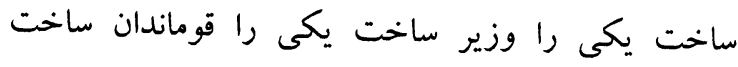

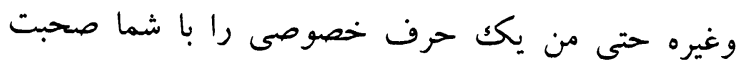

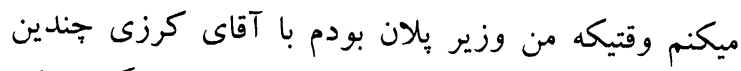

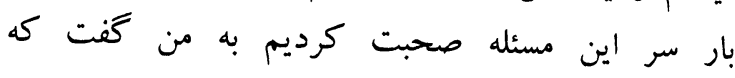

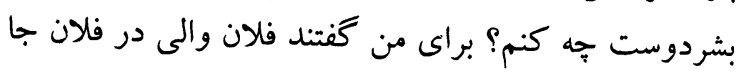

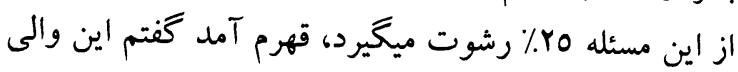

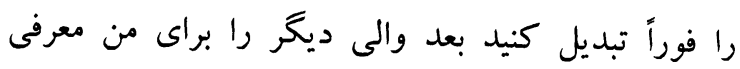

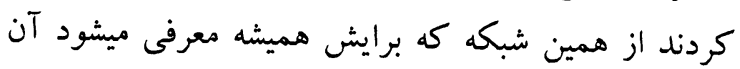

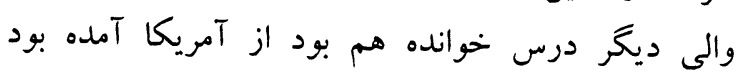

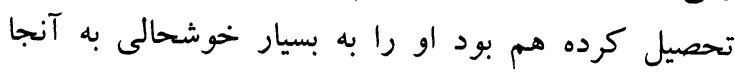

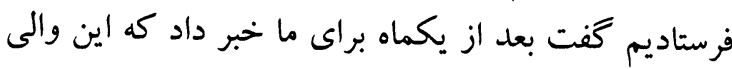

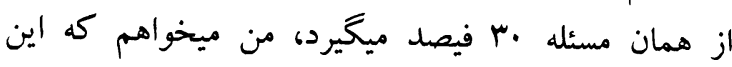

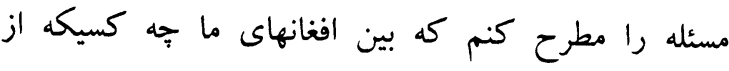

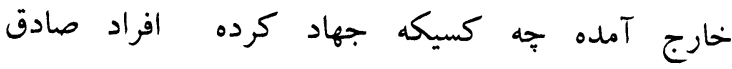

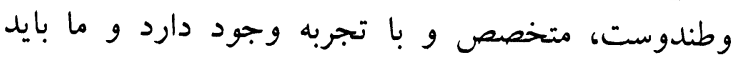

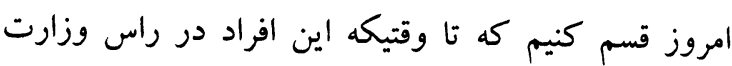

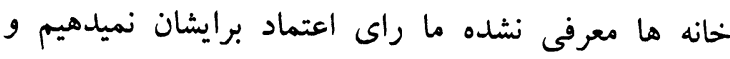

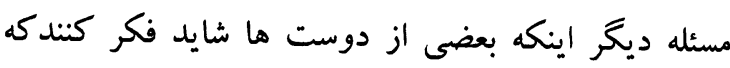

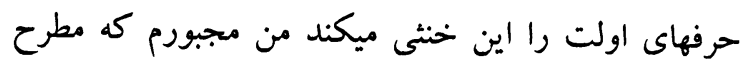

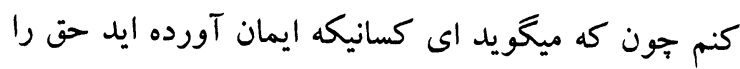

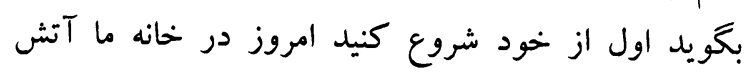

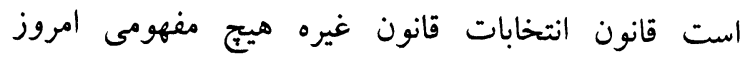

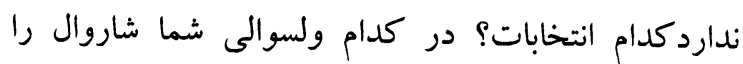

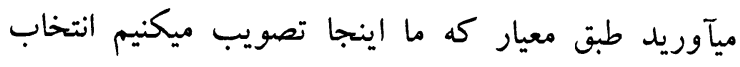

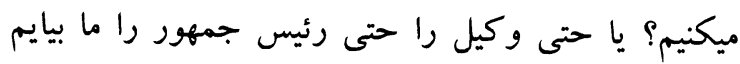

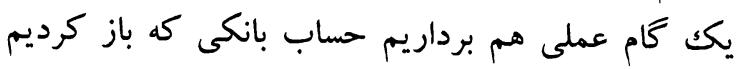

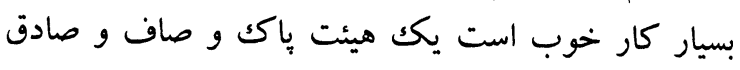

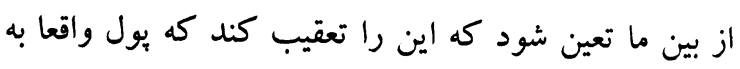

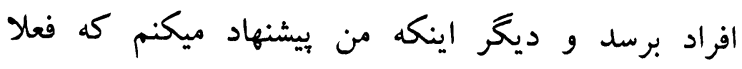
زمستان است هوا سرد است به آب معدنى ماد ما زياد نياز
درتو كيو، برلين و واشنكتن براى اين ملت تا امروز دست

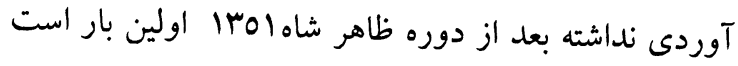

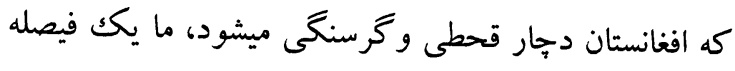

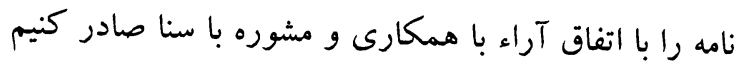

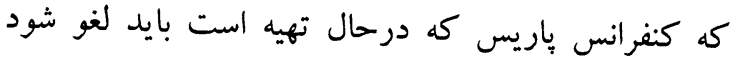

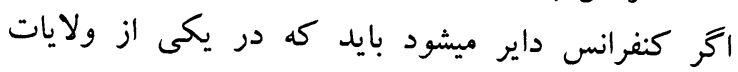

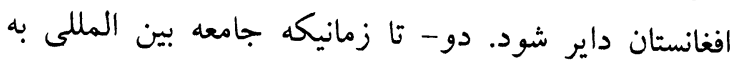

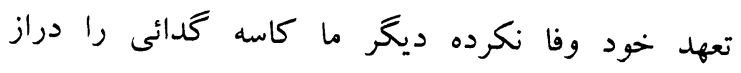

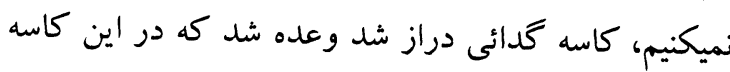

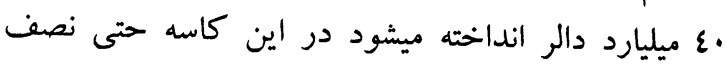

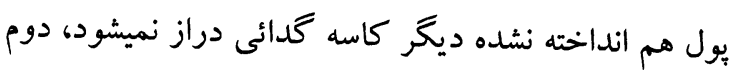

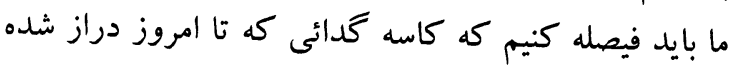

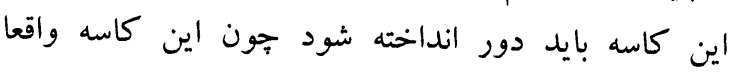

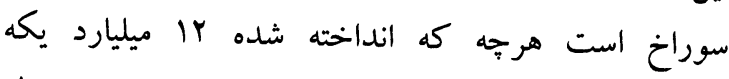

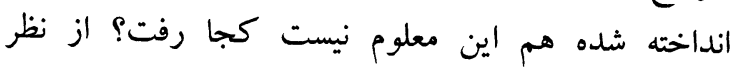

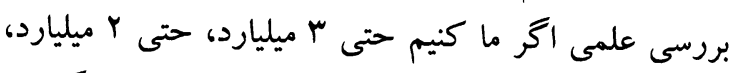

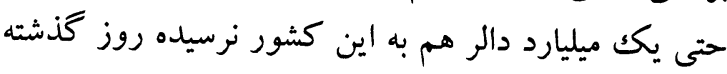

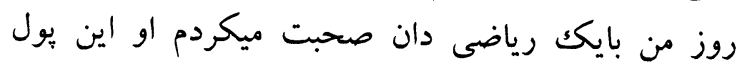

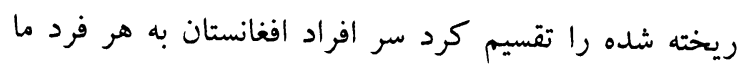

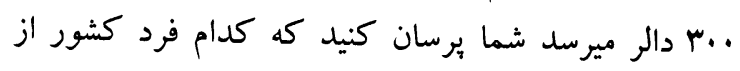

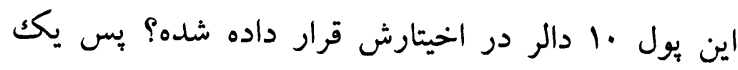

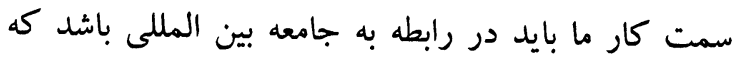

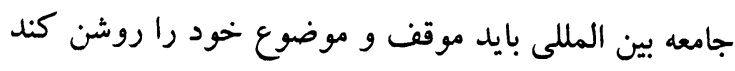

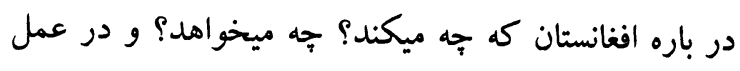
جه كامى برداشته؟ دوم ييشنهاديكه من دارم همانطوريكه

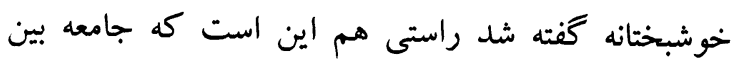
المللى به خصوص امريكاى ها آنها ميكويند، در صحبتى دانى

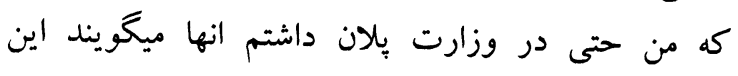

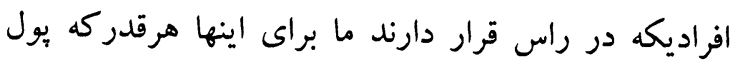

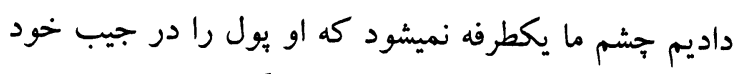

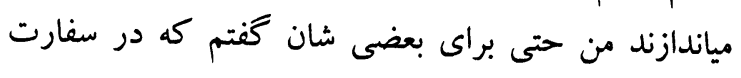

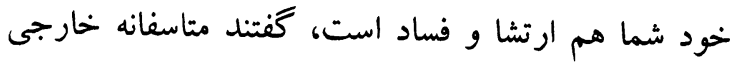

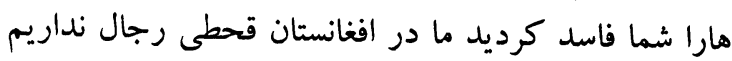

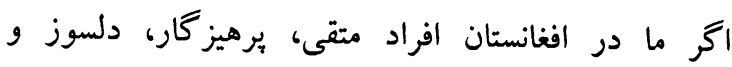

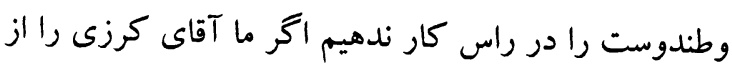


شوق اوري، نن د جايان او آينده د بِاريس مجلس د د افغانستان د كومكونو د اخيستو مجلس دى ولى ولو كه دا بيسبي

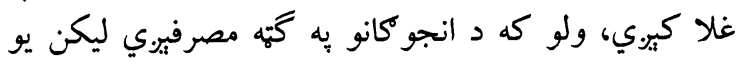

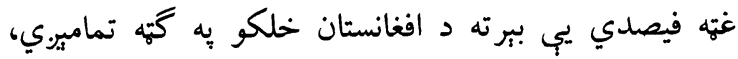

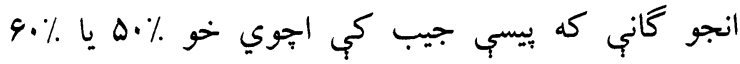

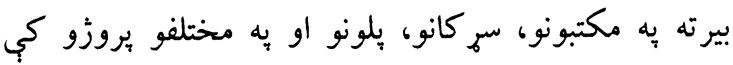

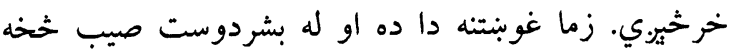

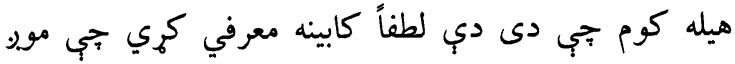

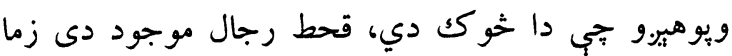

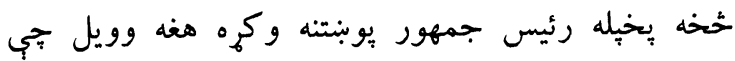

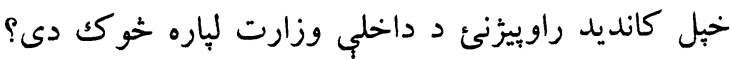

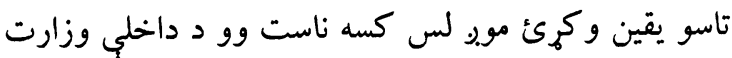

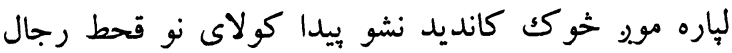

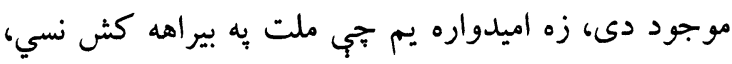

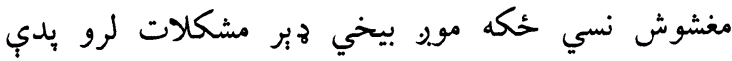

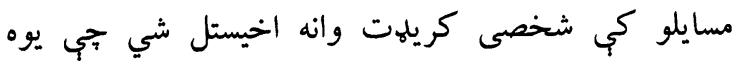

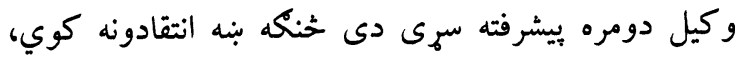

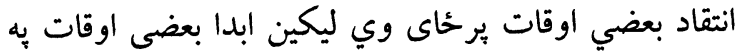

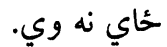

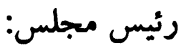
وكيل صاحب هاى محترم! اجنداى ما بحث در مورد نتيجه كيرى از دو روز مكمل استجواب بود ماح كه شما از از كميته

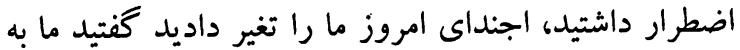
ادامه بحث هاى دو روزه بالاى آن بحث ميكنيم اين

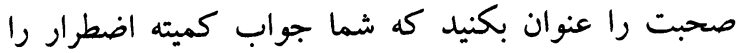
شنيديد از وزير صاحب هارا شنيديد از رئيس صاحب هارا

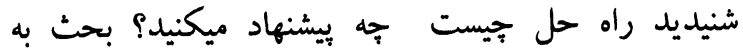

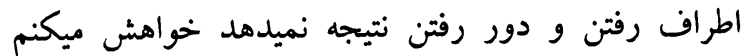

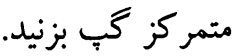
سيد مخبت شاه كاشانى:

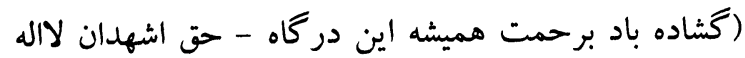

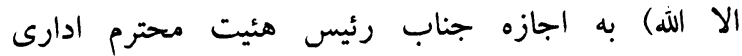

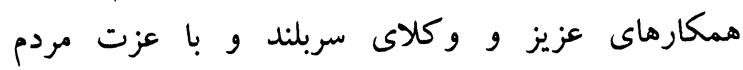

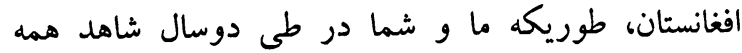
قضايا هستيم مسايلى كه در شورا بيشكش ميشود بيشتر ما
نداريم، ... Pr افغانى آب معدنى ما در ماه ميشود بيايم

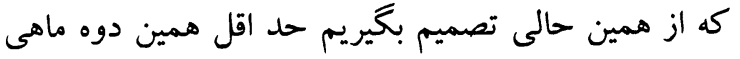

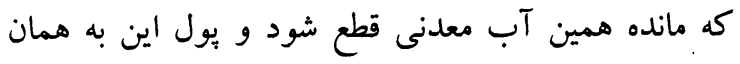

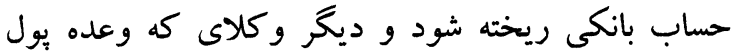

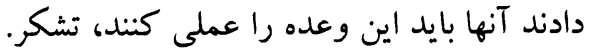
هاكتر اسد الله ممتيار:

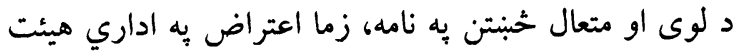

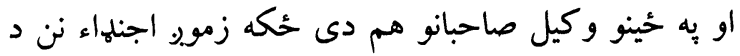
خه شي للاره ده، د بشردوست صاحب نظر تها ته زه ده احترام

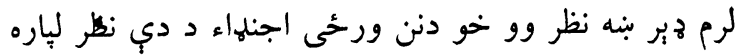

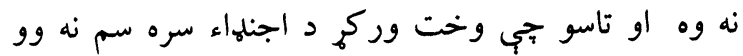
بايد هغه ته مو ويلي واى تي وخت تاسي ضايع كوئ، سُورى ته تاسو وقفه وركوئ ترخو جبي شورى دي د خبلب

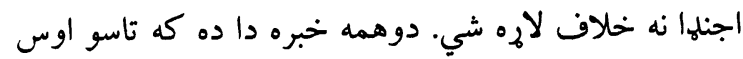

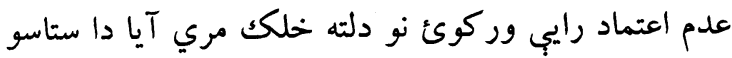

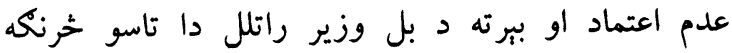

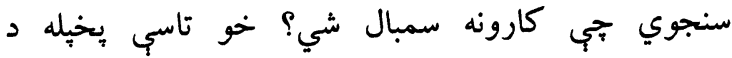

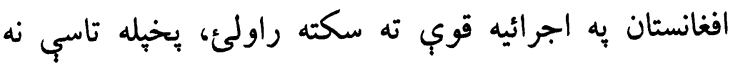

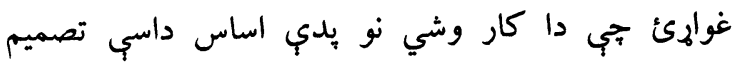

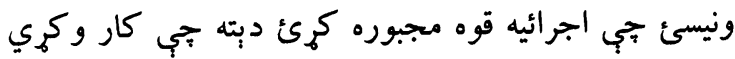

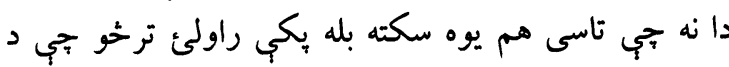

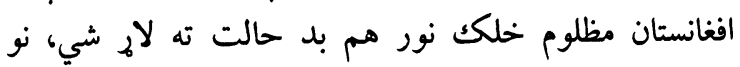

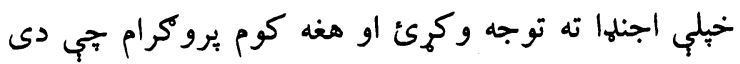

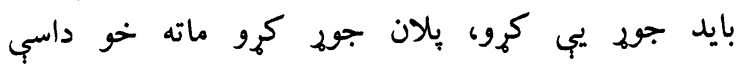

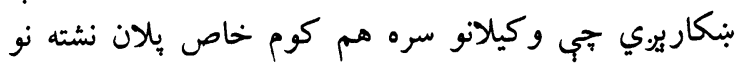

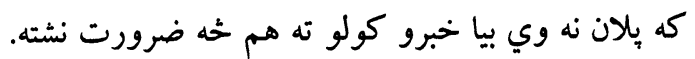
خالد بشتون: زما اعتراض بِه محترم وكيل صيب بشردوست دي دى علاوه

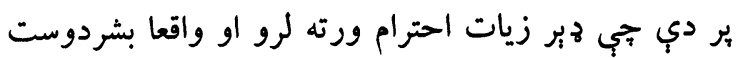
يو ملي سرى دى او موبو هميشه د ده خبري ستايلي ليكن

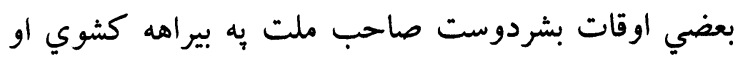

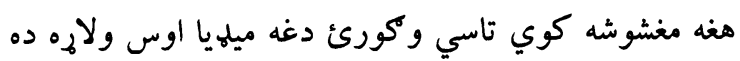

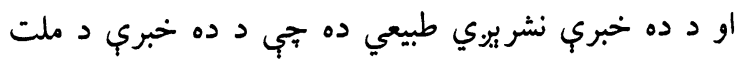

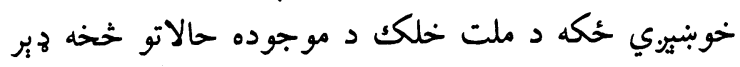

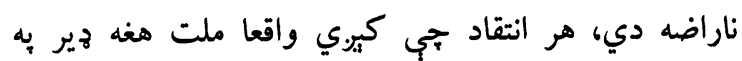




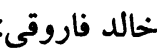

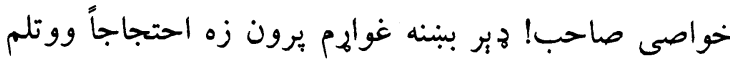

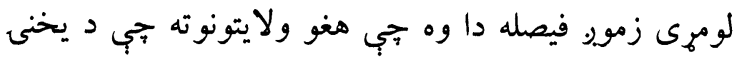

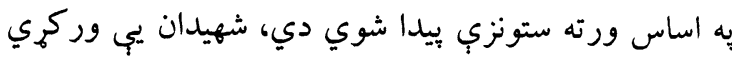

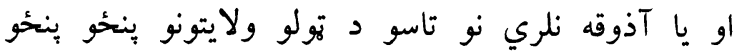

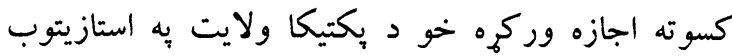

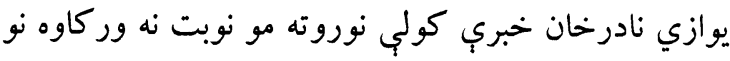

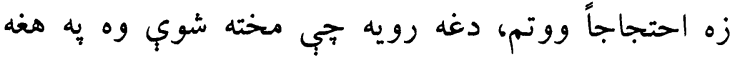

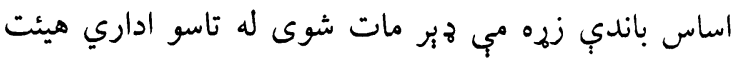

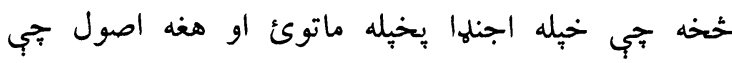
تصويبي بيل هغئ تهاري ته احترام نلرئي، ومن الله التوفيق.

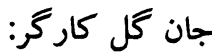

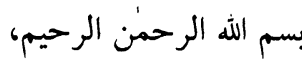
به اجازه رئيس صاحب و وكيل الرحيب هاى محترم، واقعاً در

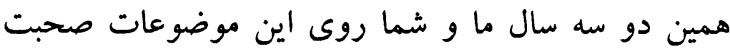

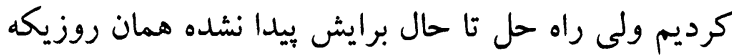

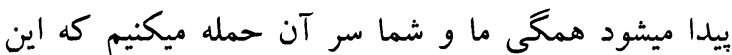

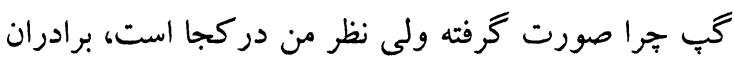

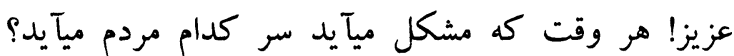
بالاى همان مردمى ميآيد كه بيجاره، غريب، نان ندان ندارند،

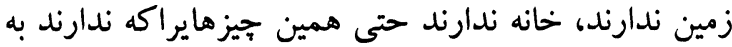

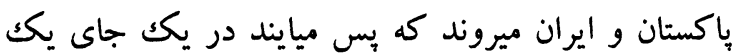

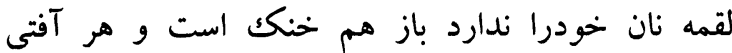

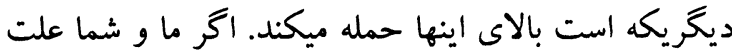

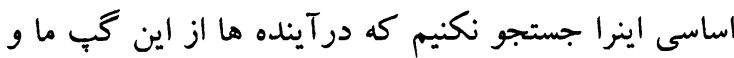

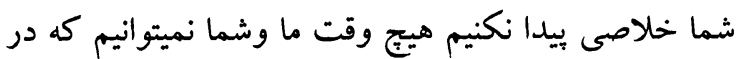

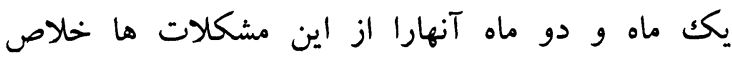

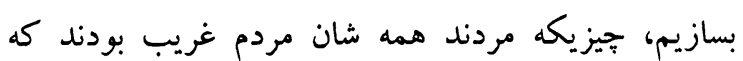

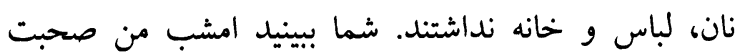
وزير صاحب ماليه را شنيدم كه بودجه امسال ما نسبت به به باله

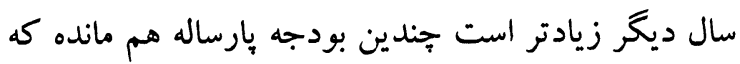

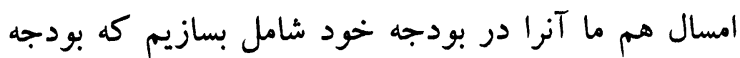

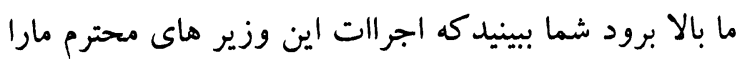

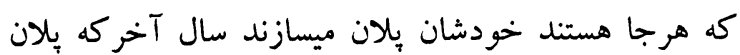
خود را ارائه ميكند كه ما اينقدر تطبيق كرديم اينقدر
روى احساسات سر مسئله يكروز و دو روز خود راوقف

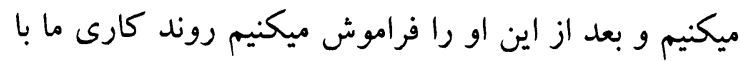

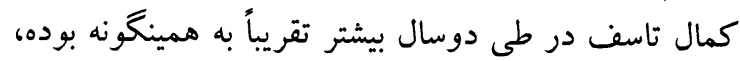

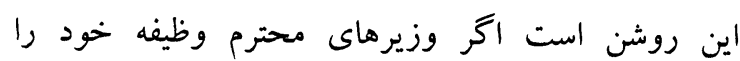

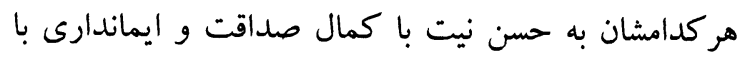

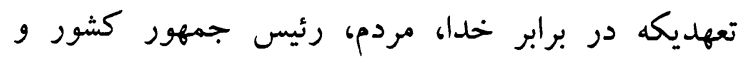

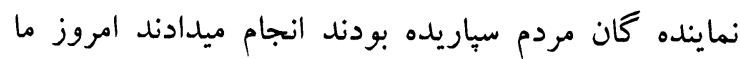

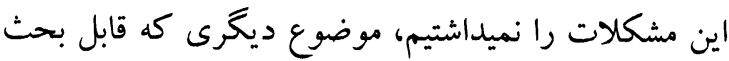

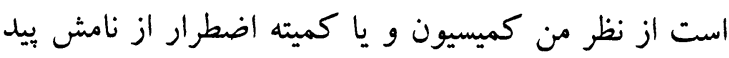

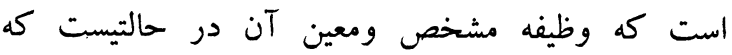

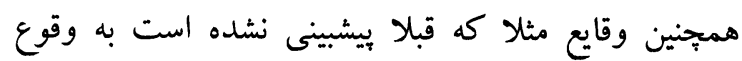
مييوندد، حالت اضطرار اينست كه بايد اين كميسيون عمل كمل كئل

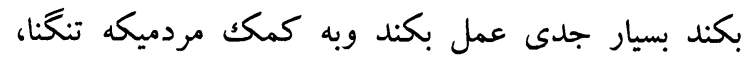

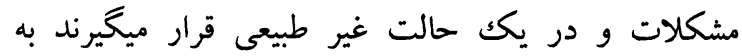

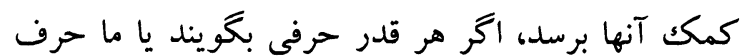

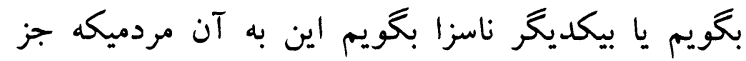

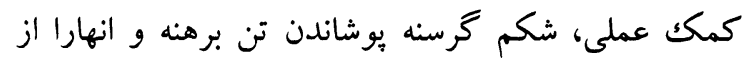

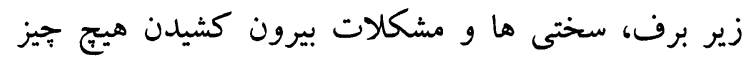

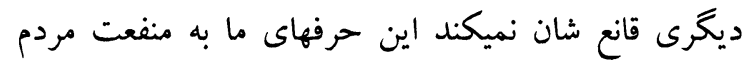

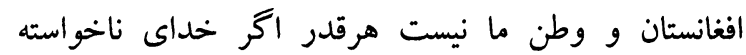

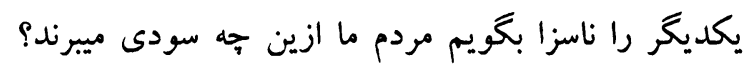

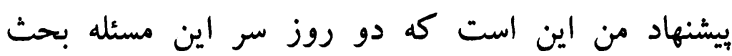

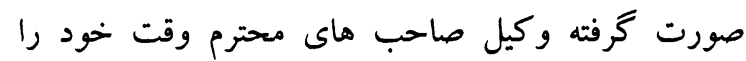

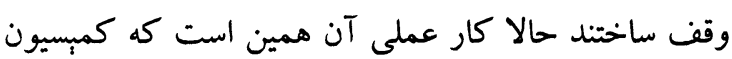

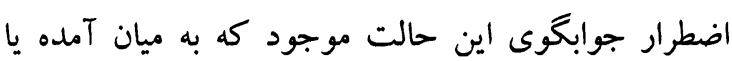

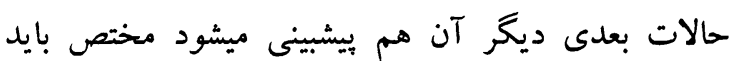

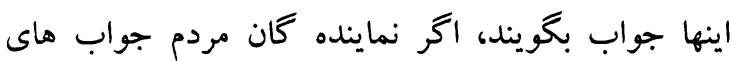

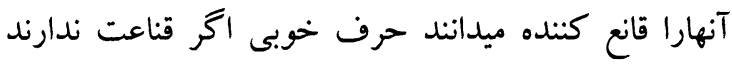

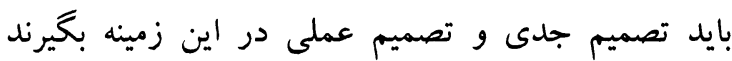

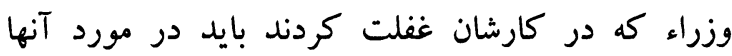

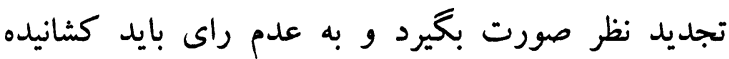

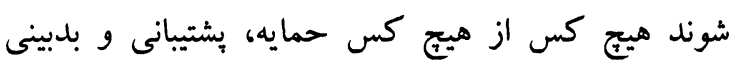

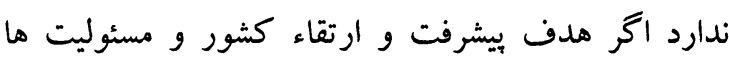

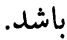


طرف دولت تقدير هم شود. جناب رئيس صاحب يكك

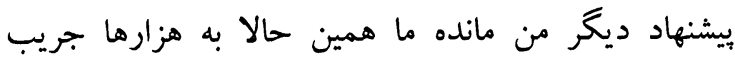

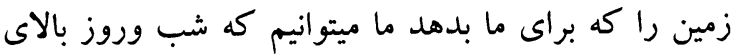

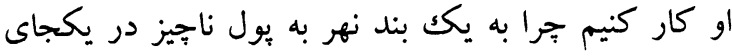

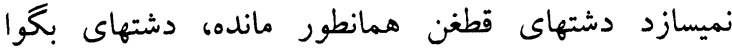

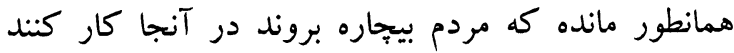

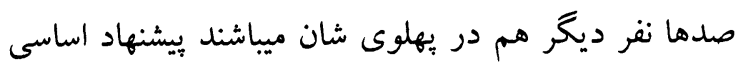

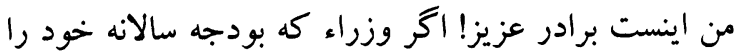
به همان حسن نيت خود به رقم خدمت مردم انجام داده انها را بايد است كه تقدير بكنيم، هر وزيريكه نتوانسته اين بودجه سالانه خود را كه جهار سال، ينج سال همينطور

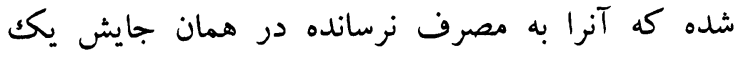
مصرف است كه براى هر كس بخشش داده باشد كسانيكه

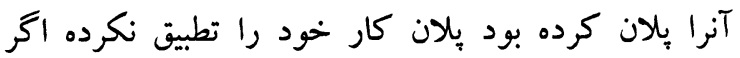

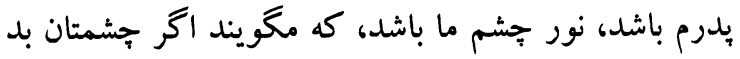

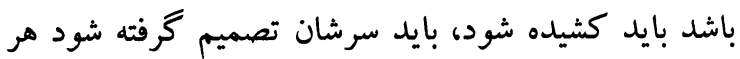

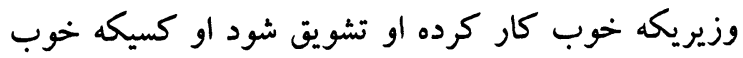
كار نكرده او بايد است كه از كابينه كشيده شود هم همين يبشنهاد من بود، تشكر.

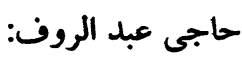

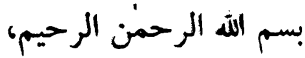

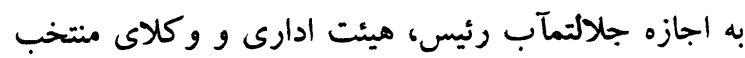

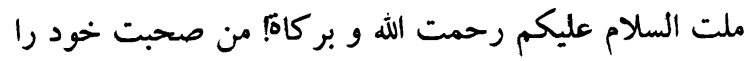

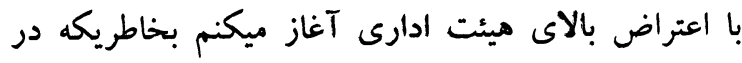

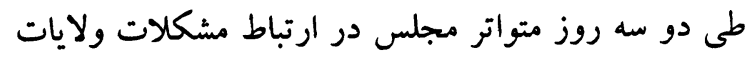
افغانستان و در مجموع ملت مظلوم افغانستان در اين خحانه

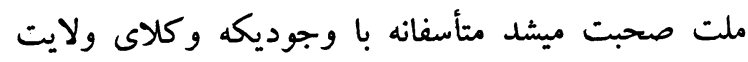

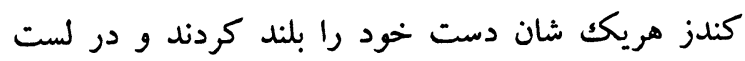

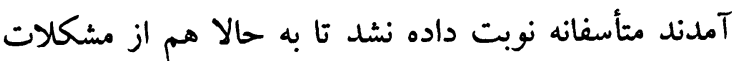

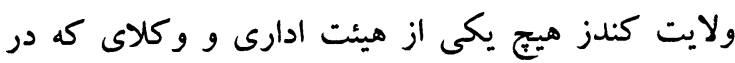

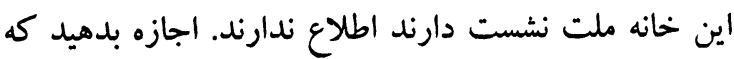

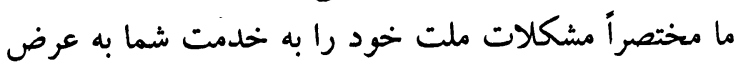
برسانم و در يايان صاحب يشنهاد هم دارم، قبل از اينكه

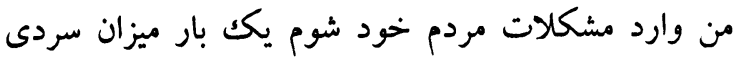

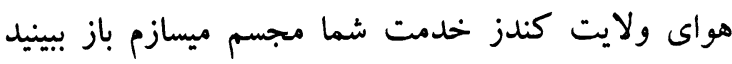

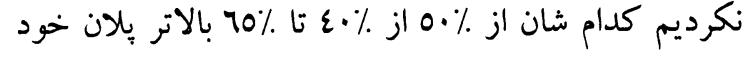

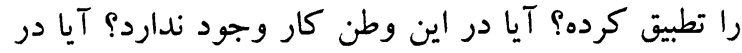

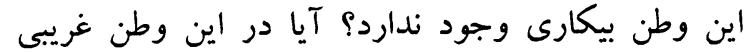
وجود ندارد؟ آيا در اين وطن مردم ونود زمين كار ندارد؟

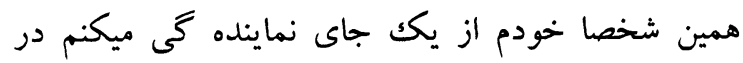

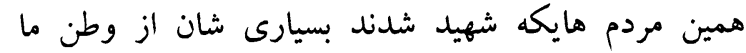

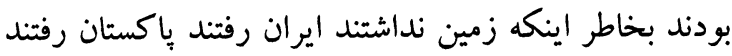

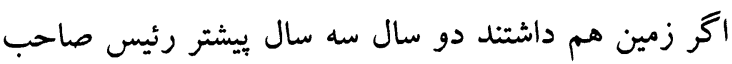
براى شما هم يكك درخواست داده بوديم براى همين كميته دو دئه

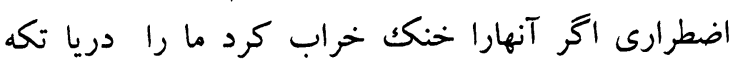

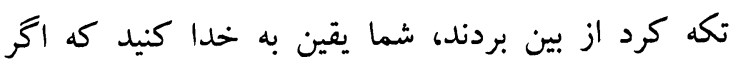

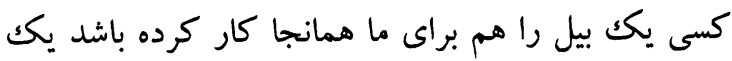
عالم يول داشتند از يك سال به سال ديخر اينها انداختند اكر دولت دلسوزى عام وتام خودرا به اين مردم بيجاره

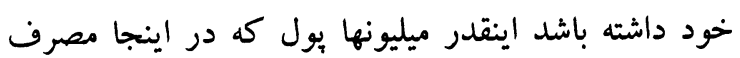
شد جرا اين زمين هاى بكروبايريكه در دشتها و بيابان

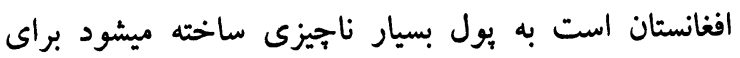

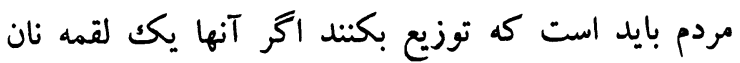

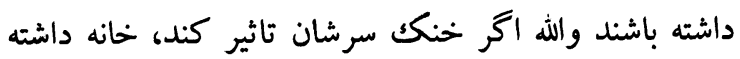
باشند خنك سرشان تائير نميكند، زمين داشته باشد همانجا

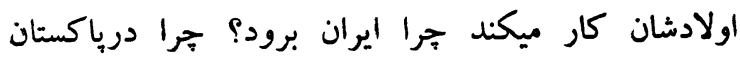
برود؟ جقدر سرحد شما ميبيد هزاران هزار من من نميفهمهم

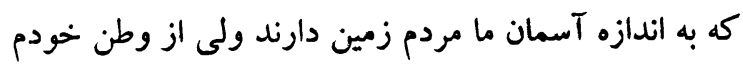
كه ميبينم \% 0.0

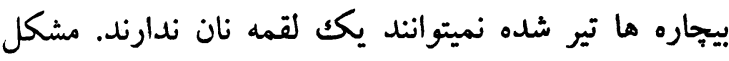

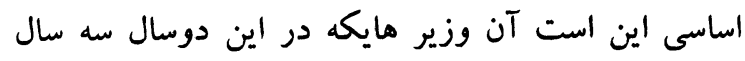

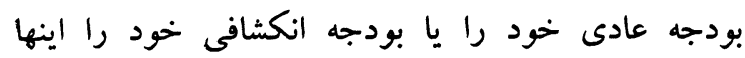

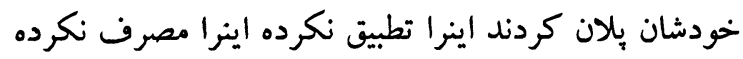

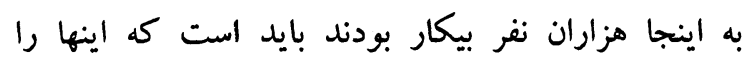

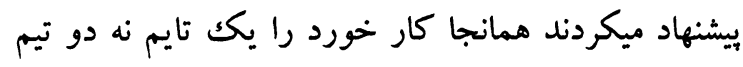
وسه تيم به انجام ميرساندند كه براى مردم كار بيدا ميشد،

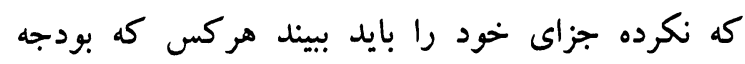

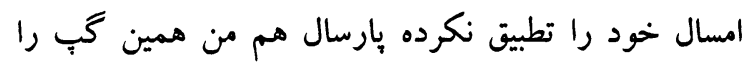

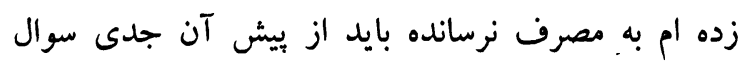

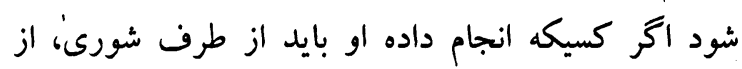


ميكويم من يكك بار براى شما مجسم بسازم كه مشكلات

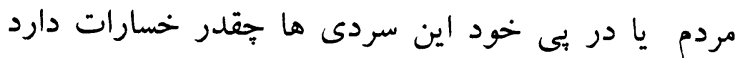
بعد از آن ما به بيشنهاد خود كَفته ميتوانيم. رئيس مجلس:

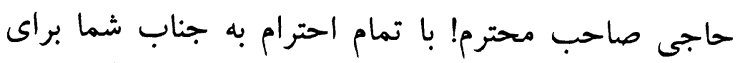

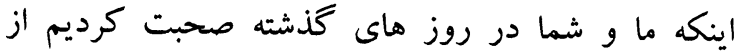

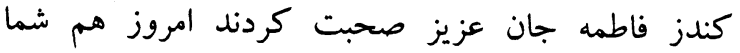

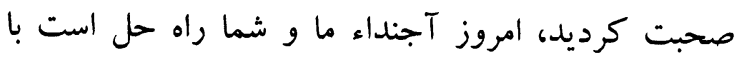

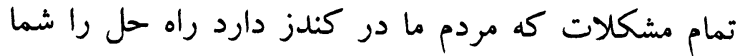
جه بيشنهاد ميكنيد؟

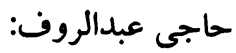

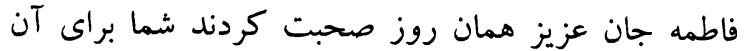

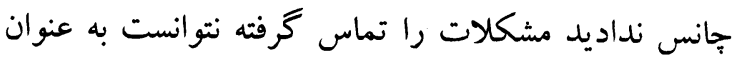

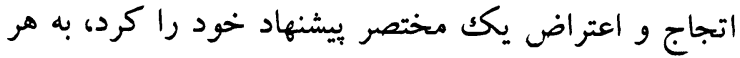
حال بيشنهاد ما مشكل تمام افغانستان يكسان است بيشنئهاد من مشخصاً همين است كه حالت اضطرار ميكوئيم ما در يش يش روى قانون اساسى داريم در قانون اساسى در ماده

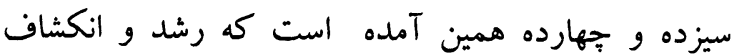
مردم مالدار و زراعت ييشه در اينجا مكلفيت هاى به به عهده

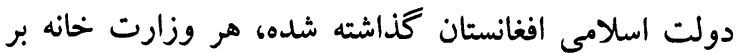

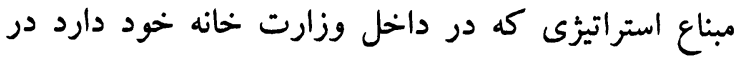

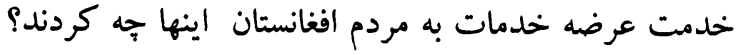

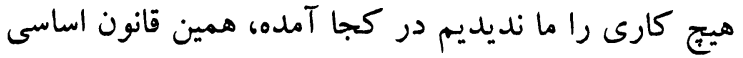

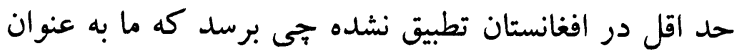

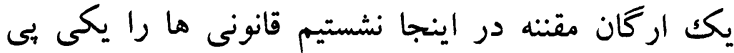

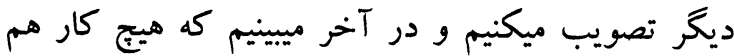

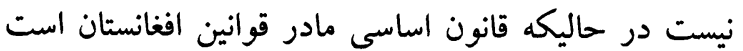
به اين اساس بيشنهاد ما همين است كه ما دا در صورتيكه

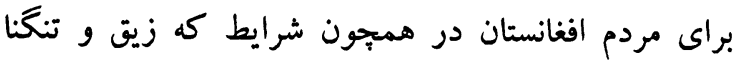

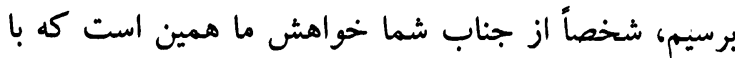
جناب رئيس صاحب دولت اسلامى افغانستان و ممجنان إنان قاضى القضات و همراه جامع جهانى يكجا نشسته با توجه

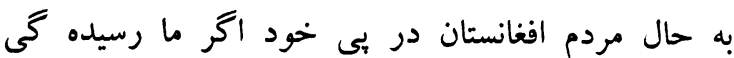

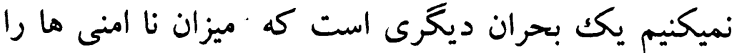
بالا ميبرد بخاطر همين صاحب يكك جلسه اضطرارى شما
كه در بايان بيامت اين سردى ها در سطح كندز حهـ بوده،

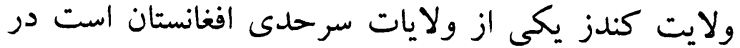

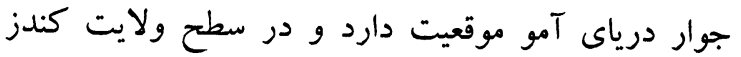

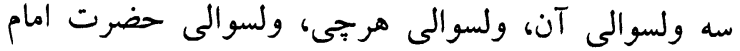

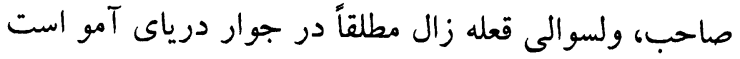

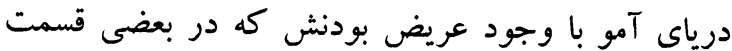

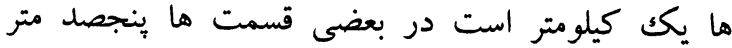

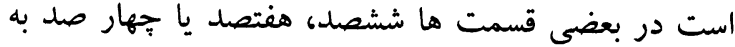

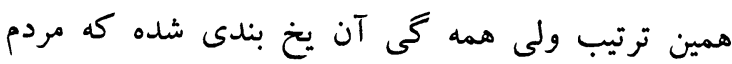

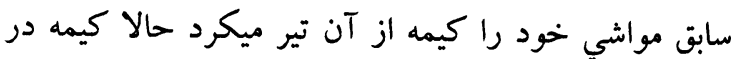

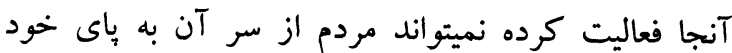

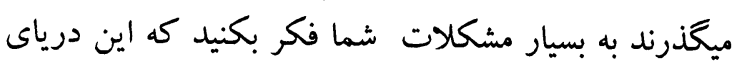

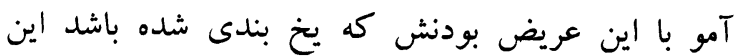

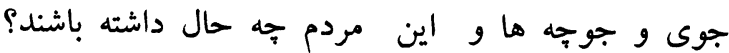

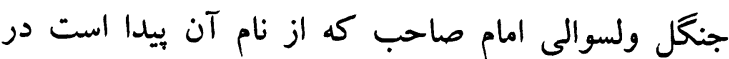

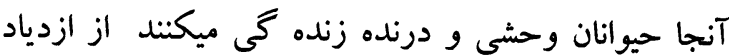

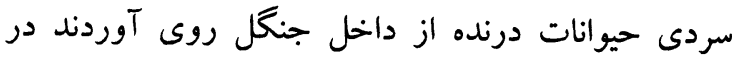

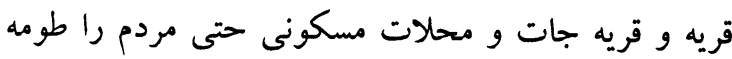

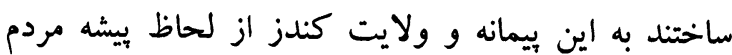

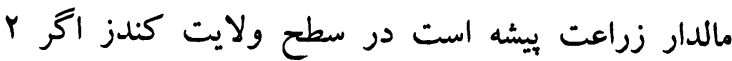

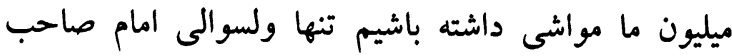

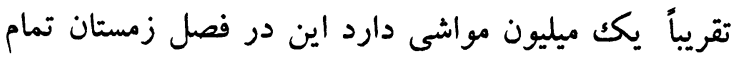

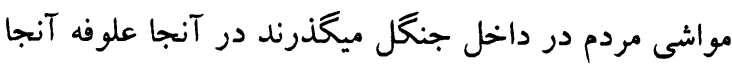

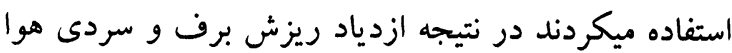

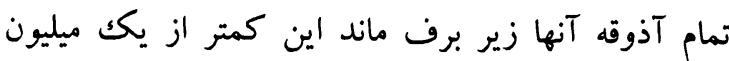

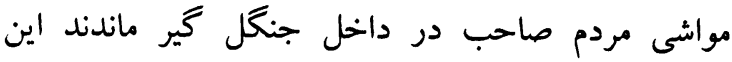

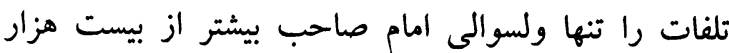

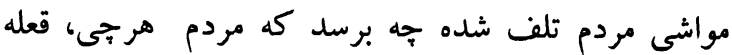

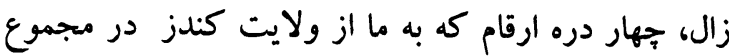

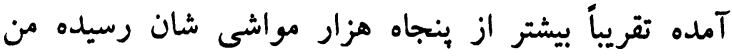

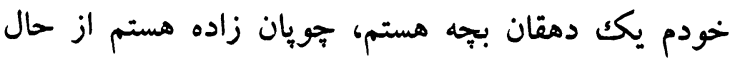
مالدار خود خبر دارم اين مالى كه زنده ماندان مانده جناب رئن رئيس

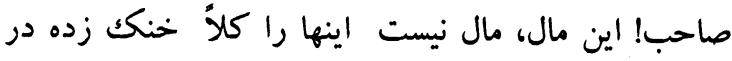

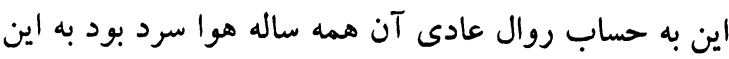

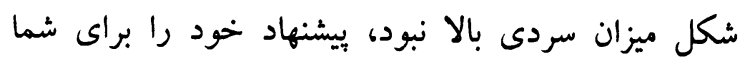


رسانيده شود و در قسمت وزراء كه كارآمد ندارند شورى

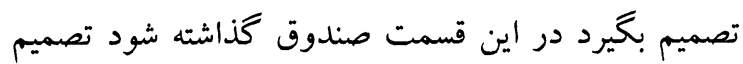
بكيرد هر كه توانائى كارى ندارد اينها بايد رد صدين صلاحيت شوند در خانه هاى شان روان شوند، وقتيكه وزيرى مثلاً ما ما مانيات

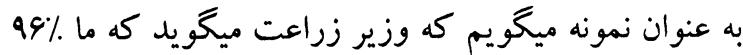

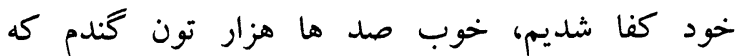

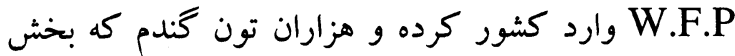

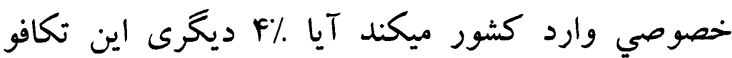

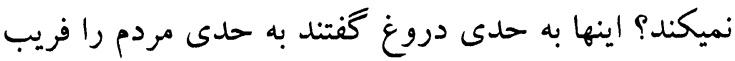

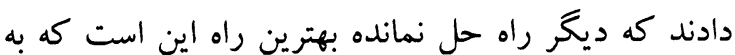

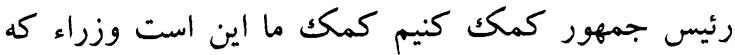

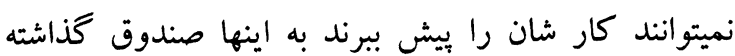

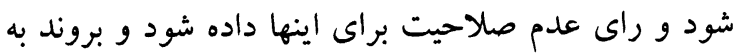

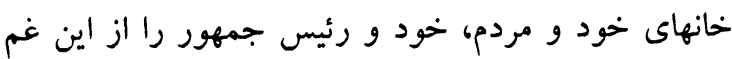

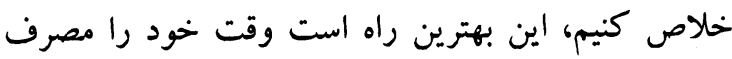
نكنيم همين شيوه بهترين شيوه است، والسلام عليكم. فضل اعظيم زلمى مجددى:

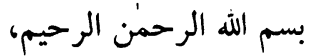

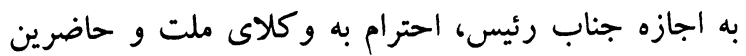

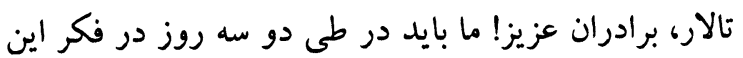
ميشديم كه جه قسم بتوانيم به مشكل هموطنان ما به كسان

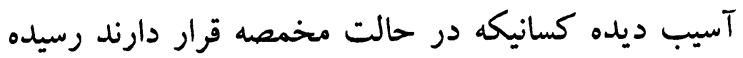
گى كنيم مشكل شان را حل بسازيم و يكك استراتئى

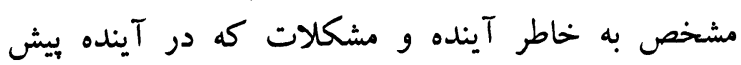

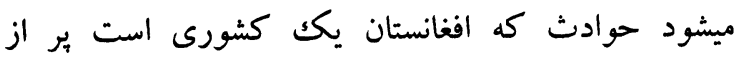

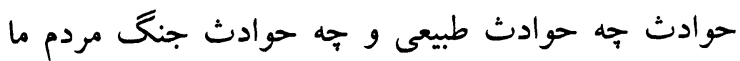
را متضرر ساخته در طول سى سال و هميشه اين تكرار

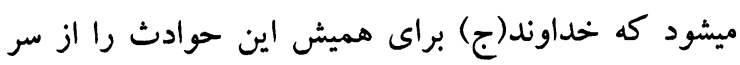

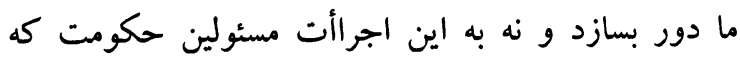
آمدند كزارش دادند، همه ما متاثر هستيم كه واقعاً اينها

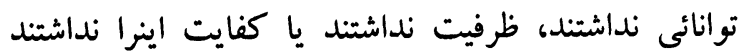

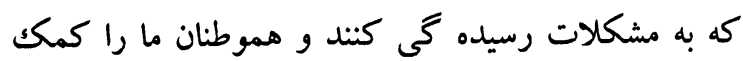

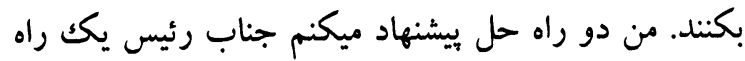

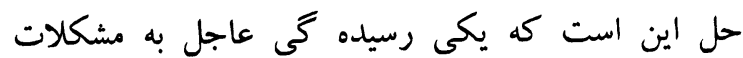

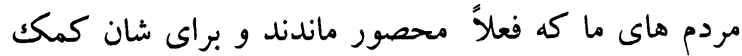

با جناب رئيس صاحب دولت بخيريد همراى جامع جهانى

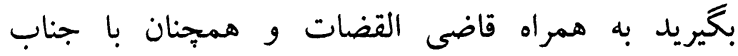
مجددى يكجا برويد عاجل يكك كمكك فوق العاده براى مردم صورت بخيرد. انحنير محمد عالم قرار: بناغلى رئيس صيب! تاسو يرون تشريف نه درلود خير بيا

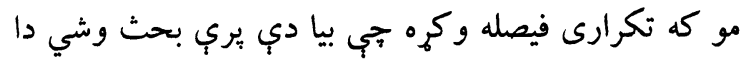

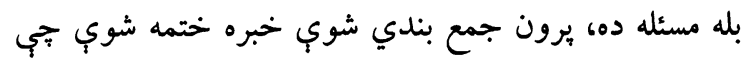
يو يو د استازى د ولاياتو خخه يوخاى د د اقتصاد له له له

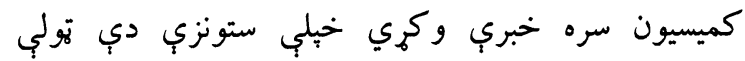

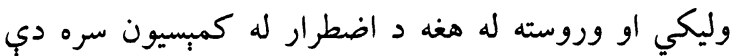

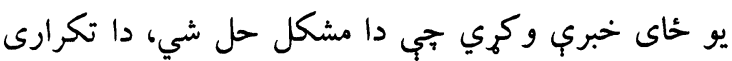

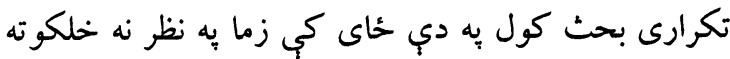

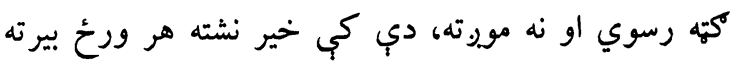

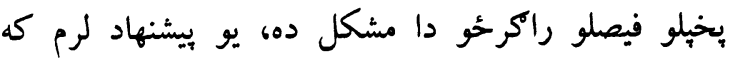

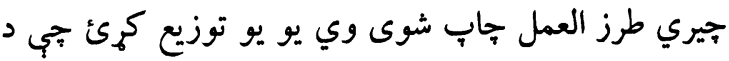

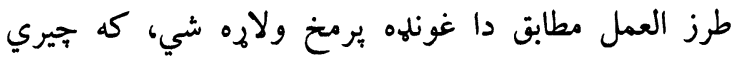

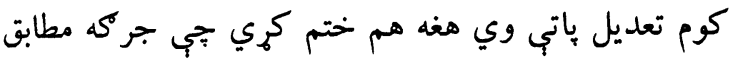

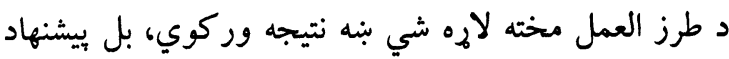

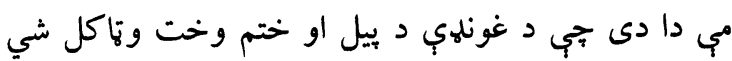

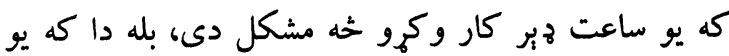

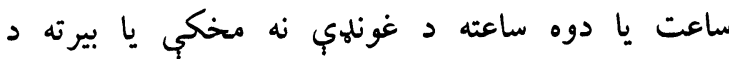

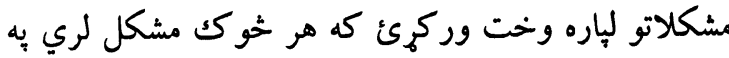

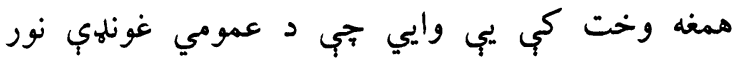
جريان خراب نكري. قربان كوهستانى:

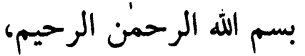

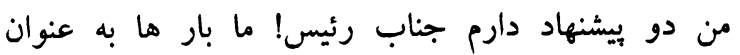

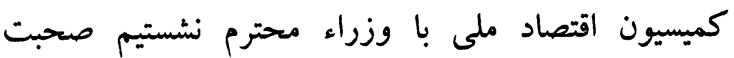

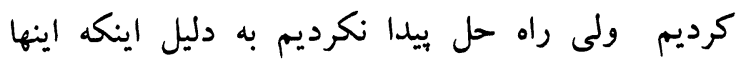

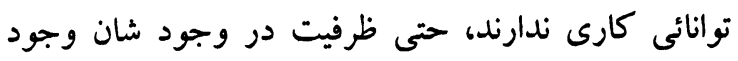
ندارد، وزارت خانه هاى شان فقط بران براى مارى معاش نشستند اينها كار ميكنند بهترين راه حل همين است يكى همين صندوق

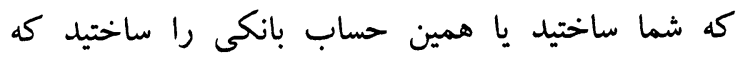
كمك جمع شود توسط خود ولسى جر گه براى مردم 
بخاطر رسانيدن كمكك به همين مردم و هر راه كه

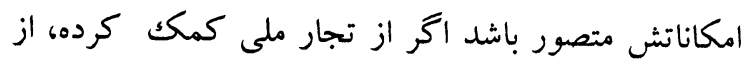
نماينده كان ملت شما با وجوديكه صدا كرديد تا حال هيج كس حاضر نشده اكر حاضر هم شدند اعلان نكان نكردند

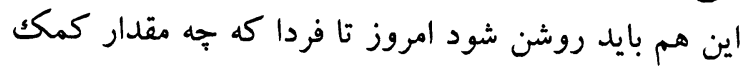

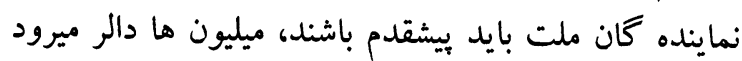

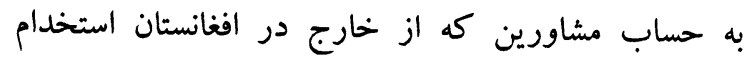

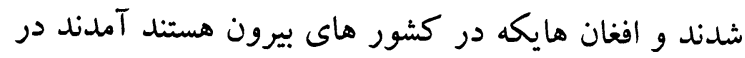

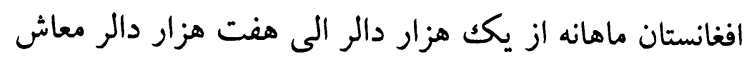

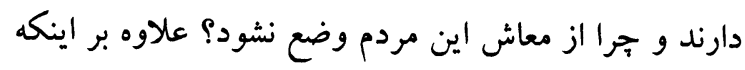
ما كمكك ميكنيم و تجار ملى كمكك ميكند از اين مردم

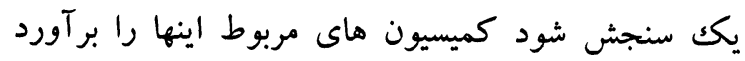

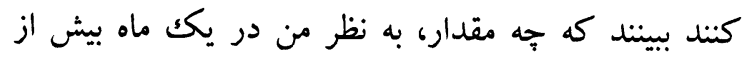

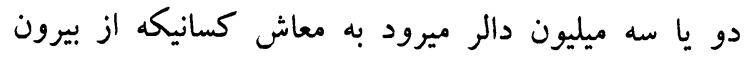

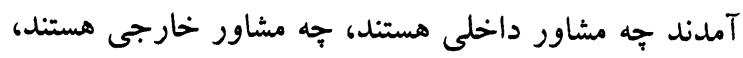

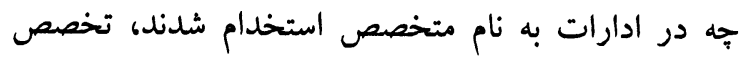

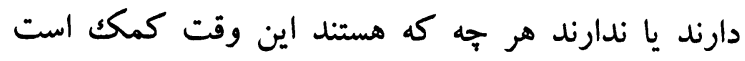

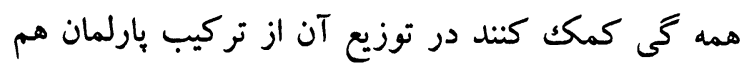

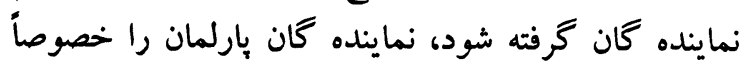

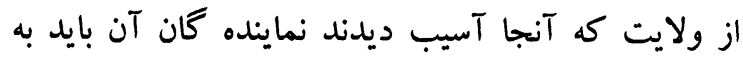
توزيع شريك شوند و در شكل توزيع هم اينها بايد نظارت

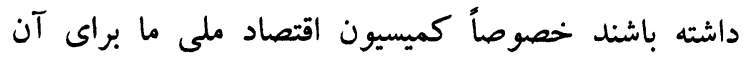

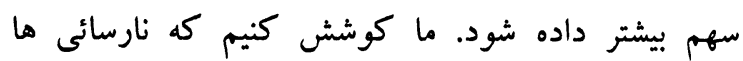
حكومت را اصلاح بسازيم اينطور اكر حكومت ضعن اده

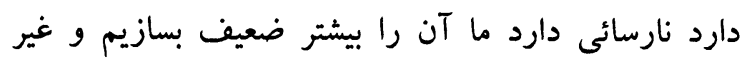

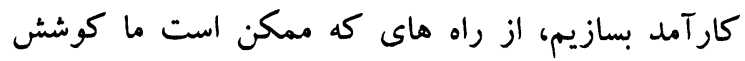

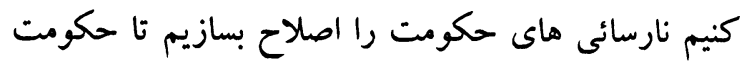

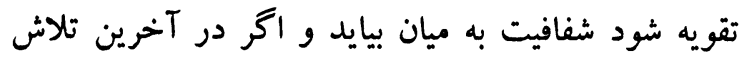
هاى مان بخاطر بهبود وضعيت به خرج دهيم، تشكر. قارى رحمت الله:

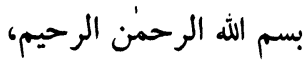
جناب رئيس! خوب شد كه ولايت كندز هم نوبت بيدا كرد و مشكل را كه ديخر ولايات داشت آنها كُنتند، بيشنهاد من همين است كه بارلمان قوه مجرئيه نيست بلكه ولك

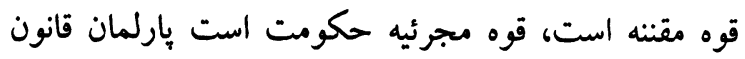

نرسيده جان خود شان و دارائى شان در خطر است، دارائى شان منظور من از اين است كه يكك تعداد ولايات است

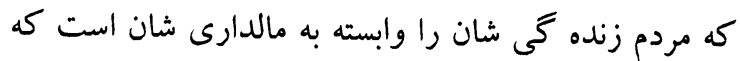

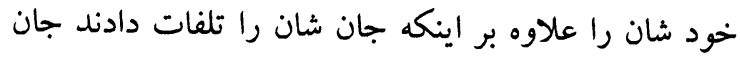
شان هم در معرض خطر قرار دارد و آن مناطق كه راه

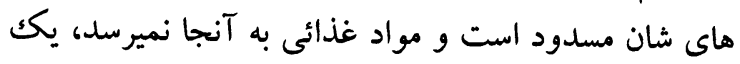

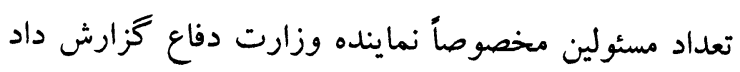

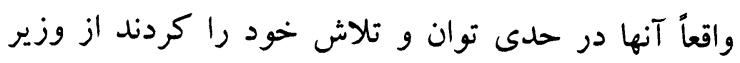

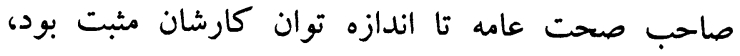

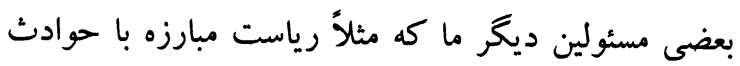

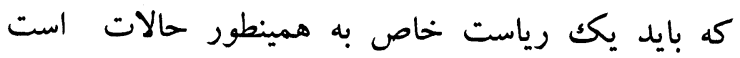
رياست است كه آن واحد بودجوى نيست از طرف ديخ بهاه

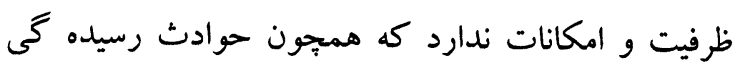

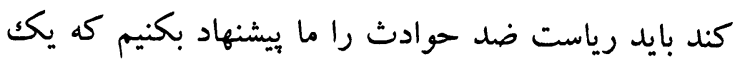

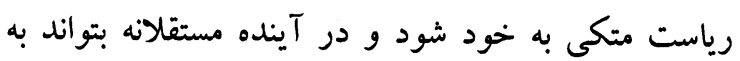

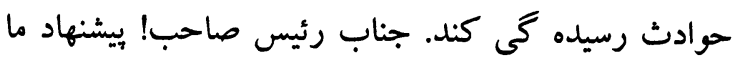
اين است كه از ولايات كه آسيب ديده وكيداب وكلا و و نماينده

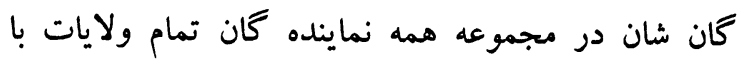
تركيب هيئت ادارى و جناب رئيس صاحب جمهور دئه ديده

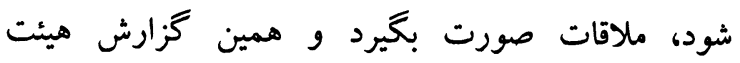

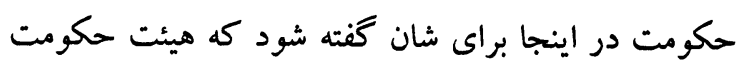

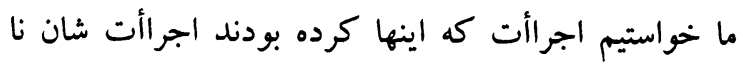
موفق بود و يا اينكه اينها ظرفيت نداشتند يا استعداد انهاد نداشتند يا امكانات، به جناب رئيس صاحب جمهور كفته

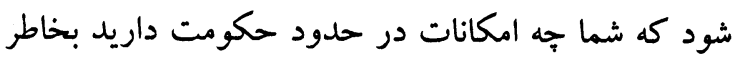

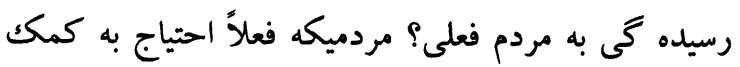

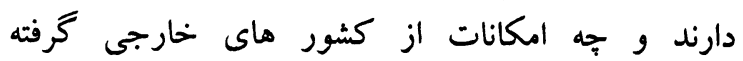
ميتوانيد؟ تا حال كدام كشور با ما وعده كرده؟ به به جناب

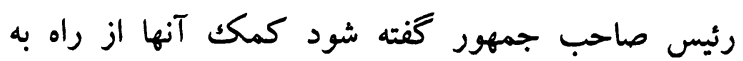
اصطلاح واقع بينانه اينطور نه كه مايكت ييش ماحث ما آمد مثل دوست ما آقاى بشر دوست بسيار دوست صميمى ما است

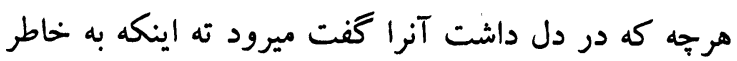

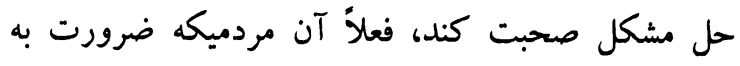

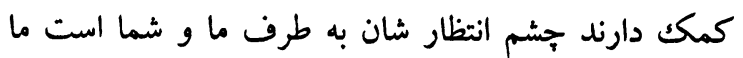

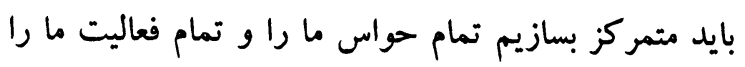


ماده بِانزدهم هردو آن تصريح ميكند كه اينها بروگرام

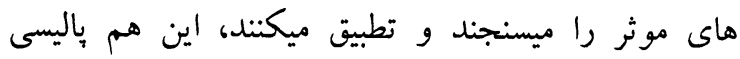

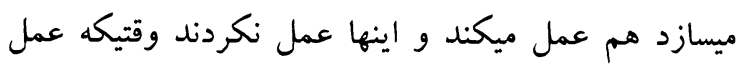

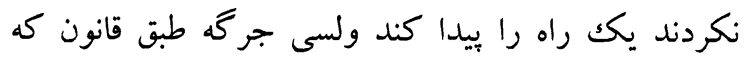
آن وزير صاحب هايكه ميخواهند كه كار اجراأت كنند

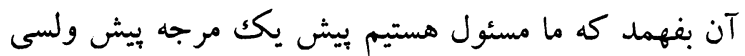

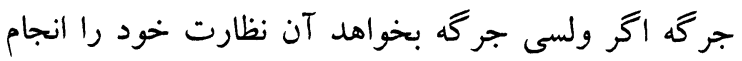
بدهد ما كوتاه ميائيم بايد ما انجام بدهيم، حالا فعلاً آنها

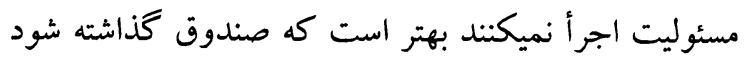

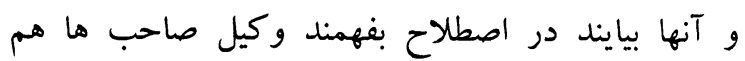

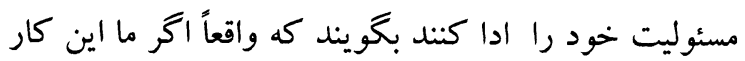

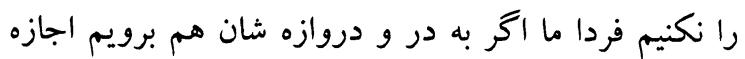

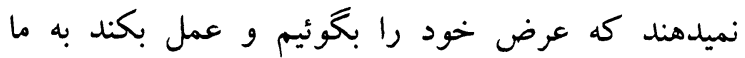
ميگويند كه ما ياليسى ساز هستيم ما عمل نميكنيم و آنها

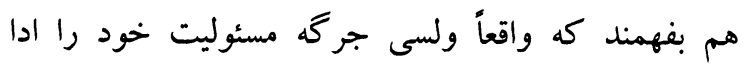

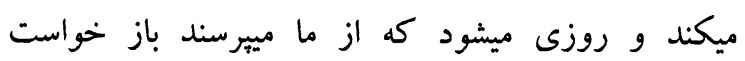

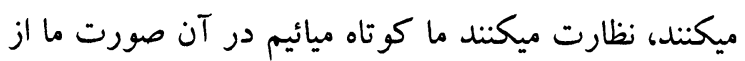
يست خود برطرف ميشويم اينها انتظار اين سخن رئن را داشته دئه

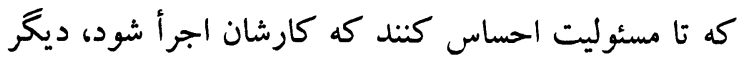
سخن اينكه عاجل اجراأت كنند. فاطمه نظرى:

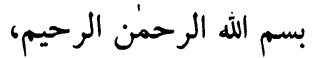
به اجازه حضار محترم و هيئت ادارى، نظريات كه من يكك الرحن جند مورد را يادداشت كرده بودم تقريباً دوستان همه اينها

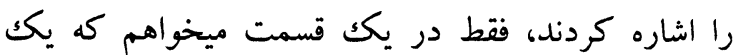

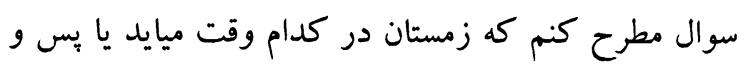

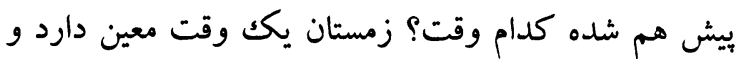
يكك مشكلات هاى مشخص دارد متأسفانه وزارت هاى

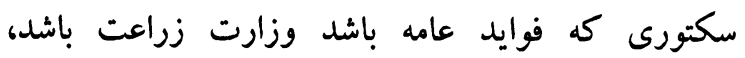
وزارت هاى كه خواسته شده بود يا بخش اضطرار بايد

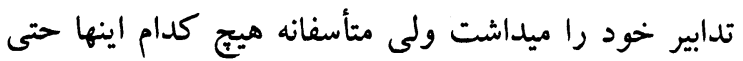
شما در جريان بوديد كه قاضى زاده صاحب ديروز كفتند كه حتى يكك لودر هم نداشت، حتى يكك تعداد مشكلات

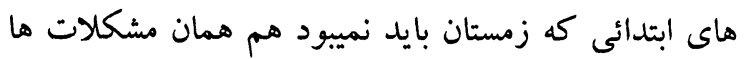

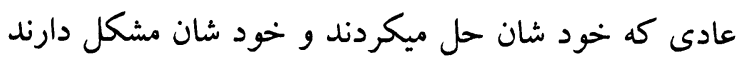

تصويب ميكند و نظارت ميكند، بارلمان وظايف خود را درك كند و بفهمد كه واقعاً وظايف پارلمان جه است؟ از يكك طرف مسئول است و از طرف ديكر هم مسئول نيست، مسئوليت آن همين است كه بايد آن وظايف كه در

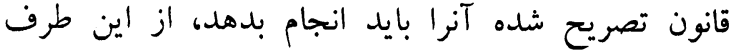
مسئول به اين نيستند كه وكلا كمى دل سرد هستند به نسبت اينكه قانون تصويب ميكنند تا جاى نظارت هـ هم

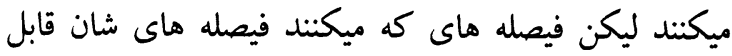
تحميل نيست عملى نميشود و نظر من در رابطه به اين است كه وزير صاحبان كه در حكومت حضور دارند اكثر نمثرد

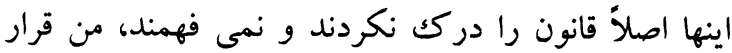
كه برداشت كردم از صحبت هاى وزير صاحب هاح ها سخن

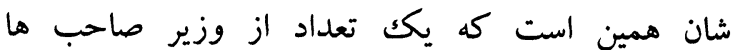
خصوصاً وزير صاحب زراعت در سخنرانى شان گتفتند كه من مثل سابق وزارت سابقه زراعت نيستيم كه ما آنقدر

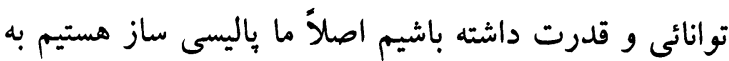

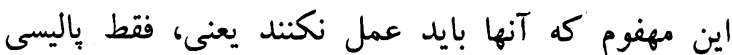
بسازند مثل ولسى جر گه و در اصطلاح مطرح كنند و مردم عمل كنند، مردم كار خود را ميفهمند، مردم كه دارائى ورأى

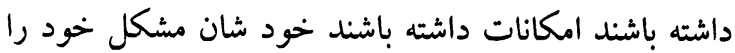
حل ميكنند مكر گَب اين است كه اصلاً قوه مجرئيه اكثر

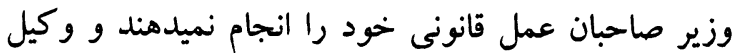

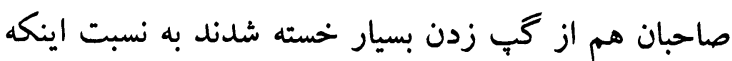

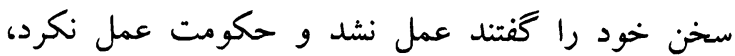
خصوصاً وزير صاحب خارجه ما سخن را دور نميبريم

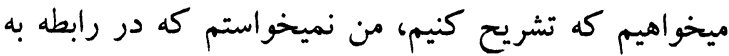

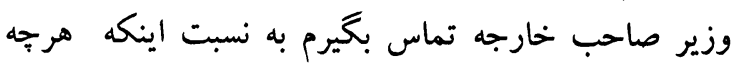

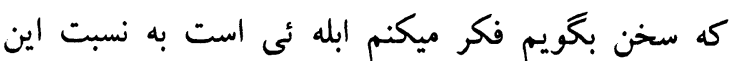

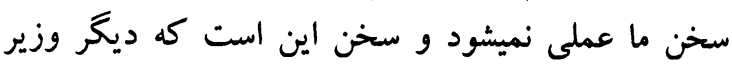

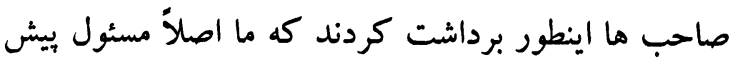

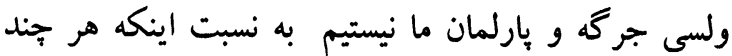

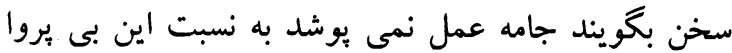

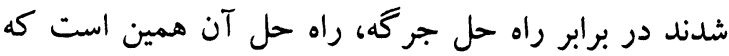

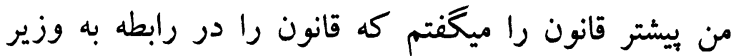

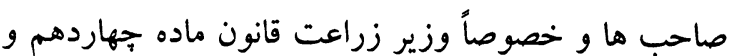


موب. او تاسو بخيلو كورونو كي يو اندازه تهيه خو ورته

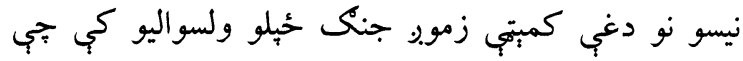

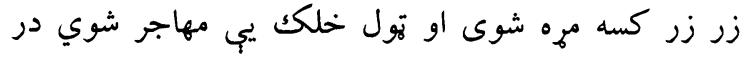

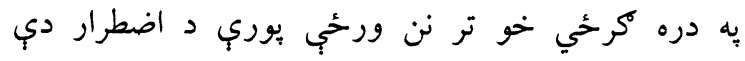

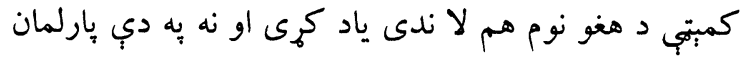

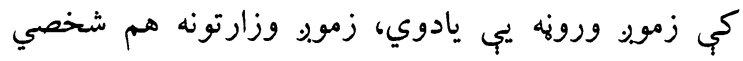

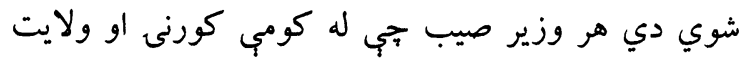
خخه جي وزير شوى دى د هغه ولايت وكيل هم تري

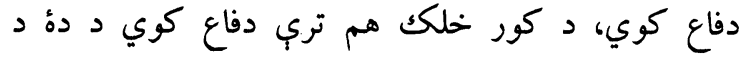

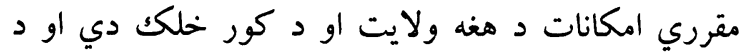

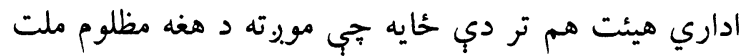

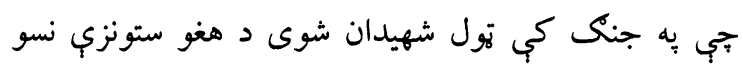
ويلاى، د زابل ولايت د V ولسواليو لاره يوه مياشت كيري

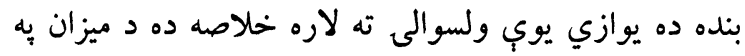

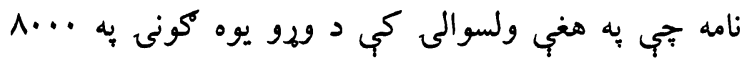

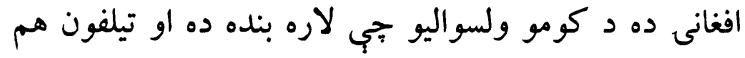

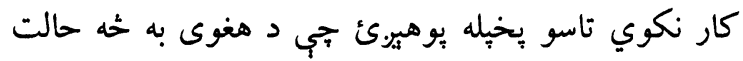

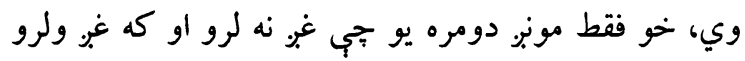
موبه وزير هم نلرو جبي هغه ته ووايو او هغه به يه كابينه كي

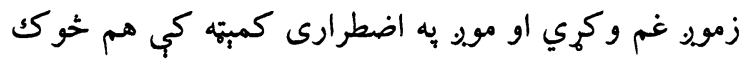

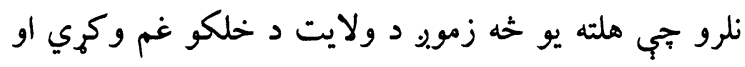

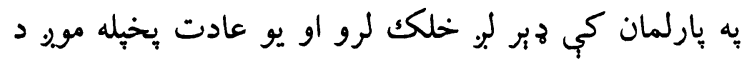

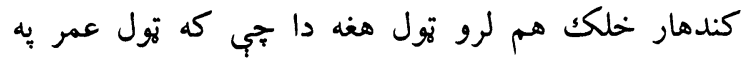

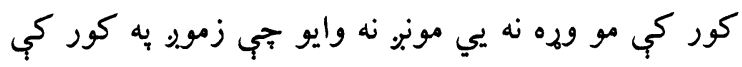

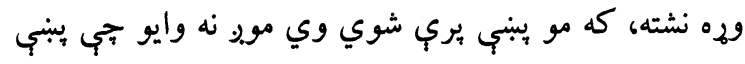

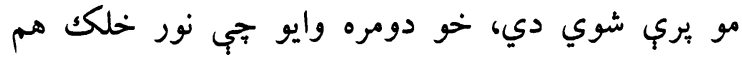

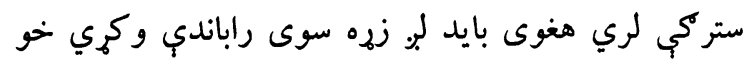

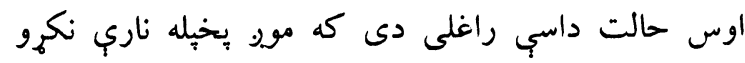

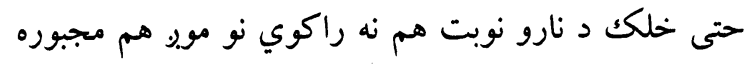

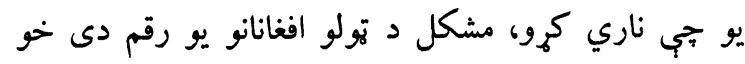

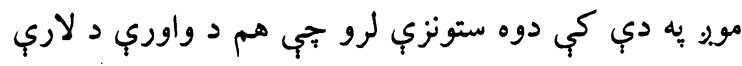

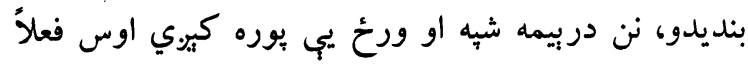

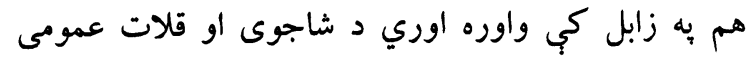

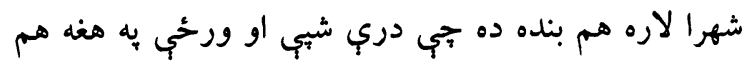

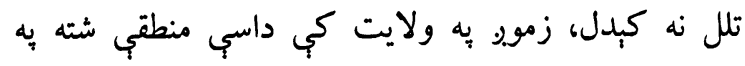

بس اين عدم توجه مقام وزارت است و ما مسئول هستيم

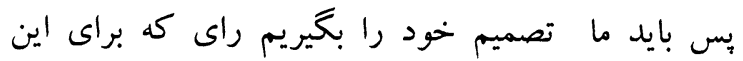

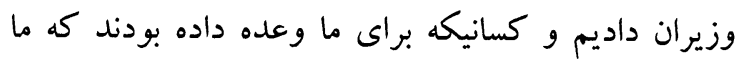

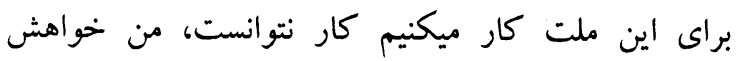

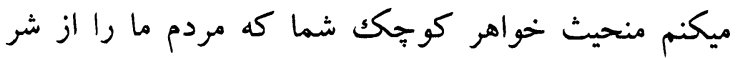
اين وزراء خلاص كنيد به هر قيمت كه ميشود خون مردم را كوشش نكنيد كه همراى شان شريكك شويم ما، آنهاء

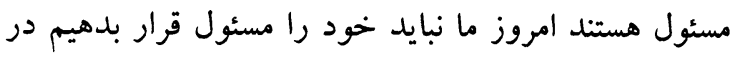

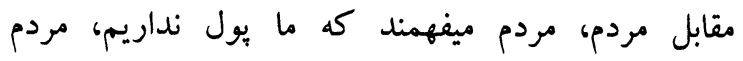

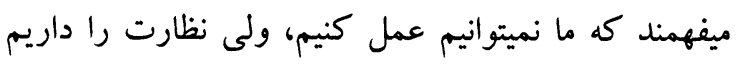

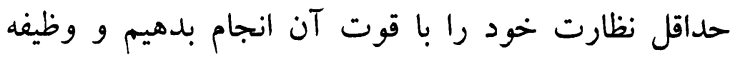

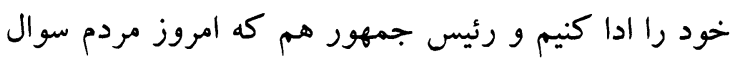

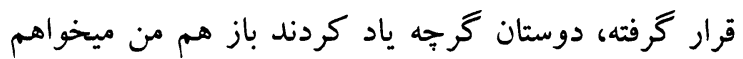

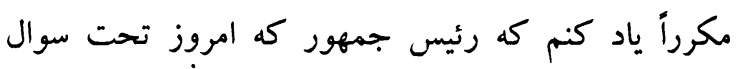
است، فاصله كه بين ملت و دولت به وجود وزئ آمده همين

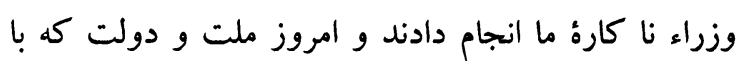

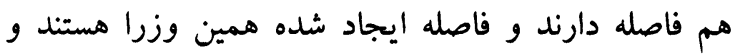

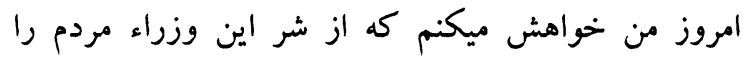

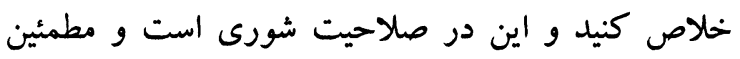

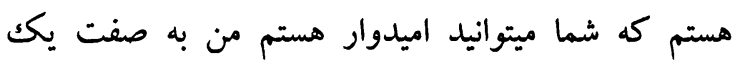

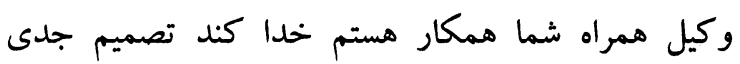
بخيريد، انشاء الله. حميد الله توخى:

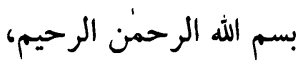

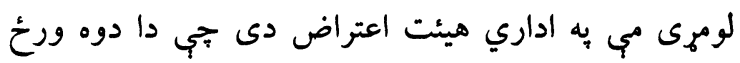

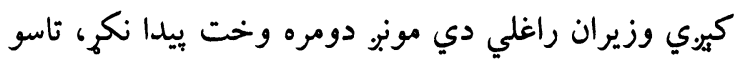

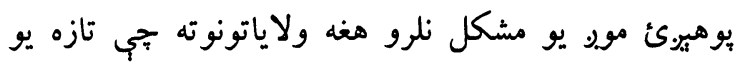

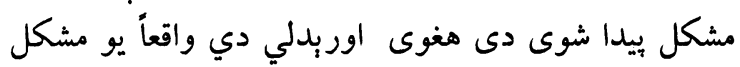

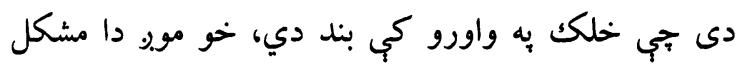

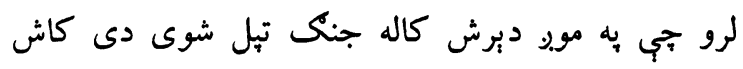

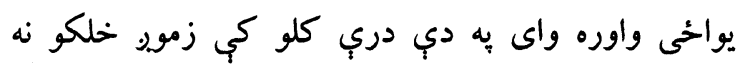

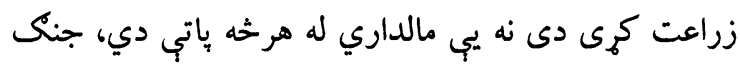

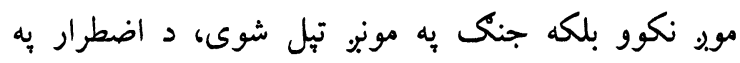

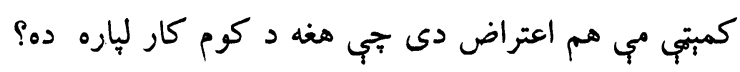

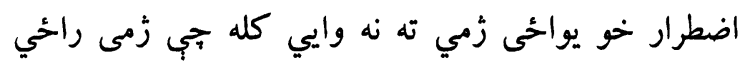


ملا تاج محمدمجاهد:

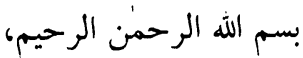

به اجازه جناب رئيس صاحب و همكاران محترم، جناب آرسم، رئيس صاحب! صحبت هاى اعضاى كميته اضطرارى را شنيديم صحبت هاى كه آنها كردند نبود امكانات، نبود امبلانس هوائى، راه بندان، نبود مواد بيش بينى شده

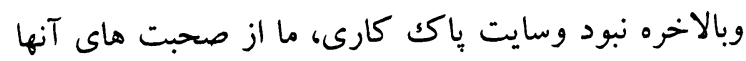
دو تصميم بايد بكيريم يكى اينكه در دراز مدت بردائ براي

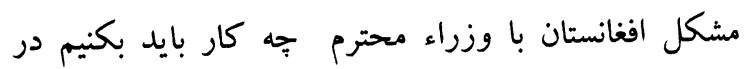
مسايل اقتصادى، در مسايل بيش رفت و آبادانى، در مسايل همه عرصه هاى زنده گ گى مردم در افغانستان با اعضاى محترم كابينه با وزراء محترم، دوم اينكه در بخش كو تاه

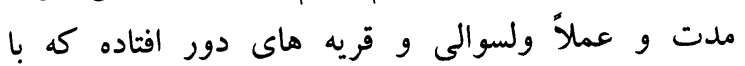
مشكلات راه بندان و برف روبرو هستند كميته اضطرارى به جز از يكك مقدار مواد ناجيزى بيش بينى شده هيج كار جديد در طول يكك ماه كه حادثه بزرگ رخ داد داده عملاً اقدام نكردند، يك كاريكه رئيس صاحب اين كميته و اعضاى كميته جمعاً نشسته باشند مواد جديد، كمك ركائس جديد، يول جديدى بالاخره گره گُشائى بر اين مشكل قطعاً ما نشنيديم، من يسشنهاد ميكنم جناب رئيس صاحب!

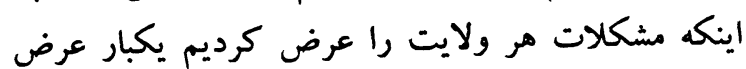
كرده بوديم تقريباً موثر نه افتاد كه تكرارى عرض كرد كرديم، بيشنهاد من اين است جناب رئيس صاحب كه زمستان يكى

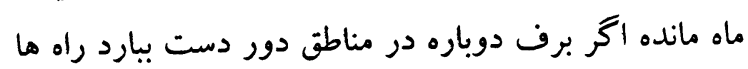
بند باشد مشكل افغانها اضافه تر ميشود ممكن بسيارى از دوستان ما تلف شوند، ممكن دولت و كميته اضطرارى مواد سوخت، مواد غذائى رسانيده نتواند اما آن جيزيكه بسيار ضرور است و مكلف است اين كميته كند دولت هستيم صحبت هاويرو گرام هاى ما بايد مطابق همين حالت باشد، من يسشنهاد ميكنم كه در بخش راه باز كردن و راه باز نگهداشتن اگر در ولسوالى هاى دور افتاده بدخشان، غور، بادغيس، باميان، كنر و هرات تصميم كرفته نشود راه هاى بين ولايات و راه هاى بين ولسوالى ها ولايات و راه هاى بين قريه هاى بزرگ و ولسوالى ها اگر باز نشود ممكن ما و شما براى افغان هاى كه به مشكل روبرو هستند
داى جويان، خاكث افغان ولسواليو كي له دوه مترونه زياته

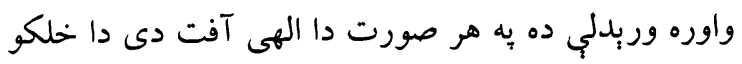

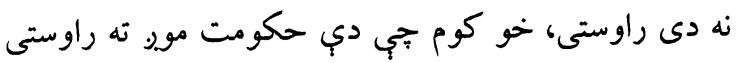

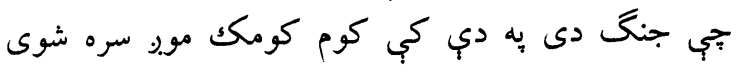

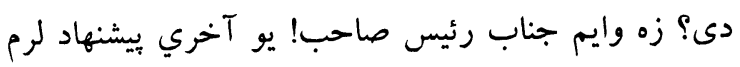

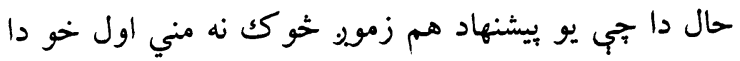

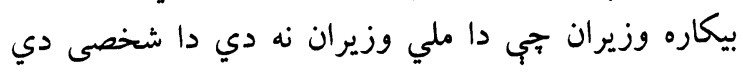

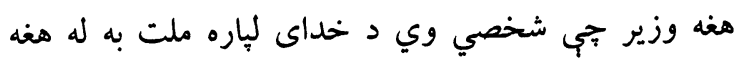

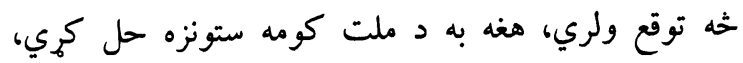

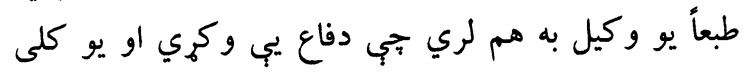

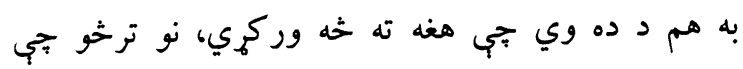

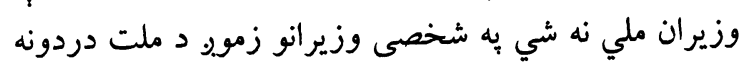

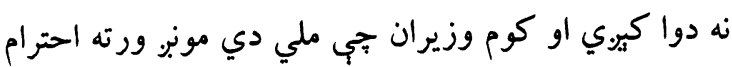

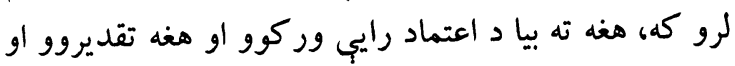

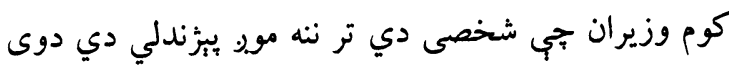

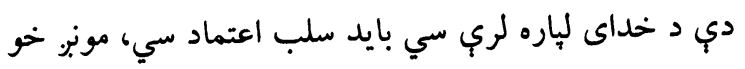

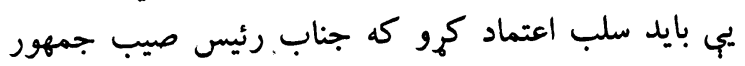

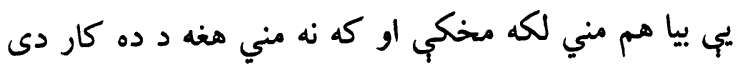

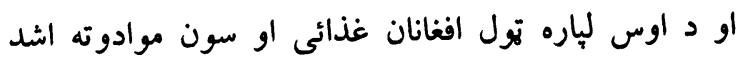

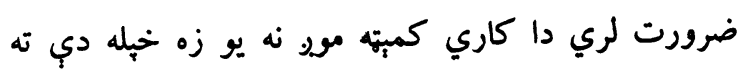

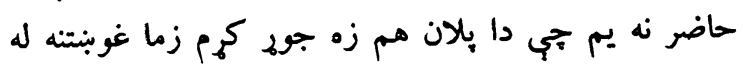

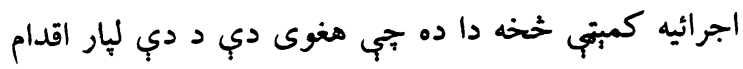

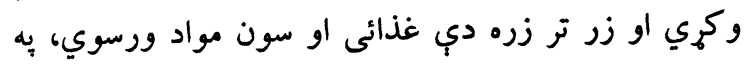

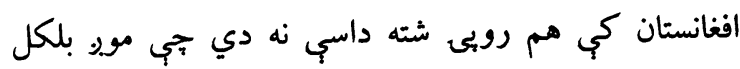

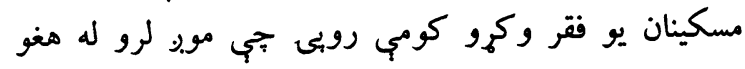

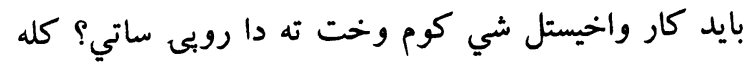

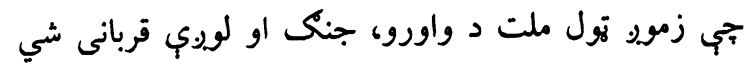

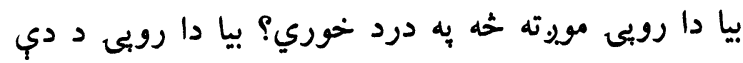

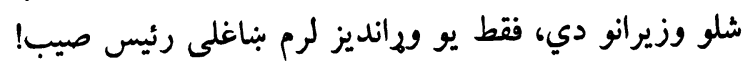

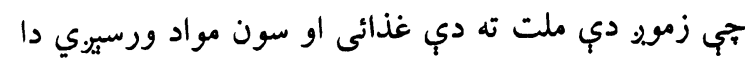

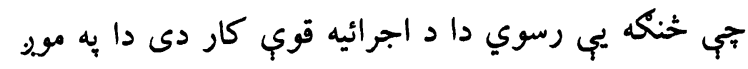

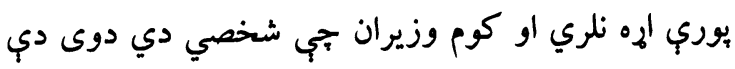

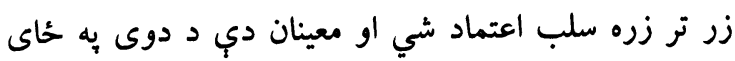

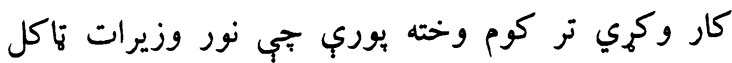
كي.ري. 
را در جنگ مصرف ميكند و يكك ميليون دالر را در

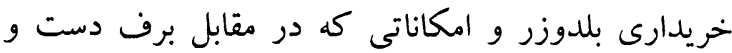

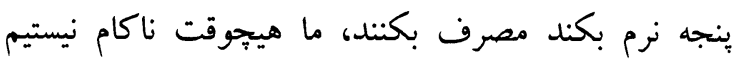

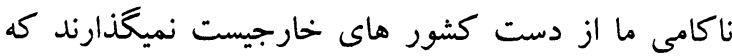
دولت ما قوى باشد در تضعيف بارلمان كوشيدند، در

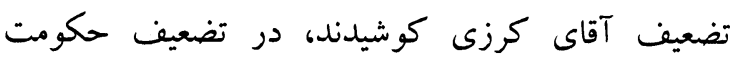

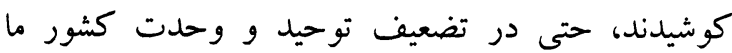

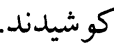

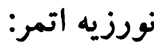

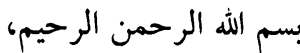
د قدرمند رئيس صيب او محترم وكيل صاحبانو به اجازهن،

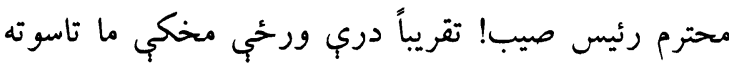

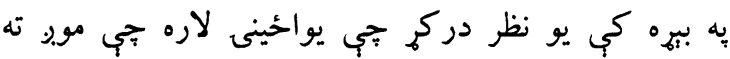

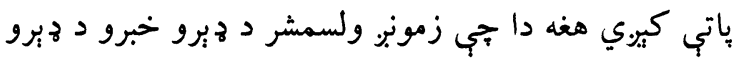

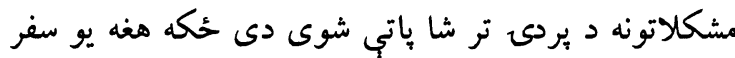

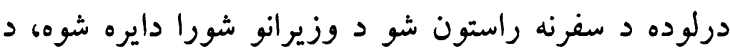

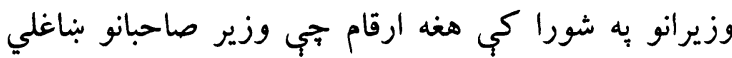

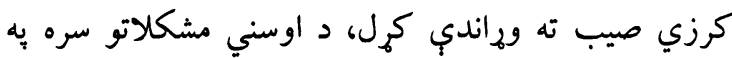

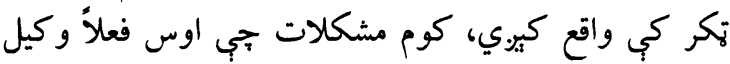

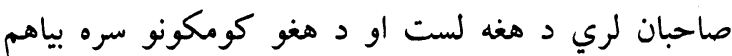

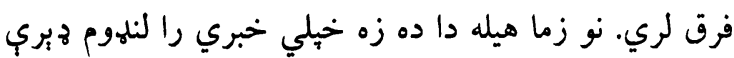

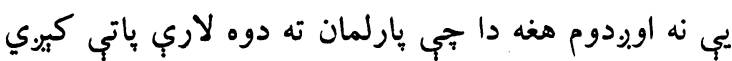

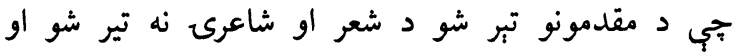

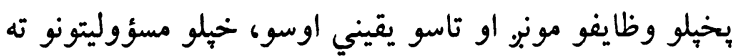

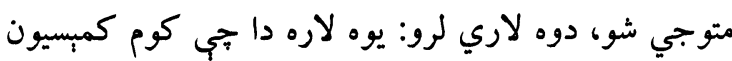

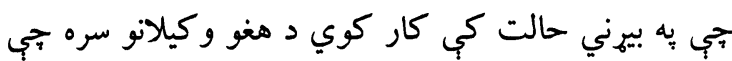

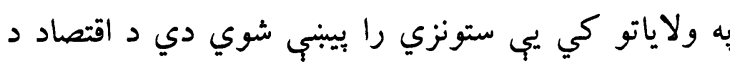

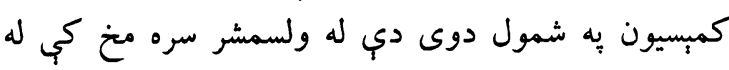

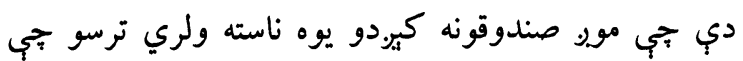

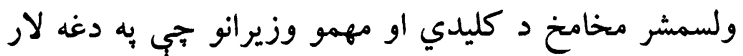

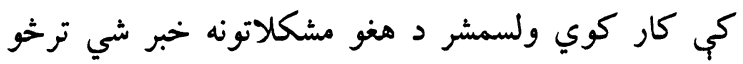

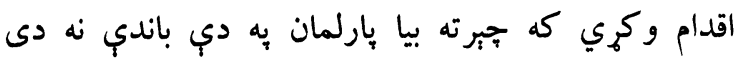

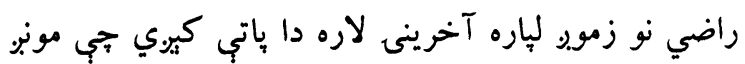

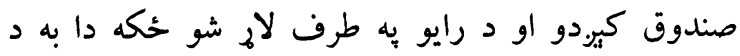

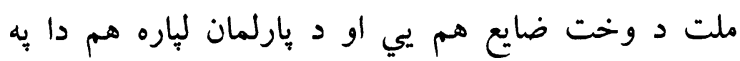

هيج كمكى كرده نتوانيم، جون دوا را هم رسانيده

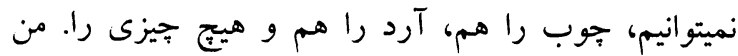

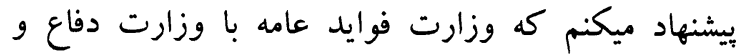

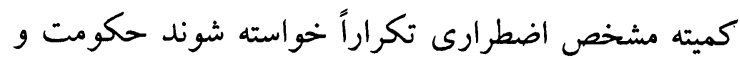

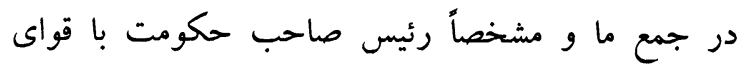
خارجى عاجل بنشند و اين هفت روز ونس است كه اين مشكل

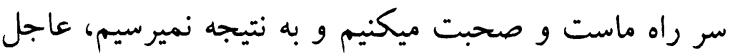

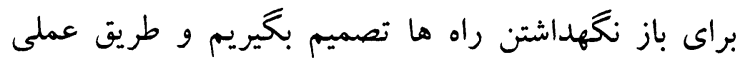

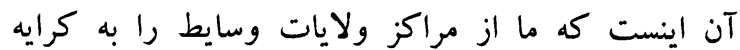

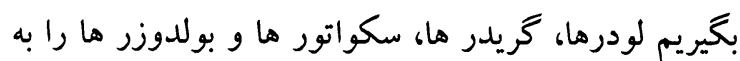

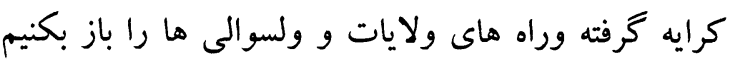

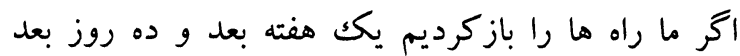

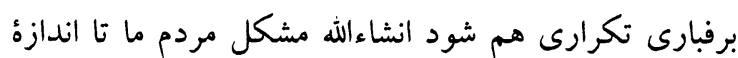

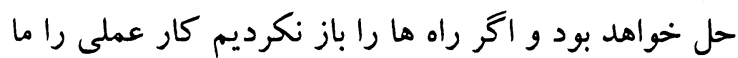

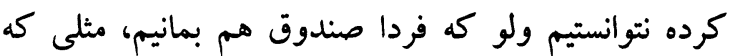

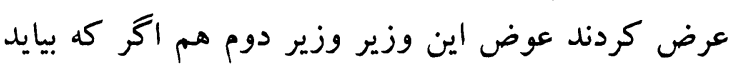

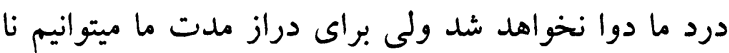

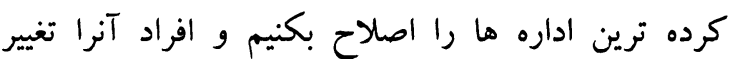

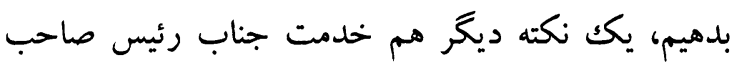
من عرض ميكنم و انشاءالله مفيد خواهد بودي بود و و آن اينكه

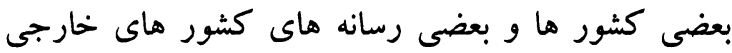

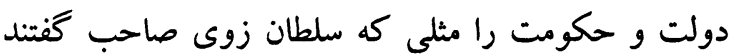

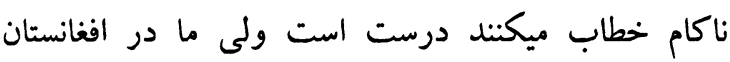

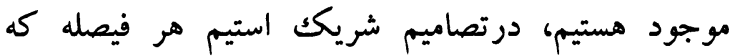

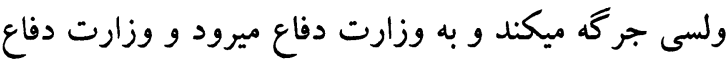

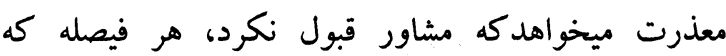

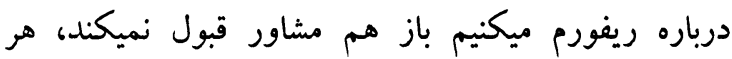

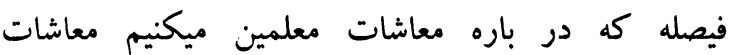

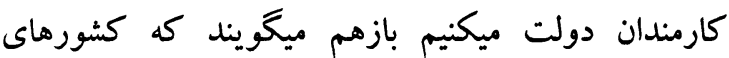

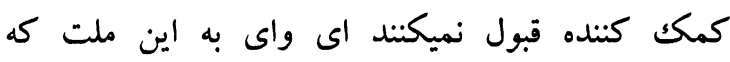

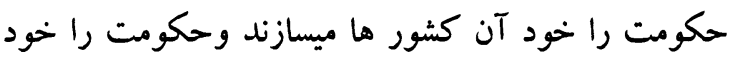

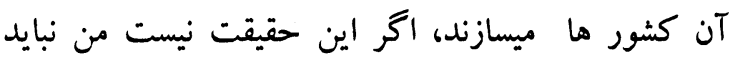

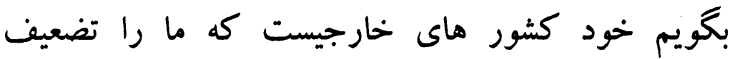

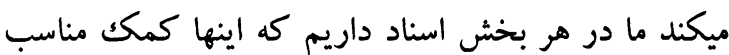

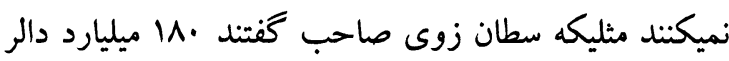


جان ميدهند، اين قسم مصيبت باور كنيد در طول تاريخ

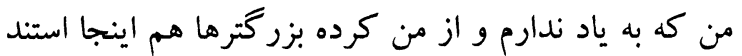

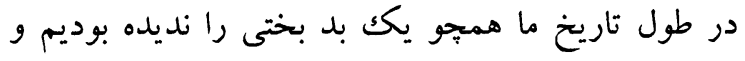

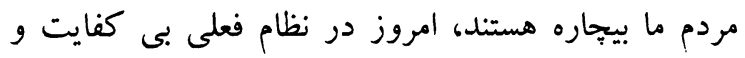

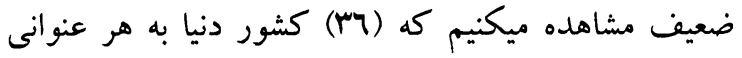

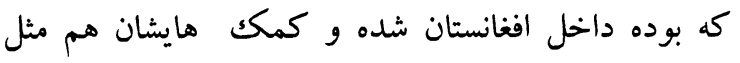

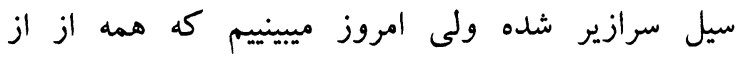

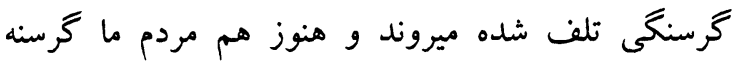

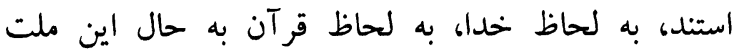

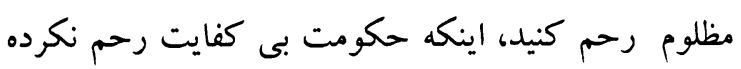

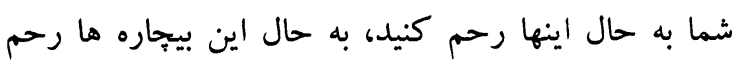

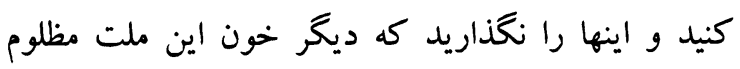

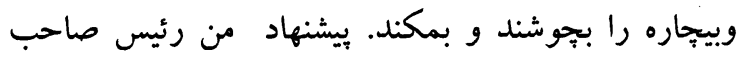

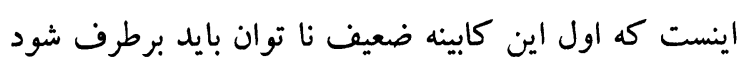
بس است اينقدر جزا و اين قدر خاكت زدن ها در جشم بنم اين ملت مظلوم، بيشنهاد دوم من اينست كه به تمام مردم

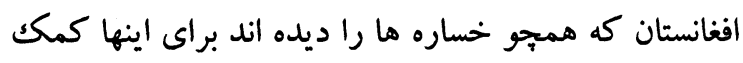

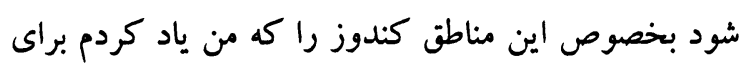

$$
\begin{aligned}
& \text { اينها هم كمكك شود، تشكر. } \\
& \text { داكتر عبد الكبير رنجبر: } \\
& \text { بسم الله الرحمن الرحيم، }
\end{aligned}
$$

باعرض احترام مجدد جناب رئيس! ما بايد امروز يكن الريك

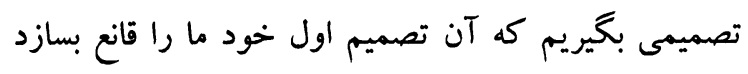

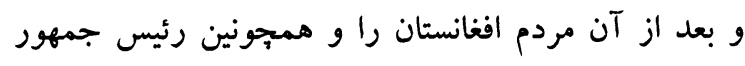
كشور ما را كه تصميم بعدى هم مربوط به آنه آنها ميشود.

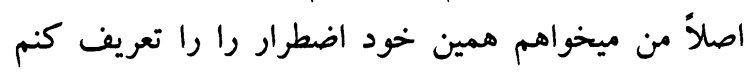

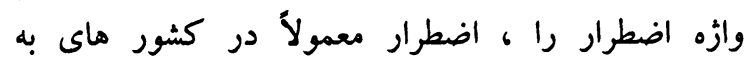

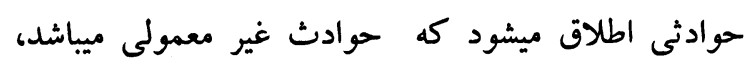

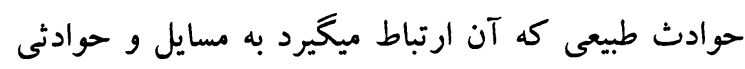

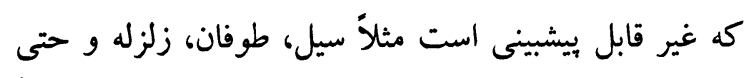
در ارتباط به زلزله هم علم حال آنقدر ييش رفئ رفئه كه بعضاً

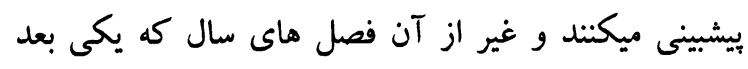
ديخر تكرار ميشود آن قابل بيشبينى است آن و مان ما نميتوانيم

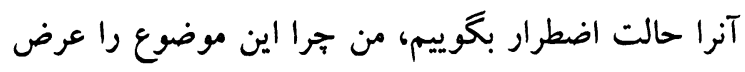

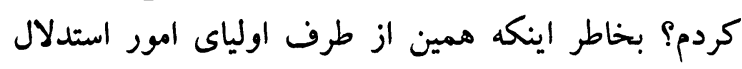

نقص تماميري دا يه كتهّ نه دى، زه فقط خيل آخرينى خبري به هغه شعر كي بيا وايم جي وائي: تش د لفظونو جواري ده د وفا به نامه ونه

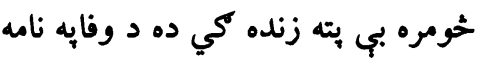

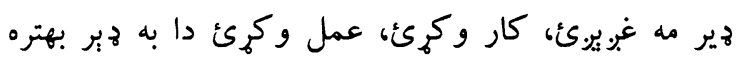
شكريه بيكان احمدى:

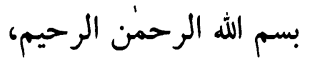

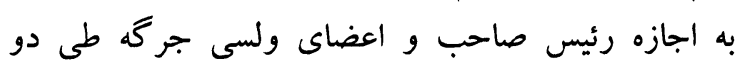

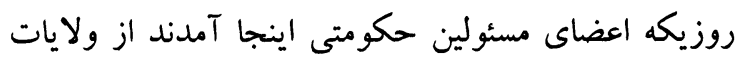
آسيب ديده ززارشى اريه كردند ولى متأسفانه، متأسفانه

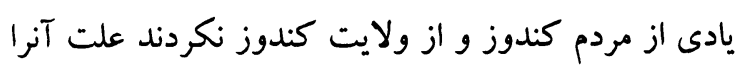

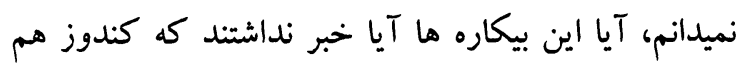
در جمع آسيب ديده كان بود؟ آيا اين بيكاره ها خبر ائري

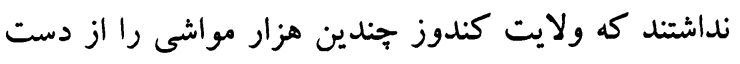

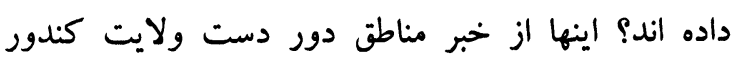

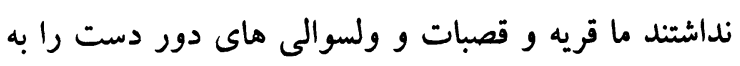

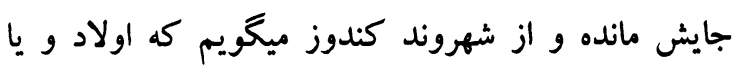

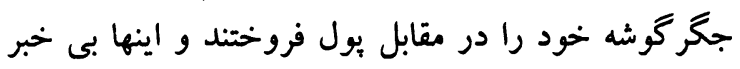

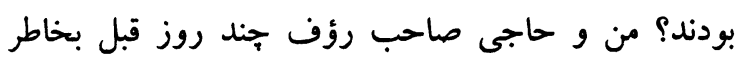

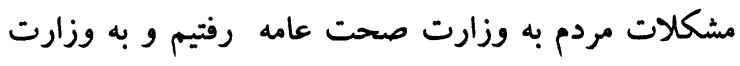
انكشاف دهات رفتيم، به وزارت زراعت رفته رفتيم و تا امروز

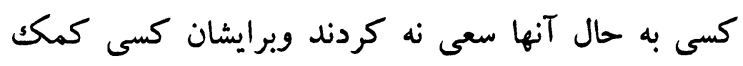

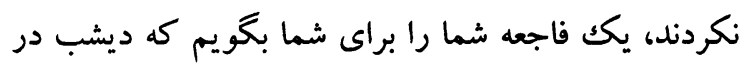

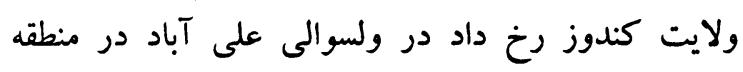

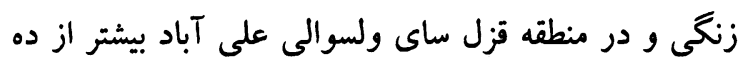

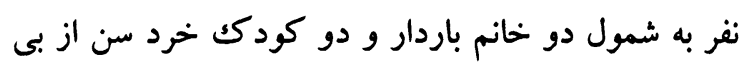

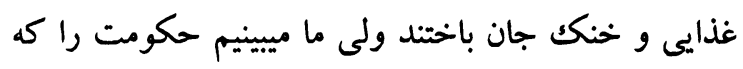
بى تفاوت است به لحاظ خدا رحم كنند، من به عند عنوان نماينده كندوز باور كنيد كه خجالت ميكشم كه اين كَّب

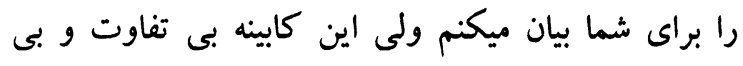
كفايت جاى تأسف نيست، جاى شرم نيست كه اينها هنوز

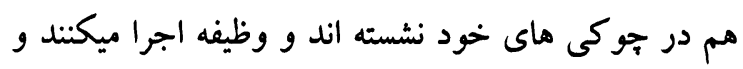

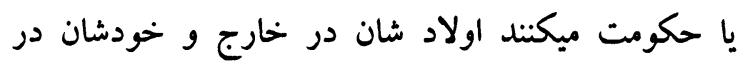
جاى گرم ولى مردم بيجاره و مظلوم ما درسردى زمستان 
معمولاً دركشور هاى ديخر بعد از (.q) روز صورت

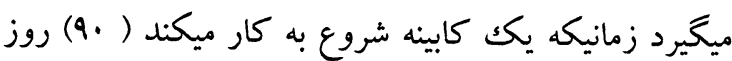
وقت برايش ميدهند سه ماه، بعد از سه ماه ماه معلوم ميشود

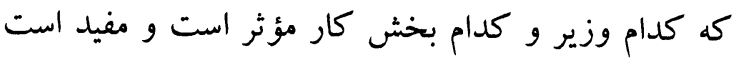
به كار است و كدام بخش ضعيف است به آن تجديد نظر

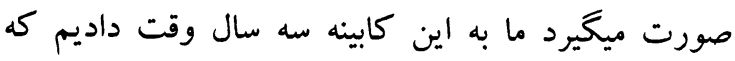

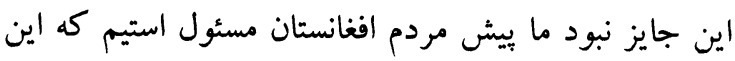

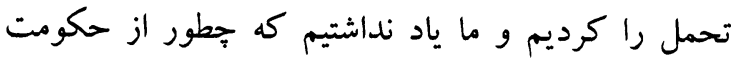

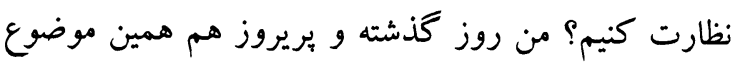

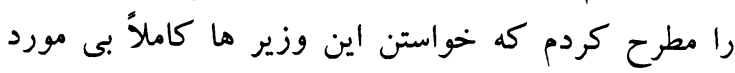
بود به همين شكلى كه ما آنرا انجام داديم يعنى اينها باز

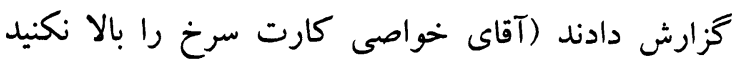

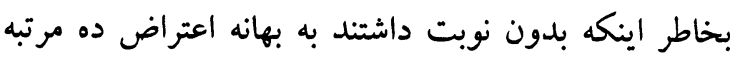
بيشتر از من صحبت كردند و حالا كه من صحبت ميكنم

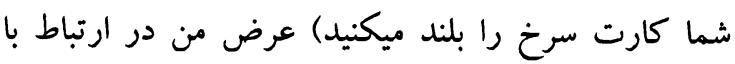

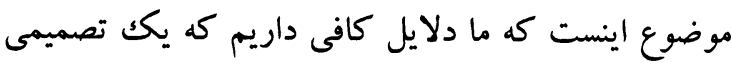

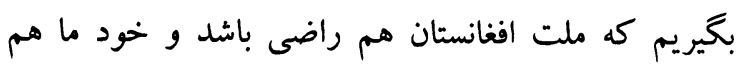
راضى باشيم ما در كميسيون تمام كارى هاى را كه بائ بايد واندي

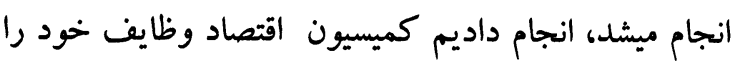
بسيار به درستى و امانت انجام داده است و يكت كميسيون انجان

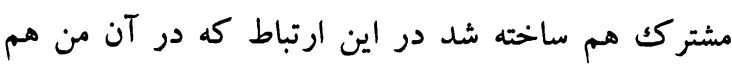

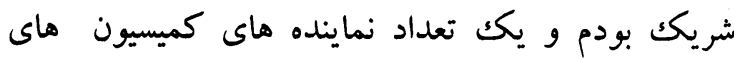

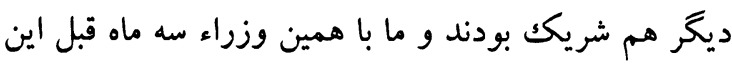

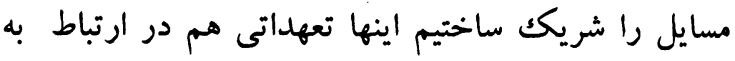

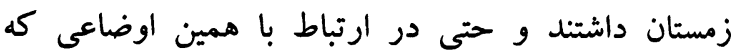

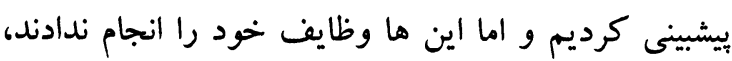

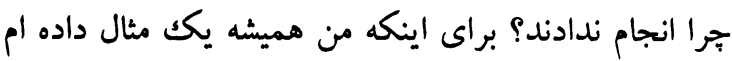

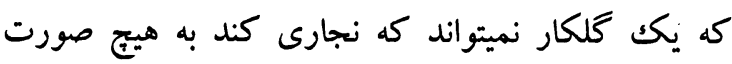

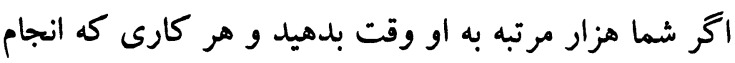

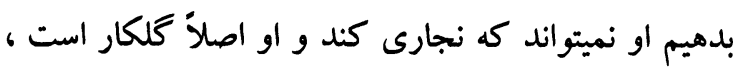
وظيفه اش نجارى نيست وزراء در دو حالت ناكام استند:

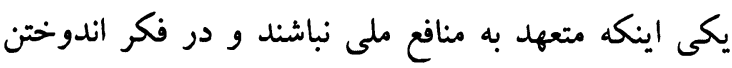

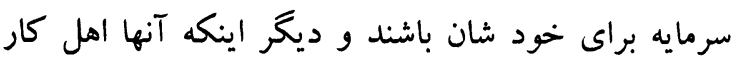

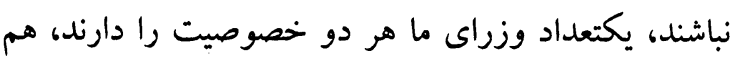

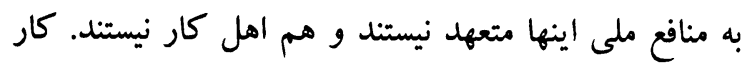

ميشود كه گُويا يكك حالتى آمدكه ما نميتوانستيم كه آنرا يبشبينى كنيم، ببنيد يك ساختمانى كه ساخته ميشود معمار

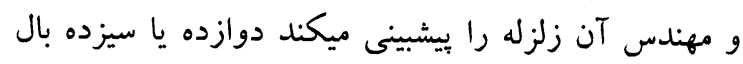

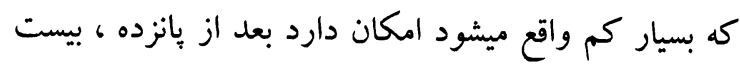
سال و حتى هيج واقع نشود اما بيشبينى ميشود و ساختمان

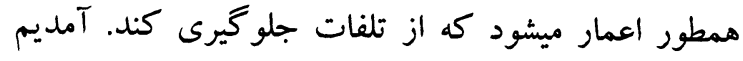

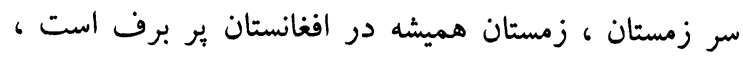

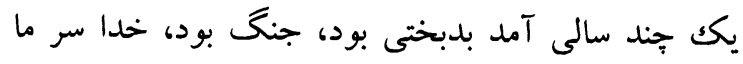

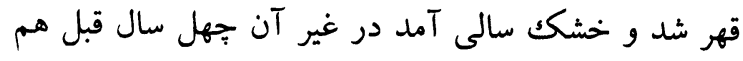

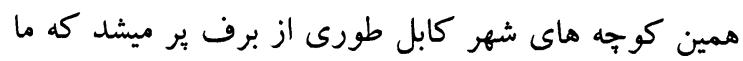

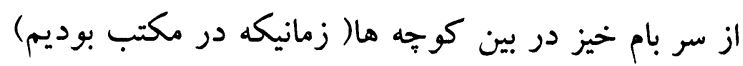

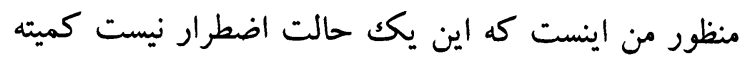
اضطرارى در اين ارتباط اكر كدام وظايفى را انجام ميدهد

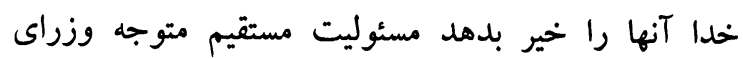
است كه ارتباط ميخيرد به همين حالتى كه در افغانستان

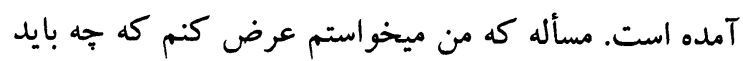

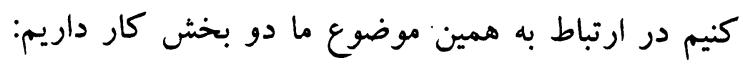
يكى بخشى كه جطور كمك كنيم با مرد خود كه امروز مبتلا به نتايج اين موضوع استند ، كرسنه استند، گير مانده

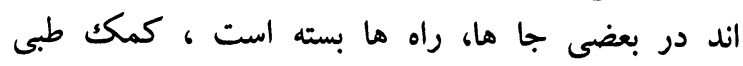
نميرسد، كمكك غذايى نميرسد، اين بخش ارت ارتباط ميخيرد

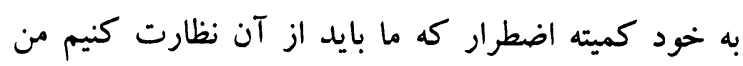
كاملاً مخالف همين كميسيون هاى هستم كه در كار هاى

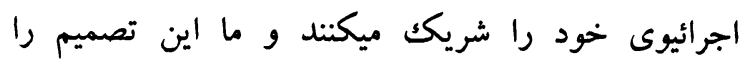
كرفتيم و براى من ديروز نوبت نرسيد و من من صحبت كرد مرده

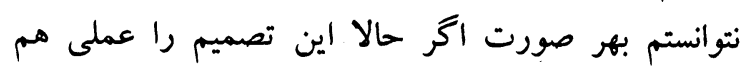
ميكنيد نتيجه ندارد و بعداً ما را هم مسئول ميسازند كه اينها لهورئ

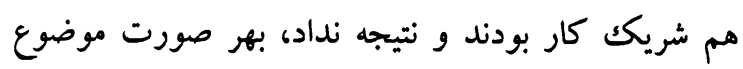

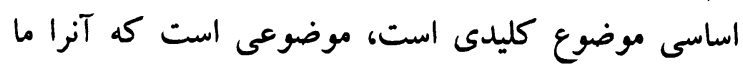

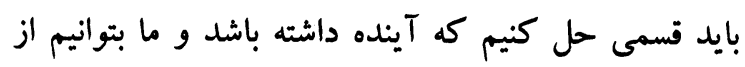
آن نتيجه جدى و درست بـيريم و اين در ارتباط با همين

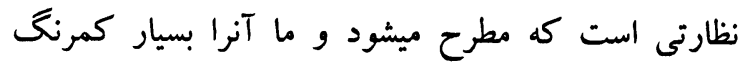

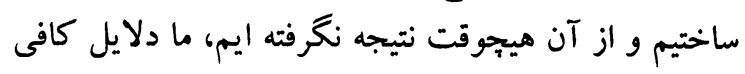
و مقنع داريم كه يكك خانه تكانى كنيم جناب قانونى صاحب! يا بعباره ديخر كابينه تكانى كنيم اين كابينه تكانى 
ست كه ما ميبينيم كه نتايج آن بسيار تاريكك است، بايد

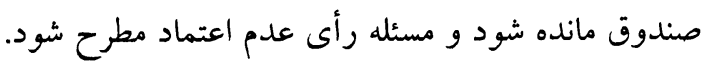
سيد داوود هاشمى:

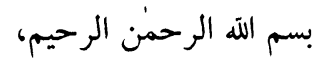

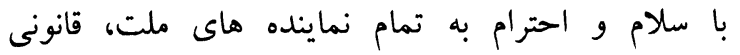
صاحب! امروز روز سوم است كه ما بخاطر مشكلات

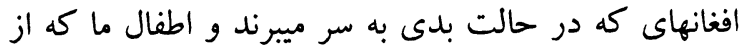

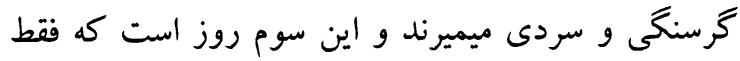

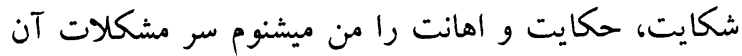
بيجاره ها هيج حرف زده نميشود يا وزراء از بين بروند

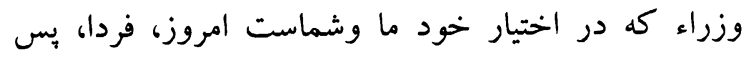
فردا من با وزراء كار ندارم من سر آن بيجار درداره هاى

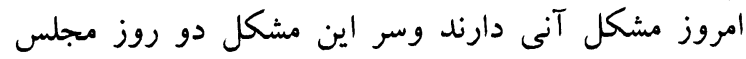

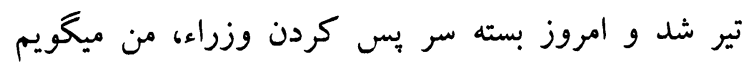
مشكل آن بيحاره هاى كه كمكك كاردارند و اين كمك ونك

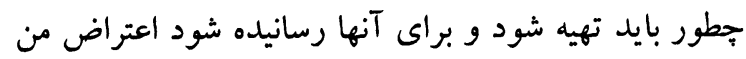

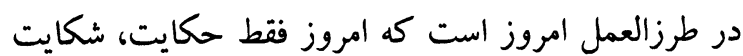

$$
\text { و اهانت است سر مشكل حرف زده نميشود. }
$$

محمد باقر شيخ زاده:

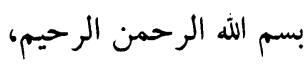
و به نستعين، جناب رئيس صاحب! لرحب من زياد حرف نميزنم

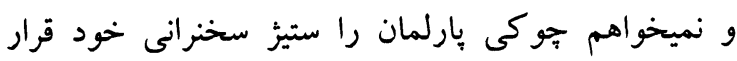

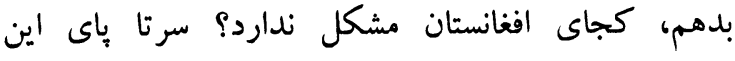

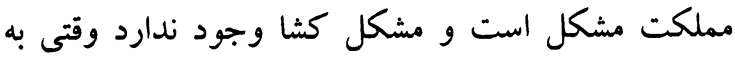
دروازه ها ميرويم هيجكس مسئوليت احساس نميكند

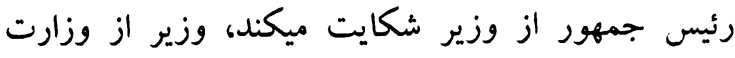

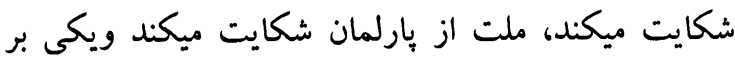

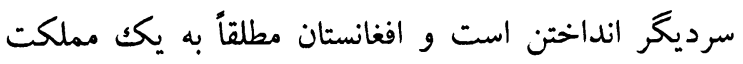
مشكلات مواجع است. شما تنها همين سرما زمستان را

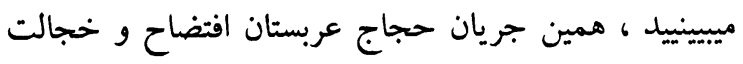
نيست ويكك خجالتى مهمى در همين هيروسه است ولى مدينى

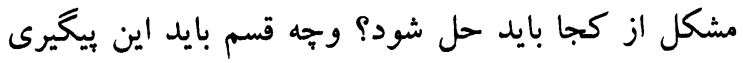

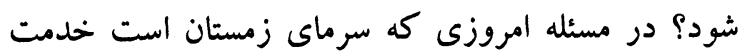

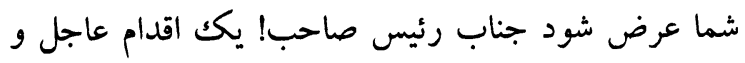

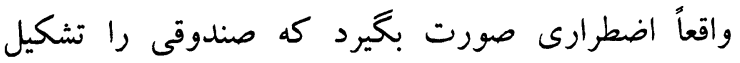

طورى بايد شود به نظر من اينست كه همين يكتعداد وزرا

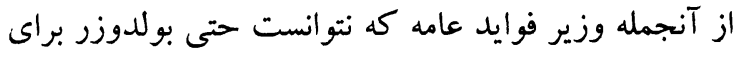
يكك ولايت تهيه كند، يكك وسايل عادى كار را رانه

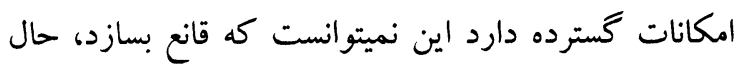

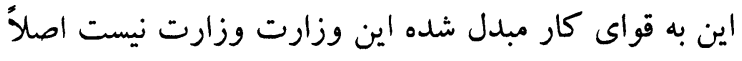

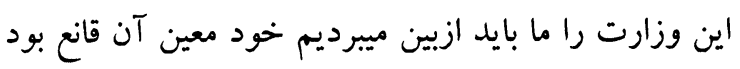

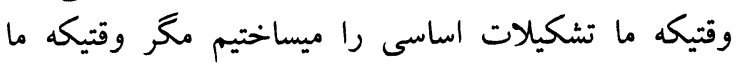

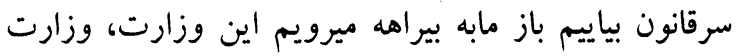

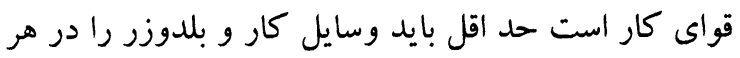
ولايت تهيه ميكرد درهمين سه ساليكه او وزير بود ديكر اليح

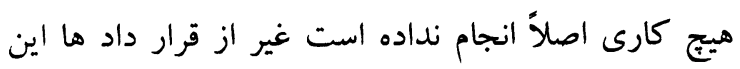
وزارت بى كفايت بود بى كفايت كار كرده ديخر وزارت تجارت است كه من توجه همه را به اين جلب ميكنم تنها وزارت تجارت نيست و بدبختانه وزارت تجارت و و صنايع رابن

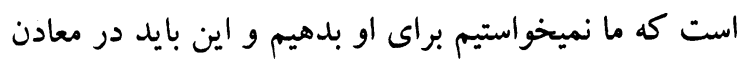

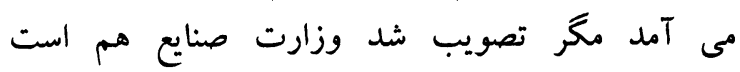
كوجكترين كارى را در اين سه سال انجام نداده است،

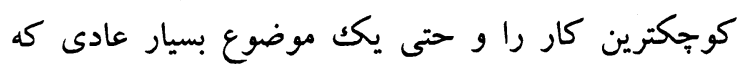

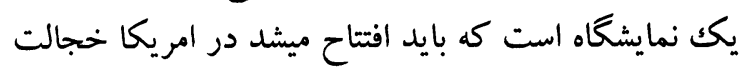
آور است هميشه در مسايل دييلوماتيك (مداخله رئيس

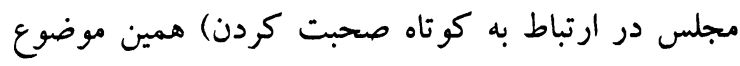
را مختصر ميسازم كه اين بخاطر اين اهل كار نيست كور كه

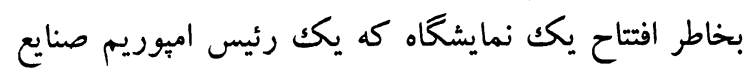
بايد ميرفت خودش امريكا رفته است براى اينكه من يقين

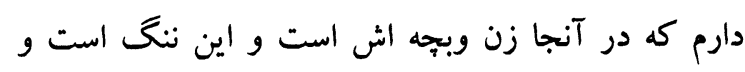

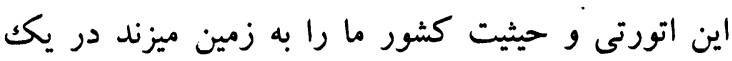

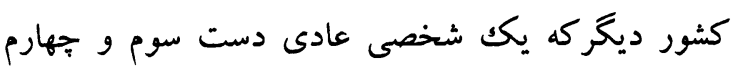

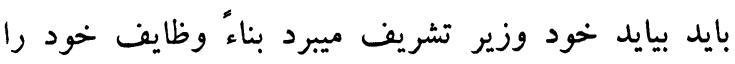
اينها انجام نداده اند و وقتيكه استيضاح صورت مئ ميكيرد

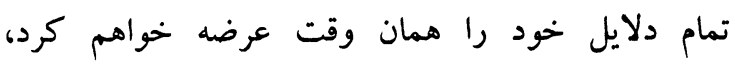

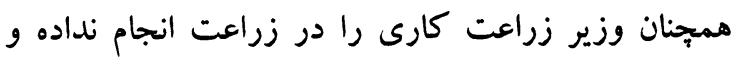

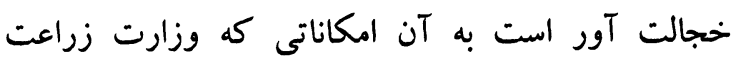

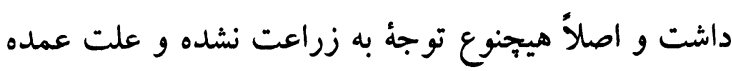

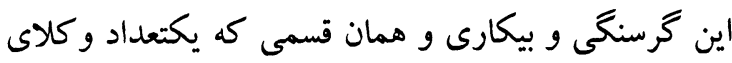
ديخر هم عرض كردند به مناسبت همين بيكاره گیى وزراء 
ها ميشود و آن اينست كه جناب رئيس صاحب! در طى دوز دو روز مجلس به نظر من خوب اداره نشد ميكانيزمى كه إنس

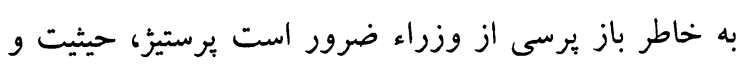

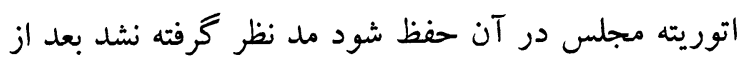

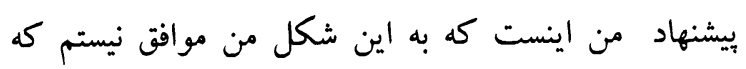
وزراء و هر مهمان ديخرى به مجلس خواسته شوند ما بايد

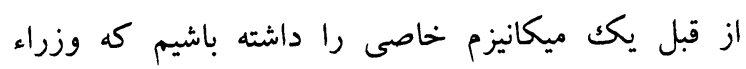

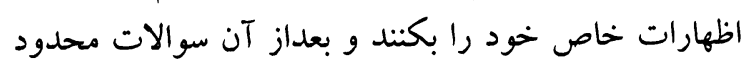
از طريق كميسيون اختصاصى يا اكر به ولايات تقسيم

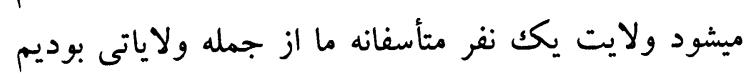

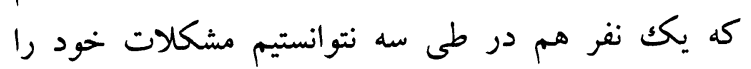

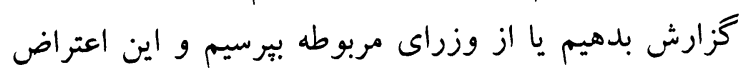

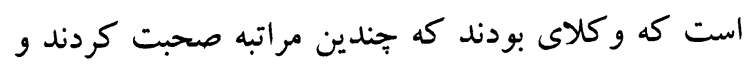

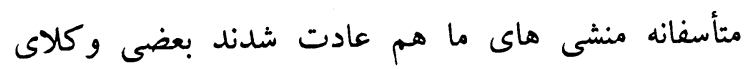

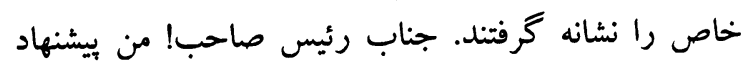
ميكنم كه اين معضله يكك روزه نيست بلكه معضله همه

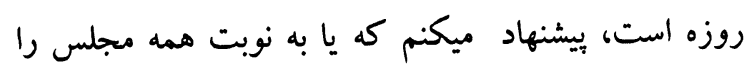

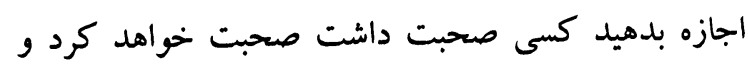

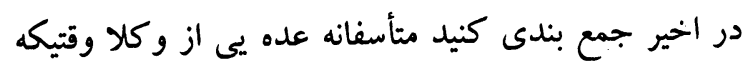

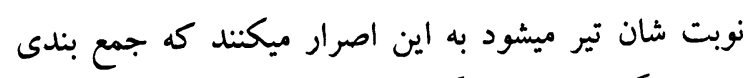

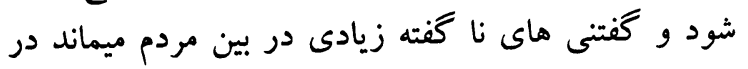
اين رابطه در روز هاى بعدى صحبت خواهيم كرد هال حالا

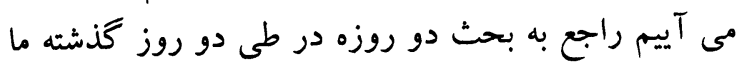

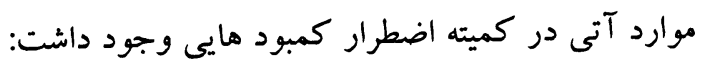

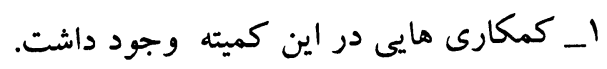

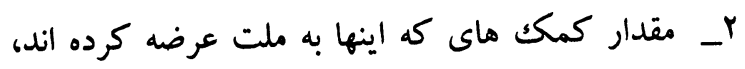

$$
\text { بسيار كم بوده. }
$$

rــ به موقع عمل نكرده اند.

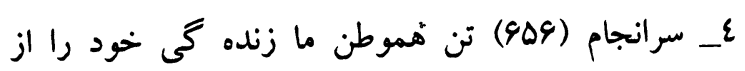

$$
\text { دمت دادند. }
$$

0_ تا حال راه ها هنوز هم بند است.

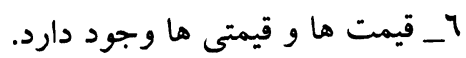

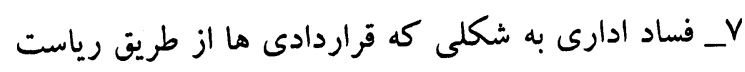

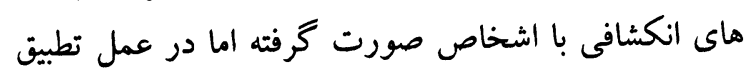

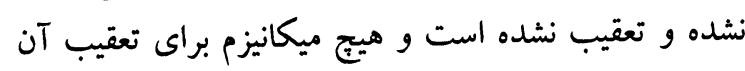

كرديد و حساب بانكى را افتتاح كرديد كار خيلى نيكى الى إنى

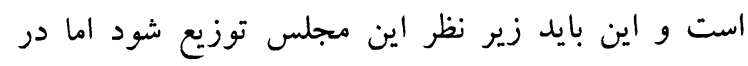

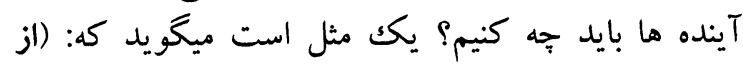
طبيبى خورد خون تو مرهم نه طلب) يا همان شعر معروفى مانى

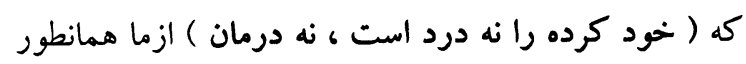

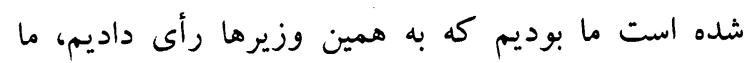
بوديم كه هر شب به مهمانى هاى شان رفتيم و فردا آمديم

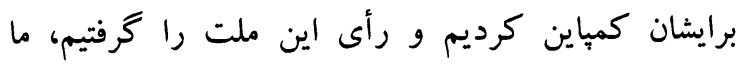
بوديم كه واقعاً در مقابل اينها در طول دوسئ وسال آرام. نشستيم

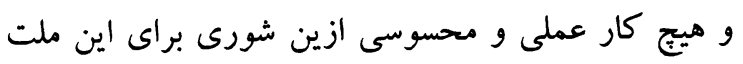

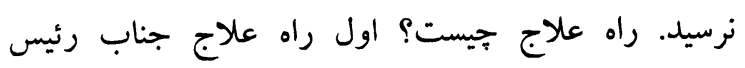

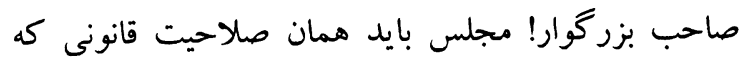

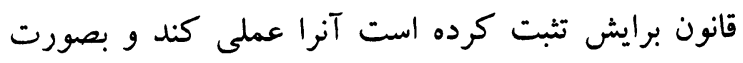

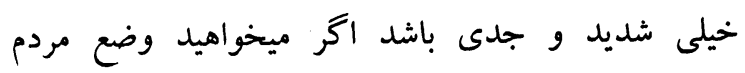

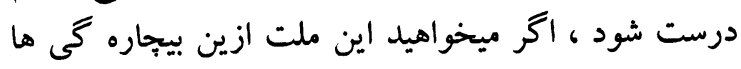

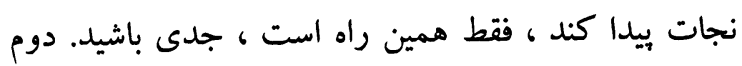

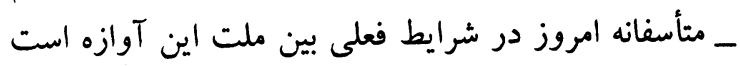

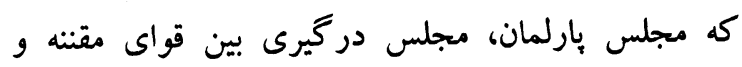

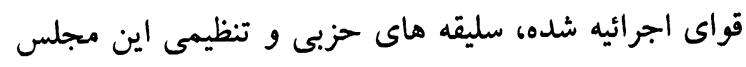

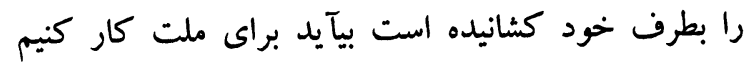
سال سوم وقتى به اين جوكى مينشنيم تمام سليقه هاى

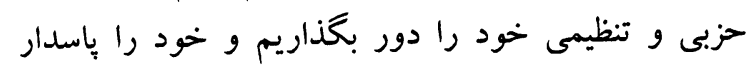

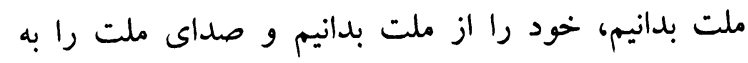

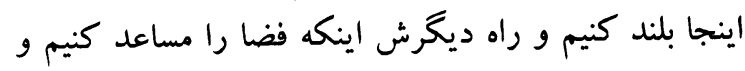
اين فضا در مساعد كنيم كه اعتراض بين قواى مجرئيه و و و

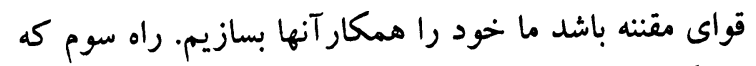

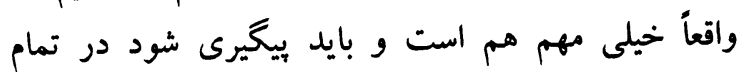

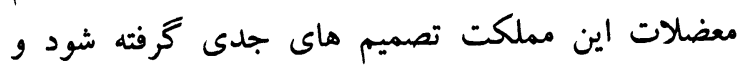

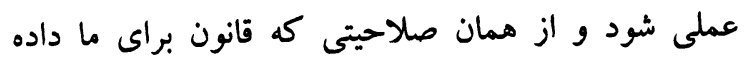
همان را بيخيرى كنيم، تشكر. داكتر فضل الله مجددى: بسم الله الرحمن الرحيم،

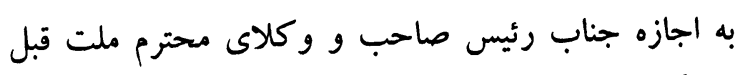

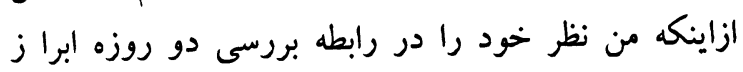

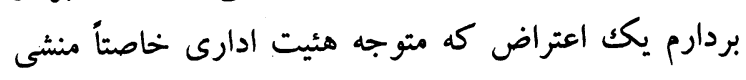


غور بكنند و و كلاى محترم تصميم جدى بحيرند كه اگر

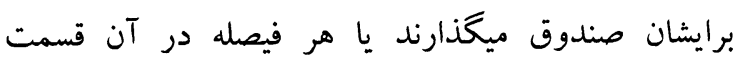

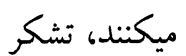
فكورى بهشتى: - فيكن

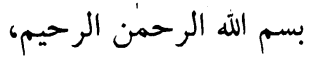
جناب آغاى رئيس و و وكلاى محترم! صحبت ها زياد شد الرد

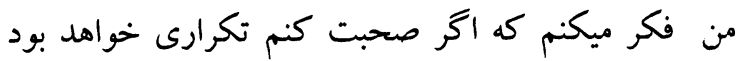

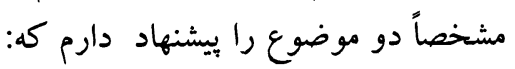

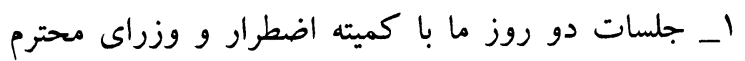

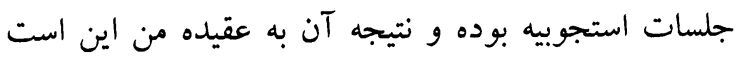

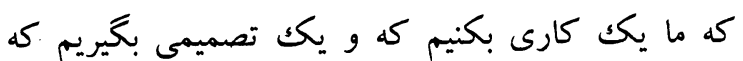

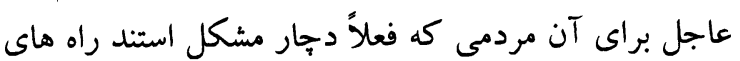

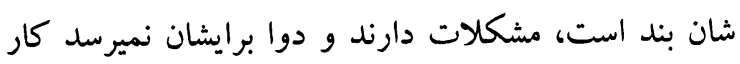

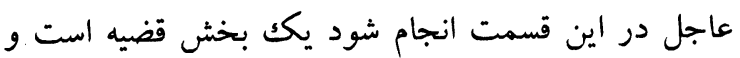

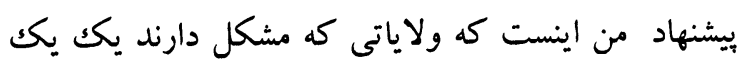

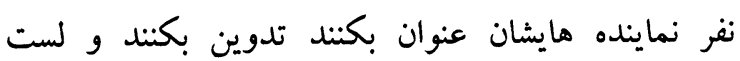

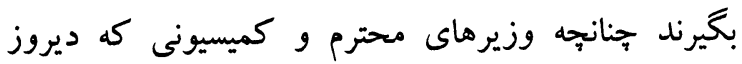

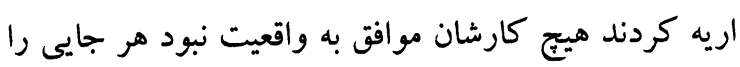

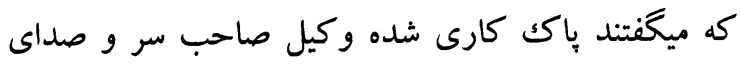

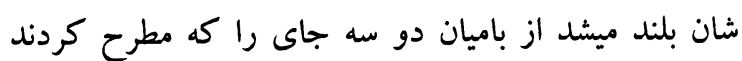

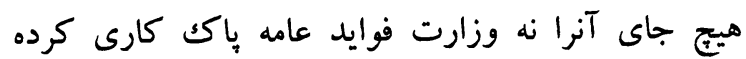

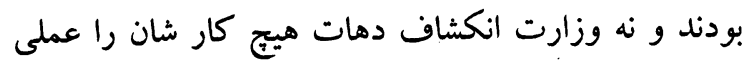
نكرده اند.

Y- بـ مسئله بررسى استيضاح است كه فكر ميكنم اين را

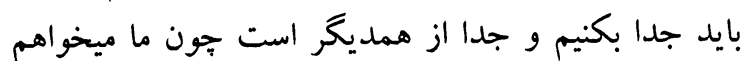

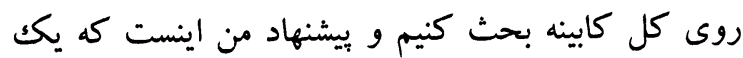

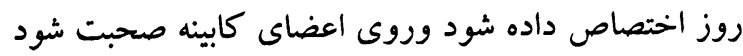

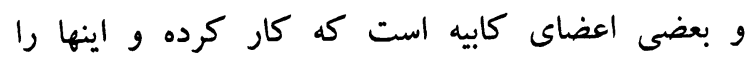
نميتوانيم كه در يكث رديف قرار بدهيم و و همانطوريكه

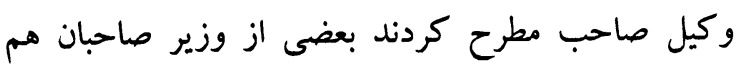

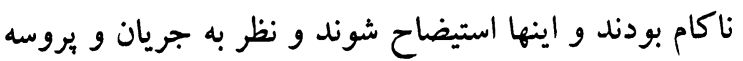
استيضاح اقدام شود، تشكر.
وجود ندارد، هرجند وزارت فوايد عامه از طريق (P.R.T)

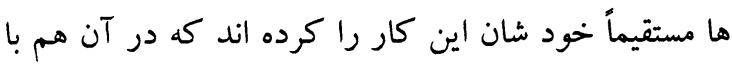

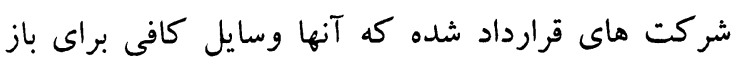

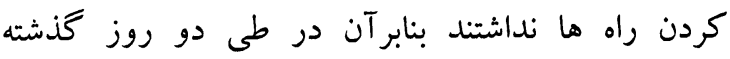

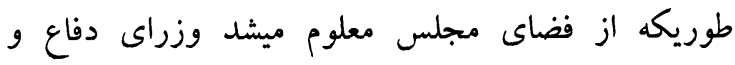

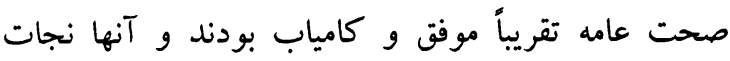

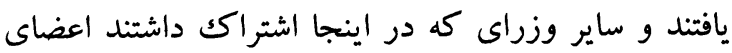

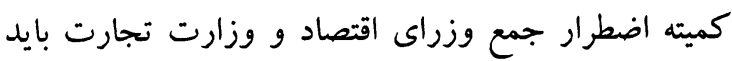

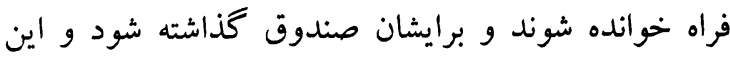

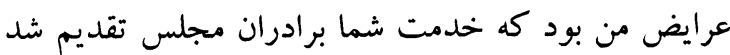

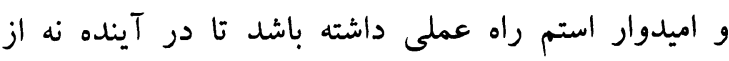

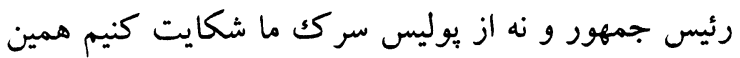
حالا صلاحيت هاى قانون خود را داشته باشيم. انجينير محمد عباس نويان: بسم الله الرحمن الرحيم، من بازهم به مثل ديخر دوستان اعتراض ميكنم به به نحوى الري

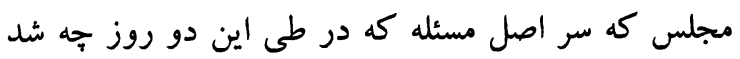

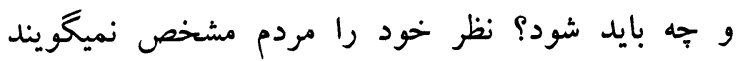

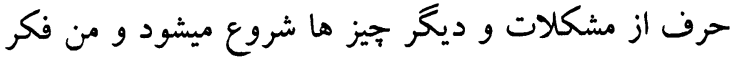

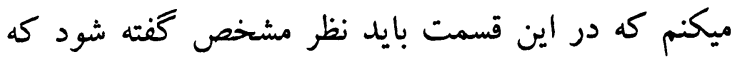

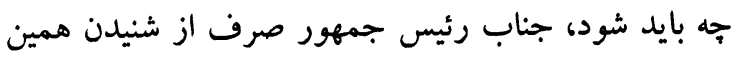

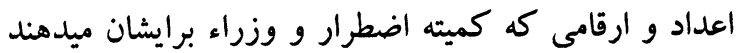

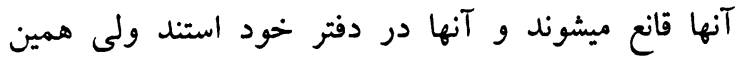

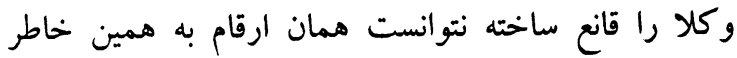

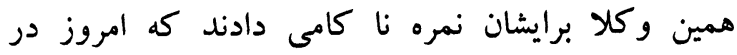
جرايد و مجلات به تيتر درشت نوشته شد. ندان دوم اينكه بعضى از دوستان لطيف المزاج ميكويند كه اخر إنر

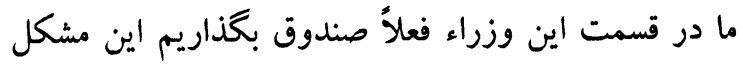

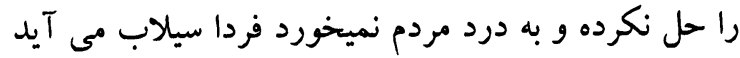

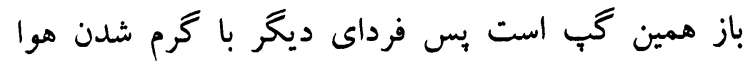

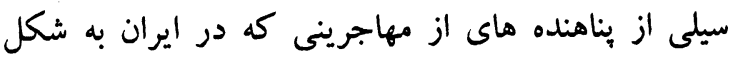

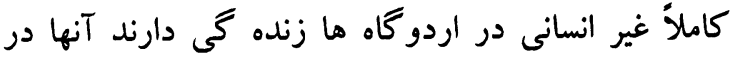

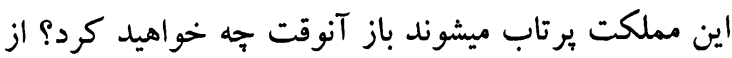

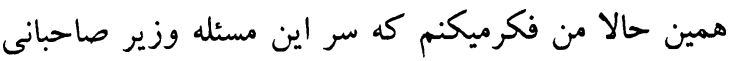
كه كفايت لازم نشان نداده اند بايد سر اين مسأله جدى ماحئ مانى 
تشنگى بايد جشيد) حال مقدارى كه كارميشود كار بايد سيد محمد على جاويد:

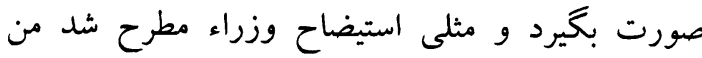

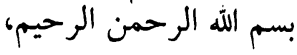

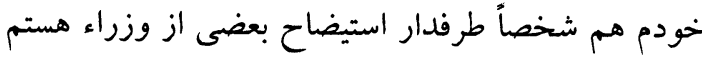

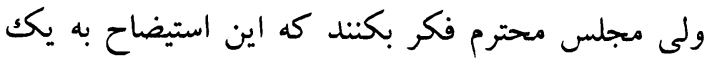

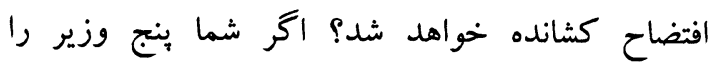
استيضاح كرديد ويس كرديد دو باره داستان دو وزيرى

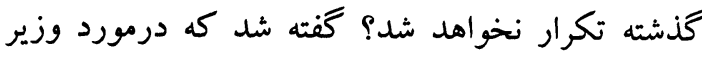
عودت مهاجرين هم دلايل موجه نبوده ولى به احترام

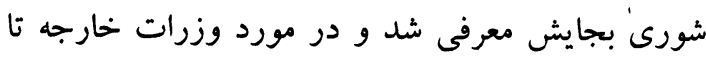
هنوز مسله باقى است، انسان كارى بايد بكند كه زوري دور مورد

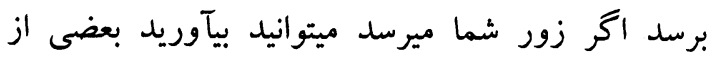

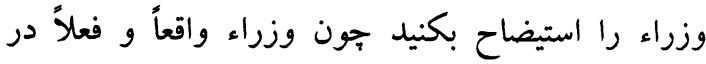

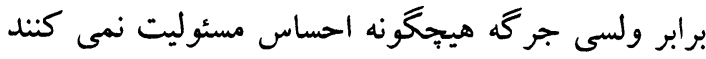

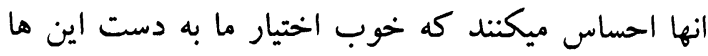
نيست اين ها اگر راى عدم اعتماد ياسلب اعتماد بدهند ممكن است از يكك مرجع ديگر جلو راى عدم اعتماد و

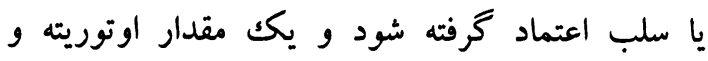

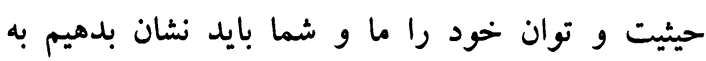
وزراء حال وزير صاحب صحت عامه بريروز آمد ديروز

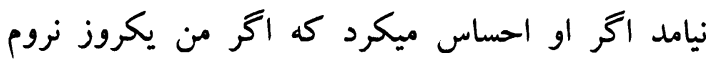
ممكن است به استيضاح كشانده شوم حتماً ميآمد ديروز

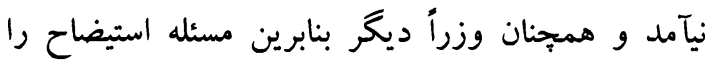

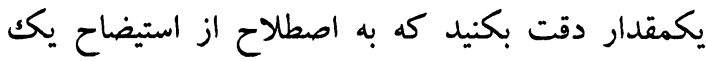

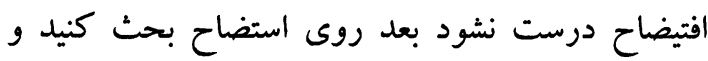
مسئله حالت اضطرار را كه عرض كردم.

انجينير محمد خان:

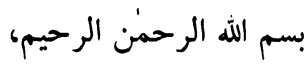

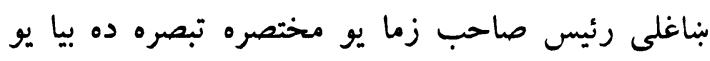

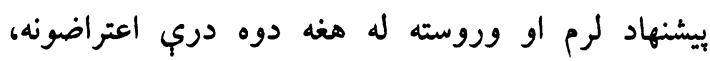

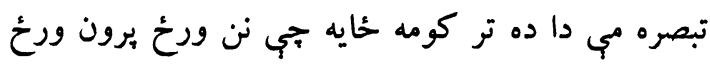

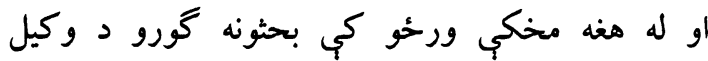
صاحبانو نظريات تول قابل د قدر دي ولبي د اقتصاد د د دئي

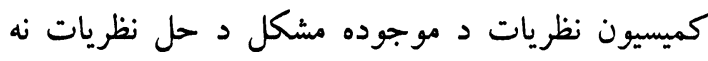

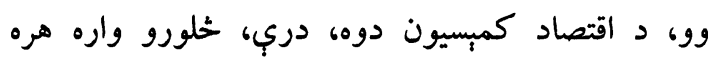

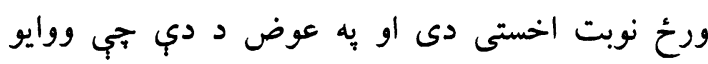
البته معلوم است كه كشور در يكك حالتى اضطرار و در البر

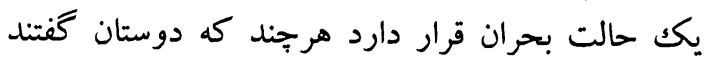
كه آمدن زمستان حالت اضطرار نيست ما هم اينرا قبو ل

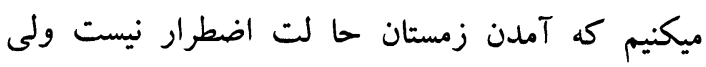

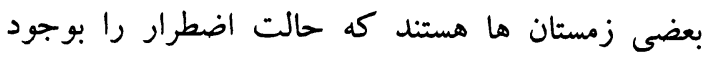

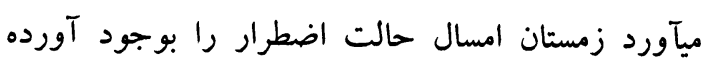
يكك واقعيتى است، آمدن سيل حالت اضطرار نيست ولى إنى

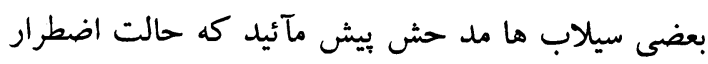

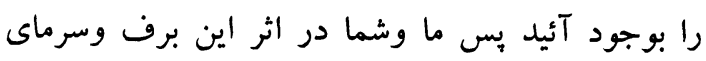

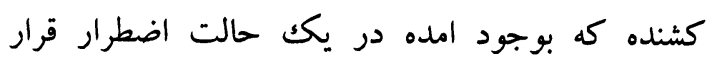
داريم، خوب ما دو بحث داريم بلكه سه بحث داريم يكى بحث اين است كه فعلاجه كار بايد بكنيم يعنى به به داريه كار بايد بكنيم كه بدرد مردم بخورد؟ بحث بحث دوم اينكه

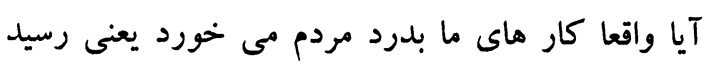

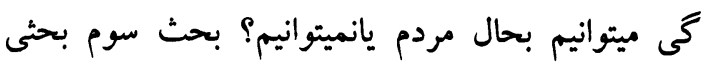

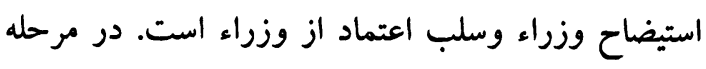

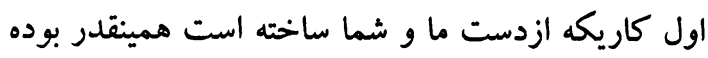

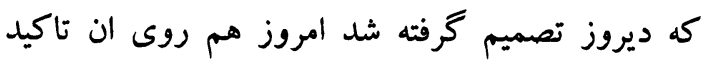
شد كه ولايات آسيب ديده همراى كميسيون اقتصاد

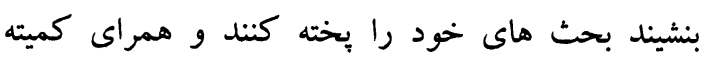

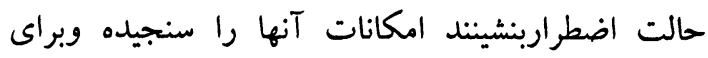
مردم كمكك بكنند ولى من مطئين هستم كه اكراين

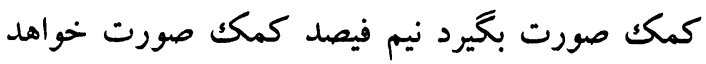

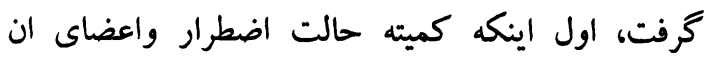
آنقدر امكانات ندارد كه كمكك كنند و ديكر اينكه وسايل ندارد كه كمكها را برساند و ديخر اينكه هزارها

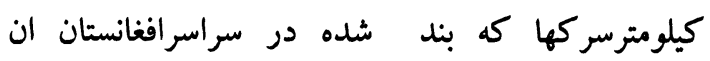

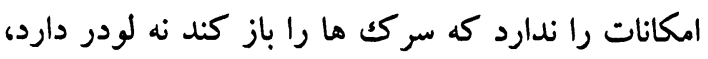
نه گريدر، نه ديخر وسايل دارد كه اين سركهارا باز

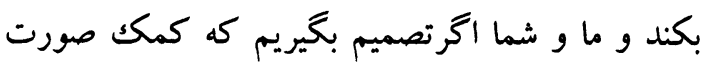

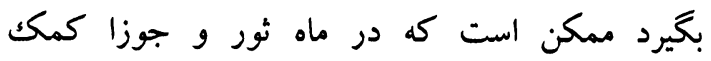

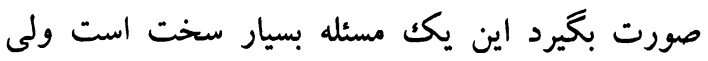
ميخويد (اكر آب دريا را اكرنتواند كشيد-هم به قدرى لينه 
كارآئي ومكورئ هغه دي راشي دلته دي تري يوبنته

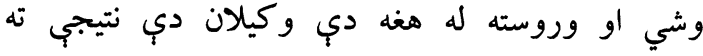

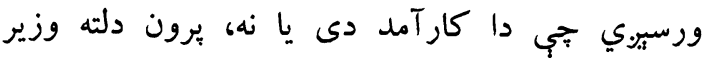

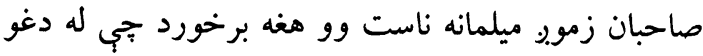

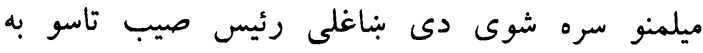

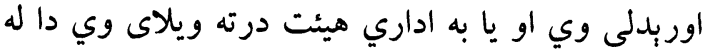

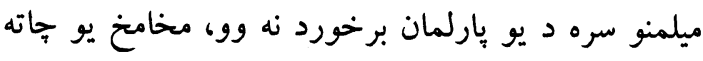

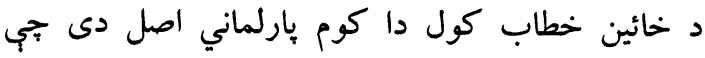

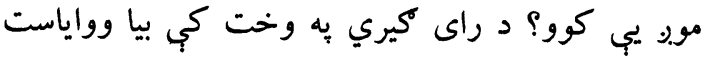

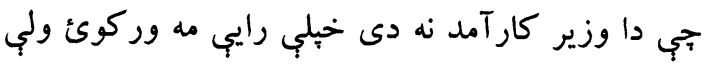
مخامخ يو جاته د خاين خطاب كول دابل دا خو نه اله افغاني

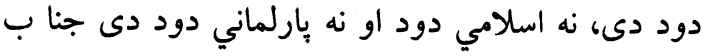

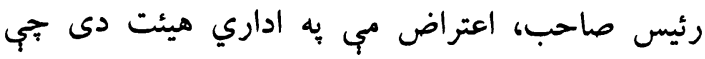

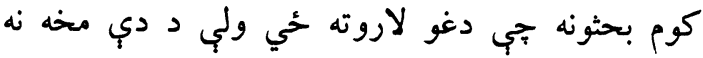

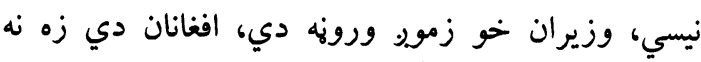

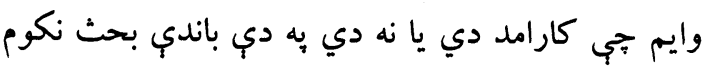

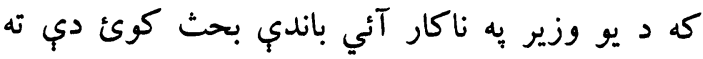

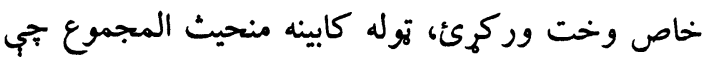

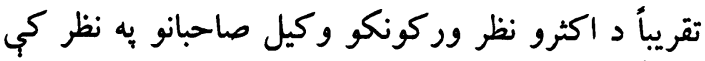

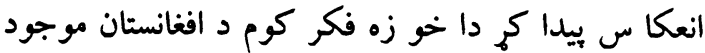
بحران او مشكل نشي حل كولي.

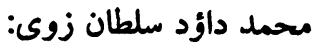

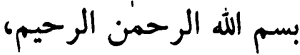
جناب رئيس! به برادر بسيار عزيزم انجينير صاحب بايد عرض بكنم كه كميسيون اقتصاد ملى ولسى جرئه كميسيون اجرائيوى نيست ما وظيفه ما نيست كئس كه

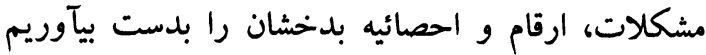

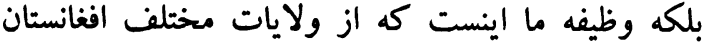

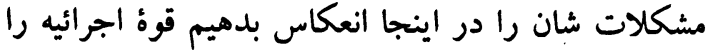
بخواهيم همرايشان صحبت كنيم كه Tيا آماده هستيد كه اين توقعات مردم را براورده بسازيد؟ آيا آماده هستيد

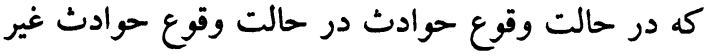
مترقبه شما وظايف خود را الجرا بكنيد؟ كميسيون اقتصاد

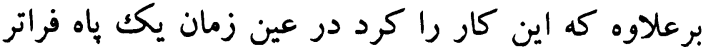
كذاشت و اعضاى كابينه را، وزراى مربوطه را خواستند

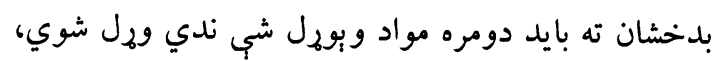

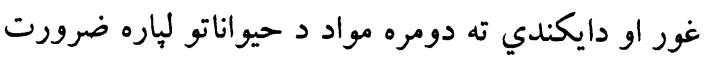

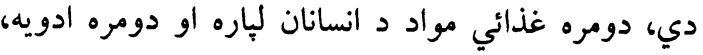

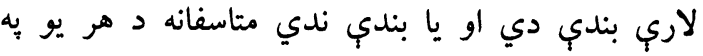

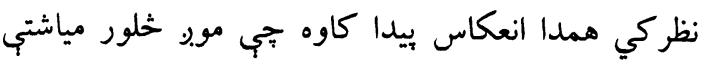

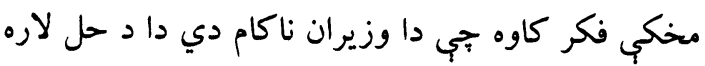
نده جناب رئيس صيب! خيل بيشنهاد مي دارد دي دي رئيس

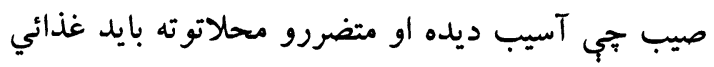

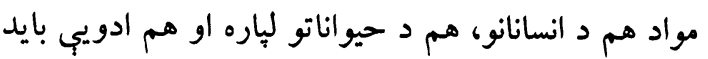

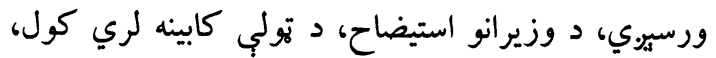

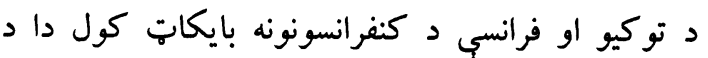

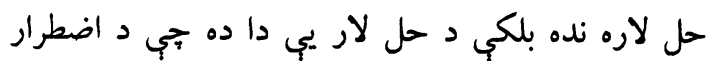

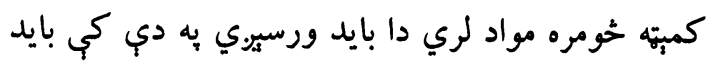

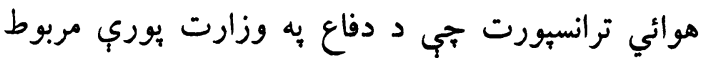

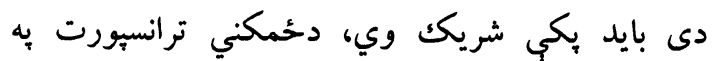

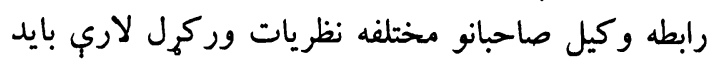

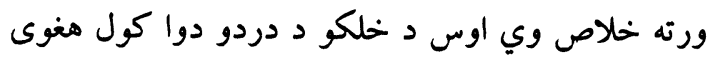

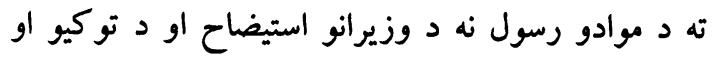

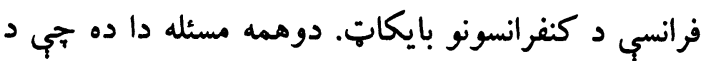

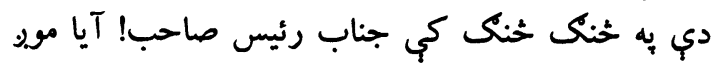
مواد لرو كه نه؟ به تاسف د اقتصاد كمبسيون تر اوسه

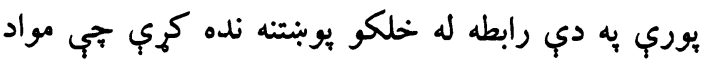

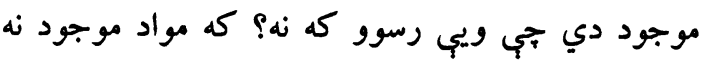

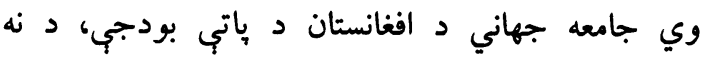
مصرف شوي بودجي كه جهاني بانكك ورسره موافق وي باني

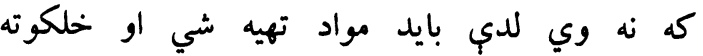
ورسيري(ادويه، غذائي مواد انسانانو او حيواناتو لياره).

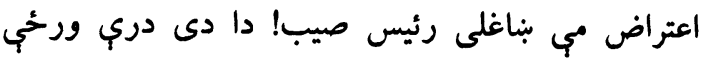
كيري بحث د خ خلكو، د متضررو كسانو، له منخه تللو

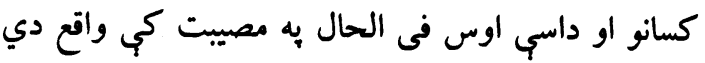

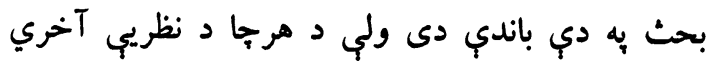

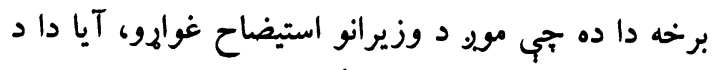

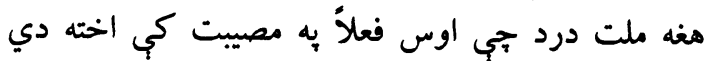

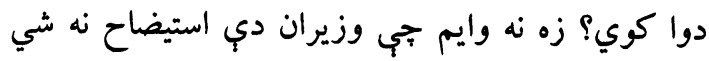

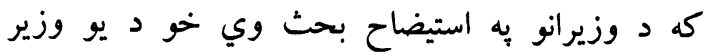


نداشتيد مجبور هستيد كه بحث هاى خود را دوام بدهيم

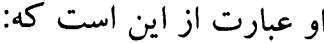

آقاى قاضى زاده امروز نمى فهمم كه از كدام آن بهام بهلو

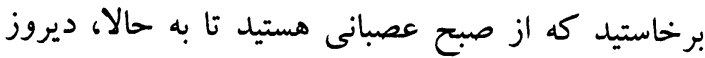

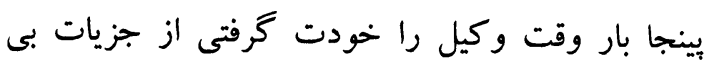
مورد گب زدى تا به آخر اجازه بدهيد كه ديخر وكيل

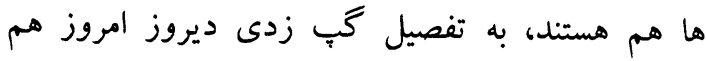
بيوسته بيوسته قاضى زاده صاحب از اخلاق هئيت ادارى به نهي

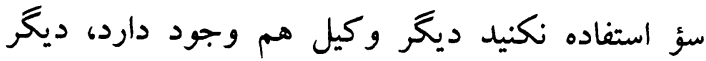

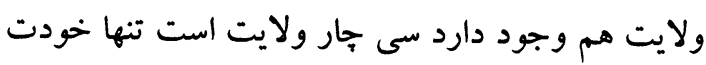

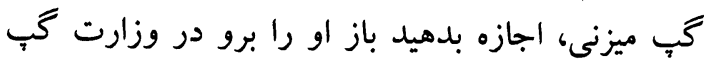

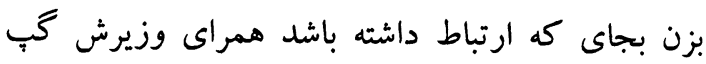

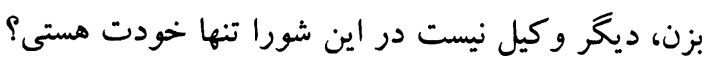

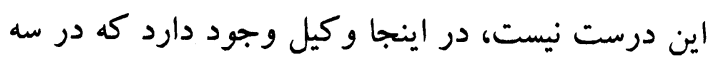
روز يك كلمه تاحال صحبت نكرده. وكيل صاحبان محترم! دوفيصله شما بدهيد، اكر صحبت راح رال دوام ميدهيد وكيل صاحب ها دوام بدهيد سر از فردا باز تكرار،

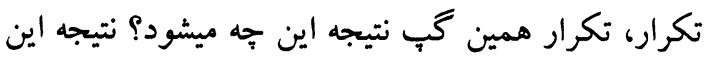

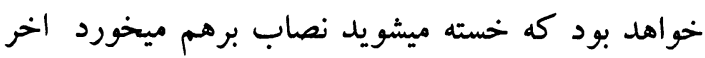

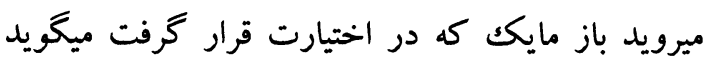

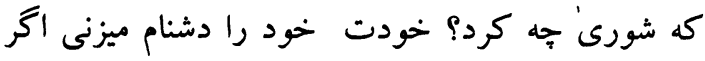
ميخواهيد كه به يكك نتيجه برسيد درد همان هموطن كه

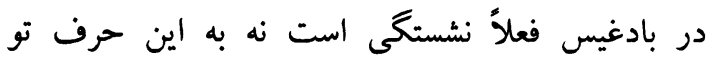

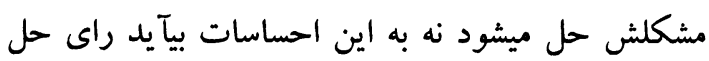

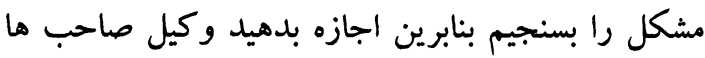

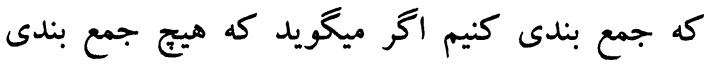

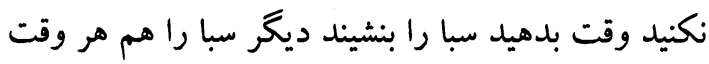

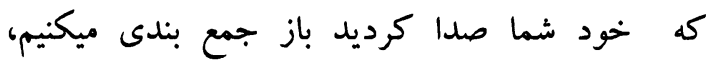
بنابرين وكيل صاحبان خوب دقت كند

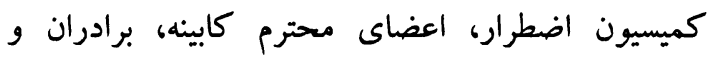

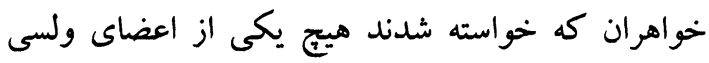

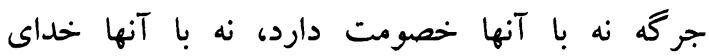
ناخواسته سمتيتى مخصوص دليليكه كه شما و كلا من بار

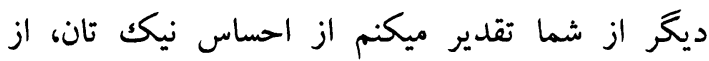

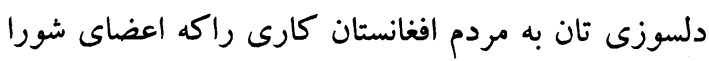

راجع به موضوعات حتى ما به ارتباط موضوعات منحيث

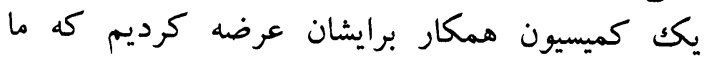
ميتوانيم همراى شما در اين موارد همكارى حتى بكنيم

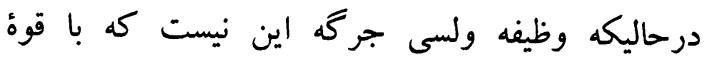

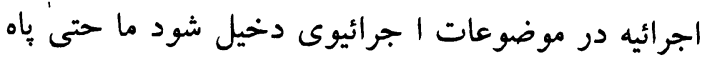
فراتر كذاشتيم كفتيم اين كار ها راهم ما اميدواريم كه ده دائه

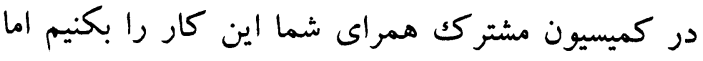
وظيفه كميسيون اقتصاد ملى اين نيست كه ارقام و اعداد

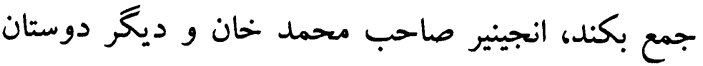

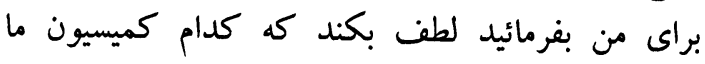
ظرفيت تخصصى و ظرفيت استف دارد ارقام جمع بكند

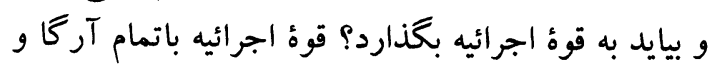

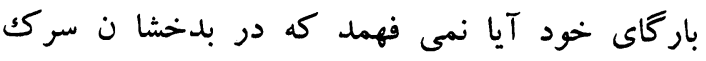

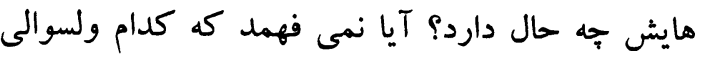

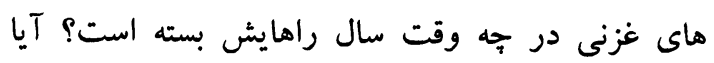

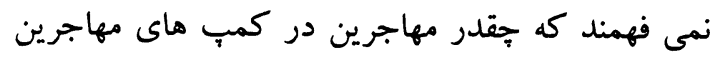
تشريف دارند و فرستاده مى شود به افغانستان؟ آيا اين

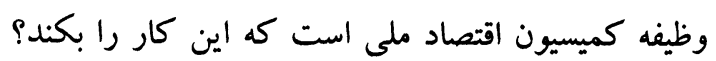

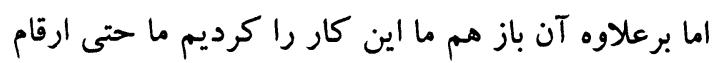

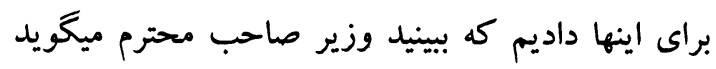
كه اين قدر غله ضرورت است اينقدر غله داريم، اينقدر ديخر وارد شود كميسيون اقتصاد برايشان كفت ما ما اينقدر غله نداريم ما اينقدر غله تخمين ميكنيم كه داريم ما دارد بين كميسيون اقتصاد تاجرها ملى داريم كه تمام ارقام

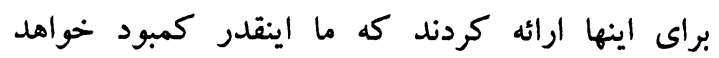
داشتيم همان راست برامده امروز جناب رئيس! ما اينجا

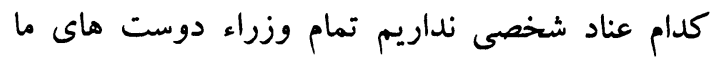

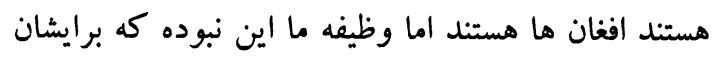
احصائيه بدهيم. رئيس مجلس: اگر زياد بحث رأ دوام بدهيم نصاب مجلس برهم

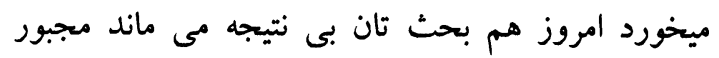

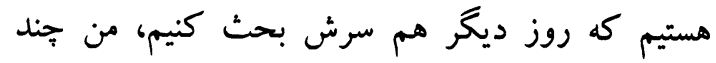

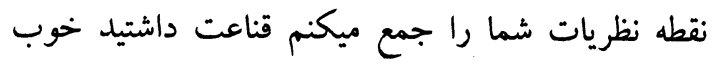


وزيرصاحبان ما موفق بودند، كميسيون منحيث كل

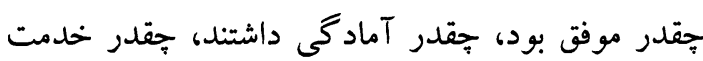
انجام دادند، جققدر انجام ندادند، برنامه هاى آينده ايشان

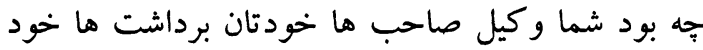

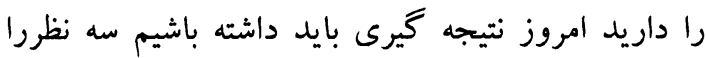
من از لابلا نظريات شما وكيل صاحب هارئ ها امروز بيدا

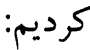
1- يكك تعداد از و كلاى عزيزما حرف شان به اين است كه نتيجه كار راديديم، گزارش را شنيديم، مردم مظلوم

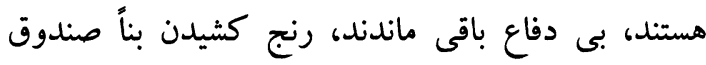

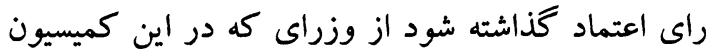
كار مى كردند از اينها سلب اعتماد صورت بخرد، يكك تعداد وكيل صاحب هاى ديخر ما اصطلاح آقاى نويان

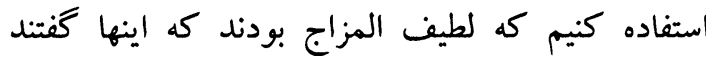

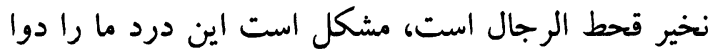
نمى كند گذاشته شود هيئت ادارى بشمول تعداد از از وكلاً بروند خدمت رئيس جمهور آنرا در جريان قضايا

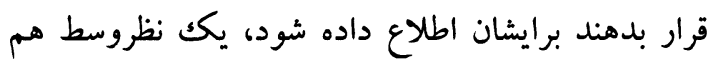
مطرح شد و آن اينست كه براى دوست هان مان مطرح

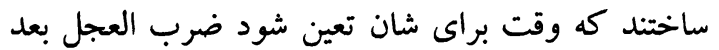
به استيضاح خواسته شوند، نظريرا كه من ميخواهئ تصنم خدمت شما عنوان بكنم وكيل صاحب ها تصميم را شما

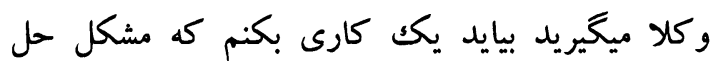

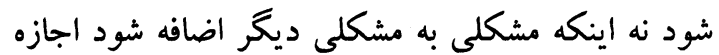

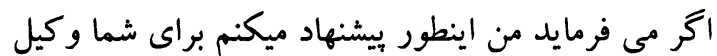

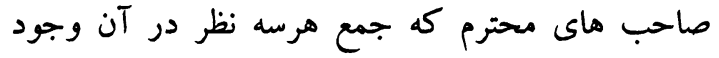

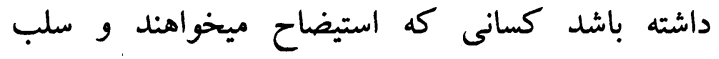
اعتماد، كسانى كه به فكر از اين هستند كه رئيس جمهور در جريان قرار داده شود، كسانى كه يكك مقدار

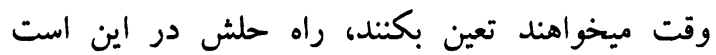

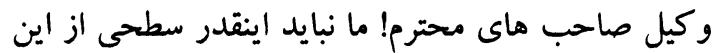
مسايل تير شويم كه حيثيت شورى به زمين بخورد، نبايد

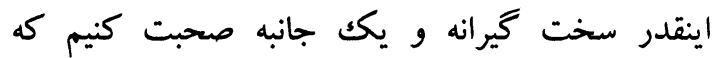
خداى ناخواسته باز هم حيثيت عملى بودن تصا ميم سورى زير سوال برود من اينطور از لابلاى نظرى شما
ميتواند انجا م بدهد استفاده از همين كار نظارتى است.

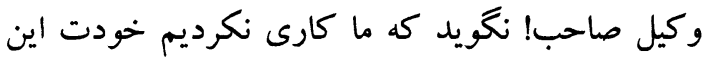
همين كار را انجام داده مى توانيد همينكه كميسيون را هاري

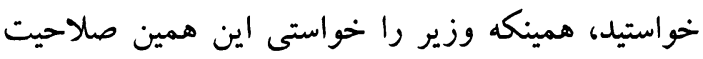

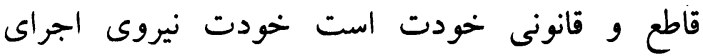
نيستى، خودت بلدوزر تهيه كرده نميتوانى، خودت

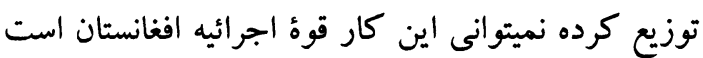

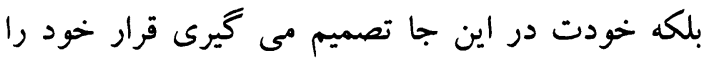
صادر ميكنى، خودت نظارت پيارلمانى ميكنى كه قانونى

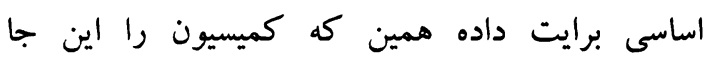

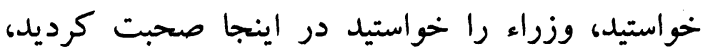

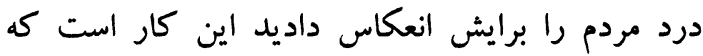

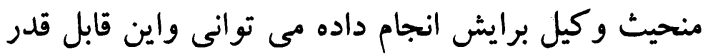

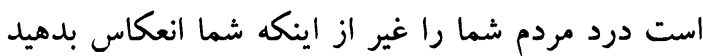
كى انعكاس بدهد؟ همين كار است وكيل صاحب ها نكويد كه كارى نكرديم. دو- وكيل صاحبان بين كار

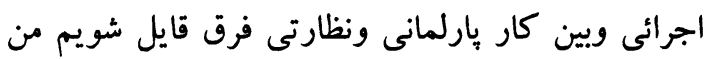

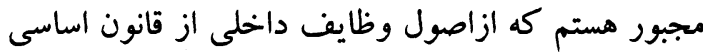

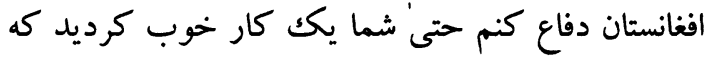
يكك صندوق اهانه باز كرديد اين كارتان قابل قدر است

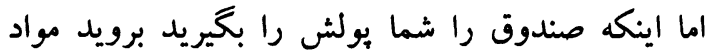
بخريد اين كار اجرائى است اين كار ما و شما نيست

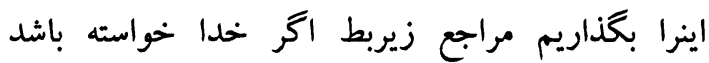
كارش را دنبال بكند. سه- وكيل صاحبان محترم از لا لا مرئ بلا ى صحبت ها ى سه روزه شما من سه نقطه را در

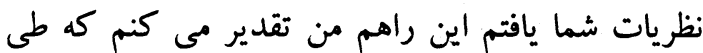

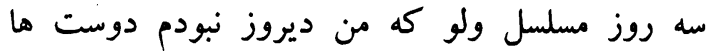

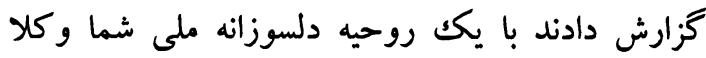

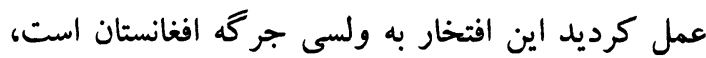

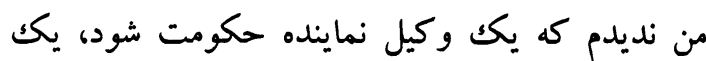
وكيل نما يند ملت شود اينرا من تقدير ميكنم قابل قدر يدر يند

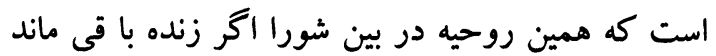

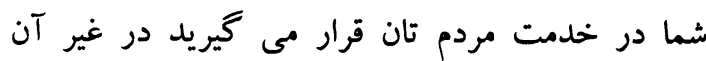

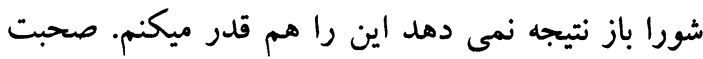
هاى كه صورت گرفت شما خودتان ديديد كه جقد إندر 
نقطه نظر عملى حه تغيرى در مردم بادغيس خواهد

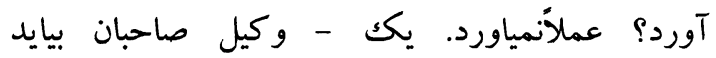

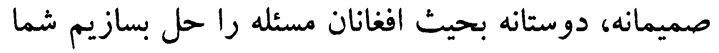
همين لحظه بيايد صندوق راى سلب اعتماد را بخَذاريد

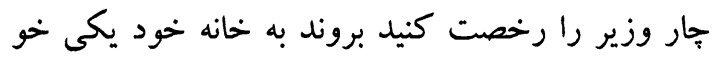
اصول وظايف داخلى خود را در مدنظر بخيريم. دو -

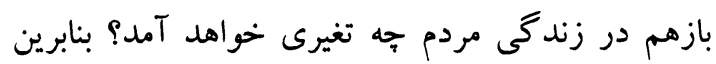

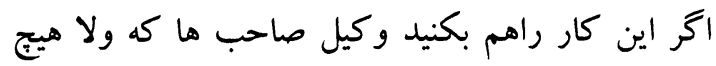

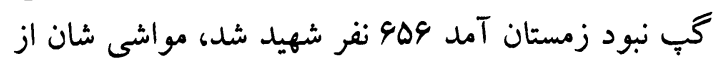

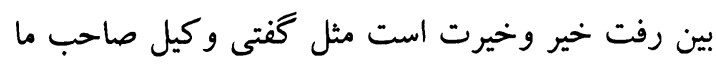

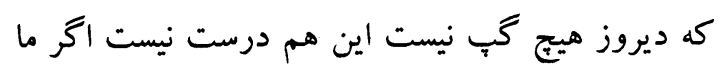

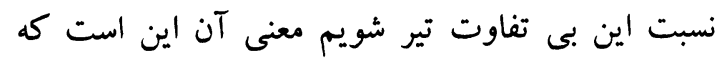

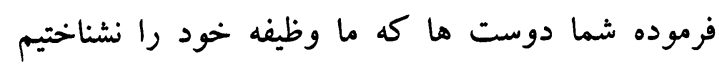
راى حل معقولش به همين است جانس بدهيد ضرب العجل تعين كنيد كه برويد وزير ما، رئيس ما، مدير ما مان ماند در خدمت مردم قرار بحيريد مشكل آنهارا حل كنيد

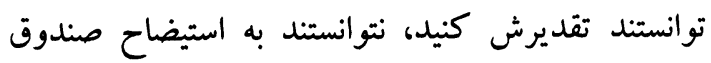

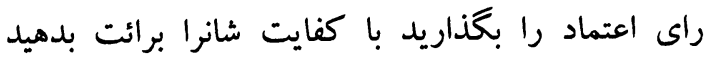
خداى ناخواسته كسى كه موفق نبود سلب اعتماد كنيد.

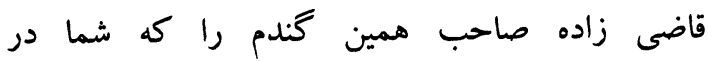

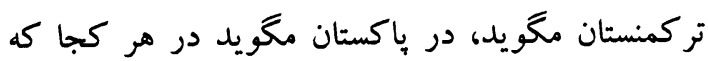

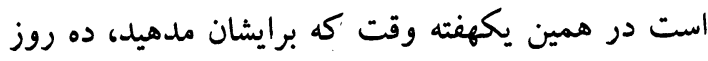
وقت كه برايش ميدهيد جز وظيفه آنها همين است كه

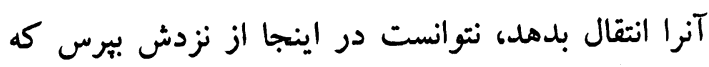
وزير صاحب جرا نتوانستى؟ درست است؟ موافق كارت

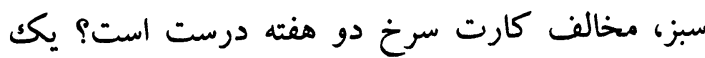

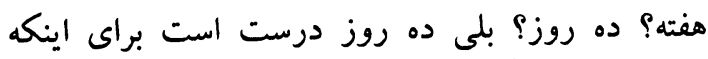

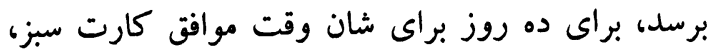
مخالف كارت سرخ درست است به اكثريت بر آراء تصويب شد در ده روز ضرب العجل موفق بودند خوب نبودند مى آيند استيضاح و صندوق سلب اعتماد، تشكر. "واخر دعوانا آن الحمدلله رب العالمين. "

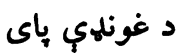

بيشنهاد ميكنم كه اهمين حالا مردم ما 909 نفر به ارقام

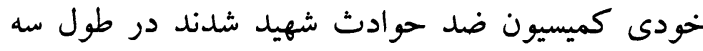

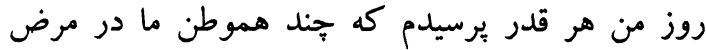

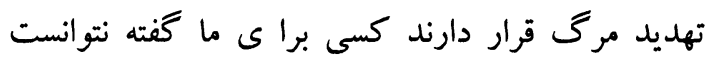

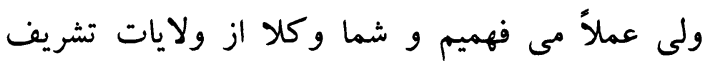

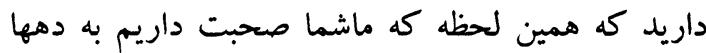
طفل، زن، مرد هموطن ما در مرض تهديد مرى هر قرار

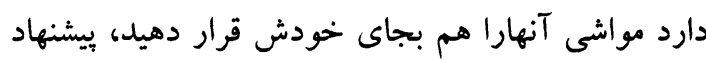

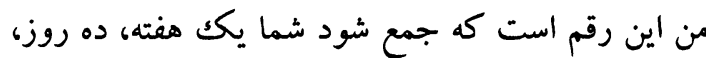

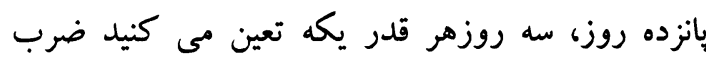

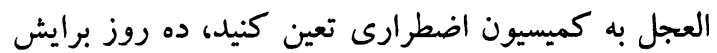

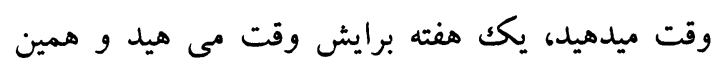

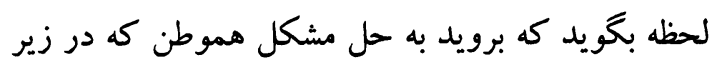

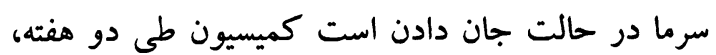

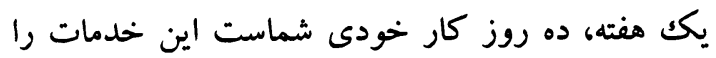

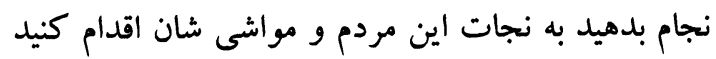

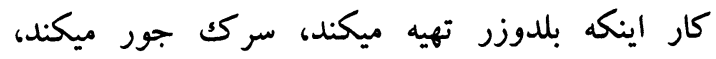
تراكتور ميخرد اين كار ما نيست كار اجرائى است بهور خودشان مى فهمد و كارشان در ختم ده روز يكار يكهنته،

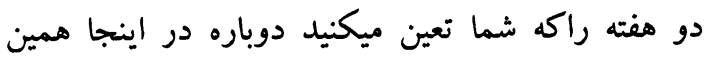
كميسيون را و وزراء را شما دوباره به شورى بخ بخواهيد

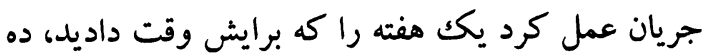

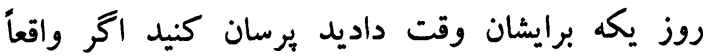

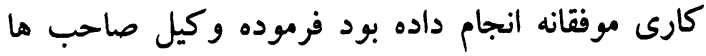

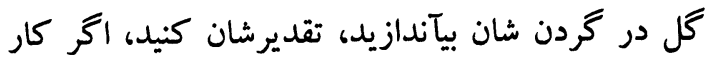

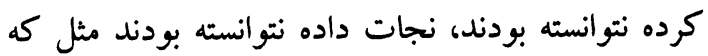

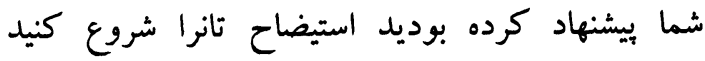
صندوق سلب اعتماد را برايش بخذاريد راى كه ميتواند هم مشكل مردم حل شود نظريات شما جمع شود به نظر

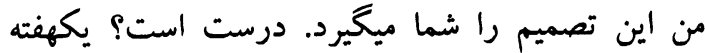

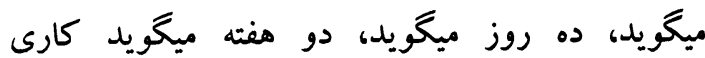

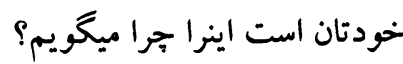

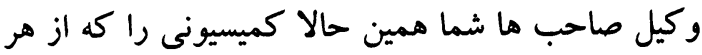
ولايت بيآيد با كميسيون اقتصاد ملى ما برود بنشيند مئ براي توحيد مشكلات ولايات ما كارى خوب است اما از 
محترم مذكور در تماس شديم كه قانون مذكور از بين نميرود اگر اداره از بين برود عيبى ندارد، قانون به جاسى

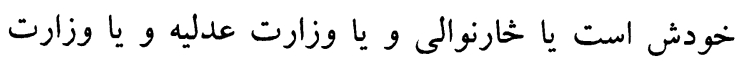

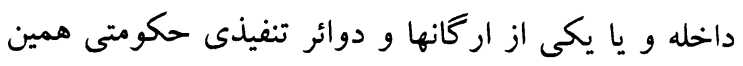

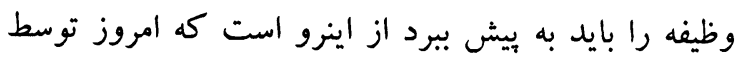

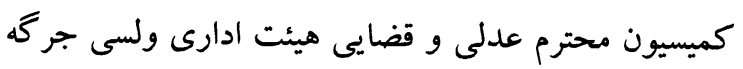

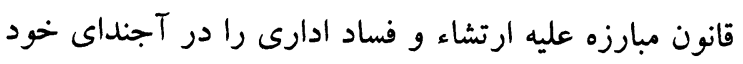
دارد .

$$
\text { نائب منشى : }
$$

و كلاى معزز يكك جيز ديخر را هم خواستم كه خدمت

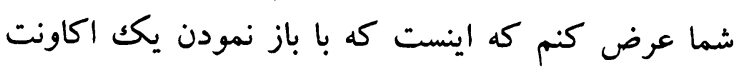

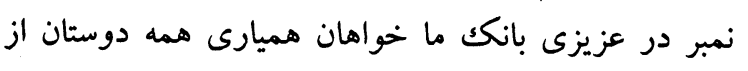

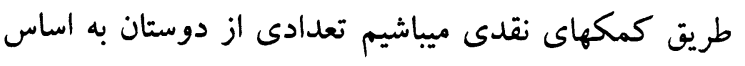

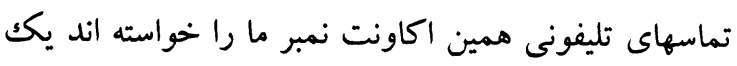

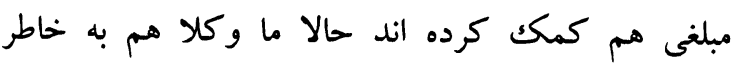

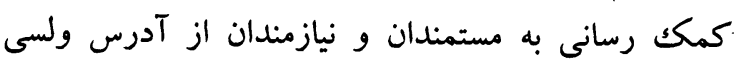

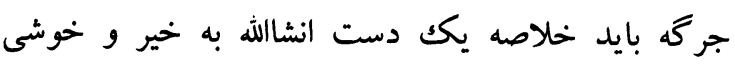

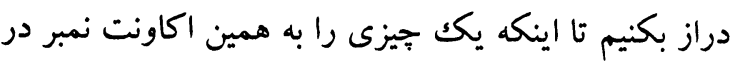

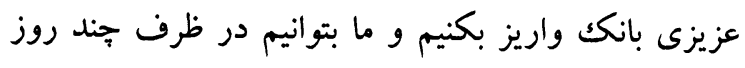

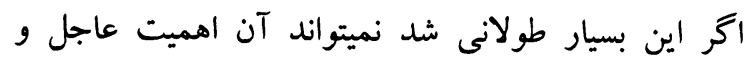

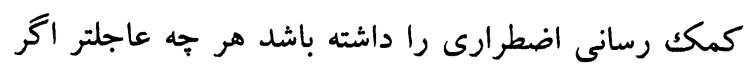

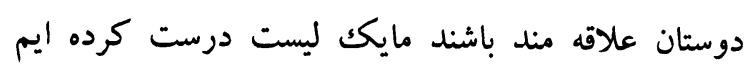
همين ليست هر كس به اندازه وس، توان و رضايت خهود يكك جيزى كمكك كنند تا ما به آن شماره حساب انتقال بدهيم و بعد هم از طريق خود وكلا از آدرس ولسى دهى

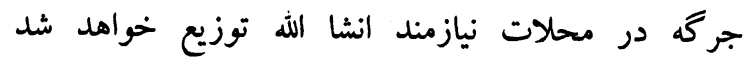

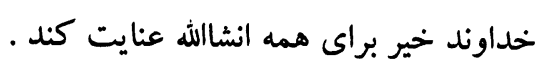

صديق احمد عثمانى : بسم الله الرحمن الرحيم، مئماني جناب منشى صاحب همان قسمى كه شما صحبت كرديد

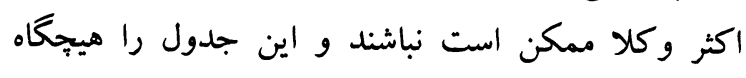

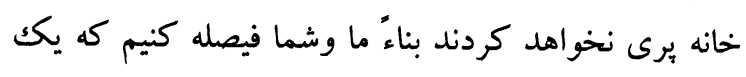

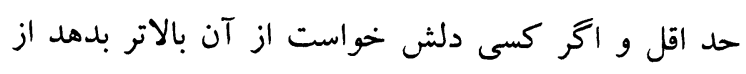

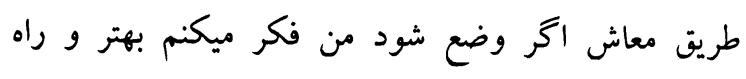
آسان خواهد بود در غير آن وكلاى كه اينجا حضور
د IrA\& مجري لمريز كال د سلواغي د مياشتي IV مب نتهب بشيه ريوت .

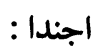
بحث روى قانون مبارزه عليه ارتشاء و فساد

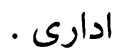
حسابات قطعيه سال ع^شا و ادرى

$$
\text { بائب منشى مجلس : بله الرحمن الرحيم، }
$$

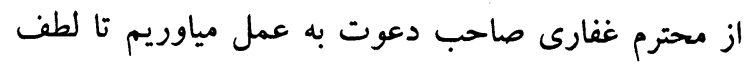

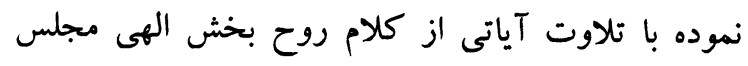
امروزى ما را نورانى بفرمايند. تلاوت قران كريم توسط شيخ نعمت الله غفاري . ..... نائب منشي مجلس : جلالتمآب رئيس لطف نموده مجلس امروزى ما را رسماً شروع نمائيد . مالاتئ رئيس ميرويس ياسيني د ننتي غونلهي رئيس :

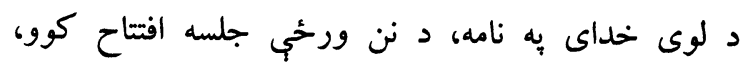

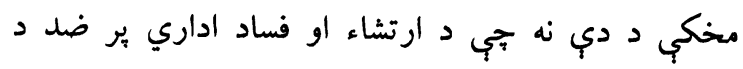

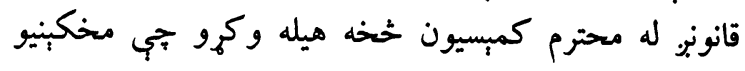

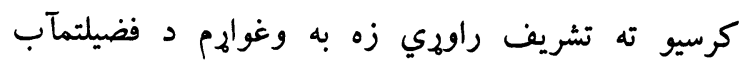

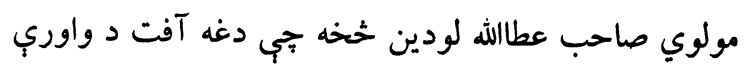

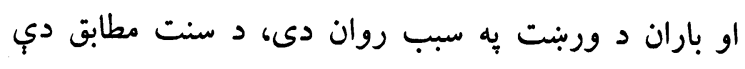

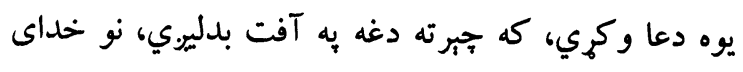

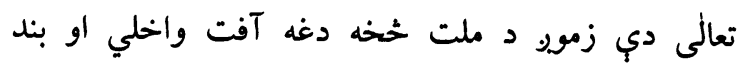
كمي . نمالي دي مولوي عطالله لودين د وربنت د كتورتيا له هاره دعا وكره . روك رئيس مجلس : قبل از اينكه كميسيون محترم عدلى و قضايى به كار خود

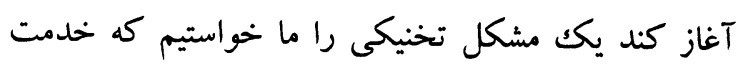

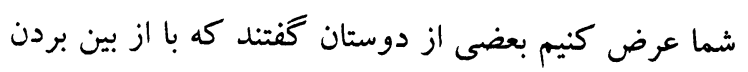
اداره ارتشاء و فساد ادارى تشكيلات اساسى دولت اين إن دوني

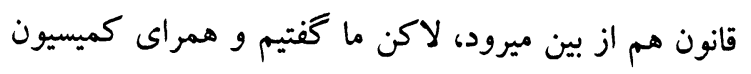


زبو ويونكو كور ده ولي دا مون. په ستر كو باندي وينو تجب

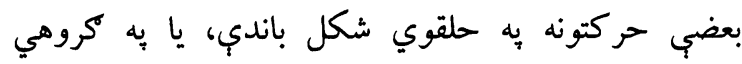

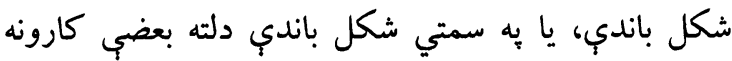

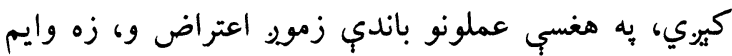

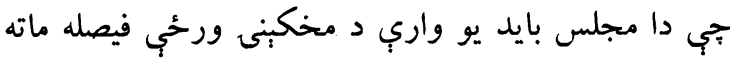

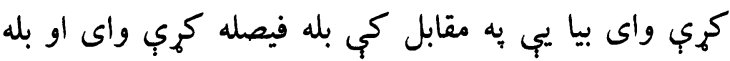

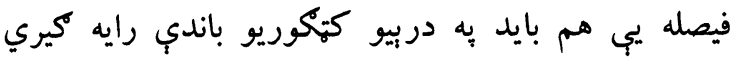

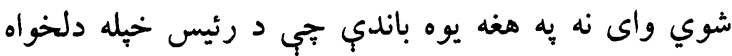

وه، تشكر ! سوي له

انجنير محمد خحان :

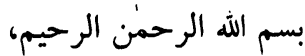

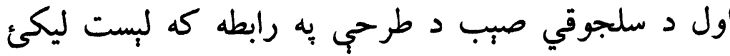

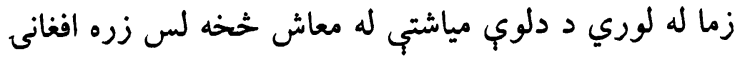
يه همدي يادداشت كي وليكئ دا يوه مسئله، دوهمه جناب لئه

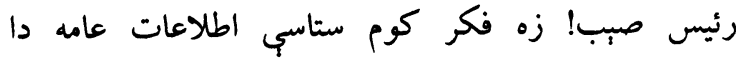

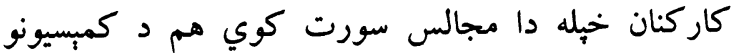
مجالس، كوم تجي يب زهه وي هغه نشر ته سياري او كوم جي زهره يبي نه وي هغه نشر ته نه سياري، يه دي دي رابطه موير

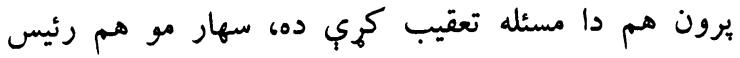

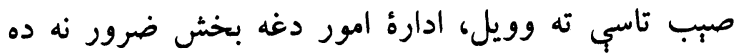

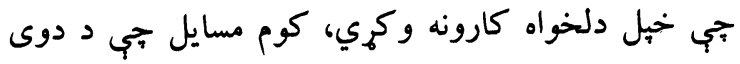
زهره وي هغه تلويزيون ته وركمي او نشر ته يب وسباري او كوم جي يي زلهه نه و هغه دي نه سياري، د هغه جملي نه

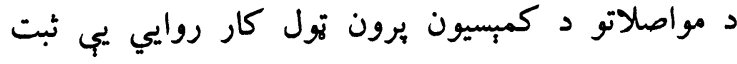
شوي هم ده تر هماغه مرجع يوري تجي بايد ملي تلويزيون

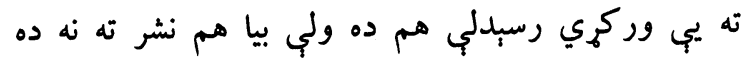

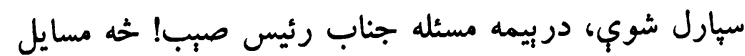

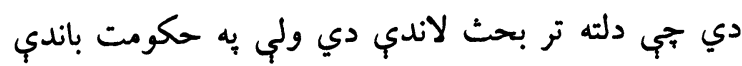

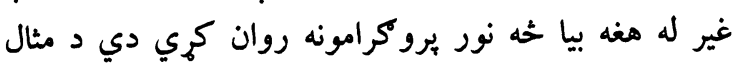

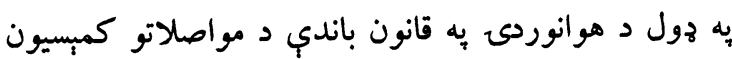

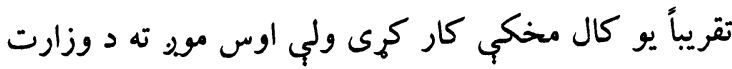

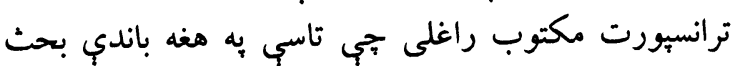

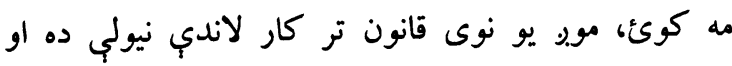

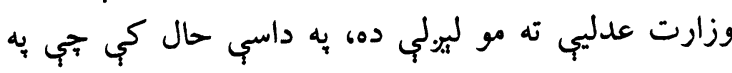

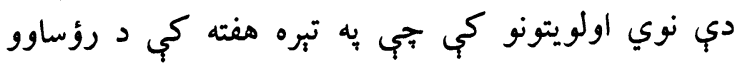

نخواهد داشتند هيجحًاه از آنها يول كرفته نخواهد شد

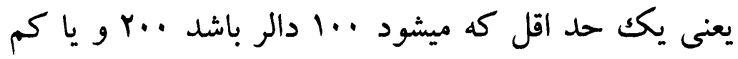

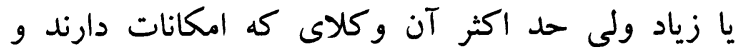

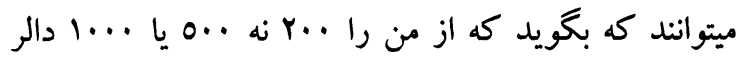
وضع كنيد ولى حد اقل تثبيت شود و از طريق معاش وضع شود .

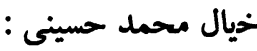

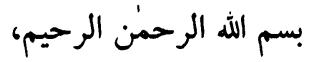

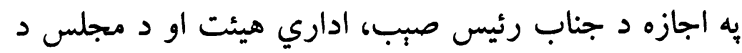

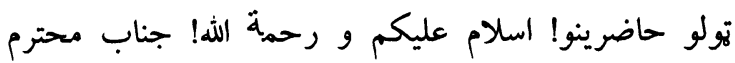

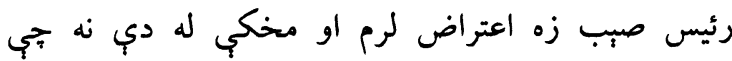

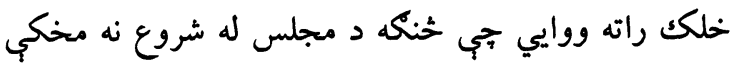

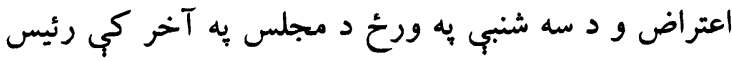

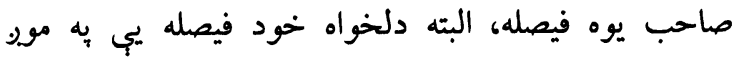

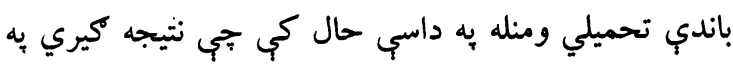

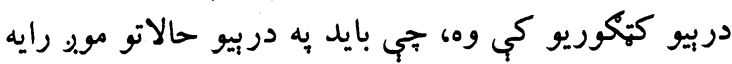

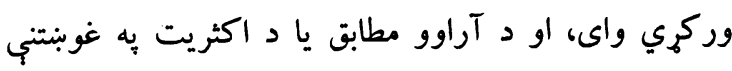

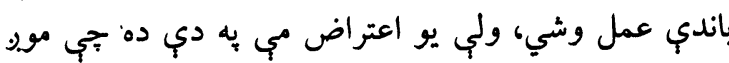

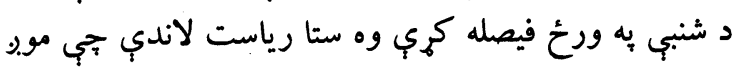

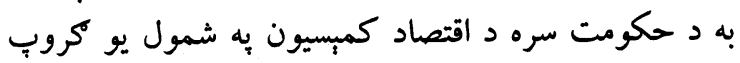

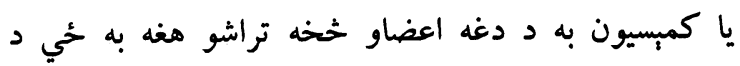
حكومت له دغه اضطراري كمبسيون يا كميتي سره به به به ديه

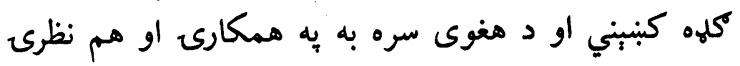

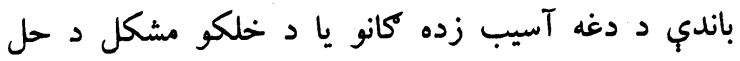

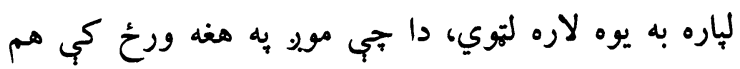

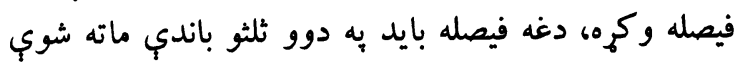

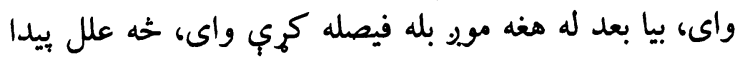

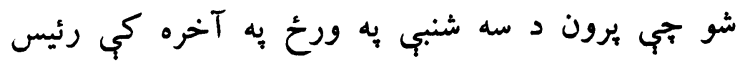
صبب هغه فيصله نقض كرهه او يه مقابل كي يجي بي بله فيصله

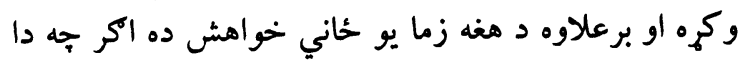

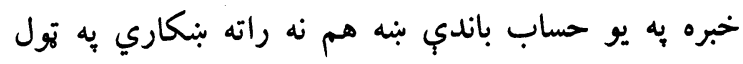

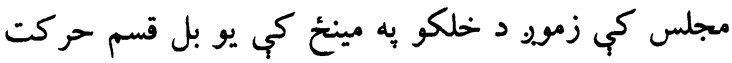

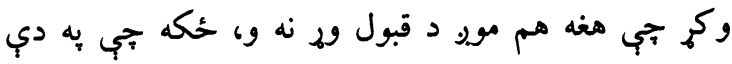

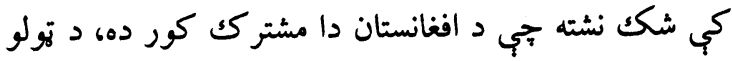

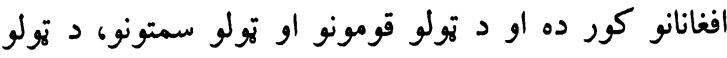


مولوي عطا الله لودين :

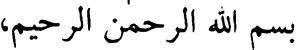

دوستانو! تاسو ته معلومه ده تجب د تبري تقنيني دوري به به

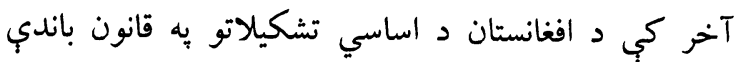

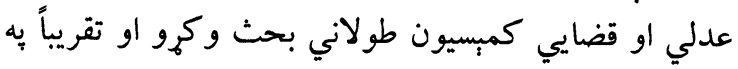
آخري ورخو كي دا بحث نهايي شو، ما سوا د دوه، دري موضوعاتو نه جب هغه ضمائم و د اساسي تشكيلاتو ضمائم

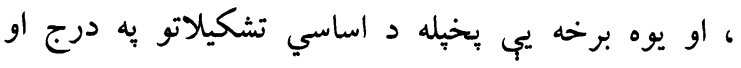

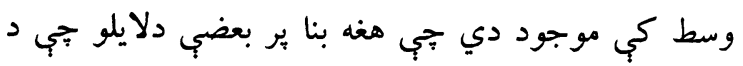

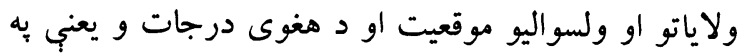

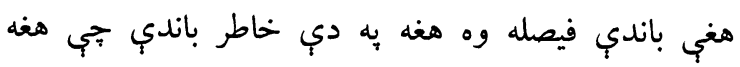

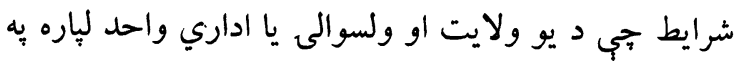

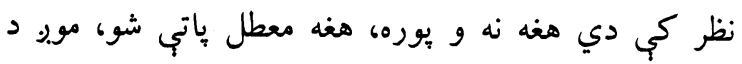

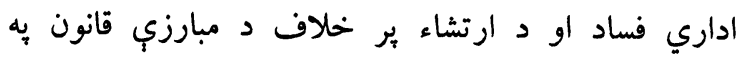
هماغه وخت كي به دي خاطر باندي معطل كم جي ولهي ولسي جركي ته د عدلي او قضايي كمبسيون د هغه دلايلو ير بنا

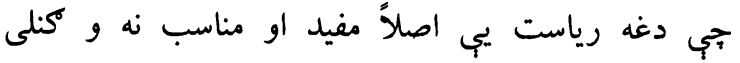

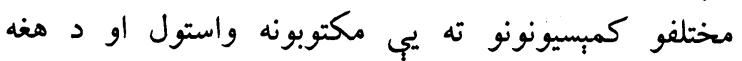
مكتوبونو خوابونه راغلل كمبسيون ته، بالاخره به ولهيه ولسي

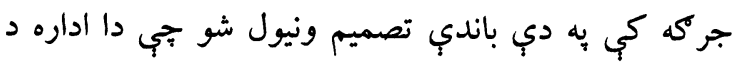

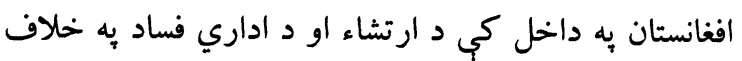

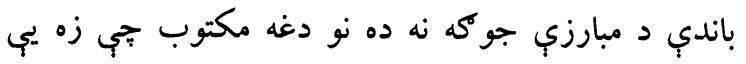

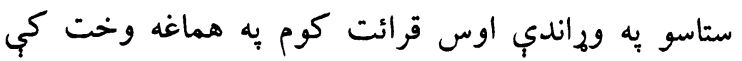

$$
\text { 11 كمبسيونونو ته وليره هغه دا ده : }
$$

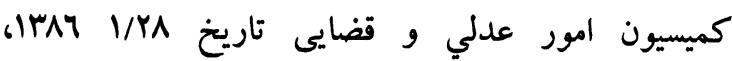
كميسيون امور عدلى و قضايى جهت عملى ساختن تقسيم

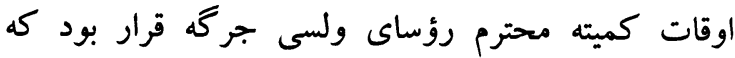

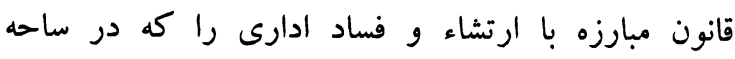
صلاحيت اين كميسيون است مورد غور و بررسى قرار

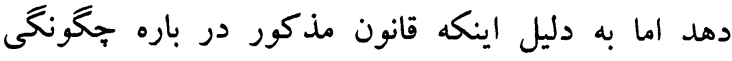
مبارزه با فساد ادارى نبوده بكله وظايف وصله وصلاحيتهاى

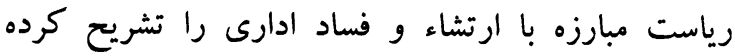

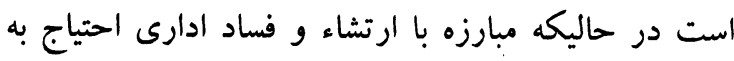

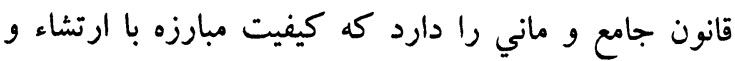

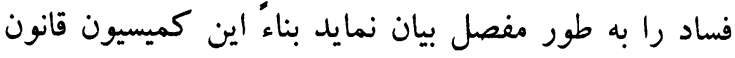

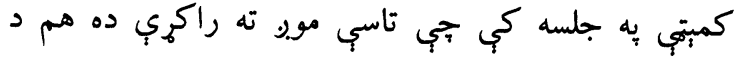

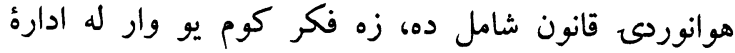

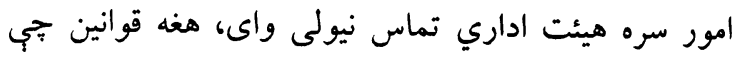

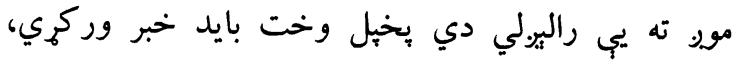

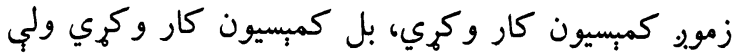

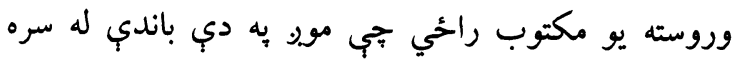

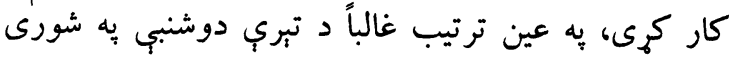

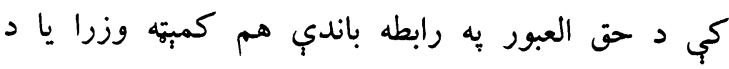

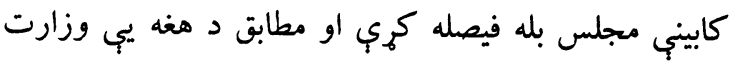

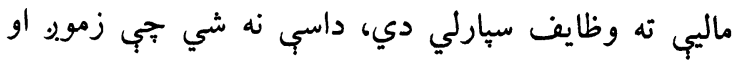

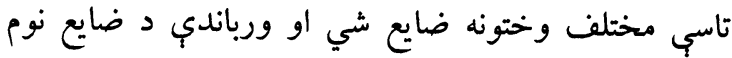

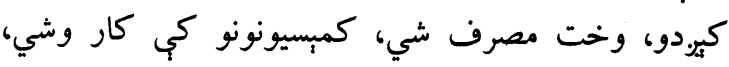

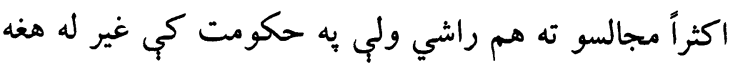

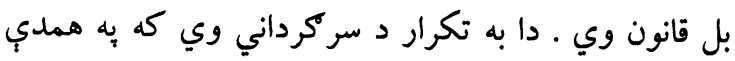

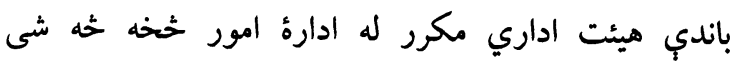
غوبنتي واى، مننه ! رئيس مجلس :

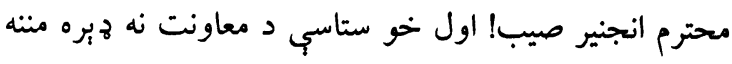

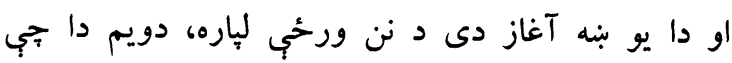

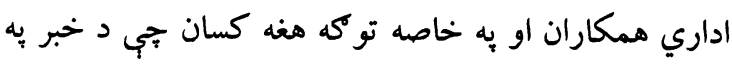

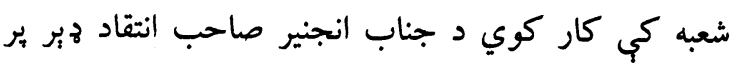

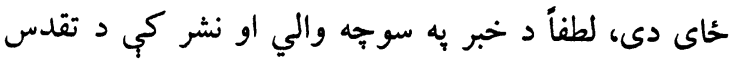

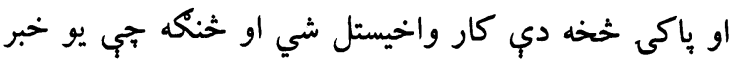
وي هغسي بايد نشر شي، يعنب بخهيله خوبنه به دا دارئه

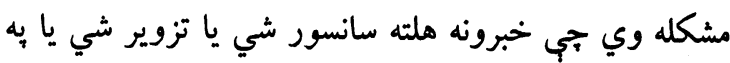

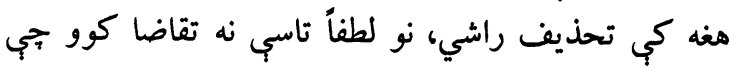

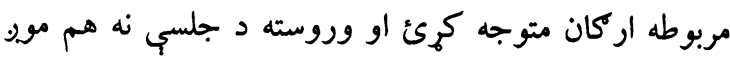

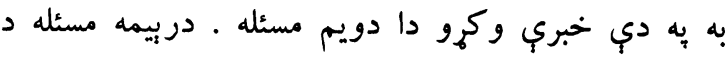

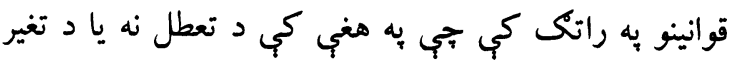

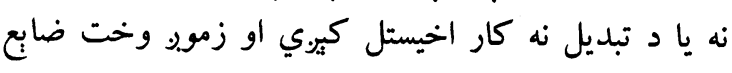

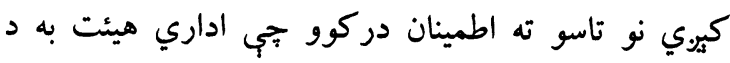

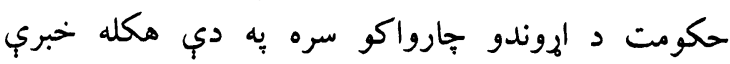
وكمي جب د دي نه مخنيوى وشي او دا معضل به انشالله حل كرو . حل 
ششم : در تعديلات توحيدى تشكيلات اساسى دولت نيز اكر كميسيونها بر حسب رياست مبارزه با ارتشاء و فساد ادارى تأييد داشتند.

بناءً دلايل فوق الذكر كميسيون عدلى و قضايلى خواهنان

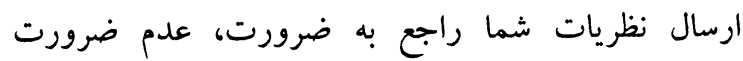

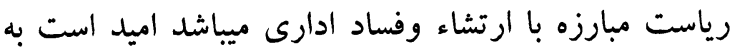

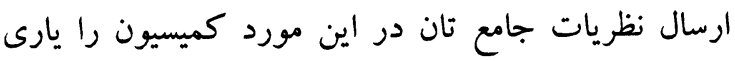

دا هغه مكاتيب دي جبي د مختلفو كمبسيونونو خخخه به دي سلسله كب موب. ته رارسبدلي دي، زه فقط دئ دو كمبسيونونو

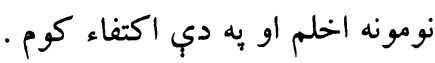

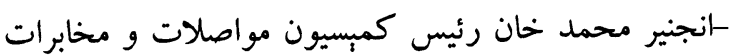

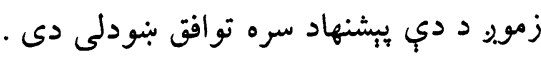

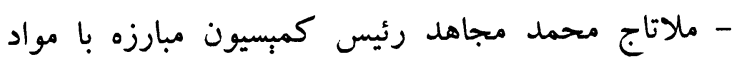

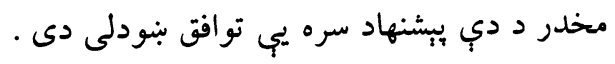

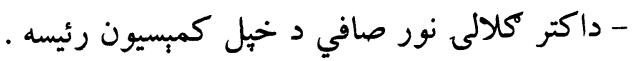

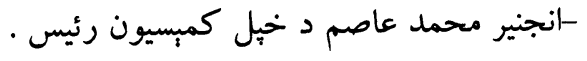
- سيد مصطفى كاظمي مرحوم د خهيل كمبسيون به به نماينده كي تاييد كرى . سيد معطى - استاد برهان الدين رباني د خجيل كمبسيون به نماينده كي باندي . - فيض الله ذكي رئيس كمبسيون منابع طبيعي و محيط زيست.

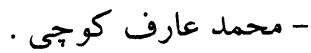

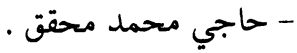

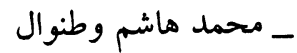
جي يو تعداد مكتوبونه لا زموي لاس ته نه دي راغلي، يا

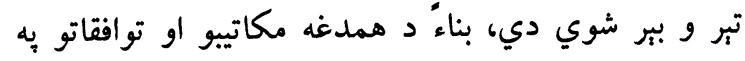

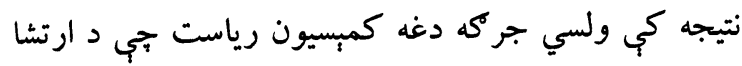

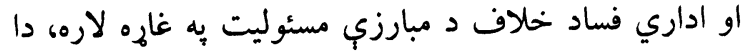

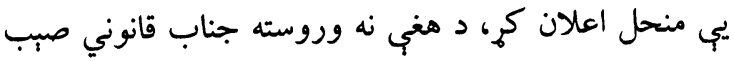

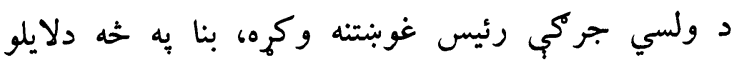

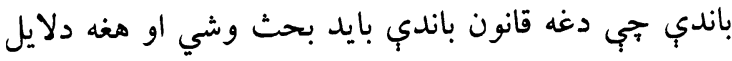

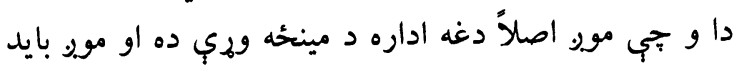

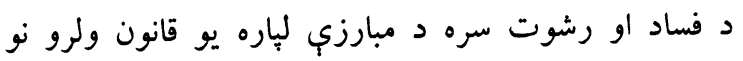

مذكور را قابل بحث ندانسته علاوه بر آن بيشنهاد مينمايدتا

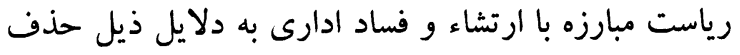

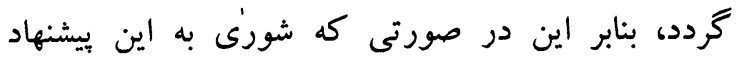

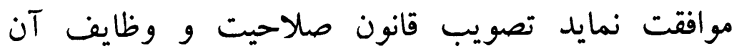
رياست لغو خواهد بود . موافيت

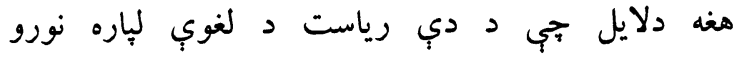

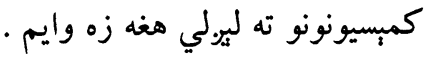

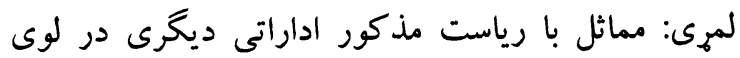

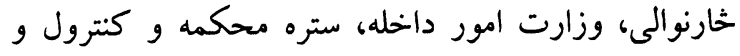
تفتيش وجود دارند كه به نحوى وظايف مشابه رياست ورن

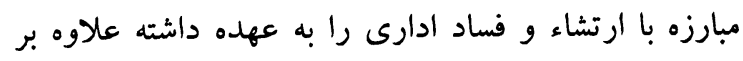

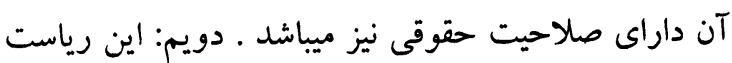

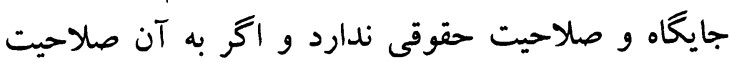

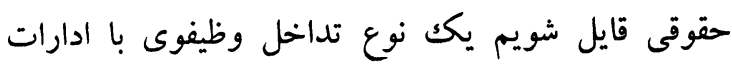

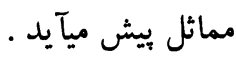
دربيم: در ديدارى كه اعضاى كميسيون امور عدلى و ولئ

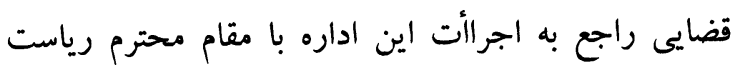

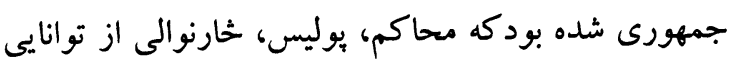

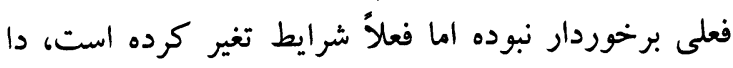

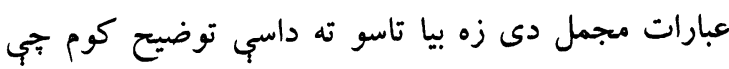

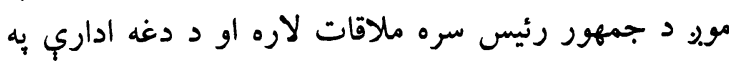

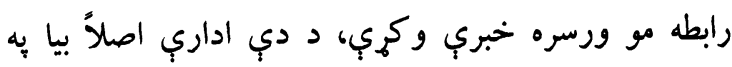

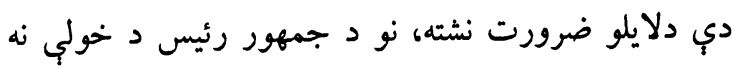

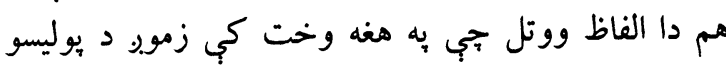

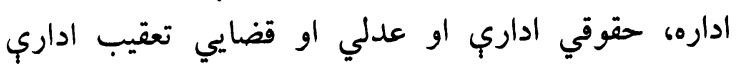

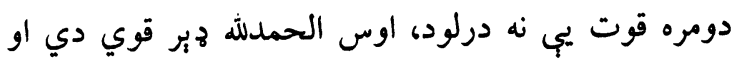

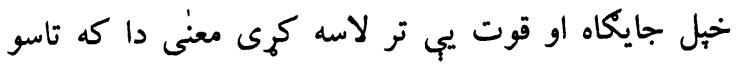

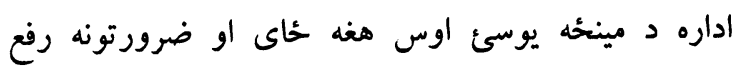
شوي دي، د دي مطلب دغه و .

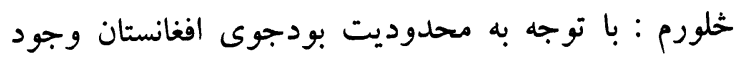

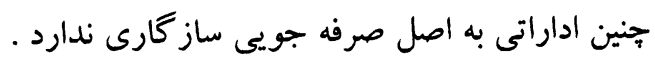
ينجم : اين رياست در طول مدت فعاليت خويش تا كنون دستآورد قابل ملاحظة نداشته رياست در طول مدت فعاس . 
اخلالوي او د همدي قانون If مه ماده بِه دي صراحت لري او هغه داسي وايي بجي: ( احكام اين قانون وظايف و واده صلاحيتهاى مندرج در اسناد تقنيني نافذه ساير ادارات

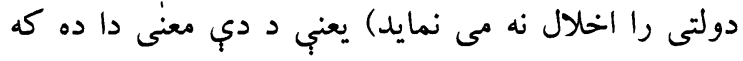

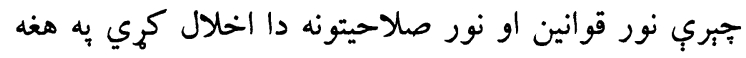

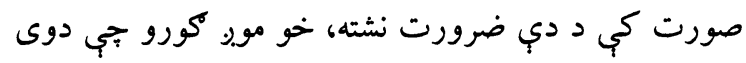
به يا د كشف وظيفه ترسره كوي جي دا دا د دوى ديه

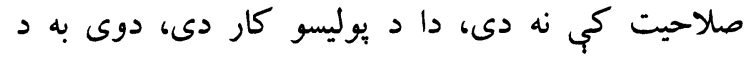

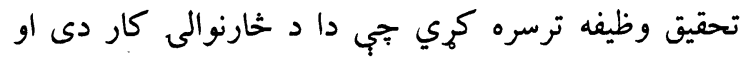

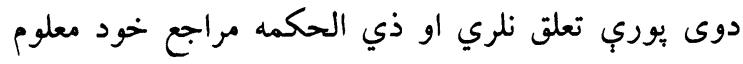

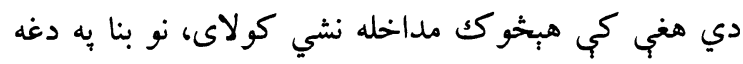

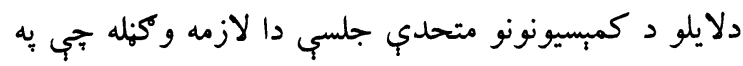

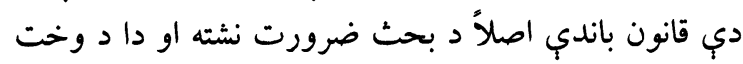
ضياع ده، راغلو د هغه دلايلو يه حصه كي جناب باب قانوني

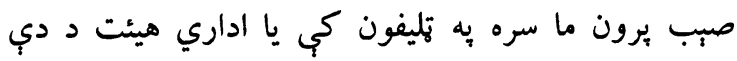

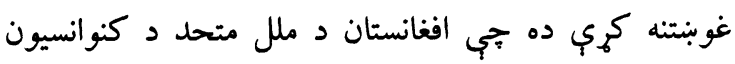

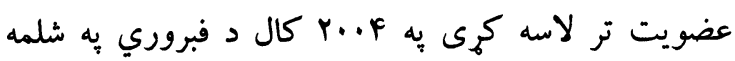

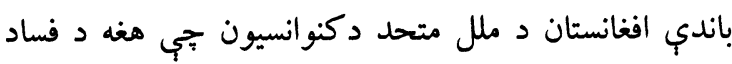

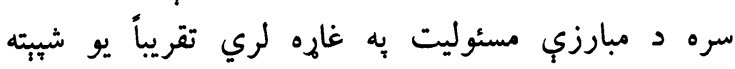
هبوادونه يي عضويت لري، افغانستان هم دا تعهد امضاء

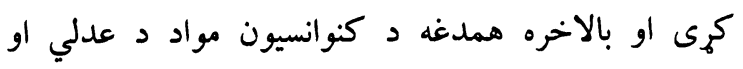
قضايي كمبسيون له طرفه ولسي جركي ته راغله او بلاخره

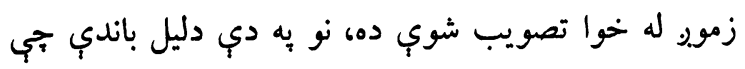

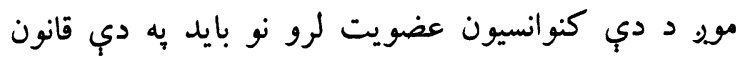

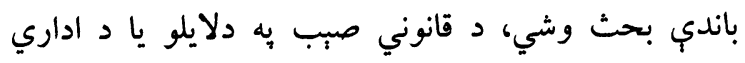
هيئت به دلايلو يوه خبره دا وه او د هغبي نه علاوه دي دو فساد

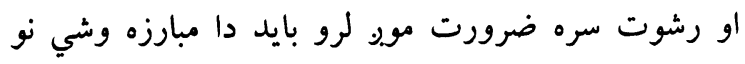

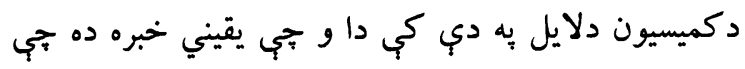

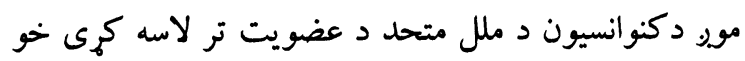

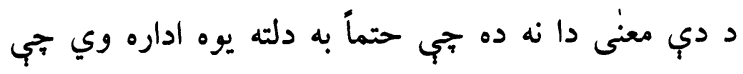

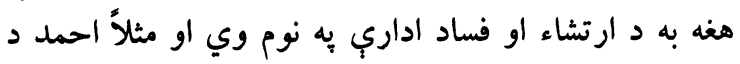

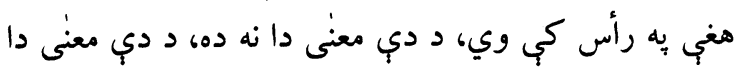

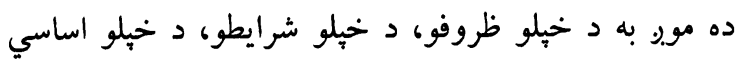

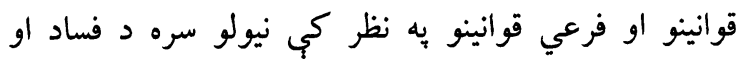

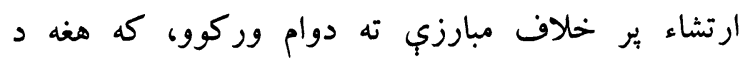

فلهذذا بايد بهه دي قانون باندي بحث وشي، كه دا اداره نه

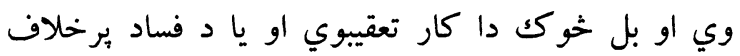
مبارزه كوي نو بايد يو قانون ورته ولرو نو هماغه و و تجي وني

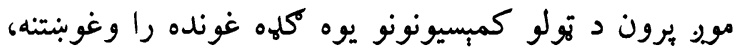

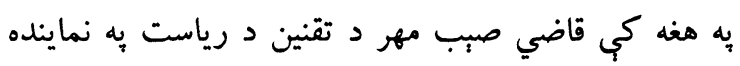

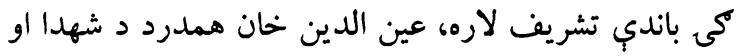

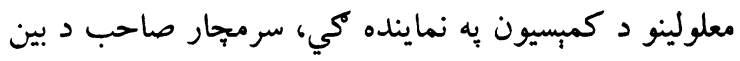

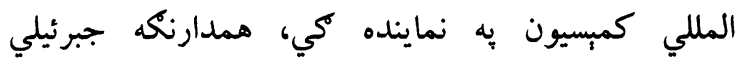

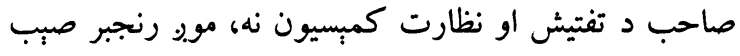
ته هم دعوت وركمى و حجي بايد دوى راشي، فهيمي

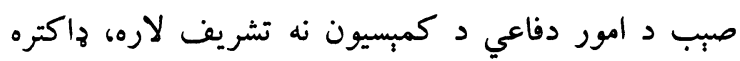
كلالى نور صافي د صحت د كمبسيون نه تشريف لاره او

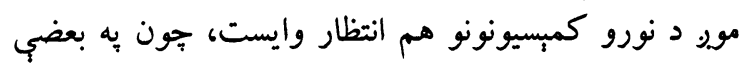

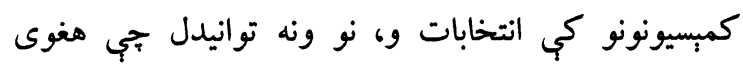

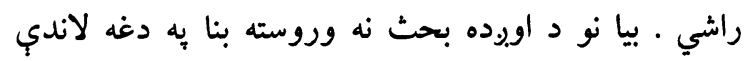
دلايلو باندي جي هلته هم ذكر شوي دي او دي دود دوست وستانو

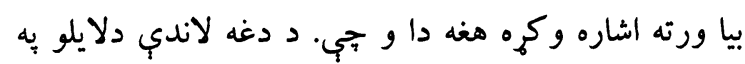

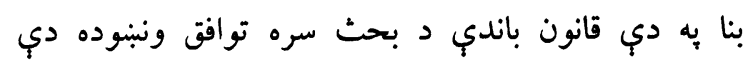

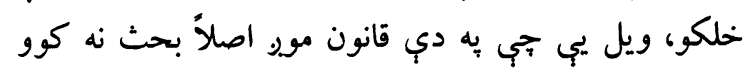

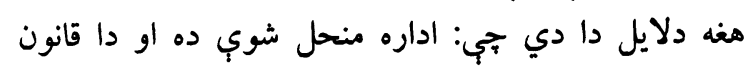

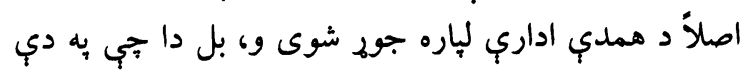

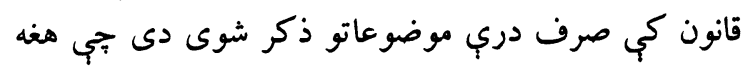

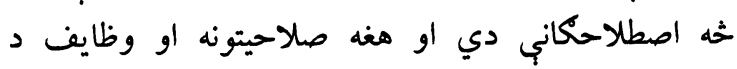

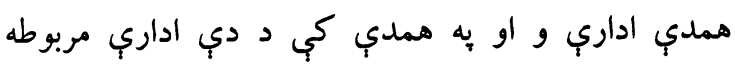
تشكيلات دي يعني دي كي داسي كوم فوق العاده شيان

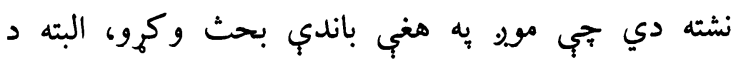

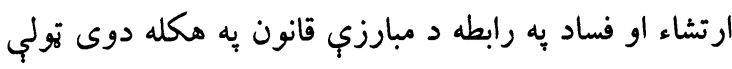

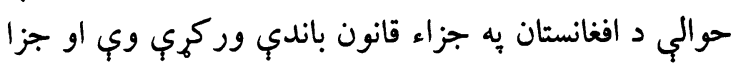

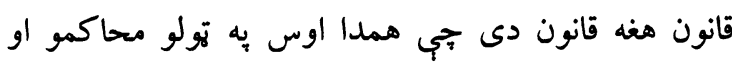

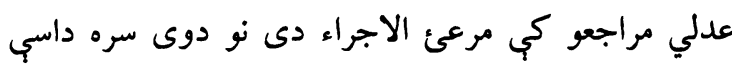

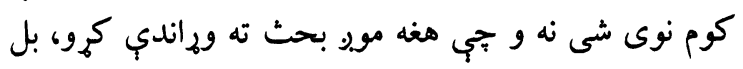

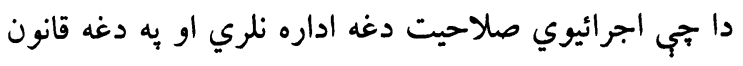

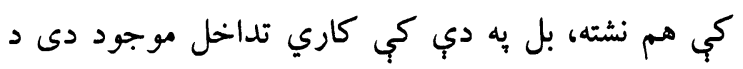

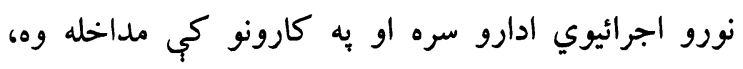

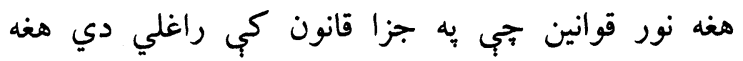


معلوم دى جب بروسيجر يجي خنكه دى حبي موبو يوه فيصله

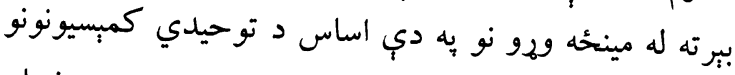

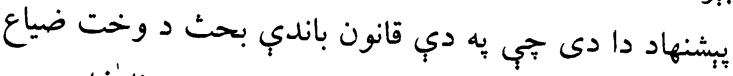

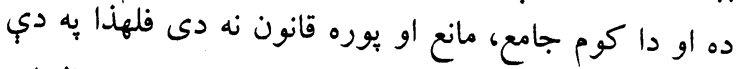

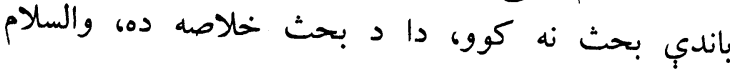

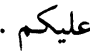

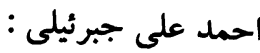
جناب لودين صاحب! لطف جلفئ كرديد توضيح خوبى داديد منتهى من يقين دارم كه بعضى از همكاران محترم ما به له

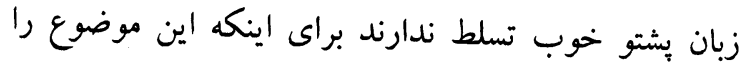

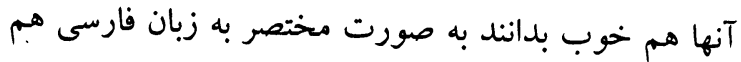

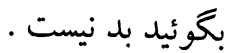
مولوى عطا الله لودين :

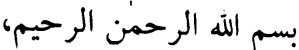

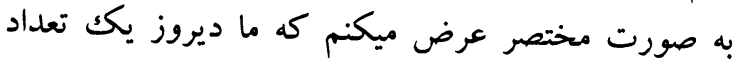

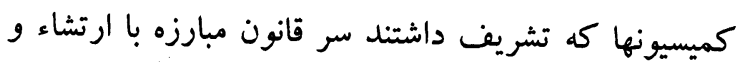

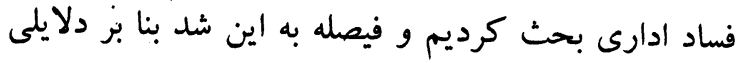

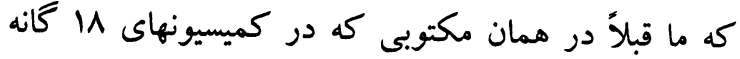

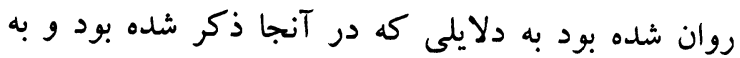

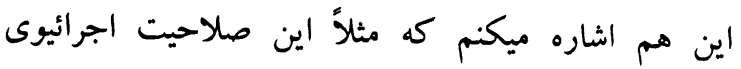
ندارد، تا با مبارزه با فساد و ارتشاء مؤفق باشند، شايد

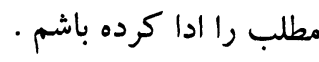

قدريه ابراهيم يزدانيرست :

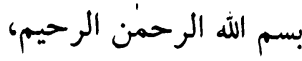

اسلام عليكم و رحمة الله و بر كاته ! صحبتها را دوباره

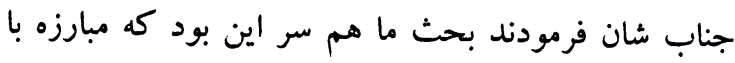
ارتشاء و فساد ادارى يكك امر منحصر به فرد و يكك ارثان

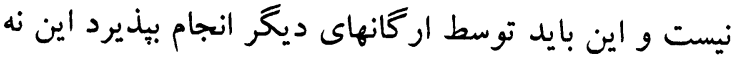

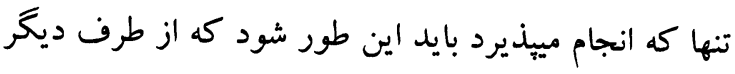

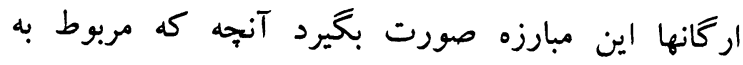

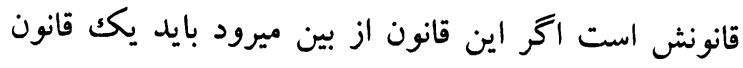
ديگرى جاكزين آن شود كه او به همه ادارات ارتباط

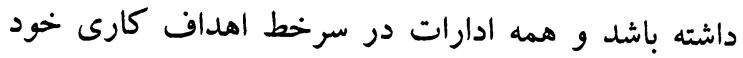
اين را قرار بدهند ولى به هر صورت ائر قانون به طور
خارنوالى له خوا نه كيري، كه هغه د يولسيو له خوا كيري،

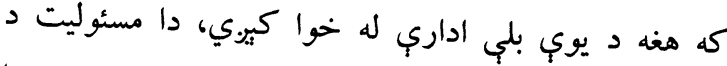

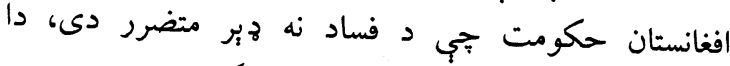

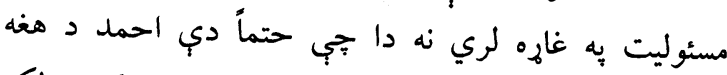

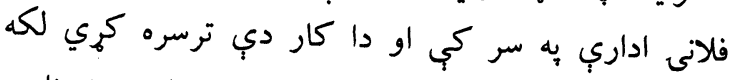

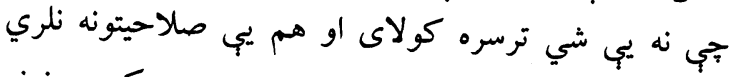

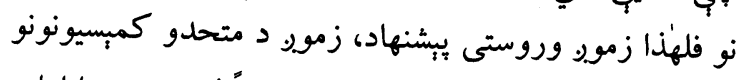

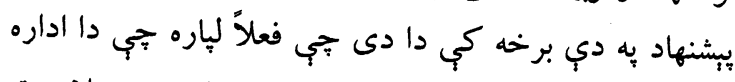

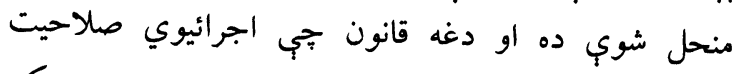

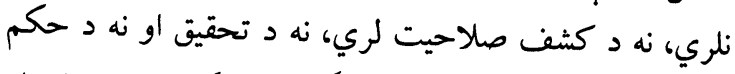

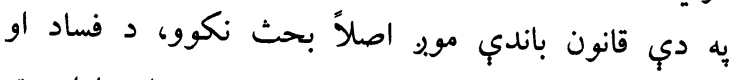

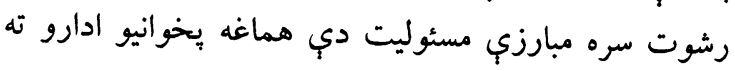

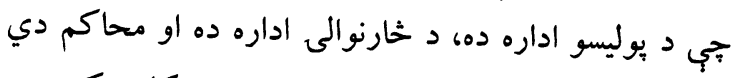

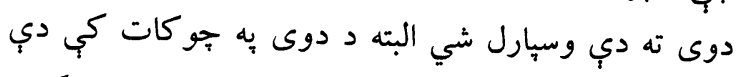

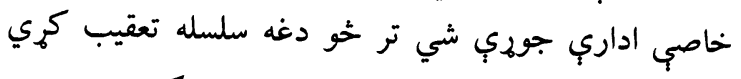

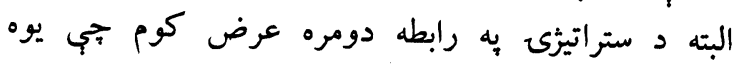
ستراتيرّى باندي بحث روان دى د د جناب قاضي القضات

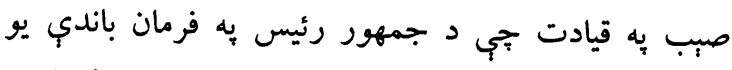

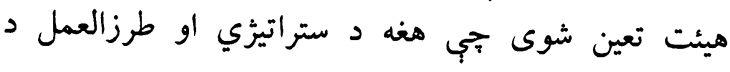

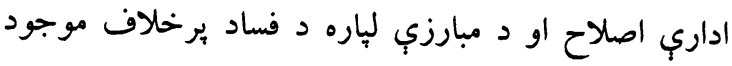

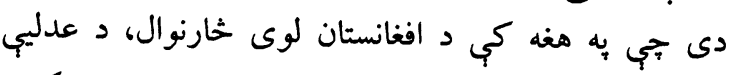

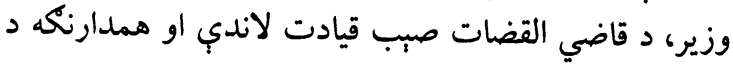

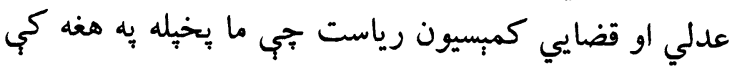

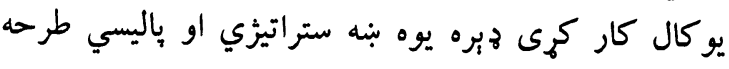

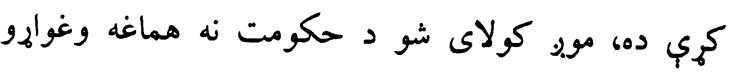

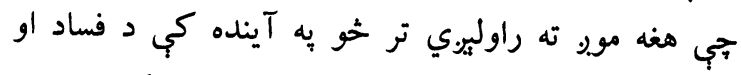

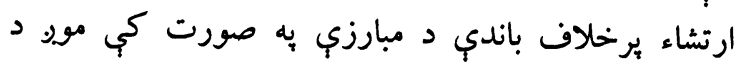
هماغب باليسي او ستراتيزّي نه كار واخلو او هماغه زئري

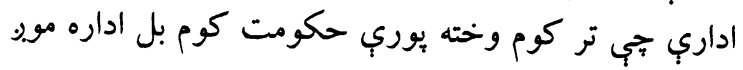

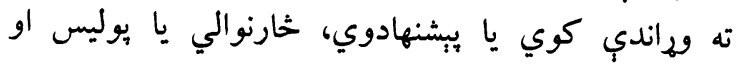

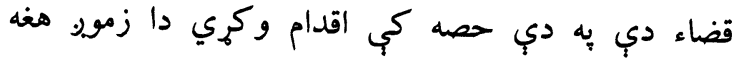

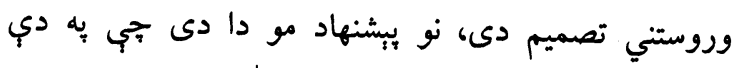

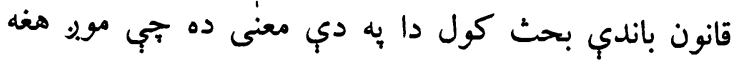

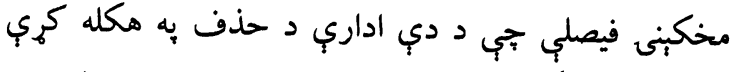

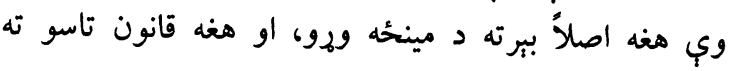


مواد مشخص و معينى داريم و اما او كافى به هيج صورت نيست و ضرورت يكك قانون جدا كانه، قانونى كه تمام زواياى اين قضيه را در بر بحيرد خود فساد ادارى تعريف

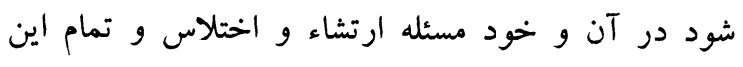

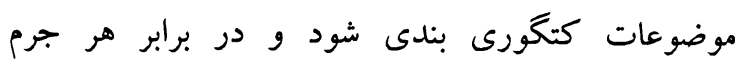

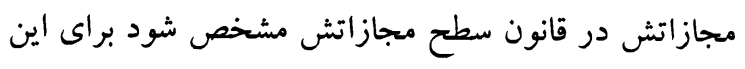

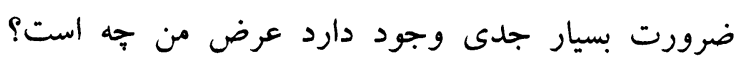
منظورم اين است كه همين قانون بايد رد شود و و به هيج

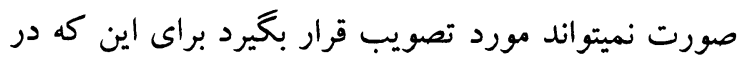

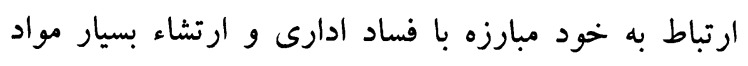

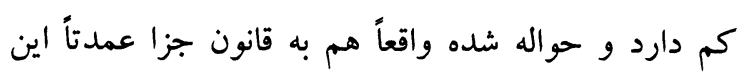
مسئله تشكيلات است، تشكيلات يكك اداره اين است كه وارد ونه

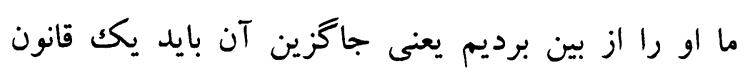

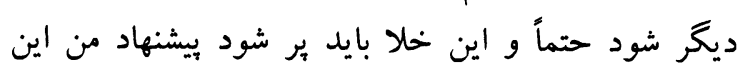

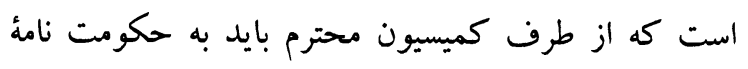

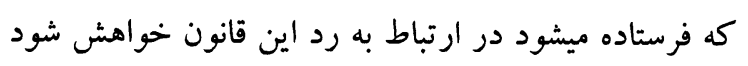

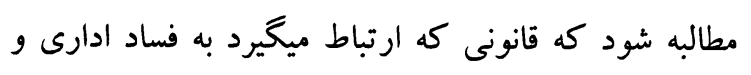

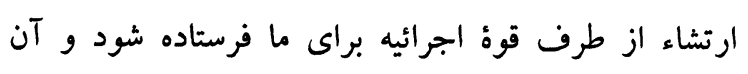

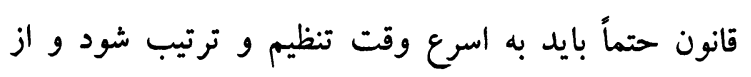
طرف ولسى جر گه در آينده به تصويب برسد و من من فكر

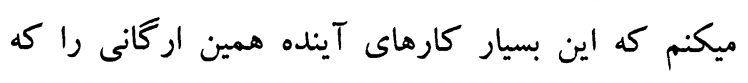

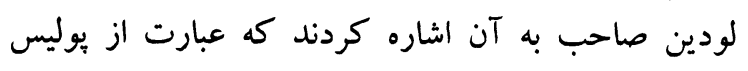
است، خارنوالى است و محاكم است كارهاى آنها را بسيار

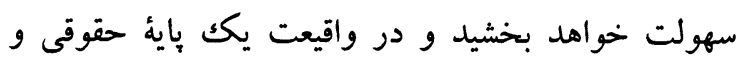

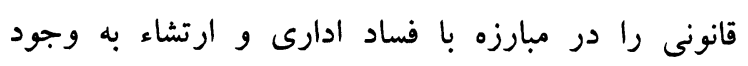

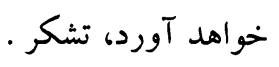
داكتر مضان بشر دوست : به نام خداوند بزرگ و به ياد شهداى عزيز افغانستان، شما در جريان هستيد كه در لويه جر گه قانون اساسى آقاى حامد كرزى آن زمان علناً در مقابل نماينده هاى مردم

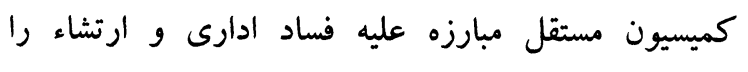
ساخت و من خوب به ياد دارم كه آنجا آقاى كرزى مئي كفتند كه من در رأس اين كميسيون كسى را مق مقرر ميكنم

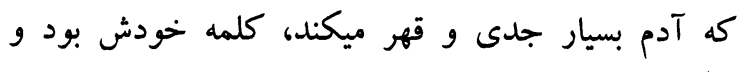
حتى آقاى رئيس جمهور اضافه كردند كه ما در مدت فيكن
كلى از بين ميرود خلاى قانون به وجود ميايد به همه حال بايد يك قانون لاحق جاى قانون سابق را بخيرد، تشكر .

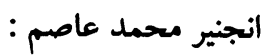

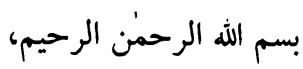
من هم احترام خود را خدمت هيئت محترم ادارى و و الرمبا

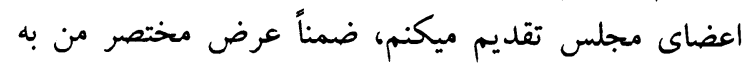

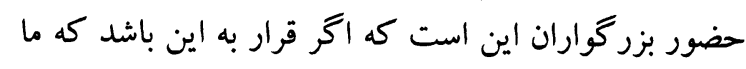

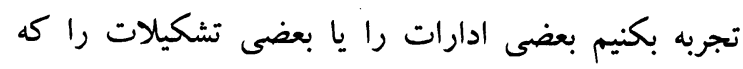
تصور ميشود كه ما را كمكك بكند در عرصه اداره و حكومتدارى در بخش مبارزه ارتشاء و فساد ادارى، همين

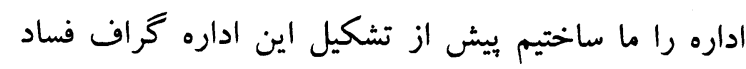

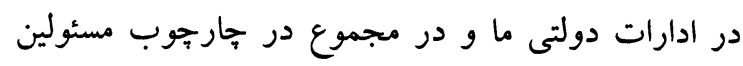

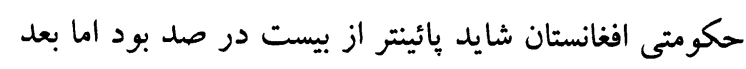

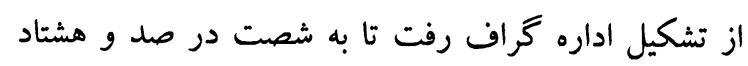

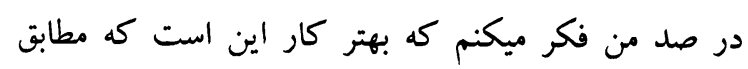

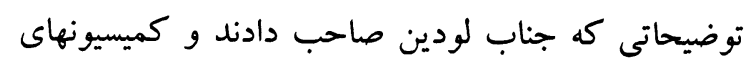

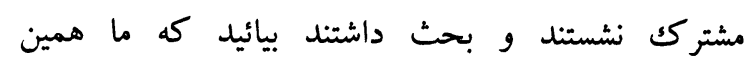
دوبلكيشن و دو گانگگى را هم در ادارات از بين ببريم و هم

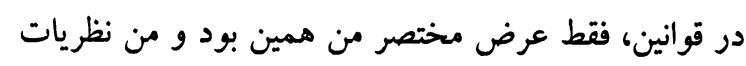

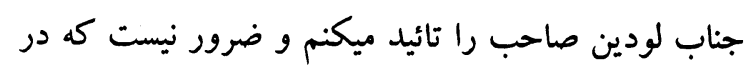

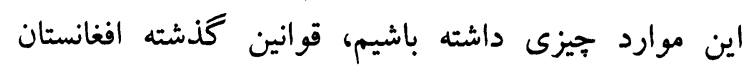
كافى است . داكتر عبدالكبير رنجبر :

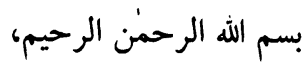
با عرض سلام و احترام جناب رئيس، و نماينده هاى المت الرحن

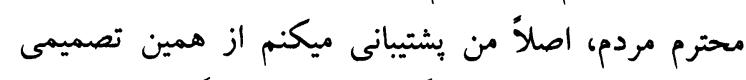

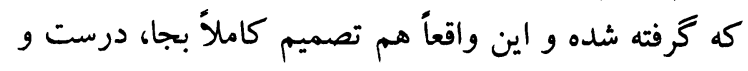

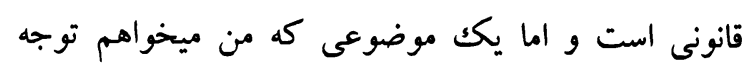

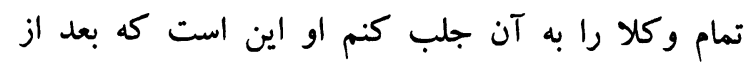

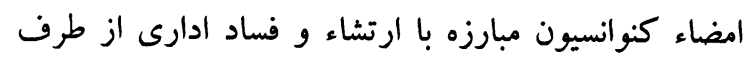
ولسى جر گه يك مكلفيتى جدى در خود همان مان كميسيون

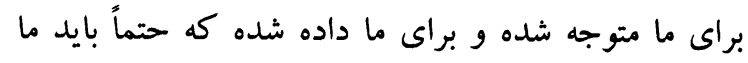
قانون مشخص، قوانين و مقرراتى در ارتباط با همين مبارزه

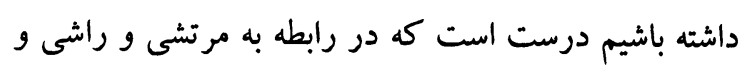

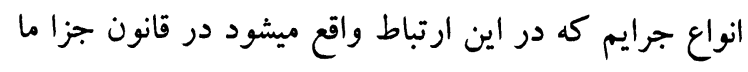


جزاى شان را مى بيند، من افرادى را ميشناسم كه در

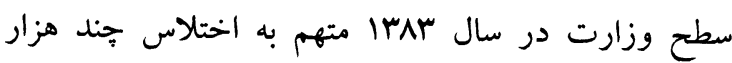

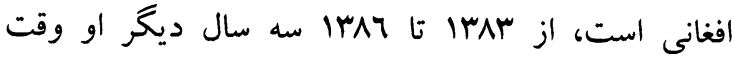

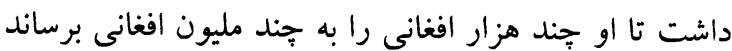
از نظر حقوقى، از نظر منطقى از نظر علدلى اين فكر ميكنم

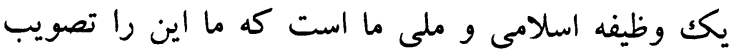

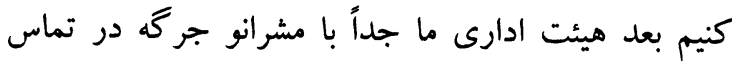

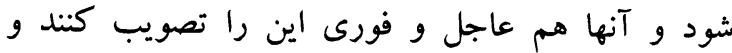

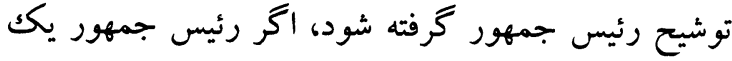
روز معطل كرد توشيح نكرد و كار شكنى كرد ماد ما بايد

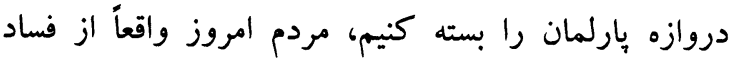

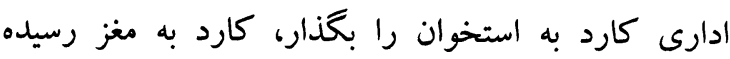

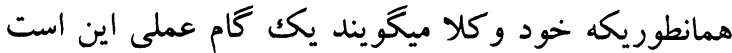

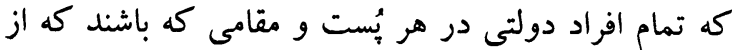

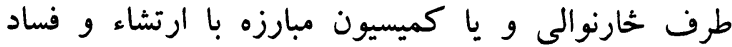

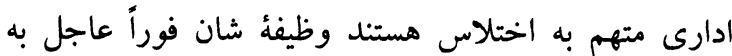

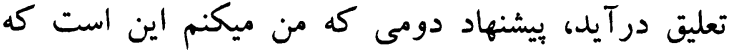

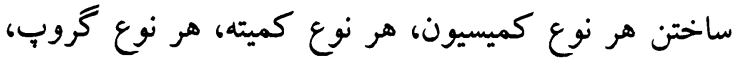

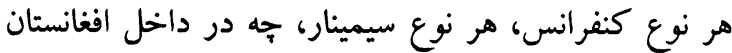

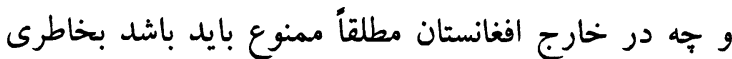
كه هر سيمينار هزاران افغانى مصارف دارد و اين فقط

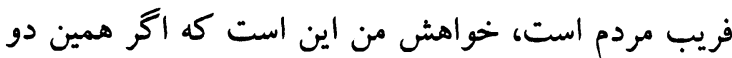

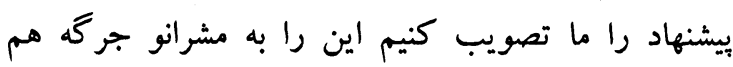
بفرستم تعقيب كنيم يك خلاى بزرگ از از بين ميبرد و

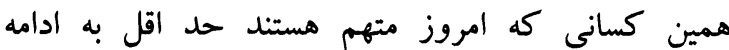
جنايت شان مؤفق نخواهند شد، تشكر از توجه شما . محمد اقبال صافى :

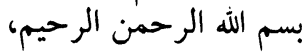
جلالتمآب رئيس و هيئت محترم ادارى و نمايند آران معزز

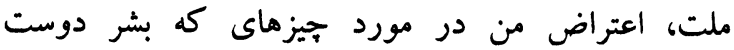
صاحب گفتند است، اگر مواردى داشته باشند با اسناد كه هورد يادآور شدند همان را براى شما بدهند كه همه وكيل

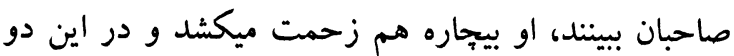

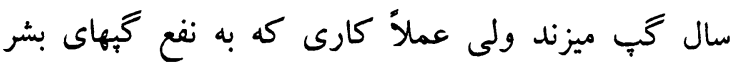
دوست صاحب صورت گرفته نشده، تنها گَب ميزند همان كمان
شش ماه فساد ادارى را در افغانستان از بين ميبريم، نتيجه آنرا ما بعد از دونيم سال، سه سال ميبينيم كه فساد ادارى نه نه آنه

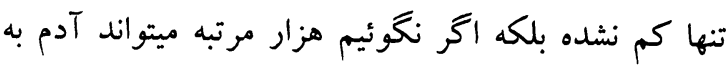

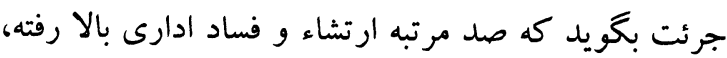
بعد رئيس جمهور ما يكك كميسيون عالى مبارزه عليه

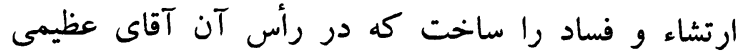

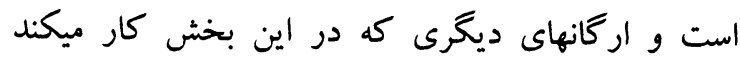

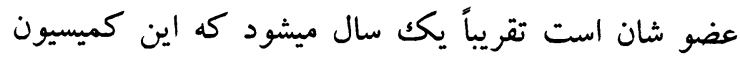

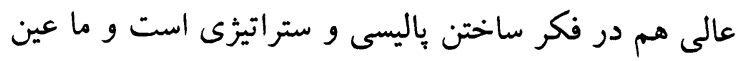
زمان شاهد هستيم كه در وزارت ماليه ما يك دم كميته مبارزه

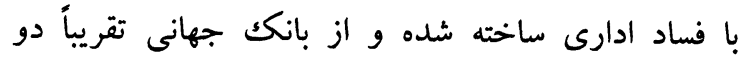

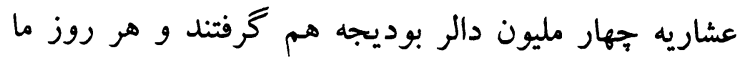
تقريباً در افغانستان، در كابل شاهد هستيم كه يك دئ سيمينار

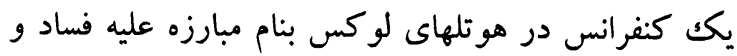

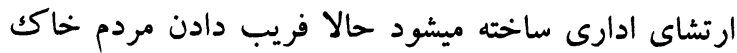
به جشم مردم انداختن هم يكك حدى داخئه مارد، متأسفانه مقامات عالى دولتى ما شرم و حيا هيج ندارند، ييشنهاد من هن هن

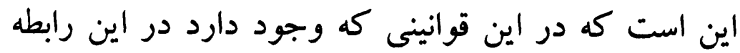

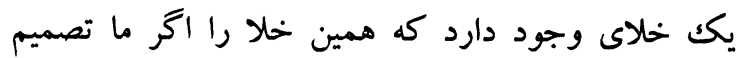

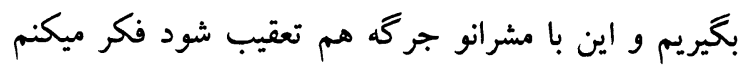

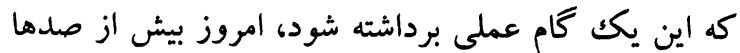

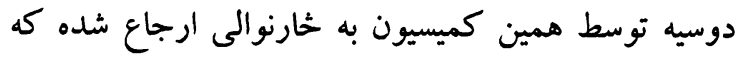
مقامات ارشد دولتى ما متهم به اختلاس و فساد ادارى

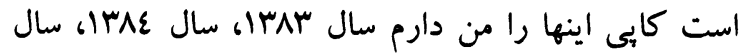

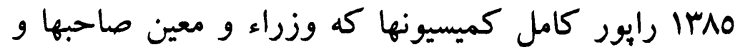

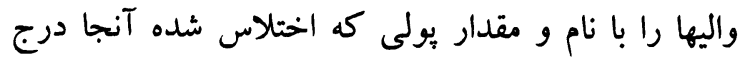

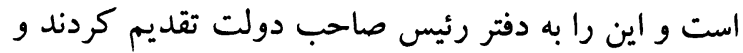
وطندوستها يك كايى آنرا به من در خيمه ملت آرودند، وند

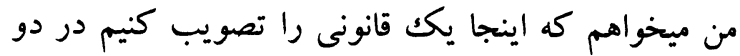

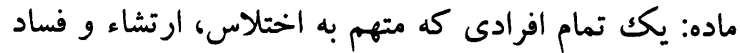

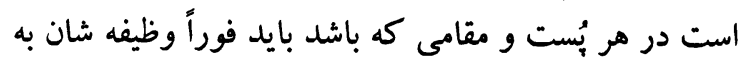

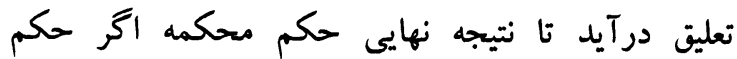

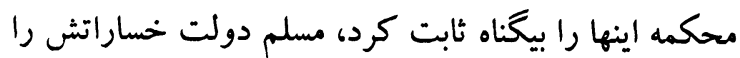

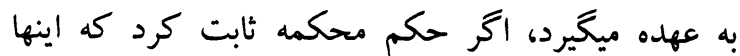
واقعاً طبق تحقيقات ابتدائيه كه شده اينها محكوم هستند مهرد 


$$
\text { نائب دوم : }
$$

بشر دوست صاحب لطفاً بنشينيد هميشه انتقاد ميكنيد صحنه

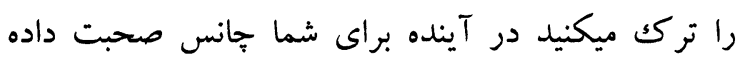

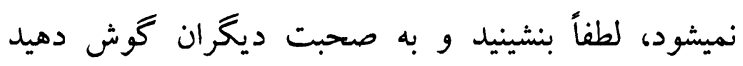

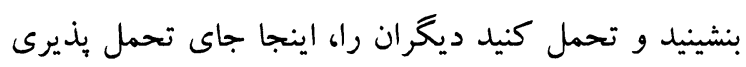

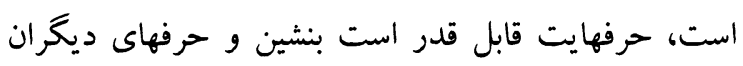

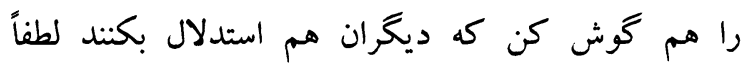

$$
\text { تشريف داشته باشيد . }
$$

ادامه صحبت ماى سيد داوود ماشمى :

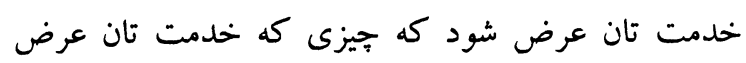

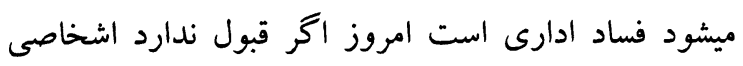

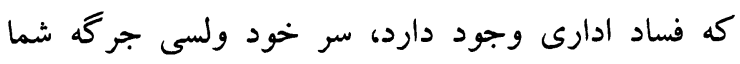

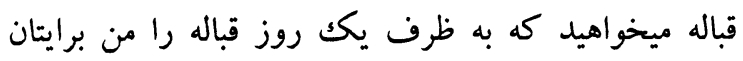

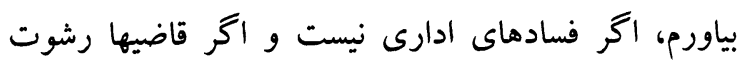

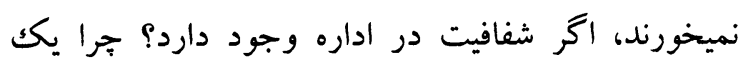
بسوه زمينى كه در كابل شما بدون قباله بيدا كرديد زمين ونين

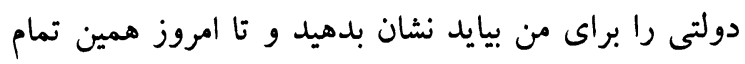

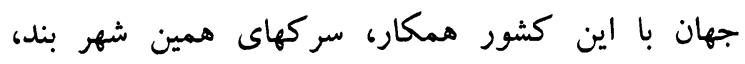

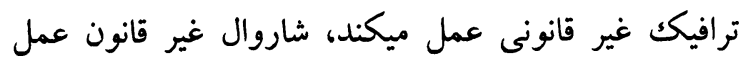

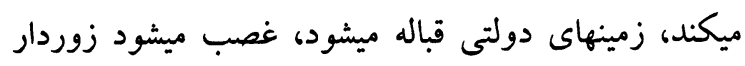
زور ييدا كرد و كمزور كمزور شد يسيسه دار ييسه دارتر شد و كسى كه غريب بود بالايش ظلم بيشتر شد در همين ئل شهر، در يايتخت شما ميبينيد كه قانون نقض ميشود و هيج بيج كسى نيست كه از قانون سوال بكند كه قانون اين كشور

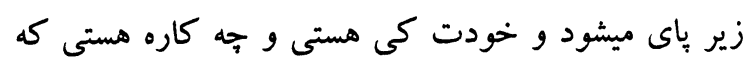

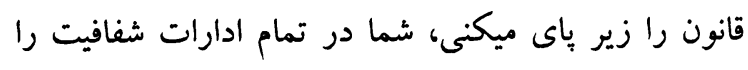

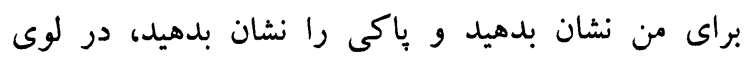

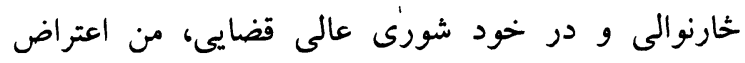

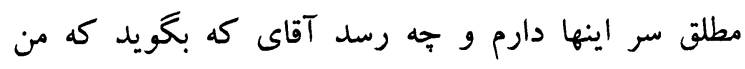

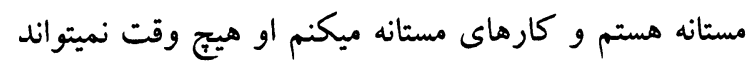

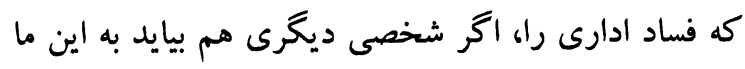
سر قانون جزا و قانون مدنى كشور بحث ميكنيم .
را بدهند به هيئت ادارى همه ما بيينم همان مواردى كه

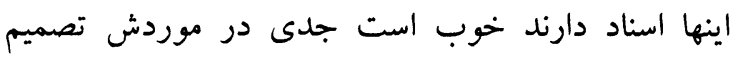

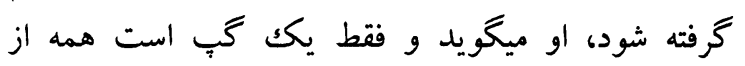

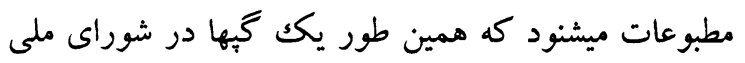

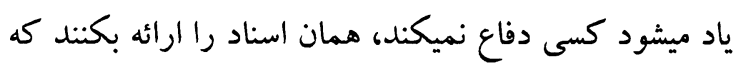

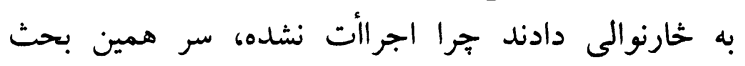
بكنيم كه ضرورى هم است .

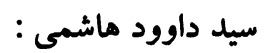

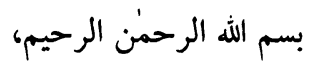

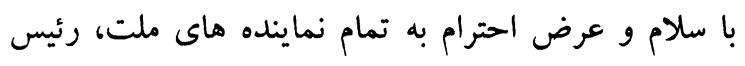

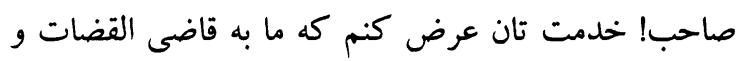

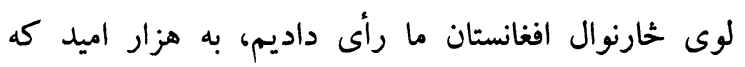

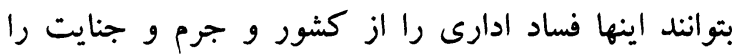

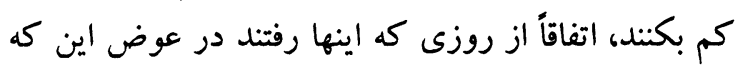

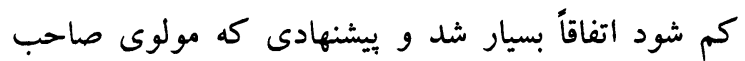

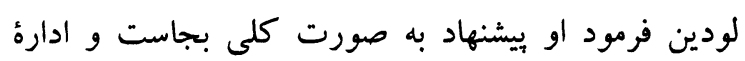
كه به خيانت متهم ميشود و او ميآيد و در رأس اين اداره

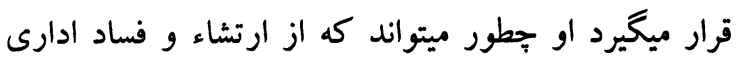

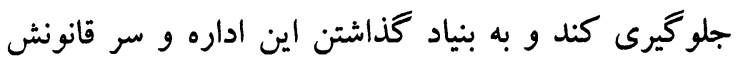

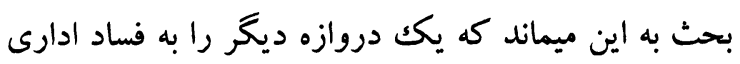

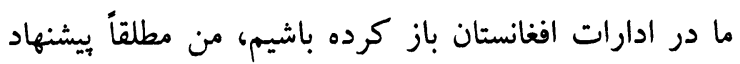

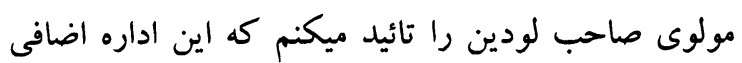

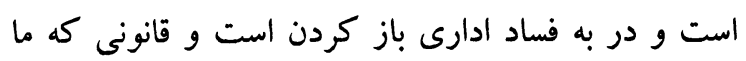

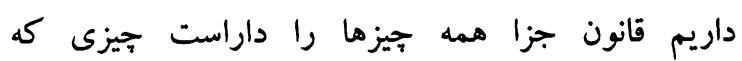

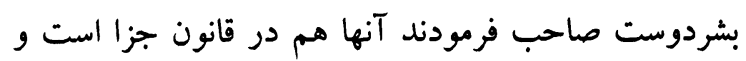

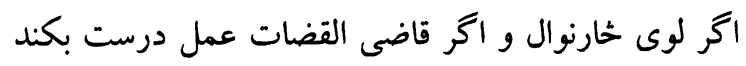

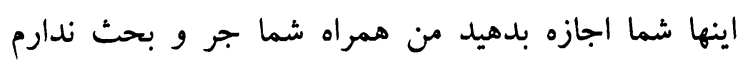
جيزى كه در قانون جزا نهفته است شما بييند كه من من نه

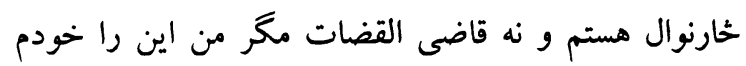

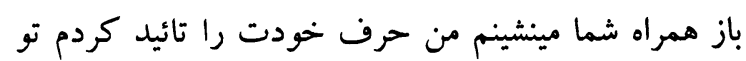

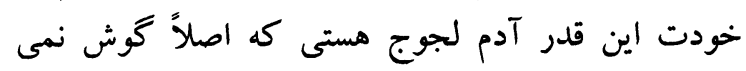
كيرى . رئيس مجلس : بشر دوست صاحب دقيق است ما ديخر ديالوگ نداريم . 
بكنيم بلكه اين قانون بايد لغو شود ميماند اين بحث كه آيا

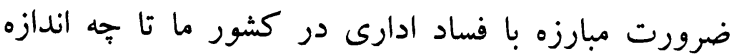

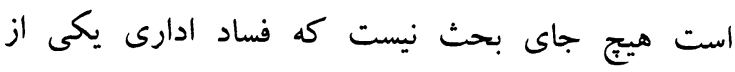

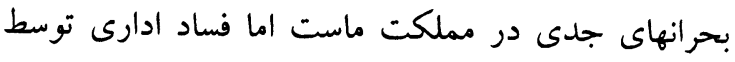
يكك نهادى كه او نهاد هيج نوع صلاحيتى قانونى ندارد

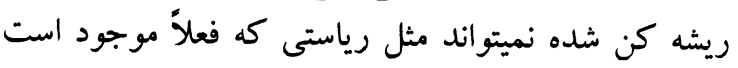

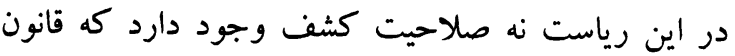
اساسى ما اين صلاحيت را به بوليس داده داده نه صلاحيت تحقيق وجود دارد كه باز قانون اساسى صلاحيت را با به به

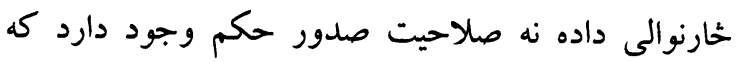
اين صلاحيت مطابق قانون مربوط به محاكم ماست بنابرين يكك رياست يا يكك نهاد يا يكك ارثانى است كه اساساً وجهه و جايگاه قانونى ندارد صرفاً خاصيت اين نهاد ميماند

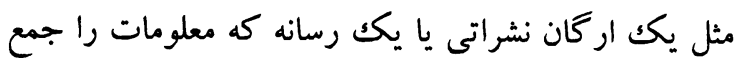
بكند و آن معلومات را لاقل رسانه ها در افكار عامه منتشر

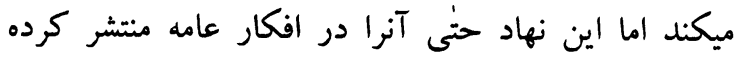

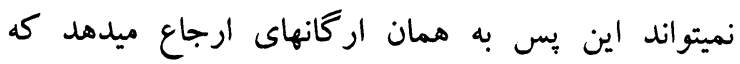

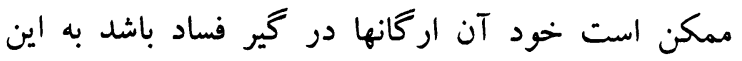

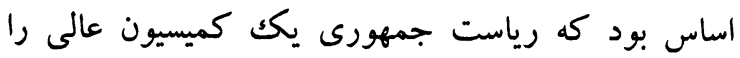

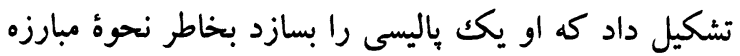

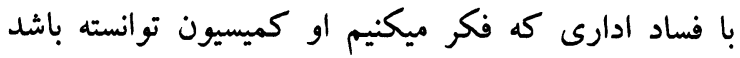
كارشان را نهايى بسازد يا اين كه طرح آن كمادي كيسيون بيايد به شورى به عنوان يكك راهكار حقوقى و قانونى مورد

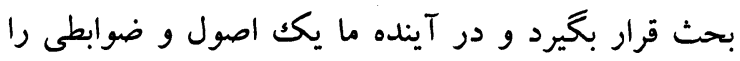

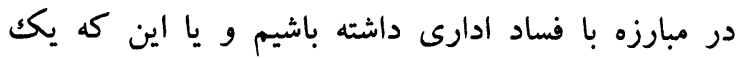

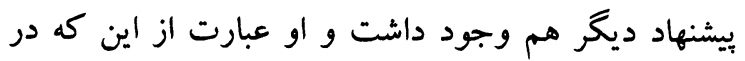

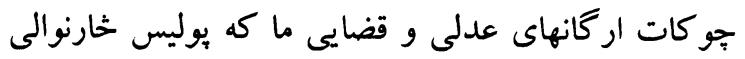

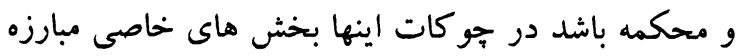
با فساد ادارى بوجود بيايد تا او نهادها از طرفى بانس مشكل بهل قانونى نداشته باشد يوليس مبارزه با فساد ادارى بتواند

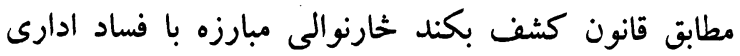

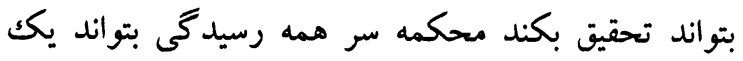

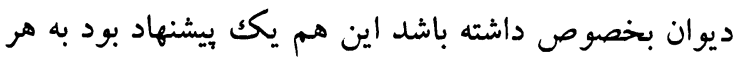

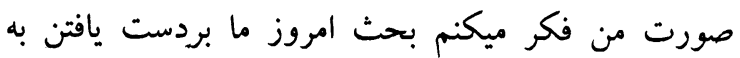
يك راهكار عملى براى مبارزه با فساد ادارى نيست بيشتر
محمد سرور جوادى :

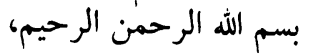
من با وجودى كه كمى ديرتر رسيدم اما فكر ميكنم يك الك الكمبه

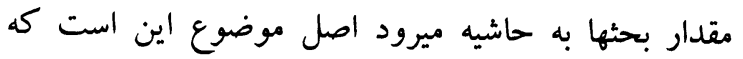

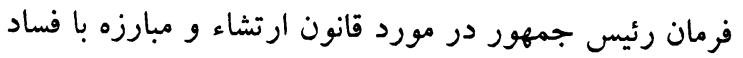

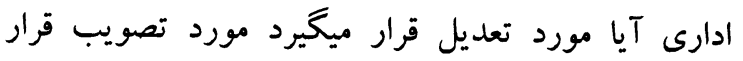

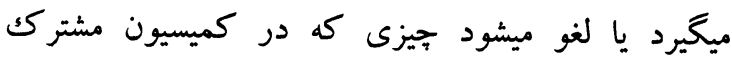
ديروز سر آن بحث شد تقريباً اتفاق آراء بين كسانى كه ده دئي

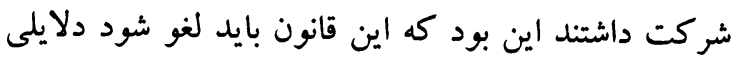
كه براى لغو اين قانون وجود دارد عمده ترين دلين ايل اين اين

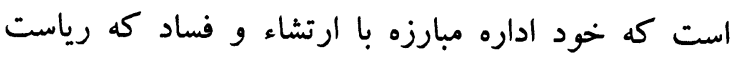

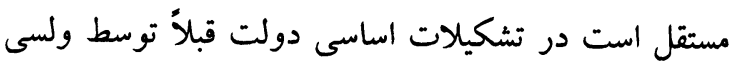

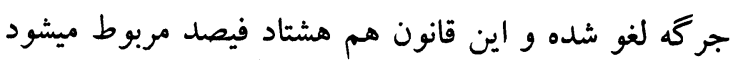

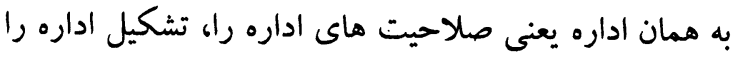

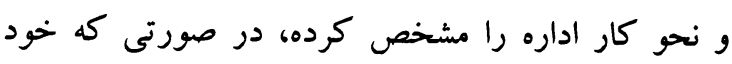

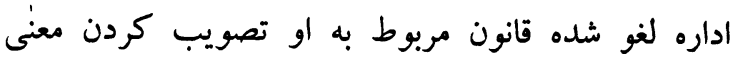

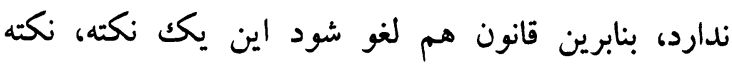

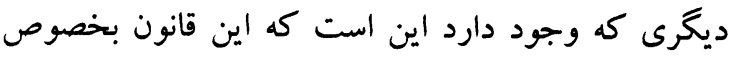

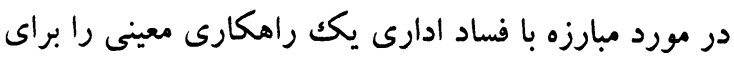

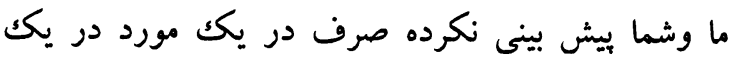

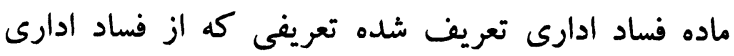

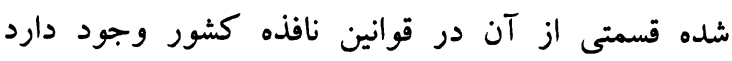

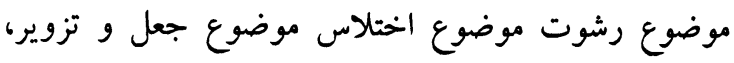

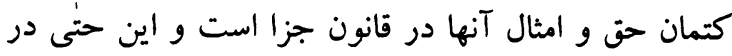
آن موارديكه گفته اين تخلف از قانون است و فساد ادارى انها در است كدام جزائى هم تعين نكرده كدام راهكارى هم آنم مشخص نكرده مواردى هم در اينجا در اين تعريف آمده تهرد

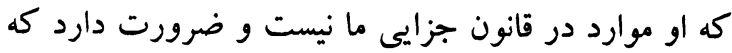

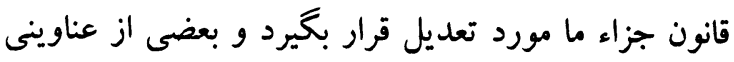

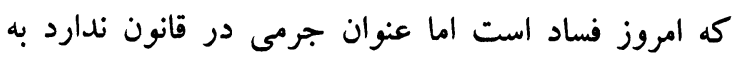

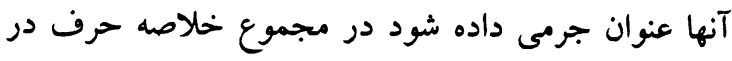
مورد اين قانون از نظر كميسيون و از نظر دوستهاى كه ازه از

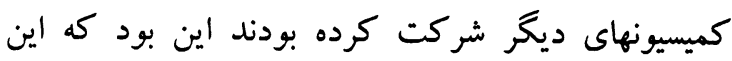

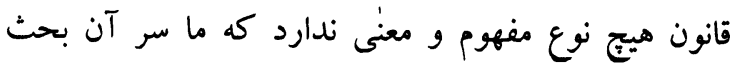

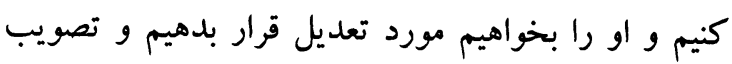


تكرار يبي بنه نه دى هغه د بارلماني زبي د بارلماني قانون،

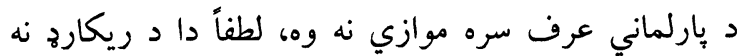

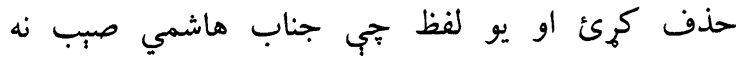

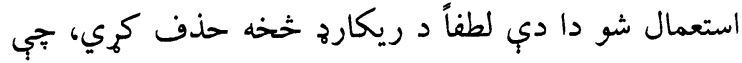

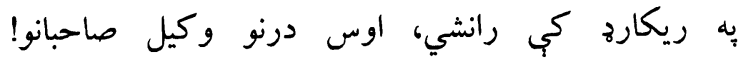
بفرمائيد . بها

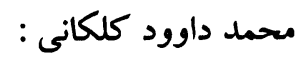

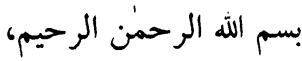

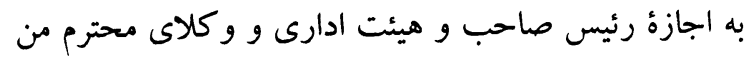

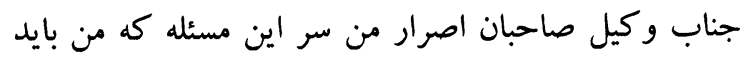

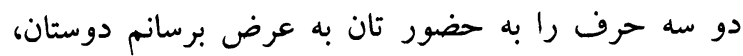

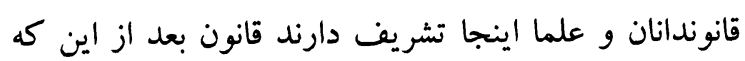

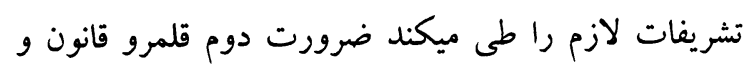
ضرورت سوم ضمانت اجراى قانون است، ضمانت اجرائى ضئى

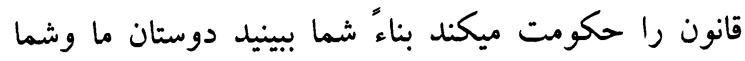

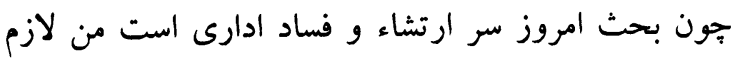

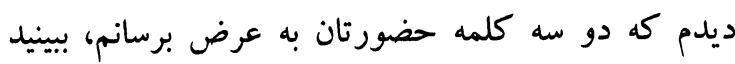

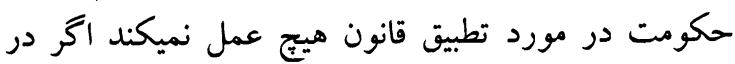

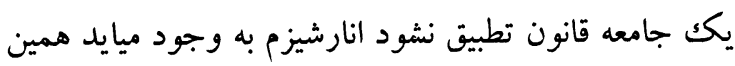

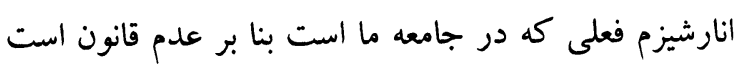

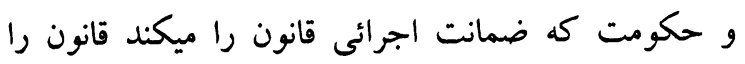

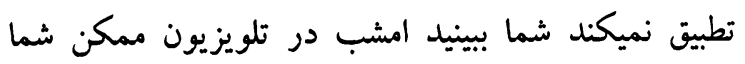

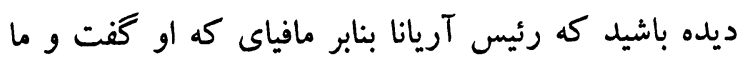

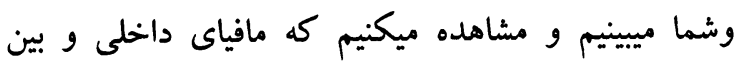

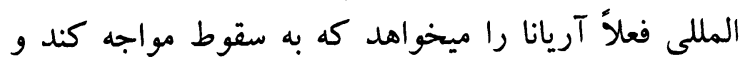

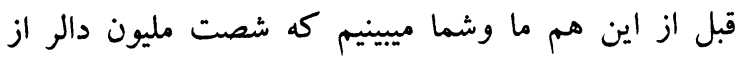

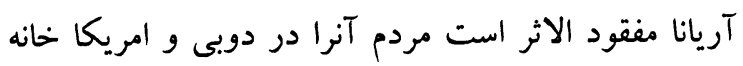

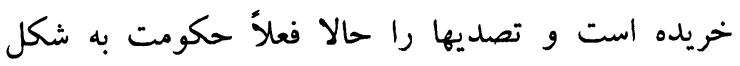

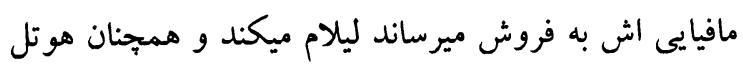
كانتينينتال را من نميدانم ما وشما كوش دوش داريم نماينده مردم هستيم نماينده اين ملت هستيم يول و دارايى اين ملت خو مونم همه به يغما برده ميشود ما وشما جه مسئوليت داريم در

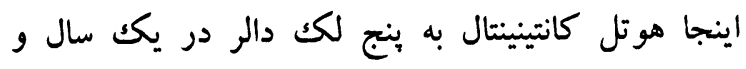

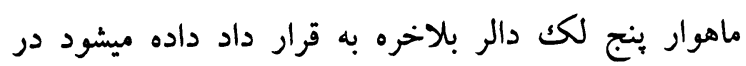

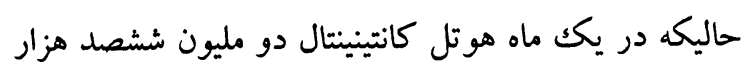

بحث ما اين قانون است كه به دلايلى كه من عرض كردم

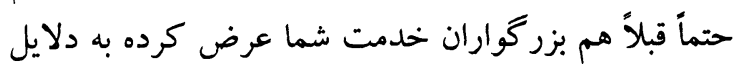
مختلف كه ما هفت دليل را قبلاً هم در كميسيون نوشته و ونما

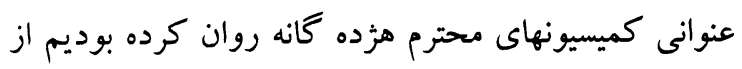

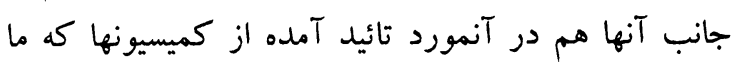

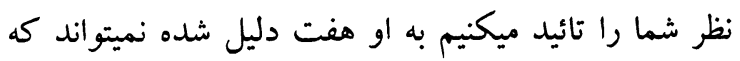

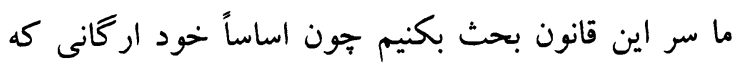

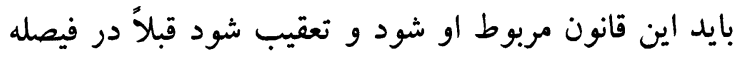
شورى ملغى اعلان شده. رئيس مجلس : تُورى ملفى تشكر جوادى صاحب! وكلاى محترم! درنو مونو وكيل

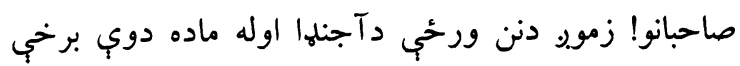

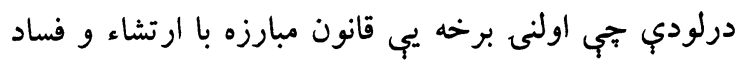

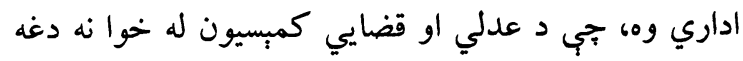

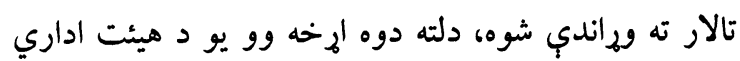

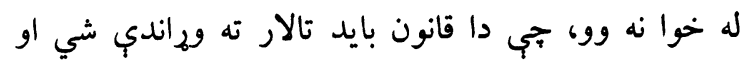

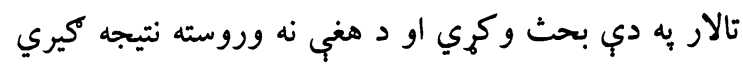

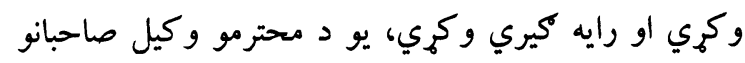

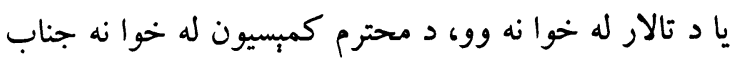

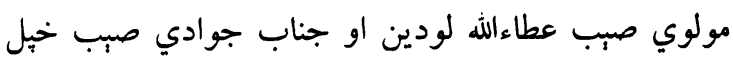

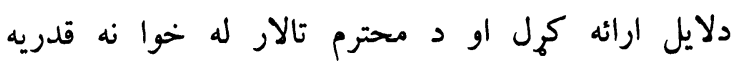

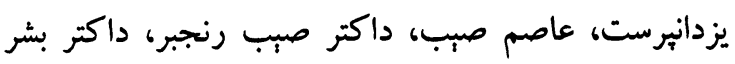

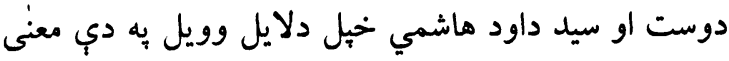

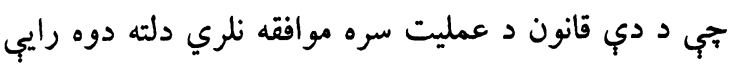

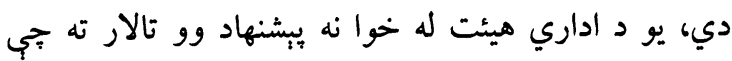

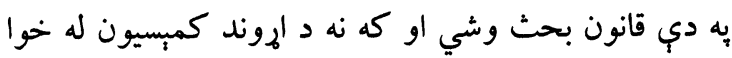

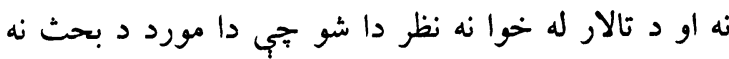

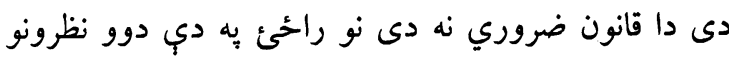

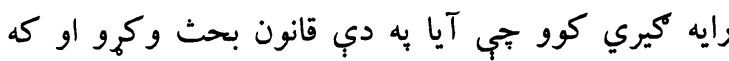

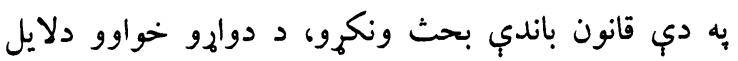

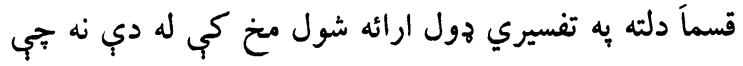

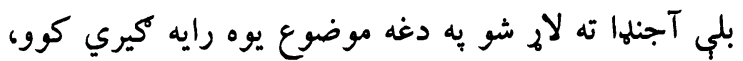

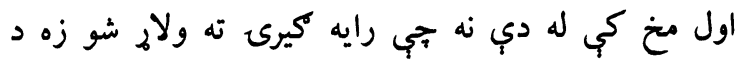
اداري هيئت او د اداري همكارانو حخخه هيله من يم تجي لهي

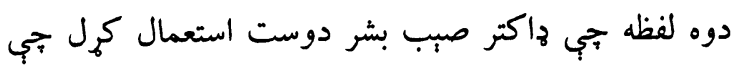




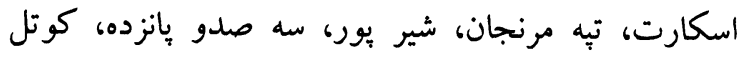

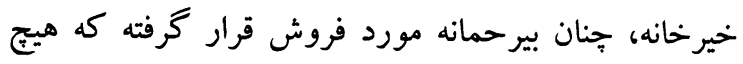

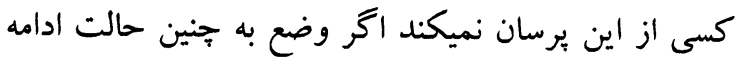

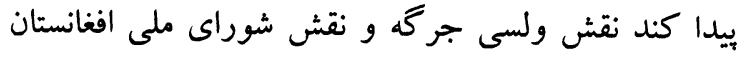

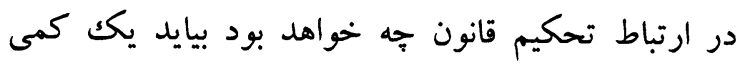

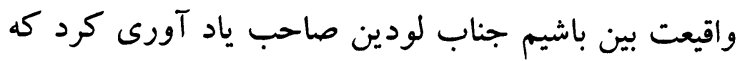

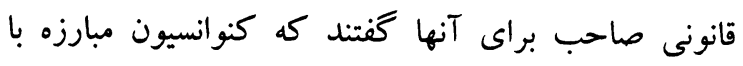

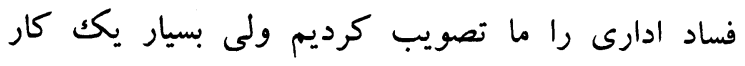

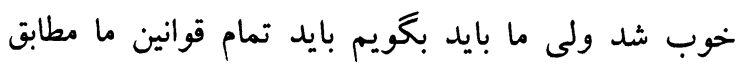

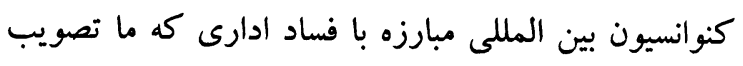

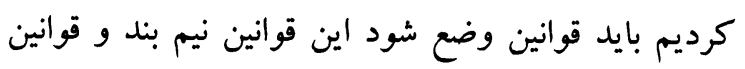

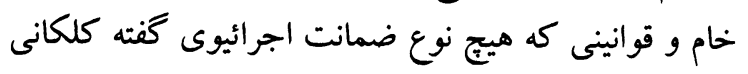

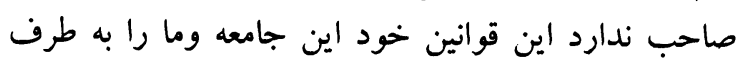

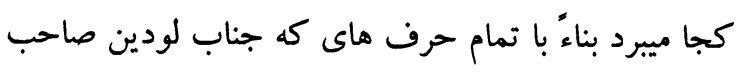

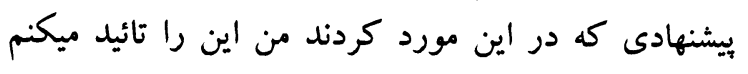

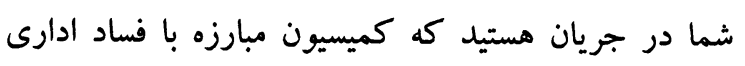

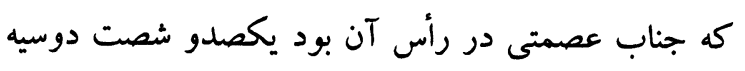

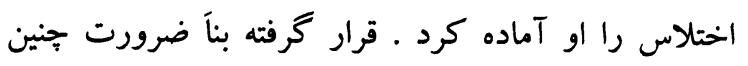

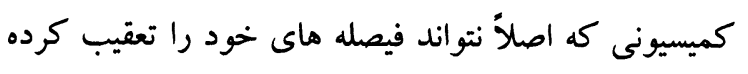

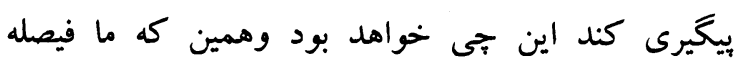

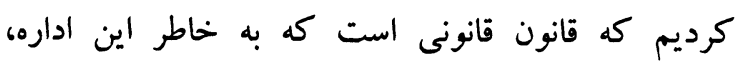

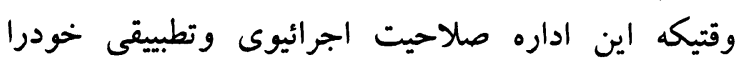

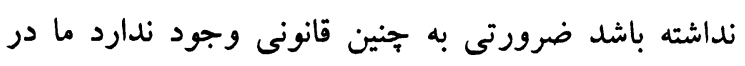

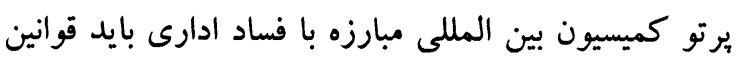

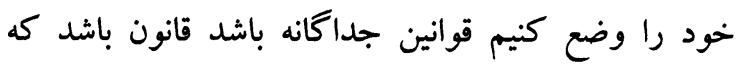

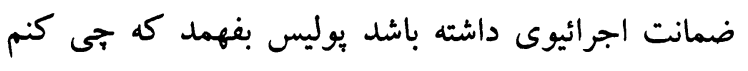

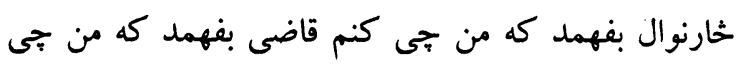

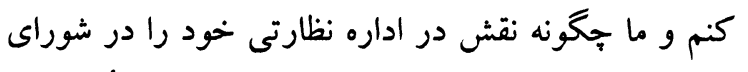

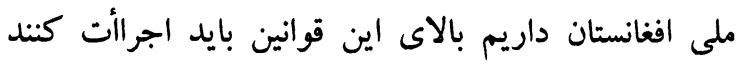

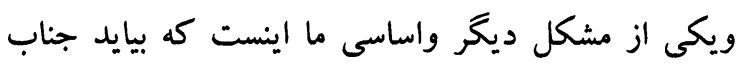

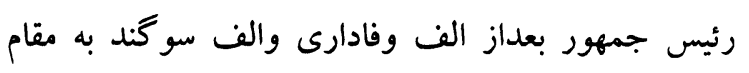
رياست جمهورى اعلان كرد كه من ثبت دارئي تمائ تمام افراد

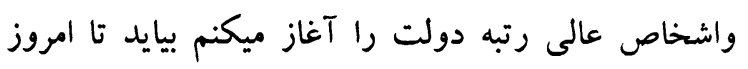

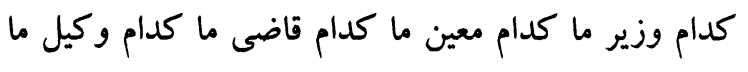

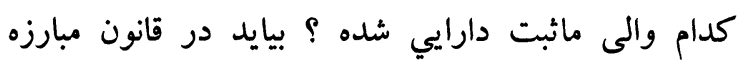

عوايد داشته است، در ده ماه بناءُ دوستان عزيز ما وشما

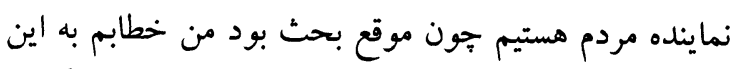

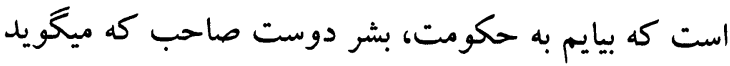

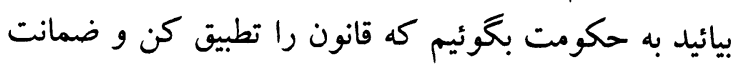

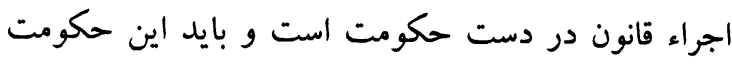

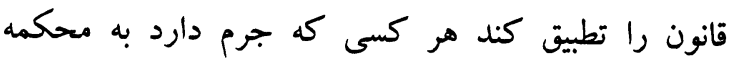

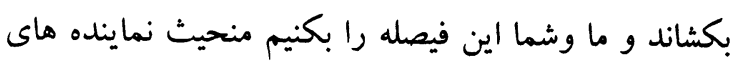

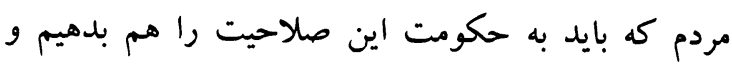

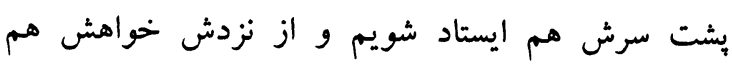

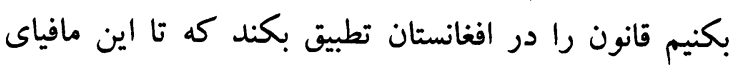

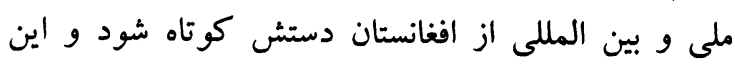

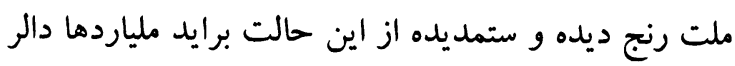

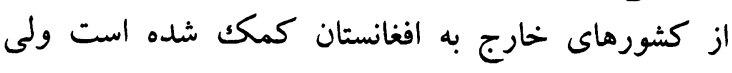

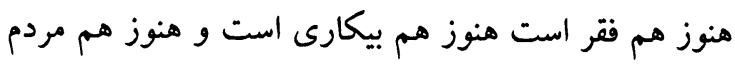

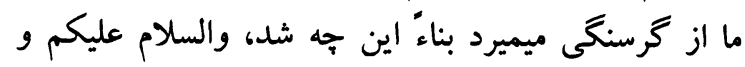

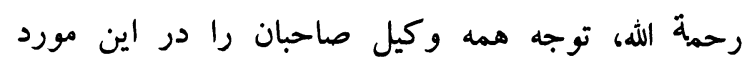
ميخواهم . ميكة

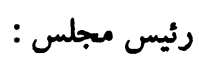

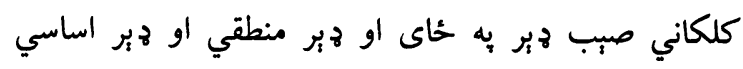

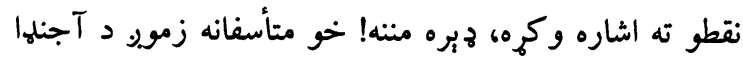

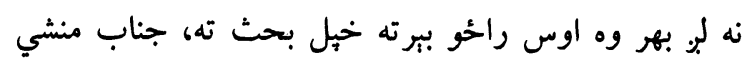

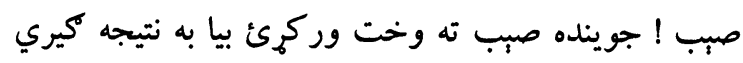
وكئو . مير احمد جوينده :

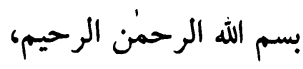
جناب رئيس وكلاى محترم طوريكه شما آكاهى دارئ ماريد

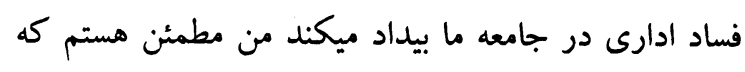

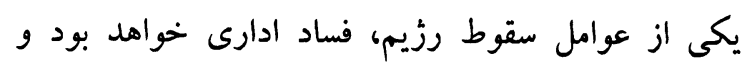

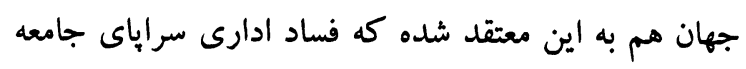

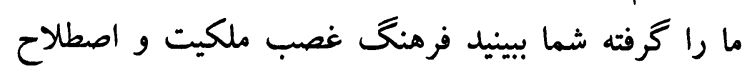

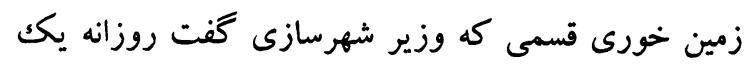

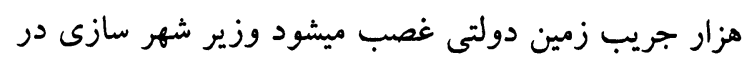

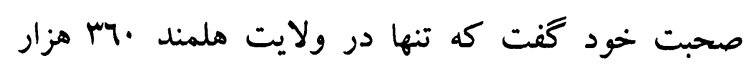

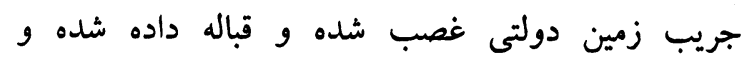

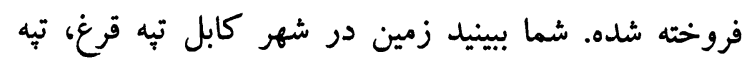




\section{دونلهي رئيس :}

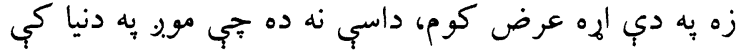

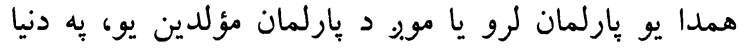

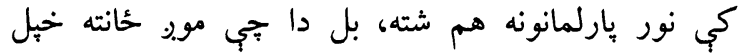
اساسات لرو، هغه الفاظ، جي هي هغه د د مجلس د د ليكلو

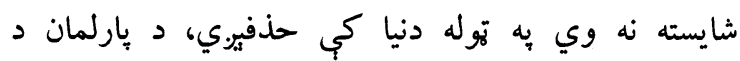

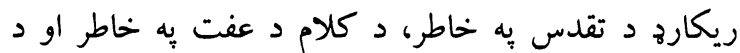

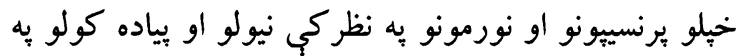

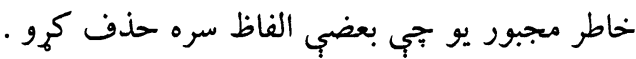

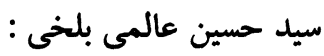

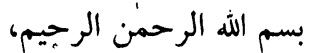

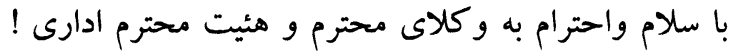
من صحبتهايم دو بخش دارد يكك بخشش تقريباً همينطور

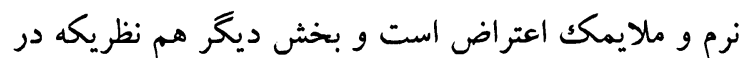
رابطه به همين موضوع دارم، همين آجندا را كميته رؤسا

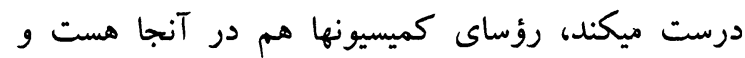

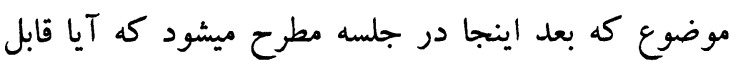
طرح است يا نيست به خصوص كميسيون مربوطه ميكويد كه اين قانون ضرورت بحث در آن آن وجود ندارد جطور

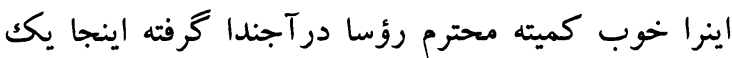

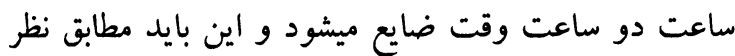
كميسيون تنظيم ميشد و اين بايد مطابق نظر كميسيون تنظيم ميشد هم جوادى صاحب نظرش همين هست هم

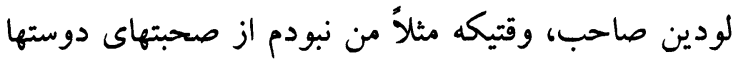

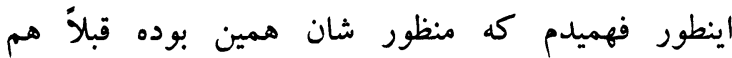
دركميسيون صحبت شُهد بود كه با توجه باينكه اداره

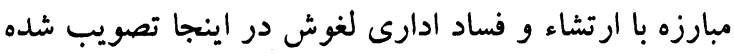
و مشكلات ديخرى وجود دارد من تعجب ميكنم كه

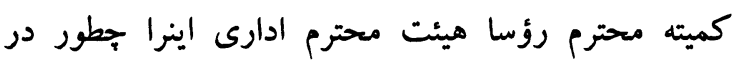

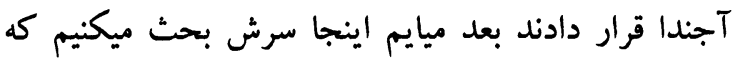

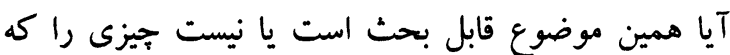

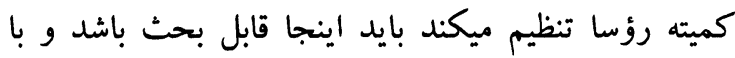

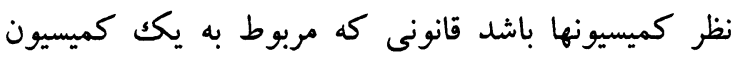

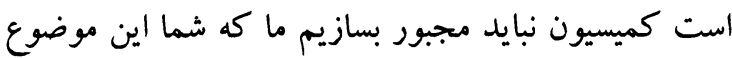
را حتماً بياوريد در جلسه طرح بكنيد و بعد اينجا هم نظر
بافساد ادارى اين را شامل بسازيم كه ثبت دارايي هاى تمام

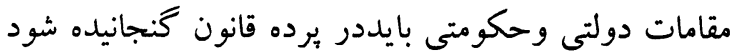

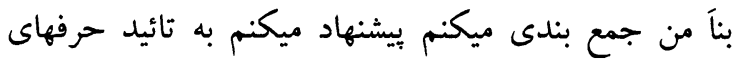

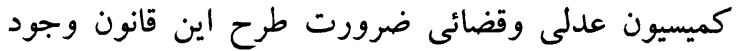
ندارد ما بايد دريرتواحلاق در كميسيون مبارزه با فساد ادارى قانونى را بسازيم كه ضمانت اجرائيوى داشته باشد وبتواند تطبيقى باشد . تشكر . مارئ. محمد على ستيخ: بلى اعتراض من بالاى هئيت ادارى بود به اساس فرمايش

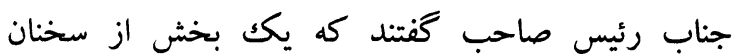
جناب سيد داود هاشمى و داكتر صاحب بشردوست راب

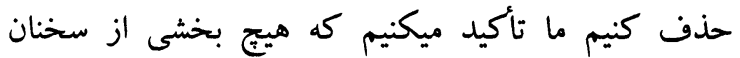

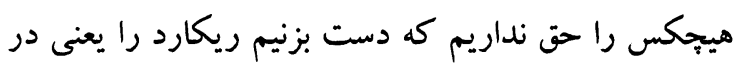

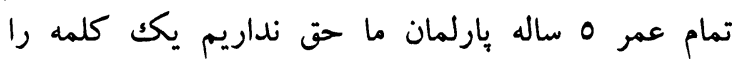
حذف كنيم بلكه هئيت ادارى ومقام عالى دارالانشاء موظف ومكلف است كه تمام ريكارد وتمام جيزيكه در

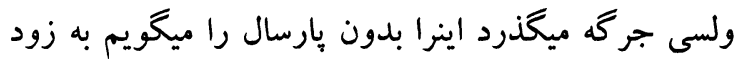
ترين وقت بدسترس مردم قرار بدهد تا مردم بداندكه كدام

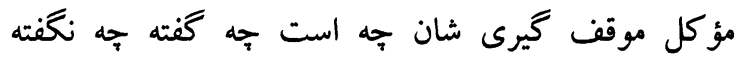

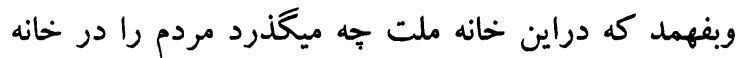

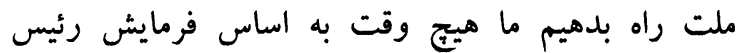

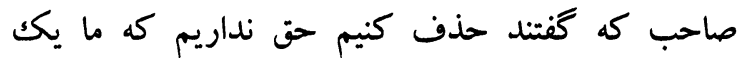
كلمه را حذف كنيم بايد با سلامت آنرا در بيرون نشر

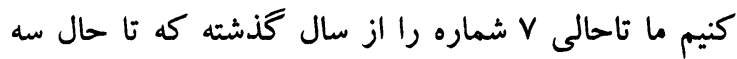
سال ميشود بيرون به نشر داديم ما بايد . مانس منشى مجلس : ستيغ صاحب سخنانى را كه شما ميكوئيد نكته به نكته نوشته ميشود حتى من گفتتم همين كسيكه مه ميگويد همان

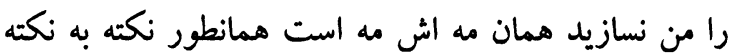

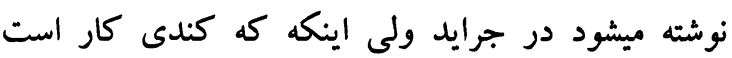
انشالله رئيس كه براى اطلاعات و ارتباط عامه است انشالله او مقرر ميشود بعضى وكيل صاحبان قبلاً همانطور كفته بودند جيزي راكه وكيل صاحبان ميگويند بايد همانطور نوشته شود. 
مجلس ميايد كميته رؤسا سرش دقت كنند نظر كميسيون

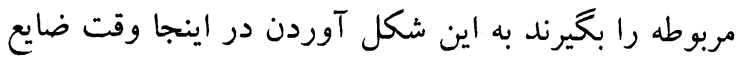

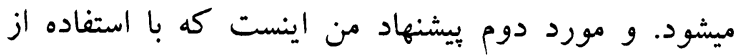
ماده قانون اساسى يكك كميسيون جور شود از همين ولسى دئ دئه

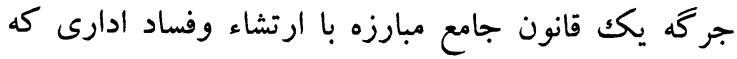

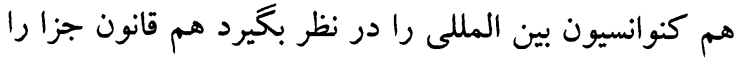

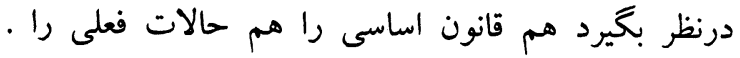

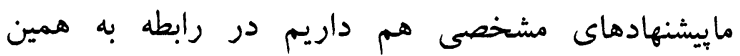

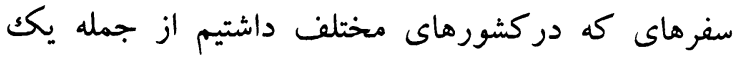

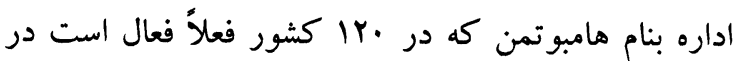

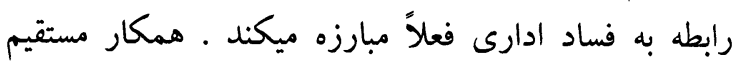

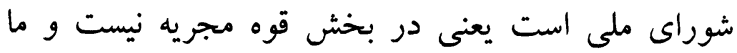

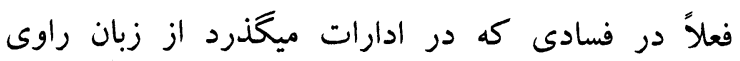

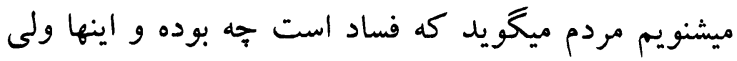
خود ما يكك شعبه نداريم كه بخصوص در مر اين مورد كار كند و مسايل را مستند بكند و و كلا بتواند در آن مورد

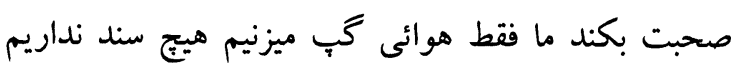
عرض من همين است كه كميسيون جور شود قانون جامع تهيه بكند و ميتوانيم كه مؤفق باشيم انشالله اين نياز به بحث ندارد . رئيس مجلس : بحت : وكلاى محترم ! در مورد قانون مبارزه با ارتشاء و فساد ادارى توسط كميسيون عدلى وقضائى بحثهاى مقنع صورت كرفت و وكيل صاحبان هم ابراز نظر داشتند

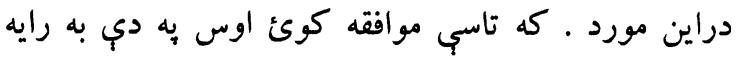

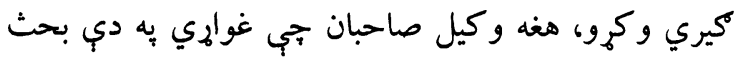
ونشي شين كارت، هغه جي غواري ويري بري بحث وشي سور

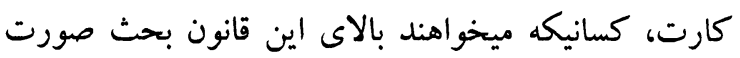

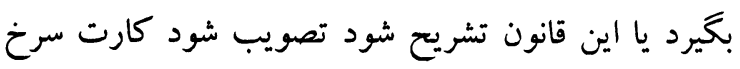

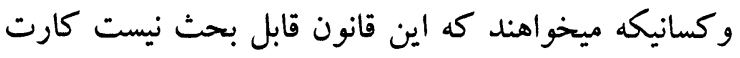
سبز · به اتفاق آرا و اكثريت آرا تصويب شد كه اين قانون مورد بحث نيست، به كمك برورد

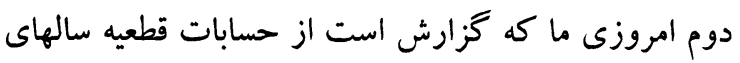

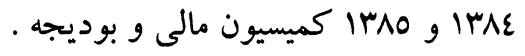

كميسيونى باشد كه ما نيازى به اين نميبينيم كه موضوع در

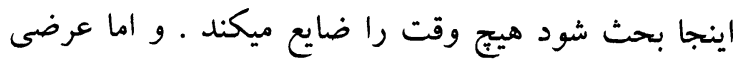

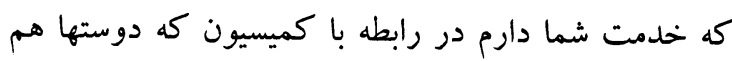

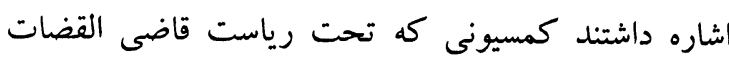

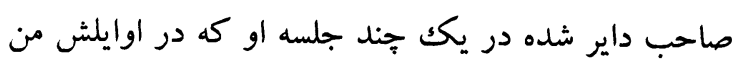
هم شركت ميكردم او كميسيون يكك استراتيزى جور

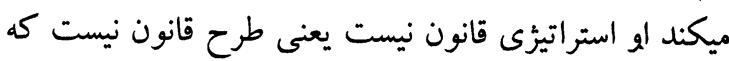

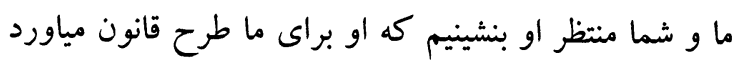

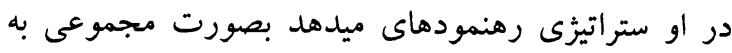

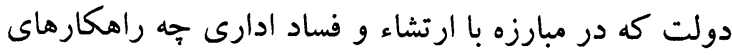

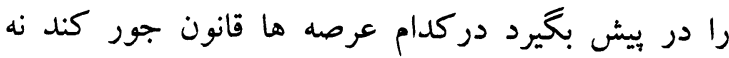

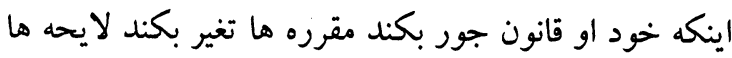

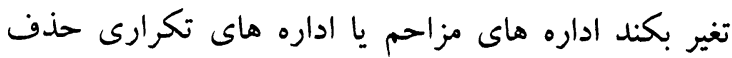

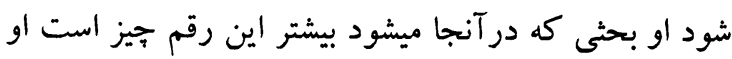

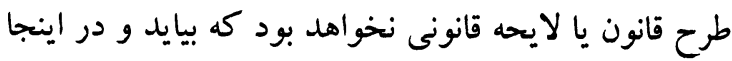
مورد بحث قرار بكيرد و من فكر ميكنم كه باتوجه به به بانه

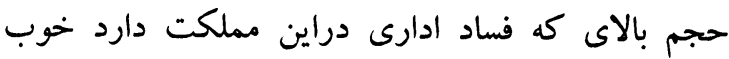
است كه يا حكومت يا اكر ميشود ما استفاده بكنيم از

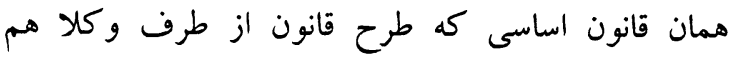

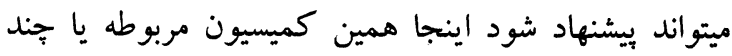

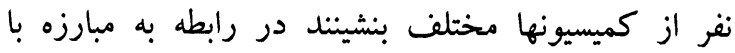

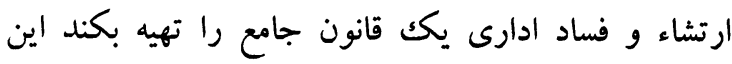
قانون كه واقعاً نه بدرد فساد ادارى ميخورد نهاد نه همجيو

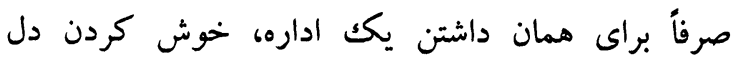

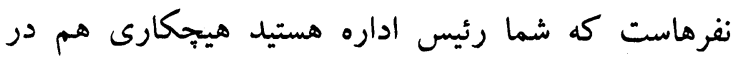

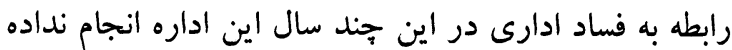

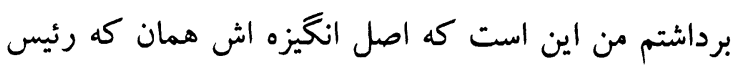

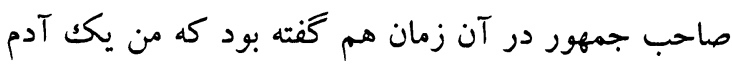

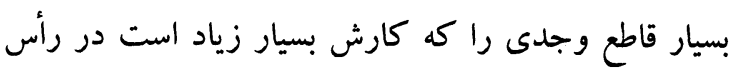

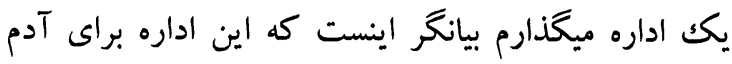
خاص جور شده بود ميخواست براى آن شخص يك اديك اداره وجود داشته باشد و از قانونش همينطور معلوم ميشود ماند قانونش را هم اكر بيينيم وضعيت همان قسمى دارد صرفاً

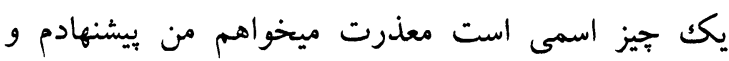

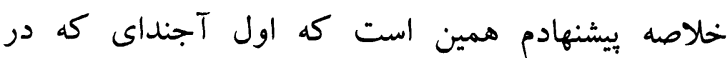


نيم ساعت يا 10 دقيقه دوام بدهيم كاغذها انشالله تيار

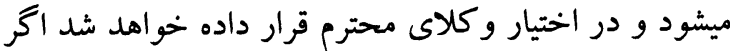

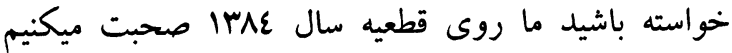
مقدماتش را كَب ميزنيم تا آنوقت كاغذها و اوراق قطعيه آماده ميشود و در اختيار وكلاى محترم قرار داده خو اهد الهد

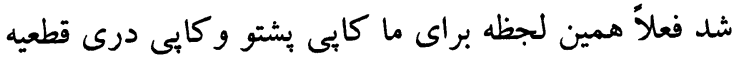

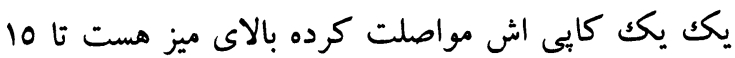

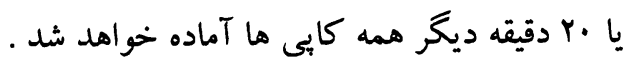

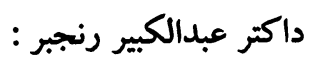

عفو ميخواهم جناب محمد صديق عثمانى صاحب، اصلاً

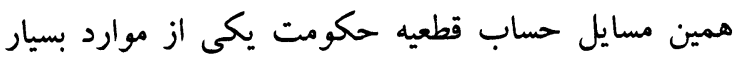

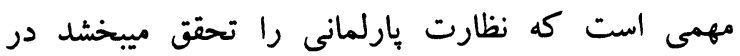
ارتباط به همان مصارفى كه دولت انجام ميدهد كه آيا اين

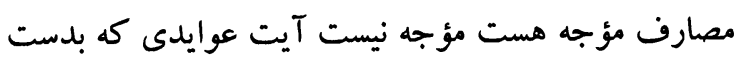
آمده درطول سال مطابقت به بيشبينى هاى قبلى در بوديجه مؤه

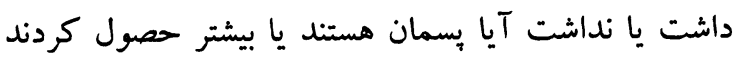

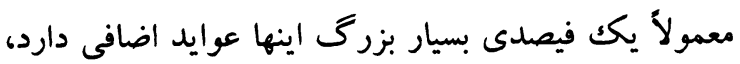

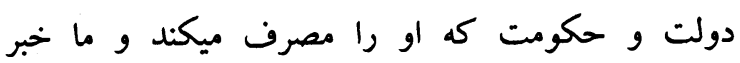

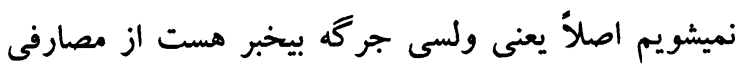

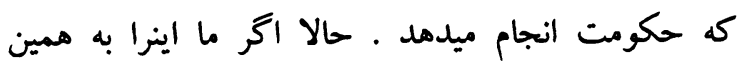

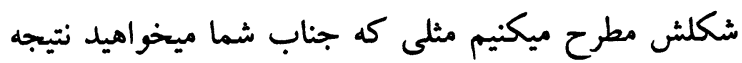

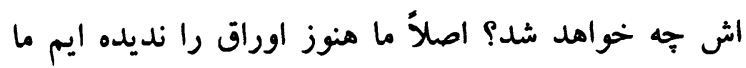
بايد او را دقيق مطالعه كنيم روى او كار كنيم كار بسيار دقيق و جدى يعنى كار خانگى منظورم هست كه هر و كيل رون

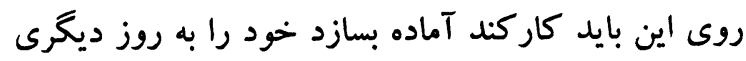

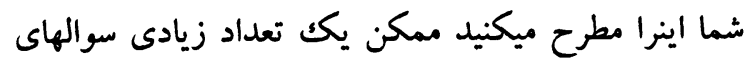

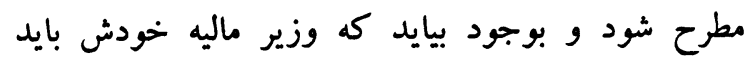

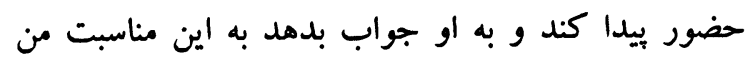

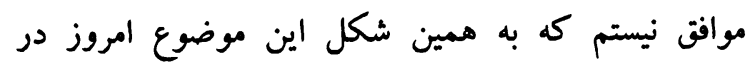

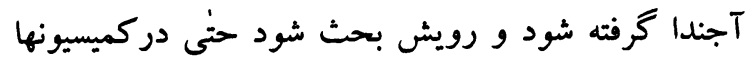
بايد رويش كار شود، تشكر . على اكبر قاسمى :

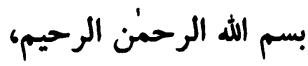

به اجازة رئيس وحضار محترم، من به تائيد صحبتهاى الرحيما

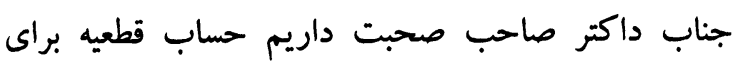

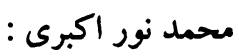

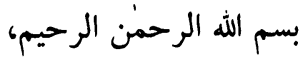

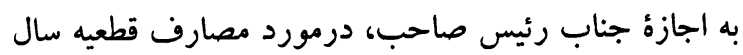

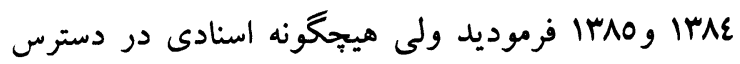

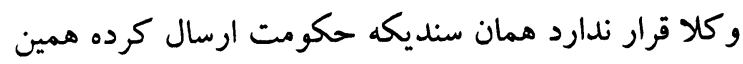

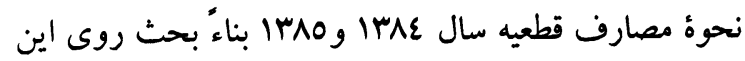
در يكك خالى ذهن بودن من فكر ميكنم كه و كلاى محترم

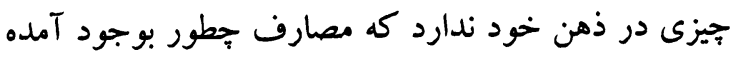

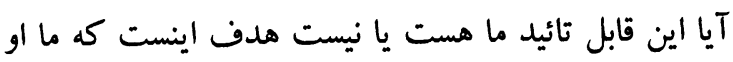

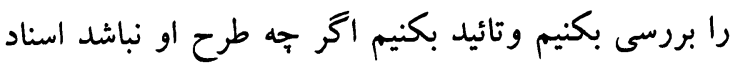

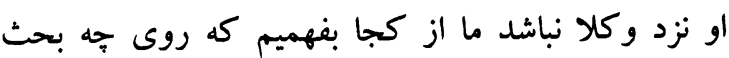

ميكنيم، تشكر . د غونلي رئيس : جناب اكبرى صاحب او جناب بلحنى صاحب : داحب د آخرني

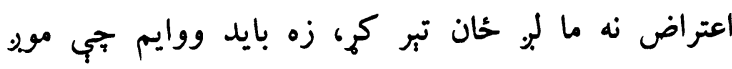

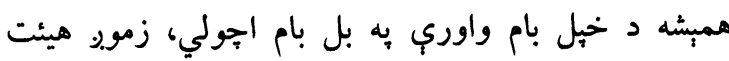

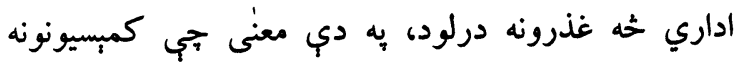

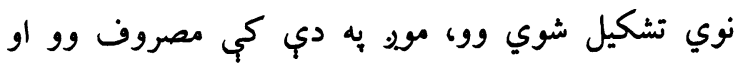

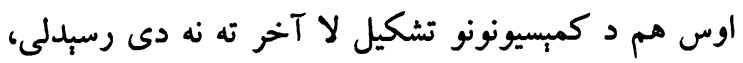

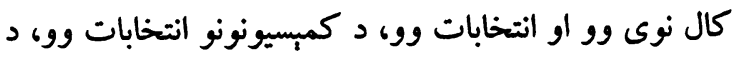

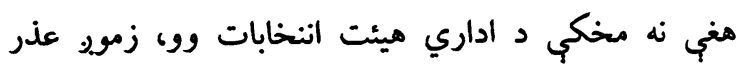

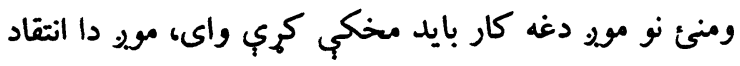

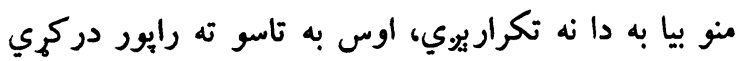

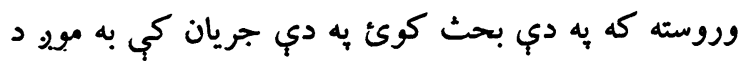

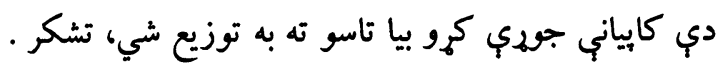

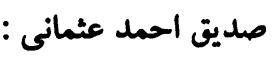

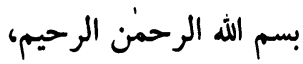

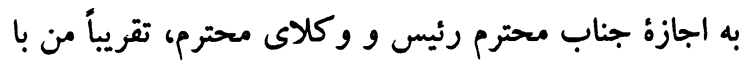
صحبتهاى اكبرى صاحب موافق هستم كه اوراق قطعيه

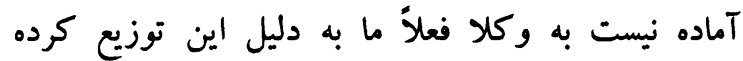

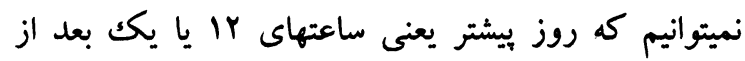

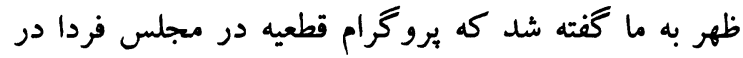

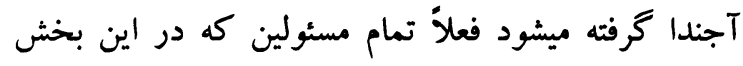
كاغذ تهيه ميكند آنها مشغول جاب إنداب اوراق قطعيه سال

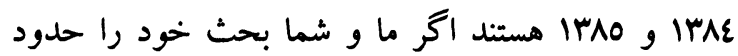


محمد داوود كلكانى :

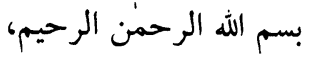

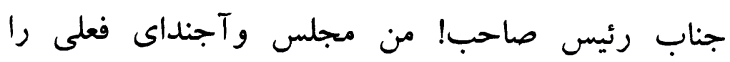

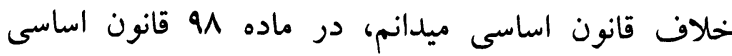
كفته كه حساب قطعى بوديجه سال مالى قبل در مانون الشلال

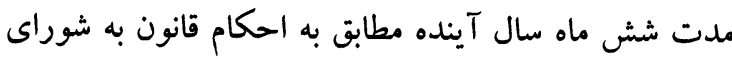

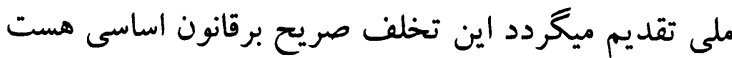

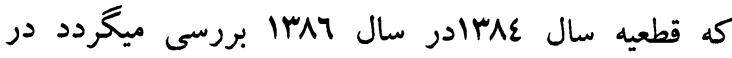

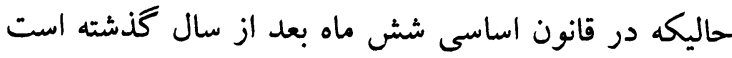

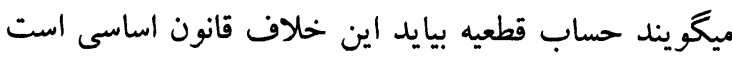

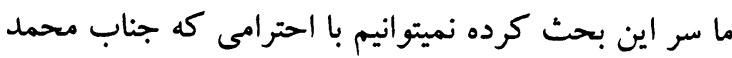

$$
\begin{aligned}
& \text { صديق عثمانى صاحب دارم، والسلام . } \\
& \text { شكريه باركزى : }
\end{aligned}
$$

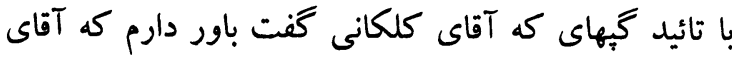

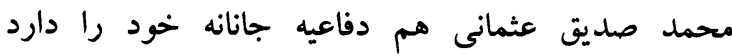

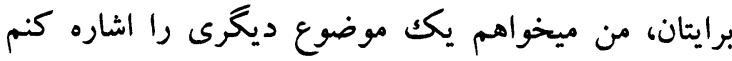

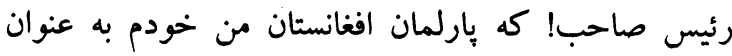

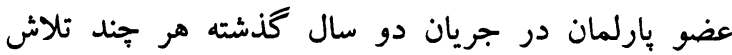

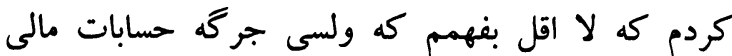

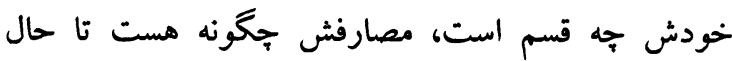
نتوانستم دريافت كنم · وقتيكه ما حسابات قطعيه را از حكومت تقاضا داريم آيا خود ما هم نميتوانيم به عنوان يكك حساب لااقل به وكلاى كه اينجا هستند حساب بدهيم كه اين بولهايكه ميآيد جه قسم مصرف ميشود كاب كجا ميرود

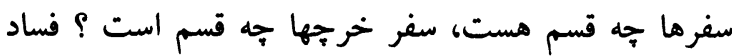
ادارى كه در داخل خود پارلمان امروز افغانستان بيداد

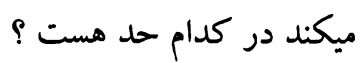

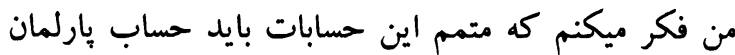

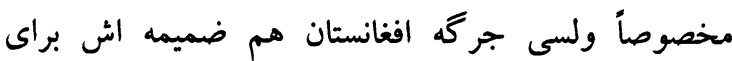
وكلاى ملت داده شود به سمع شان رسانيده شود اين إنمان

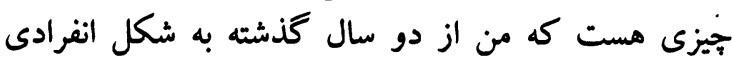

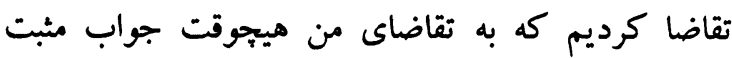

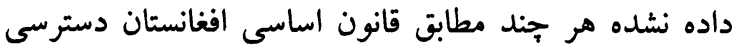

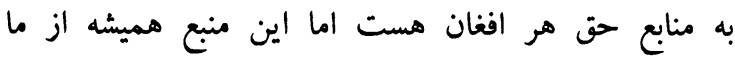

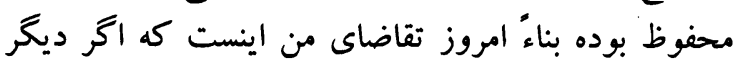

مردم و اعضاى شورا نهايت مهم اند و نبايد از سر اين

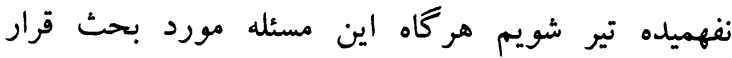

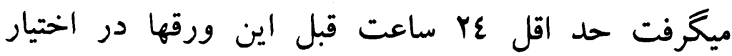

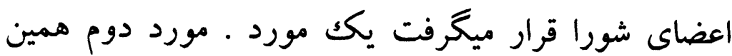

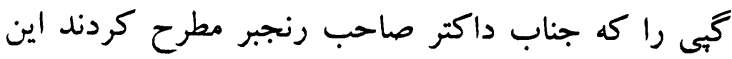

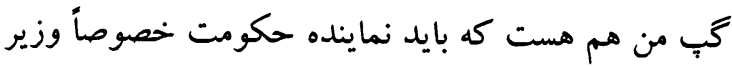

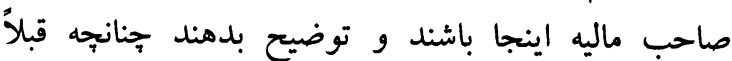

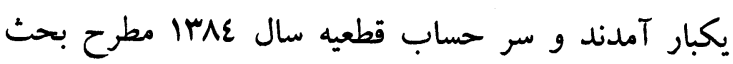

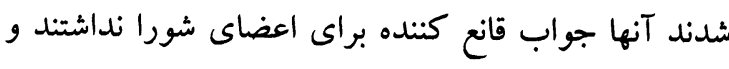

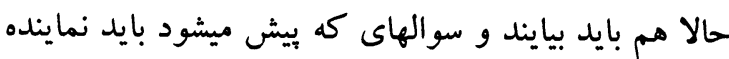

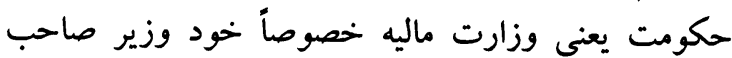

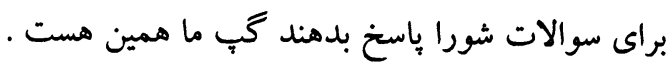

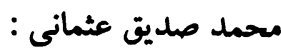
وكلاى محترم من به صحبتهاى داكتر صاحب صنمان رنجبر

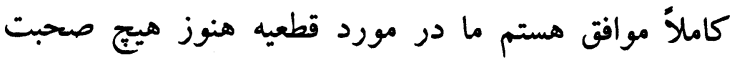

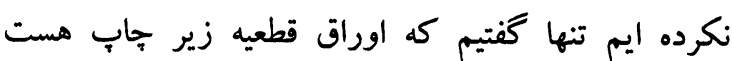

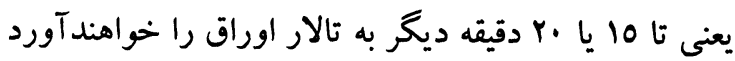

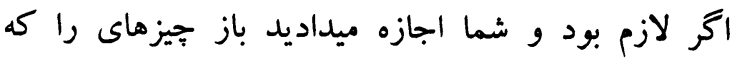

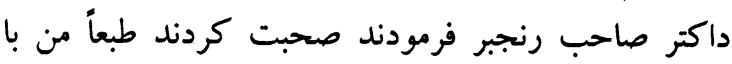

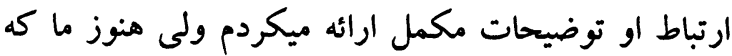

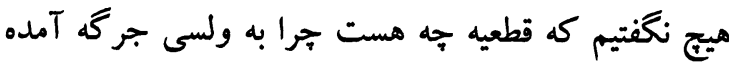

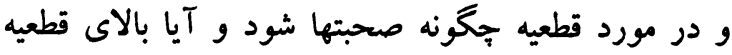
در مجلس علاوه از اينكه صحبت ميشود آيا رأى گيرى

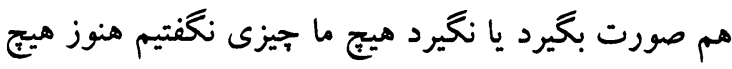

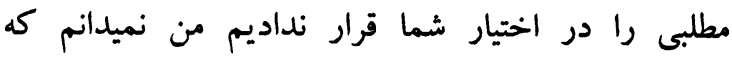

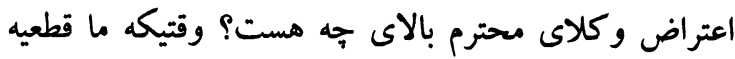

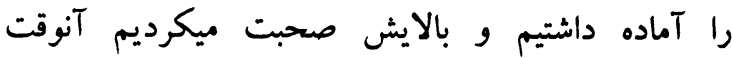

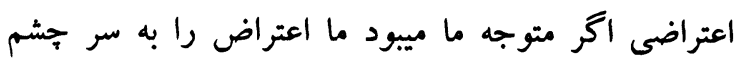

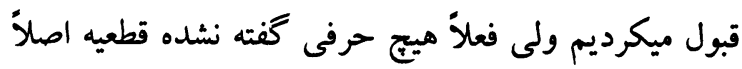

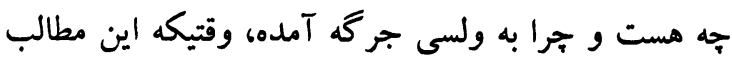

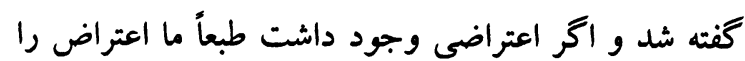

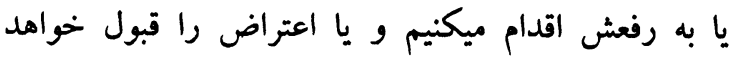

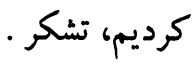


تن از رؤساى شان ديروز در كميسيون مالى و بوديجه

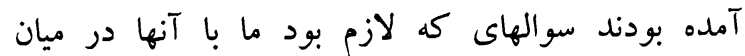

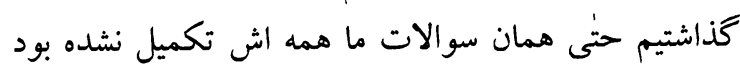

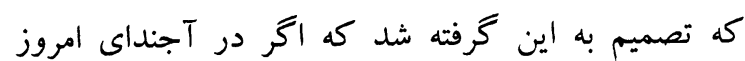

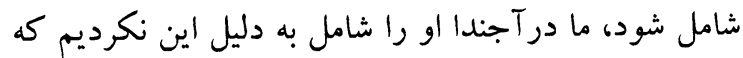

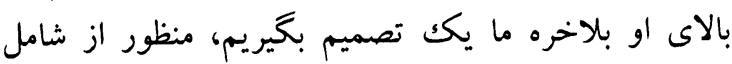

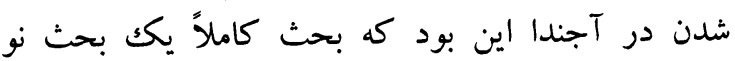
هست قطعيه يكك موضوع نو هست، فهميده شود كه قطعيه

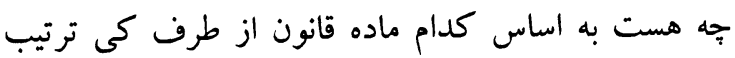

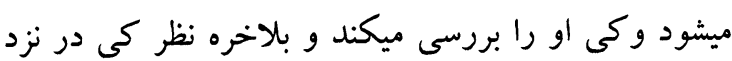

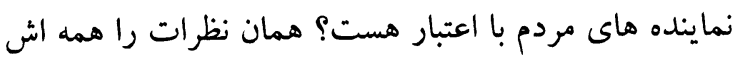

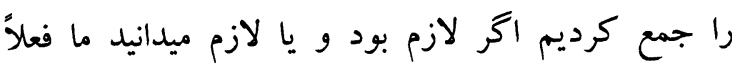

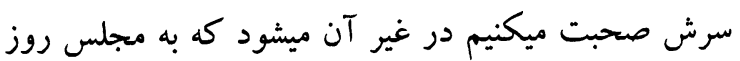

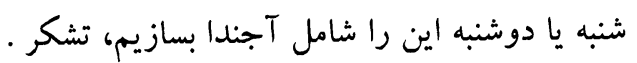
رئيس مجلس : عثماني صبب ! د دي لِياره جب د د وخت نه مو اعظمي

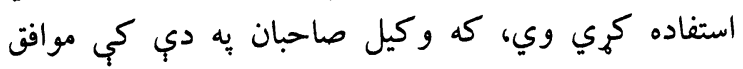

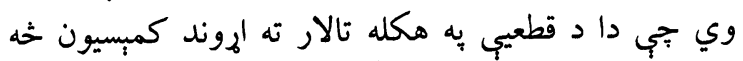

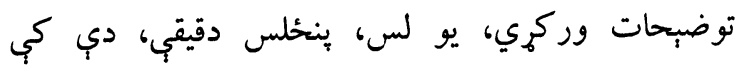

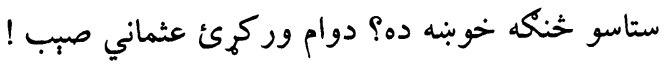

$$
\text { سيد حسين عالمى بلحى : }
$$

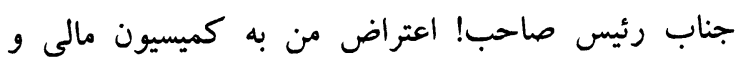

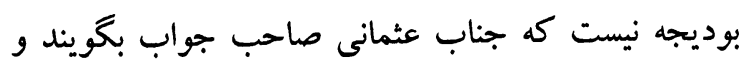
موضوع قطعيه را هم سال كذشته همان قسمى كه آنهاني كفتند اينجا صحبت كردند وطعيه ركميل صاحبان بايد بفهمندكه

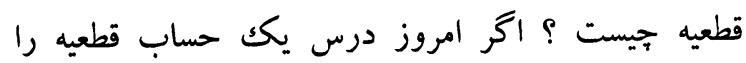
براى ما توضيح ميدهند آجندا همانطور اعلان ميشد بهتر بود ولى بحث سر خود قطعيه هست معذرت ميخواهيم

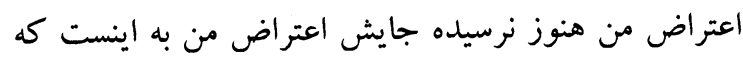

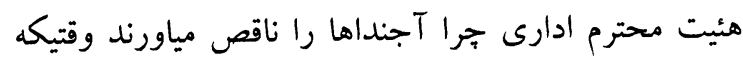

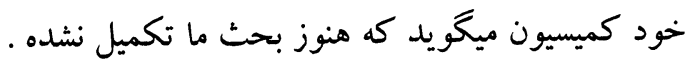
رئيس مجلس : جناب بلخى صاحب ! من به زبان بشتو خدمت تان تان عذر

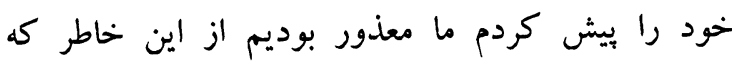
انتخابات كميسيونها بود و ما در كارهاى هئيت ادارى سال مال
همكاران هم موافق باشند در كنار اينكه ما حساب قطعيه

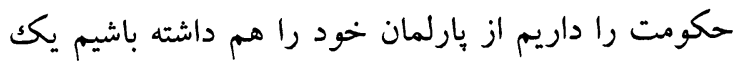
مورد . مورد دوم اينكه بارلمان ما متأسفانه الزاماً بايد كسانيكه در هئيت ادارى هستند بيطرف باشند من با ثبوت

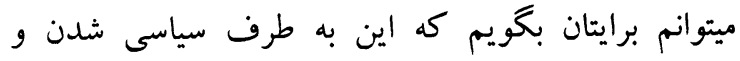

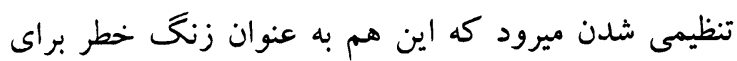

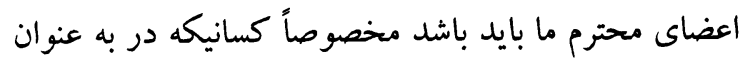

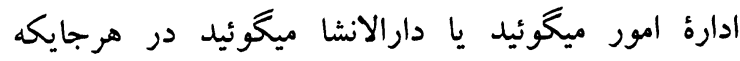

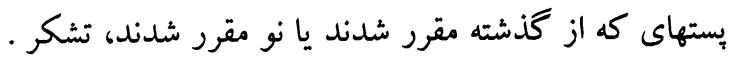
منشى مجلس : مانس

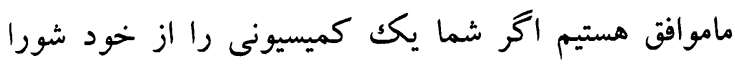
تعين بكنيد كه همين حسابات خوب هست ما ما بايد اول

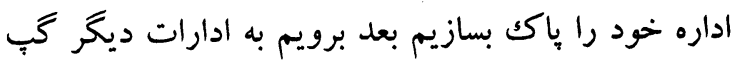

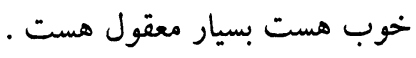

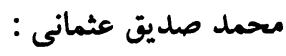

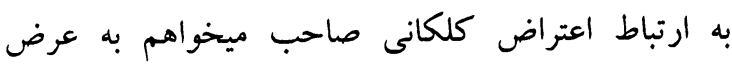
برسانم كه قطعيه سال ع^با در اواخر تعطيل نزديكك به به

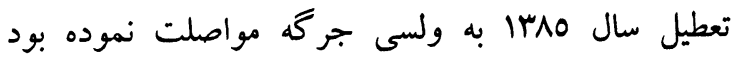

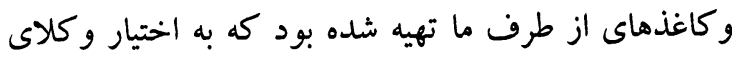
محترم قرار داده شود ولى يكروز يا يكك وقتيكه من در

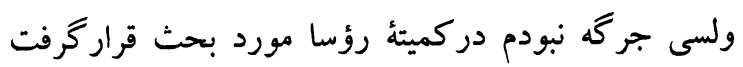

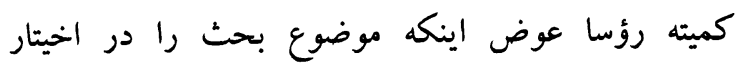

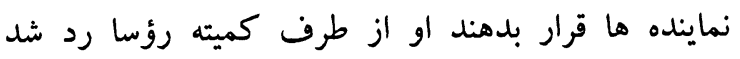
دوباره به وزارت ماليه رفت وزارت ماليه يكك سلسله دلايل

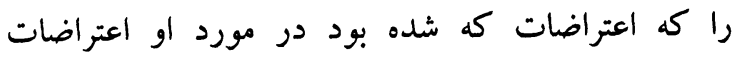

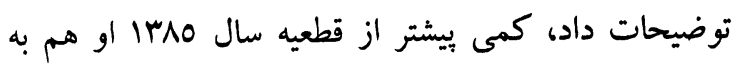
كميسيون مالى و بوديجه رسيد كميسيون مالى و بوديجه

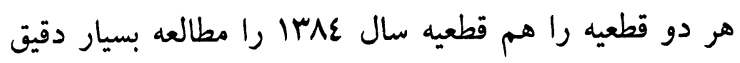

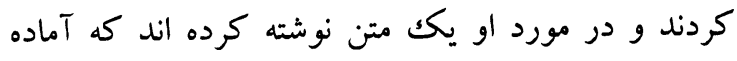

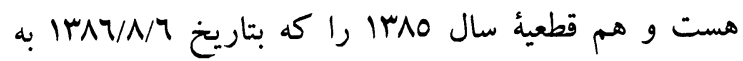
ولسى جر گه رسيده بود او را هم مورد بررسى قرار دار داد

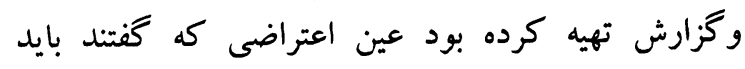

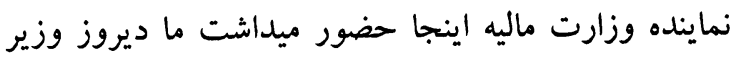

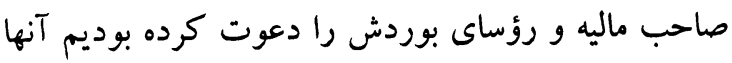
در سفر بودند نيستند در افغانستان فعلاً در جايان هستند سه رؤه 
طبعاً ولسى جر گه هست خواهش ميكنم كه اكر علاقه

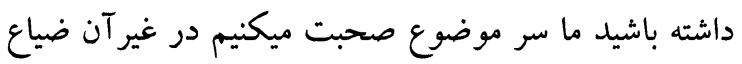
وقت براى شما نشده باشيم من فعلاً راجع به قطعيه سال

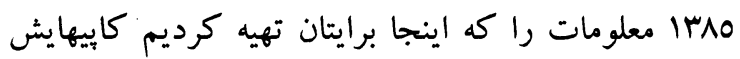
كسى بنام عبادى صاحب حالى مياورد در راه هست همين حالى من صحبت كردم همراه شان راجع به قطعيه سال ميال

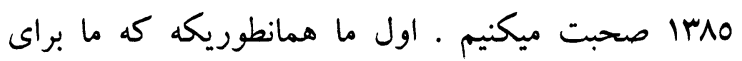

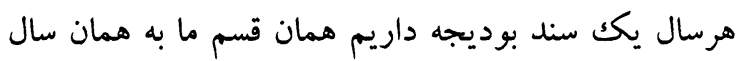

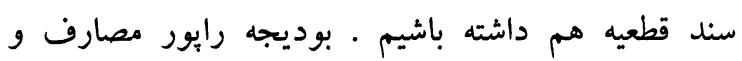

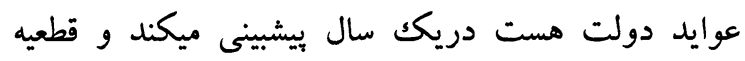
رايور عوايد و مصارف دولت را از سال گذشتّه را ارائه

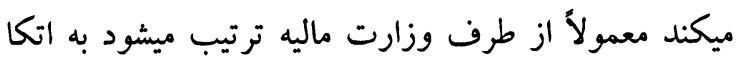
به قطعيات كه از طرف ادارات واحدهاى بوديجوى ترتيب ميشود . قطعيه سال ميتوده ما ما و شما و قطعيه سال ع^rا ما و شما از طرف واحدهاى ادارى دولت يا واحدهاى بوديجوى دولت ترتيب شده بعد از طرف وزارت مالية توحيد شده و وري در اختيار اداره تفتيش وكنترول شوراى وزيران او فرو فرار

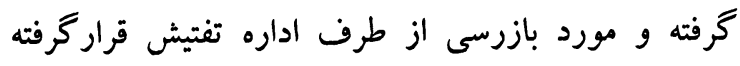
همان قسمى كه كلكانى صاحب فرمودند قطعيه بايد در برد خلال نيمه اول سال ما بعد بايد مطابق به ماده هو هو قانون

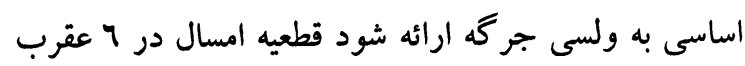

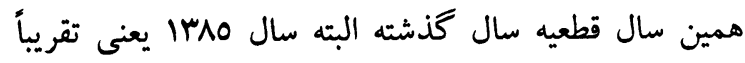

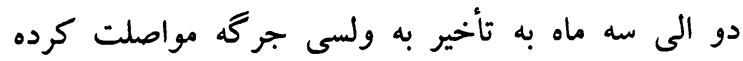

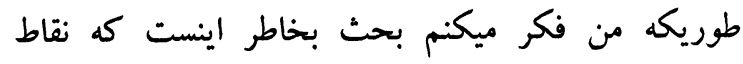

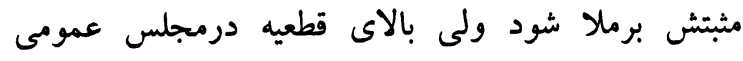

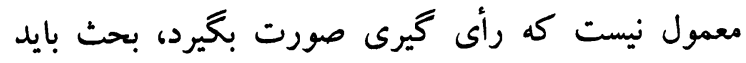

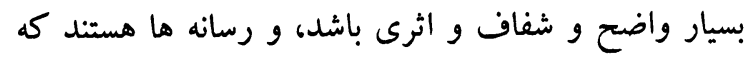

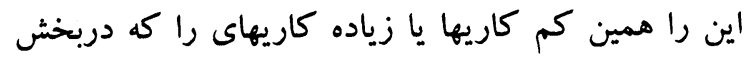

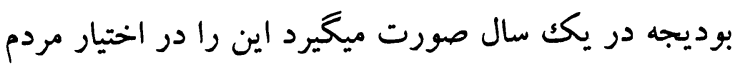

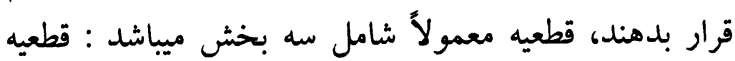
بوديجه عادى كشور است، قطعيه بوديجه انكشافى است، وقطعيه عوائد است، در اين قطعيات دويش يعنى فئى قطعيه بوديجه عادى و قطعيه بوديجه انكشافى از طرف رئ رياست دورئ

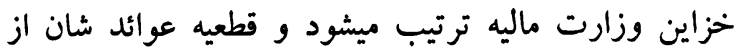

نو بود از اين خاطر ما عذر را قبول كرديم انشالله اين دو

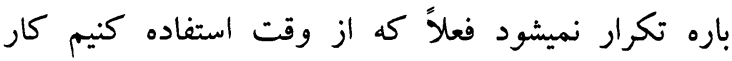
خوبى هست جناب عثمانى صاحب اينرا به بيش بيرد . منشى مجلس : منوبى مسن جناب جناب بلخى صاحب ! رئيس صاحب زياد از خود گذذرى كرد، همين آجندا را كميته رؤسا ترتيب كرده از إئ تمام

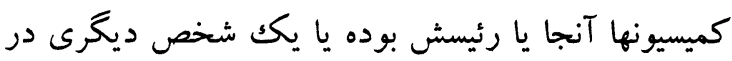

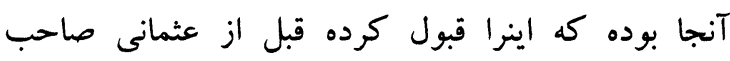

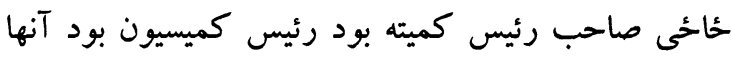
قبول كردند كه ما در ارتباط قطعيه ميتوانيم در آنجا

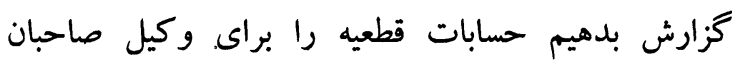

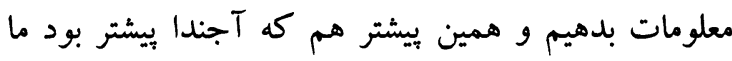

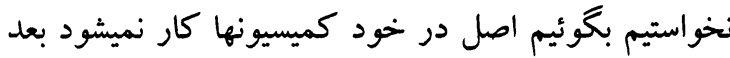

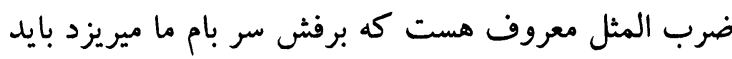

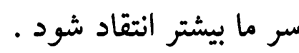

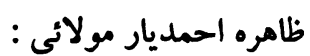

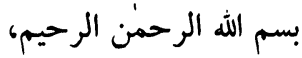

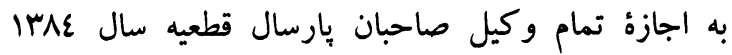

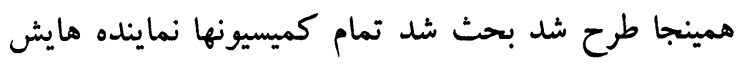
بود منتهى جون كمى وكاستيها از طرف وز وزارت مات ماليه

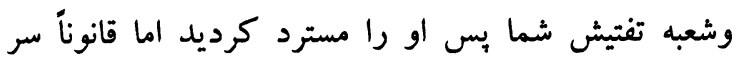

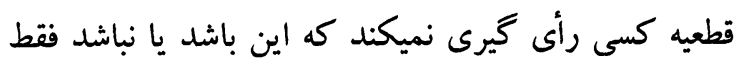

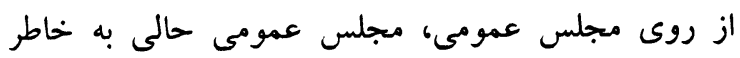

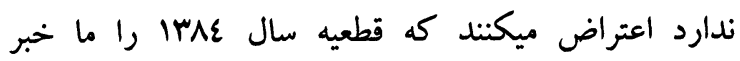

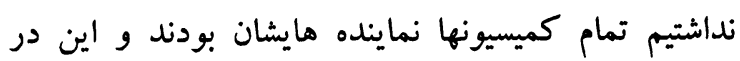
مجلس عمومى طرح شد از مجلس عمومى يس دوب دوباره كفتند كه اين نواقص دارد دوباره مسترد كنيد ما هم مست مسترد كرديم حالا كه امسال اينجا آمديم ما نميدانيم كه اين

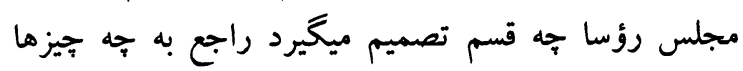

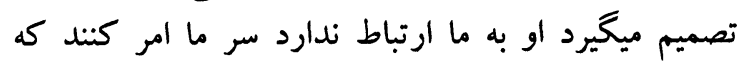

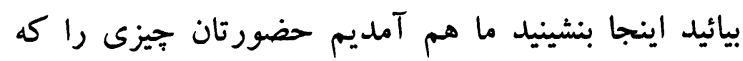

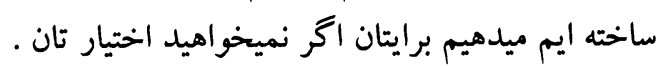
صديق احمد عثمانى :

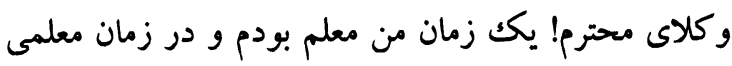

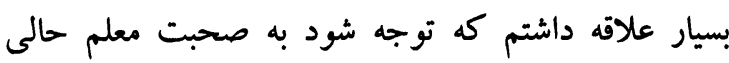


و سه مليارد افغانى بانكك بول داده، يعنى مقدار بول راكه بانكك داده يك عشاريه شصت و دو مليارد افغانى بانى كمتر

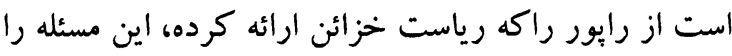

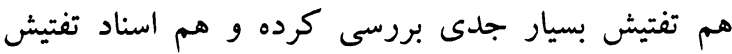

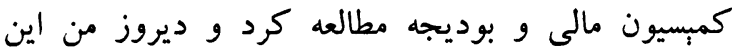

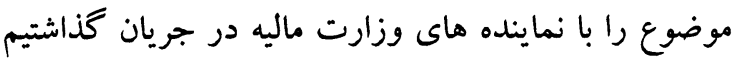

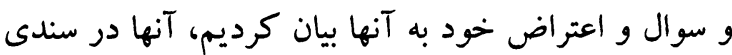

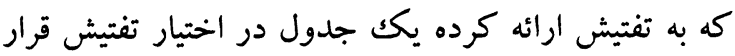

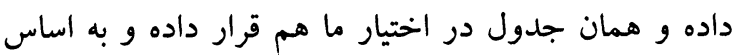

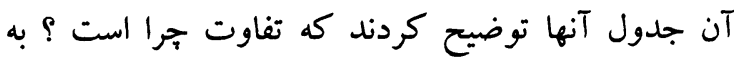

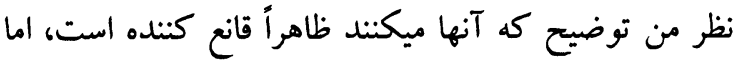

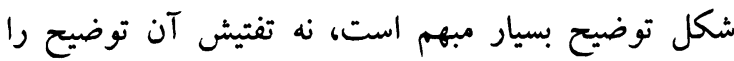

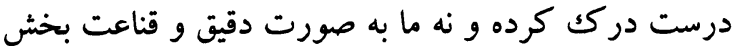

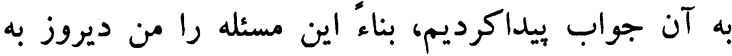

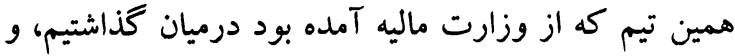
بحث بسيار طولانى داشتيم، قناعتى كه دركميسيونها حاصل شد آنقدر به نظر كميسيون دلجسبِ نبود، يعنى

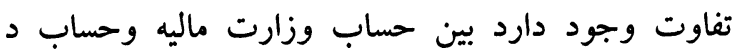
افغانستان بانكك بوديجه عادى كشور، يعنى همين بخش

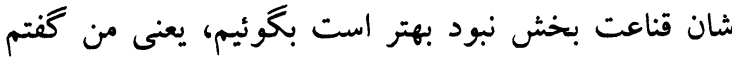

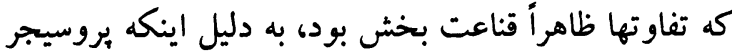

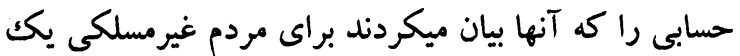

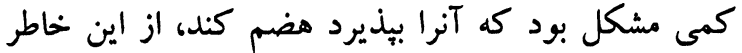
من به وزارت ماليه وظيفه سيرديم كه قطعيه ها را كه بعداً ترتيب ميكنند طورى آنرا تنظيم كنند كه حسابات ورات داله وطيه افغانستان بانكك وحساب خزاين وزارت ماليه يكى باهم مطابقت داشته باشد، و اگر مطابقت نداشته باشد دلايل شان بسيار واضح و روشن باشد، در بوديجه هميشه يول كه مصرف نشده البته، يول مصرف نشده نظر به رايور قطعيه واصل بررسى و وسط سال در بوديجه عادى يك عشاريه

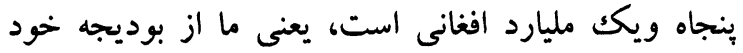

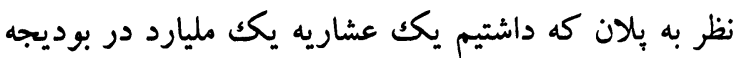
عادى ما مصرف كرده نتوانستيم، جيزى مهم كه و كلاى

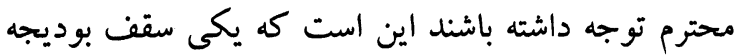

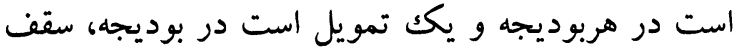

طرف رياست وزارت ماليه ترتيب ميشود و همزمان به اين

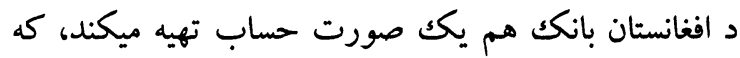

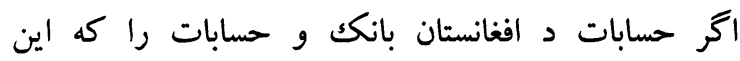

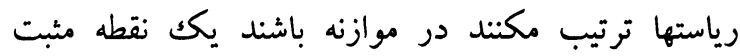
قطعيه همين خواهد بود، قطعيه به اساس سند بوديجه سال ماقبل ترتيب ميشود در سند بوديجه سال ما قبل بوديجه

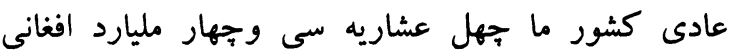
بيش بينى شده بود و اين در بررسى وسط سال كه معمولاً

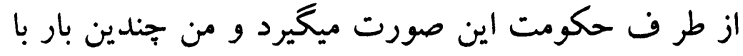

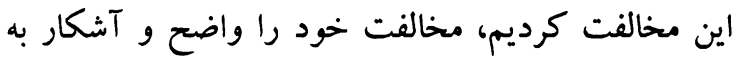
وزارت ماليه، به معين صاحب وزارت ماليه به مؤن رؤسايش

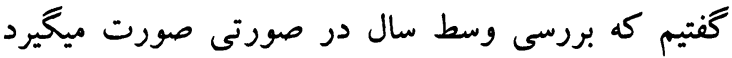

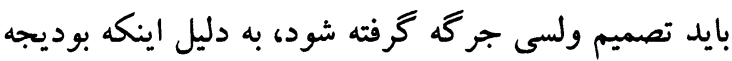

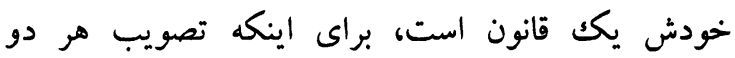

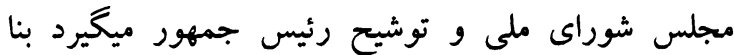

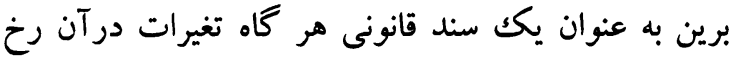

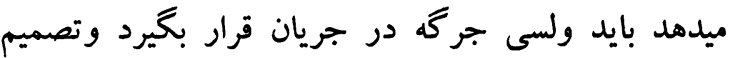

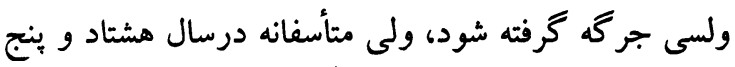

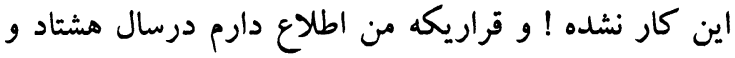
شش هم هنوز بررسى وسط سال كه در حكومت منظور شده ولى در ولسى جر گه نيامده و سرش بح بحث نشده، و و در رايور قطعيه كه از طرف دولت ترتيب شده همين بوديجه عادى جهل وجهار عشاريه شصت و هفت مليارد افغانى است، يعنى اينكه درعرصه از اين هم در بوديجه سر سال

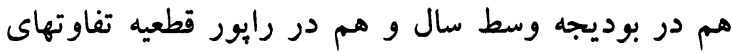
اندكك درآن ديده ميشود، كه اين تفاوت آنقدر زيطاد نيست، ولى به هر حال يكك تفاوت است، و ميشود كه سرش بحث كرد، در بوديجه عادى ما دو جيزى بسيار مهر مانه

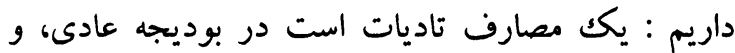
ديخر عوايد است دربوديجه عادى، به اساس رايور رياست

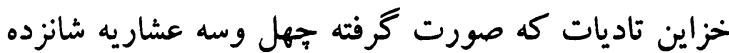
مليارد افغانى است، يعنى رياست خزاين اسناد كه توسط آن يول اجراء ميشود، جهل و سه عشاريه شانزده مليار افغانى معرفى كرده، اما د افغانستان بانكك دهنده بول است، وله

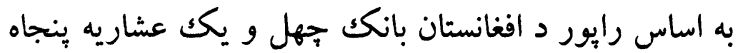


غلط شده بود بايد همان غلطى را اصلاح نموده دوباره به

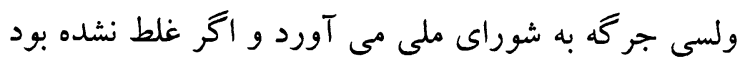

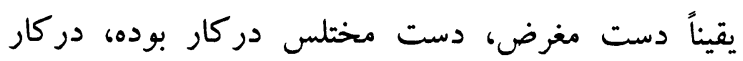

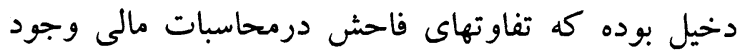

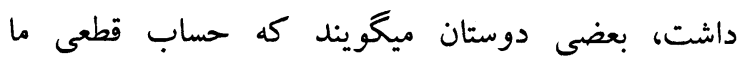

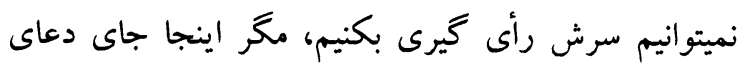

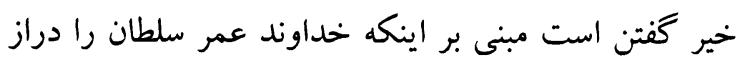

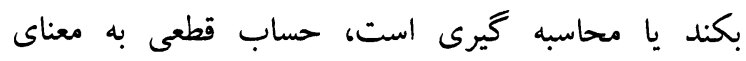

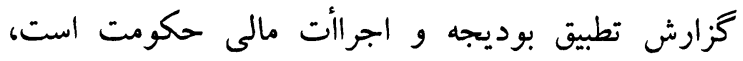

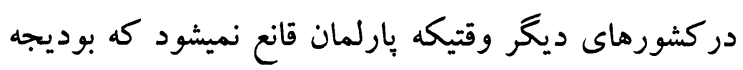

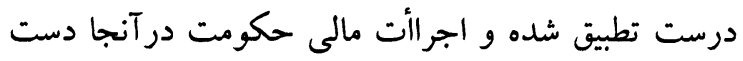

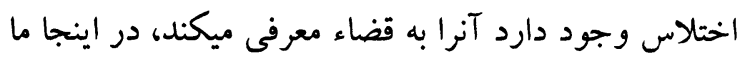

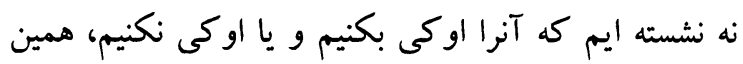
كه گزارش قطعى بوديجه سال سيزده هشتاد و جهاراگر

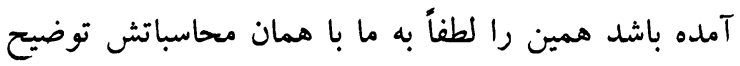

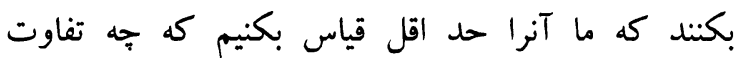

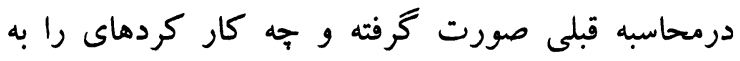

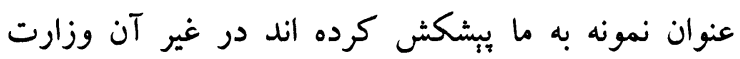

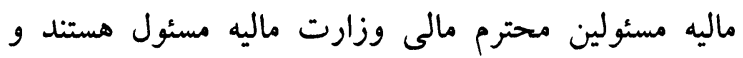

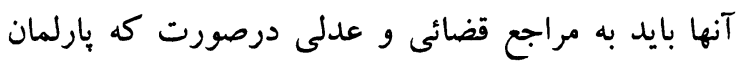

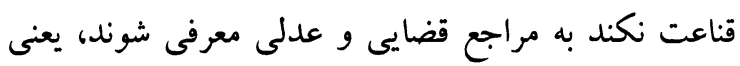

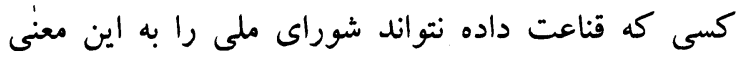

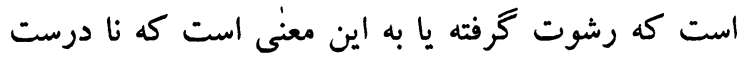
به گونه به مصرف رسانيده بنابرين اين مسئله را بسيار

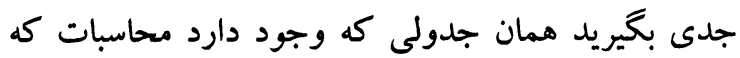
دوباره آمده همان را توزيع بكنيد كه حد هد اقل بفهمم كه ونه

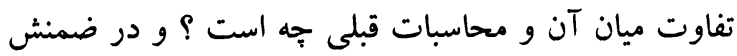

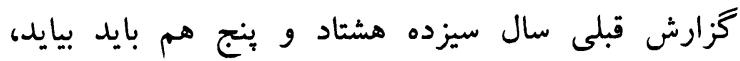
تشكر . داكتر عبدالكبير رنجبر :

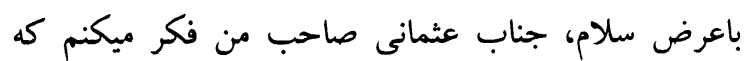

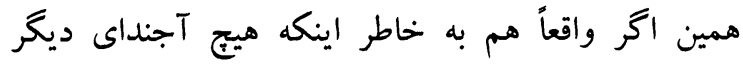

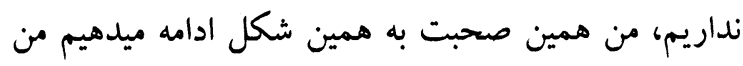

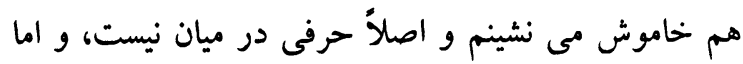

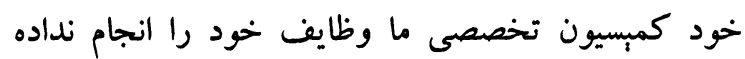

بوديجه همان است كه در بررسى وسط سال از طرف

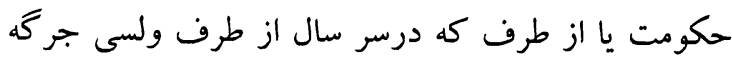
تعين ميشود، ولى تمويل آن است كه به همين حساب كه در د افغانستان بانكك حساب شش صد صد يكك صد است است، در

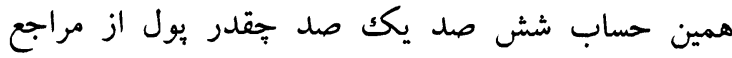

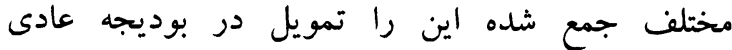
ميكويند، به اساس رايور كه ما آنجا مطالعه كرديم تمويل تمويل بسيار بالابوده است از سقف بوديجه، تمويل در بوديجه عادى ما وشما بوديجه دولت افغانستان بانكك شصت ويك النك

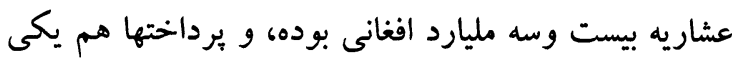

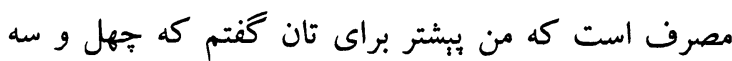

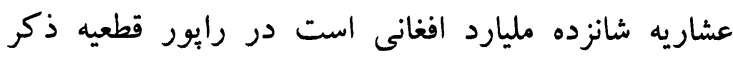
شده، ولى در بهلوى مصارف يكك سلسله حسابات ديخرى كه است كه آن به حساب مصرف نميرود وله ولى از حساب تمويل كم ميشود، كه آن جهل ينج عشاريه صفر ينج

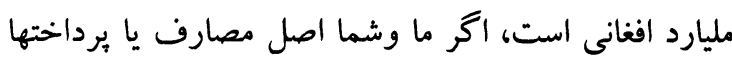

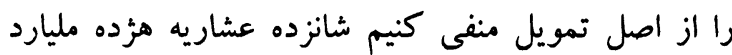

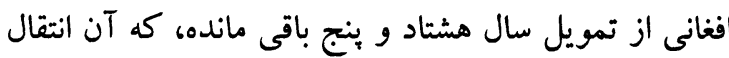

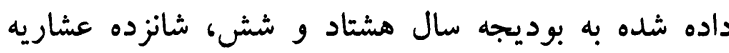

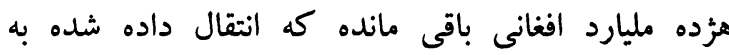

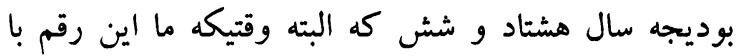
رقمى كه درسند بوديجه هشتاد و شش در در جست ونت مقايسه

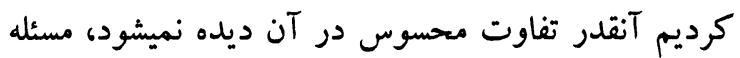
كه در قطعيه بسيار مهم است و تفتيش هم بهد آنه آن بسيار

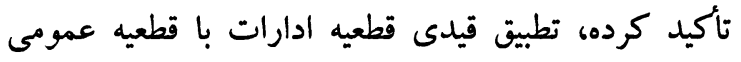

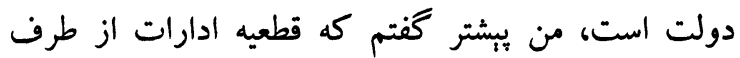

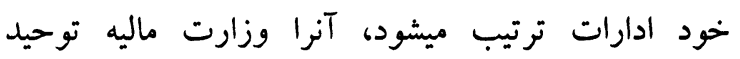
ميكند. سردار محمد رحمان اوغلى :

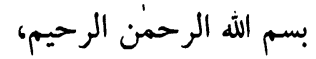
به اجازة هيئت محترم ادارى، جناب رئيس الرحيس صاحب! اكر

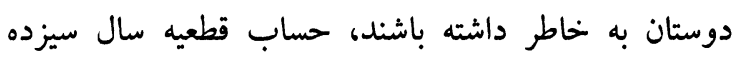

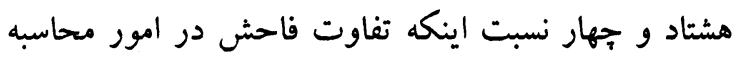

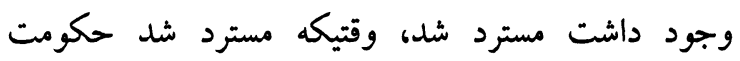

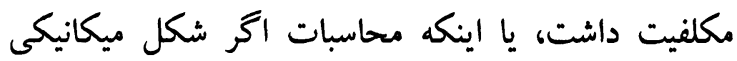


كشورها معمول است كه حكومت يكك مقدار مسائل مالى

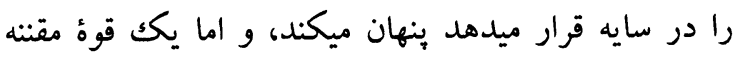

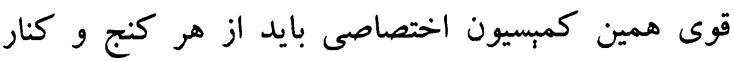

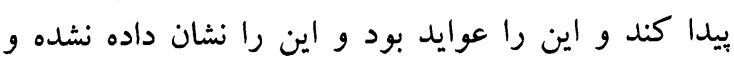

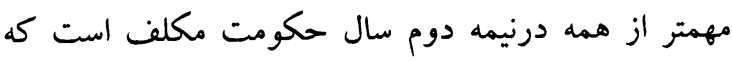

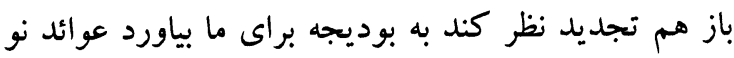

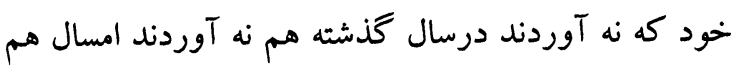

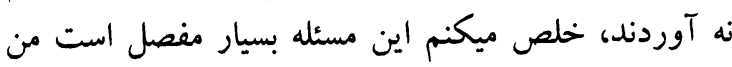

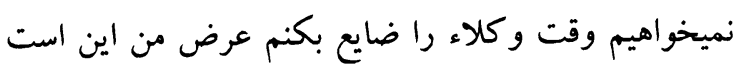

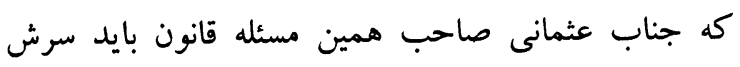

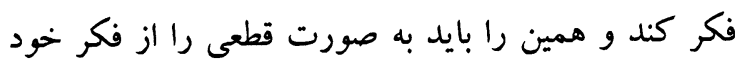
بكشد كه ما دعاى خير ميكنيم من حتماً مثليكه رحمان

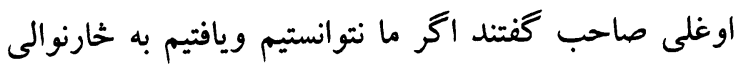

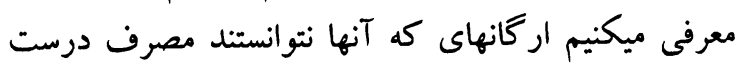

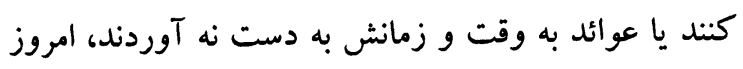

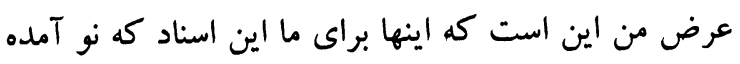

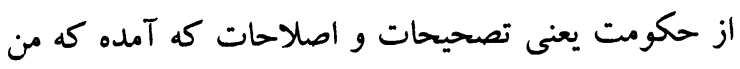

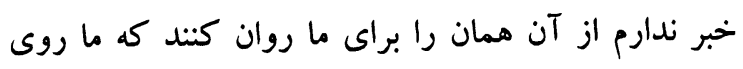
آن دقت كنيم خوب سرش فكر كنيم روزى ديخرى كه ان مهان

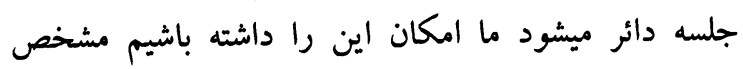

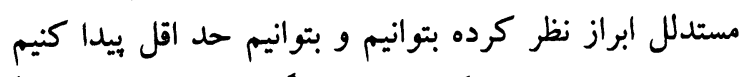
همان نارسايى هاى حكومت و اصلاً دعاء ميكنيم كه اصلاً

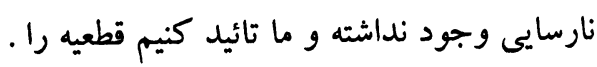
رئيس مجلس :

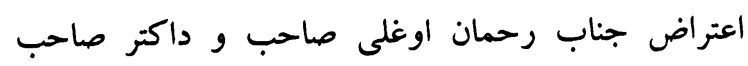

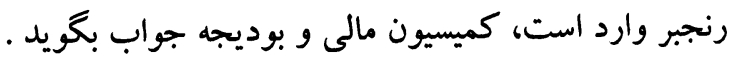
محمد صديق عثمانى : مدئ

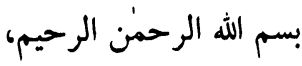

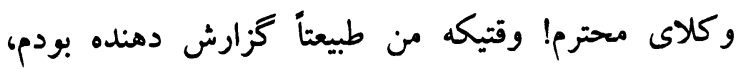

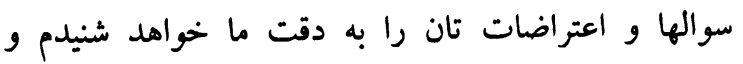

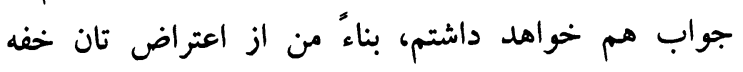
نيستم ولى به دقت شما هم گَوش كنيد، قطعيه سال هشتاد

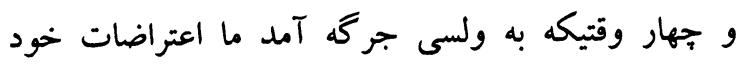

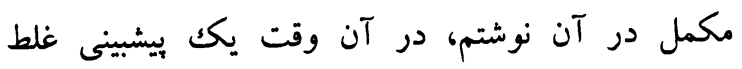
دركميسيون شُه بود، البته به دليل اينكه ما مكمل در رايور
جناب رئيس صاحب! وظايف خود را به صورت قطعى

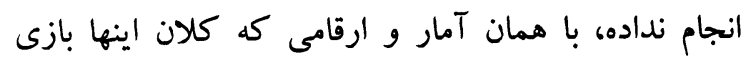

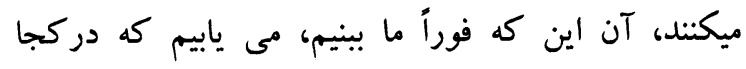
جقدر منفى ميشود و جقدر مثبت، در مجموع و اين بسنده

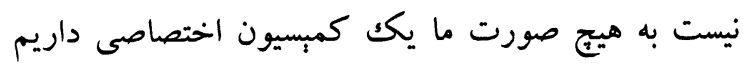
كه آنها بايد بسيار دقيق روى همين آمار و ارقام كار كنند،

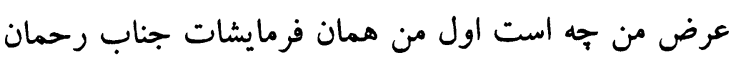

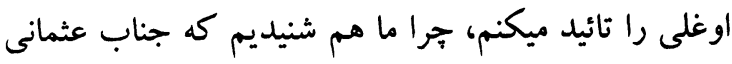

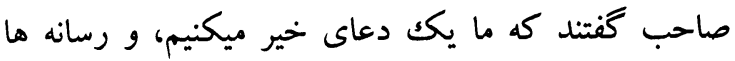
باز انعكاس خواهد داد همين موضوع قطعيه را، اينجا خرا

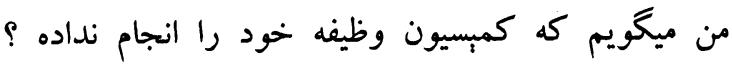

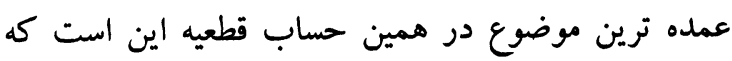

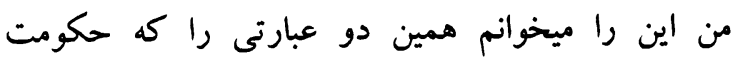

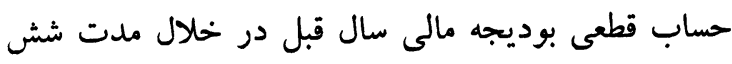

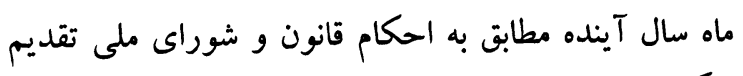
ميگردد، اين قانون طلب است جناب عثمانى صاحب، باحن بايد قانون تصويب شود در اين جهار سال، سه سال بايد تصويب ميشد، حد اقل از طرف حكومت بون بايد همين طرح

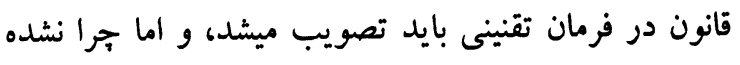

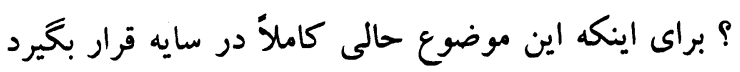

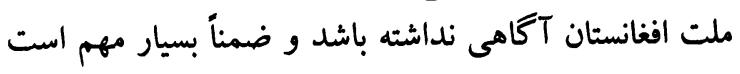

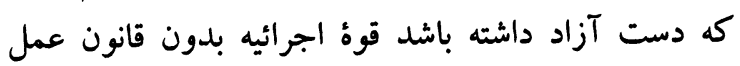
كند، همين حالى كه ما ولسى جر كه داريم همين

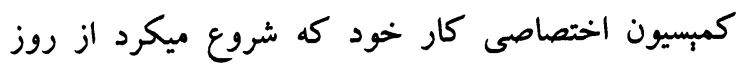

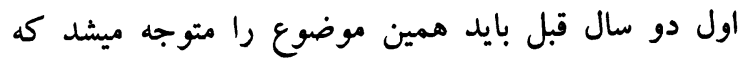
قانون حسابات قطعى را مطالبه ميكرد از قوه اجرائيه كه مه مئه

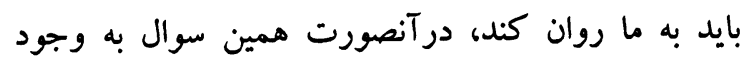
نمى آمد كه عثمانى صاحب كفتم كه ما ما دعاى خير

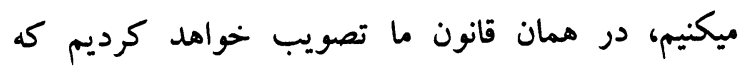

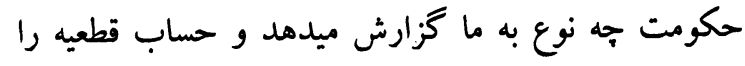

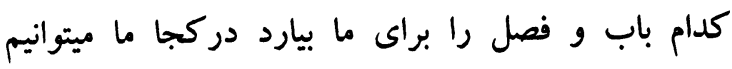
نظارت كنيم از مصارف حكومت در اداراتش و هميجنين بسيار مهم اين كه باز هم من عرض ميكنم كسرو مس متوجه

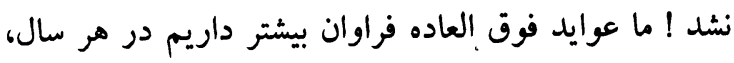
نسبت به جيزى كه به ما روان ميكند در الماده فران بيشت داريم در هر اين درتمام 
قطعيه را زير بحث گُرفتم و از ما دعوت شد كه شما

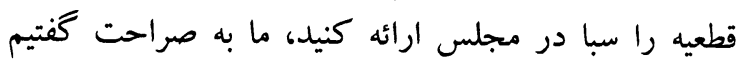
كه اسناد كه در اختيار و كلاء قرار بگيرد آن اسناد آماده

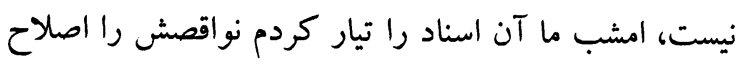
كردم، صبح وقت به اختيار دستيار خود قرار دادم، دستيار يك يكك كايى اش را به من آورد، ديخر كايبها هفت ورق وقد

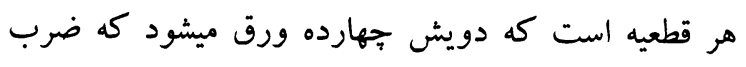
دو صد كايى، دو هزار و هشت صد ورق آن آن بايد از طريق

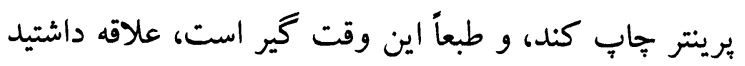

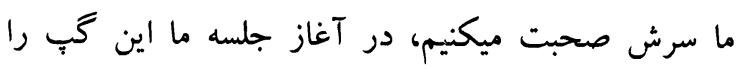
كفتيم، يعنى من فكر ميكنم كه ما كوتاهى در اين مورد

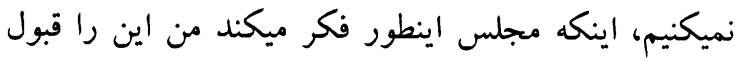

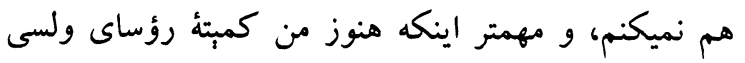

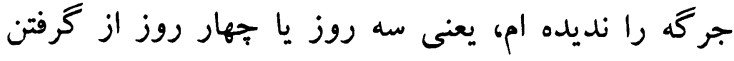

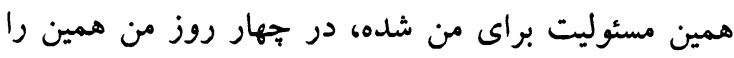

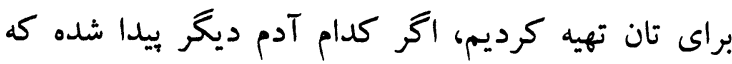

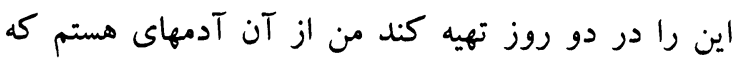

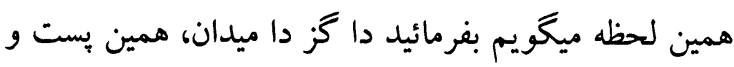

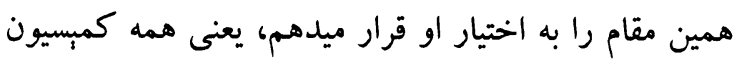

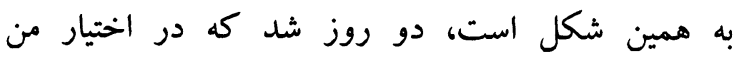

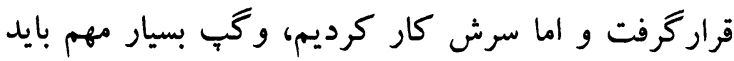

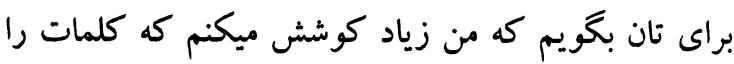

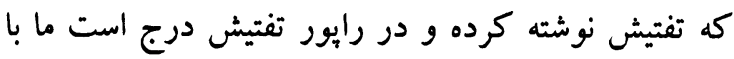
كلمات بسيار ساده بيان كنيم به دليل اينكه بحث قون قطعيه

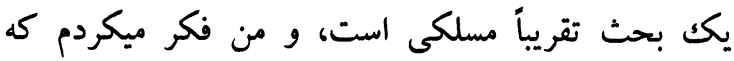

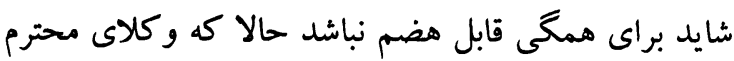

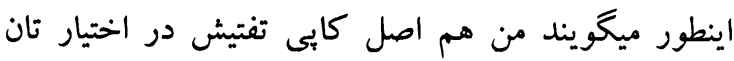

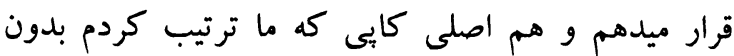
اينكه من اينجا توضيحات بدهم براى تان من قرائت ميكنيم

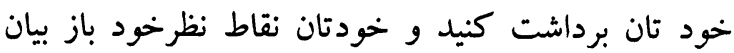
كنيد، تشكر .

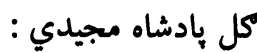

جناب رئيس صبب! رنجبر صبب د قطعيب د قانون يه باره

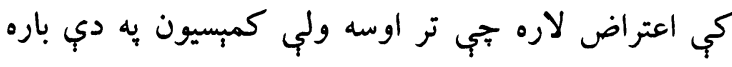

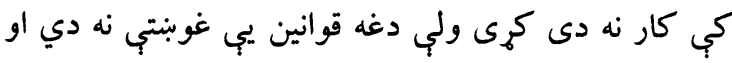

تفتيش در آن وقت در اختيار ما قرار نمى دادند، فقط يكك

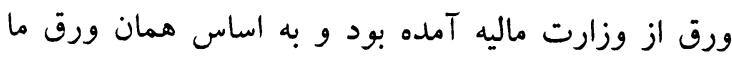

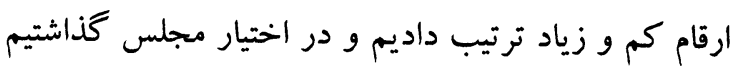

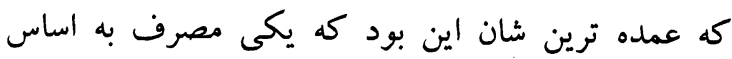

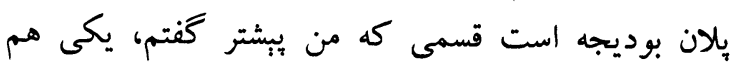

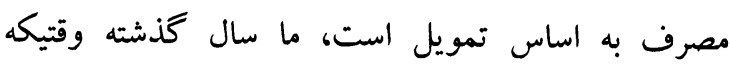

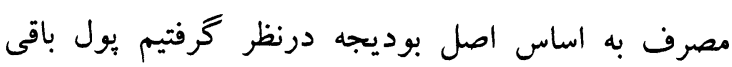

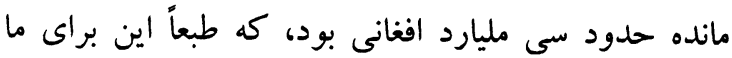

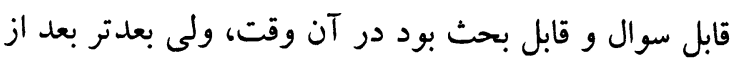
سوالات معلومات كه از وزارت ماليه خواستيم و اوراق

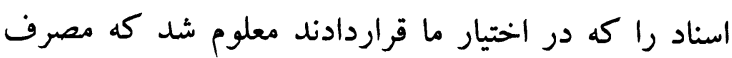

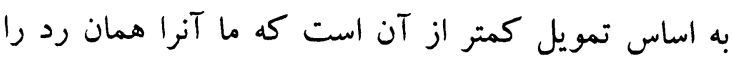

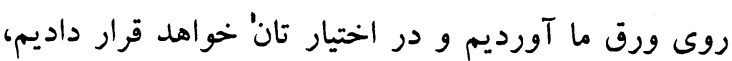
ميآيم به سر صحبت كه داكتر صاحب رنجبر فرمودند ما ما ورديم

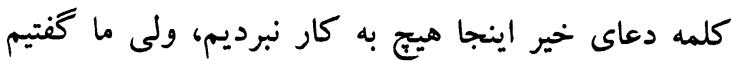

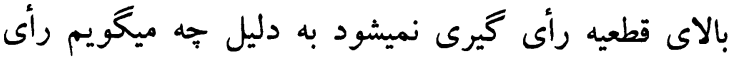

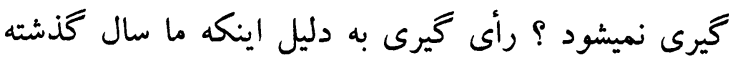

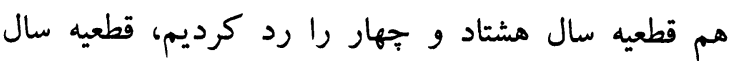

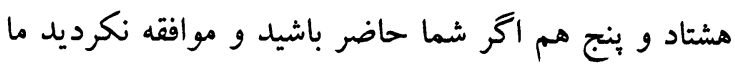

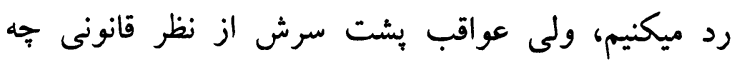

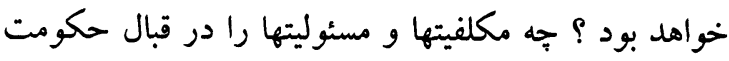

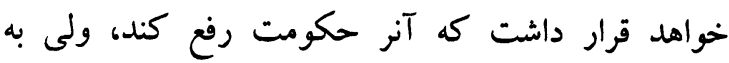
ارتباط اينكه نقصان دركار بوده از سوء استفاده در اجرأن

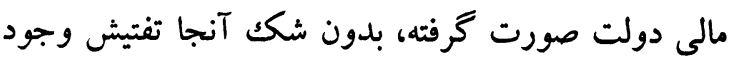
دارد، و ما نقاط نظر خود را به تفتيش گگفتيم دركزارشى كه ما تهيه ميكنيم وتهيه كرديم، هم به وزارت مارد ماليه كفتيم

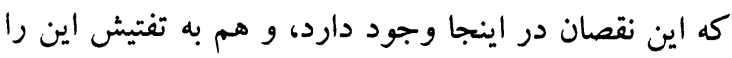

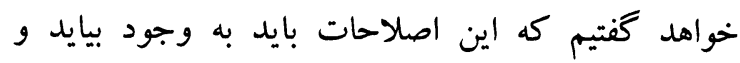
نواقصى كه است اكر از نظرحسابى و مالى سوء استفاده

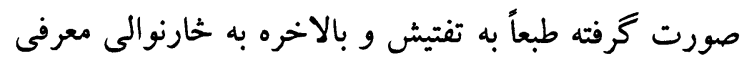

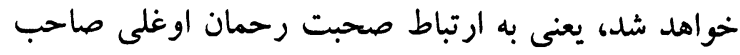

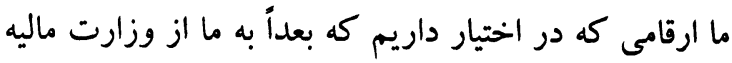

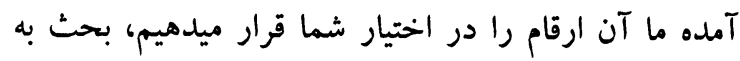

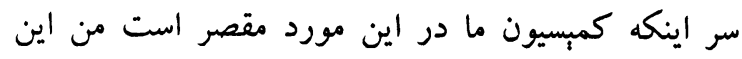

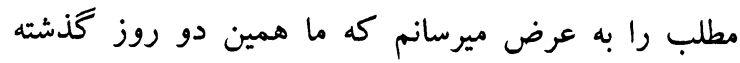


عمده سال مالى جديد كه اين مكلفيت وزير ماليه است،

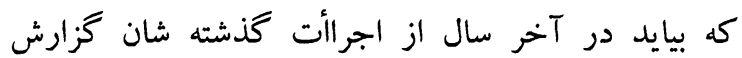

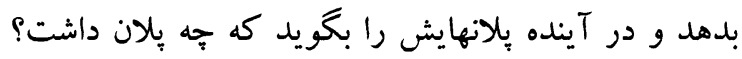
و همجنان حساب قطعى كه ميكويند حساب قطعى سال

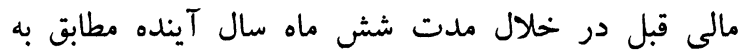

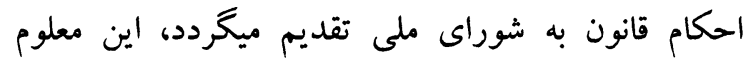

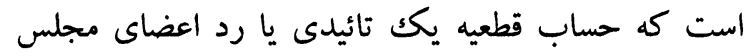

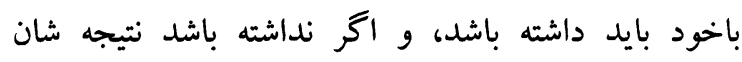

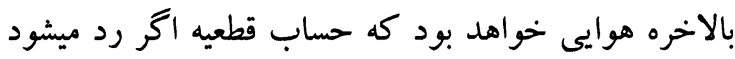

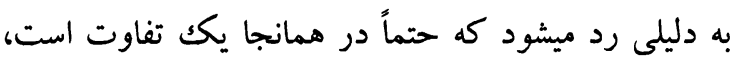

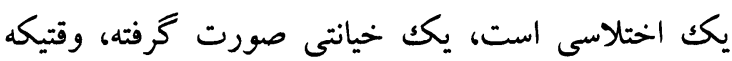

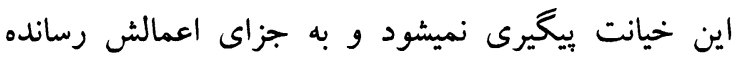

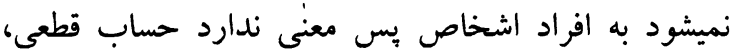

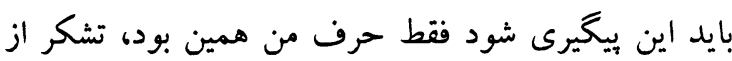

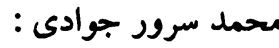
بسم الله الرحمن الرحيم، كرجه كارت من سبز بود شايدصحبتهاى من محتواى الرئ

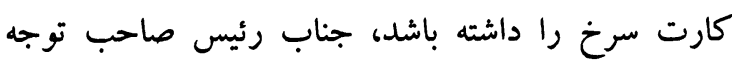

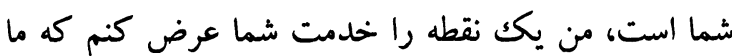

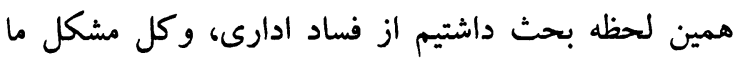
همين است، شما بييند در رابطه با بوديجه جه اله حساب

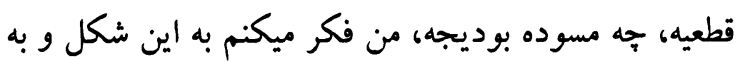

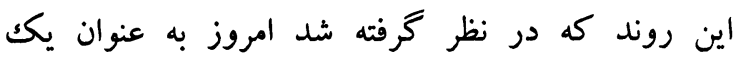

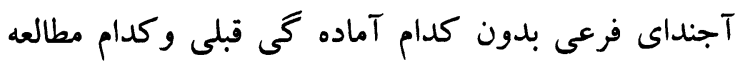

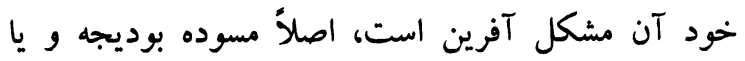
ترتيب بوديجه و يا تصويب بوديجه به شكل يك آنك قانون آنون

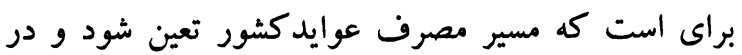

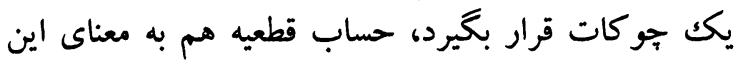

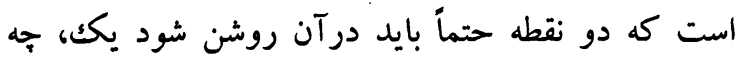

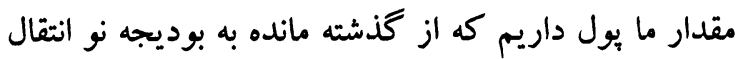

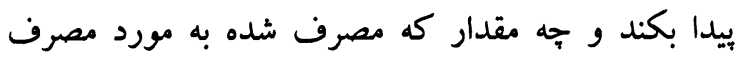

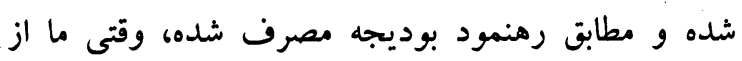

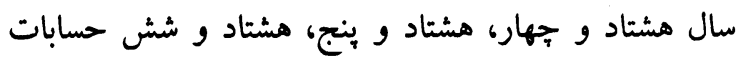
قطعيه ما رسيدگى نشده معنايش اين است كه در طى اين
دلته يي باس كئى نه دى، هغه ته يب خواب ورنكه إى شو،

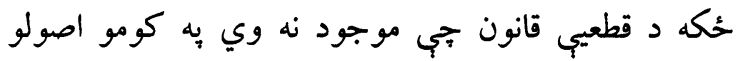

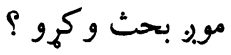

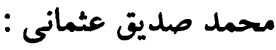

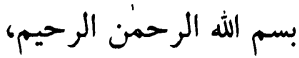
وقتى ما و شما قانون اساسى افغانستان را مطالعه كنيم در

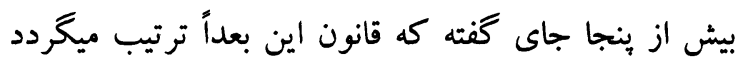

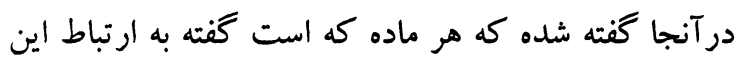

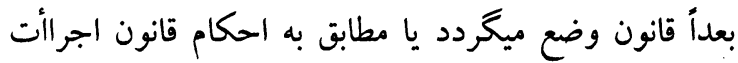

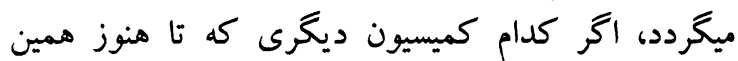

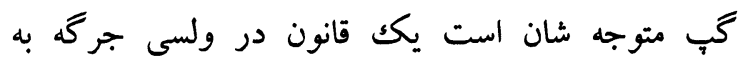
شمول جناب رنجبر صاحب عرضه كرده باشد ما ما مقصر

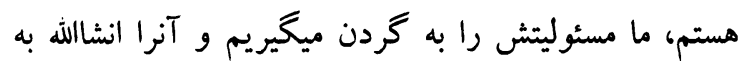

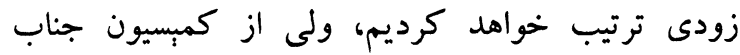

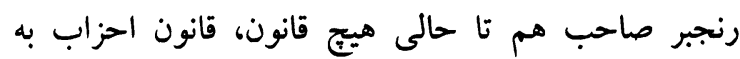

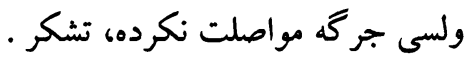
قاضى محمد ايوب مهر : بسم الله الرحمن الرحيم، به اجازة جناب رئيس صاحب، هيئت محترم ادارى و

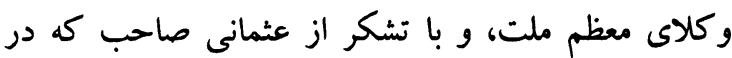

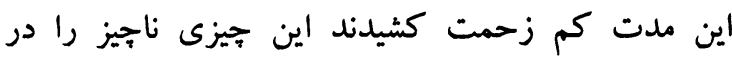

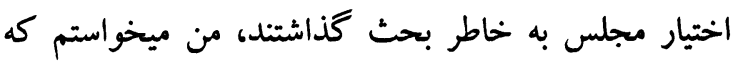

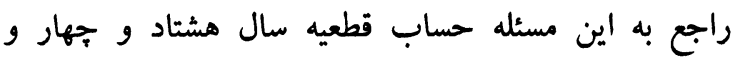

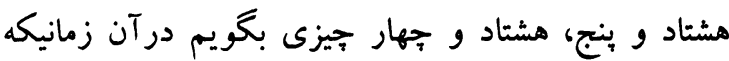

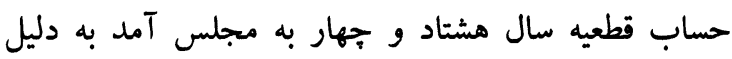

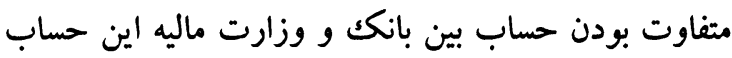

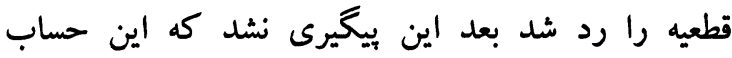

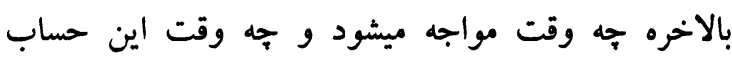

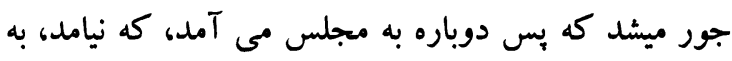

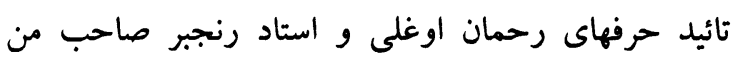

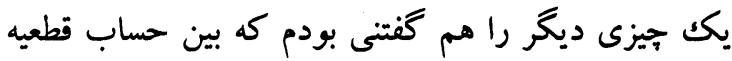

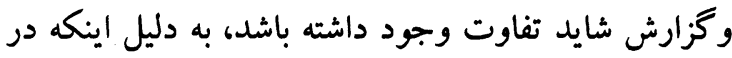

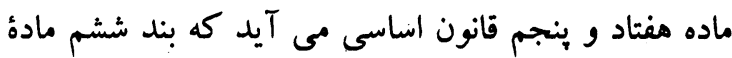

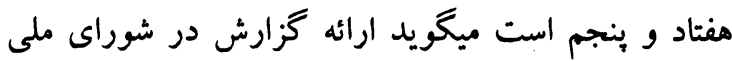

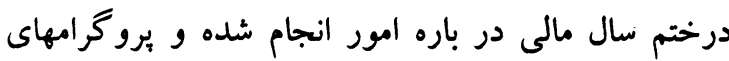


دغونلهي رئيس :

جناب جوادى صبب! اوس ادوني : وفي همكاران كوشش كوي جي د قطعيب اوراقو كابياني تاسو تولو محترمو وكيل

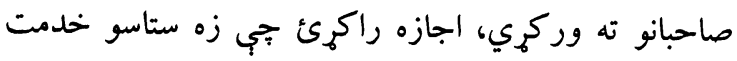

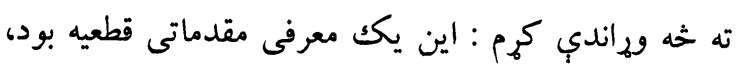

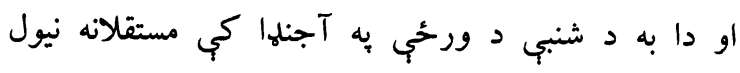
كيري دا خو داسب نه دى جي نن خلاص شو، دوه ورحئ وني

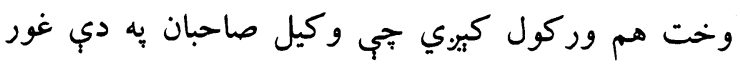

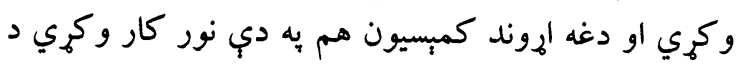

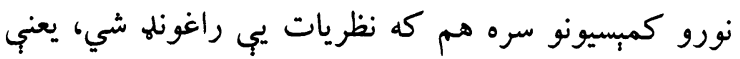
دا سطحي نه تبر يوي، سطحي آجنلها ته نه ده راغلي، به ديه دي

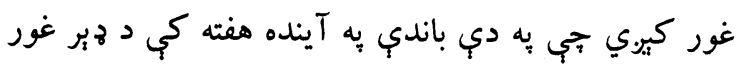

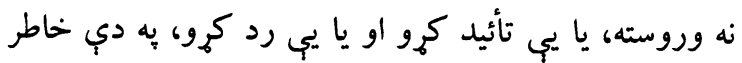
تاسو ته اطمينان دركوم .

فاطمه نظرى :

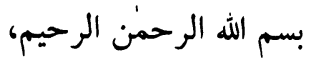

به اجازة رئيس صاحب و هيئ رهبرى و و وكيل صاحبان النيا

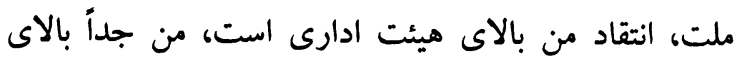

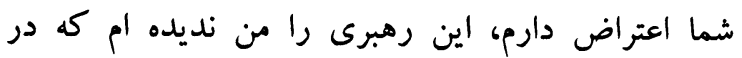

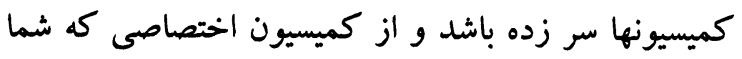

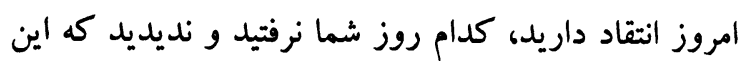

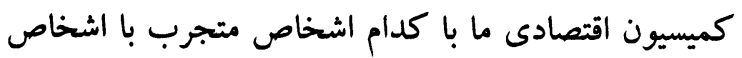
مسلكى اينها جرو بحث دارند. اما امروز بيينيد كميسيونها هايه هاى اصلى شوراى ملى است، وقتيكه كميسيونها در

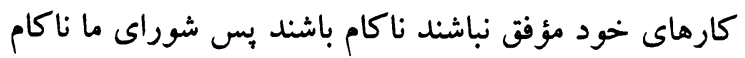

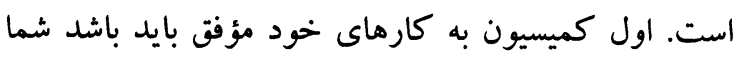
بايد بررسى بكنيد، امروز بينيد ما بسيار زياد سخنهاى ديخر

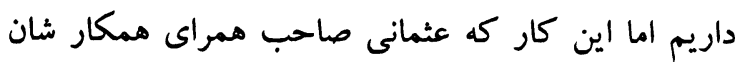

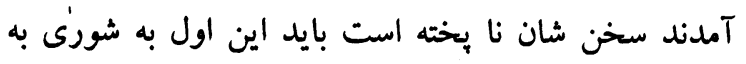
كميسيونها به بخته گى ميرسيد بعد از آن ميآمد. من شخصاً

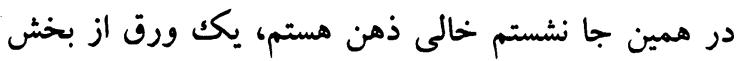
همين موضوع بيش من نيست، تشكر از شما .
سه سال بوديجه به هر شكل كه مصرف شده خود سرانه هم كه مصرف شده مصرف شده، به همين دليل است كه به به به بنيد وقتى جدول بوديجه مى آيد بروزه هاى ماى ما اكثراً

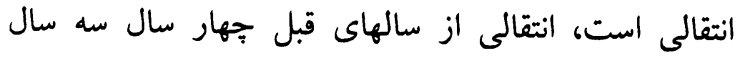

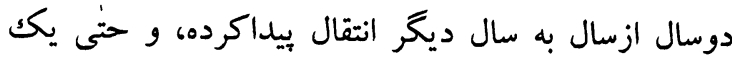

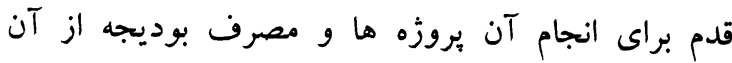

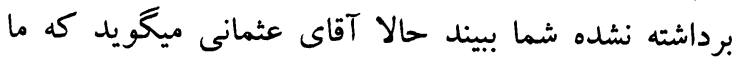
در مورد اينكه در بوديجه عادى تمويل شده تمويل بيشتر از مصرف است، يعنى ما حتى در بوديجه عادى نميتوانيم

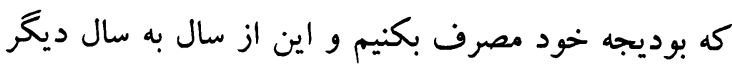

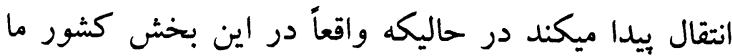
مشكلات و هر وقت هم به وزارت ماليه گَثته ميشود

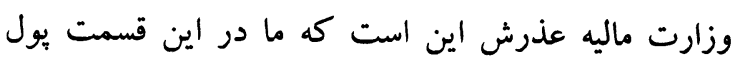

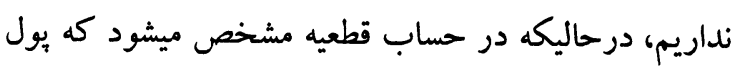

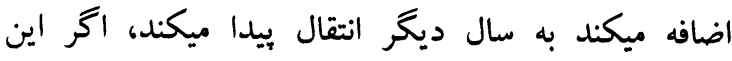

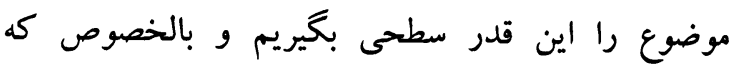

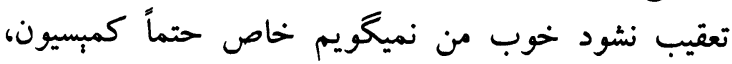

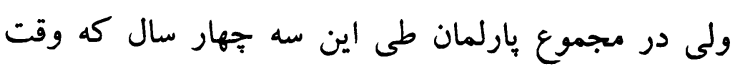

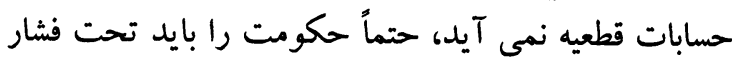

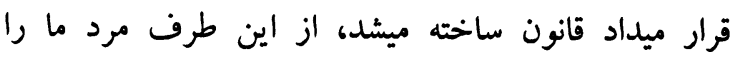

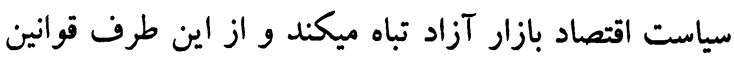

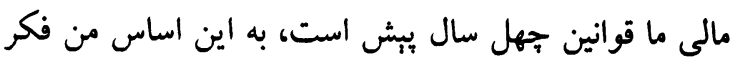
ميكنم اين موضوع را شما بسيار سطحى وارد آجندا كرديد و من مستقيم جون نميخواهيم به آقاى عثمانى و همكاران

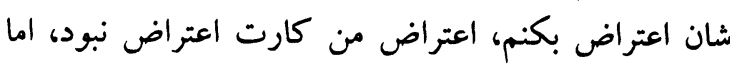

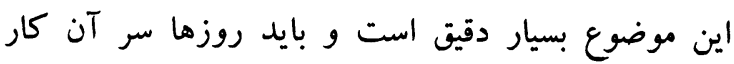

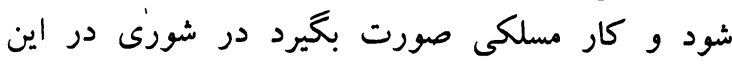

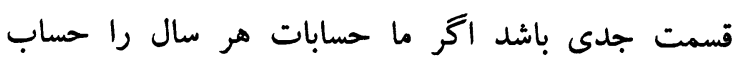

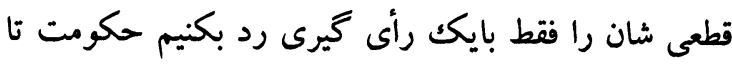

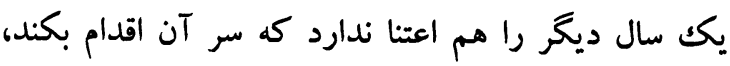

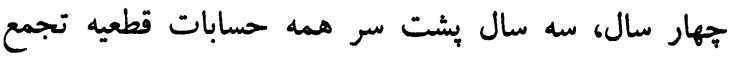

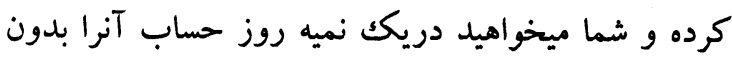

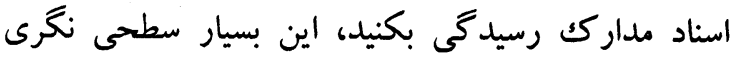

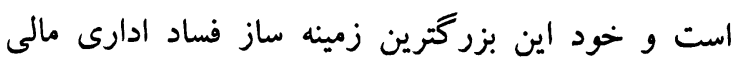


ما غربال كنيم و همه ما و شما ميدانيم كه در اين سر زمين

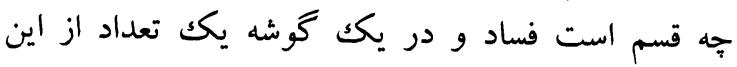

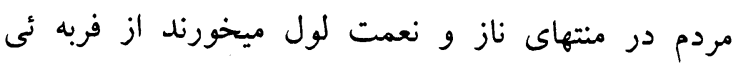

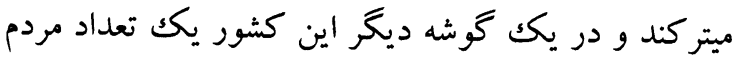

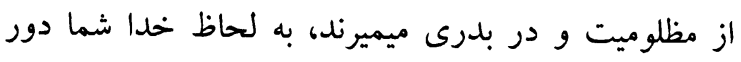

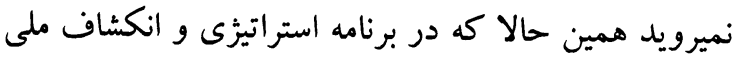

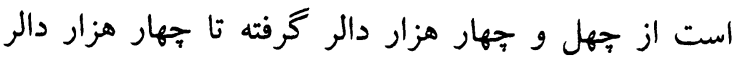

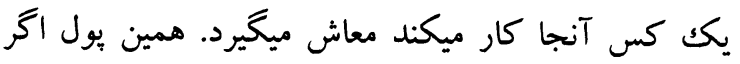

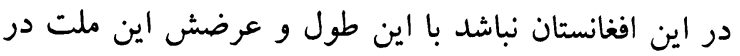

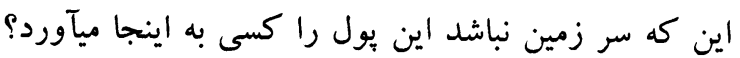

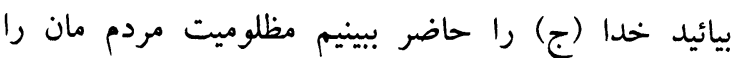

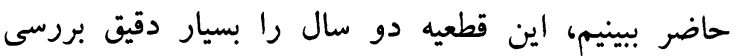

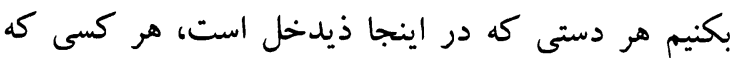

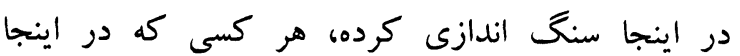
اختلاس را مرتكب شده آن به جزاء اعمال خود برسد، اقداء

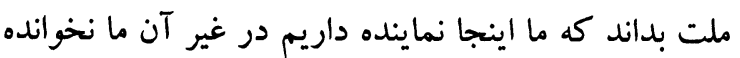

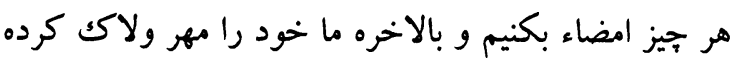
به هر جيزى فتوا بدهيم اين سخن بسيار نادرست است. اميدوار هستيم كه ما و شما دقيق عمل كنيم و و كارى كنيم إنيم

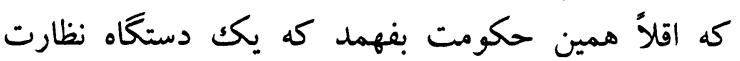
كننده بر اعمال ما است و ما جهرا همين صلاحيت كه خود بهد مان داريم همين مفت و رايگًان از دست ميدهيم، تشكر از مداز

صديق احمد عثمانى : و كلاى محترم! يكى دو كلمه است سر صحمبت : صحت اورنخ

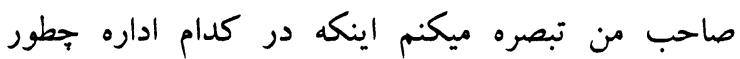

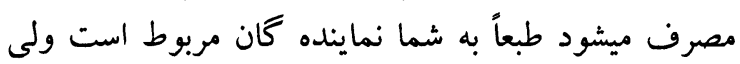

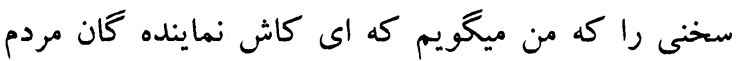
به اساس تخصص، مسلكك و تعليم در اين مجلس راه ييدا ميكردند. ما نماينده كان مردم هستيم، مردم براى مان ما بنابر

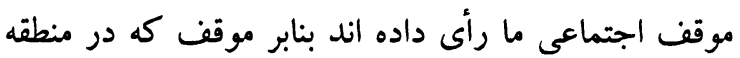
داريم رائى دادند، بنابر نامى كه در منطقه داريم رأى دادند.

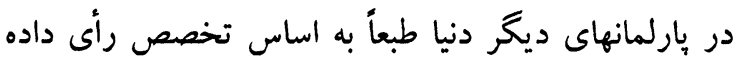

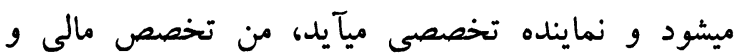
بوديجه ندارم اورنخ صاحب، من تخصص دو در تعليم، تربيه
سلطان محمد اورنگ : بسم الله الرحمن الرحيم،

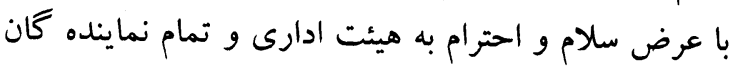

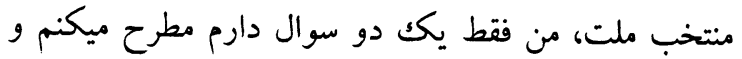

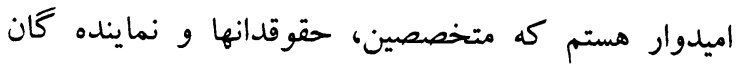

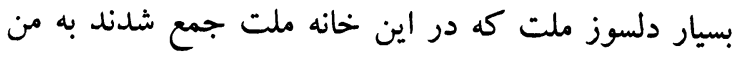

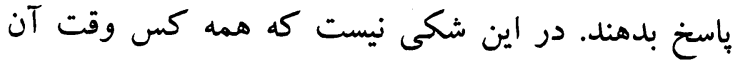

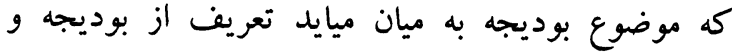

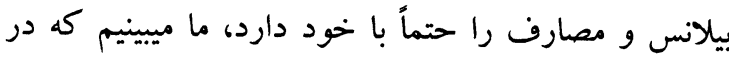

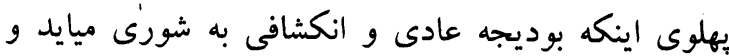

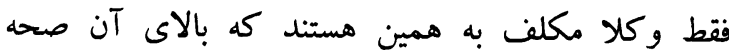
بخذارند و با بلند كردن كارت سبز بر بـ آن مهر تأيد

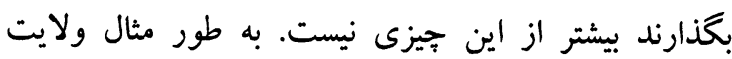

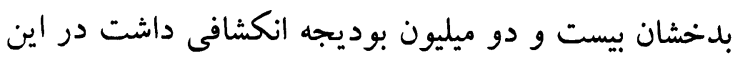

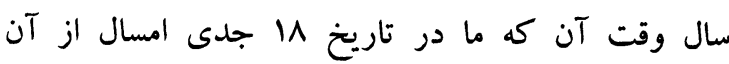

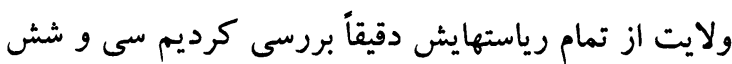

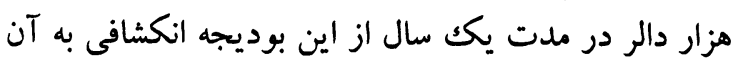

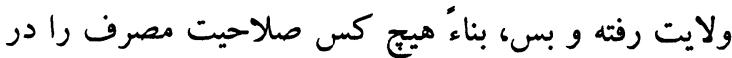

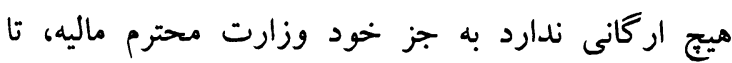

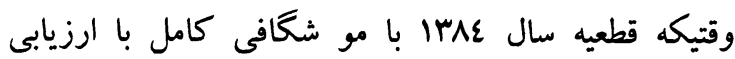

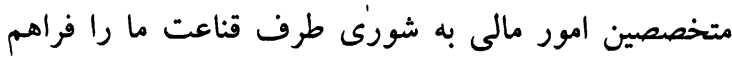
نكند ما منحيث يكك نماينده مردم، منحيث يك بك انسان

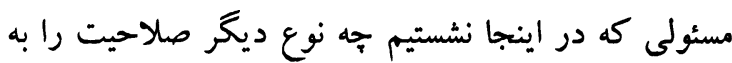
خود مى بينيم كه ما بالاى قطعيه سال

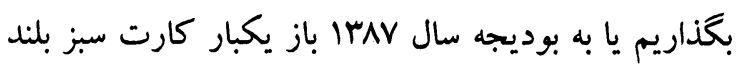

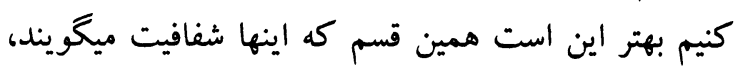

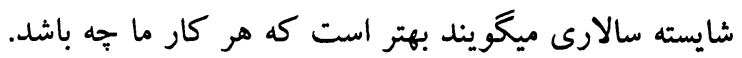

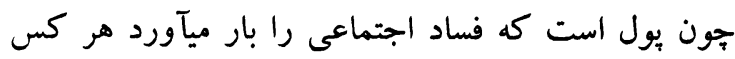

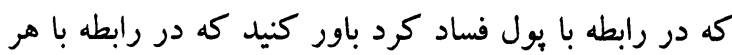

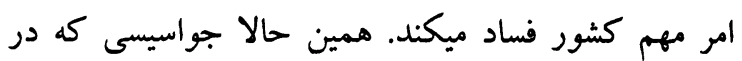

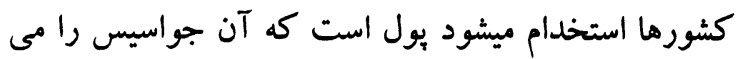

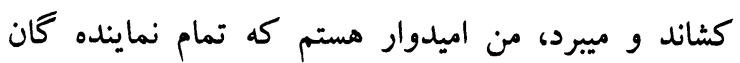
ملت متخصصين امور مالى ما با دلسوزى كامل به ميه اين ماند كشور روى قطعيه عیזا بحث دقيق بكنند بحث كار

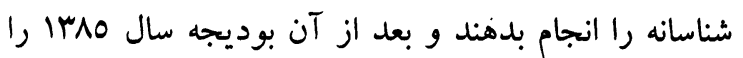




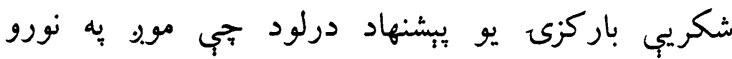

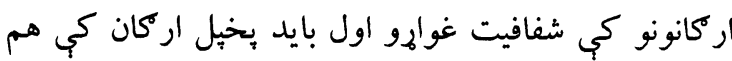
شفافيت ولرو، كه د وكيل صاحبانو خوبنه وي اداري باري

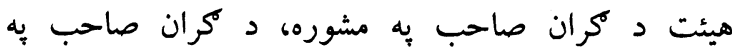

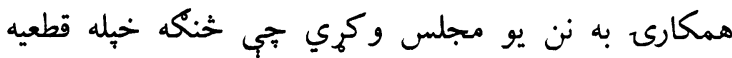

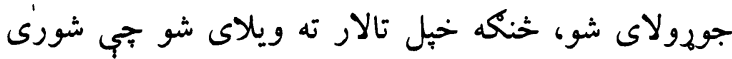

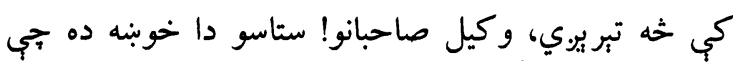

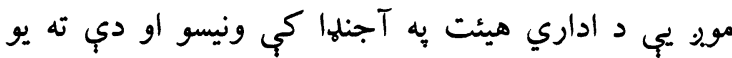

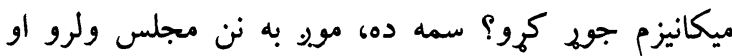

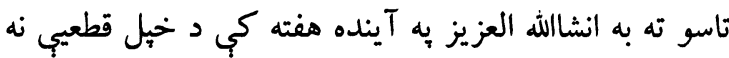

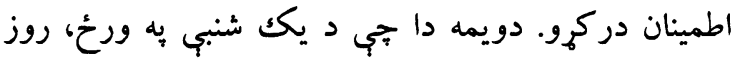

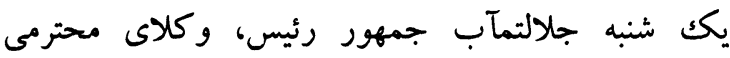

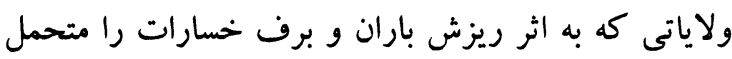

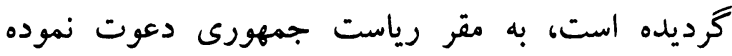
است، سا ولايت، هلته هغوى ملاقات لري د جله جلالتمآب رئب

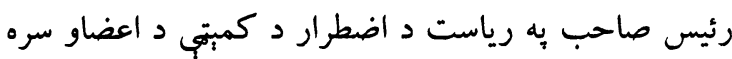

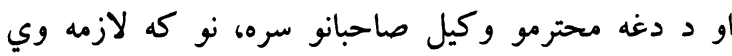

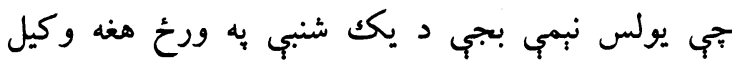

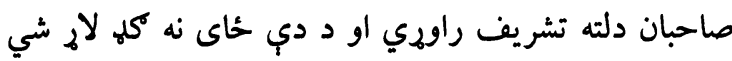

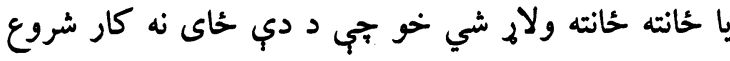

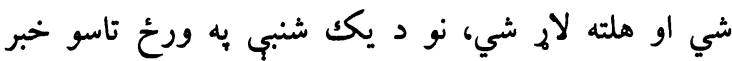

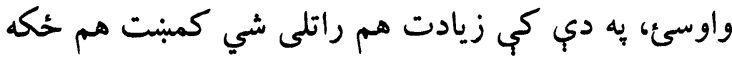

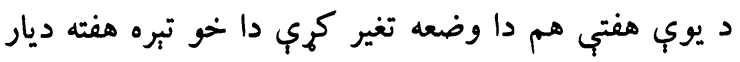

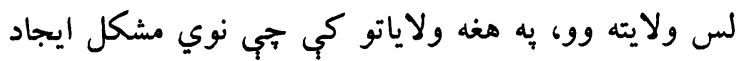

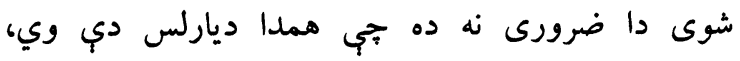

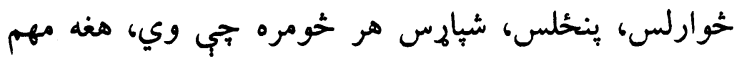

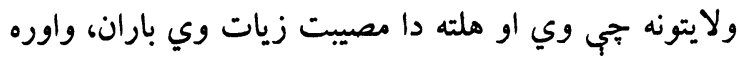

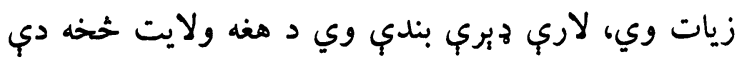

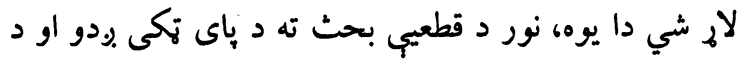

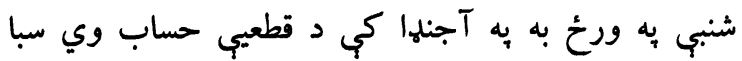

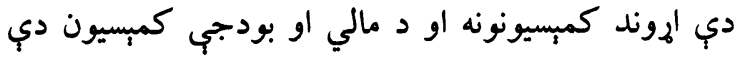

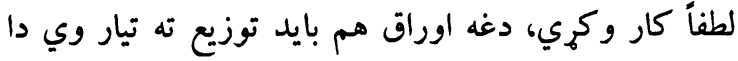
لطفاً توزيع كري كار وكي، دفا
و معلمى دارم اكر من در كميسيون معارف ميبودم سخن

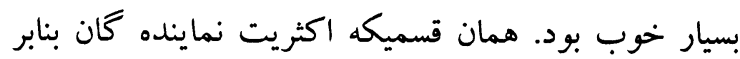

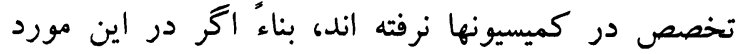

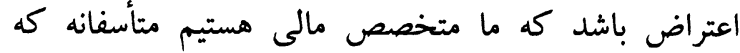

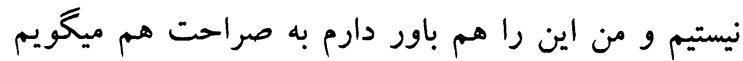
جلنج هم به اصطلاح ميدهم كه كمتر كسى ييدا خواهد

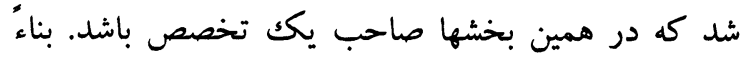

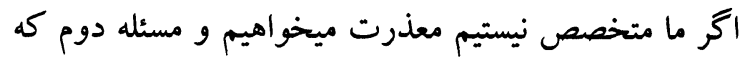

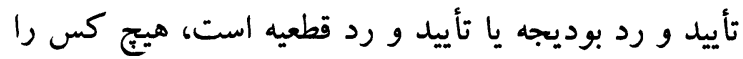

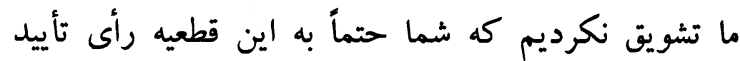

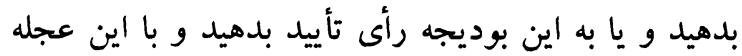

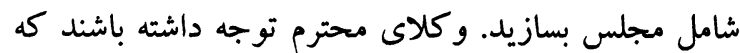

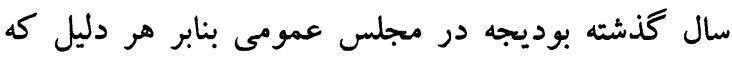

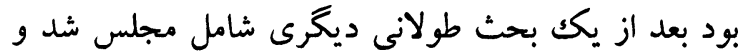

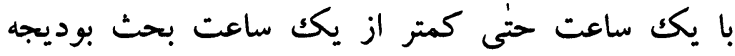

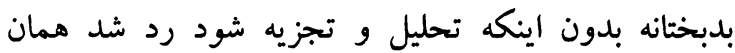

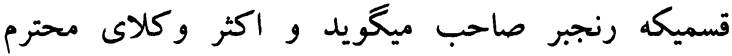

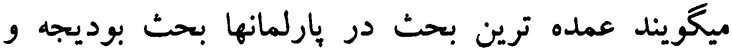

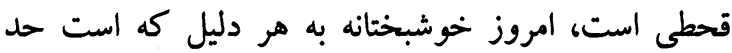

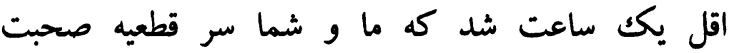

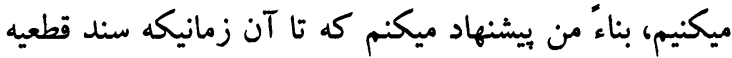

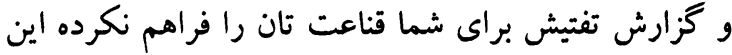

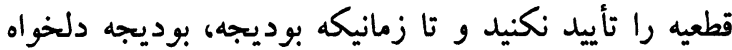

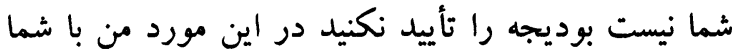

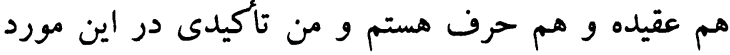

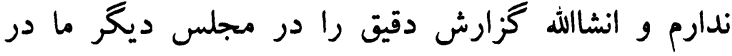

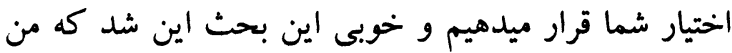

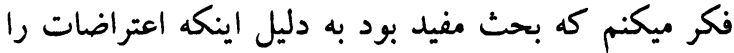
كه شما امروز داريد اين اعتراضات را ما فردا هم ميداشتيد.

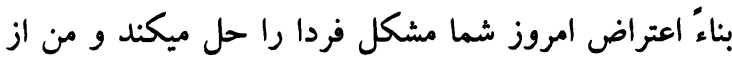
شما تشكر ميكنم .

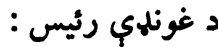

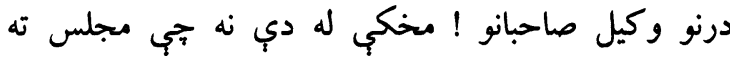

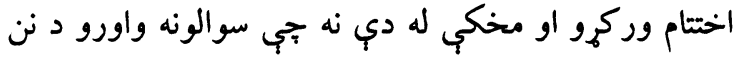
ورحجي مجلس نه يو دوه نقطب تاسو ته عرض كوم تجي 


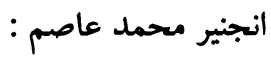

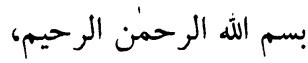

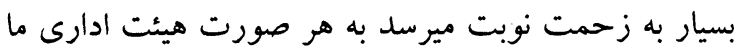

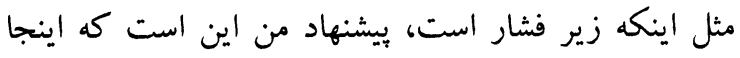
اشارات دوستان داشتند، من به هيئت ادارى ويشنهاد ميكنم

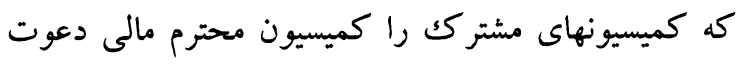
كنند در روز ديخر همين بحث قطعيه در كميسيون مشترك بحث شود، حالا كه نسخه توزيع ميشود وكيل

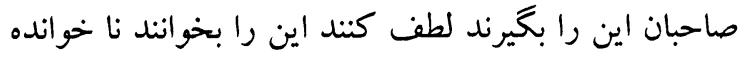

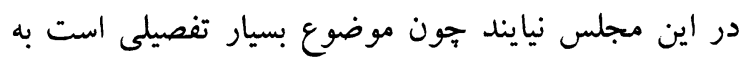

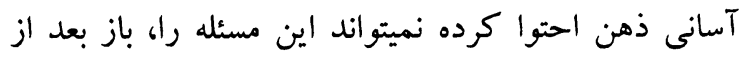
بحث در كميسيون مشتر كك باز به جلسه عمومى ميائيم و در مورد اينكه قانون بوديجه و مالى بايد ساخته شود رنجبر مانس

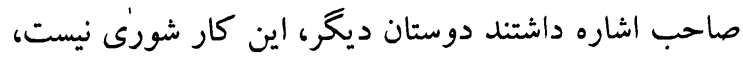

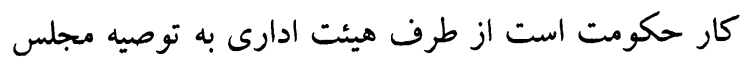

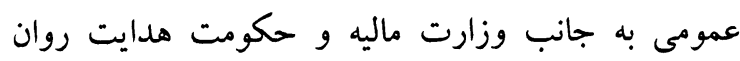

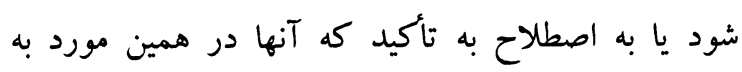
اصطلاح طرح قانون را به مجلس روان كنند، تشكر . أدتر اسدالله همتيار :

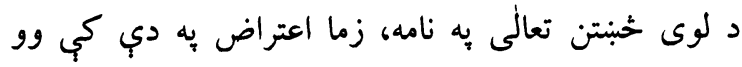

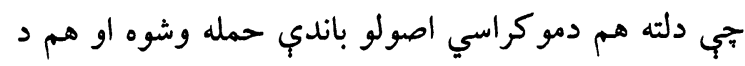

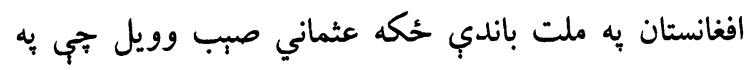

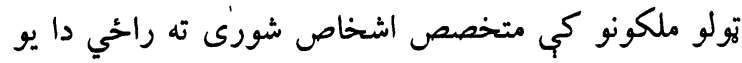

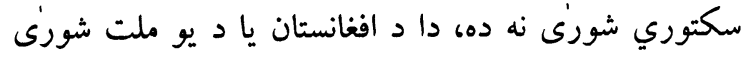

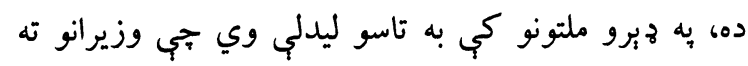

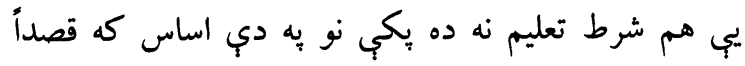

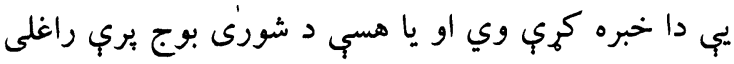

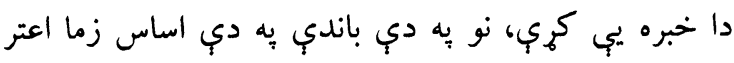

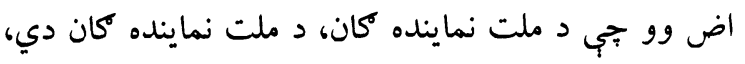

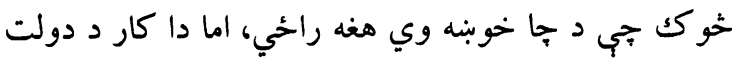

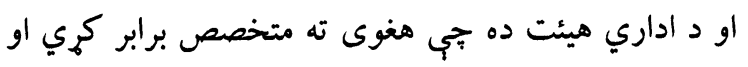

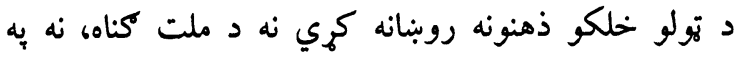

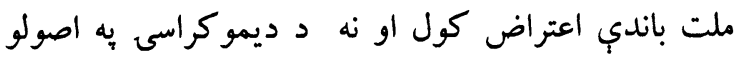
باندي اعتراض كول، به ديموكراسى كي دا دا اصول دي

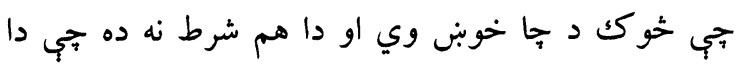

نائب دوم مجلس : جناب رئيس صاحب! به خواهران و و برادران حتماً وقت ميدهيم ولى يكك جيزى را كه من ميخواهم اشاره كنم آن آن

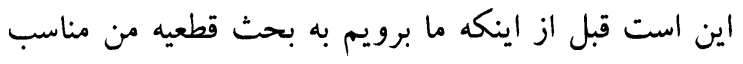

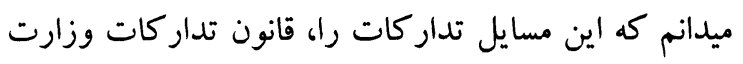

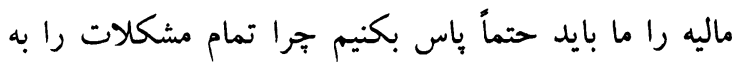

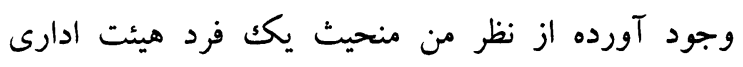

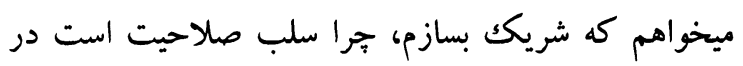

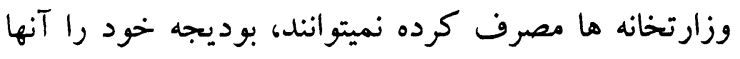

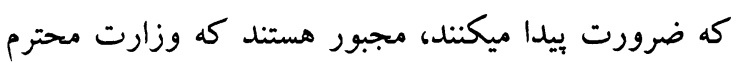

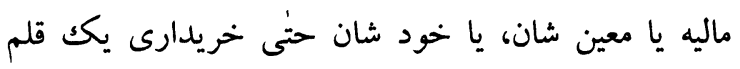

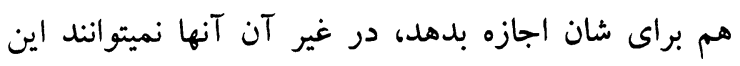

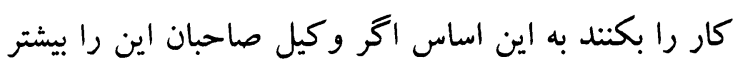

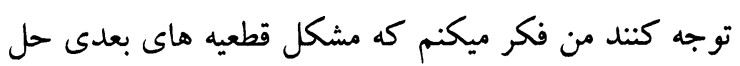

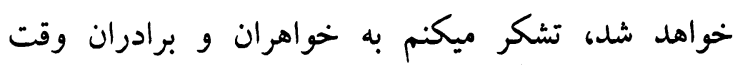

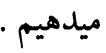

انجنير محمد خحان:

رئيس صبب! زمويو د كمبسيون به يرونى جلسه كي يون يوه

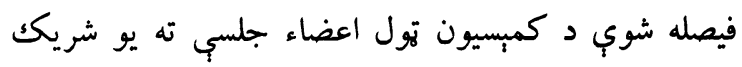

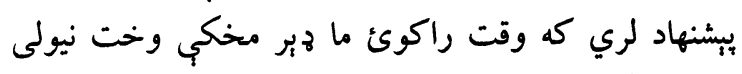

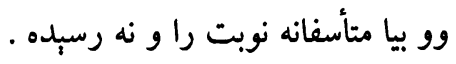
قربان كومستانى :

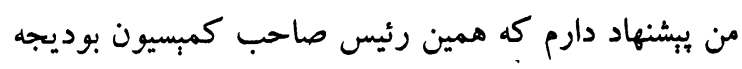

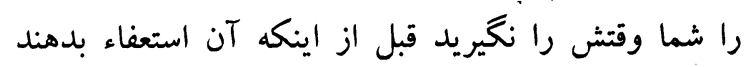

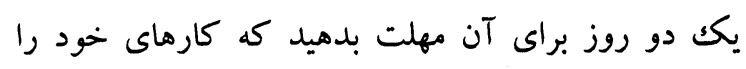

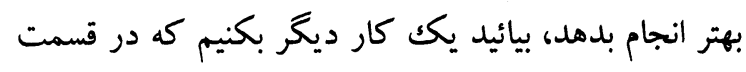

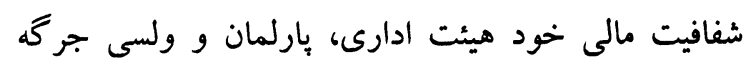

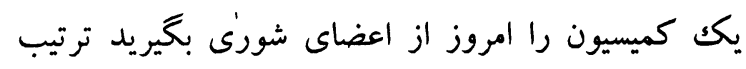
بدهيد قبل از اينكه مجلس ختم شود كه اينها بيايند يكك بكري

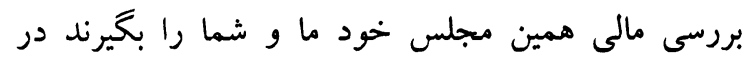

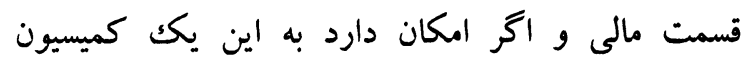
تشكيل شود و اين كميسيون امروز انتخاب شود ود كه كارهاى خود راشروع كند . 
شكيبا هاشمى :

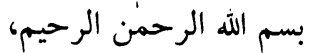

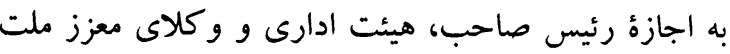

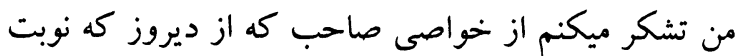

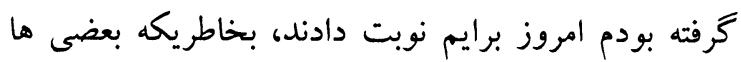
هستند از همين به حساب حنجره خود امرو از مهارتهاى حنو حنجره

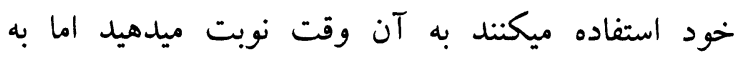
كسانيكه صبر، حو صله و شكيبائى و اصول وظايف داخلى

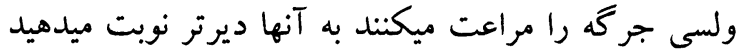

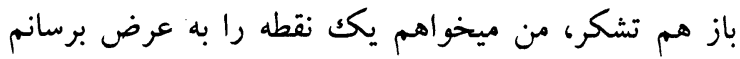

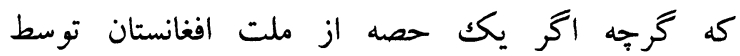

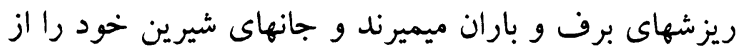
دست ميدهند يكك حصه ديخرى افغانستان است كه امروز از كاسه صبر و حوصله شان از دست بى امنيتى و وسنى اختطافهاى كه به لباس بوليس ملى ميشود بسيار كاسه صبر

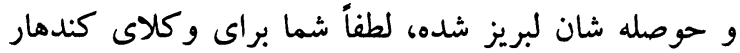

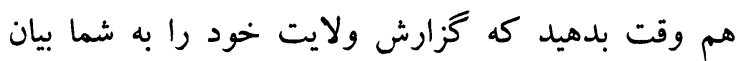

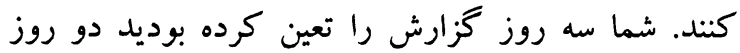
وقتيكه گذشت به روز سومى حوصله ولسى جرگه به به رونه خيالم به تنخ آمد، امروز مردم ما در كندهار يكك جلسه بهو

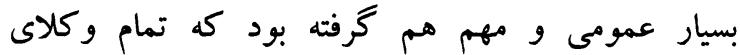

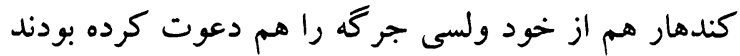

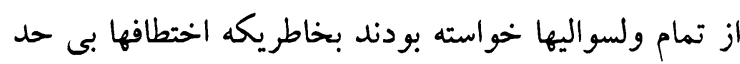

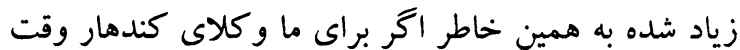

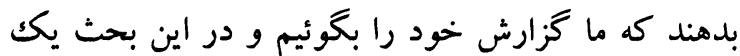
سر آن شود كه بايد جه شود تشكر.

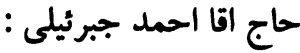

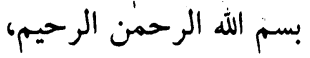

جناب داكتر صاحب سلجوقى فرمودند كه كميسيونها فردا جلسه مشترك داشته باشند به ارتباط حسابات قطعيه كه فه فر

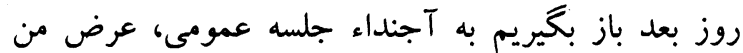

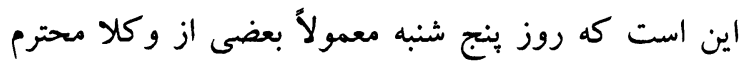

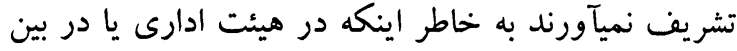

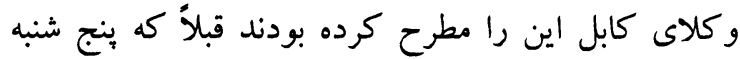

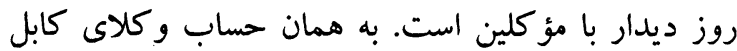

يو سكتورى شورىى وي، دا د ملت شورنى ده، نه دا جبي متخصص اشخاص دي دلته راحي .

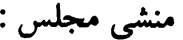
و كلاى محترم فردا كمبسيون مالى و و بوديجه انشالله جلسه

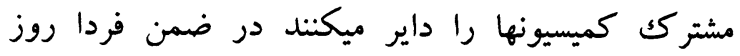
ينجشنبه ما امروز تمام كاييها را انشالله براى كميسيونهاى مئي

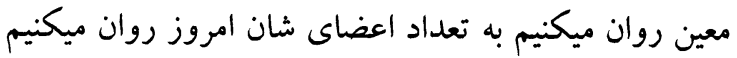
و فردا جلسه مشتركك داير خواهد شد يكك، دوم اينكه

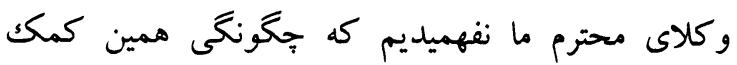
رسانى و اهداء و كلا را جِكونه انجام بدهيم، ميكانيزم آنرا

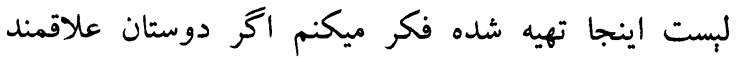

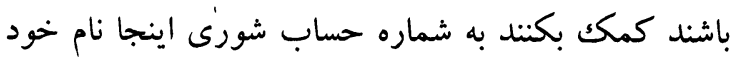
را نوشته كنند يا يكك ميكانيزم ديخرى كه از عموم و كلا

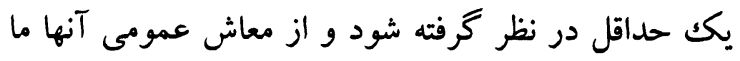
در اين ماه كسر كرده بتوانيم، سوم جيزيكه ميخواهم ونم خدمت شما عرض كنم موضوعى است كه فردا ينج شنبه 1N دلو سال جارى به مناسبت رحلت شوهر محترمه هوا علم نورستانى صاحب محفل ختم قران عظيم الشان در

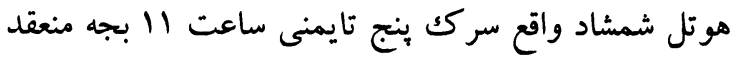

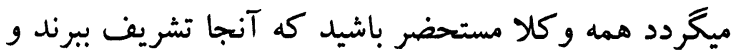
همجنان امروز فاتحه هم است كه و والده آقاى حسين

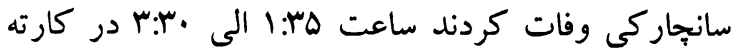
سه گولاى يل سرخ مسجد عمر جان كندهارى نيز فاتحه منعقد است. ديروز تقريباً شئ كميسيون را همراه با محترم ياسينى صاحب رفتيم و كميسيونهاى محترم هنوز آماده

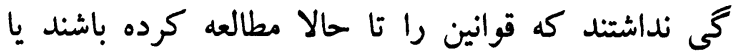

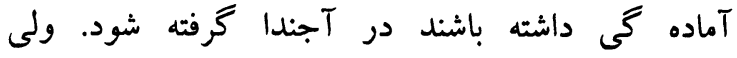
كميسيون مالى و بوديجه واقعاً همكارى كردند واده و همين

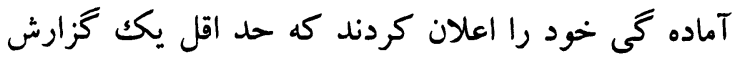
يكك بحث روى اين موضوع داشته باشيم. كميسيونهاى

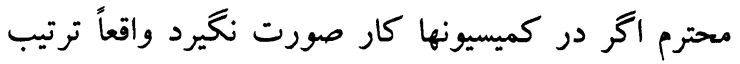

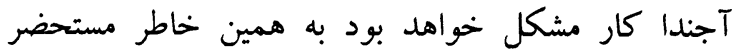

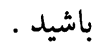


خيرات يا نورو مسايلو اعلان تبر شي زه كوم اعتراض نلرم، ولئ

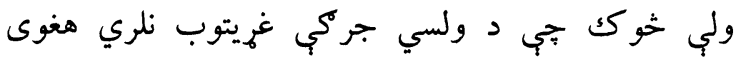

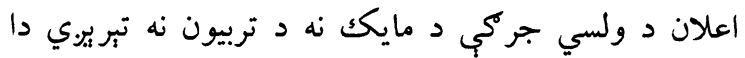
ولسي جركي ته سيكاوى دى، دلته راجيو نه ده نو نو بيا اعلان

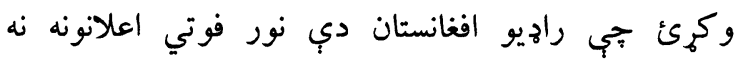

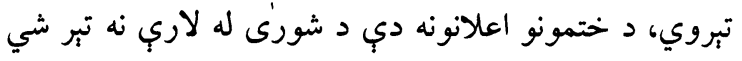

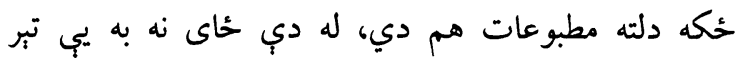

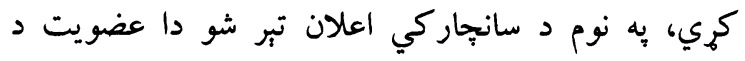

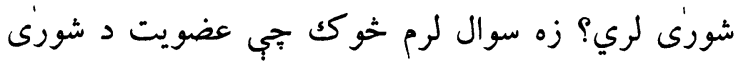

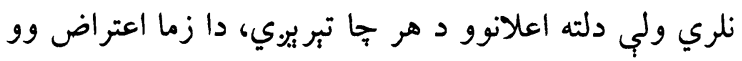
هيله من يم جي بيا تكرار نشي.

\section{انجنير محمد خان : بسم الله الرحمن الرحيم،} د مجيدى صبب د اعتراض به تأييد جناب رئيس صبب! زه إنه

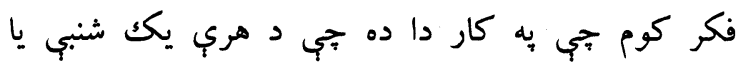

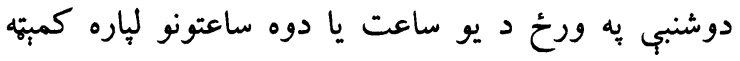

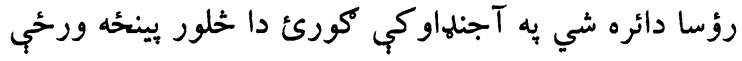

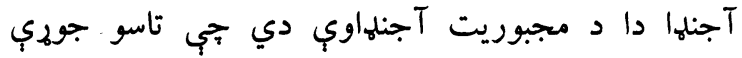

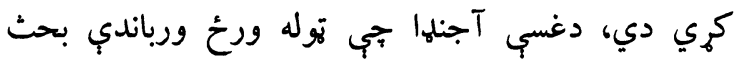

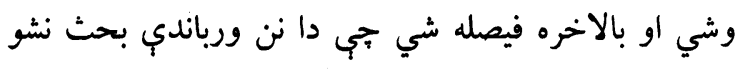

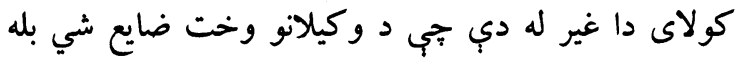

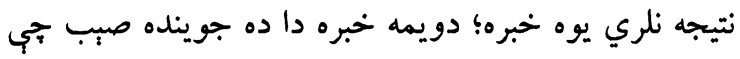

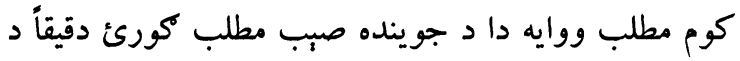

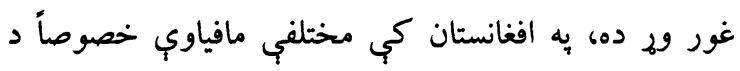

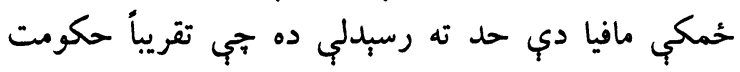

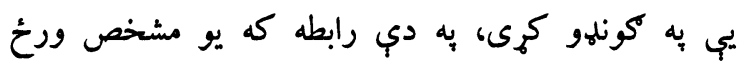

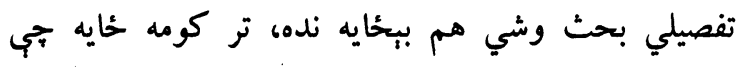

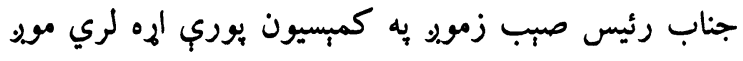

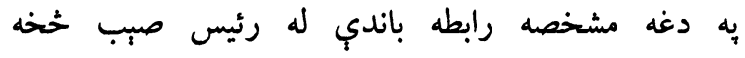

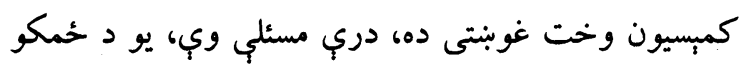

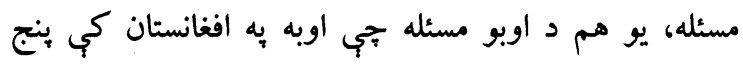

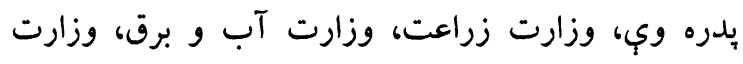

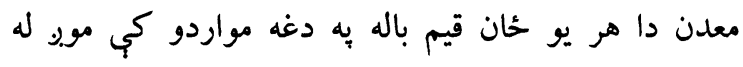

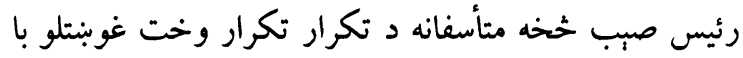

نوعاً تشريف نميآورند بعضى وكلاى ديكر هم به تأسى

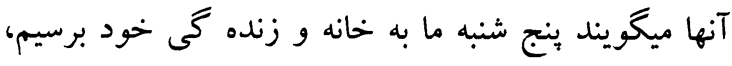

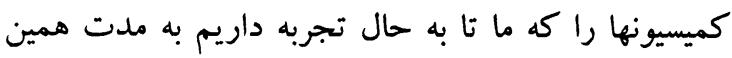

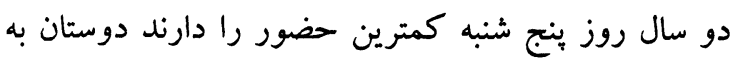

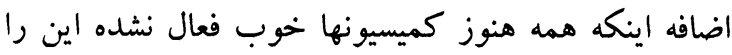

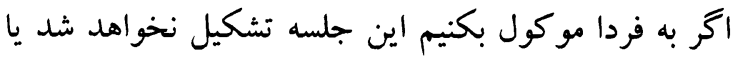

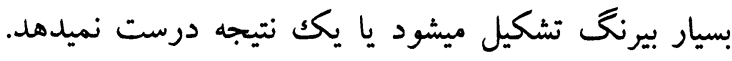

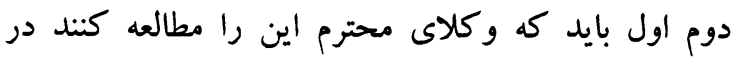

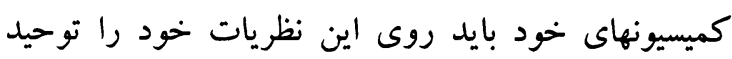

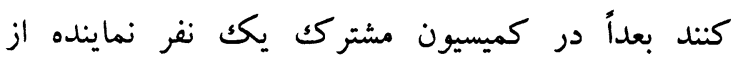

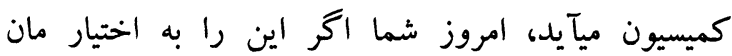

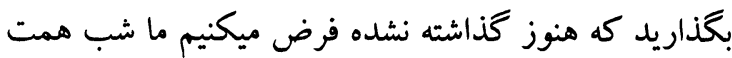

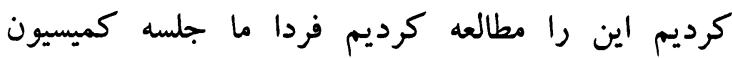

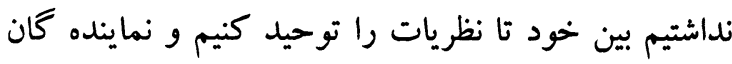

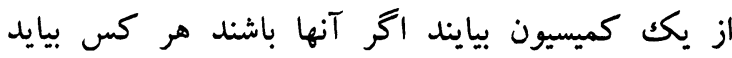

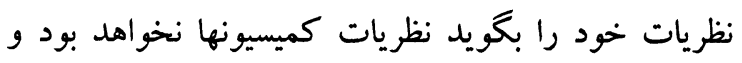

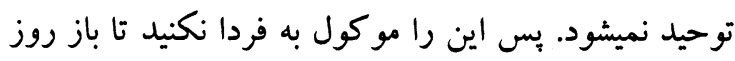

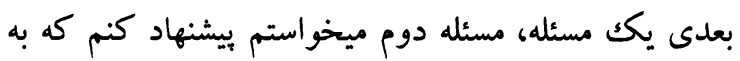

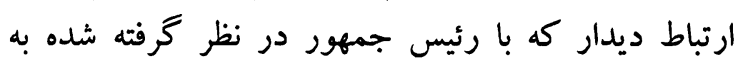

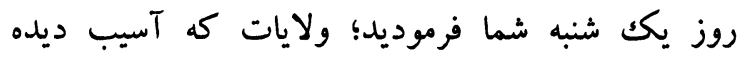

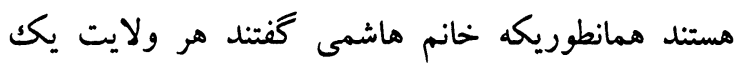

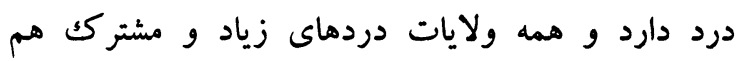

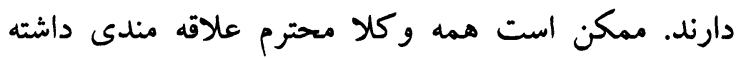

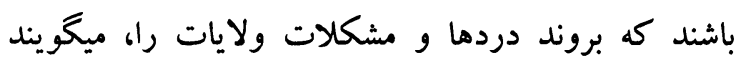

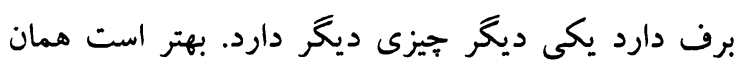

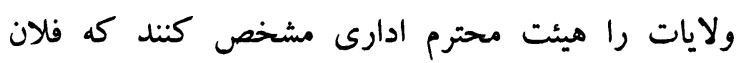

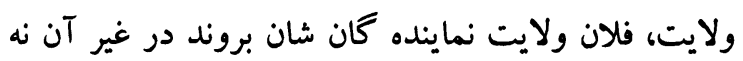
ظرفيت دارد آن سالون رئيس جمهور كه اينقدر نماينده را

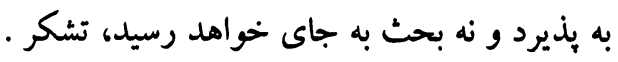

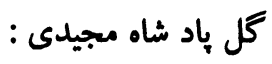
بسم الله الرحمن الرحيم،

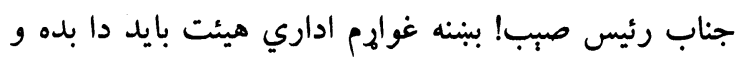

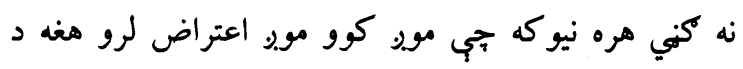

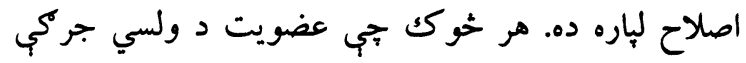
ولري كه د هغوى فاميل اعلان تبر شي يا د دوى د د ختم 


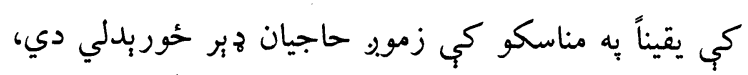

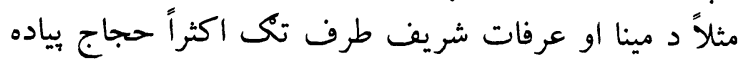

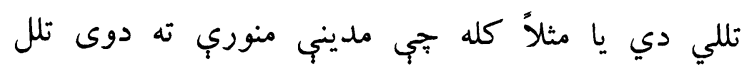

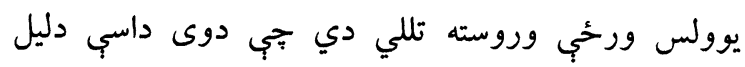

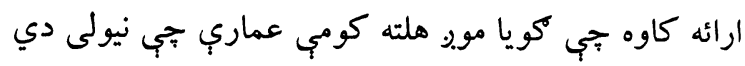

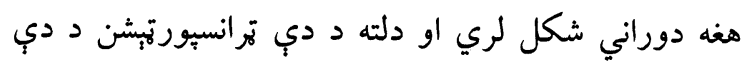

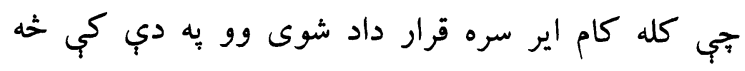

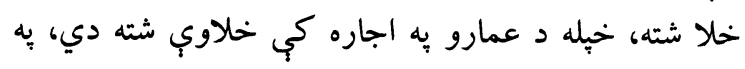
دي مامورينو كب، يعنب موي. يو سلسله دلايل را سره شته

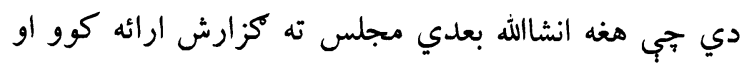

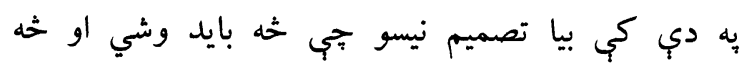

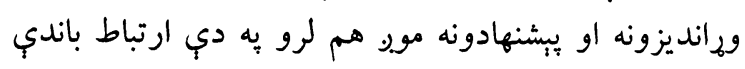

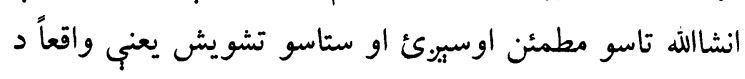

$$
\text { منلو وهـ دى . }
$$$$
\text { رئيس مجلس : }
$$

درنو وكيل صاحبانو! د مجلس يه آخر كي د د قضائي او

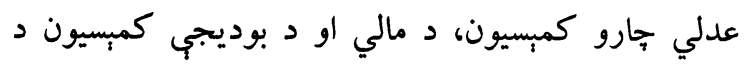

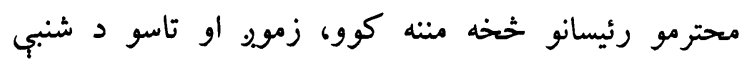
ورحي آجنها د قطعيب به باره كي ده، نن مودر او تاسو هغه

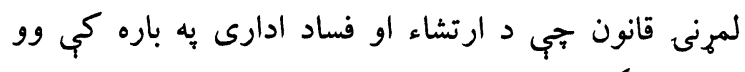

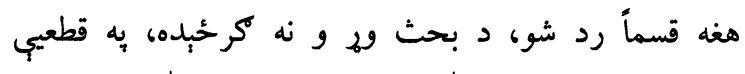

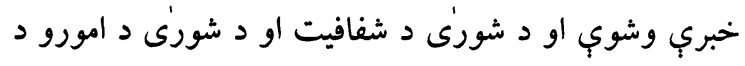

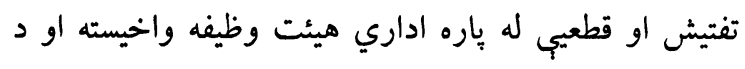

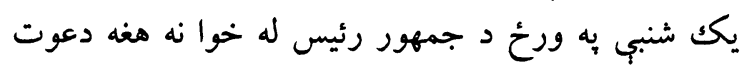
تاسو ته ابلاغ شو.

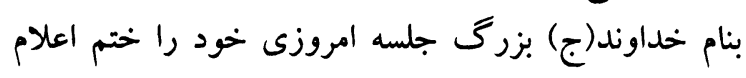

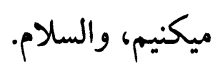

و Tخر الدعوانا ان الحمدلله رب العالمين د غونلهي هاى الحمال

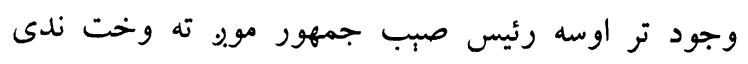

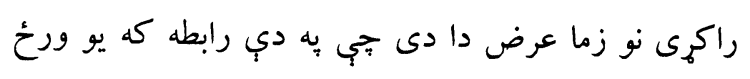

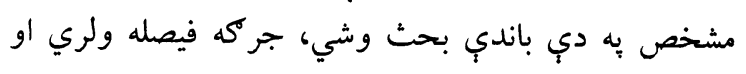

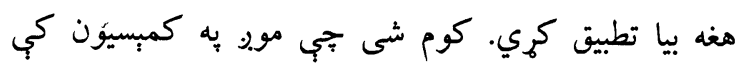

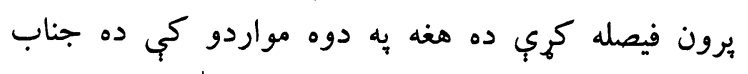

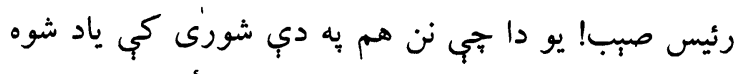

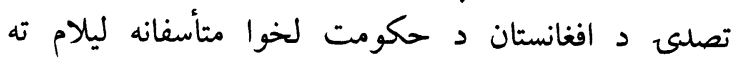

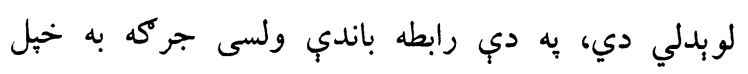

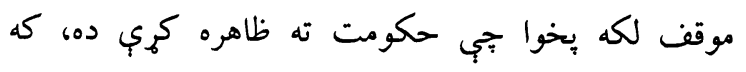

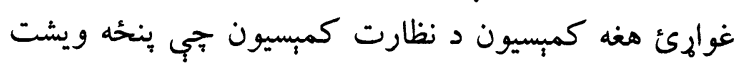

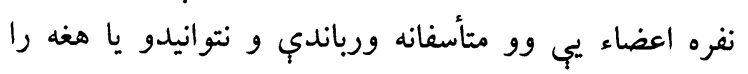

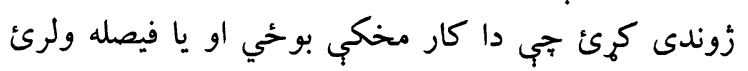

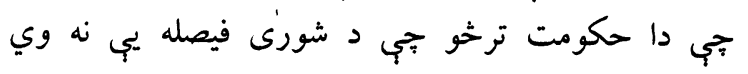
اخيستي نو د تصديو له ليلامه صرف نظر وكري.

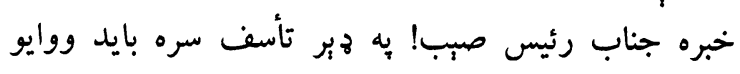

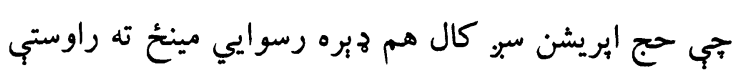

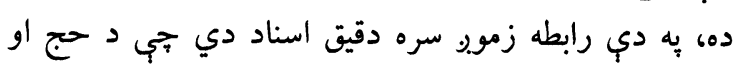

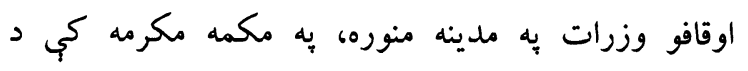

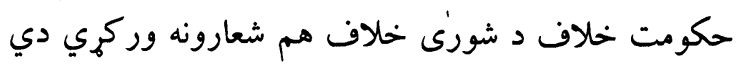

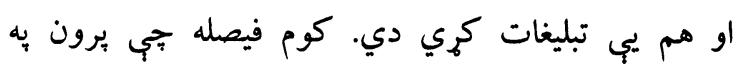

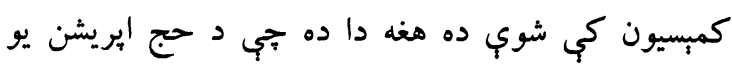

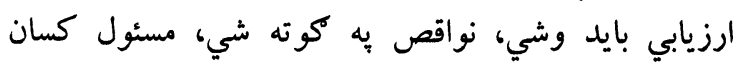
حكومت ته وبنودل شي او به راتلونكي كي هغه خحلاكّاني

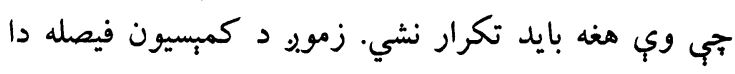

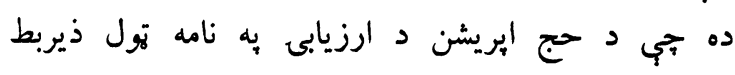

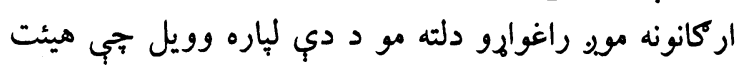

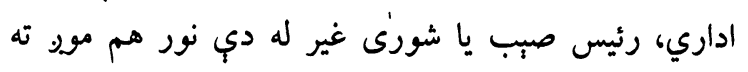

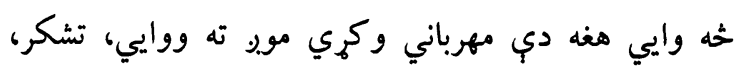
منته

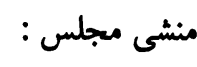
بسم الله الرحمن الرحيم، مجلئ

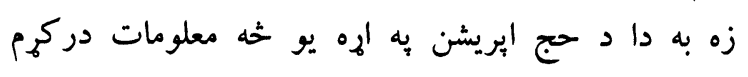

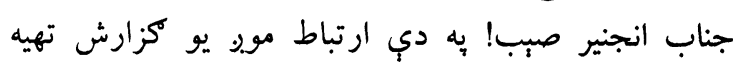
كمى دى ستاسو خبره كاملاً معقوله ده، تاييد ده او انشا الله

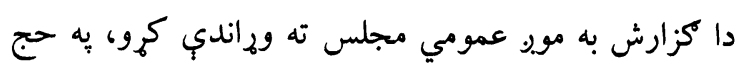


حيثيت ولسى جر گه است ،اكر ياد دوستان باشد جند روز

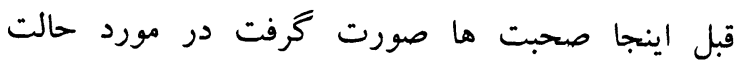
اضطرار و سوالهاى اينجا مطرح شد و مو من اينجا اظهور كردم كفتم اكر من وزير ميبودم و به اين تعداد افغانها

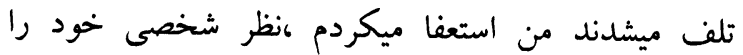
اظهار كردم واينجا ضرور نبود كه ديوار هاى نم كث بـ به ميه طرف خود اين موضوع را كش كنند كه مربوط خودشان

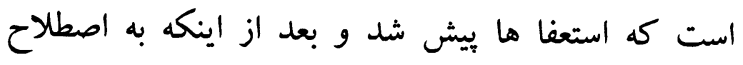

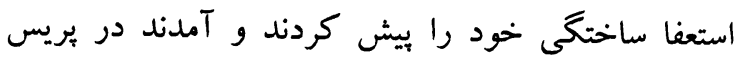

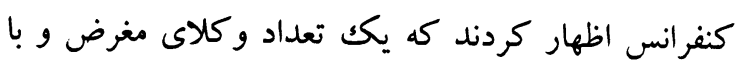

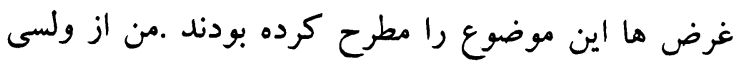

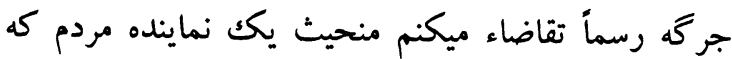
اين مصاحبه وزير صحيه به سمع تمامى و كلاء رسانده شود

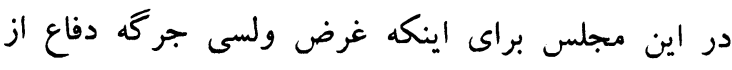

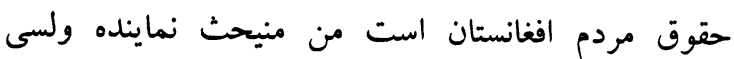

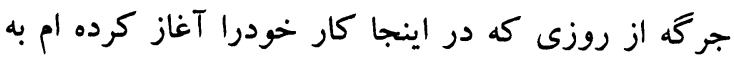

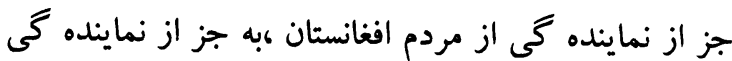

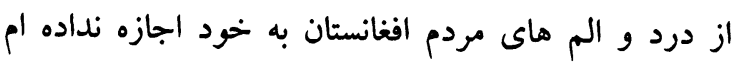

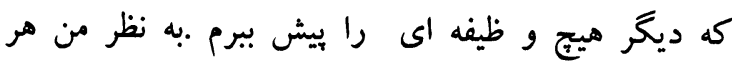

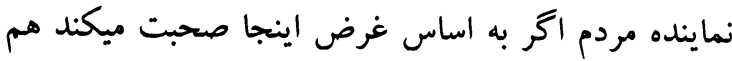

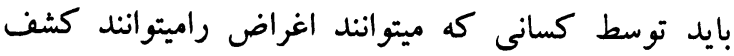
بكنند تشريح داده شود وهم هر نماينده مردم كه نماينده گى مردم غرض شمرده ميشود در صحبت هاى شان آن مان

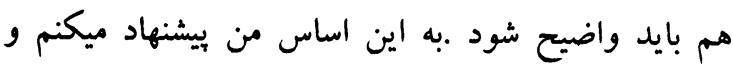

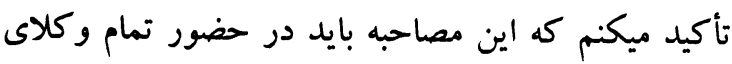

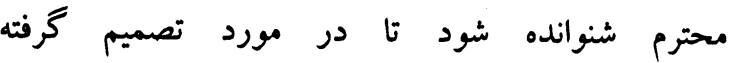

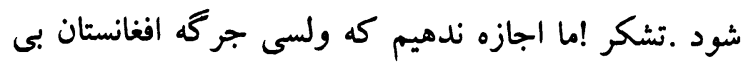

$$
\text { ريثيت شود! }
$$

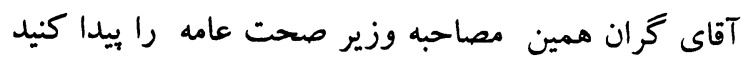

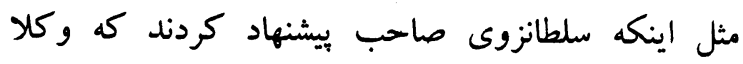

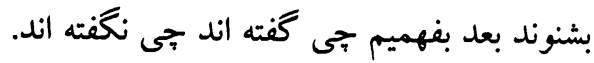

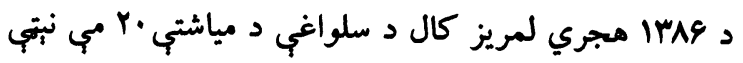
بشيه ريوت .

ندا:

د خلور اتياوم او ينحُة اتياوم كلونو قطعيه حسابونه . حسابات قطعيه سال Af و AD .

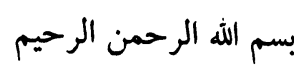

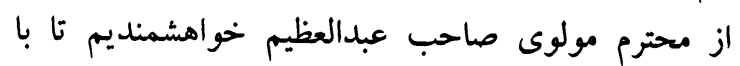
تلاوت آيات روحبخش الهى مجلس امروزى ما را شروع نمايند. منشى مجلس : ماند د محترم مولوي صاحب خخهه هُبره مننه نن د دوشنبي ورخً

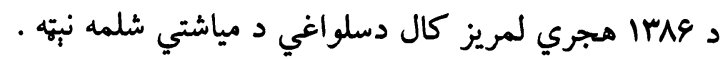

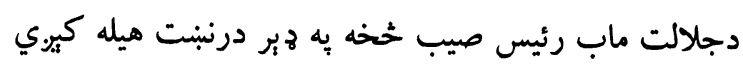

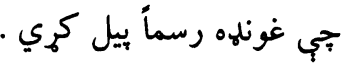
رئيس مجلس : بسم الله الرحمن الرحيم، مجلئ

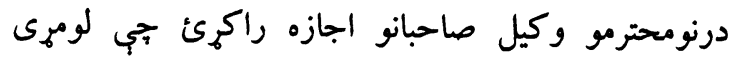
جناب فراهي صاحب ته ستري مشي وني وركمرو.فراهي

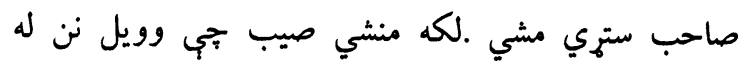
خيره سره مونبو او تاسو د اجنلها سره مطابق به فئ فطعيه

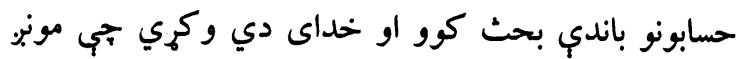
او تاسو نن دغه مسئله باى ته ورسوو او همدارنكه زمونبو او بان

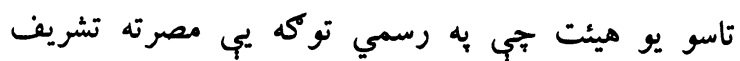
ورى وو جناب بلخي صاحب غوإي به دي دي هكله يو لنه

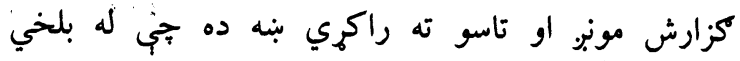
صاحب نه يو كزارش واورو.

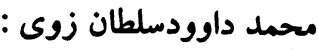

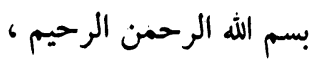

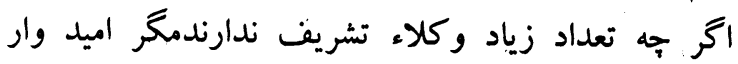

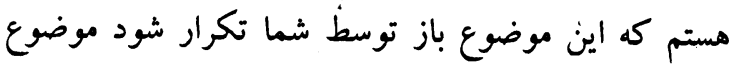


محترم بروفيسور برهان الدين ربانى رئيس كميسيون امور

$$
\text { تقنينى ،رئيس هيئت . }
$$

سيد حسين عالمى بلخى عضو كميسيون عدلى و قضايى مئي

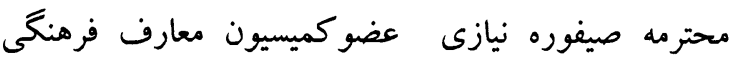

وامور دينى .

$$
\text { محترم مولوى شهزاده شاهد . مجان. }
$$

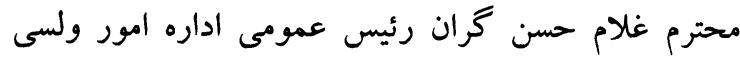

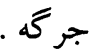

محترم خداى نظر نصرت رئيس امور هارلمانى و تقنينى . محترم محمد نذير شفيعى دستيار محترم رئيس هيئت .

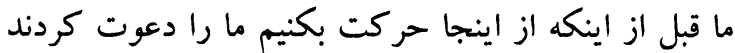
در همين اتاق روابط بين الملل براى اعطاى سفريه كه آنها

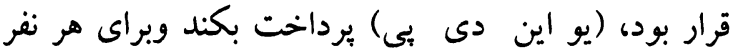

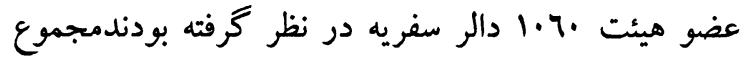

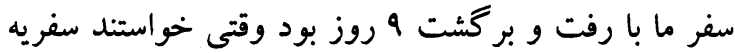

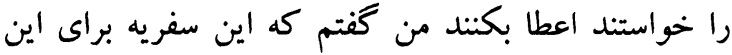

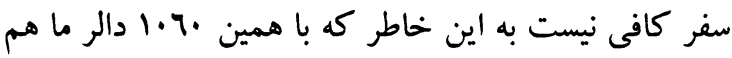

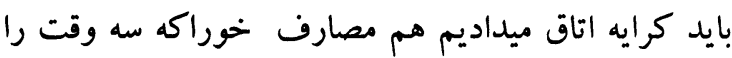
و هم بعضى مصارف جنبى كه هيش ميايد طبعاً در سفر و و

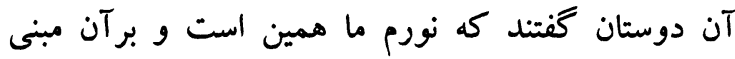

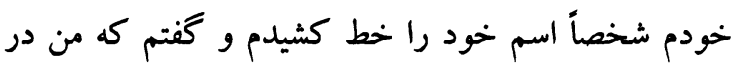
اين سفر نميروم و سفريه شانرا هم دو باره برايشان مسترد كردم جناب نيازى صاحب هم آنجا تشريف داشتند كه ونه

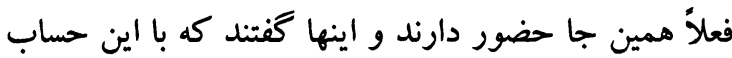
من هم در اين سفر نميروم اين سفريه جيزى است كه دها

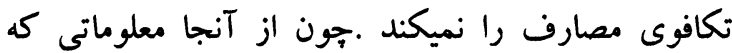

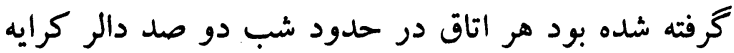

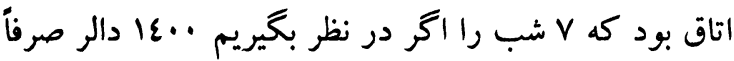

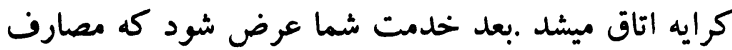

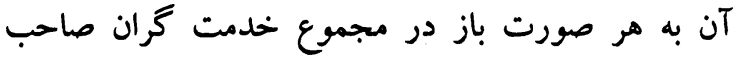

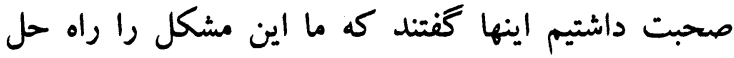

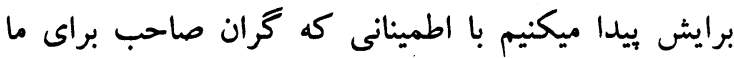

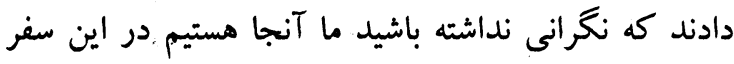

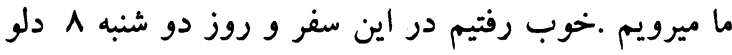

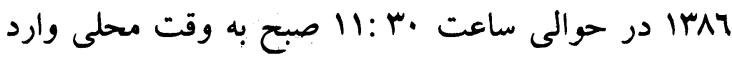

مولوى دين محمد عظيمى : بسم الله الرحمن الرحيم

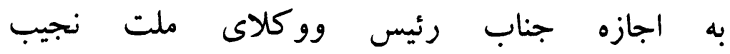
افغانستان إجناب رئيس صاحب همين ولاياتى كه متضرر

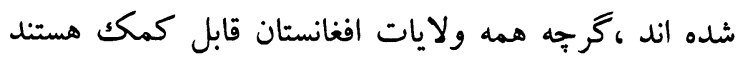

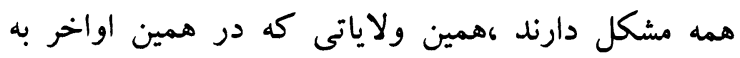
خاطر باريدن برف و سرما تلفات مواشى دارند ،همين ولاياتى را كه اولويت داده ميشوند ما نتوانستيم تشخيص برد كنيم كه جِند ولايات است بعضى وزرا هم همين تشويش

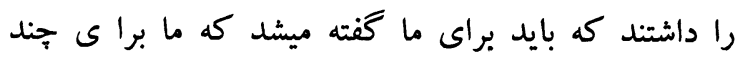
ولايت متضرر كه تلفات انسانى و مواشى زياد دارند ما ما مائد

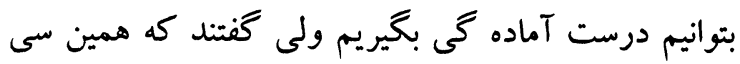
و جند ولايت افغانستان متضرر هستند ولى بعضى بـى وليت ولايات

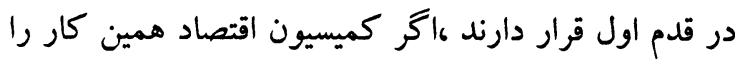

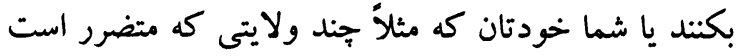

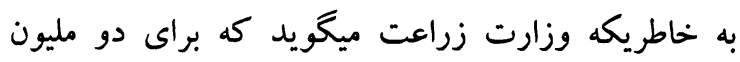

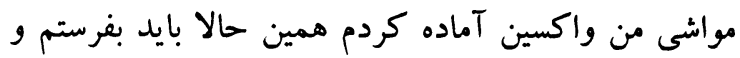

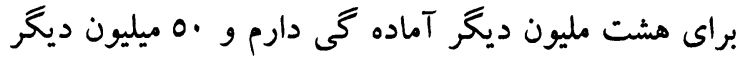

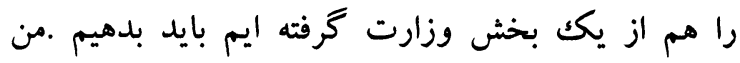
همين قدر خواهش دارم كه اكر تشخيص شود.

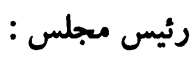

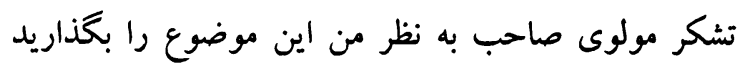

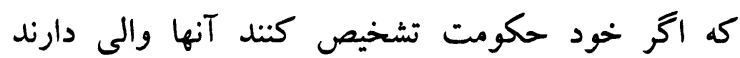
،ولسوال ما است ،قوماندان و خورد و كلان نشّته اند ، آنها مشخص بسازند به اساس اطلاعاتى كه دارند كه كدام

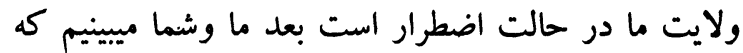

$$
\begin{aligned}
& \text { مشخص ميشود . } \\
& \text { سيد حسين عالمي بلخي : } \\
& \text { بسم الله الرحمن الرحيم، }
\end{aligned}
$$

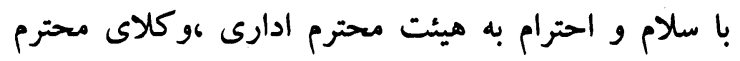

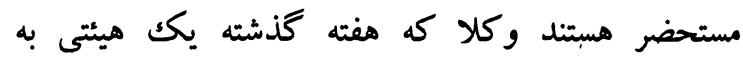

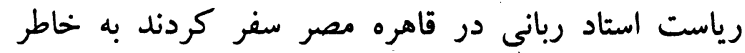
كسب عضويت افغانستان در اتحاديه بين المجالس كشور هاى عضو كنفرانس اسلامى و تركيب هيئت به قرار ذيل 
اينها از يك جاى ديخر قرض گرفتند كه اكر اين كار صورت نميخرفت وكلاى شما در آنجا كرو ميماند رئيس

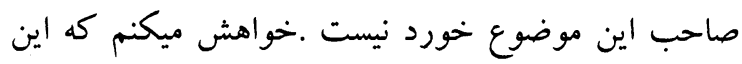
مورد توجه واقع شود ـ ماحس

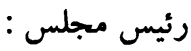
جناب بلخى صاحب اين مسئله خورد نيست مام ما جاى مطرح كردنش من گمان نكنم در جلسه عمومى باشد و و وقت كل كل

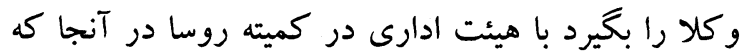

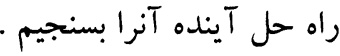

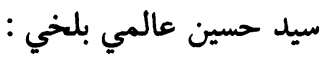

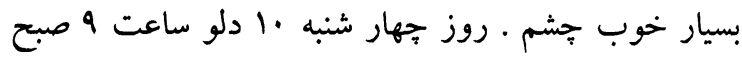

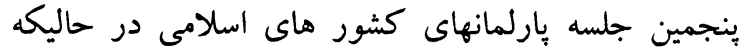
نخست محترم بروفيسور برو كسل كافوس سولكيور رئيس

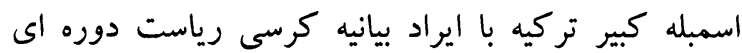

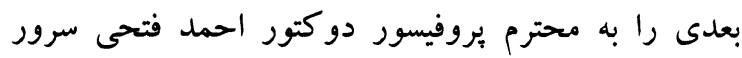

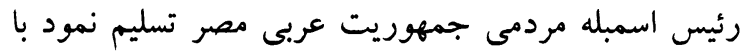

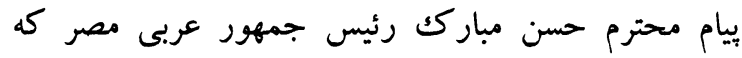
توسط دوكتور احمد نفيس صدراعظم آن كثور قرائت

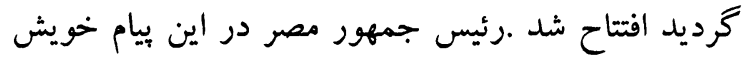

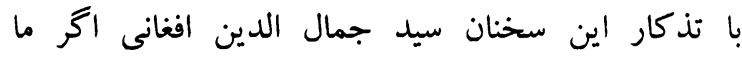

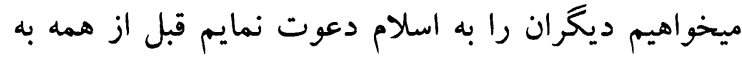

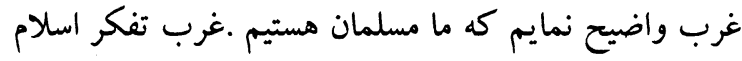
را از حالت ظاهرى مسلمانان كه به خاطر مصروفيت دران دران

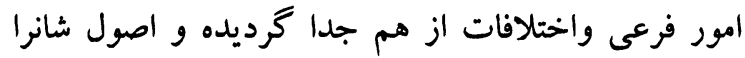
فراموش كرده اند ،نغاه ميكند ببه اتحاد جهان اسلام تأكيد

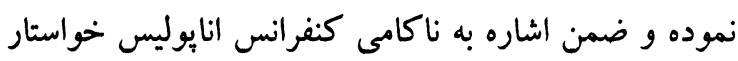
صرف مسايل كشور هاى ذيدخل براى حلى حل مسايل كشور

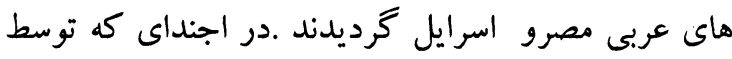

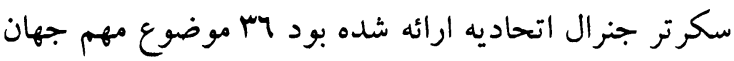

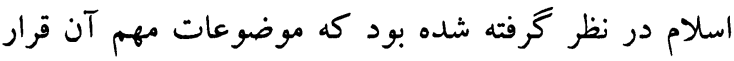

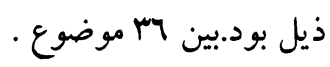

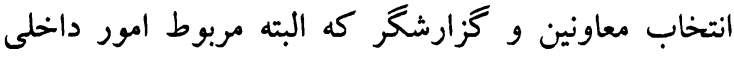
خود كنفرانس ميشد .و موضوعاتى كه در رابطه با جهان

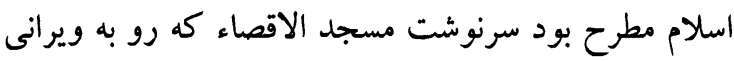

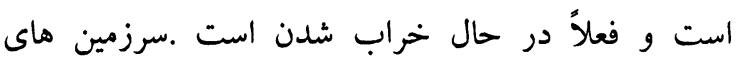

ميدان هوايى بين المللى قاهره شديم وتوسط محترم

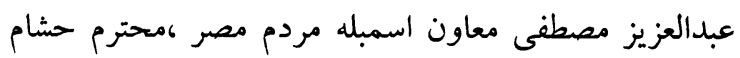
بيه نماينده جلالت ماب محمد حسن مبار كك رئيس جمهور مصر عربى ،محترم حفيظ الله ايوبى سفير كبير افغانستان در

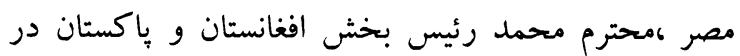

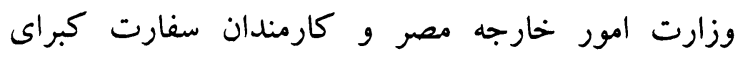

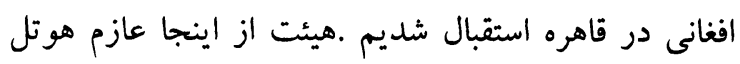

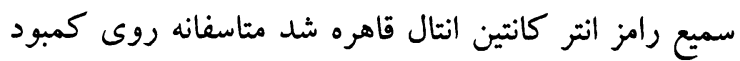

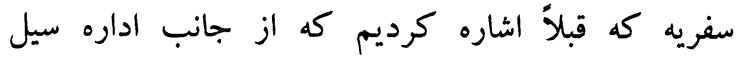

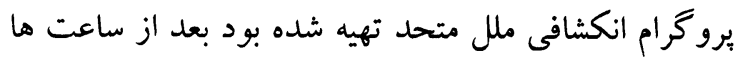

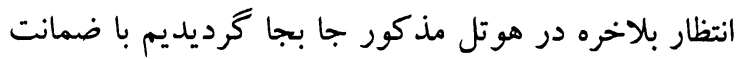

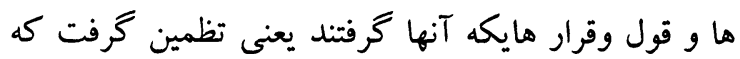

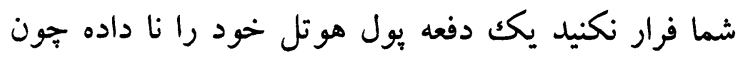

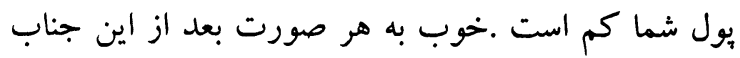

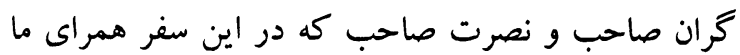

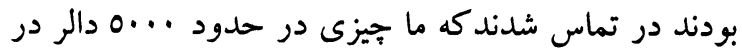
مجموع براى سفريه كسرى داريم از اينجا اينها فرستادند ra...

حزينه انتقال يول شده بود ...

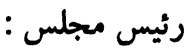
جناب بلخى صاحب محترم خواهش من اينست كه كب كب

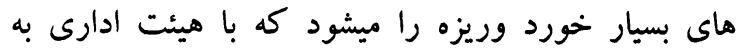
كميته روسا بخويد همان مسايل كلى را بيان كنيد كه و كلا

خسته نشود.

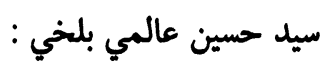

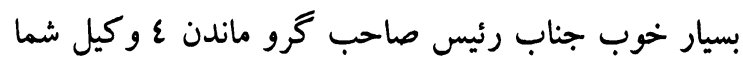

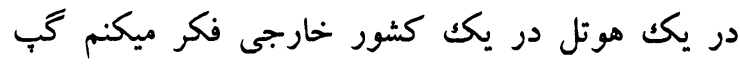

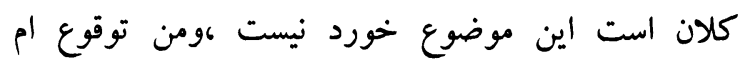

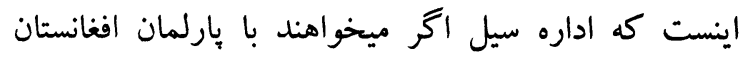

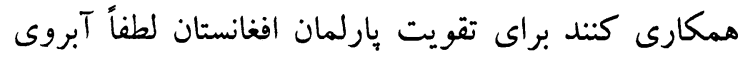

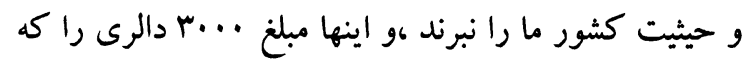

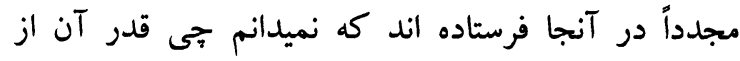

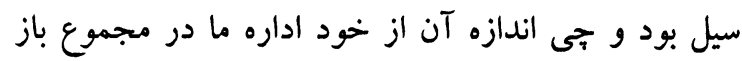

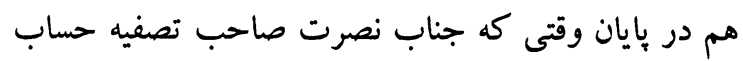

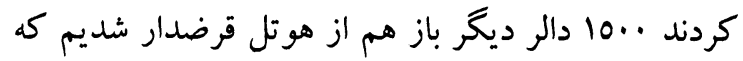


بارلمانهاى كشور هاى اسلامى بيرامون مسايل مطروحه

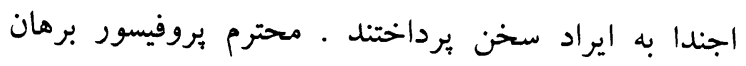

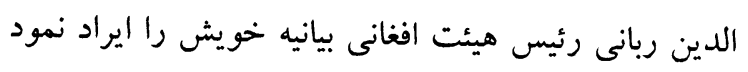
در اين بيانيه بيرامون اوضاع جارى در افغانستان و و جلب افئي

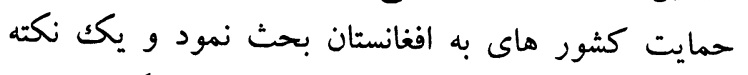

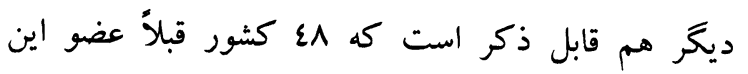
اتحاديه بودند افغانستان و سومالى اين دو كشور امسال

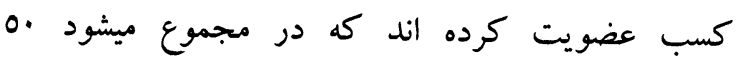
كشورالبته تمام كشور ها در آنجا حضور نداشتيند از جمان دمله

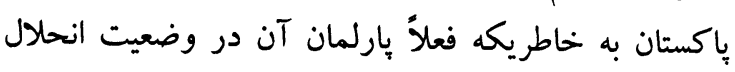

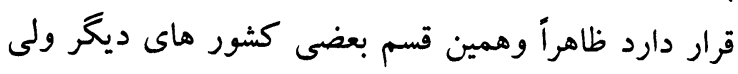
مجموع كشور هاى عضو به ل0 كشور ميرسيديم .هيئت

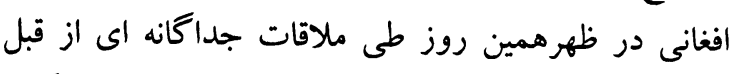

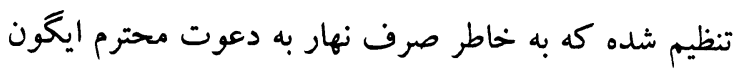

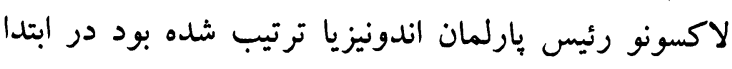

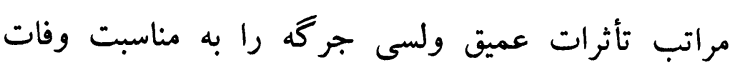
دوكتور احمد سوهارتو رئيس جمهور اسبق اندونيزيا به موصوف و توسط موصوف به بارلمان و ملت اندونيزيا

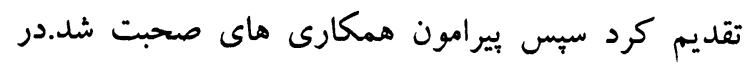
عصر روز جهارشنبه هيئ افغانى با يروفيسور احمد فتيح سرور رئيس اسامبله مردم مصر و رئيس فعلى اتحاديه و وتئيه محترم عثمان رئيس اسمبله ملى نيجر كه ظاهراً ميزبان

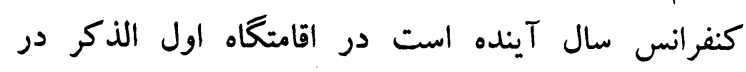
حاليكه محترم حفيظ الله ايوبى سفير افغانى نيز حضور

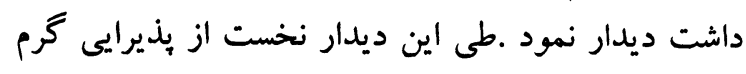

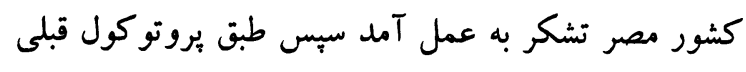

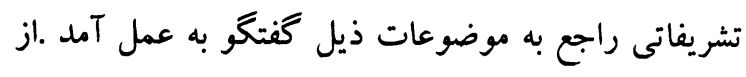

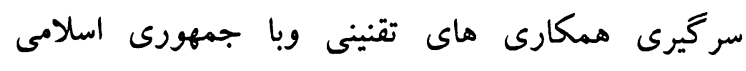

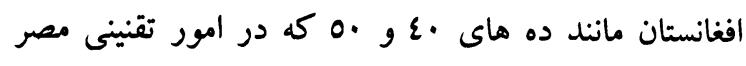

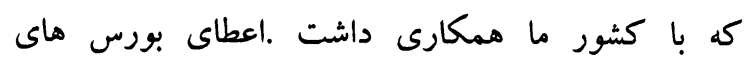

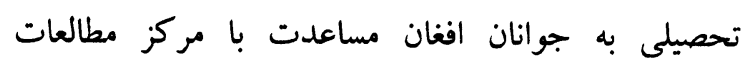
حقوقى ومسلكى اداره امور ولسى جر گه ،فراهم ساختن

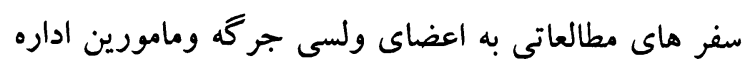

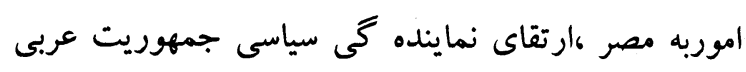
مصر در كابل به سطح سفارت حل برخى مشكلات
اشغالى عربى توسط اسرايل موضوع اسلام ستيزى توسط

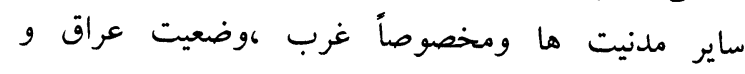
حاكميت ملى اين كشور ،وضعيت لبنان ،تروريزم جهانى

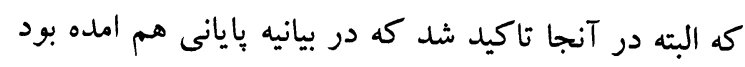
كه ما تروريزم را از مقاومت در برابر مداخله و اشغال بايد

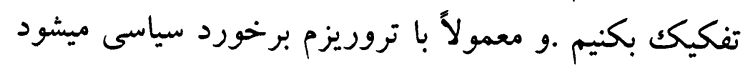

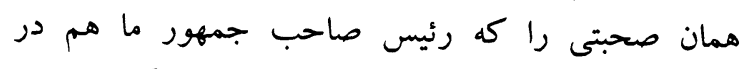
كنفرانس داووس داشت كه كلمه تروريزم كاهى جنى جنبه سياسى به خودميگيرد، روى اين موضوع هم در در آنجان تاكيد بسيار زياد صورت گرفت

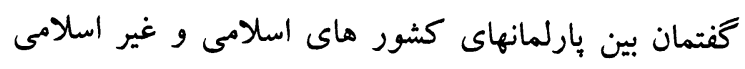

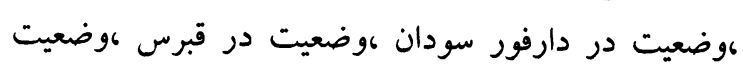

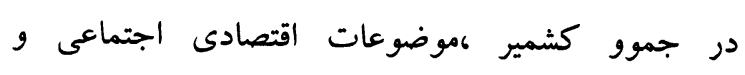
فرهنگى جهان اسلام كه هر يكك به تفصيل معرفى شده بود .محترم محمد بيروفى سفير كبير سيار كنفرانس كشور هاى اسلامى بر مبنى بيشنهاد تحريرى قبلى كه جلى ملالت

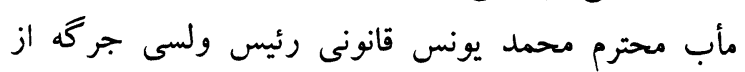
يذيرفته شدن رسمى عضويت افغانستان در اين اتحاديه

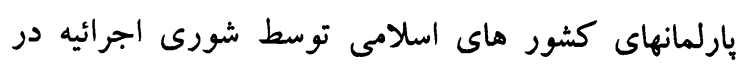

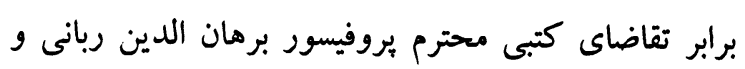

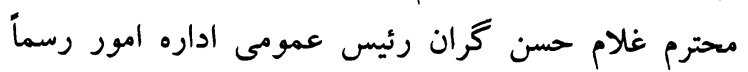

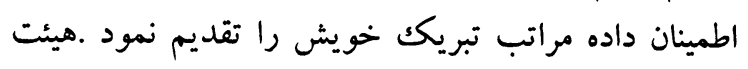

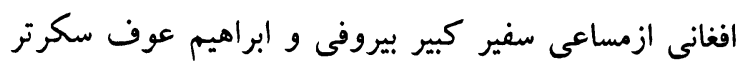

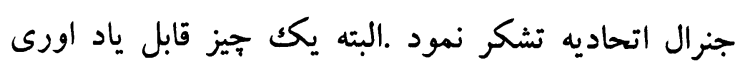
است جناب رئيس صاحب كه عضويت در اين كنفرانس

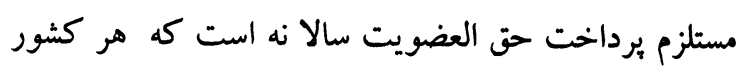

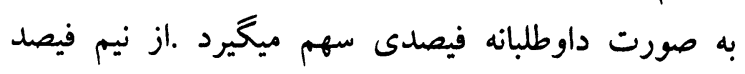

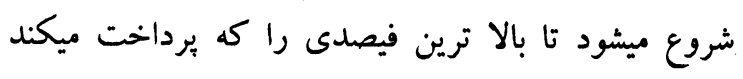

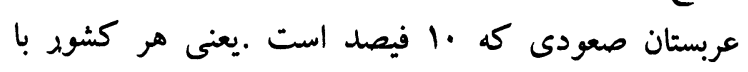

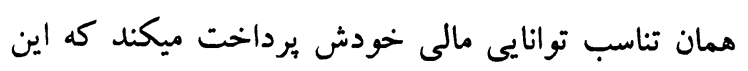

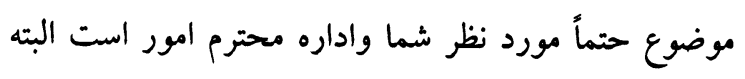

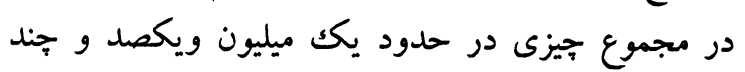

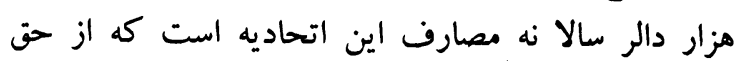
العضويت اعضا باهمان اساس در صدى كه عرض كرار كردم اله تامين ميشود .بعد از ظهر همان روز يكك تعداد روساى المان الماني 
خوبتر شد كه بيش از اين قبل از سفر هيئت تمام اين

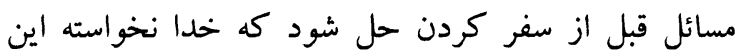

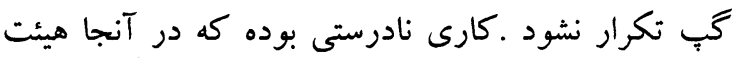

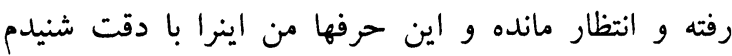

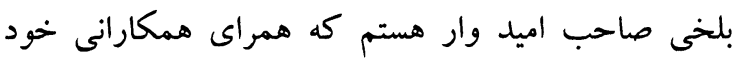

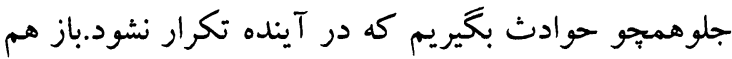
براى همه شما من تبريك ميكويم كه بِارلمان افغانستان

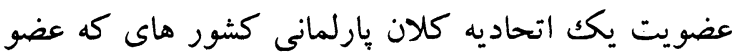
كنفرانس اسلامى را بدست آورد به همه شما وكلاى بله

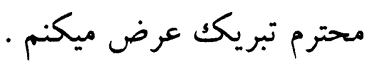
ميراحمد جوينده : اعتراض :

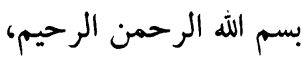
جناب رئيس صاحب هيئت محترم ادارى و و وكلاى الرحئ

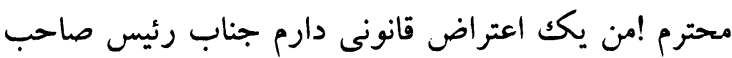

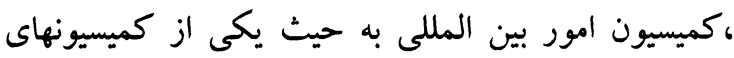

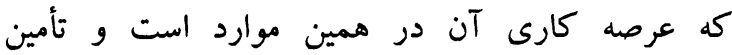

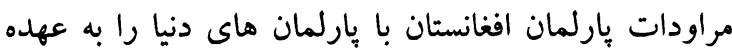
دارد وطورى كه شما درجريان هستيد كمسيون روابط بين

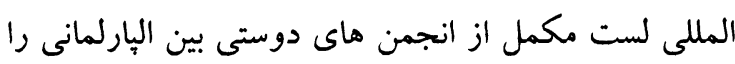

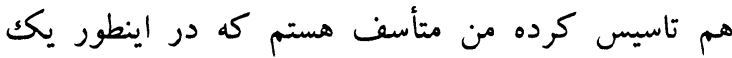

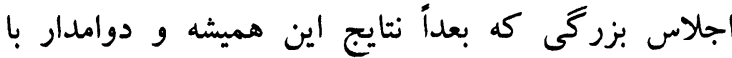

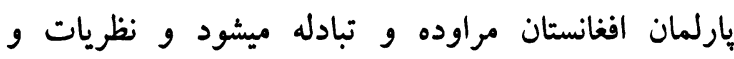

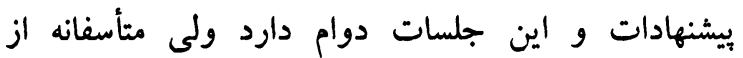

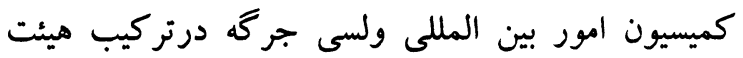

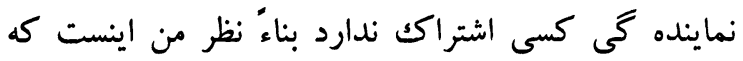

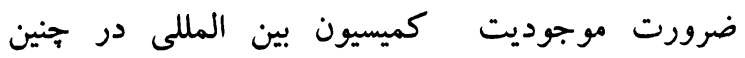

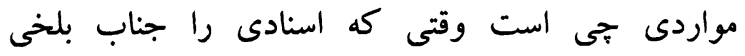

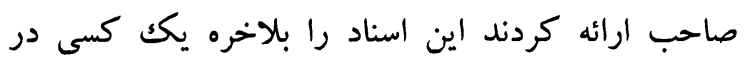

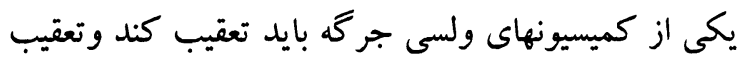

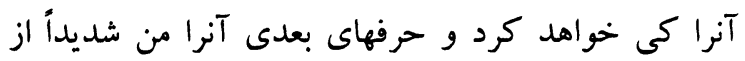

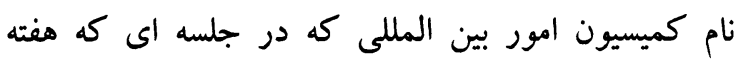

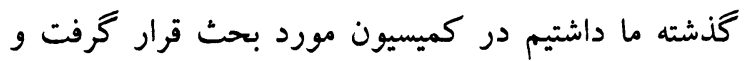

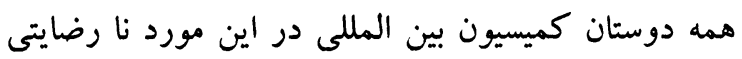

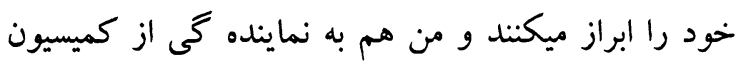
بين المللى اعتراض شديد و شكايت شديد كميسيون امور
سفارت كبرى افغانى مقيم قاهره .به دنبال اين هيئت افغانى با محترم يروفيسور جيروكسل كافوسوليكو رئيس اسمبله

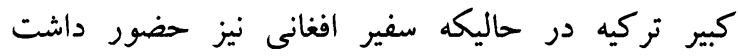
ملاقات نموده در مورد همكارى هاى بارلمانى بين هر دو دور

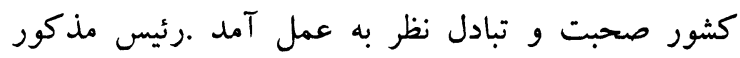

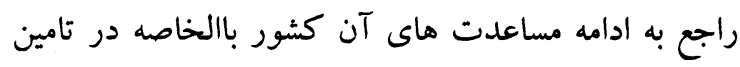

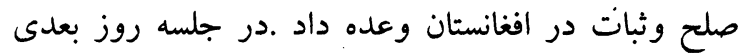

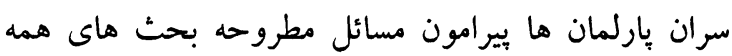

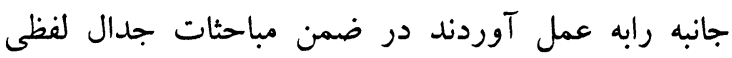

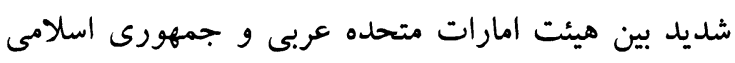

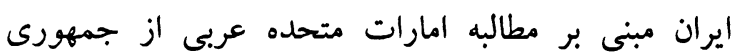

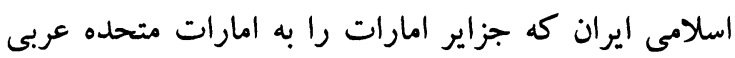

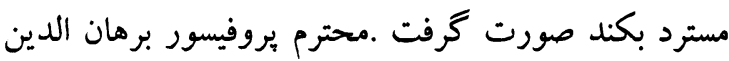

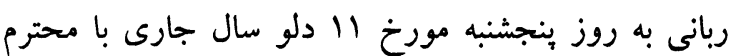

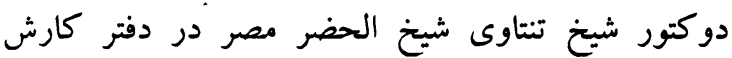

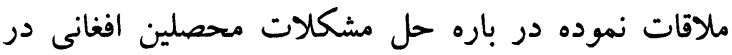
جامع الاظهر وافزايش بورس هاى تحصيلى به جوانان دان افغان

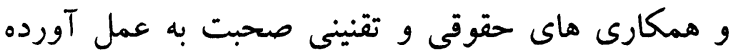

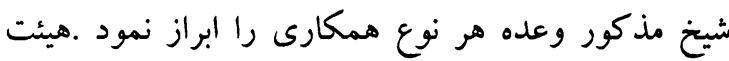

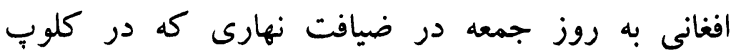
دييلوماتيك قاهره از طرف محترم ابوزيد درئ رئيس انجمن دوستى افغان و مصر وسفير كبير ان كشور در زمان شهيد

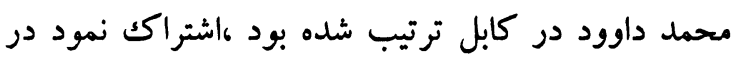
اين ضيافت محترم حفيظ الله ايوبى سفير كبير افغانستان و

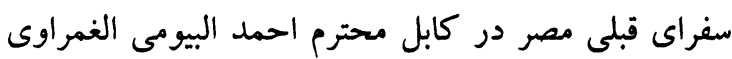
و محترم مصطفى فتحى نيز اشتراكى نموده بودند.هيئت

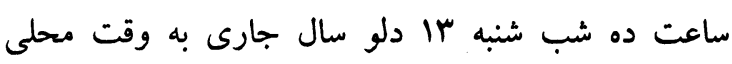

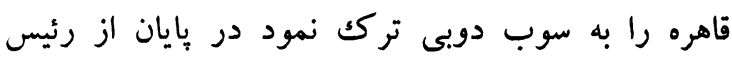

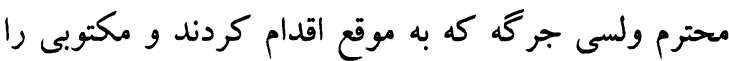

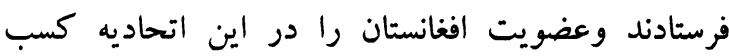

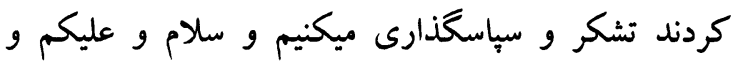
رحمت الله و بر كاته . رئيس مجلس : تشكر در مورد مشكلات لوزيستيكى را كه شما عنوان كرديد بلخى صاحب خوب شد كه براى ما وشما تجربه 
ميكنم كه به جاى معين تشريف بياورند بحث هاى خود را

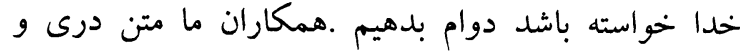

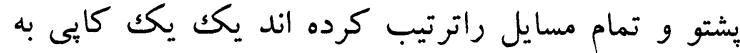
و كلاى محترم عنوان بكنيد.يش از اينكه عثمانى صاحب

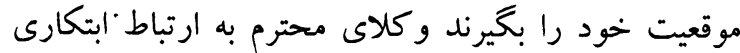

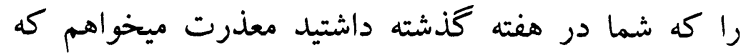
صندوق اعانه براى مصيبت زده كانيست كه در كوشه ور و كنار افغانستان مردم مستحق ما وشما وجود دارد اين ابتكار

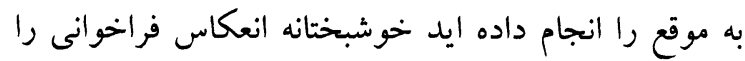

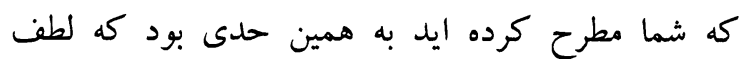

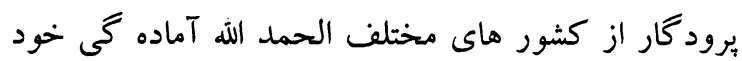

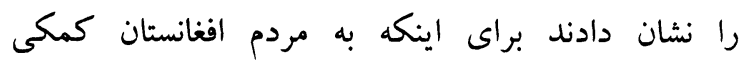

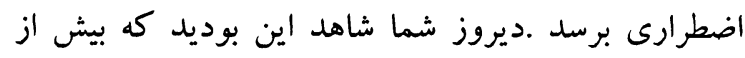

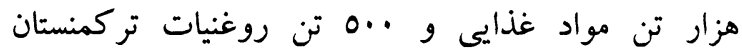

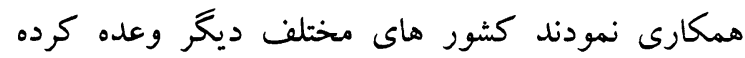

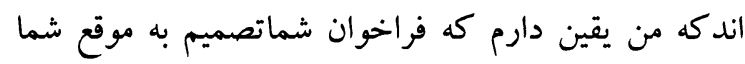
در جلب حمايت كشور هاى دوست ما بى تأثير نبوده فعلاً ياسينى صاحب در مورد همين صندوق يكك تقاضايى را

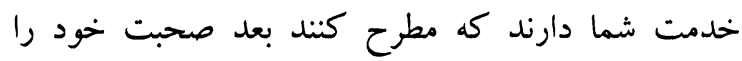

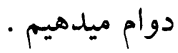

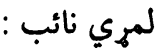
بسم الله الرحمن الرحيم، د جلالتمآب رئيس صاحب به إجازه آرحبه درنو خويندو ورونو

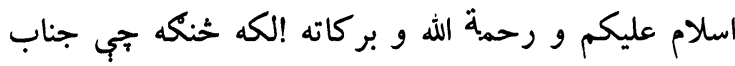

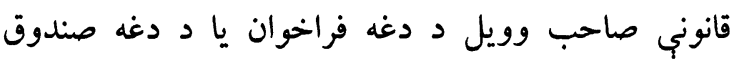

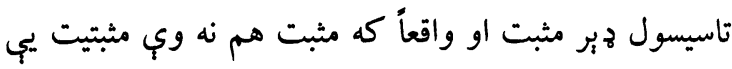

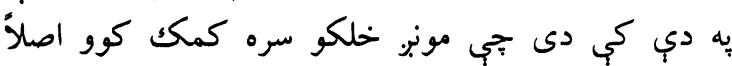

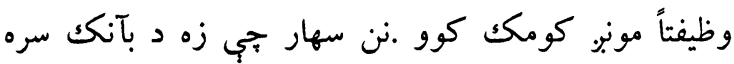

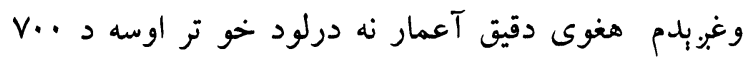

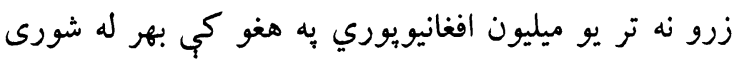

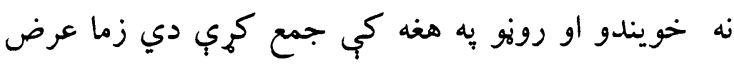

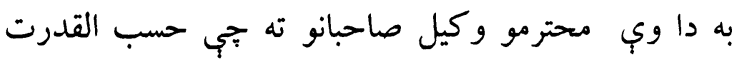

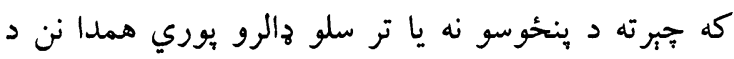

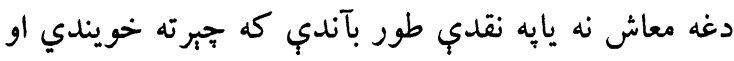

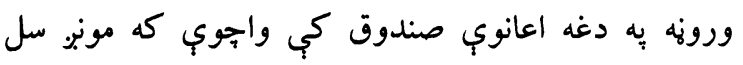

بين المللى در ارتباط عدم اشتراكك نماينده هاى كميسيون

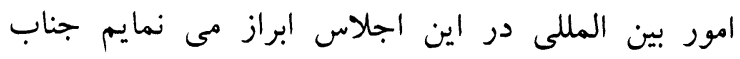
رئيس صاحب .تشكر! رئيس مجلس : تشكر جوينده صاحب فقط براى اينكه از اجنداى اصلى مجلى

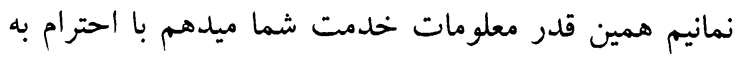

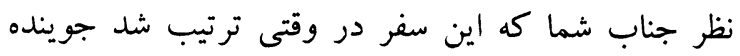

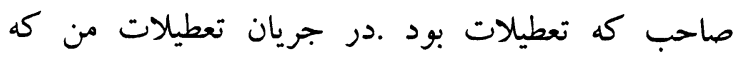
قانونى آدم هستم اين دعوت به نام رئيس ولسى جر گهه بود

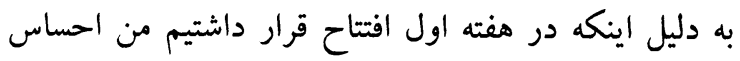
كردم كه بودن من مهم است انتخابات هيئت ادارى و غيره اجنداى ما وشماست ،ترجيح داديم كه جناب استاد رئيس كميسيون محترم روابط بين المللى تشريف ببرند به دلايل

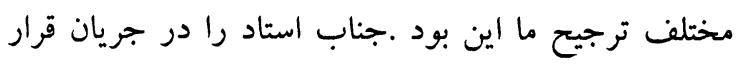

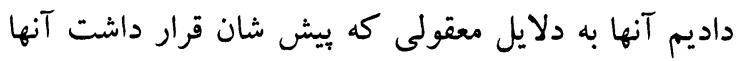
ترجيح دادند كه كسى ديخرى انتخاب شود بناً آنها رفته دئه

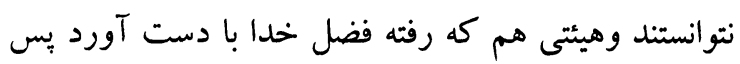

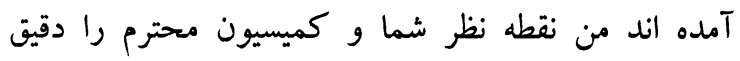
ميدانم خوب است كه در جريان جلسات بعد ترى كن كه ونه ميروند حتماً از كمسيون محترم روابط بين المللى كسى

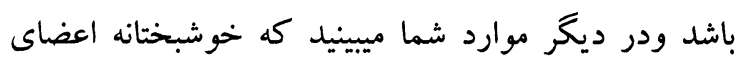
محترم كميسيون در سفر ها و در مسايل شركت دارند منجمله با اي يى يو كه سه نفر عضو دايمى اين كميسيون

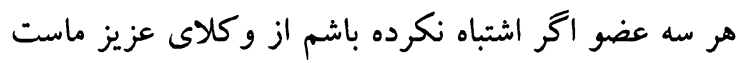

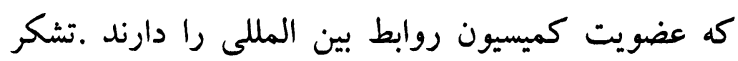
ميكنم و كلاى محترم ميايم روى اجنداى اصلى ما مثل

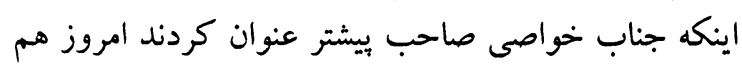

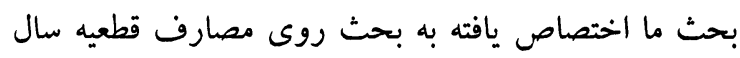

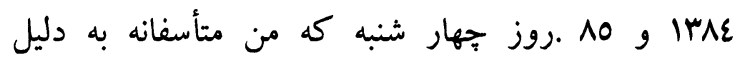
شركت در جلسه مشترك قواى سه گانه كه در ارگ

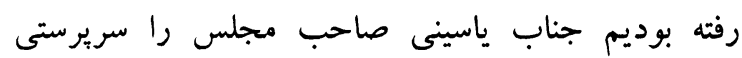

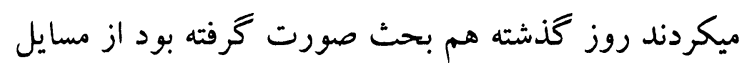

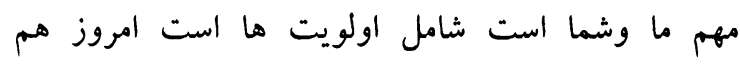

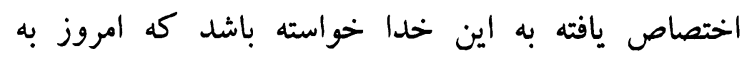

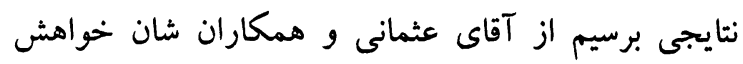


مصرف برق خود را جطور كند ؟ و ديخر مصارف خود را جطور كند؟ منشى مجلس : مانس اول خو ما دالر معاش نداريم ، معاش ما به افغانى است ماتس داكتر صاحب . مول. من راجع به همين اسنادى كه در داخل دوات دوسيه است يكك

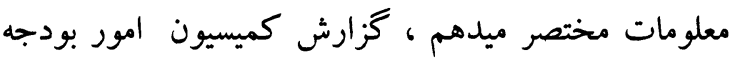

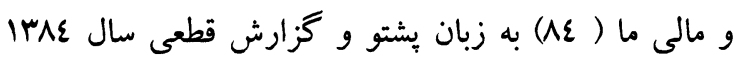

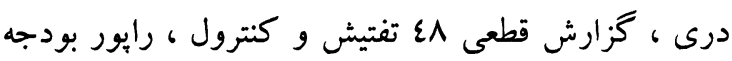
عادى سال ع^ه ، عوايد مجموعى ادارات مر كزى و ولايات

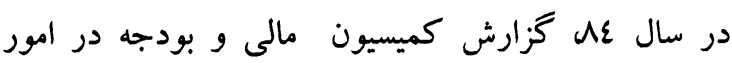

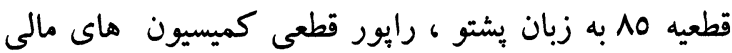

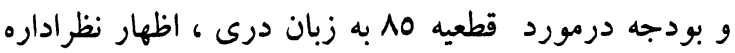

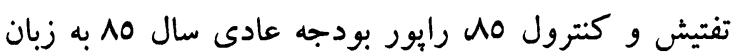

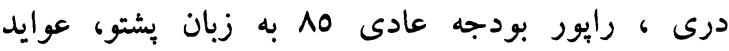

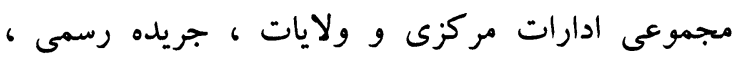

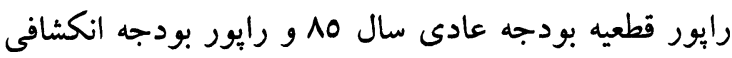

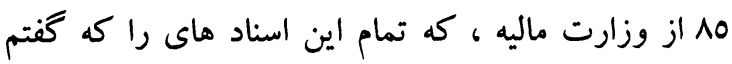

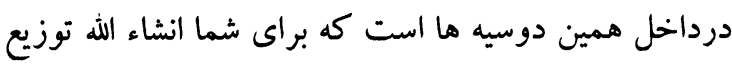

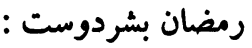

اعتر اض: - اض

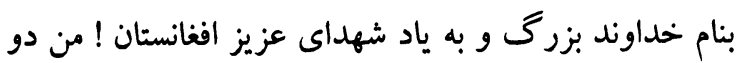

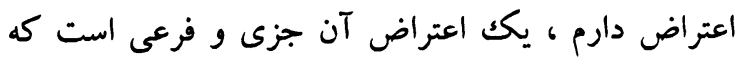

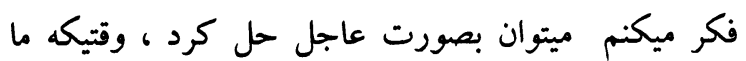

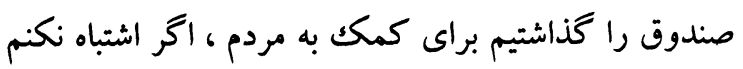

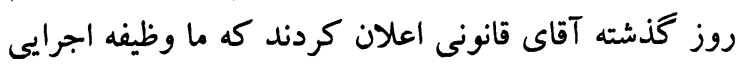

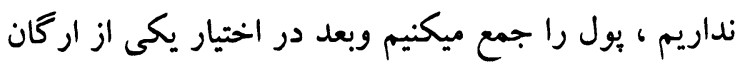

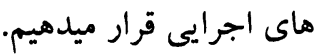

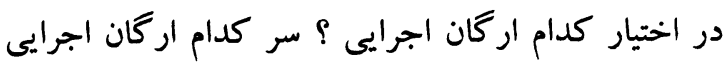

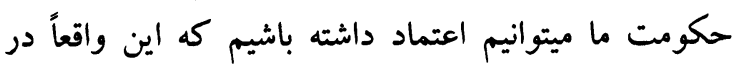

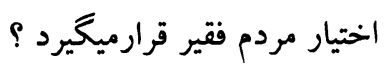

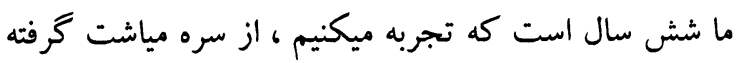

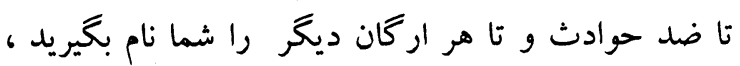
اين كمكى است كه مردم دواطلبانه ميكنند و ما فكر ادر

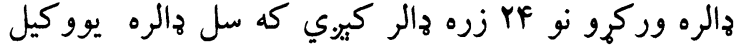

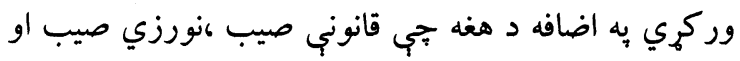

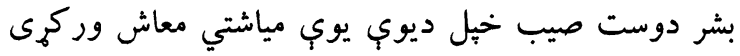

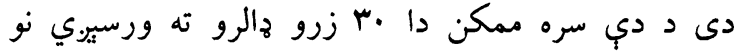

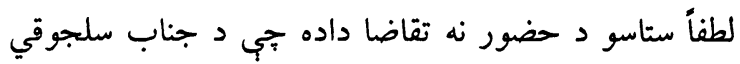

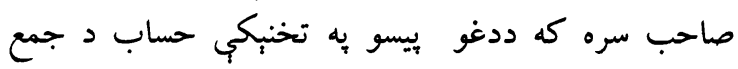

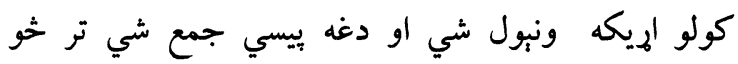

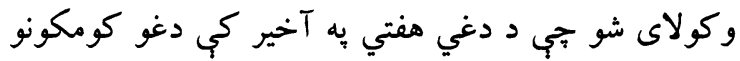

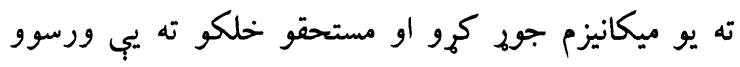
داسي و نه شي خداى نا خواسته لكه نو كريحئ خيخي له

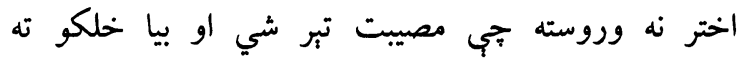

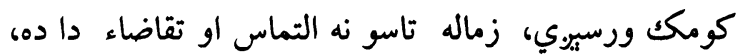
وسلام عليكم ورحمت الله و بر كاته ! خه واياست وكيل صاحبانو موافق ياست ؟

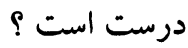
وكيل صاحبان يِينهاد به اين است كه فرض بكنيداگر

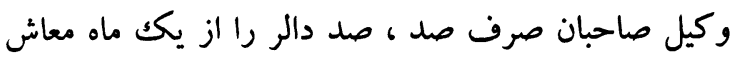

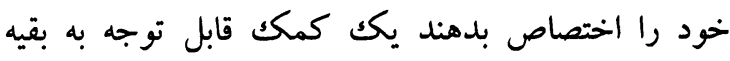

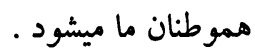

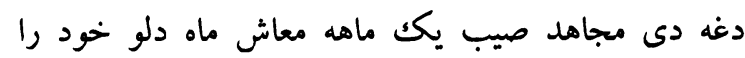

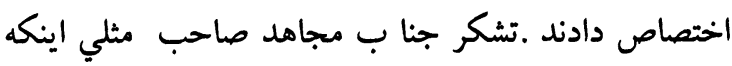
آغاى بشردوست صاحب و جناب نورزى صاحب قبلاً اين

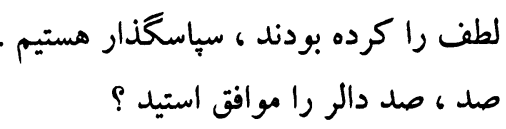
اخر شما موافق باشيدفيصله تان باشد كه باز من ماركيد كار هاى

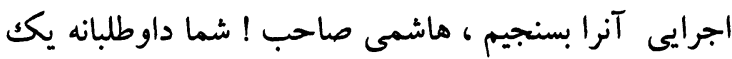

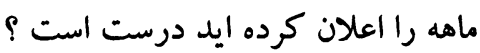
داكتر كَلالى نور صافى : ، اسلام عليكم ، رئيس صاحب ميبخشيد من يكك سوال دارئ دارم

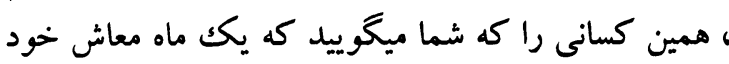

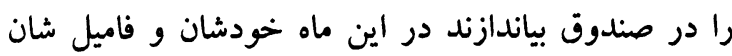
جطور كنند؟ شما گفتيد كه يكك ماه معاش خود ركندو رادر صندوق بياندازد

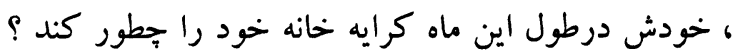


آنرا يكى ازدوستان در اختيارما قراردادند بصورت واضيح و روشن ميخويد آقاى وزير تجارت و صنايع به استيضاح نمى آيند ، اكر اجازه بدهيد نتيجه گيرى آن آن دو جمله است كه من بخوانم كه بصورت واضيح روشن شود كه آنهاره بدهيد

آنها جֶه ميكويند؟ رئيس مجلس : در جريان استيم آقاى بشردوست !

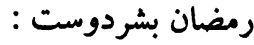

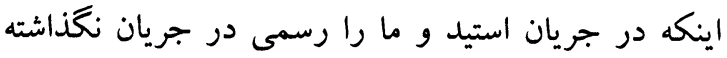

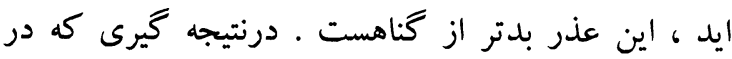
صفحه سه ميكند ، جنين نوشته : در نتيجه با ارايه دلايل فوق الذكر و حسبن نوسته هدايت مقام عالى رياست جمهورى ، دلايل مؤجه براى استيضاح وزير

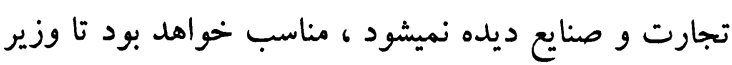

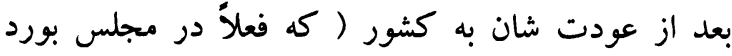
نظارت و انسجام توافق نامه افغانستان در كشور جاته حضور دارند ) در مجلس استجوابيه فراه خوانده شوند. تا تأن أنسان

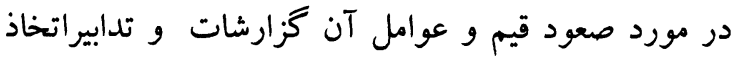

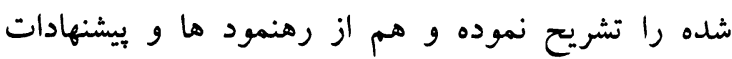
و كلاى محترم ملت براى رفع معضل مستفيد گر دند.

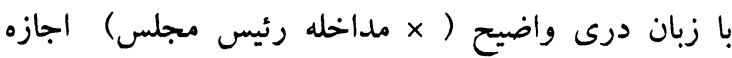

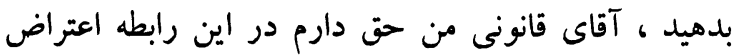

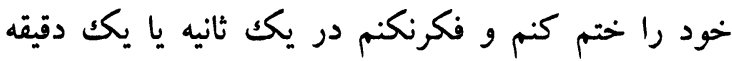

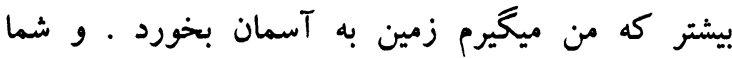

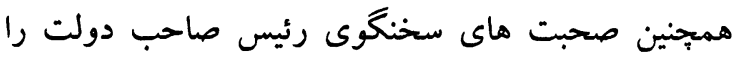
در رابطه به اين ضرب العجل كه هُ تعيين كرديد شنيديد ،

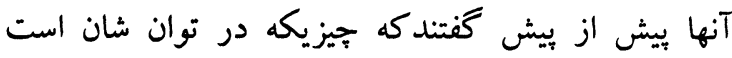

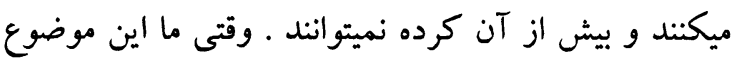

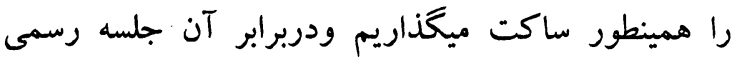

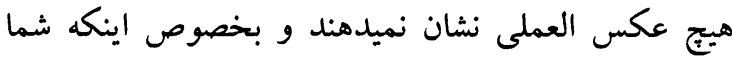

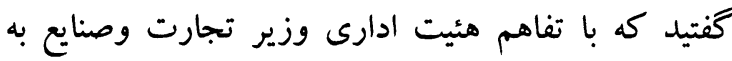

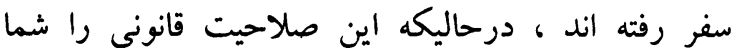

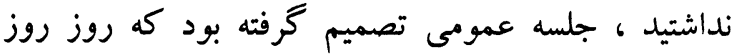

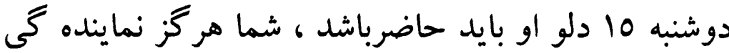

ميكنيم در اين ولسى جرگه اين ظرفيت و اين افراد را داريم و اين امكانات لوزيستكى را هم داريم كه دو ين ين سه سه

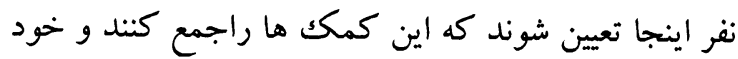

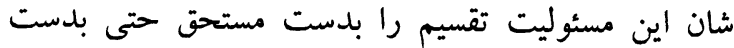

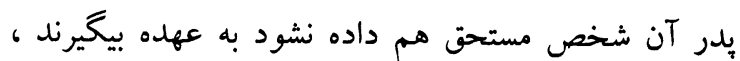

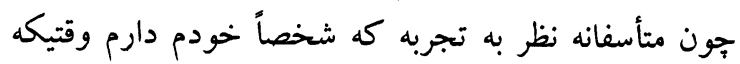
كمك دست به دست شود ، به فرديكه واقعاً مستحق است

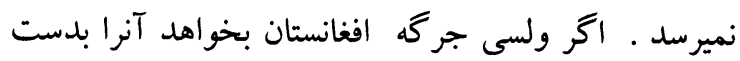

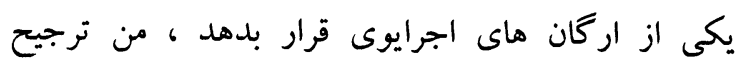

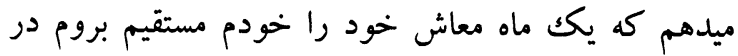
اطراف كابل براى مردمى كه در زير خيمه استند و هيج

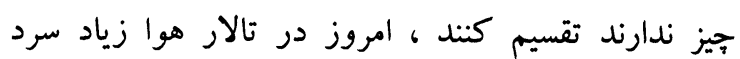

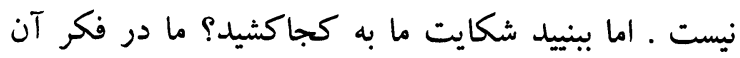

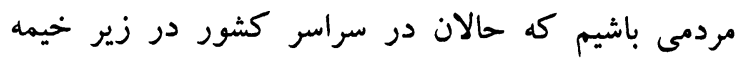

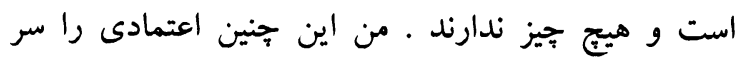

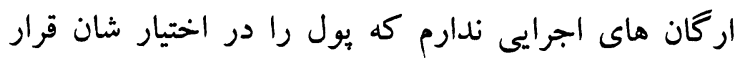

اعتراض اساسى كه من دارم اينست كه براى من بسيار

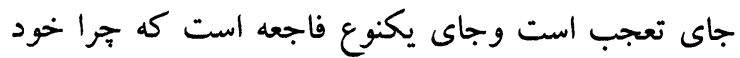

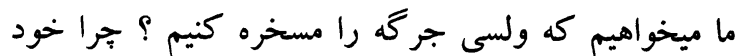

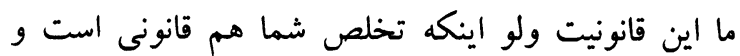

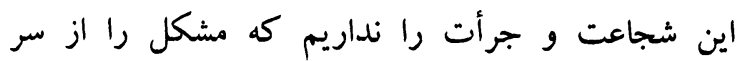

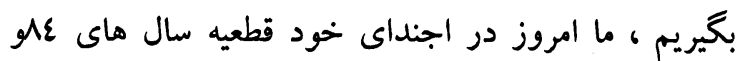

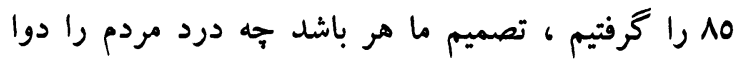

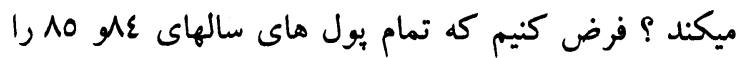

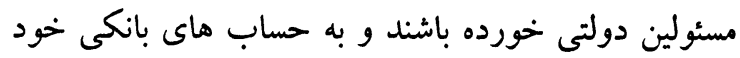
فرستاده باشند ما امروز جهه كار ميتوانيم در رابطه با قطعيه بانيه

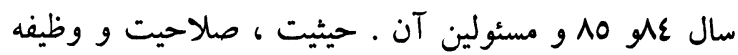
ولسى جر گه بار هاست كه زير سوال رفته است ،

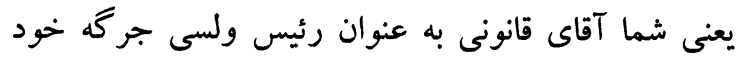

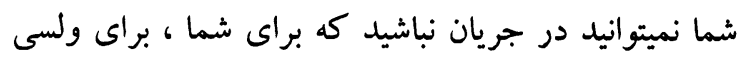

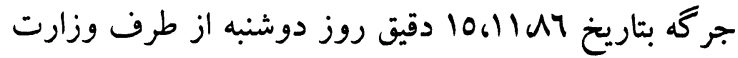

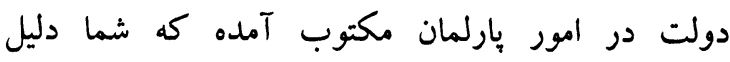
استيضاح وزير تجارت و صنايع را نداريد ، شما فقط اكر آمارد

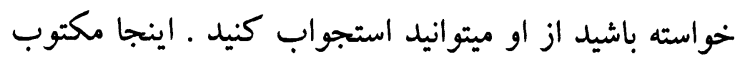


كل باجاه مجيدي :

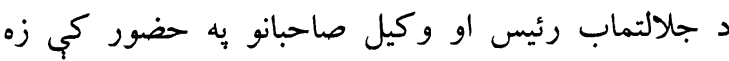

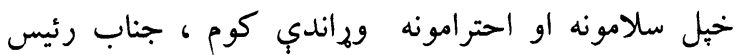

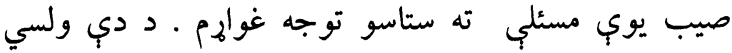

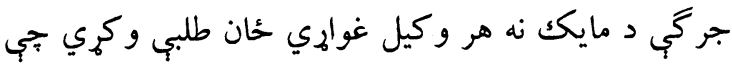

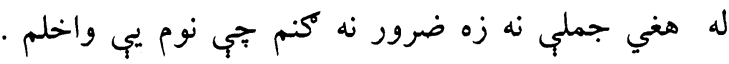

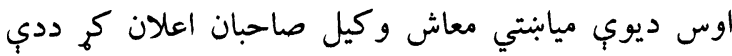

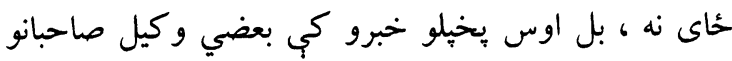

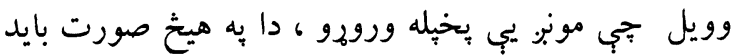

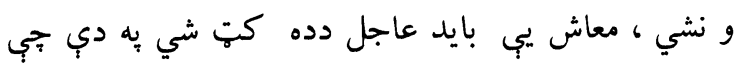

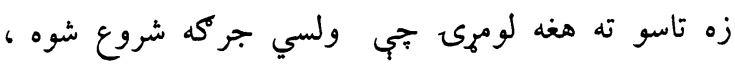
ددي خاى نه محترم وكيل صيب نوم يي نه نه اخلم لهم اعلان

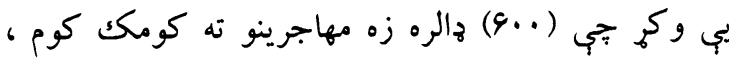

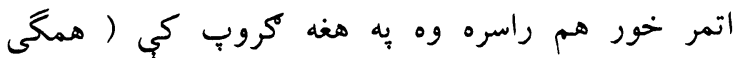

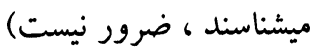
جناب رئيس صيب بشر دوست صيب وو ، دلته اعلان وكم

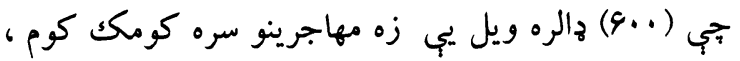

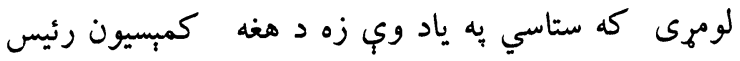

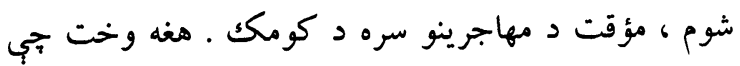

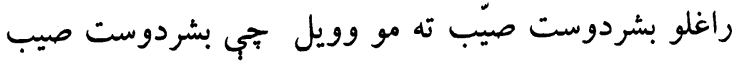

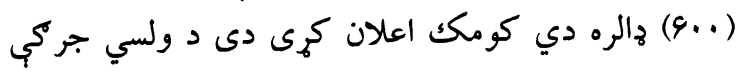

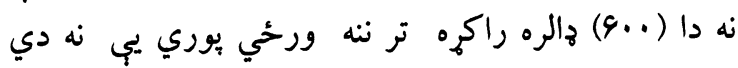

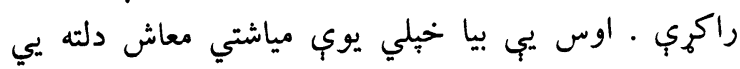

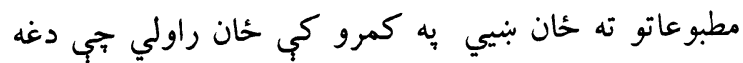

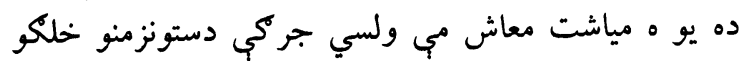

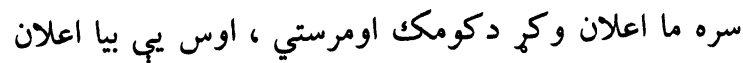

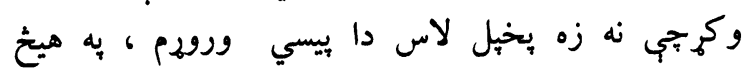

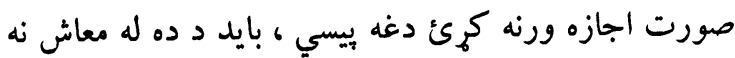

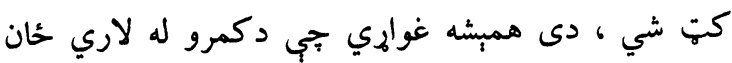

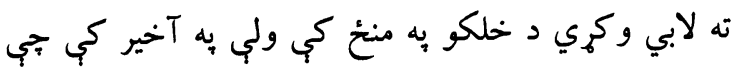

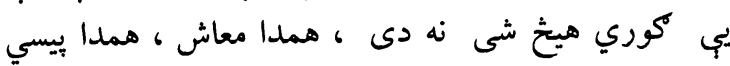

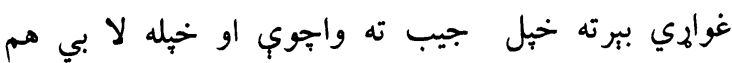

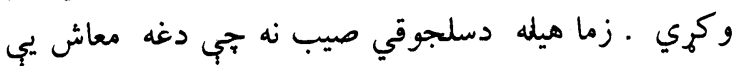

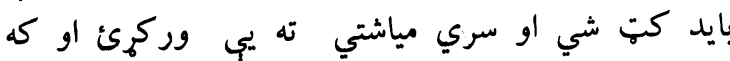

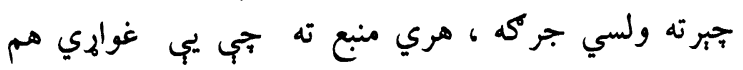

از ولسى جر گه نغرفته بوديد كه اين تصميم را به تعويق

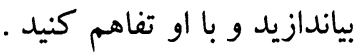

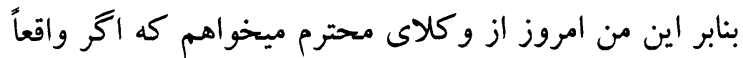
ما ميخواهيم كه جايگًاهى داشته باشيم ، مقامى داشته باشيم

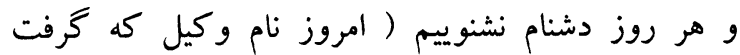

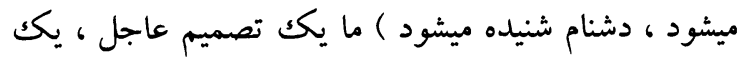

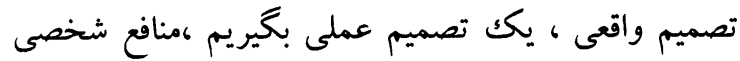

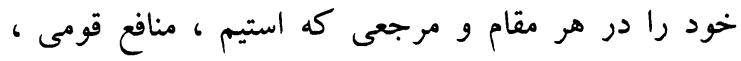

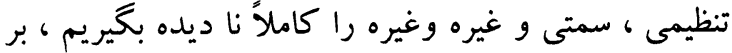

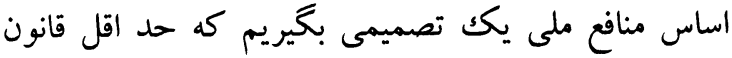
اساسى افغانستان توسط ما نقض نشود . بيشنهاد من اينست كه ( *مداخله رئيس مجلس النق )

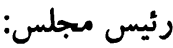
خودت هميشه مجلس ما را اخلال ميكنى آقاى بشر

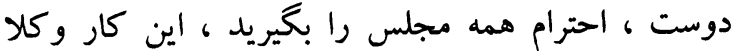
نيست ، كار هئيت اداريست . بشردوست صاحب بنشنييد ، صحبت همه كه خلاص شد ، بعد از آن .

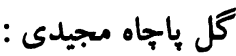

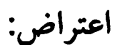

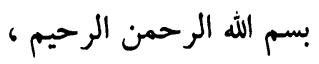
د جلالتمآب رئيس صيب او وكيل الرحيم، صاحبانو يه اجازه !

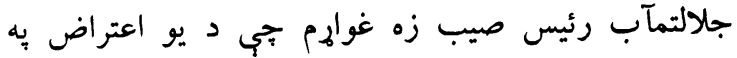

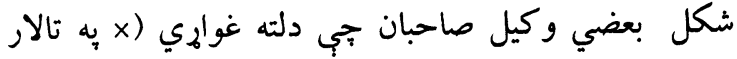
كي شور او غالمغال )

$$
\text { رئيس مجلس : ني }
$$

نوبت آقاى مجيدى صاحب ، قطعاً وقت نميدهم تا زمانيكه

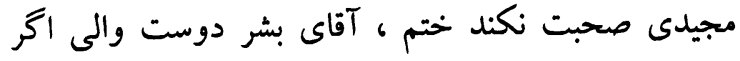

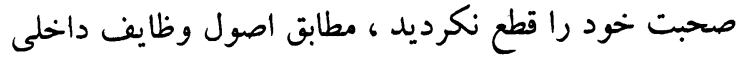

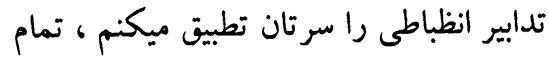
رمضان بشر دوست : اين ولسى جرگه بسته شود تا زمانيكه تصميم آن عملى دومى

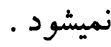


جنين است يا جنان است استيضاح صورت گرفته نميتواند

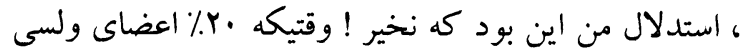

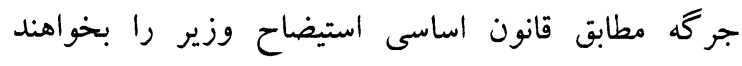

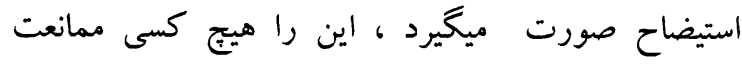

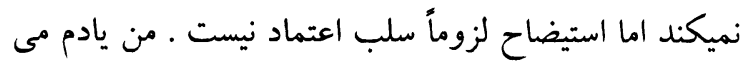

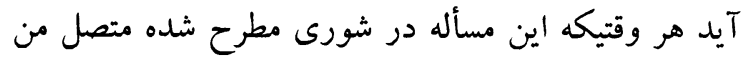

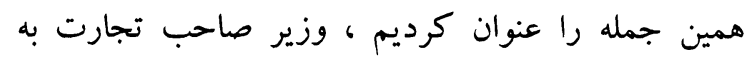

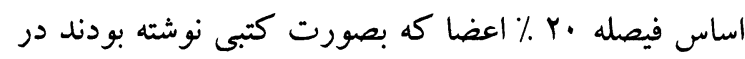
آن اجلاس ، بعد منشى صاحب هم وظيفه داديم كه رفتند

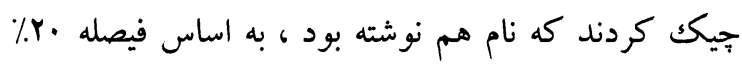
اعضاى ولسى جر گه اينها بايد به استيضاح به ولسى جرى تونه

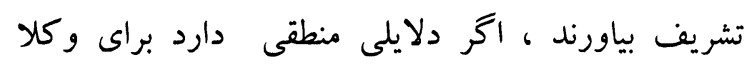

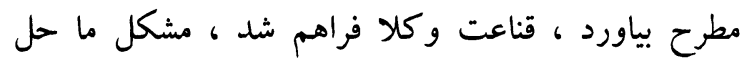

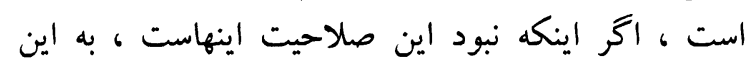

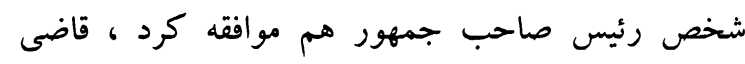

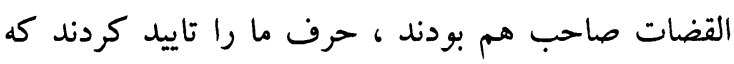

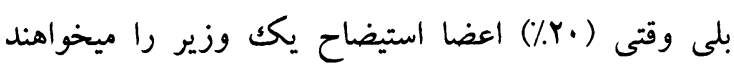

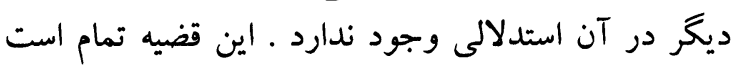

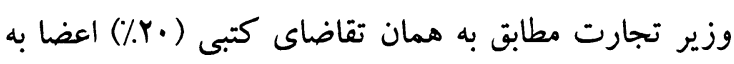

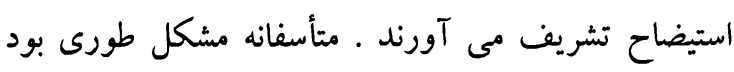

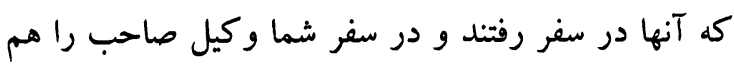

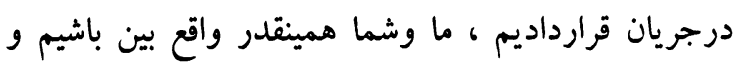

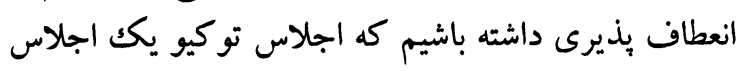
مهم وسرنوشت ساز براى مردم افغانستان است ، ما ما نبايد محكم بخيريم كه به همين خاطر كه خير امروز استيضاح

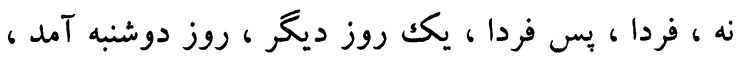

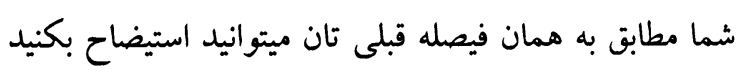

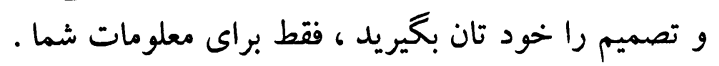

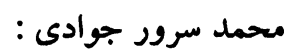
مكتوب مى آيد ، شما درجريان قرار ميخيريد ، خبر داريد

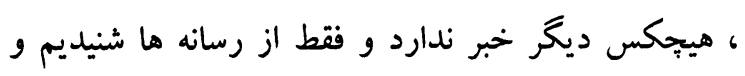

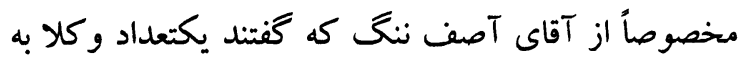

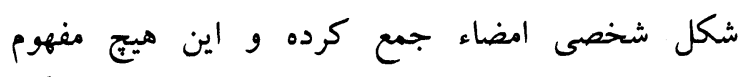

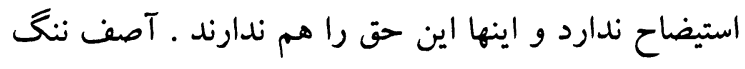

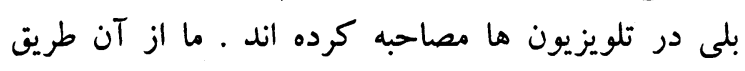

هني ته دي دا وركمل شي او ده ته بايد ببرته ورنكمل رئيس مجلس :

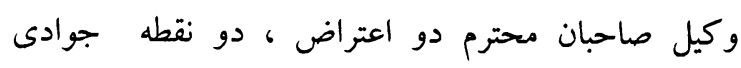

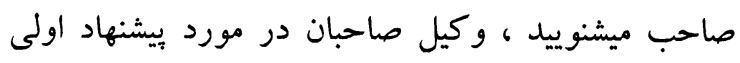

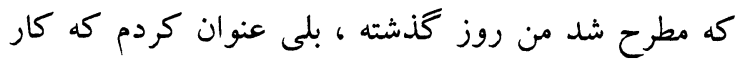

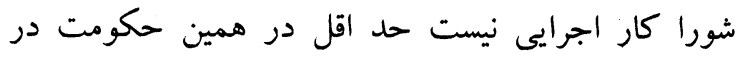

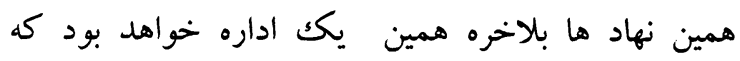

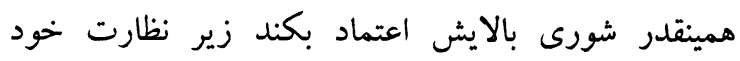

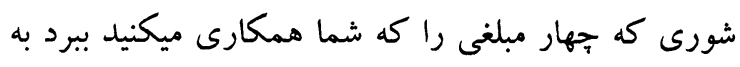

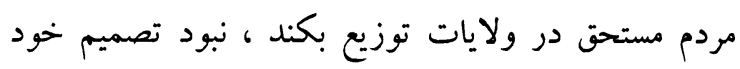
شما وكيل صاحبان است هئيت تان را تعيين ميكنيد ، همراه

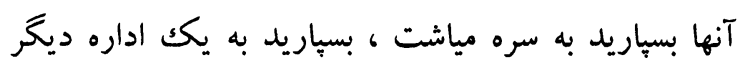

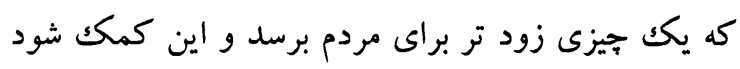

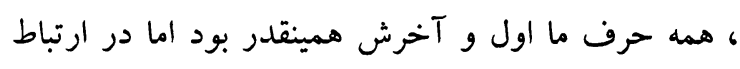

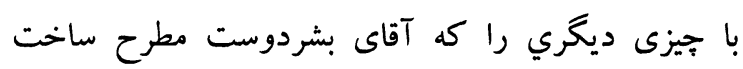

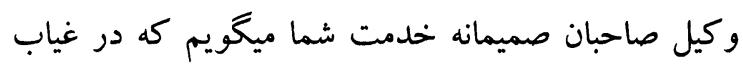

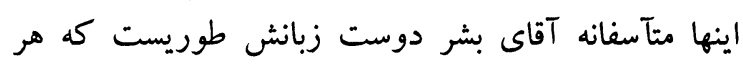

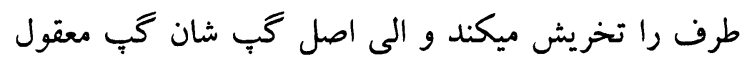
است آن به اين معنى است كه صلاحيت هاى ولسى ملى ولى الى

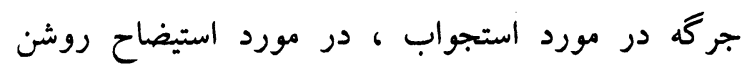

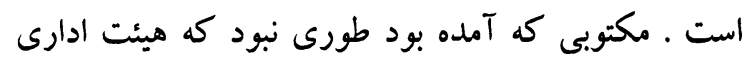

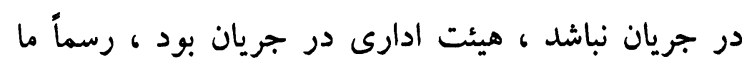
همين مكتوبى كه آمده بود از وزارت امور يارلمانى آنرا

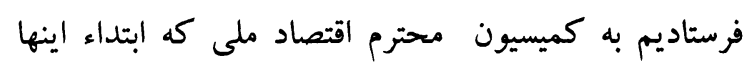

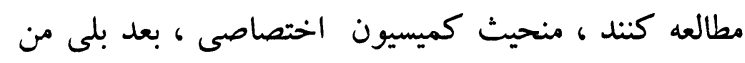

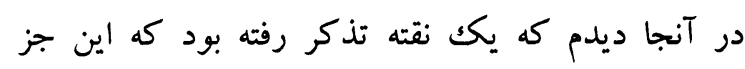

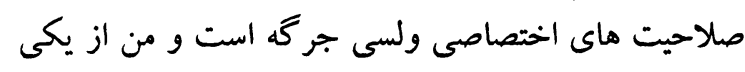
از وكيل صاحبان كه در مصاحبه خود هم ياد ماد كردند

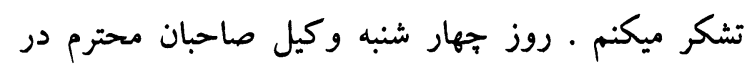

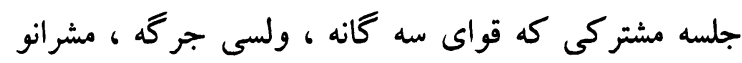
جر گه ، قوه قضائيه تحت رياست شخص مش رئيس جمهو

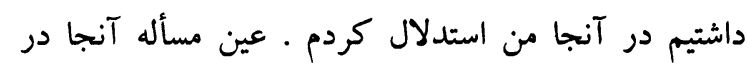

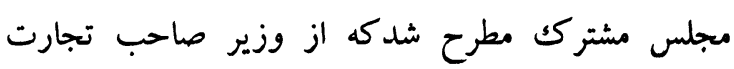

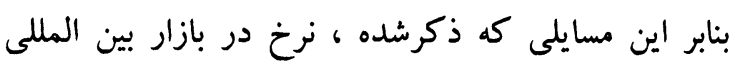


بود كه به كدام دلايل اين استيضاح خواسته شده ؟ مشوره

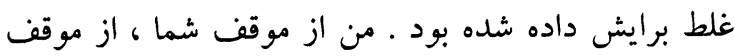
قانون اساسى در همين جلسه دفاع كردم · رئيس جمهور افغانستان قانع شد كه بلى مطابق قانون ميتوانيد كه استيضاح

$$
\text { كنيد ، عيب اين در كجاست؟ }
$$

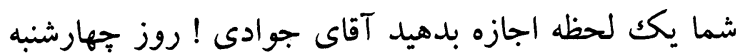

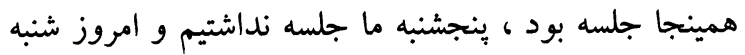

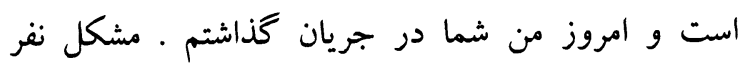

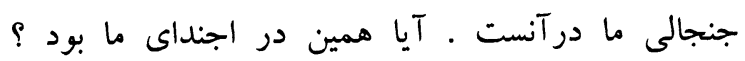
مسلسل برايش كفته رفتم كه اجازه بدهيد كه من همين همين

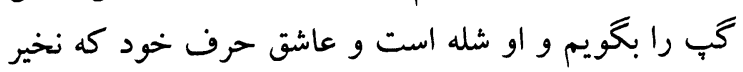

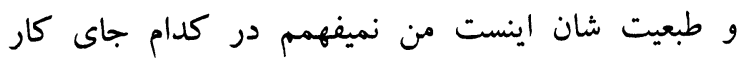
ديخرى دارد و اكثر روز ها از جلسه ميبر آيند.

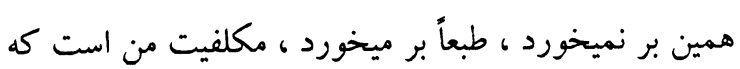

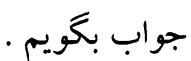
صديق احمد عثمانى :

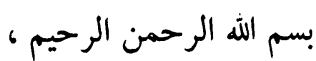

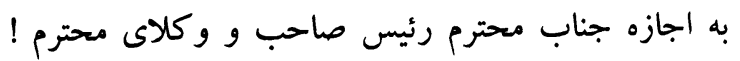

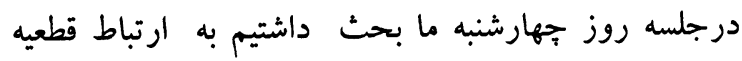

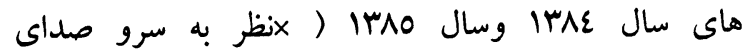
مجلس، رئيس مجلس مداخله ميكند)

$$
\text { رئيس مجلس : مجلسئ }
$$

هيجكس حق ندارد كه به آدرس وزارت بارلمانى ، مطلق

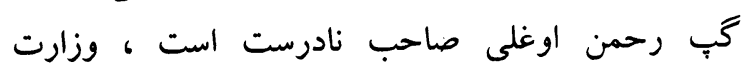

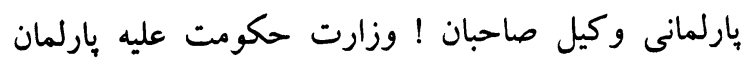

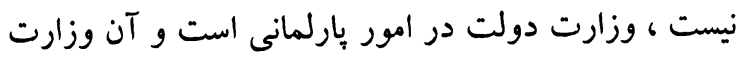

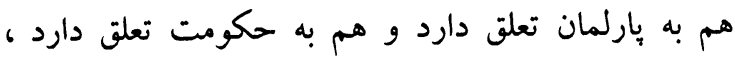

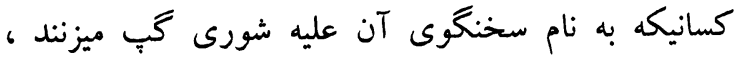

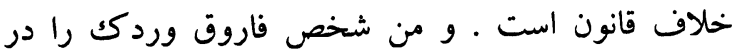

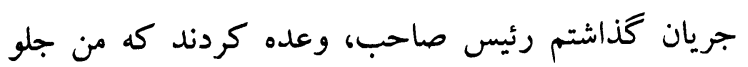

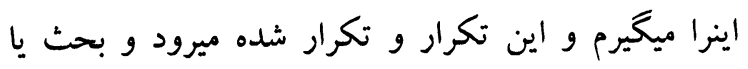

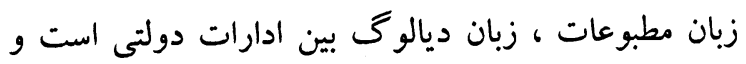
اين نادرست است و من اينرا تعقيب ميكنم ، مطمئين

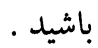

خبر ميشويم كه مكتوب آمده و محتوى اين مكتوب

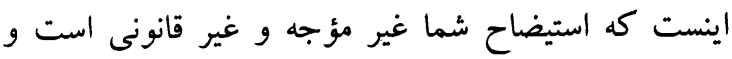

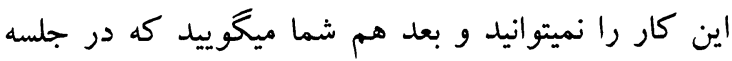

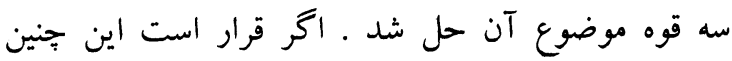

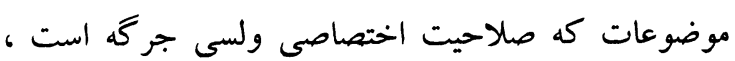
مطابق صلاحيت خود استيضاح ميكند و آنرا رئيس جمهور

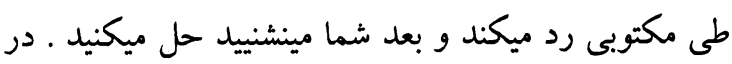

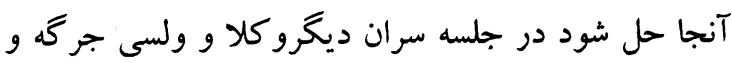

صلاحيت هاى اختصاصى معنى ندارد ـ جِه معنى دارد ؟

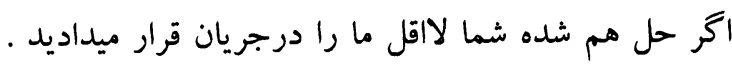

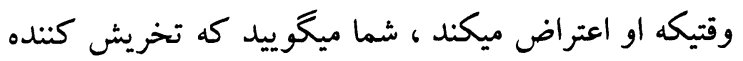

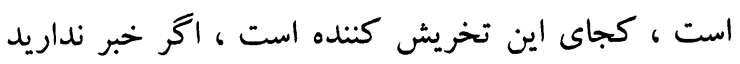
اين يكك مسأله و اخر داريد كه كتمان ميكنيد و ميخوييد

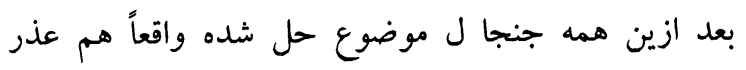

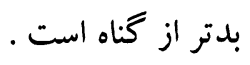
رئيس مجلس : اجازه ميدهيد آقاى جوادى! اول خواهش من من اينست كه

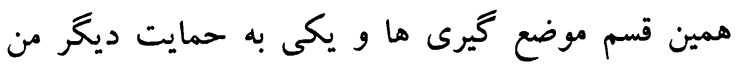

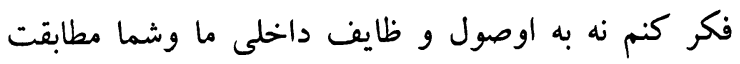

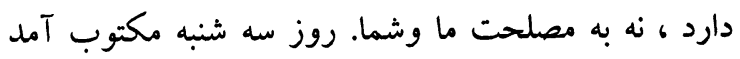

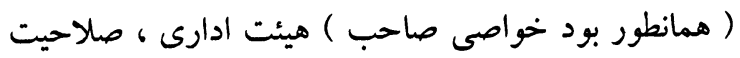

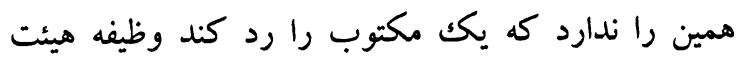

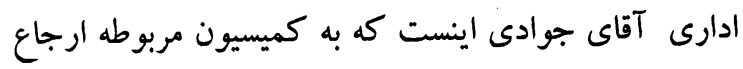
كند ما همين مكتوب وزارت امور هارلمانى را به كميسيون محترم اقتصاد ملى ارجاع كرديم ، درست ؟ ماب (x مداخله

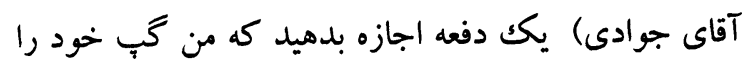

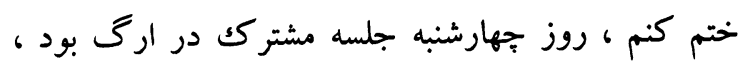

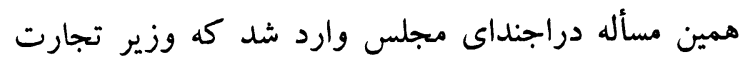

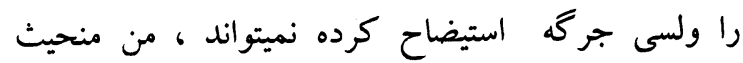
رئيس ولسى جرگه از قانون اساسى دفاع ميكردم يا

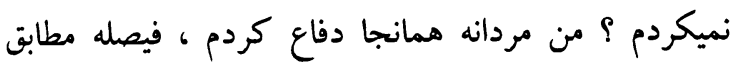

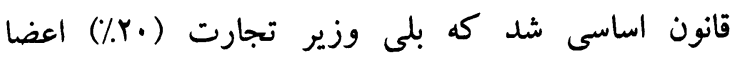

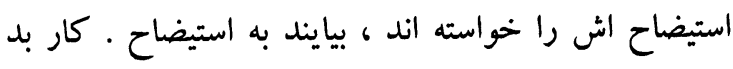

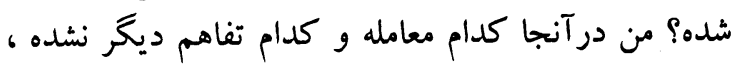
تفاهم به همين شد ، بيش رئيس جمهور سوال خلق ملق شده 
در اينجا در ماده دوم گفته شده كه : حكومت مكلف است گزارش مندرج فقره Y اين ماده را به نخستين اجلاس

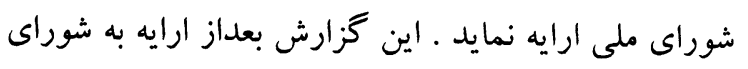

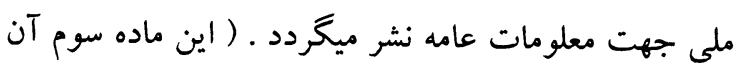
( ملى جت ( ) و همجنان به تعقيب آن نوشته است كه گزارش به شوراى ملى : حكومت ازتصاميمى كه بر مبناى گزارش تفتيش وكنترول

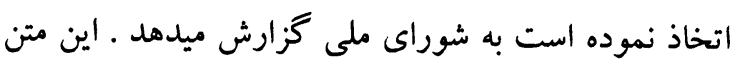
جريده رسمى اينطور نشان ميدهد كه اين حكومت است است أنت

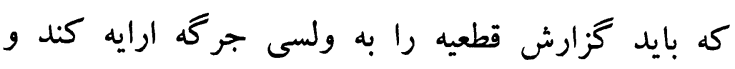

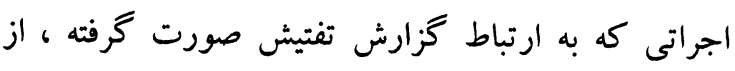
آن اجرات هم ولسى جر گه را باخبر بسازد ـ به اين منظور

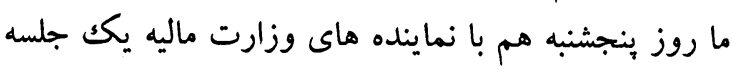

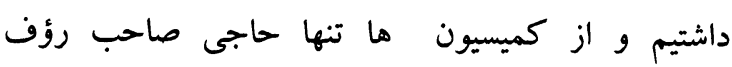

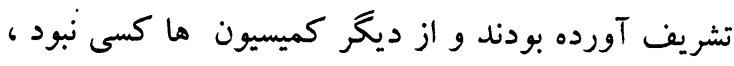
وصحبت ما با آنها طورى ترتيب شد كه ماند حتماً وزير صاحب ماليه گزارش را تهيه و به ولسى جر گكه ارايه كنند . بحثى را كه من امروز ميخواهم كه داشته باشم يكى آن آن همين است كه آيا مجلس يا جناب رئيس صاحب لا لا زم مئم

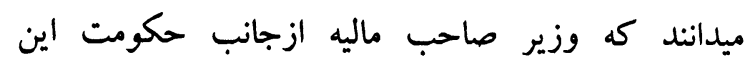

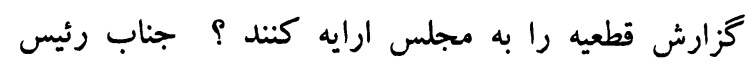
صاحب! رئيس مجلس :

فيضله خود وكيل صاحبان ، لا زم ميدانيد جرا نه ؟

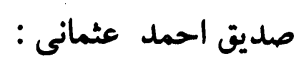
نظر به متن جريده رسمى جانب حكومت كزارش قطعيه را

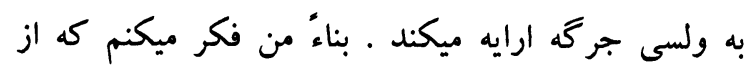

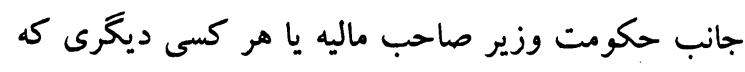

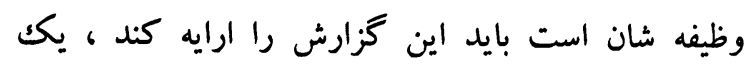
مسأله .

مسأله دوم اينست كه در جلسه آنروز ( روز جهارشنبه )

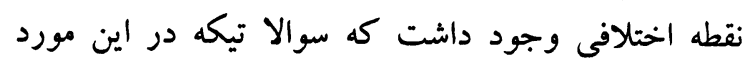

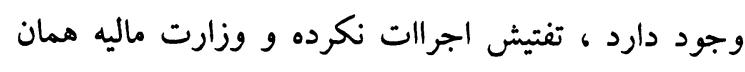
كزارش شان دقيق نيست .
صديق احمد عثمانى :

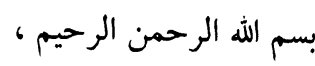

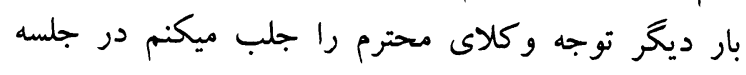

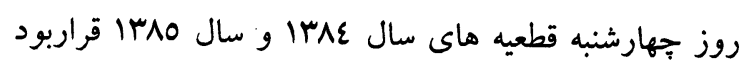

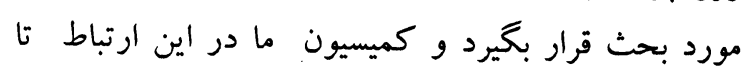

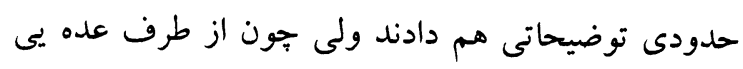

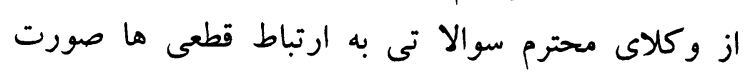

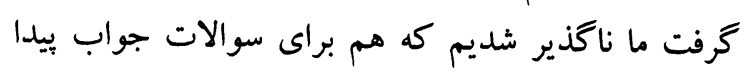

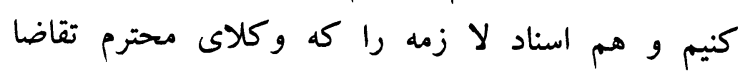

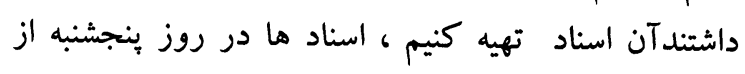

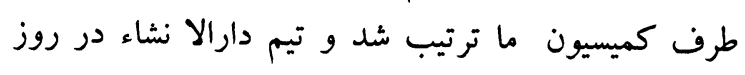

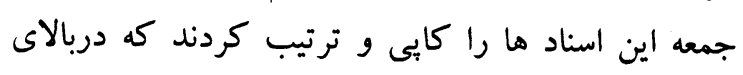

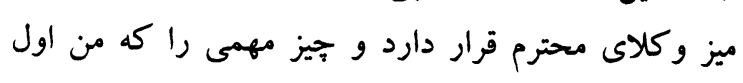

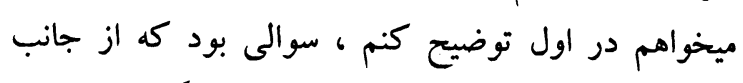

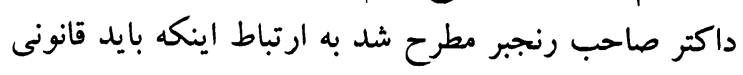

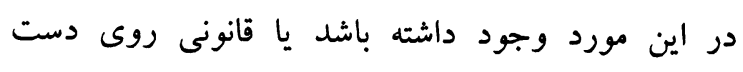

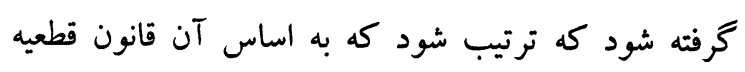

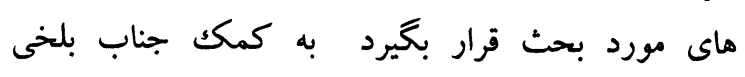

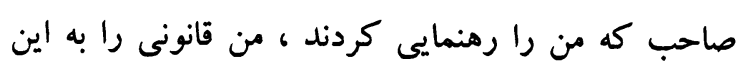

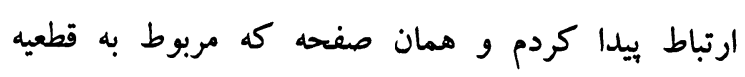

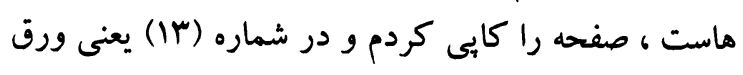

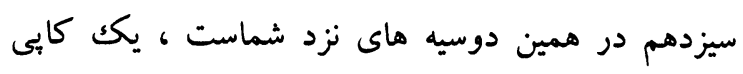

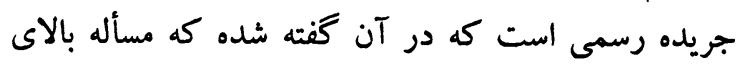

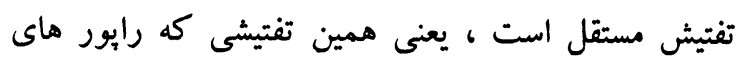

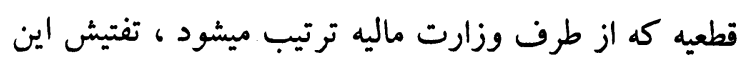

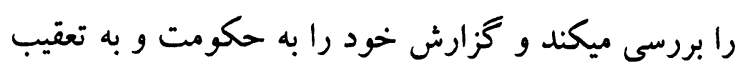

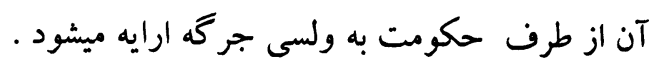

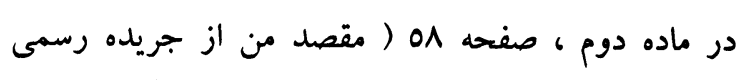

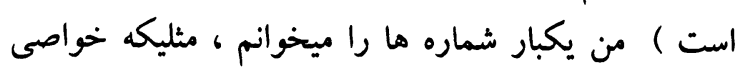

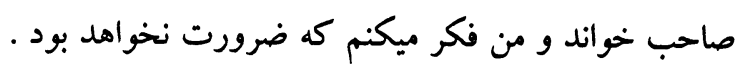

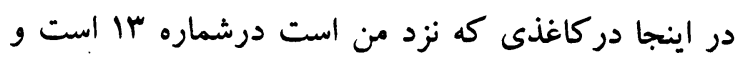

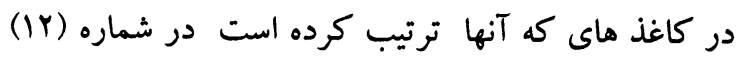
است . متن اصلى جريده رسمى راجع به صلاحيت و مكلفيت اداره كترول و تفتيش : 
بآيد جواب گوى بآشند،اين بيشنهاد من است اكر حالى

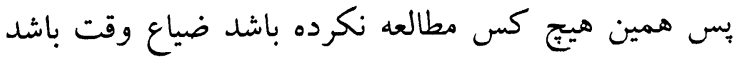

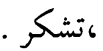

شهلا عطاء :

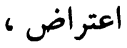

$$
\text { بسم الله الرحمن الرحيم كازئ }
$$

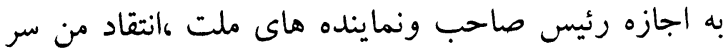

بشر دوست صاحب بود ،به تمامى تلويزون ها انهابيش از

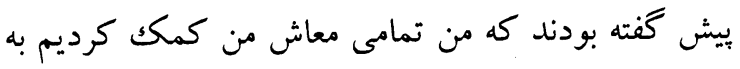

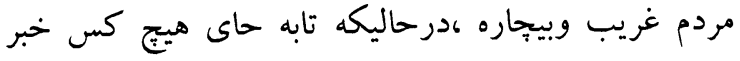
ندارد ،خوب اين فرق نميكند اقاى رئيس انهابه همه معلوم

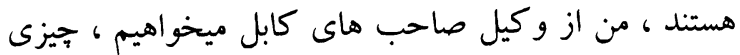

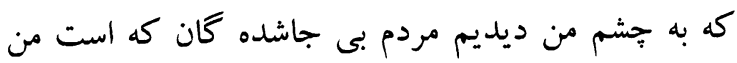

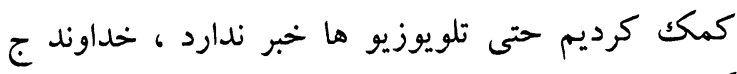

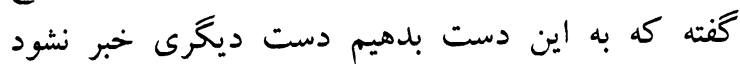

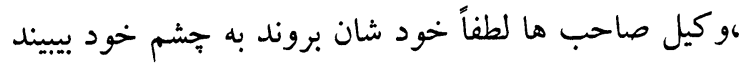

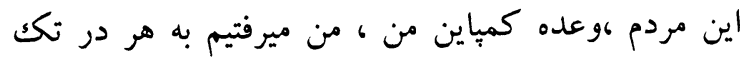

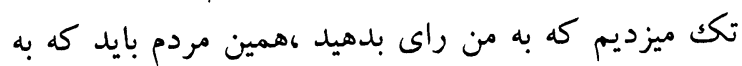

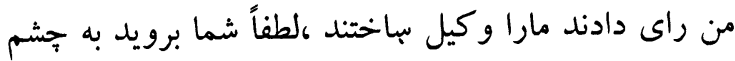

خود بيبينيد روز بعد . رئيس مجلس : تئسين

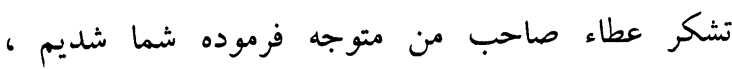

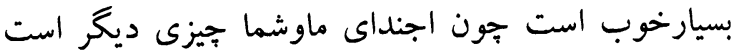

$$
\begin{aligned}
& \text { سر از آن صحبت ميكنيم } \\
& \text { انجنير محمد عاصم : }
\end{aligned}
$$

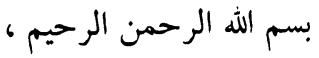

$$
\begin{aligned}
& \text { اعتراض : به }
\end{aligned}
$$

به ارتباط از اينكه وزير صاحب محترم ماليه و اعضاى

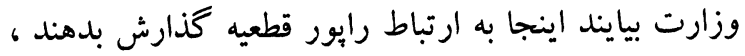

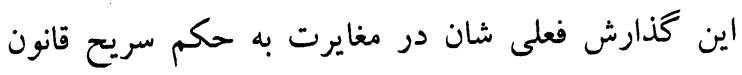
اساسى است ،جون درقانون اساسى ماده مشخص تاريخ كه

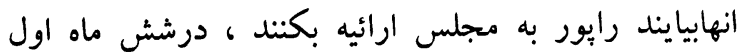

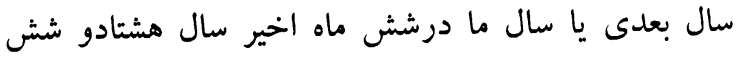

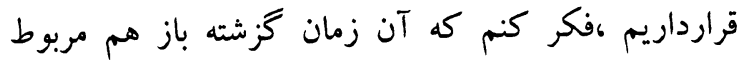
وكيل صاحب ها است اعتراض من همين بود ،يعنى
كيى ديخرى را ما كفتيم در جلسه كه روز جهارشنبه بايد

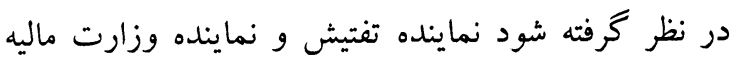

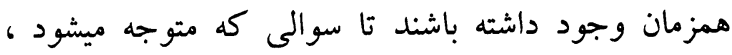

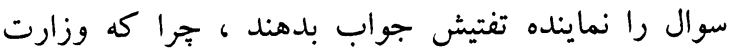

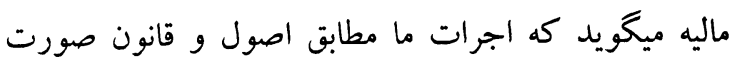

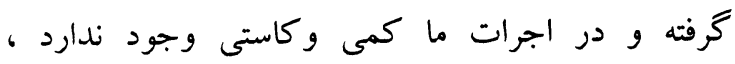

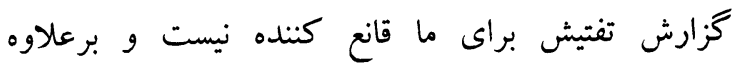

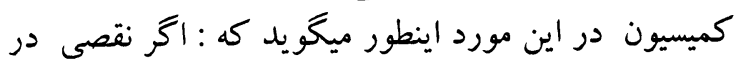

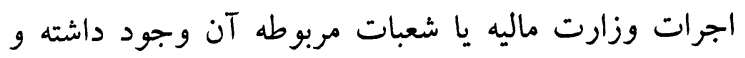

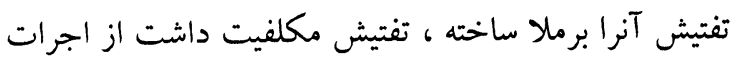

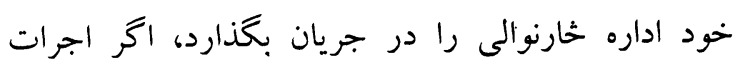

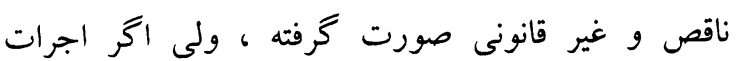

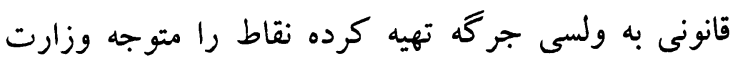

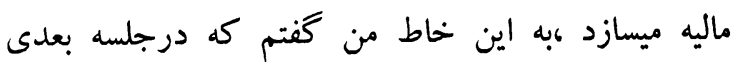

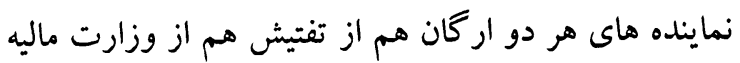

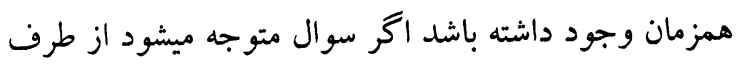

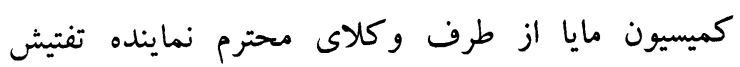

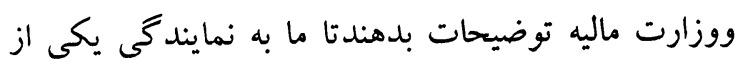

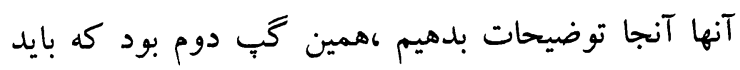

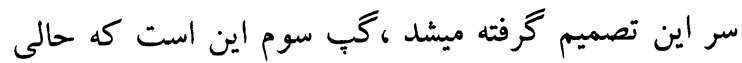

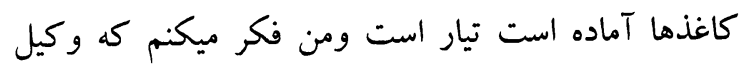

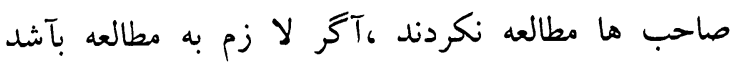

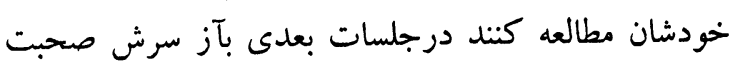

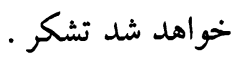

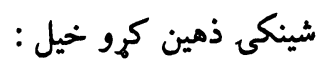

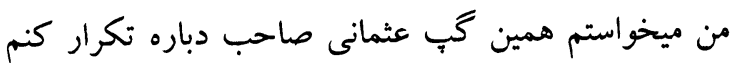

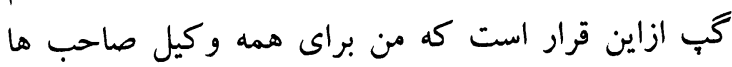

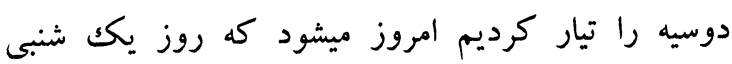

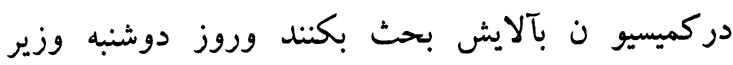

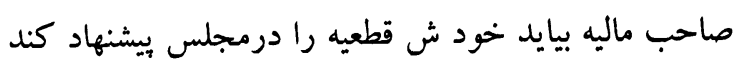
سه شنبه مادر كميسيون يكك اجلاس مشترك ماليه داشته بآشيم

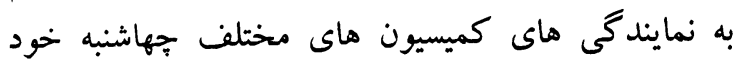

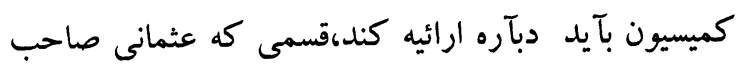

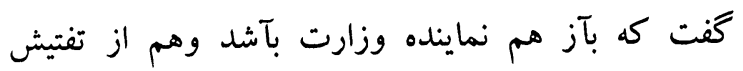
مركزى همان خلا ها ونقص هاى كه باوجود است اينجا 
كنيم وزارت ماليه را بحَّيم كه جدول هاى تان را درست

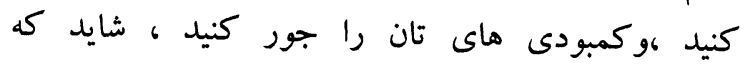
كمبودى هارا وجود داشته باشد ،قابل جور كرديودي هاند نباشد

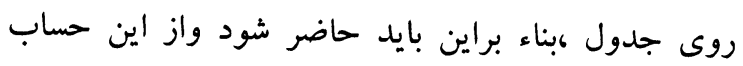

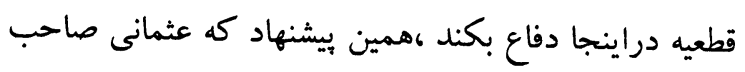

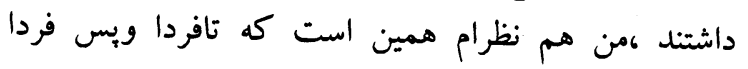
نمايند گان محترم همين دوسيه موجود را مورد مطالعه قرار

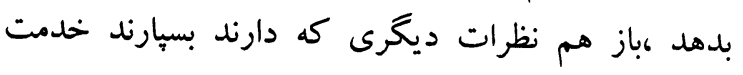

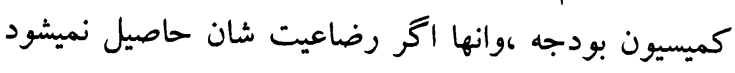

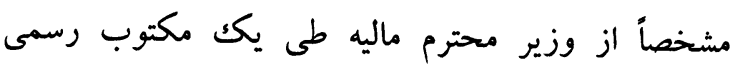
بخواهد كه حساب قطعيه فرستاده شده نميتواندبه تائيد

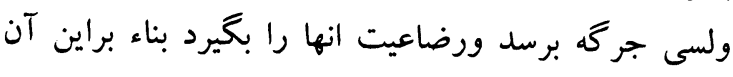

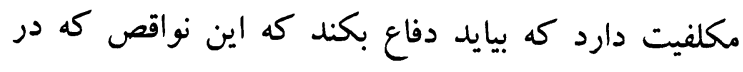

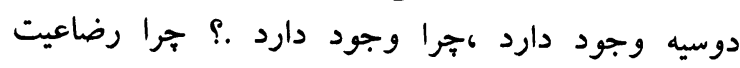

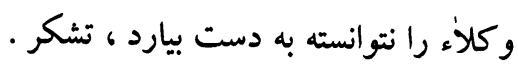

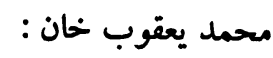

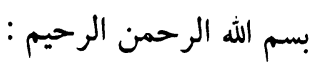

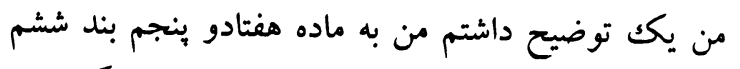

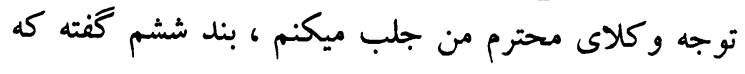

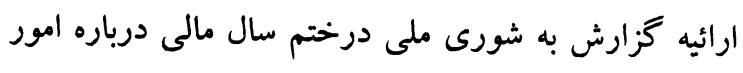

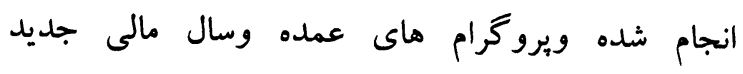
اينجاوضاحت دارد ما ميتوانيم طرح كميسيون مالى وبودجه مائ

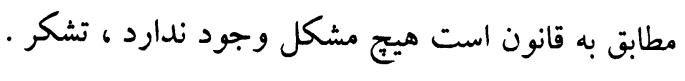

$$
\text { صديق احمد عثمانى : }
$$

جناب رئيس صاحب وو كلاى محترم ، من موافق هستم كه : فئس

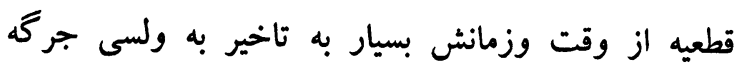

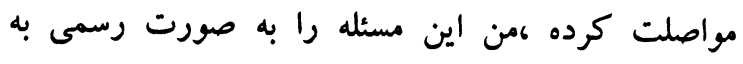

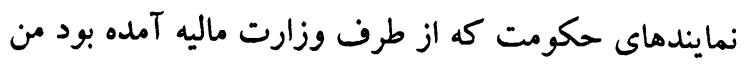
به صراحت كفتيم كه مطابق به قانون درخلال نيمه اول ولئ

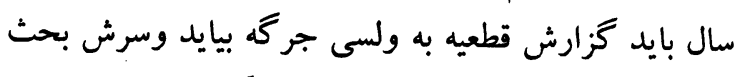

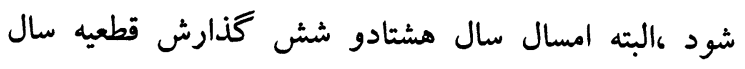

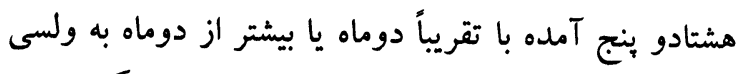

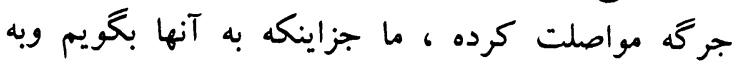
مطبوعات بيان كنيم كه قطعيه دوماه يا دونيم ماده بعد تر بر برد رسيده من فكر ميكنم كه ازاين بآلا تر ما نميدانم جه ديه دونه
وزيرصاحب ماليه بايد مى آمدند درميزان سيزده هشتادو

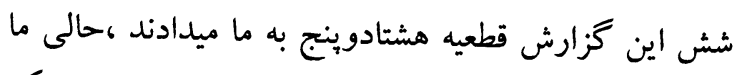

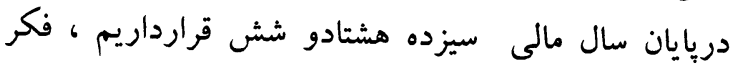

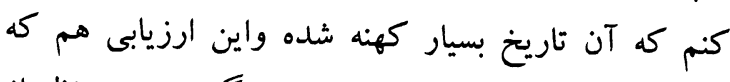

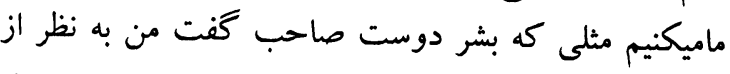

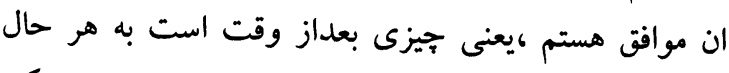

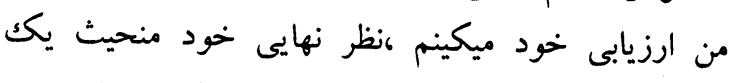

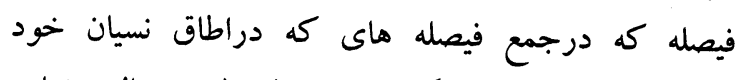

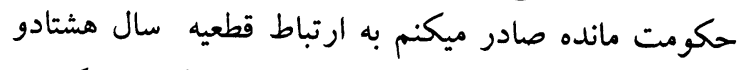

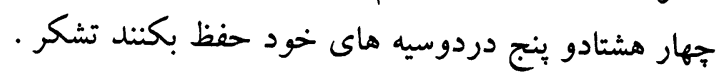
عبدالقيوم سجادى :

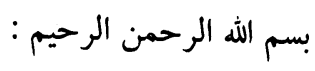

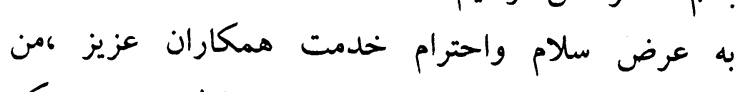
درارتباط به همين بحث بررسى حساب قطعيه دويت يك ونك

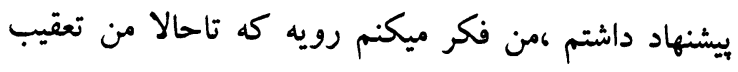

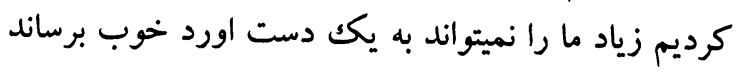

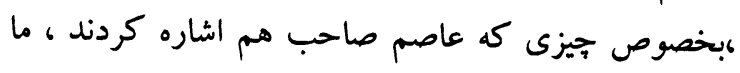

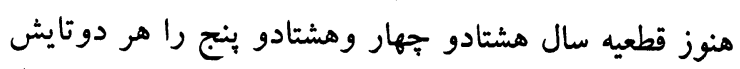
يعنى ارائيه نشده و نظر مثبت وكلاء يا تائيدى و كلاء

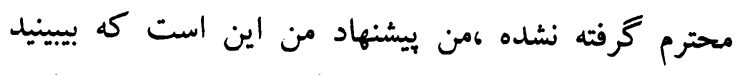

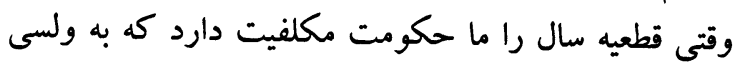
جر گه بيشنهاد بدهد لازم نيس كه وله مال ما بيايم اينجا آنرا بحث

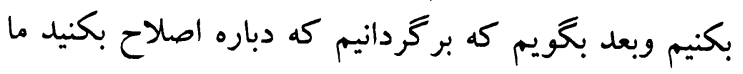

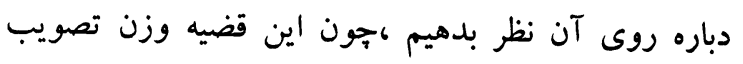

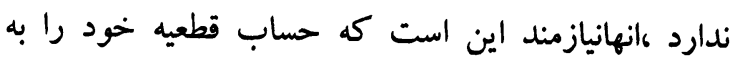
گونه مرتب بسازد كه مورد تائيد نمايندگان ملت قراريخيرد إنهاب ،كه هيجگگ مملكت به وجود نبيايد ،ييشنهاد من است كه كمئه كميسيون محترم بودجه كه تاحالا هم زحمت كشيدند اكر از حساب ائه

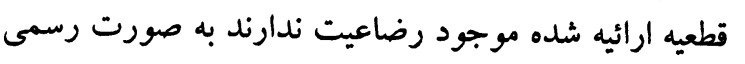

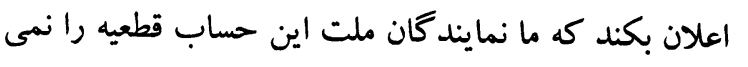
يذيريم ،آن زمان وزير محترم ماليه مكلف است كان كه بيايد

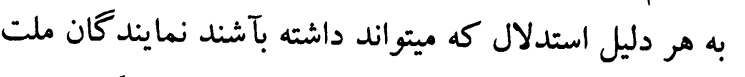

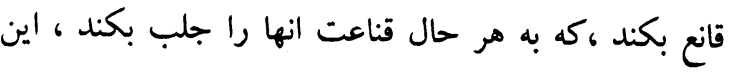

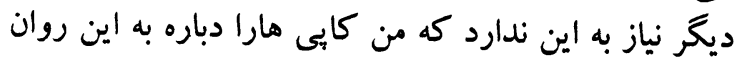


كرده بودند ، آنرا هر كس ممكن است درخانه هاى خود

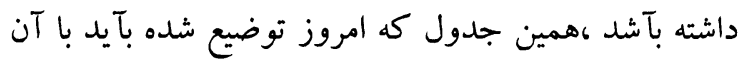

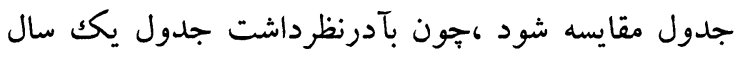

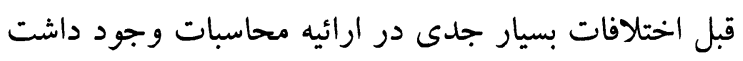

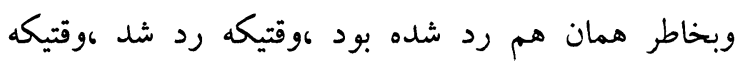

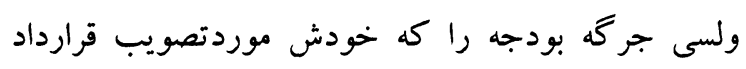

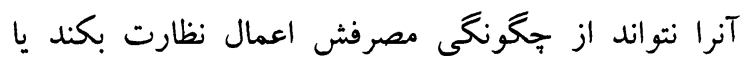

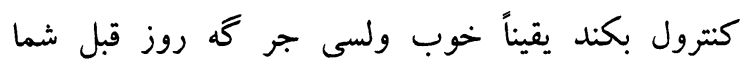
تشريف نداشتيد به مرجع ميماند كه جز از دعاى خين ونير

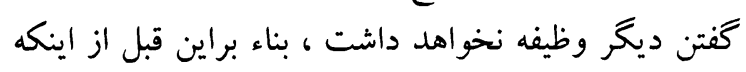
قطعيه سال سيزده هشتادو جهار نهايى شود آمدن قطعيه

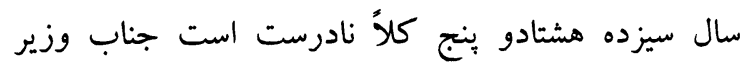

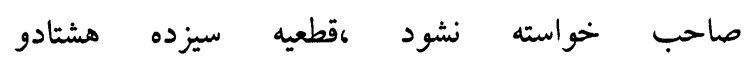
جهاراكربادرنظرداشت مناسبتات كه ممكن است غلته

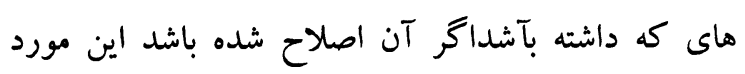
تائيد قرار بخيرد باز درآن صورت ميتوند كه قطعيه سال

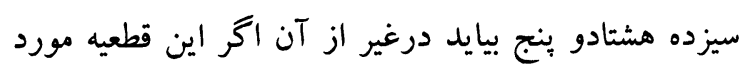

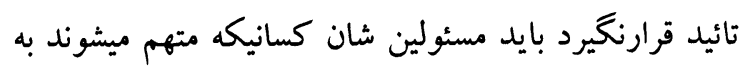

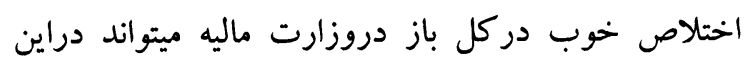

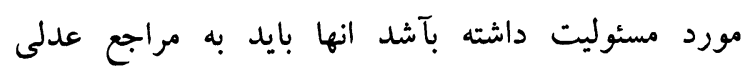

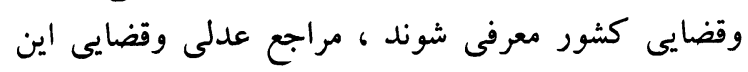

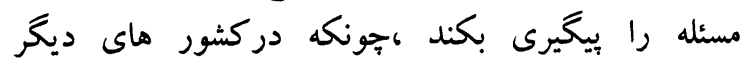

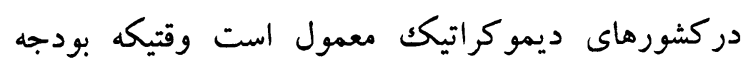
درصورتيكه درست مصرف نشود ، وحساب قطعيه شان

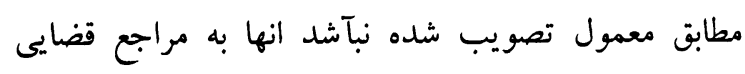

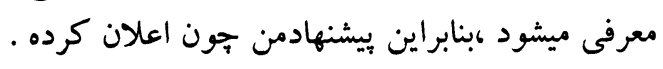

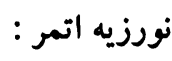

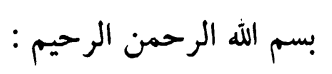
رئيس صاحب او محترموو كيل صاحبانو يه اجازه ، رئيس لهن صاحب كوم مشكل جي يه مجموع كي ددولت سره يعني مارئي

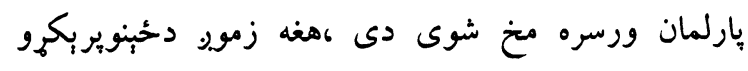

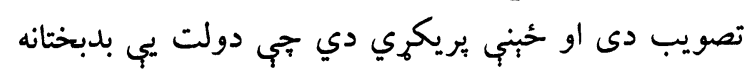
جب يه راس كي يب ولسمشر هم دى نه يبي منب زما سوال

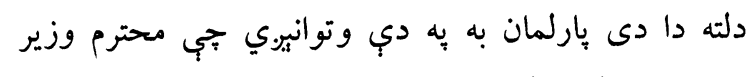

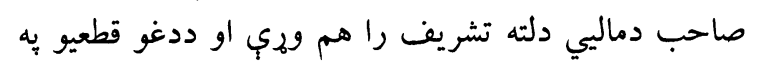

كارخواهد توانستيم ؟ اين يكك مسئله موضوع دوم اين

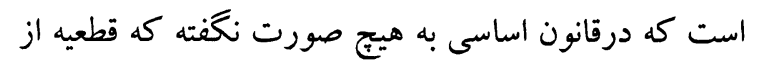
طرف ولسى جر گه رد ميشود يا تائيد ميشود ،درقانون

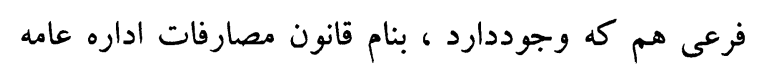

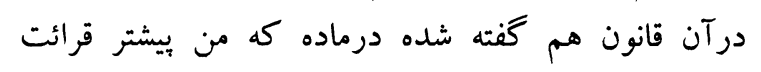

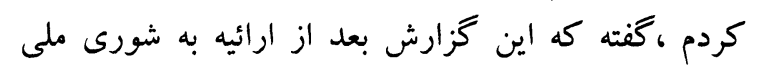

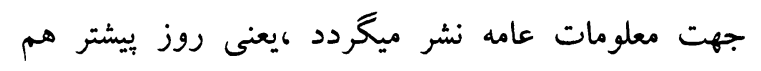

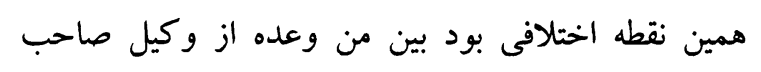

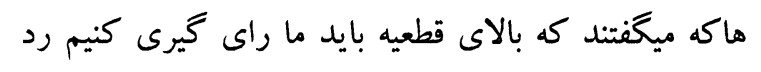
يا تائيد كنيم ،ولى من باورم اين است كه جز اينكه و كلاء

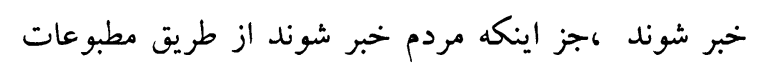

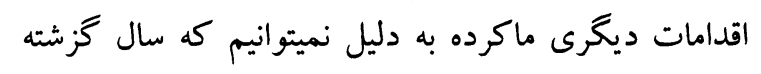

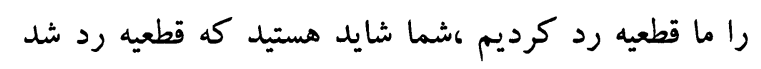
كدباره به وزارت ماليه رفت ووزرات ماته ماليه يك سك سلسله

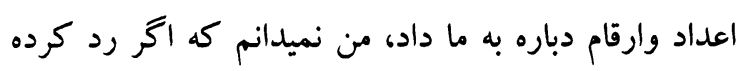

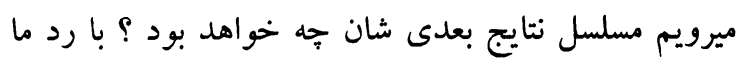

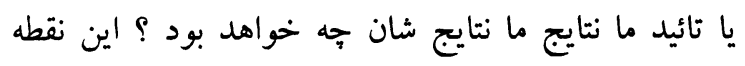
قابل بحث است .

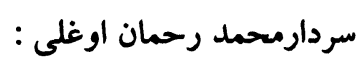

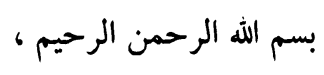

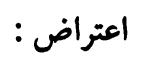
به اجازه جناب رئيس ومحترم هيئت ادارى ، جناب رئيس صاحب آن گونه كه دوست ها كفتند اقاى عثمانى سال

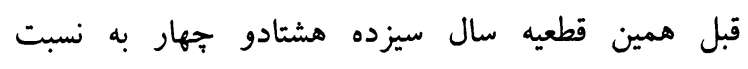

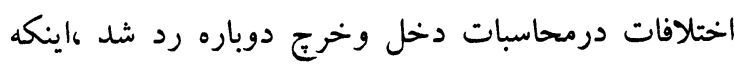
بعضى از دوست ها بخصوص جناب اقاى عثمانى استدلال

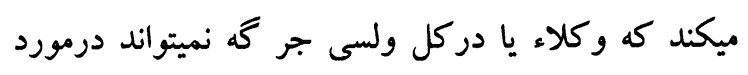

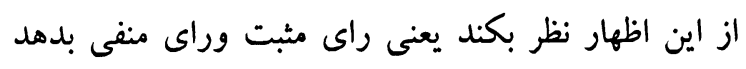

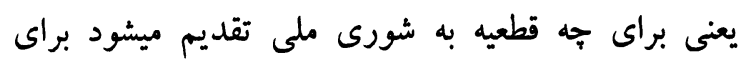

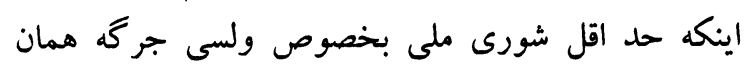

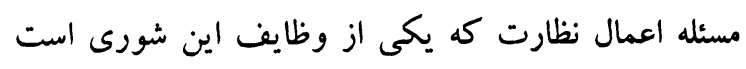

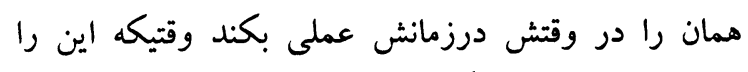

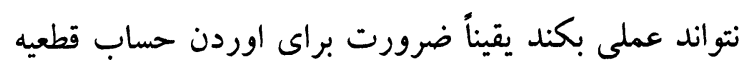

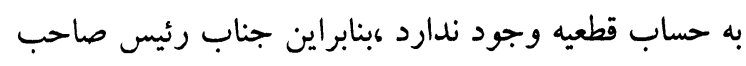
ما يارسال يكك جدول كه كميسيون محترم بودجه توضيح 


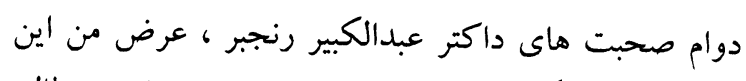

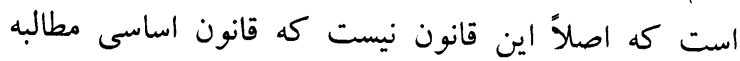

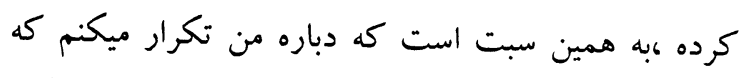

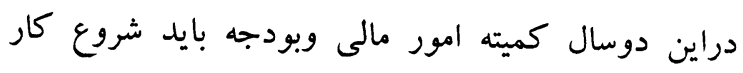

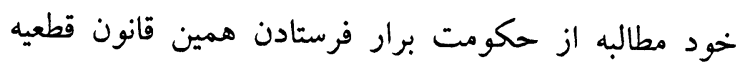

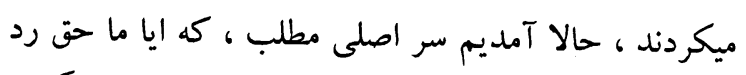

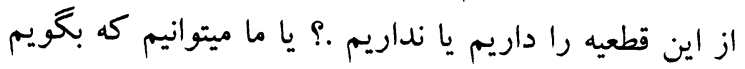

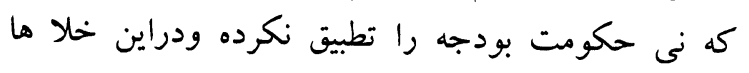

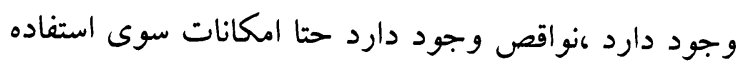

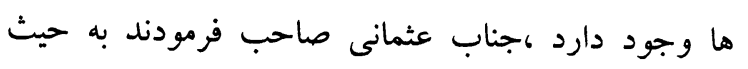

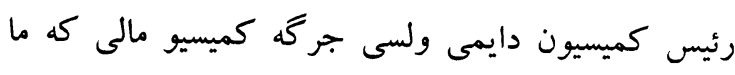

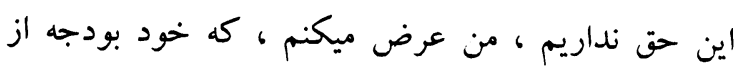

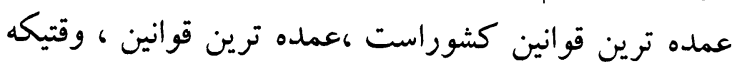

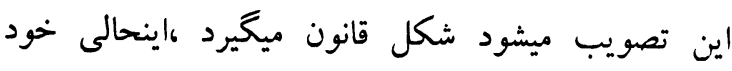

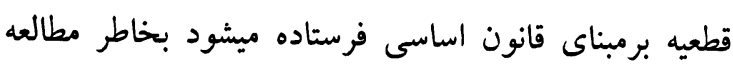

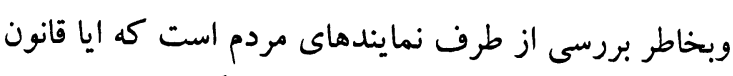

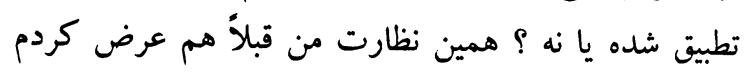

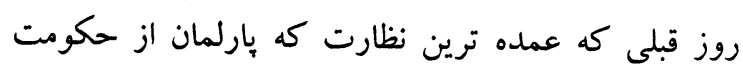

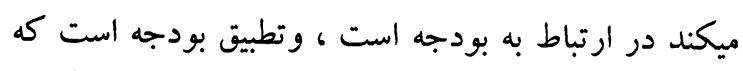

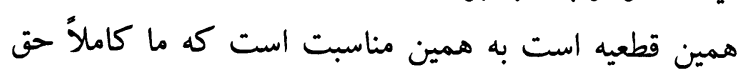

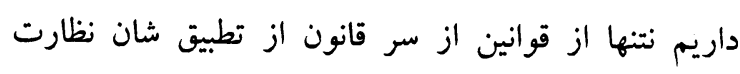

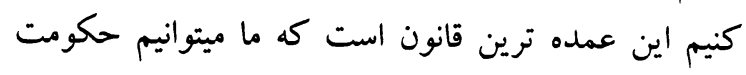

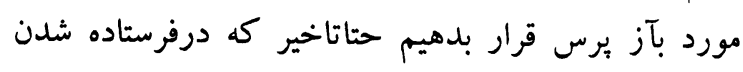

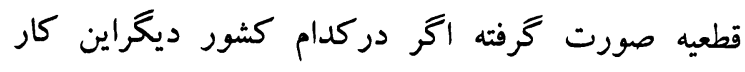

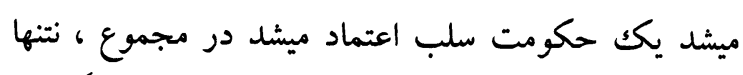
وزير ماليه شان يا اولياى امور براى از ازئنس اينكه اصلاً انهايا

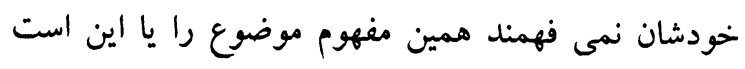

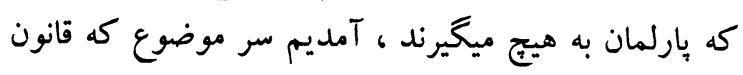

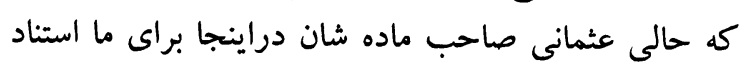

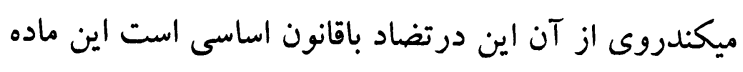

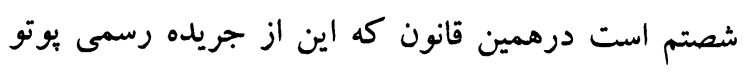

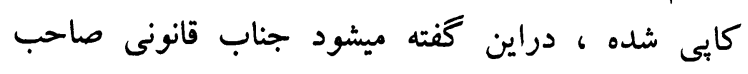

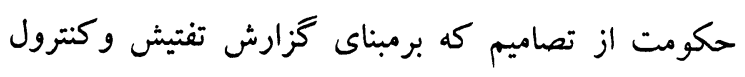

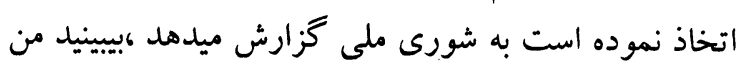
توجه همه و كلاء رابه اين جلب ميكنم ،دراين ماده شصتم مئم
هكله جي بارلمان كوم مشكلات لري او كومبي نيوكي

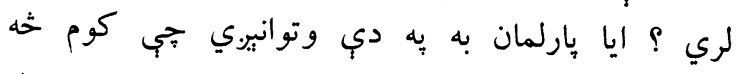

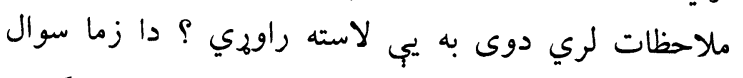

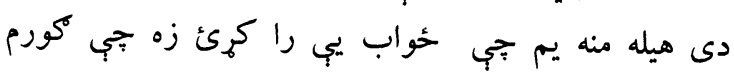

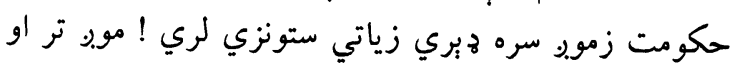

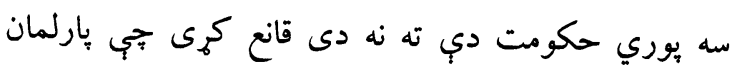

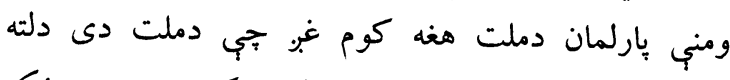

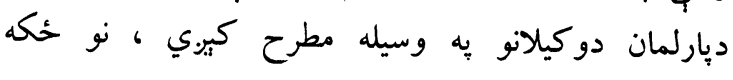

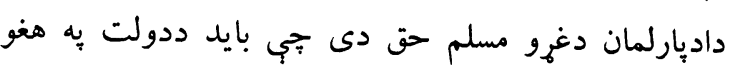

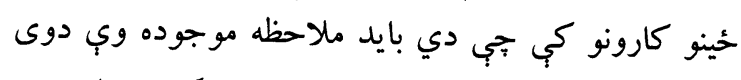

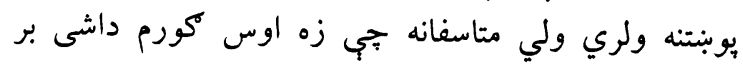

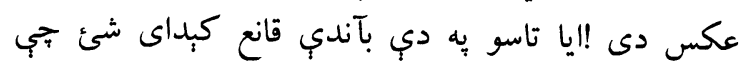

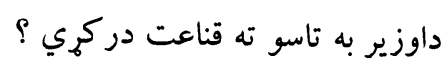
رئيس مجلس : هو ولي نه اتمر صاحب داستاسو صلاحيت دى ، كله هجي

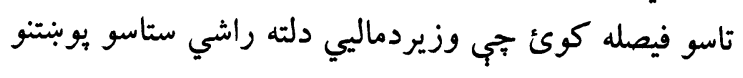

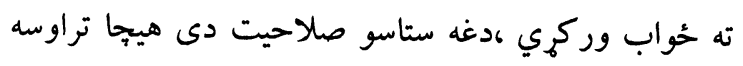

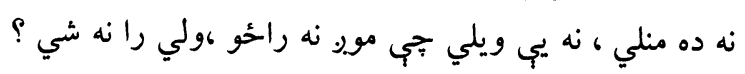

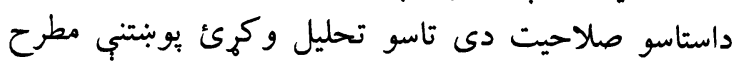

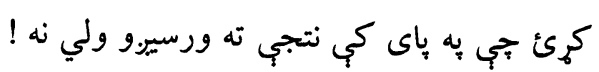

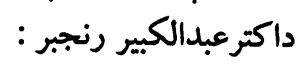

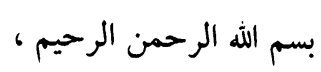
جناب رئيس نمايندهاى محترم مردم ،همين الرحين يكك سوال قبل

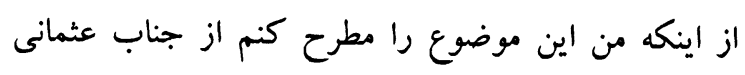

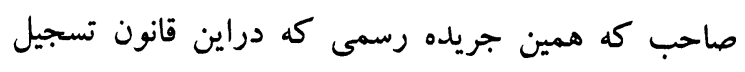

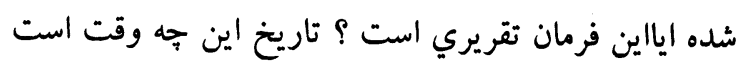

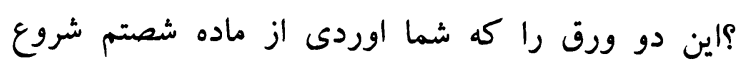

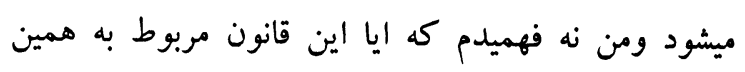

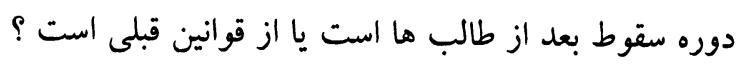

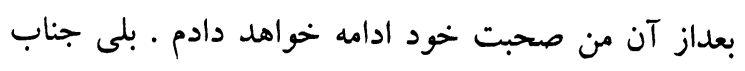

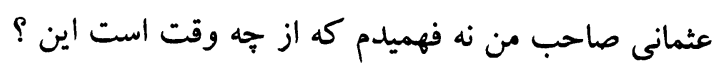

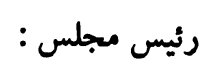

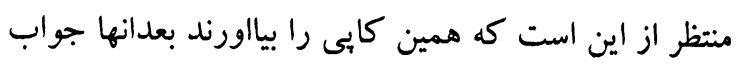
ميكويندشما صحبت تان دوام بدهيد. 
درنو فصل وشصت ينج ماده ترتيب شده وتوسط رئيس

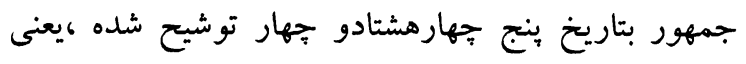

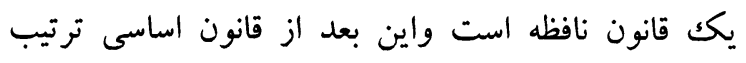

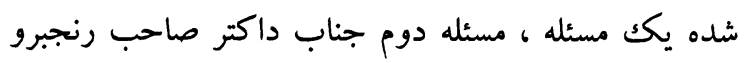

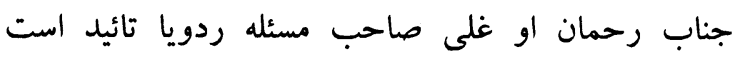

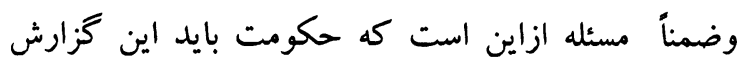
بدهد ،حكومت اين گزارش خود ترتبب كرده ، وزئل وزارت

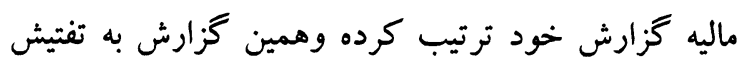

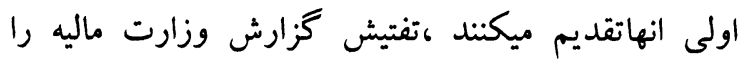
مورد بررسى قرار ميدهد درظرف دو الى سه ماه كه دهن دراين

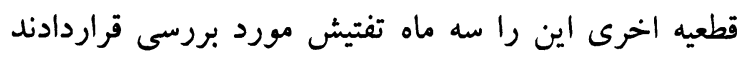

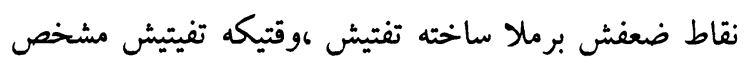

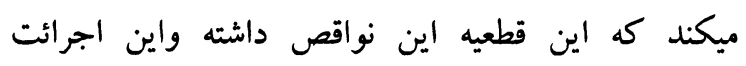
غيرقانونى صورت كرفته آن مكلفت تفتيش است فئ كه درهمان وقت وزمانش همان اجرائت قانونى خود انجام

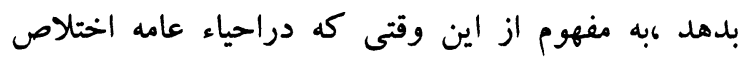
ميشود يا سوى استفاده از بودجه دولت ميشود تفتيش

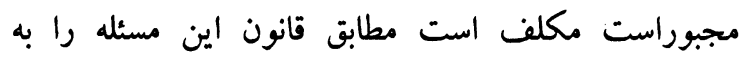
خارنوالى گزارش بدهد ، ما ما نماينده تفتيش به همين دليل

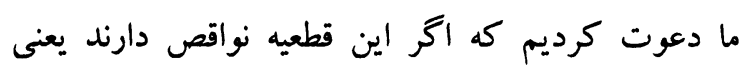

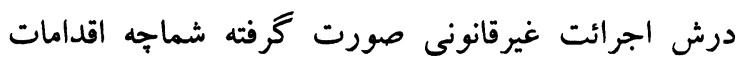

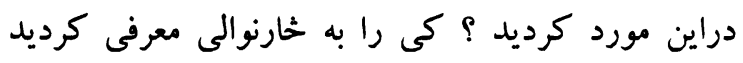
؟كدام مرجع بايد اين كاربكند واگر اجرائت درست وردي

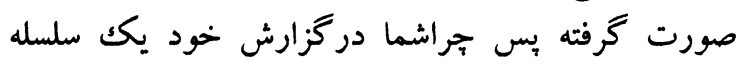
نواقص انعكاس داديد ؟ بايد قبول ميكرديد تائيد ميكرديد

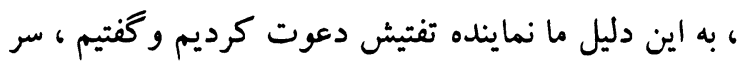

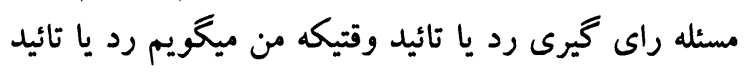

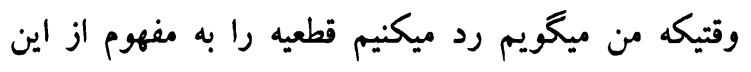

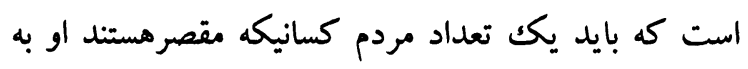
خارنوالى معرفى شوند كاين كار است كه حكومت اين كار بكند اين مكلفيت كميسيون مالى وبودجه دراين مورئ مورد نيست ،به اين دليل من تاكيد من اين كه ، ومطلب ديخ دمئرى كه جناب رحمان اوغلى صاحب كفت كه ما اظهار نظر

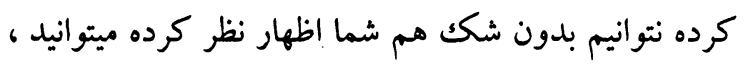

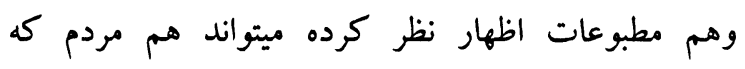

يخانه ماده است كه دراين قانون كه درارتباط به همين

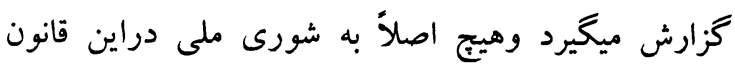

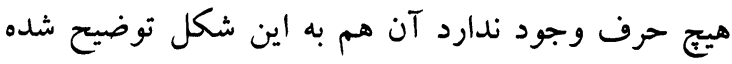
كه گزارش تفتيش وكنترول آنراتصميم كه اتخاذ كرده

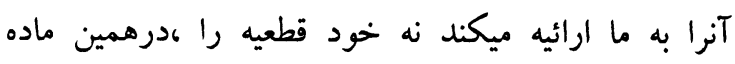
شعتم همين رقم يكك موضوع مطرح شده ،درحاليكه

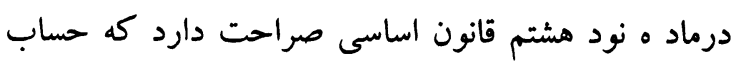

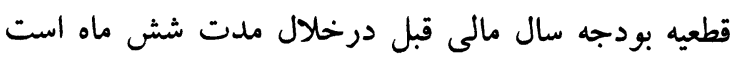

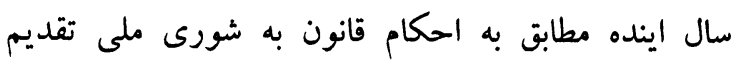

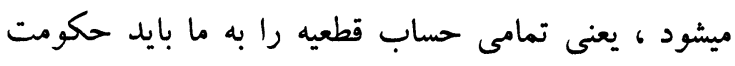

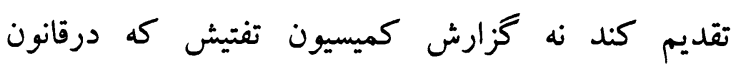
انهاتسجيل كردند ،به اين مناسبت است كه اين قانون باطل

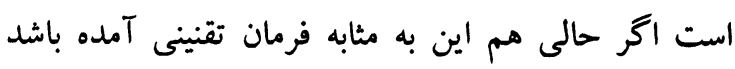

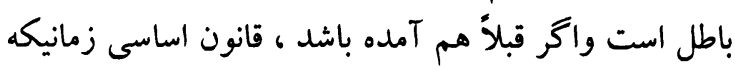

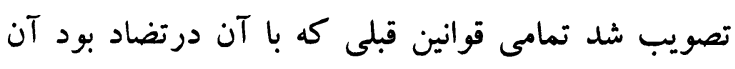

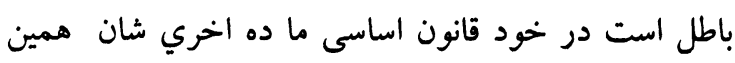

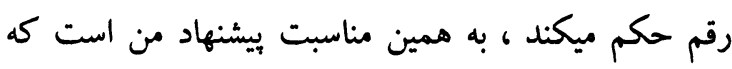

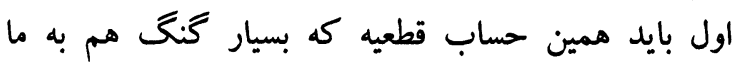

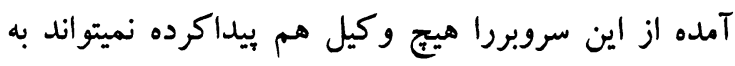

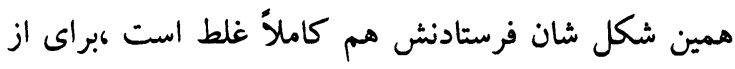

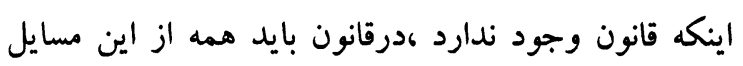
توضيح شود الارغم از اين هم بايد اين در كميسيون مورد ائرد

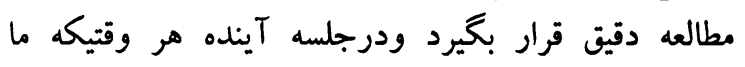

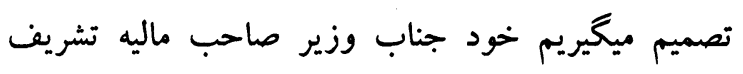
بيااورد وهمين حساب تطبيق بودجه را كه تطبيق قانون است دباره من عرض ميكنم حساب از اين را به و كلاء

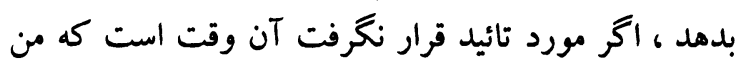
فكر ميكنم كه يك نقيصه بسيار بزرخ است دركار كاروزارت

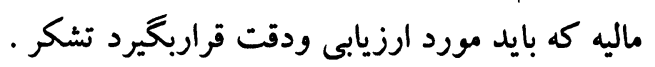

$$
\begin{aligned}
& \text { صديق احمد عثمانى : } \\
& \text { بسم الله الرحمن الرحيم : بمد عماني : }
\end{aligned}
$$

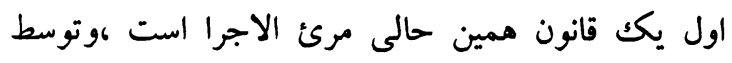

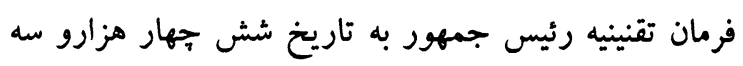

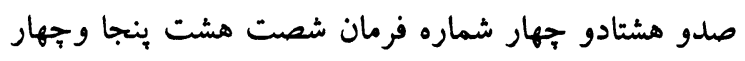
اين به داخل شصت وينج ماده از طرف مجلس هُون هالى وزراء 
كه گزارش نهايى بودجه است وآن حدود دوصفحه است

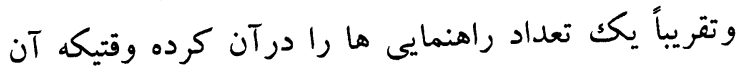

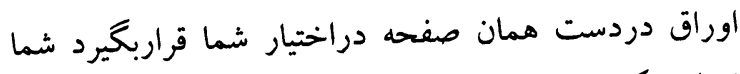
قبول ميكنيد كه همين قانون به اساس قطعيه به اساس همين دمان دران

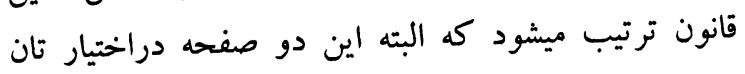

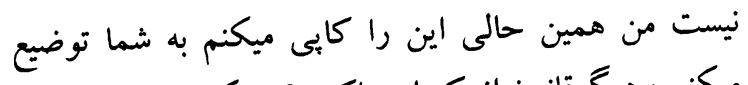

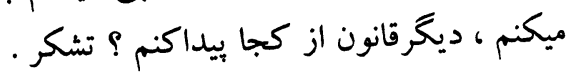

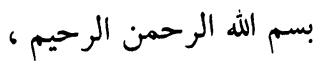

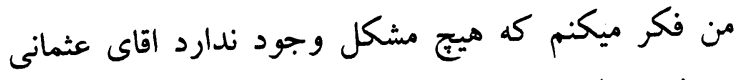

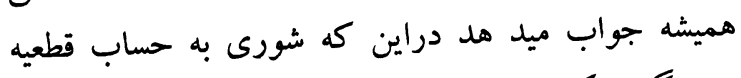

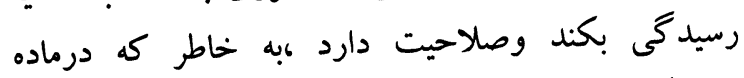

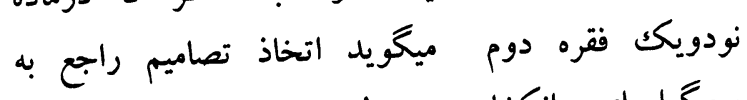

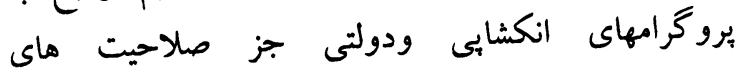
اختصاصى ولسى جر گه است واين را همه ودولى كسانيكه درقسمت بودجه واقتصاد كار ميكند ميفهمند كه كه هيج بودجه بدون حساب قطعيه ساخته نميشود ،وقتيكه تصميم

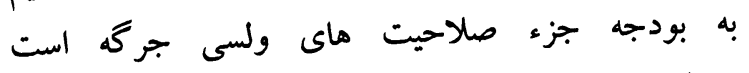
وصلاحيت هاى اختصاصى طبعاً تصميم براى رسيدگى بهى به وله

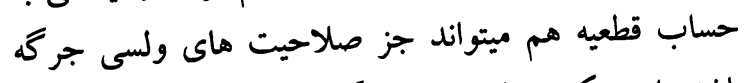

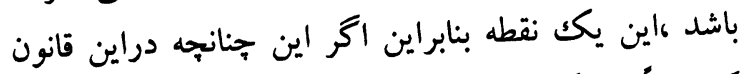

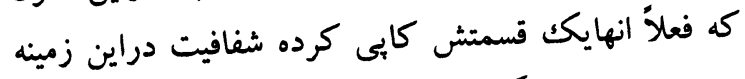
وجود ندارد به گفته اقاى رنجبر ،قانون ميتواند خلاف فاف قانون اساسى باشد وجون فرمان تقنينى يا قابل تعديل ومن

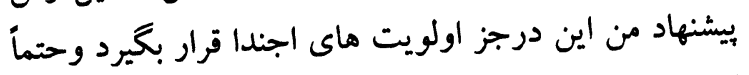

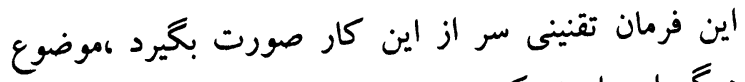

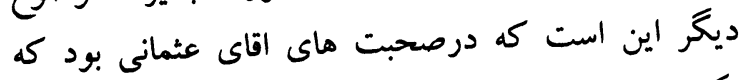
يكك تفاوت وجود دارد بين ديدگاه وزارت ماليه وديدگثاه

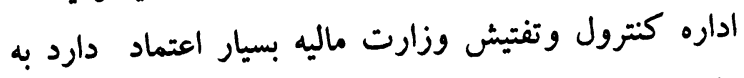

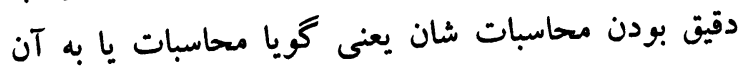
تصاديق اداره كنترول وتفتيش را قبول ندارد درحاليكه

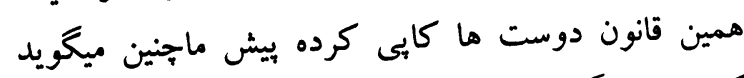

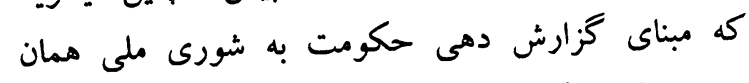

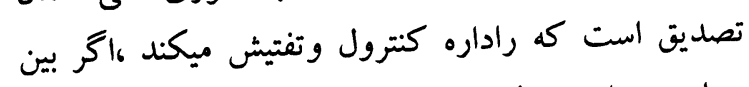

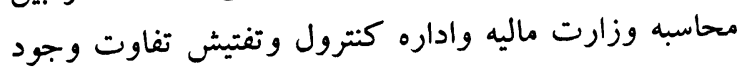

دربيرون است اين گب ميشنود ان وقت اظهار نظر دارد

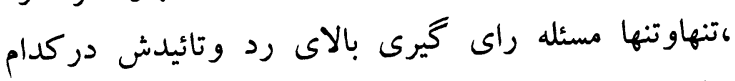

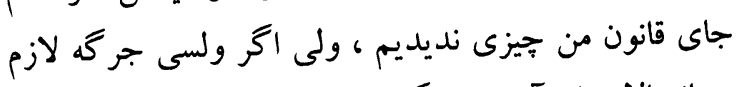

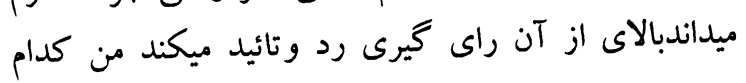

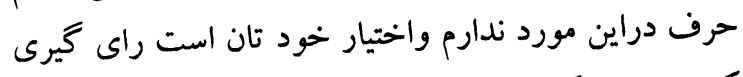

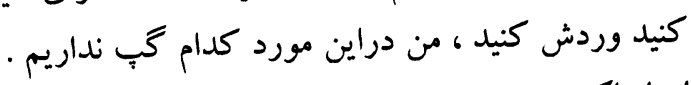
استاد اكبرى : أنيل وردث :

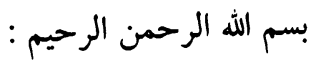

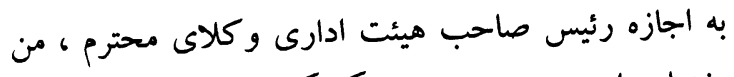

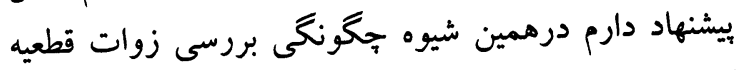

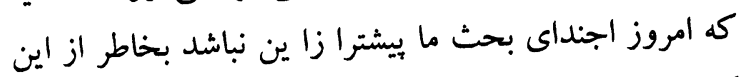

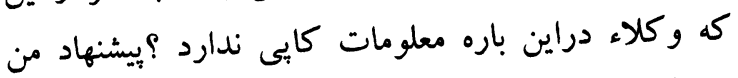

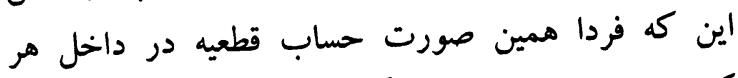

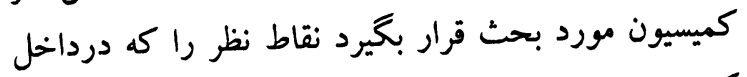
كميسيون اغضاى كميسيون دارد برجسته ميسازد ، نماينده

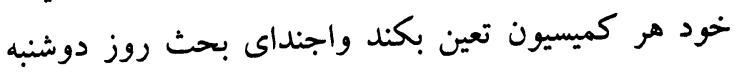

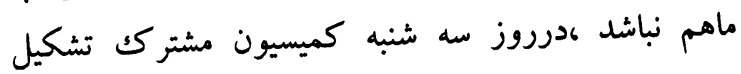

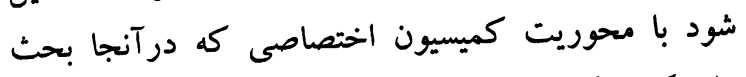

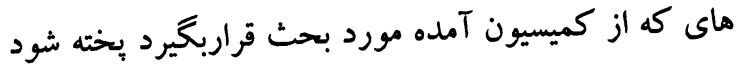
اجنداى روز جهارشنبه جلسه عمومى بررسى از همين باشد بهد

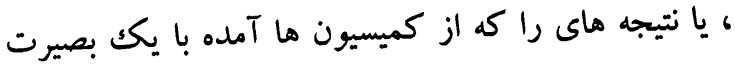

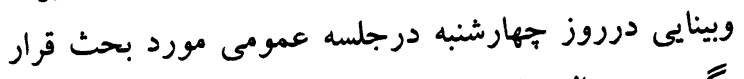

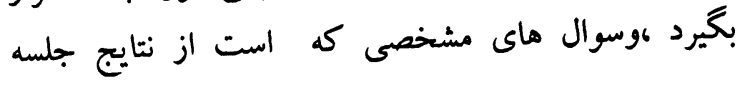

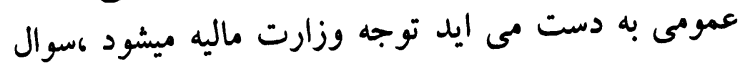

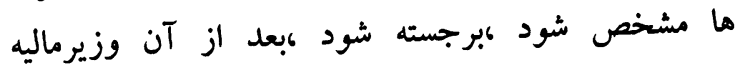

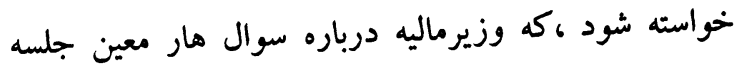

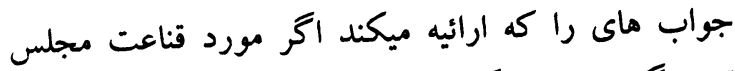

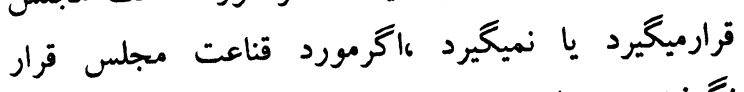

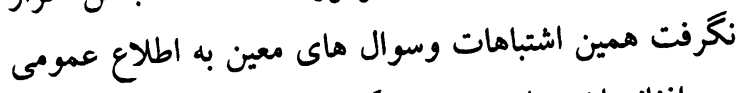

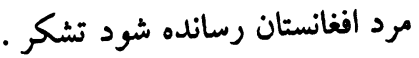
تاج محمد مجاهد :

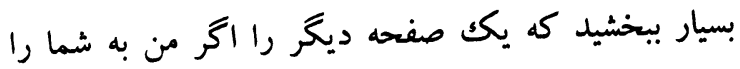

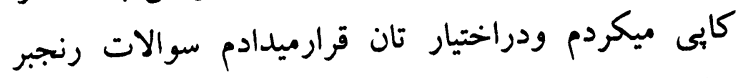

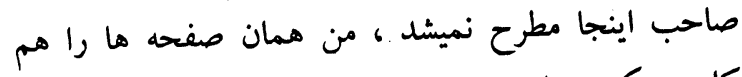

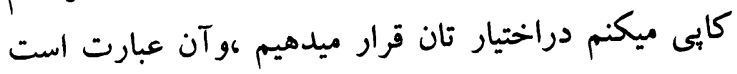




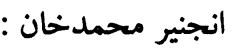

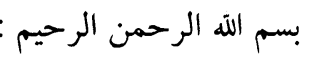

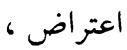

داسي يو نرم ساده غوندي اعتر اض خو به هيئت اداري وو

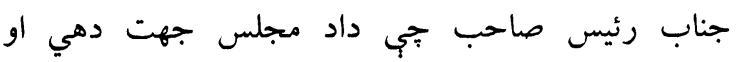

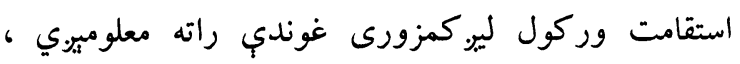

خو كت بيا هم بل تر اوسه بوري معلومه نه ده جبي شورى بايد دقطعيي

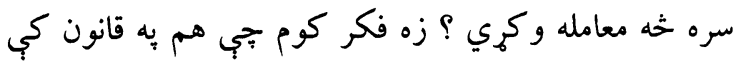

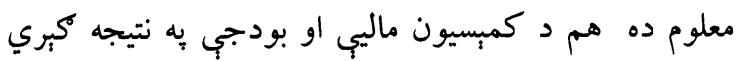

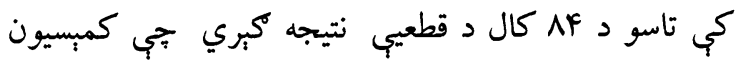

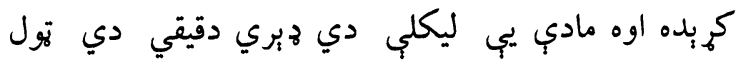

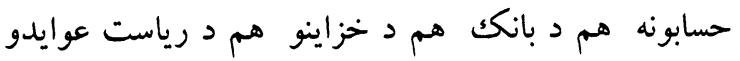

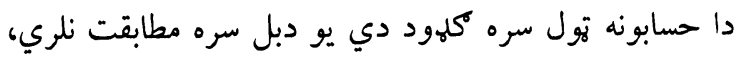

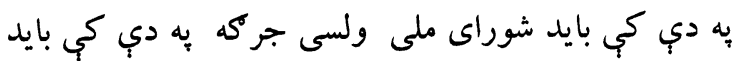

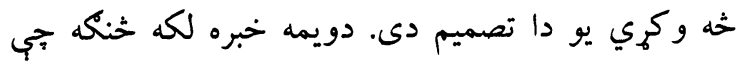
جوادي صاحب او اكبرى صاحب وويل زه زه فكر كوم مونبر

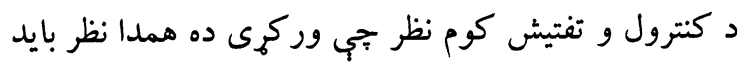

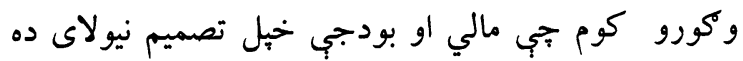

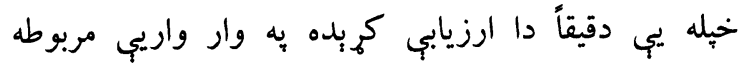

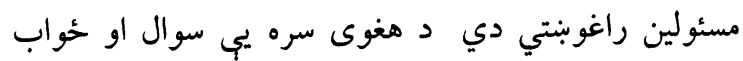

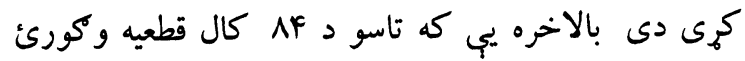

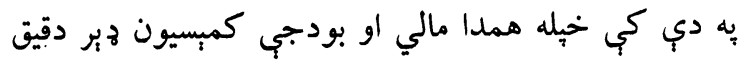
خيل اوه ماده يبي نقاط يبي ليكلي دي. كبدى شي يه يه ديهي

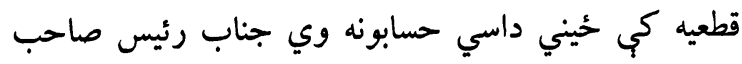

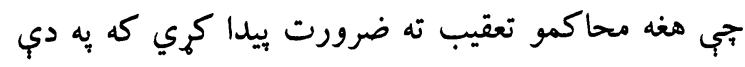

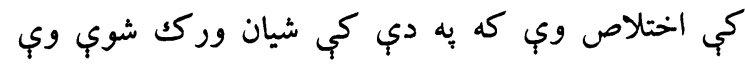
زه فكر كوم بجي مالي او بودجبي كمبسيون خيل نهي تصميم

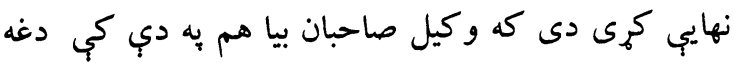

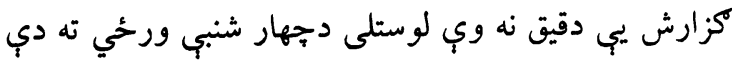

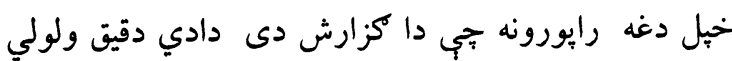

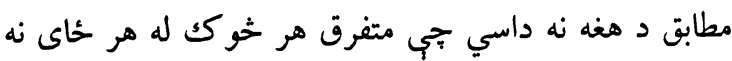

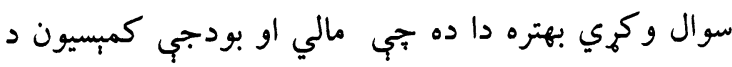

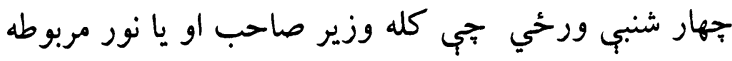
اركانونه دلته را غوإي يوري وري بايد د تفتيش مركزي مسئولين
دارد دراينجا وزارت ماليه دربرابر حكومت ودربرابر شورى

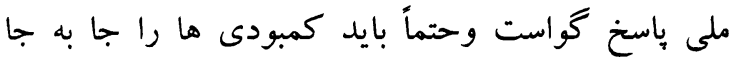

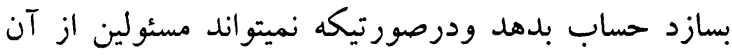

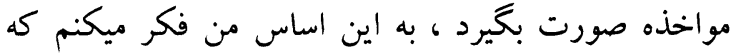
اخر يكك سنجش دقيق ويكك حاسبه دقيق اين را كميسيون

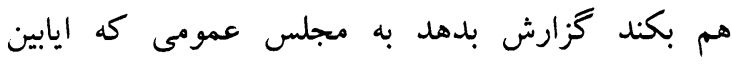
تصديق را كه اداره كنترول دارد از اسناد تصديق كرده بده بهده

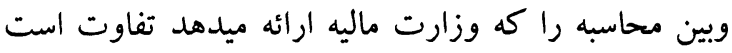

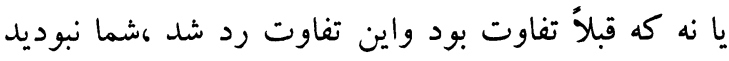
اقاى عثمانى من عرض من اين بود كه ماده نودويكك فقره

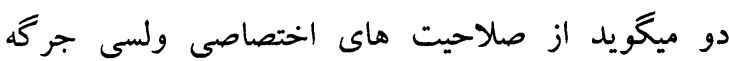

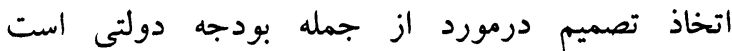

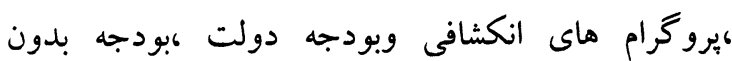

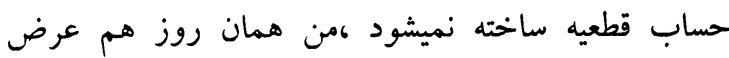

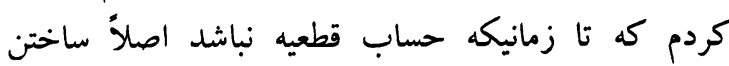
بودجه معنا ندارد همين كه درهمين سال گز شته مال بودجه زمانه را رد ميكرديم بس تصويب ميكرديم درحقيقت دقيق نبود

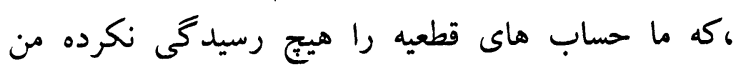

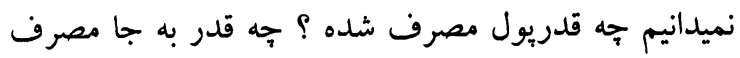
شده جه قدر كسرى داريم جه قدر اضافى داريم ،بدون از اين بودجه سال بعد تصويب ميكنيم ،وقتيكه تصميم درمورد بودجه صلاحيت ما است ،تصميم درمورد حساب

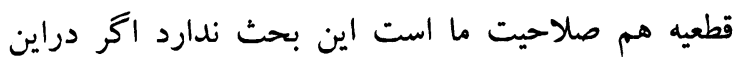

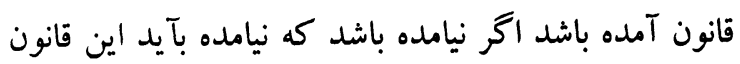

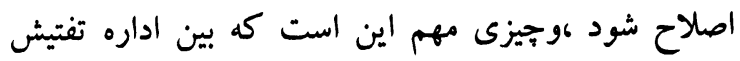
وبين وزارت ماليه آنجه كه مبنا قرار ميخيرد واصل همبن همان تصميم وتصديق اداره كنترول وتفتيش مطابق همين قانون

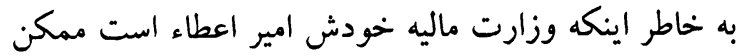

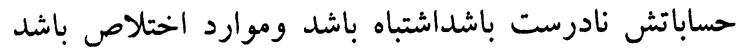

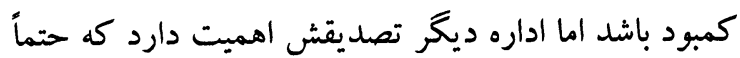
بين اين دو بايد مقايسه صورت بحيرد ومقايسه هم بآيد علمى بآشد بخصوص كميسيون سر اين كار بكند وعلاون ولاوه

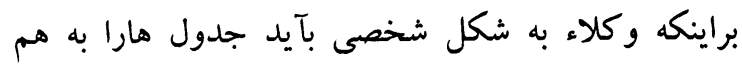

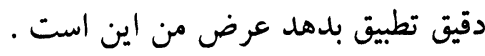


نميدهند آنها و ما دو باره ميفرستيم ميگويم برادر اين را

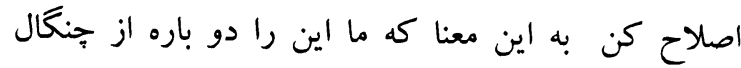

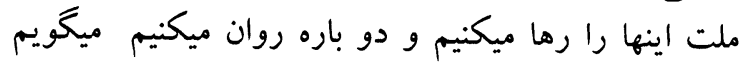
برو حساب هاى خود را درست كن كه همه جيز درست برابر بيايد اين يكك موضوع است. موضوع دوم جناب رئيس من فقط براى جهار بنج دقيقه اين را مطالعه كردم

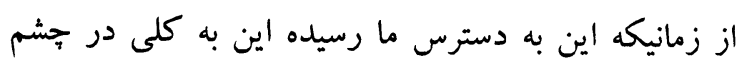

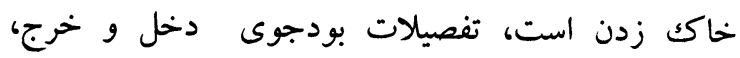

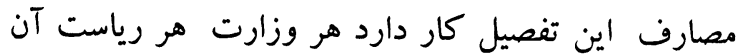
بودجه عادى، بودجه انكشافى تفاصيل اين با تمام معنا بايد

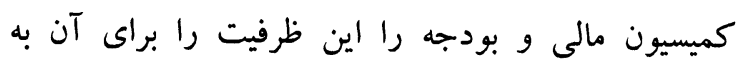
وجود بيآوريم كه محاسبين بسيار درست همراى اينها وجود داشته باشند كه تمام تفصيل بيايد اعضاى كميسيون

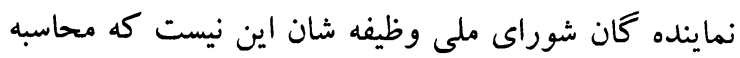

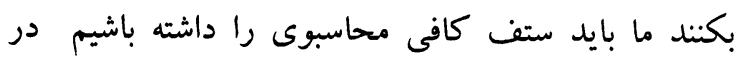

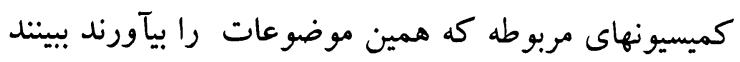

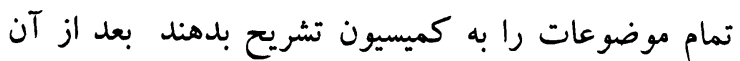

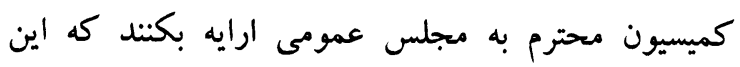
موضوعات درست است يا نيست. ما اين را اكر بينيم صاحب فقط جند وزارت و مراجع مربوطه را نوشته كردند

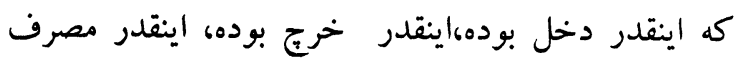

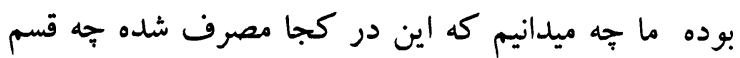
مصرف شده، درست مصرف شده، غلط مصرف مد شده اند

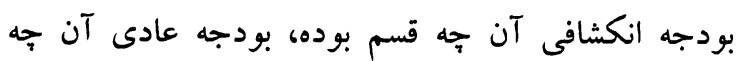

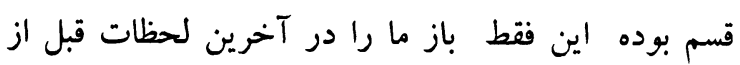

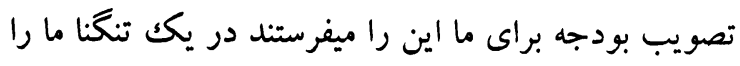

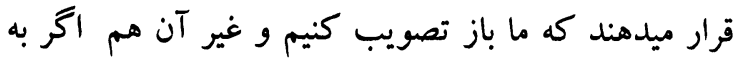

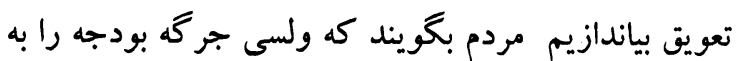

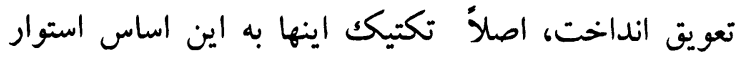

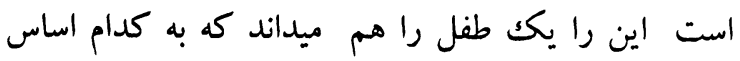

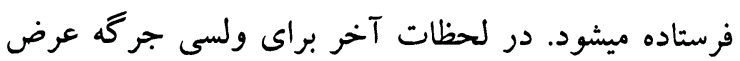

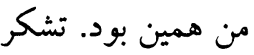
رئيس مجلس:

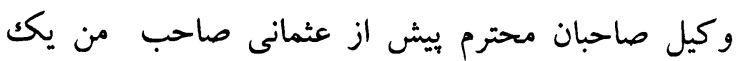

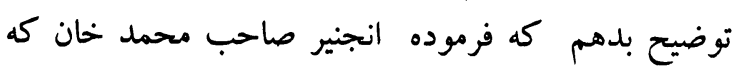

دلته موجود وي حُكه د هغوى نظر د وزارت ماليي سره

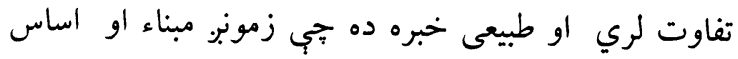

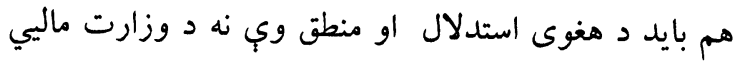

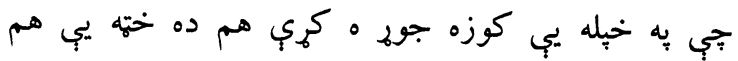

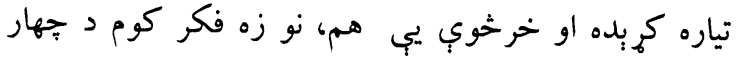

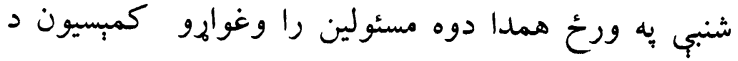

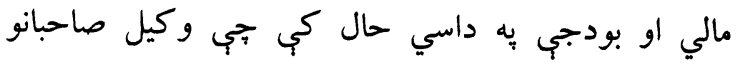

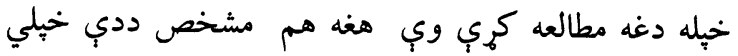

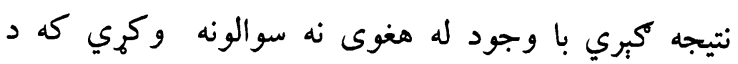

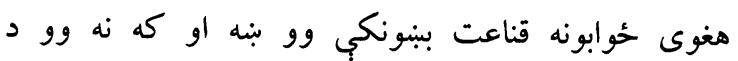

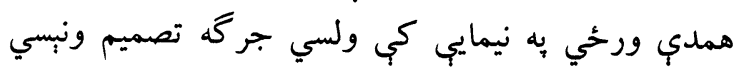

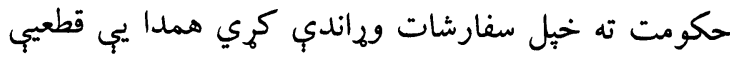

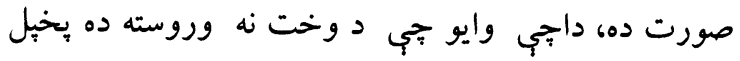

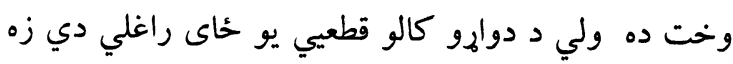

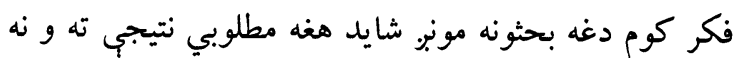

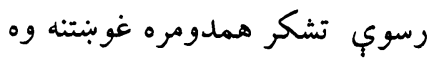
محمد داود سلطان زوى:

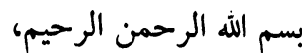
به نظر من جناب رئيس صاحب، من ميخواهم يكك مثال

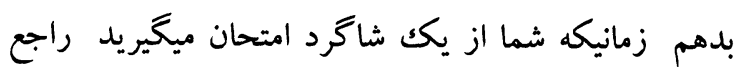

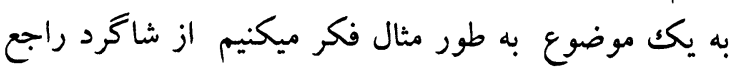

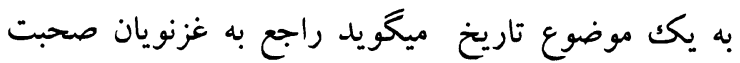

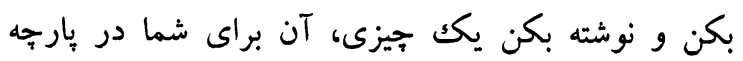

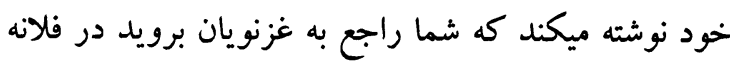
فصل تاريخ بخوانيد اين نظر من است. اينجا ما اكر قطعيه

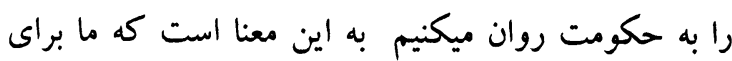
خود حكومت ميخويم به وزارت ماليه ميگويم كه برادر اين غلط بود دو باره درست كنيد آن را، قطعيه روان

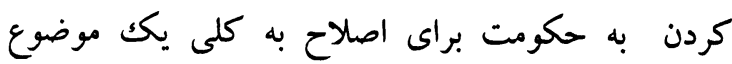
نادرست است وقتيكه قطعيه براى ما ميآيد ما بايد تصميم

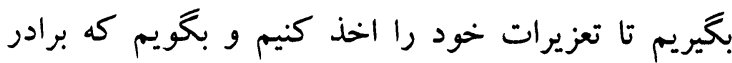

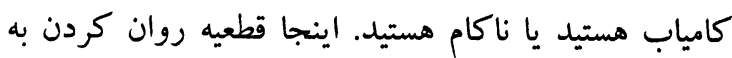

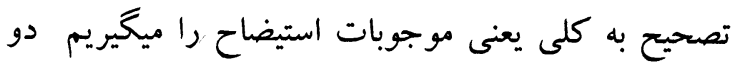

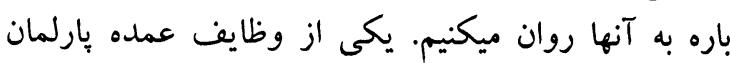

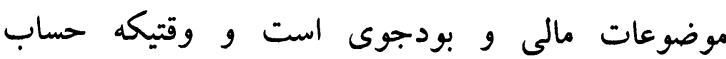


ناخواسته در اين سوء استفاده صورت گرفته يا محاسبه

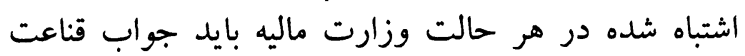
بخش به كميسيون ما بدهند بعد كميسيون محترم مالى ما

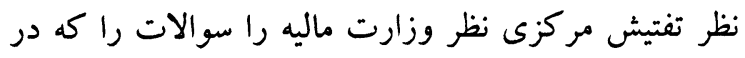

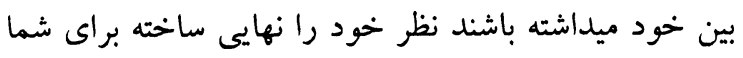

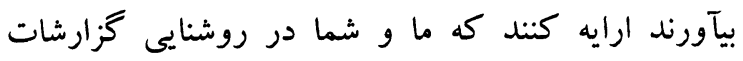

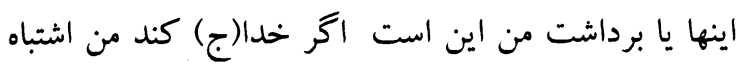

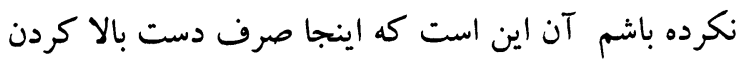

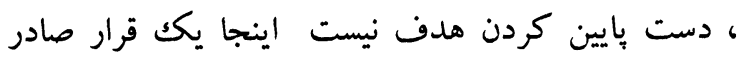

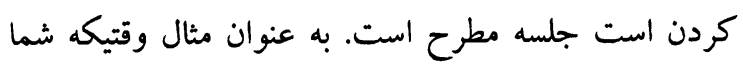

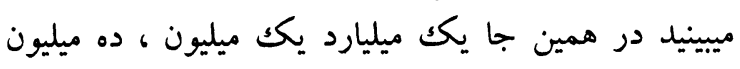

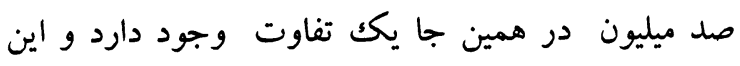

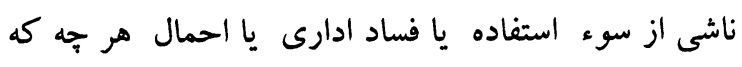

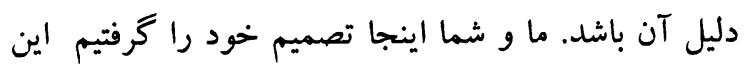

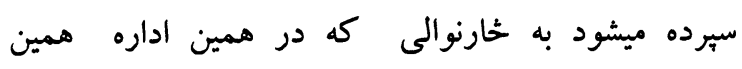
تفاوت ها وجود دارد قناعت ادارات ذيربط فراهم نشد هيد

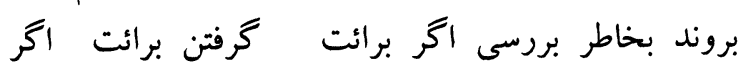

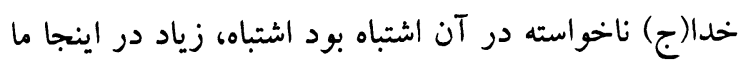

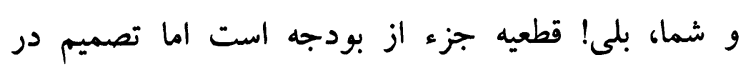
بودجه با تصميم در قطعيه كمى متفاوت است. صديق احمد عثمانى: بسم الله الرحمن الرحيم،

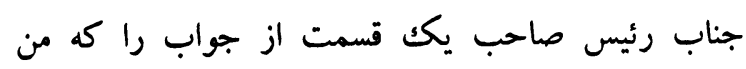
ميدادم به اختصار جناب شما بيان كردند، در روز ورئ ييشتر من در روز جهار شنبه مكمل بالاى اين مسئله ما باد توضيحات داديم يك قطعيه جطور ترتيب ميشود،اين نقطه براى وكيل صاحبان محترم خيلى مهم است.طوريكه

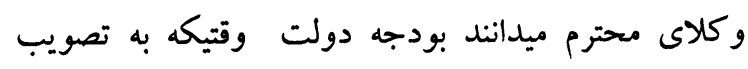

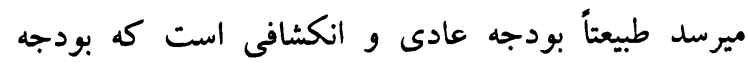

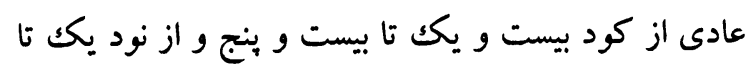

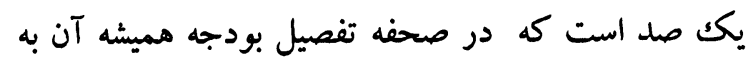
وضاحت ديده ميشود و همجنان بودجه انكشافى، وقتيكه

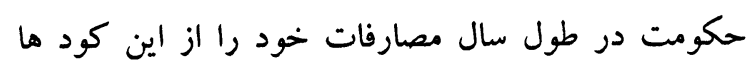

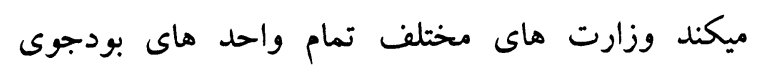

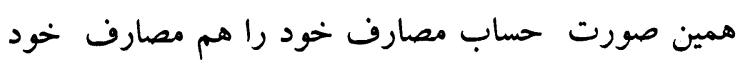

استقامت مجلس برهم نخورد. وكيل صاحبان روز گذشته

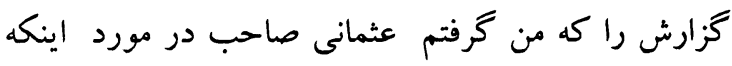

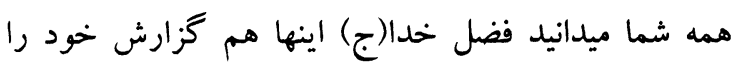

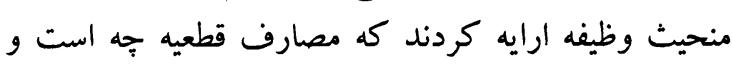

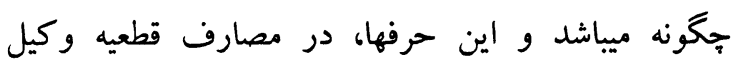

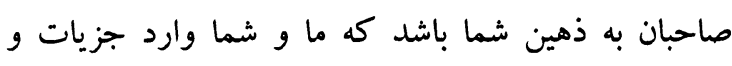

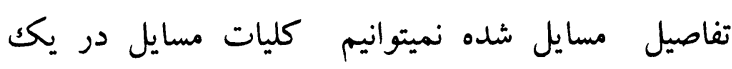

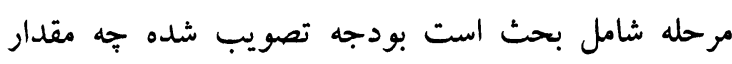

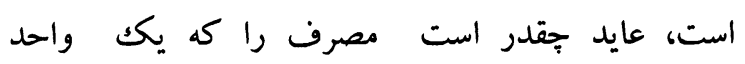
بودجوى مصرف كر ده آيا مطابق به همين است يا نيست

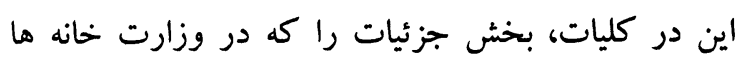

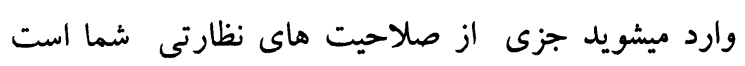

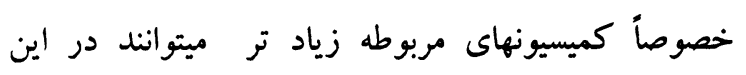

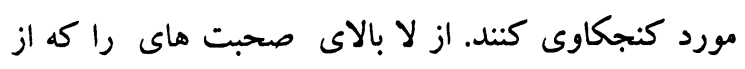

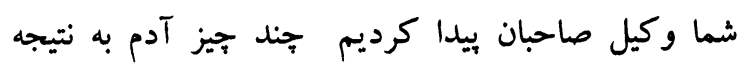

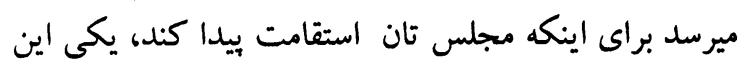

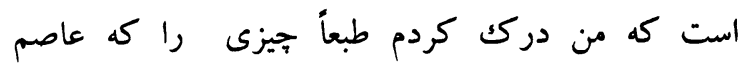

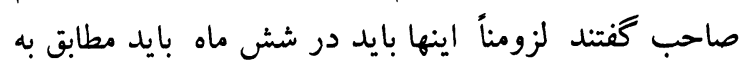

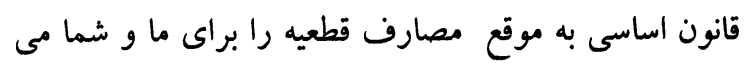

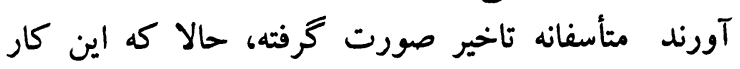

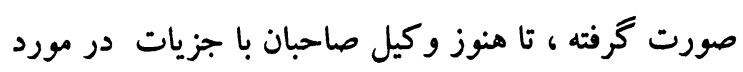

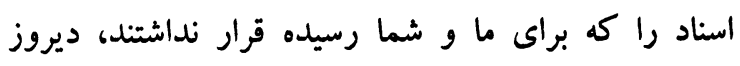
دوستان ما در اداره امور شب و روز كار كردند ونداد تمام اسناد

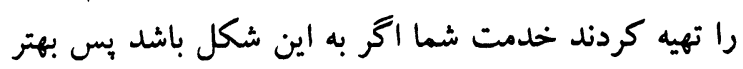
است به زمان كار داريد مثل اينكه استاد اكبرى مطرح

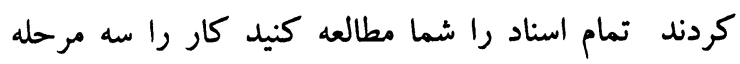

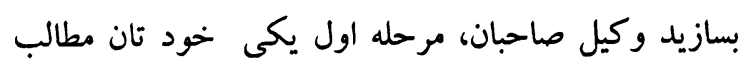

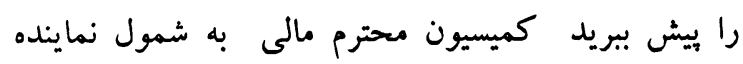

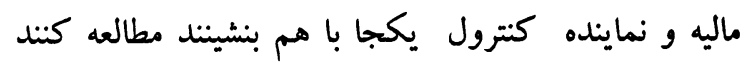
كه تفاوت كه بين گزارش وزارت مات محترم ماليه و كز ارش

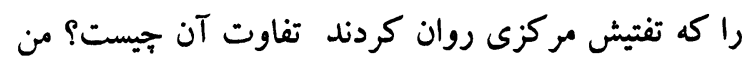

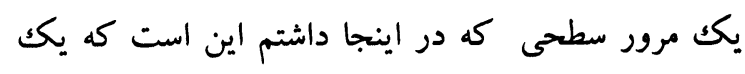

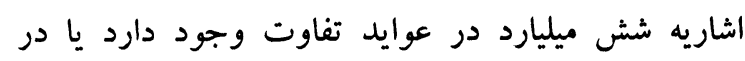

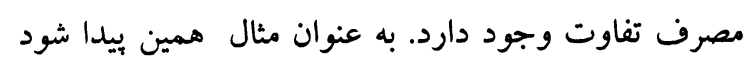

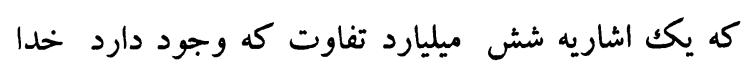


شما را در جريان قرار ميدهم باز جوادى صاحب نغويند

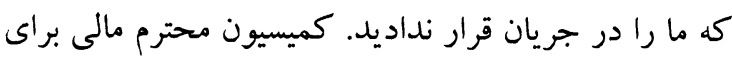

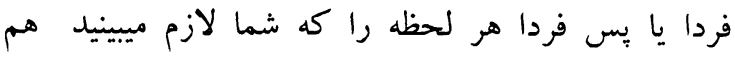

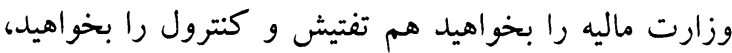

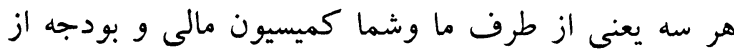

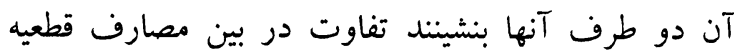

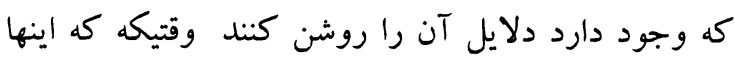

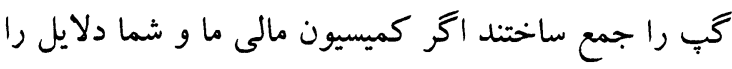

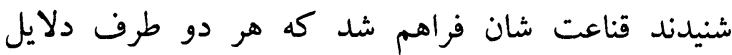
منطقى دارند ميايند به مجلس گز ارش ميدهند شما هم قبلاً

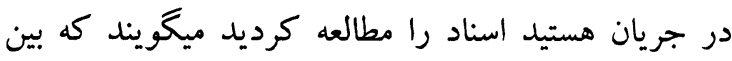
عايد و مصرف، بين بودجه تصويب شده و بين مصارف

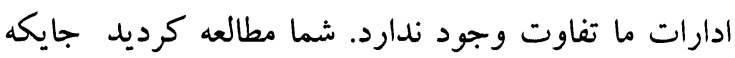
تفاوت بود شما استدلال ميكنيد كه اينجا تفاوت است، بنأ

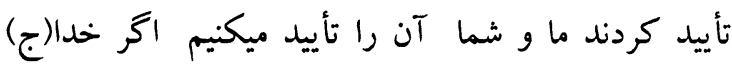
ناخواسته تفاوت وجود داشت اينها آمدند كفتند دلايل اطراف مختلف قناعت بخش نبود، يكك ميليارد، يك ميليون، صد ميليون تفاوت وجود دارد نماينده هم وزارت ماليه هم تفتيش و كنترول اينجا بيش رول روى شما مينشيند

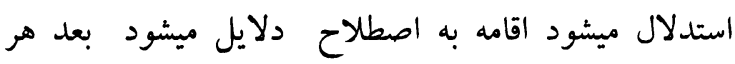

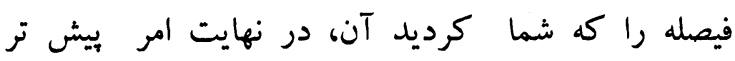

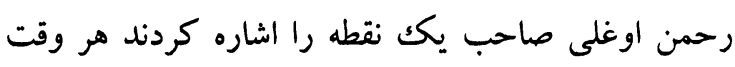

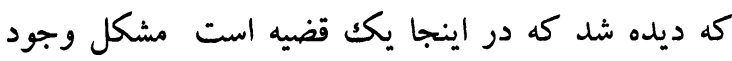

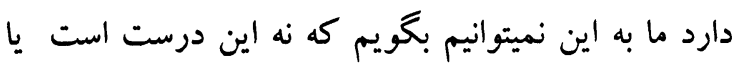

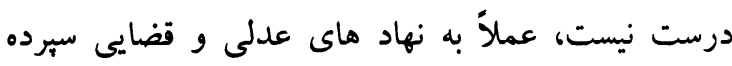

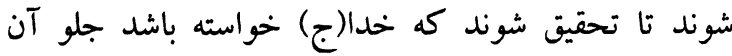
كرفته شود. انجنير محمد عاصم: اعتراض أجنير معل،

من به ارتباط فرمايشات جناب رئيس صاحب اعتراض

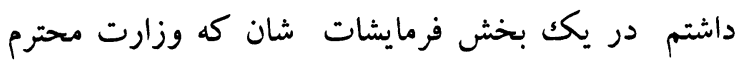

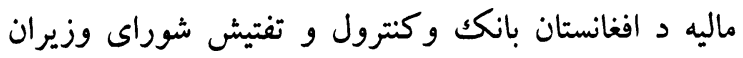

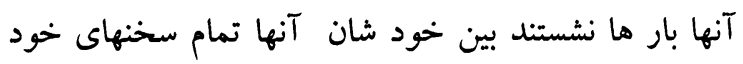
را توحيد كردند و موازنه كردند در گزارش مشتر كك شان

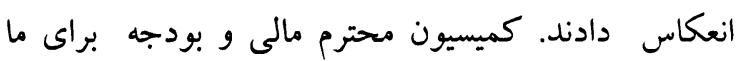

را و هم اجراأت خود را، اجراأت به مفهوم اينكه كسانيكه

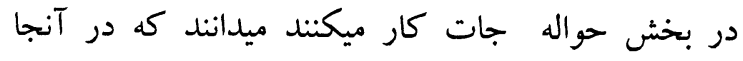
حواله قطعى است حواله طور تحويل است، بيشكى است محسوبى ييشكى است. اين اجراأت خود را وزارت مات ماليه

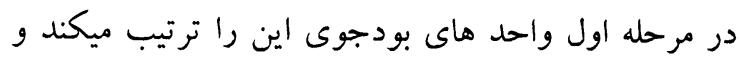

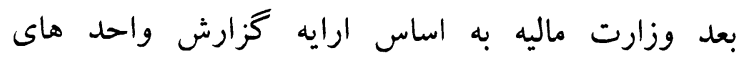
بودجوى يكك صورت حساب را ترتيب ميكند و در اختيار تفتيش قرار ميدهد كه همين اوراق كه بيش شما قرار دارد شكل توحيدى است كه خود وزارت ماليه ترتيب داده.

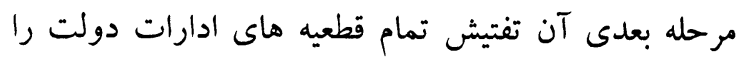

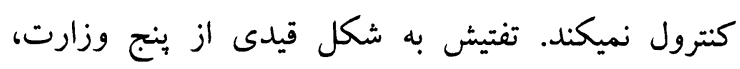

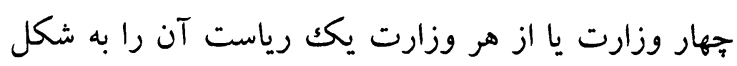

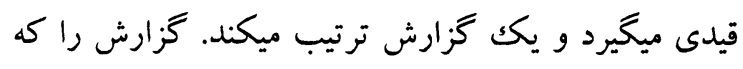
تفتيش در اختيار ما قرار داده قيدى هاى است كئ كه از

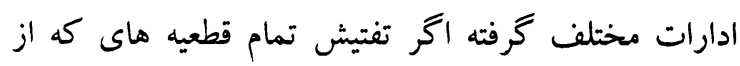

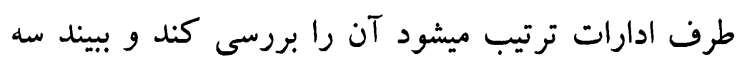

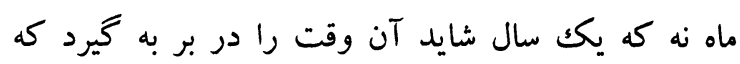
يك كزار را دقيت ارايه كند. گزارش به اساس قيدى قطى قطعيه هاى ادارات ترتيب شده. آمديم سر مسئوليت كميسيون جيزى كه ما از آن برداشت داريم من فكر ميكنم كه نه آنه

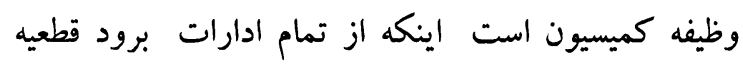

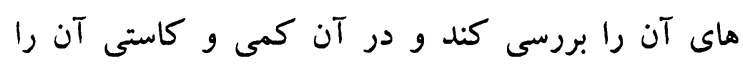

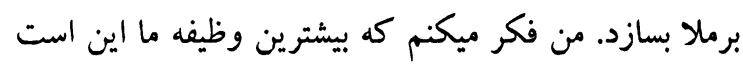

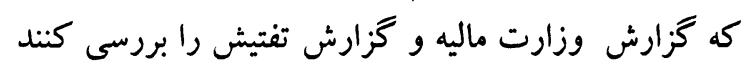

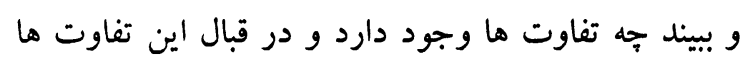

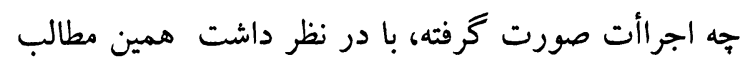

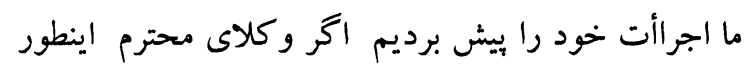

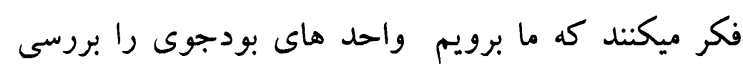

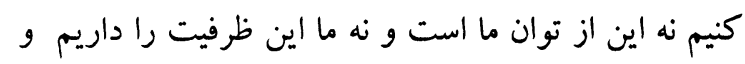

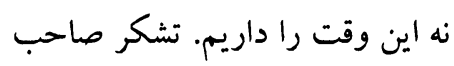

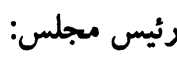
بناً وكيل صاحبان محترم فكر كنم به يكك نتيجه ما و شما

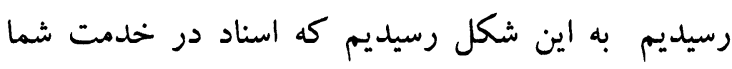
امروز توزيع شد شما هم حانس داريد كه تا فردا بس فر فردا

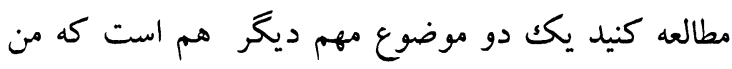


مشخص شود عاجله نكنيد در اين كار مهم، روز سه شنبه

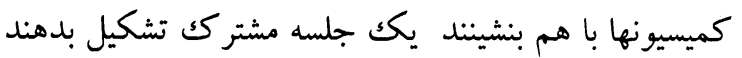

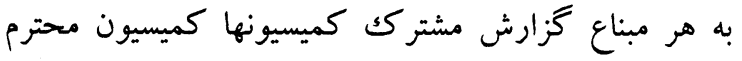

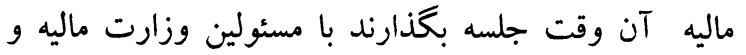
مسئولين تفتيش آنها كه شايد اصلاً به اين هفته ما نرسيم

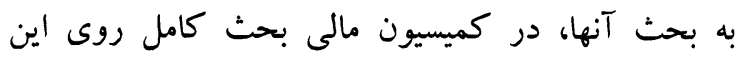

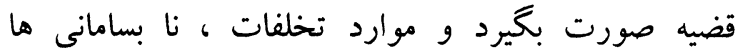

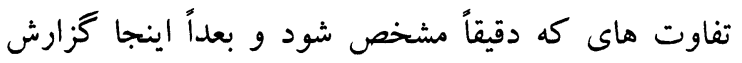

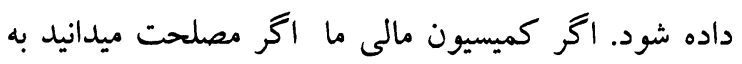
اضافى كميسيون اقتصاد و كميسيون تفتيش مركزى با آنها

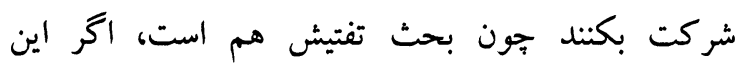

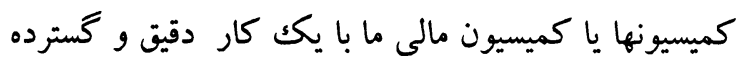
قناعت بيدا كردند خود كميسيون مالى ميايد به ما گز مارش ميدهد هيج نيازى به حضور وزير ماليه يا نماينده كان

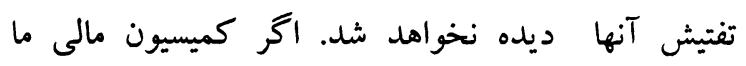

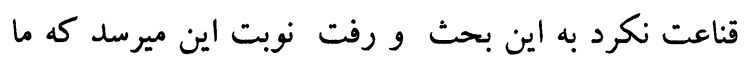

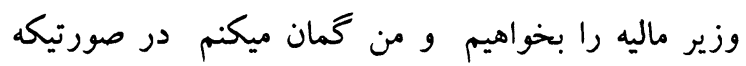

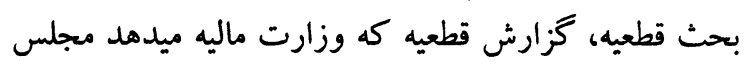

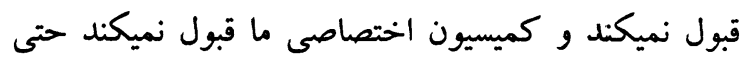

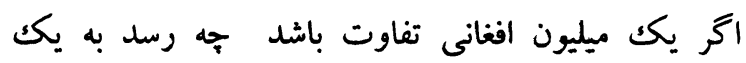

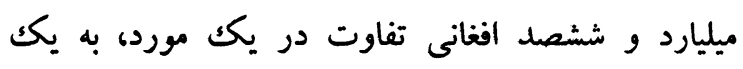

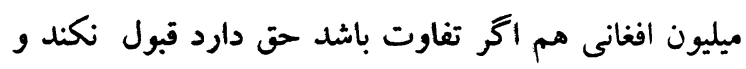

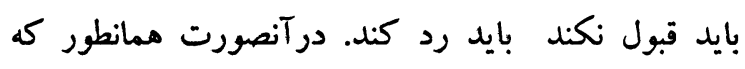
جناب سلطان زوى صاحب كفتند هيج دليل به رد رد كردن

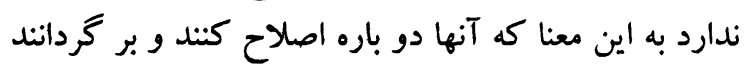

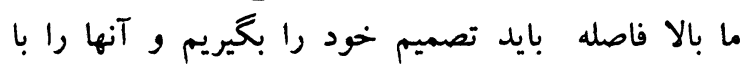

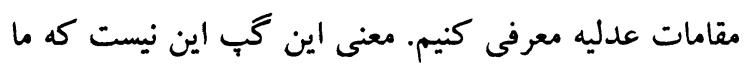
با وزير ماليه مقابله داريم يا آن متهم ميكنيم معنى معنى اين اين

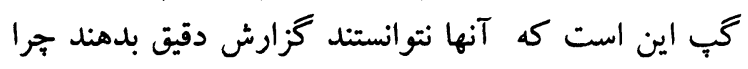

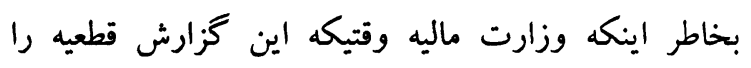

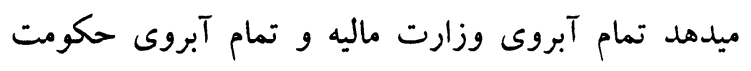
در زروى همين حسابات قطعيه است و آنها علل قايده

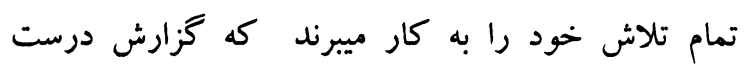

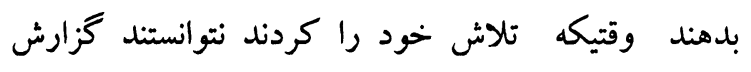
درست بدهند و حسابات آنقدر تفاوت دارد كه يكك و نيم

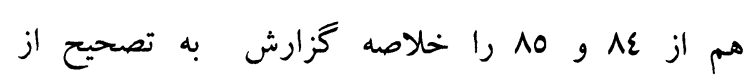

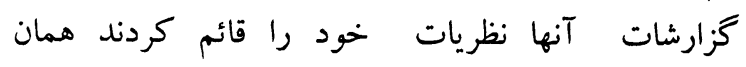
معلومات را اينجا خدمت وكيل صاحبان تقديم كردند. ييشنهاد من اين است كه بجاى اينكه اينها با آنها بنشيندان

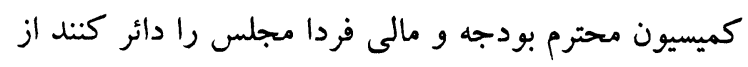

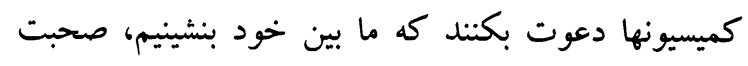

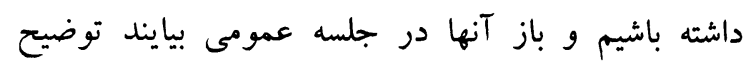
بدهند اخر قابل تأيد بود قطعيه شان، قابل تأييد قرار

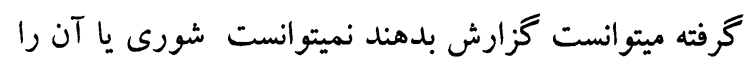

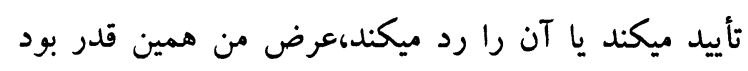

صاحب. احمد على جبرئيلى:

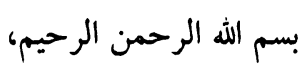

با اجازه هيئت محترم ادارى و همكاران محترم، اول الرحن

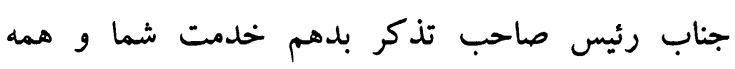

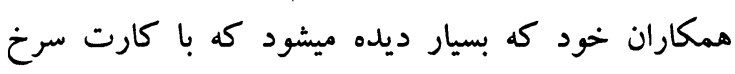

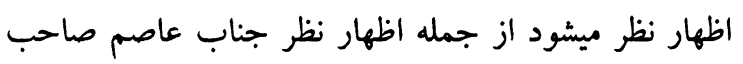

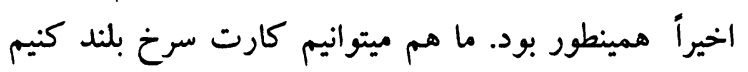

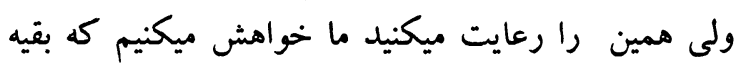

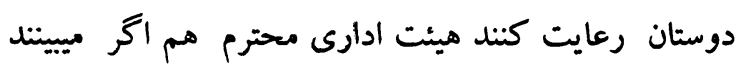

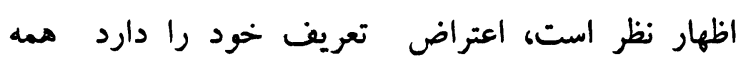

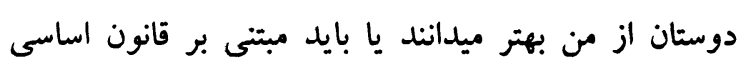

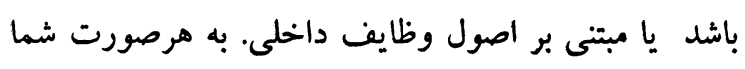

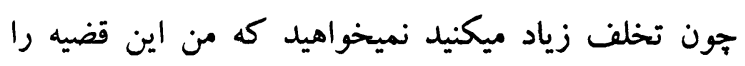
بخويم اجازه بفرمايد كه بخويم، مطالب كه ميخواستم

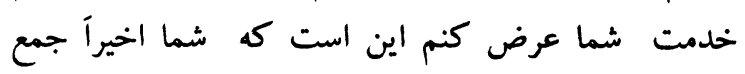

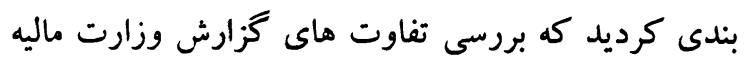

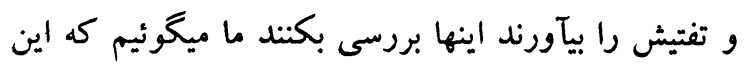
كفايت نميكند و در جلسه عمومى هم قابل بحث نئ نيست

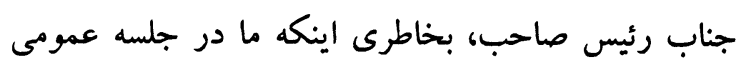
دو روز ديخر هم بحث كرديم اينجا به نتيجه مطلوب نميرسيم من همين نظر انجنير عاصم رو را هم تأيد ميكنم

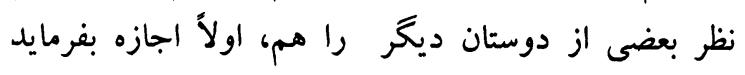
همانطور كه جناب آقاى اكبرى گفتند كميسيونهاى محترم كلأ بين خود همين قضيه را بررسى كنند نظر هر كميسيون اكيرى 
به سال آينده به ماه جوزا بايد بيايد كه اين وقت رسيده و از جانب كه ما در قطعيه ها كذشته هم ديديم وزئ وزراء

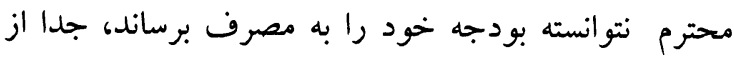

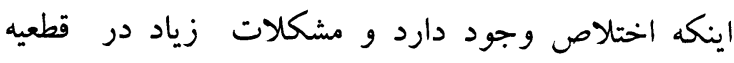

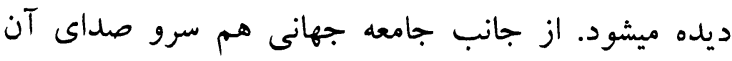

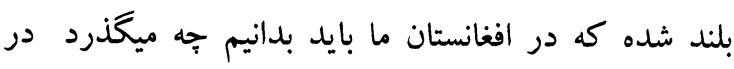

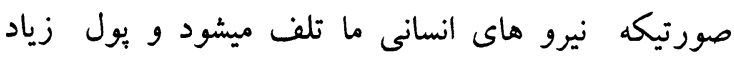

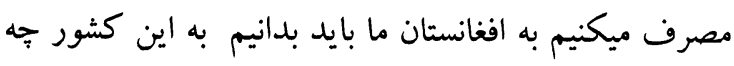

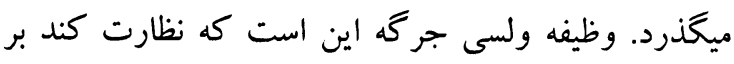

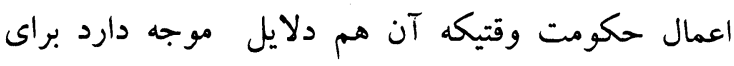

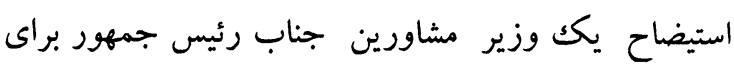
آن مشوره بسيار بد ميدهند كه اخر و ولسى جر گثه افغانستان

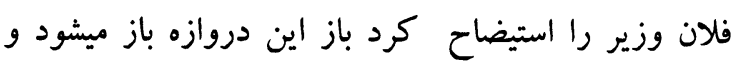
اكثر اعضاى كايينه اينجا استيضاح ميشوند. من اميدوار

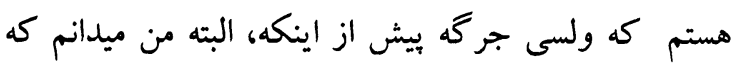

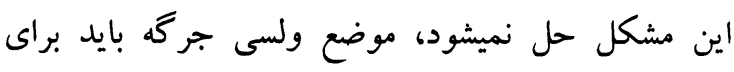

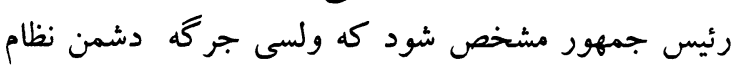

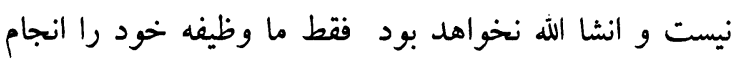
ميدهيم و اينكه ما يكك وزير را ميخواهيم به استيضاح

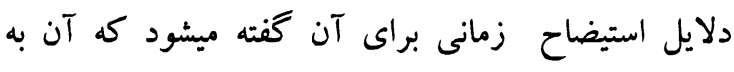

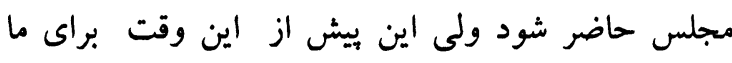
اعلان ميشود كه دلايل موجه نبود. ما دلايل رائ را اصلاً

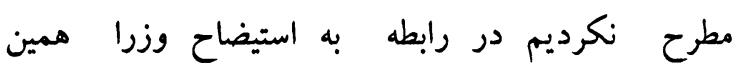

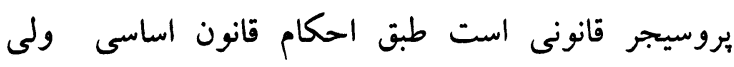
مشاورين، مشاورين خوب نيستند من فكر ميكنم. اكر الرئ

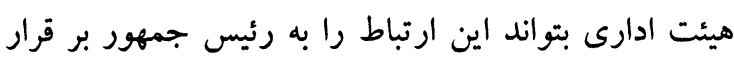

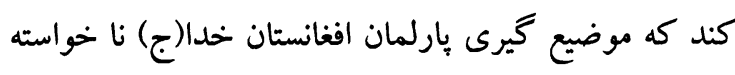

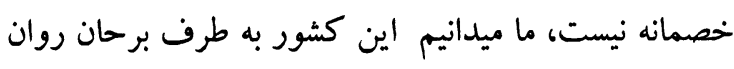
است كه امروز سر و صداى خارجى ها هم بلند شده ماند

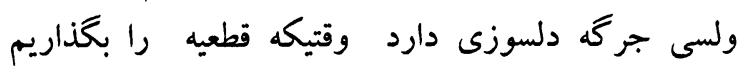

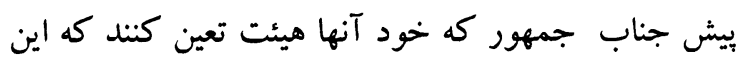
تصفيه كنند و اين را تأييد كنند. وقتيكه ولسى جر گثه اين

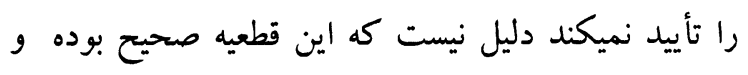
ولسى جرگه براى اين مشكل خلق كرده، من در تمام

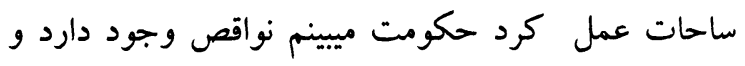

ميليارد در يكك قلم بين آن تفاوت وجود دارد يس معلوم

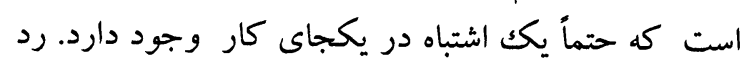

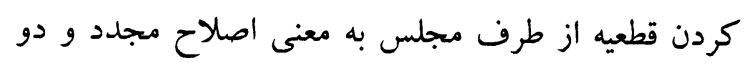

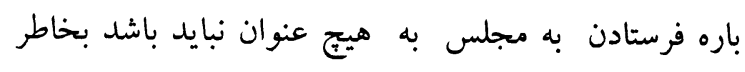

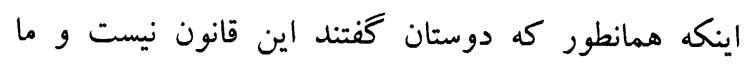

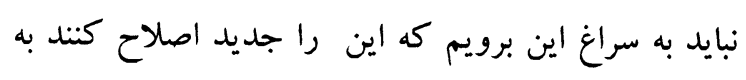

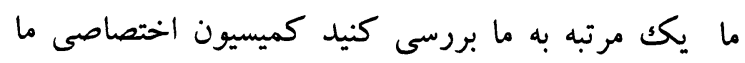

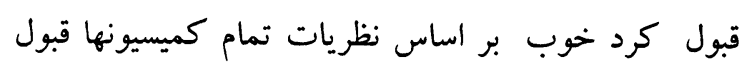

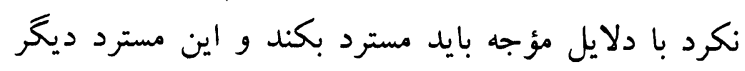

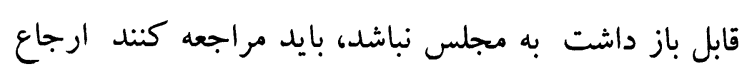

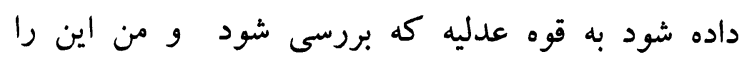

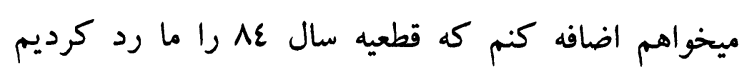

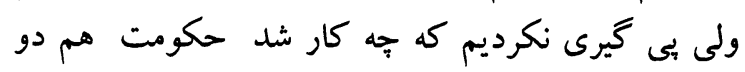

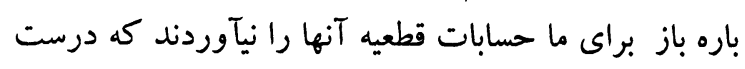

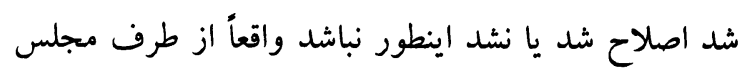

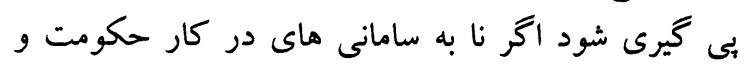

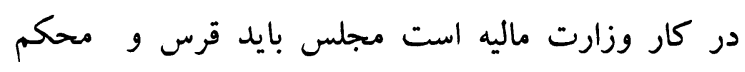

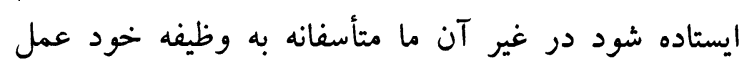
نكرديم. تشكر حاجى عزيز احمد نادم:

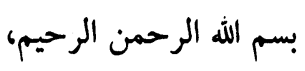

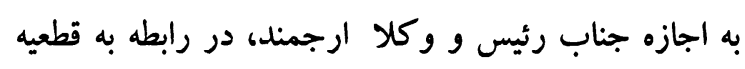

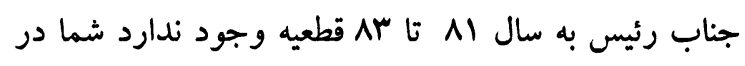
جريان هستيد. قطعيه سال 10 را هم به دلايل كه و وكلاى

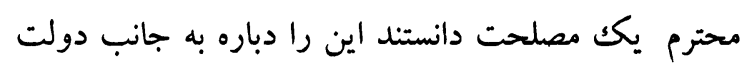

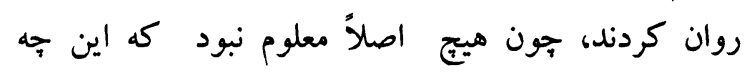

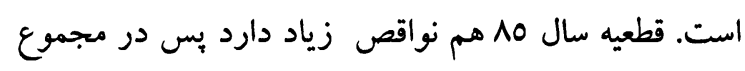

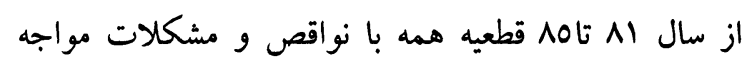
است. وظيفه شوراى ملى اين است كه تأييد كند قطعيه

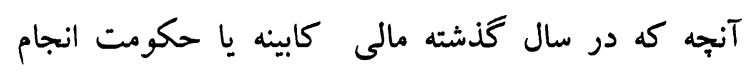
داده آن را تأييد كند و اين بيش از اينه اينكه به شورى بيايد

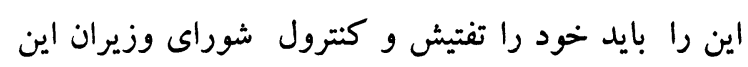

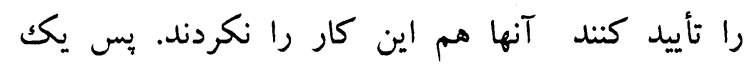
مشكل جدى است و طوريكه ما معلومات داريم از سال זی هم اولاً اين بايد به ماه جوزا ميامد يعنى قطعيه امسال 
براى تحقيق در اين مورد. درست است وكيل صاحبان؟ بناً عثمانى صاحب گب آخر را ميزنيد كه در ديخر بحث

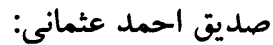

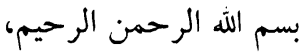

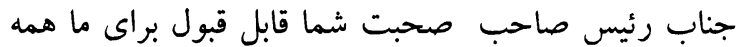
است. تنها يكك مسئله را من ميخواهم به ارتباط صحبت سلطان زوى صاحب من بيان كنم با وجوديكه در سال كذشته مسئله قطعيه يك جيزى جديد بود و كميسيون ما تجربه كافى هم نداشت سال گذشته وقتيكه قطعيه رد شده

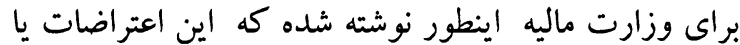
اين نواقص در كار گزارش قطعيه وجود داشته كه تفاوت در مصرف بوده، نفاوت بين حساب وزارت ماليه و د افغانستان بانكك بوده و غيره. به وزارت ماليه در اين نوشته شده كه در مورد اين سخنها شما توضيحات خود راه بدهيد كه جه كرديد در همين نواقص كه وجود داشته از جمله در ماده جهار آن ميكويد كه افراد و اشخاص كه

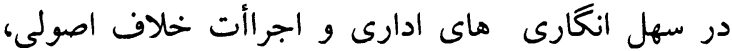
قوانين ملى و حسابى دخيل بودند طبق قانون مورد باز

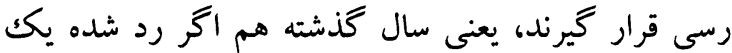
توضيح خواسته شده و دوم از آنها خواسته شده كراه كه اجراأت خود را به ارتباط همكارى ادارات بيان كنند. من

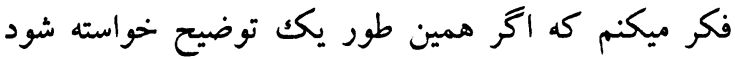

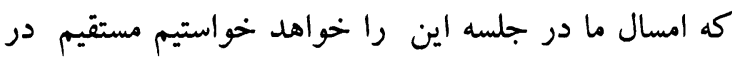
جلسه كه روز سه شُنبه داريم كه آنها توضيحات بدهن دهن ولى سال گذشته هم اكر رد شده رده به به آنها رفته بخاطر توضيحات بوده نه به خاطر اصلاحات.

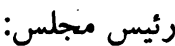
تشكر صاحب، وكيل صاحبان محترم ، به هر حال اينها

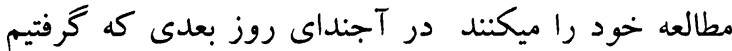

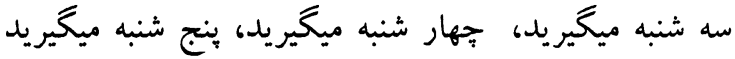

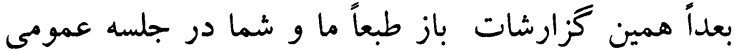
سر آن تصميم ميخيريم نظر خود را ارايه ميكنيم. وكيل
ولسى جر گه تلاش ميكند براى اصلاح اين وضعيت با

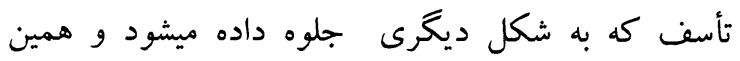

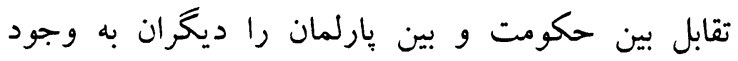

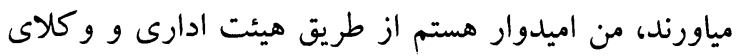

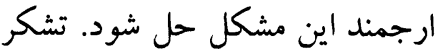

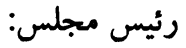
تشكر جناب نادم صاحب، وكيل صاحبان اكر موافق باشيد

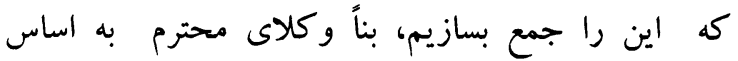

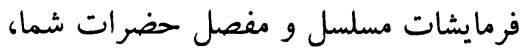

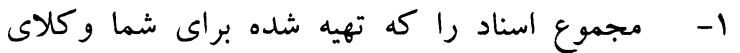
محترم توزيع شد شما در كميسيونهاى مربوطه خود و انفرادى اين را مطالعه بفرمايد.

r- كميسيون محترم مالى هر دو كار را كه وكيل صاحبان مطرح ساختند همزمان ميشود هر دو آن انجام شود آن اين است كه يكك جلسه مشترك اول كميسيونها در بين خود ميخوانند، يكك جلسه مشتركك را روز دوشنبه ميخيريد روز سه شنبه ميخيريد كميسيون محترم مالى و بودجه بخيرند به نظر من بهتر خواهد بود كه در آن جلسه

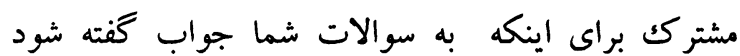
نماينده وزارت ماليه، تفتيش و كنترول باشد كه در آنجا لهرات

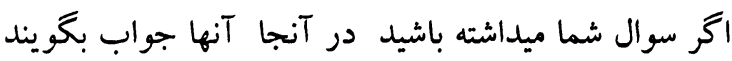
جرا كميسيون خود ما و شما به نماينده گیى از آنها براى شما جواب كفته نميتوانند، آنها هم باشند تحت نظر كميسيون محترم مالى و بودجه شما در جلسه مشترك به به هر نتيجه كه رسيديد معنى آن اين است كه شما آماده گزارش دهى به مجلس عمومى ميشويد، در مجلس عمومى يا در همان جلسه مشترك آخر شما به تفاهم رسيديد كه مصرف با بودجه مطابقت دارد عايد با مصرف مطابقت دارد مشكل نيست در اينجا ميايند وكلا تقدير ميكنند گَب ميشود تمام، اكر تفاوت داشت قناعت كميسيون ما و نماينده گان كميسيون ما در جلسه مشتر كى فراهم نشد در جلسه عمومى اهاله ميشود به خارنوالى 
بود كه بين قوأى سه كانه جلسات مشترك صورت ميخيرد و در اين گزارش كارى و و غيره مسايل در اينجا

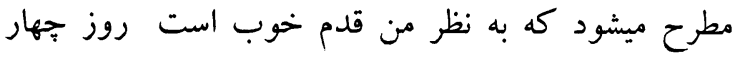

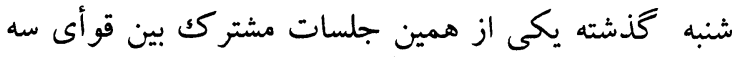

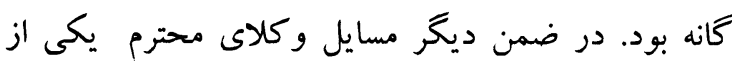

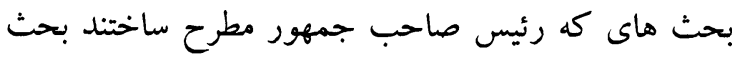

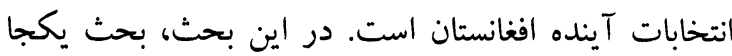

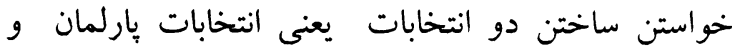

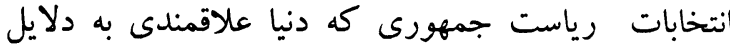
لوزيستيك حرف شان در اين است كه يك صد و وبنجاه ميليون يا سه صد ميليون در هر وقت انتخابات اين از توان

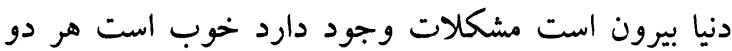

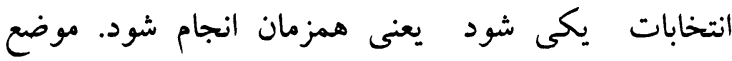

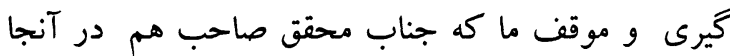
تشريف داشتند جناب استاد سياف هم تشريف داشتند در

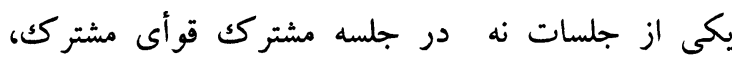

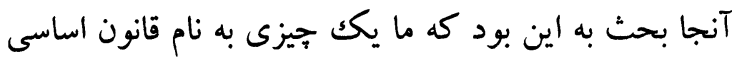

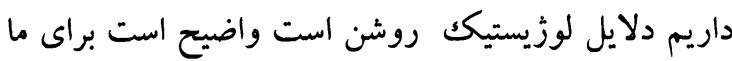

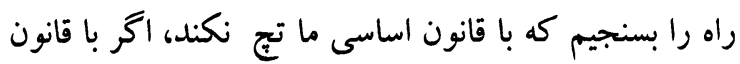
اساسى تج نكند قابل بحث است اكر در مخالفت با قانون اساسى بيايد آن باز بحث جدا است. در جلسه قبلى بحث اكر

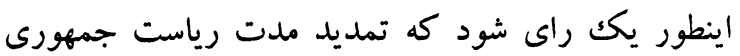
هم خلاف قانون اساسى است كم ساختن دوره شورا ملى هم خلاف قانون اساسى است آنها اينطور يك نظ نظرى را داس

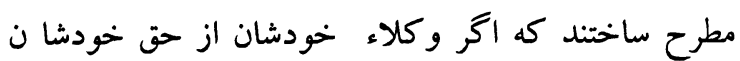

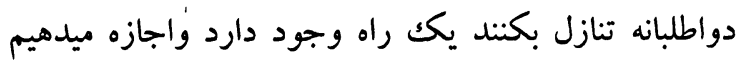

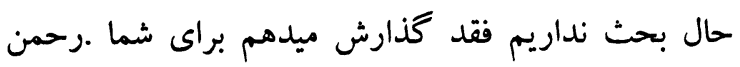
اوغلى صاحب تشريف داشته باشيد . يكك راه است وكيل

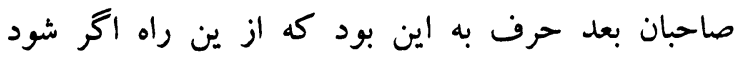
يكقابل بحث است . r- سوال هاين شد مباحيث مختلفى شد جناب ماب محقق صاحب هم يكك طرح را داشتند اين مسايل باقى ماند

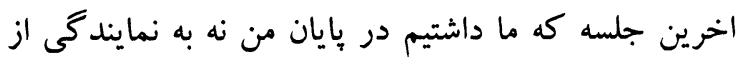
شما ومن كفتم كه من دراين جلسات مى نيشينم به عنوان شخص مى نيشينم نه به عنوان نمايندگى از ولسى جر
صاحبان محترم از اين بحث خلاص شديم يك گزارش خدمت شما دارم.

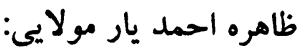

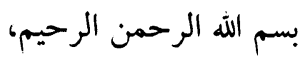

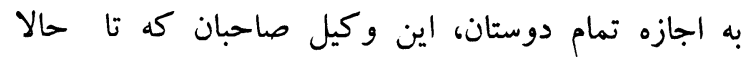

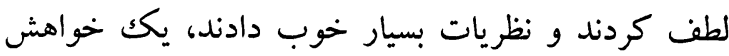

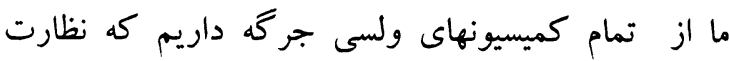

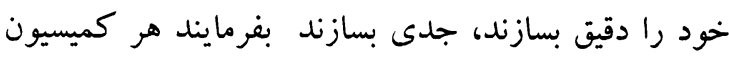

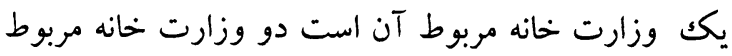

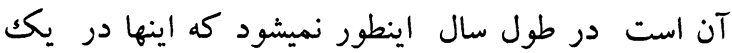

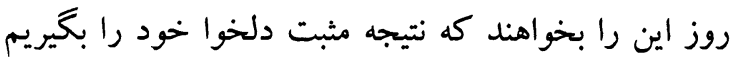

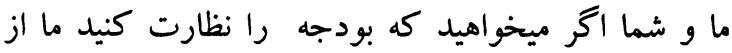

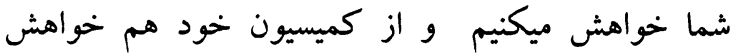
ميكنيم جدى بوديم جدى تر شويم سر اين موضوعات

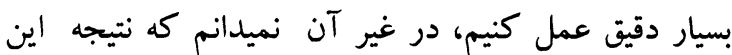
بحث هاى ما جه خواهد شد. رئيس مجلس:

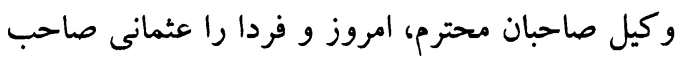

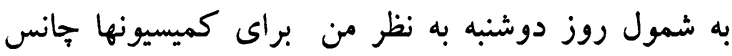

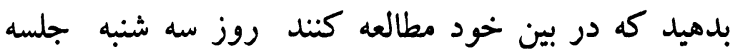

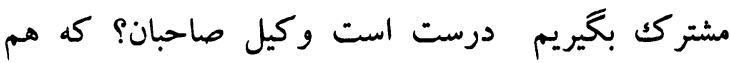
نماينده ماليه هم تفتيش و كنترول نماينده گان كميسيونها

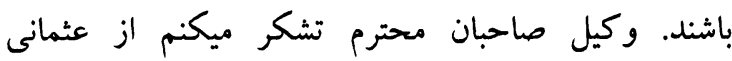

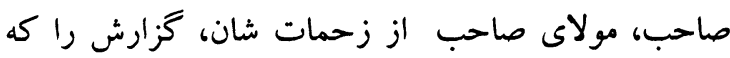
خدمت شما دارم وكيل صاحبان دقت كنيم كاحس كه مسئله

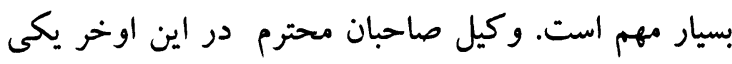

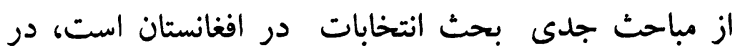

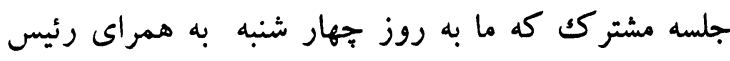

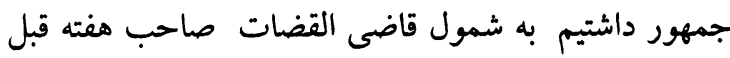
كه حضرت صاحب هم تشريف داشتند در جلسه اخير

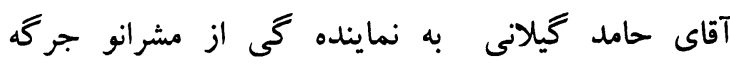

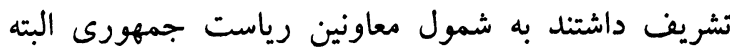

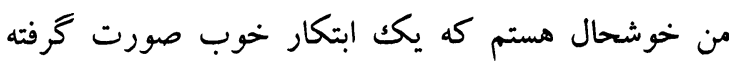

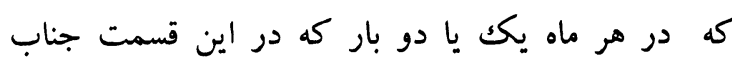
نورزى صاحب زياد تلاش كرده بودند ابتكار توسط اينها 
وجون فيصله قبلى شما است روزى دوشنبه اين حالى روز دوشنبه ترجيح شما اين است كه اول استيضاح را خلاص كنيم بعد مسئله انتخابات يا بر عكس اش؟ آن اول است استيضاح

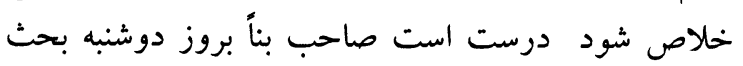

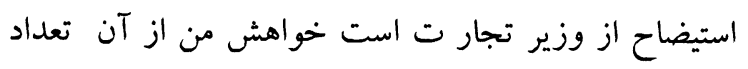

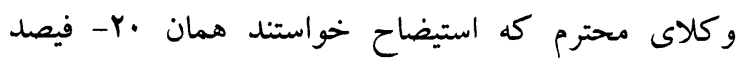

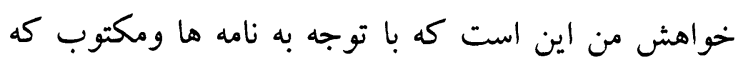

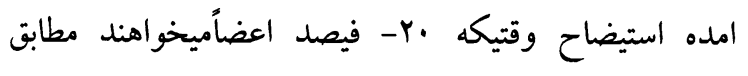
قانون اساسى حق و صلاحيت شما ست من اميدوارم هستم كه دلايل وسوال هاى كه شما مطرح ميسازيد آماده

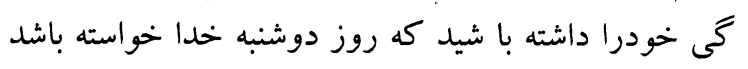
استيضاح مطابق به قانون اساسى صورت بخيرد درست

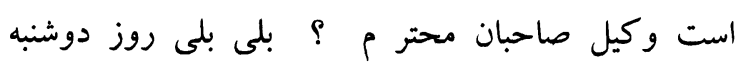

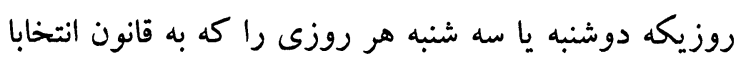
ت عنوان ميكنيم خواهش ما اين است كه كميسيون محترم

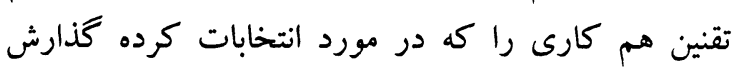

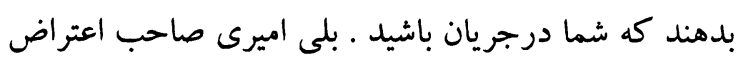

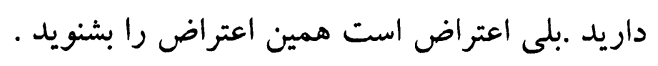
نيازمحمد إميرى : لئل

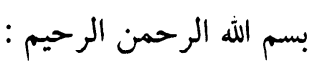

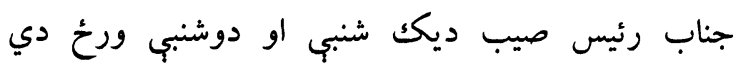

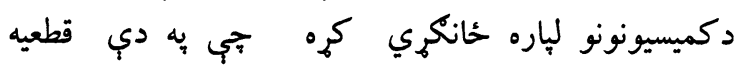
باندي بحث وكمى شي دلته مو بيرته بيا ددوشنبه ورئ

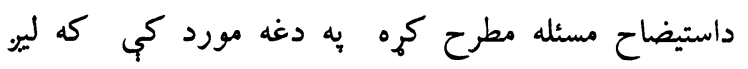

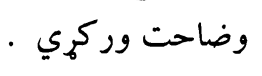

$$
\text { رئيس مجلس : }
$$

هغه اميري صاحب داخود ننه يه كمبسيونونو كي داني دا كار دى كه نه دادمصارف قطعيه باندي تاسو خيل كميسيون كي كبنئ او بحث كوئ عمومي غونلهه مونب. او تاسو نه معطله كوو ددوشنبي يه ورئ استيضا ح كوو، دسه شنبه يه ورخ تاسو عثمانب صاحب سره كبنئ بِ كهي كميسيون

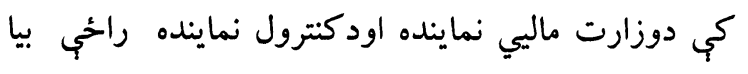

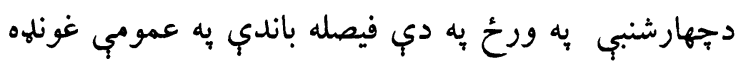

$$
\text { كجي بحث كوو. }
$$

هيج مسئله كه تصويب مجلس نبا شد من نميتوانم انرا

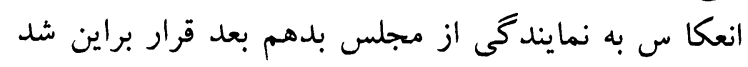

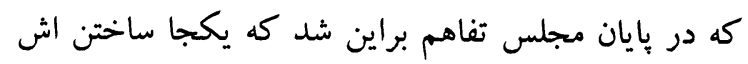

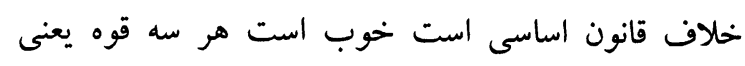

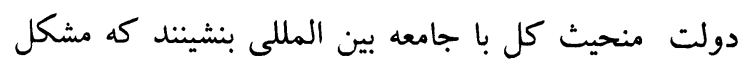

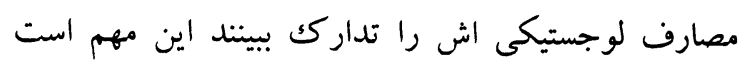

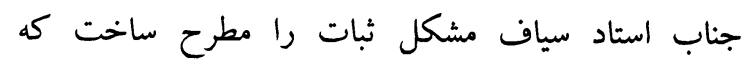
دريكك جا ساختن بى ثباتى ميايد وغيره در بايان به مجلس منسات

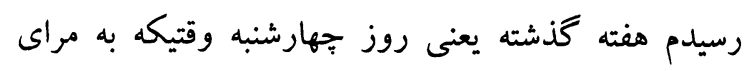
رئيس صحبت داشتيم حرف از اين بود كه توقع بعضى از

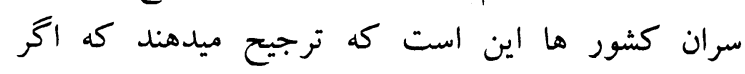

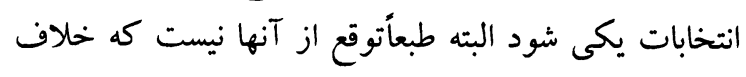

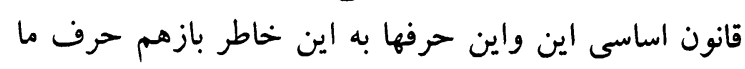

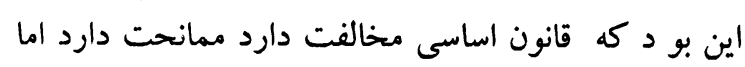
من بدون مشوره و كلاى محترم اظهار نظر كرده نميتوانم

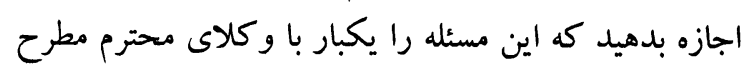
بسازيم حرف من درهمين نقطه است وكيل صاحبان كه به بهاري

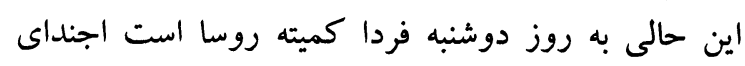

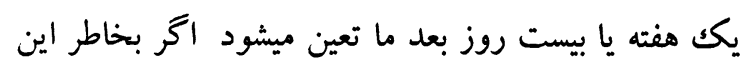

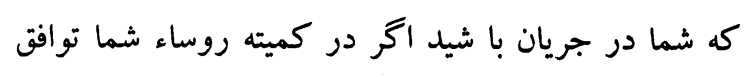

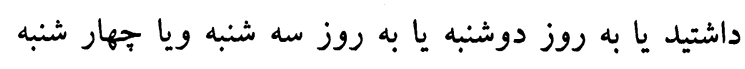

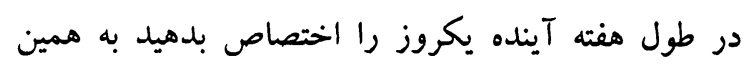

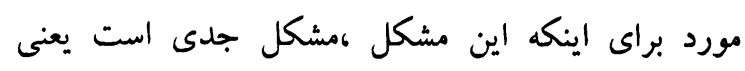
حكومت اين را به عنوان يكك اولويت شخصى رئيس ائ مورد

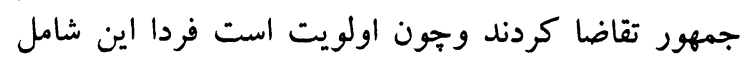

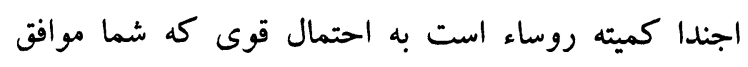

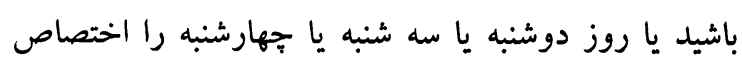

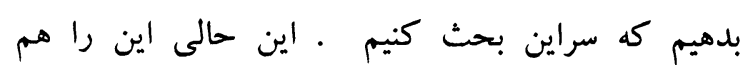

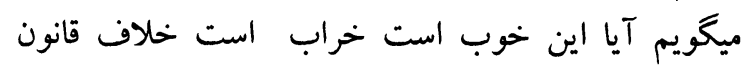
است جه رقم است اين بحثى است كه در در همان روز

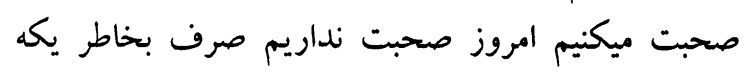

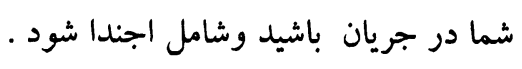
Y- وكيل صاحبان محترم روز دوشنبه فيصله قبلى ما شما

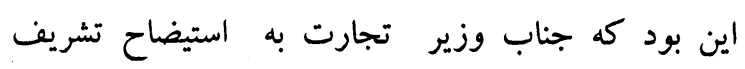

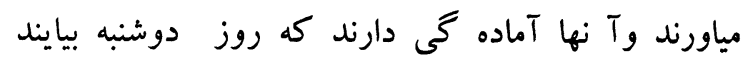


انتخابات رياست جمهورى در سال rیrا- صورت گرفته

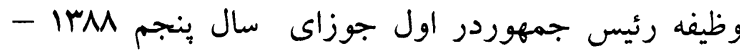
ختم ميشود .جون انتخابات شوراى ملى درسال ع^بها-

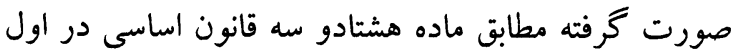

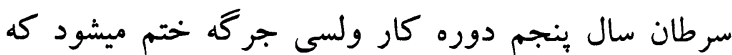

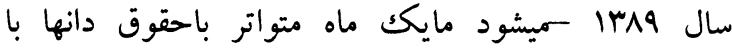
كميسيون مستقل انتخابات باجناب حكومت روى مائ ماين

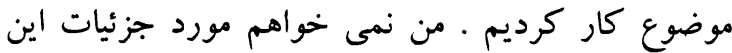

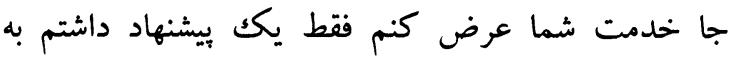

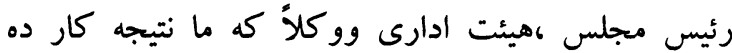

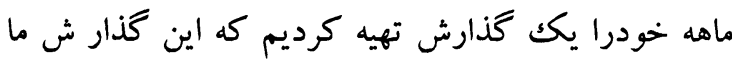
روز دوشنبه به جاب مير سد به دوزبان درى ويشتو.

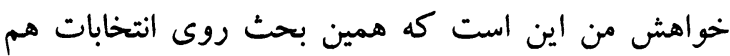

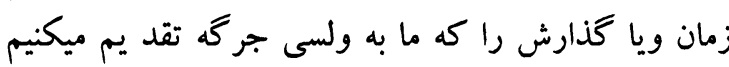

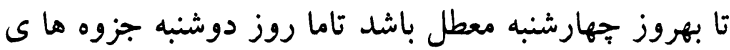

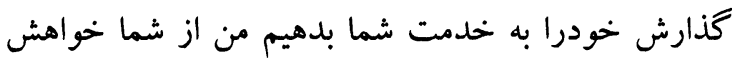

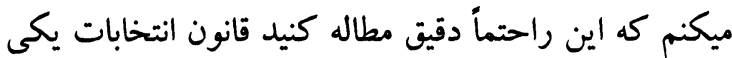

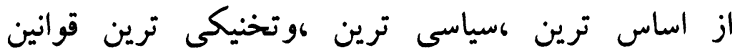

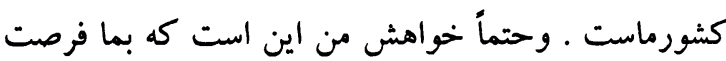

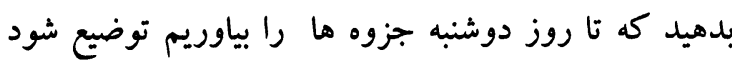
مطاله كنند و بروز جهارشنبه ويا شايدهفته بعداز آن يكروز ائيس مجلس :درست است تاوكيل صاحبان درجريان باشد درست است باز در كميته روسا اين رافيصله كند.

$$
\text { رئيس مجلس : }
$$
تشكر ريخستانى صاحب سبا در كميته روسا مطرح ميكنيم فكر ميكنم منطقش بر همه ما وشما روشن است . فوزيه كوفى : مكر مينم من اميدوارهستم كه هيئت ادارى كه وظئ وظيفه نوبت دادن كه وظيفه دونفر از منشى صاحبان است درنظر داشته باشند .

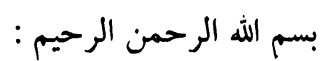

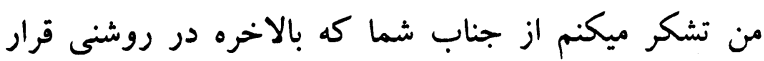

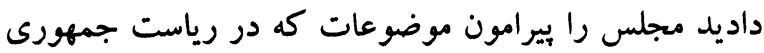

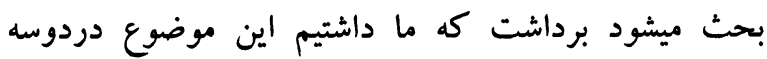

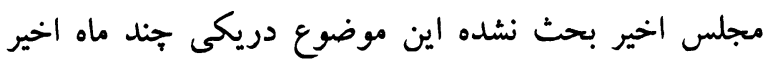

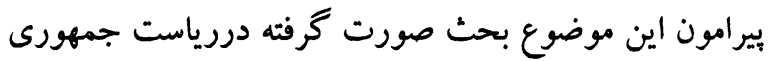

سردار محمد رحمن او غلي :

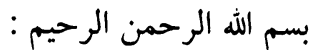
جناب رئيس صاحب يكك بيشنهاد دارم در مورد كار روز الرحمن الرحن دو شنبه مان جون مسئله استيضاح وزير صاحب تجارت ممكن است به درازا بكشد وما نتوانيم موضوع را كه شما

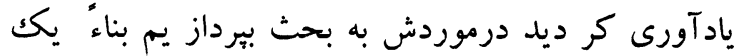

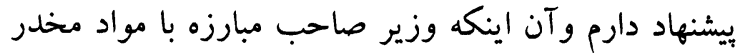

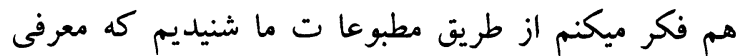

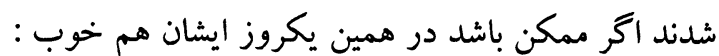
رئيس مجلس :

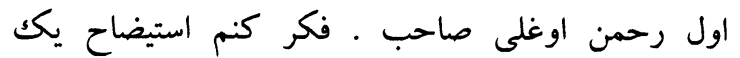

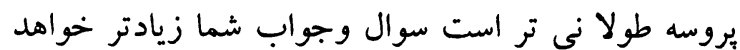
شما هم فرصت سوال كردن داشته باشيد دراين روز ديخر

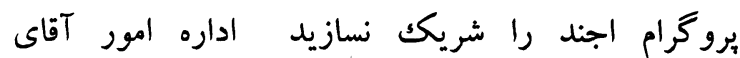

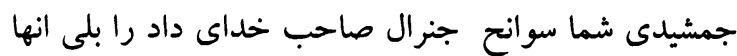

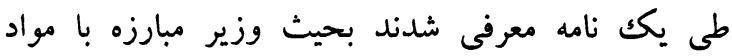

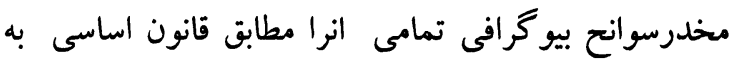

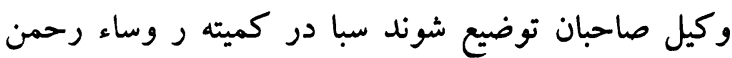

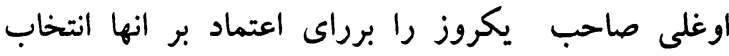

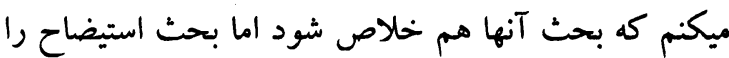
تنها بخذاريم كه وقت داشته باشيم . صالح محمد ريخستانى :

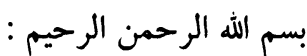
وكلاى محترم خواهش ميكنم كه به حرف ها من بدقت الرحت كوش بدهيد مدت ده ماه ميشود كه يكك كميته جهار

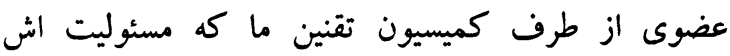
بدوش من وهمكارهاى من است مؤظف شدده تاروى قانون

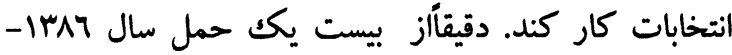
تامروز ده ماه متواتر است كه ما روى قانون انتخابات

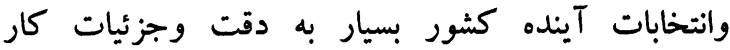

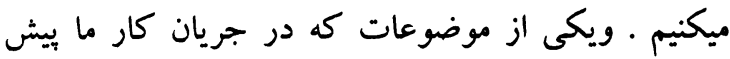

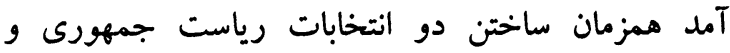
يارلمانى است كه از نظر قانون ما يكسال بين شان تفات تفاوت

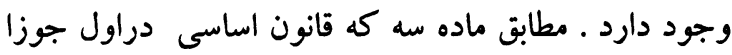
سال ينجم وظيفه رئيس جمهور ختم ميشود .يعنى جون ماده 
رئيس جمهور است . هيج وقت ما به نمايندگى از ولسى

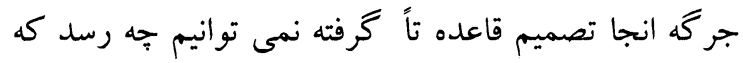

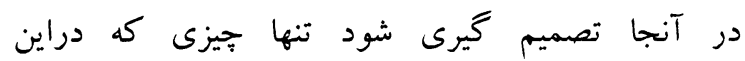
موردبحثى صورت كرفت او اين بود كه شخص ردئ رئيس

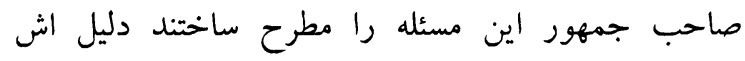

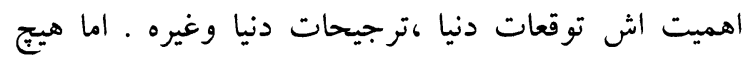

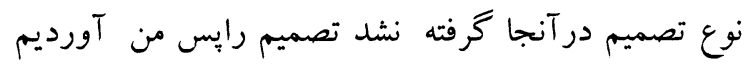

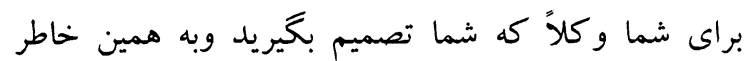

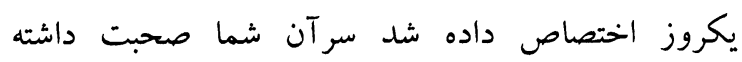
باشيد .

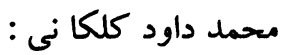

$$
\text { بسم الله الرحمن الرحيم : }
$$

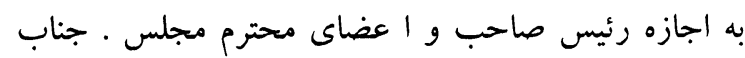

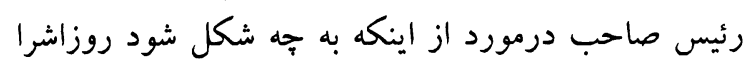

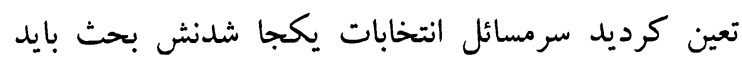
بكنيم ولى جيزى كه من قابل دقت ميدانم به تائيد حرفهاى ريخستانى صاحب وتوجه شما وهيئت ادارى راميخواهم

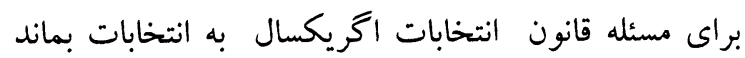
نظر به قانون اساسى افغانستان باز ماوشماسرقانون انتخابات

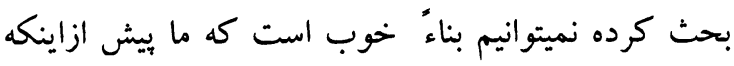

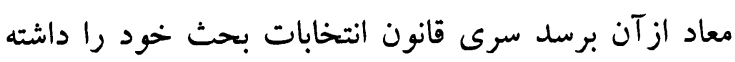

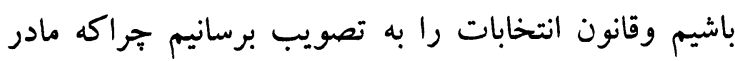

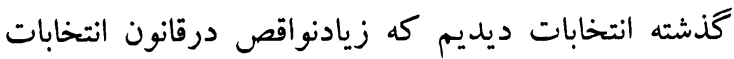

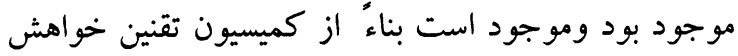

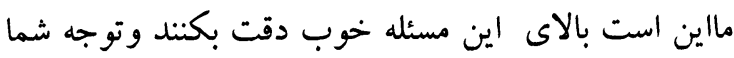

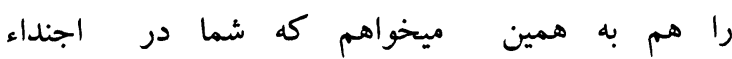
بحير يد .وسلام

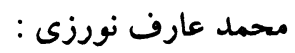

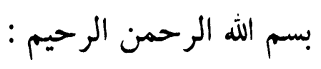
دجناب رئيس صاحب او اداري هيئت او تولو ورين وكيل

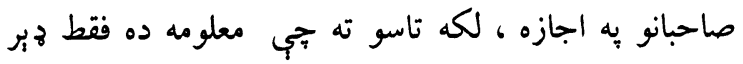

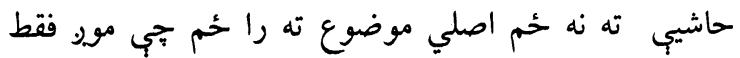

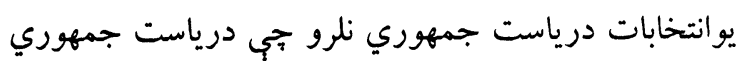

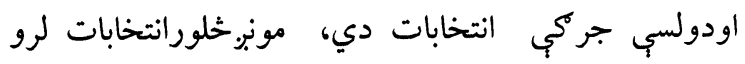
درياست جمهوري انتخابات لرو،دو لسي جركي انتخيات دئ انتابات
وطبعاًشما از آدرس ولسى جر گه افغانستان آنجا از رياست

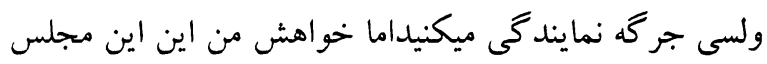

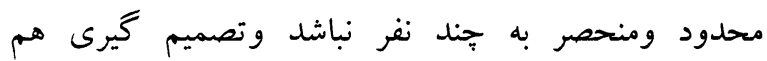
درحيطه صلاحيت جند نفر محدود نشود براى اينكه بالاخره

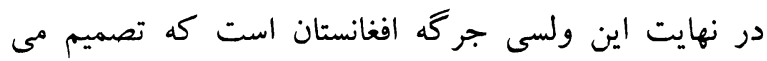
گيرد قرار باشد كه قانون اساسى افغانستا ن هم تعديل شودان

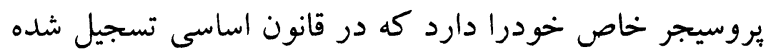

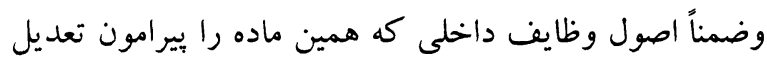

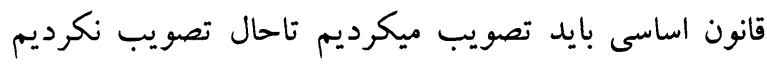

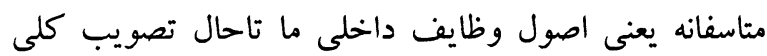
مجلس رانگر فته به دليل از ين كه ماوشما همين ماده قانون

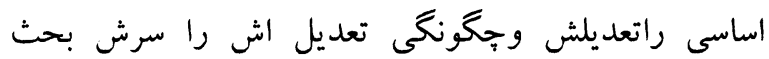

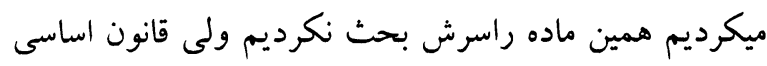

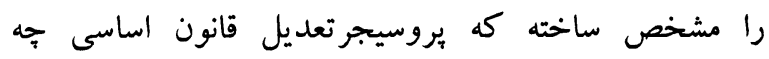
است؟ واين درولسى جر گه فيصله نهايى ميشود من نمى مئى فهمم خوب بهصورت به رئيس جمهور وبه كسانى كه دراين مجلس اشتراكت كردند صلاحيت خودشان است كه به انتخاب

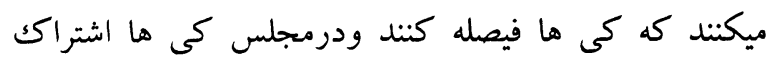
كنند به عقيده من يكك ملت زمانى ميتواند سربلند وسرفيله وفراز

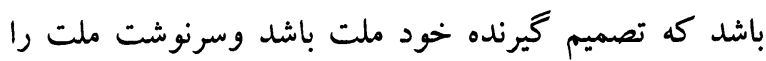

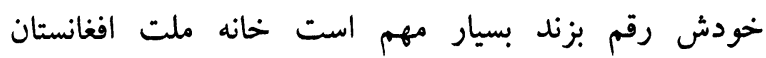

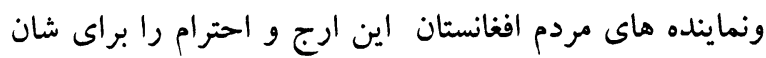
داده شود كه درسرنوشت شان خودشان تصميم بحيرند هرجند بحث روى قانون انتخابات وجزئيات تاريخ انتخابات

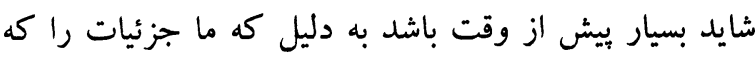

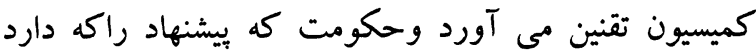

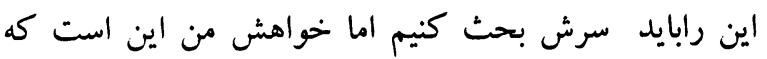
هر گونه بحثى كه در اين مورد ميشود ولسى جر كه افغانستان

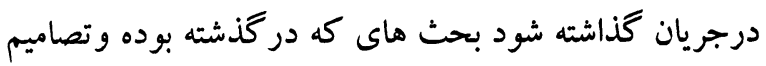

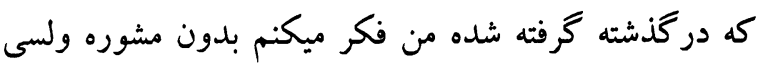
جر گه منتفى است .تشكر . رئيس مجلس : يكك جيزى راكه من براى شما اطمينان ميدهم درآغاز

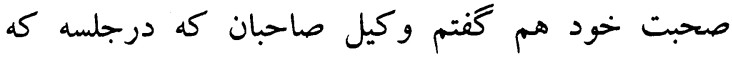

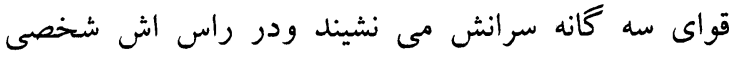


به ولاياتونه زموبر امنيت خراب نه وي ولي انتخابات نه

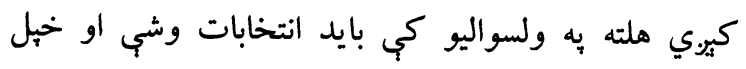

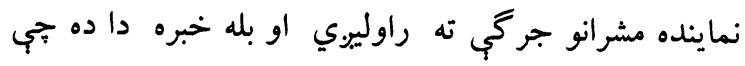

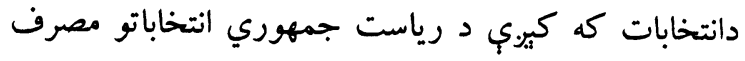
ورباندي كيري دامصرف دولسوالي دياره هم غوإئي دوي دولا

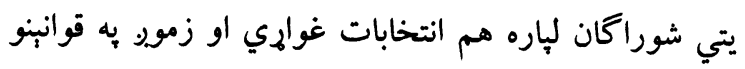

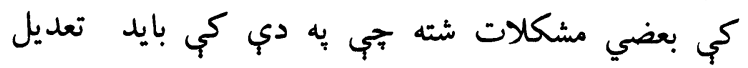

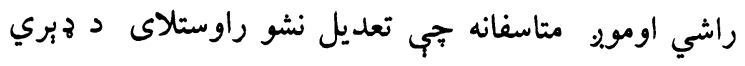

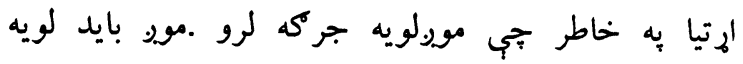

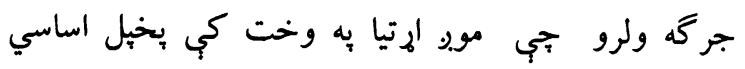

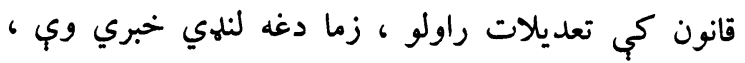
منته.

\section{رئيس مجلس :}

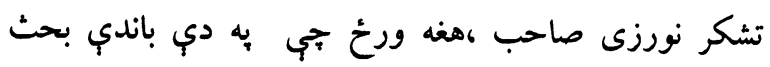

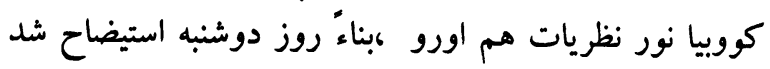

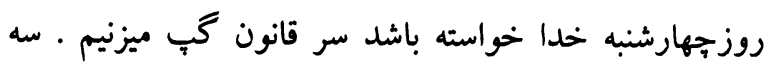

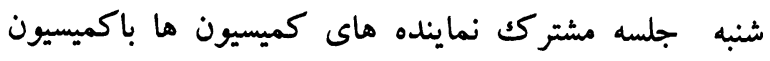

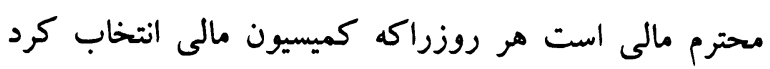

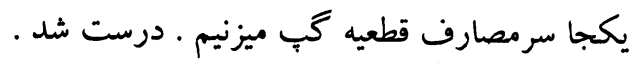

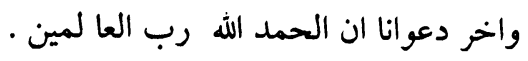

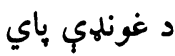

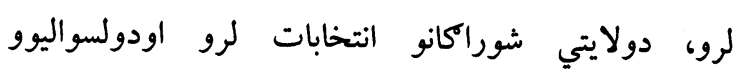

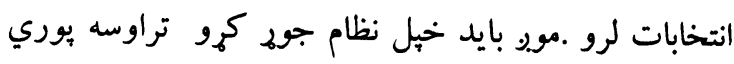

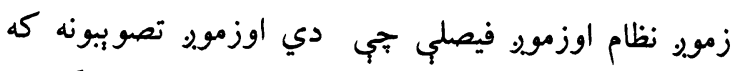

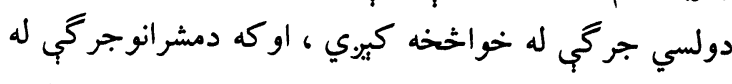

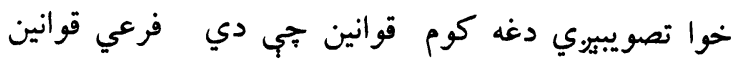
اورئيس جمهور يب توشيح كوي داتول غير قانوني دي ديه ديه خاطردشه شب هب اورئي مود. بايد كومه فيصله يا كوم قانون

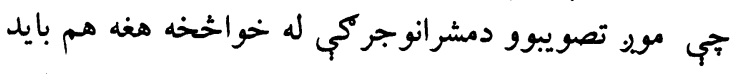

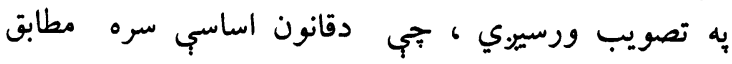

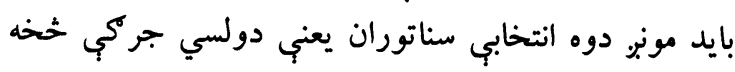

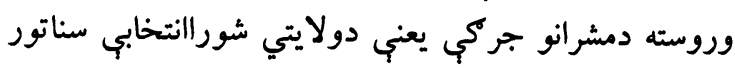

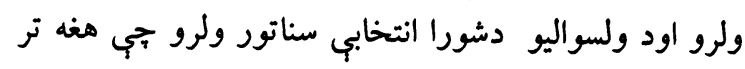

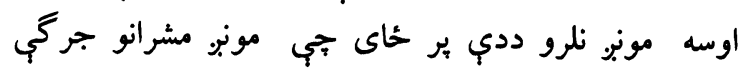

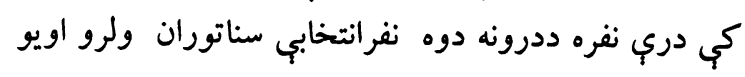

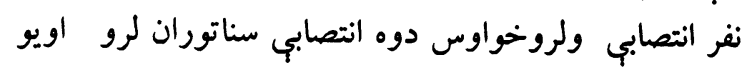

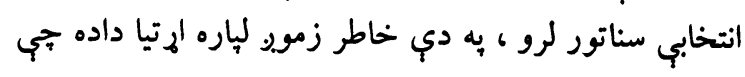

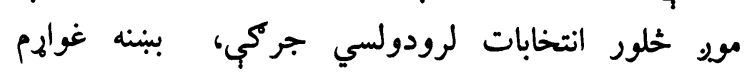

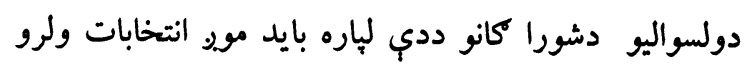

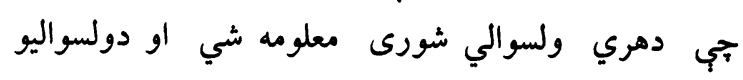

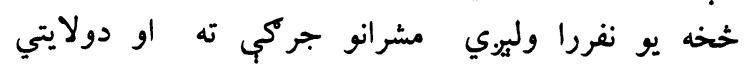
شورى حخهه هم يو نفررا ولييري مشرانو جركي ته درئي

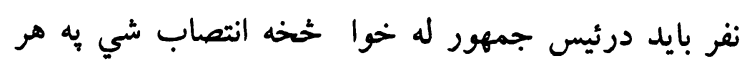

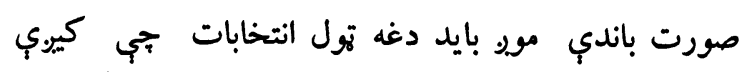

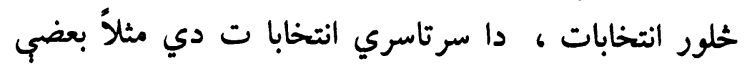
خلكك وايب جي زمونبر امنيت خراب دي كه كه كوم امنيت

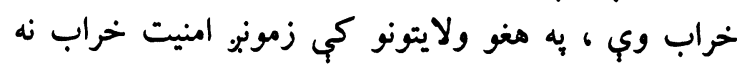
دى ولي انتخابات نه كي.ي بايد دولسواليو انتخابات وشي ولي وني اوخيل نماينده مشرانوجر كي ته راولييوي ، اوبله خبره دادي ائه جي دغه انتخابات كه كي.ي يواخي درياست جمهوري انتخابات كه مصرف ورباندي كيري دولسواليو لياره هم

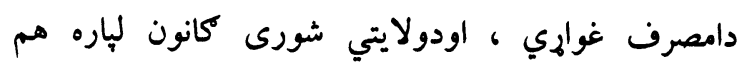

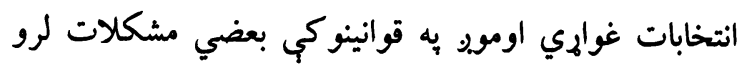

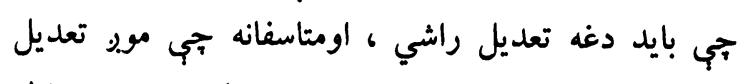

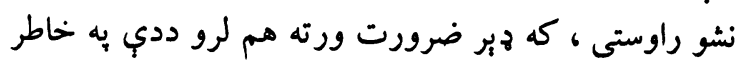

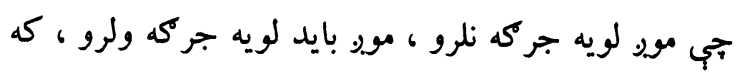


كُل اعضاء ميتواند از هر يكك از وزراء استيضاح به عمل

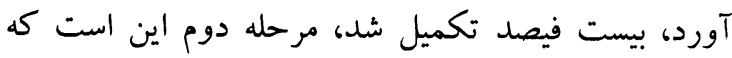

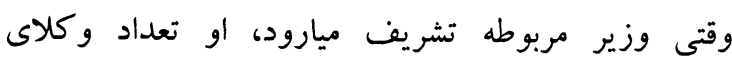

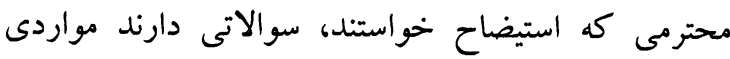

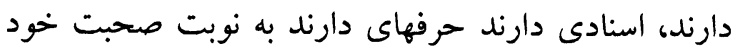

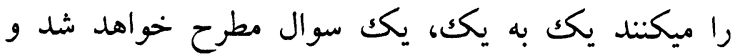

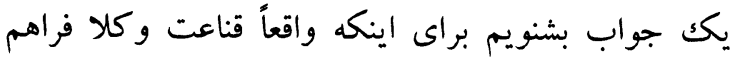

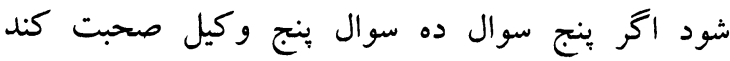
سوالات گم خواهد شد بيشنهاد ميكنيم كه يكت سوال

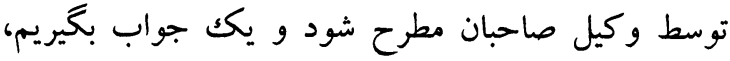

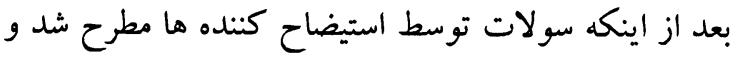
استيضاح شونده جواب ارائه كرد، مطابق قانون اساسى

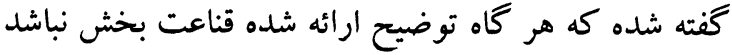

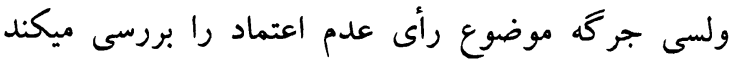
وقتى كه جوابات شنيده شد قناعت فر فراهي

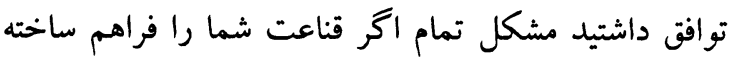

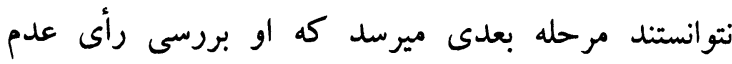

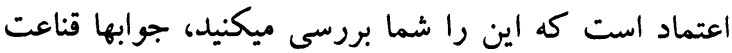

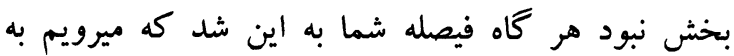
طرف رأى عدم اعتماد، طبعاً صندوقها كذاشته ميشود آندان

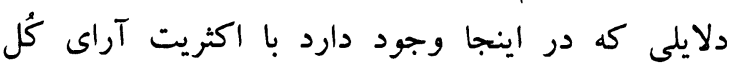

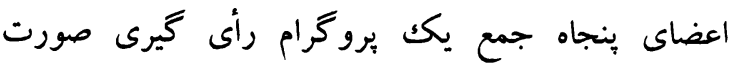

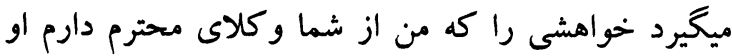

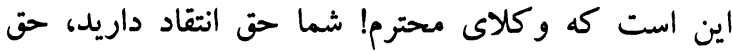

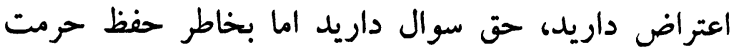

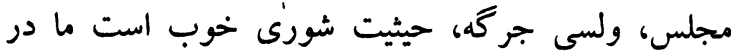

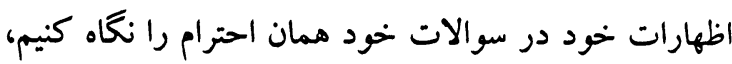

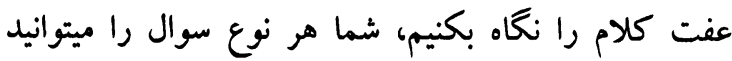

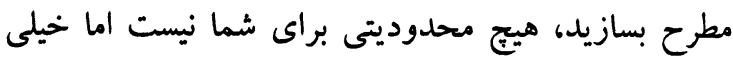

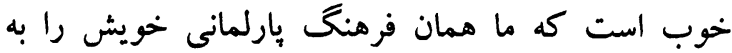

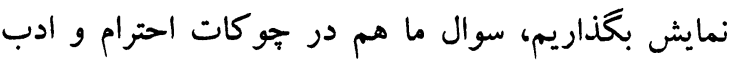

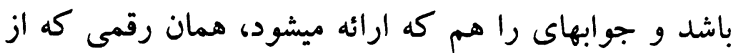

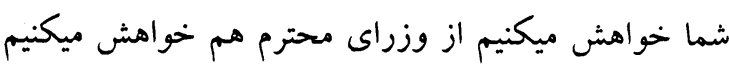

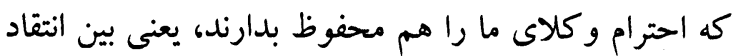
و بين اهانت ما و شما فرق قائل ميشويم هر نوع سوالى برانى

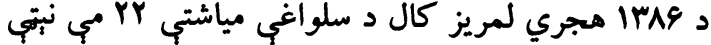

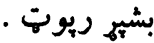

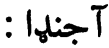

د تجارت او صنايعو بناغلي وزير صبب استيضاح . استيضاح وزير محترم تجارت و صنايع ورئ صنابع

تلاوت كلام الله مجيد توسط قاضى نذير احمد

حنفى . ............ (2)

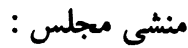

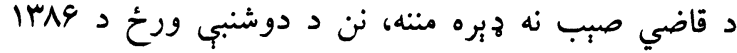
هجري لمريز كال د سلواغبي د مياشتب دوه ويشتمه نبته

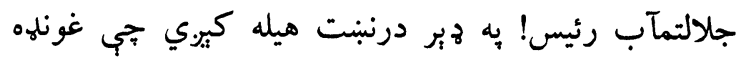

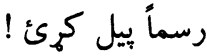
رئيس مجلس : ريما لئ

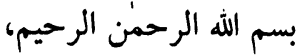
درنو، محترمو وكيل صاحبانو! د آجندا سره سم نن كه الرها

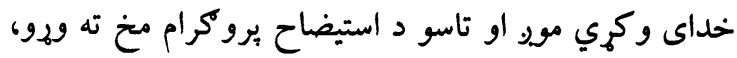

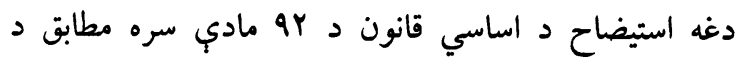

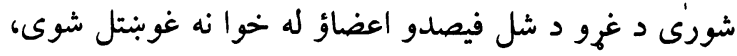

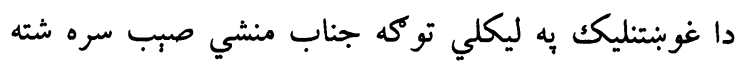

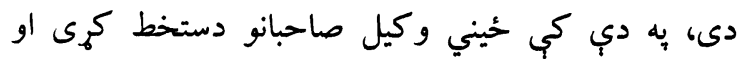

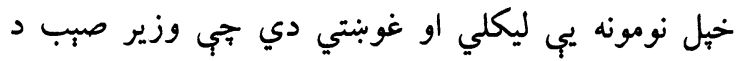

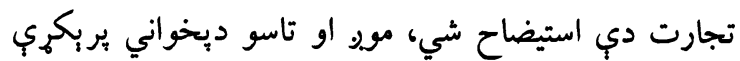

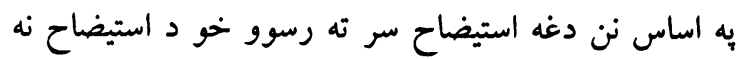
مخ كي، بيش از اينكه وزير صاحب تشريف بياورند و بحث شروع شود، جند نقطه را وكيل صاحبان محترم خدمت شما تذكر ميدهم، به اساس مادة بو قون قانون اساسى

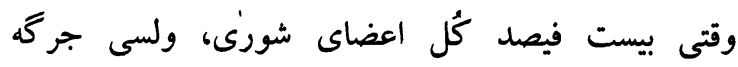
تقاضاى استيضاح وزيرى را داشته باشد ولسى جرى

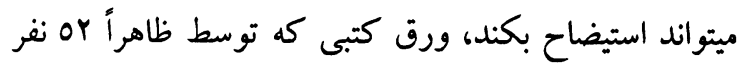

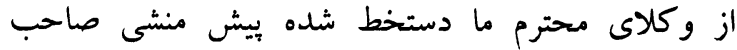

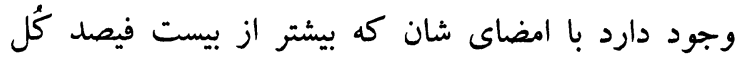
اعضاى شورى را تشكيل ميدهد، استيضاح مطابق به اين

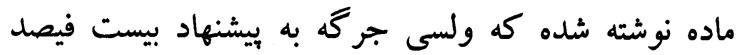




\section{رئيس مجلس :

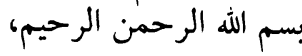
وكلاى بسيار عزيز! به نمايندگى از همة شما تشار تشريف

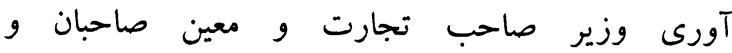

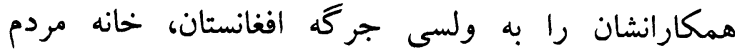
افغانستان خوش آمديد ميگويم به اساس فيصله قبلى شما

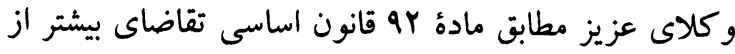

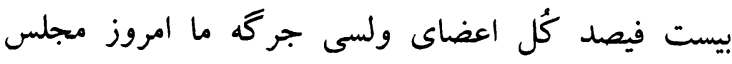
استيضاحيه از وزارت محترم تجارت را داريم به استناد مادة Yو قانون اساسى بيست فيصد اعضاى ولسى جر گه تقاضاى استيضاح را به صورت كتبى انجام دادند، اسناد استيضاح

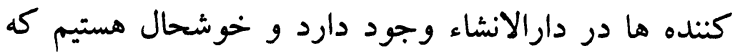

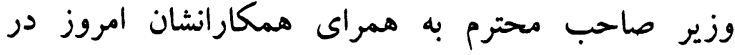

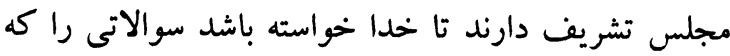

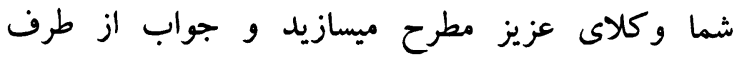
وزارت محترم تجارت ارائه شود، ييشتر و كلاى محترم ما و ميساب شما صحبت كرديم كه، استيضاح به هيج صورت به به معناى ورد

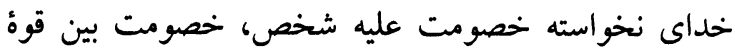

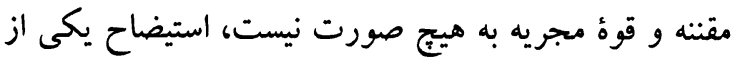

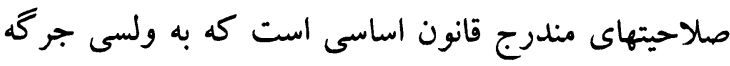

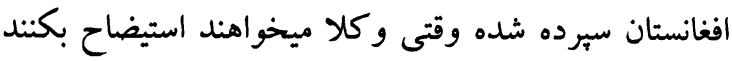

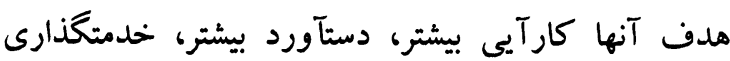

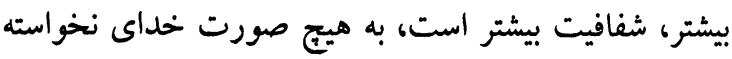

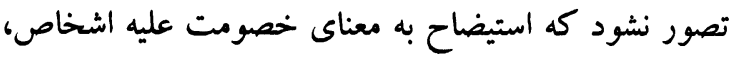

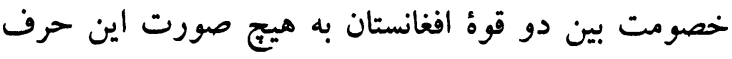
نيست، اخر جنين ميبود قانون اساسى افغانستان اساساً استيضاح را در جو كات قانون تجويز نميكرد، من اميدوار هستم كه در فضاى صميميت و با همين نيتى كه هم قوة

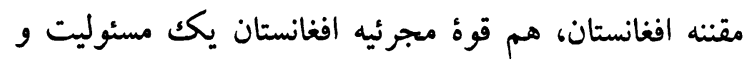

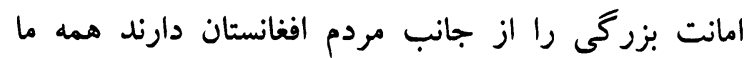
اعضاى يكك نظام به نام دولت جمهورى اسلامى افغانستان

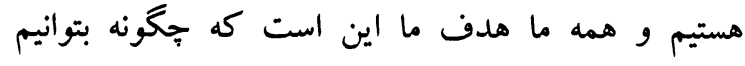

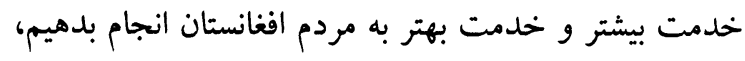

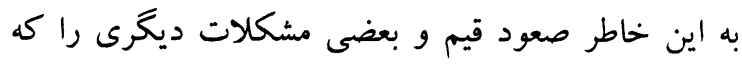

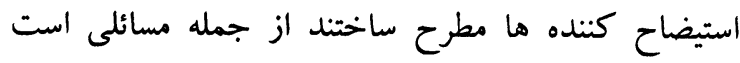

داريد شما حق داريد مطرح بسازيد فقط خواهش من همين است به نوبت صحبت خواهيم كرد اعضاى محترم

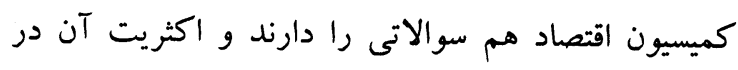
جمله همين or نو نفرى است كه امضاء كردند و و دوستان

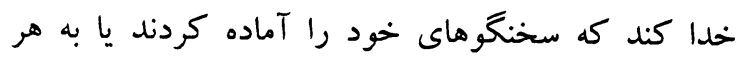
شكل كه خدا خواسته باشد بيش ببريم، سمه ده ده جناب

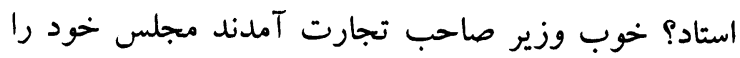
شروع ميكنيم، از ايشان دعوت كنيد كه تشريف بياورند به تالار . داكتر رمضان بشر دوست : به نام خداوند بزرى و و به ياد شهداى عزيز دوس افغانستان، اول

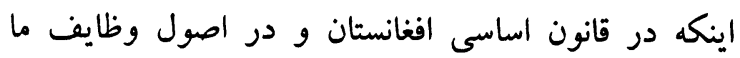

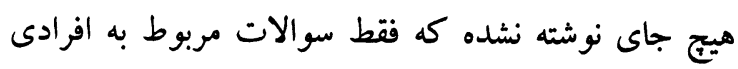

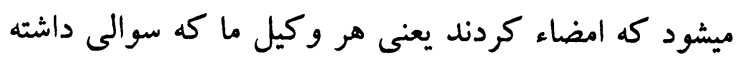

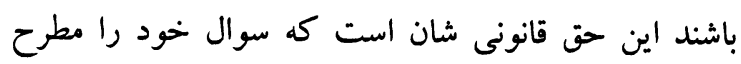

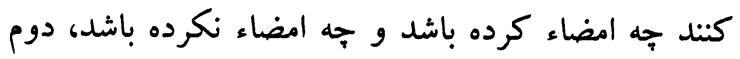

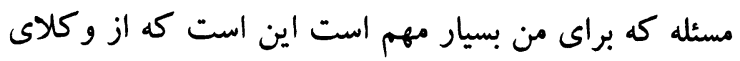

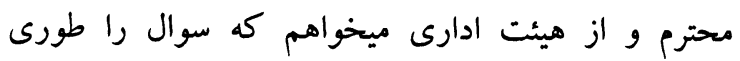

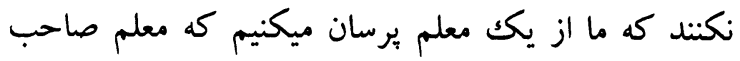
دو جمع دو جند ميشود و او بكويد دو جمع دو جهار ميشود و بعد مسئله ختم شود، مسئله بسيار مهم است، مسئله

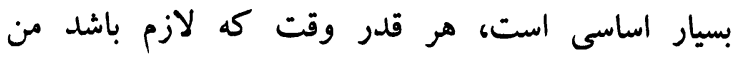
ميخواهم در اختيار وكلا گذاشته شود تا همه حرفها كُ كفته

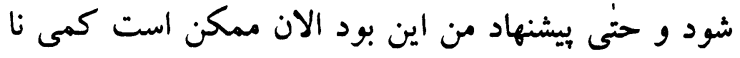

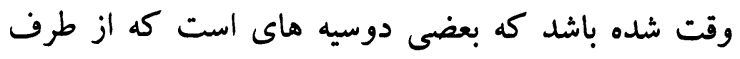

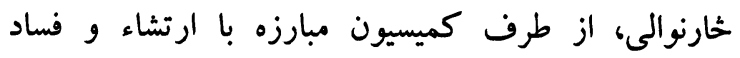
ادارى در مورد وزير صاحب تجارت وجود دارد و واين

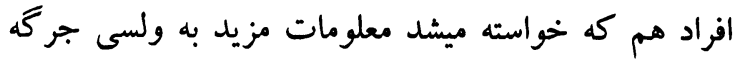

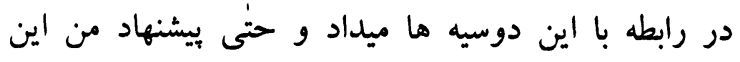

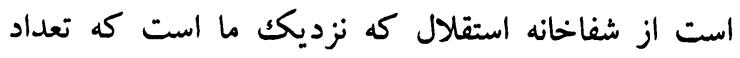

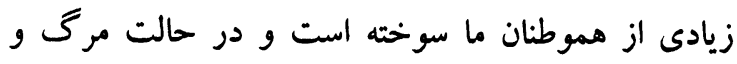
زندگى به سر ميبرد، هيئتى از شفاخانه ليسه استقلال هم مبنه

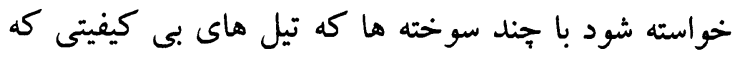

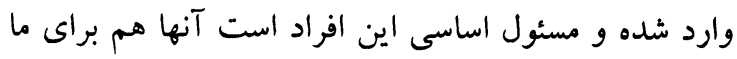
يك توضيحاتى ميدادند خوبتر ميشد . 
قبل از آن ميخواستم كه جند كلمه راجع به وظايف

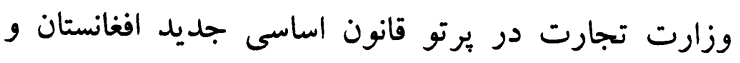

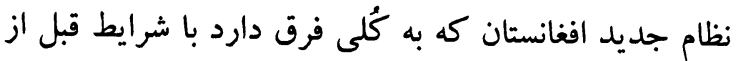

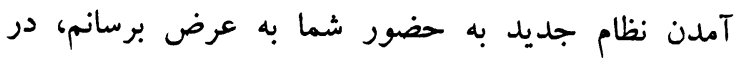

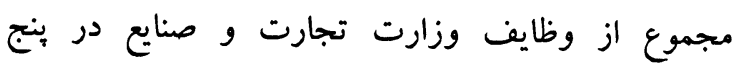
موضوع عمده و اساسى خلاصه ميشود كه عبارت است ونت ونت

1- فراهم آوردن تسهيلات جهت انكشاف يكك سكتور خصوصى فعال و رقابتى، كه در آن رقابت سالم نقس

عمده داشته باشد .

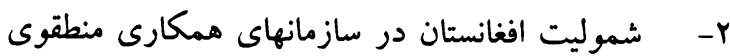
براى بهبود وضع ترانزيتى بين افغانستان و ساير كشورها كه هـانهان

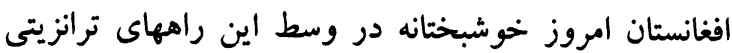

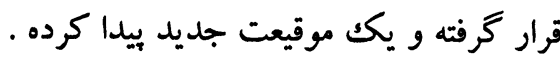

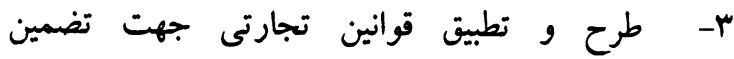
عملكرد مؤثر و عادلانه در اقتصاد بازار كه جطور ماني

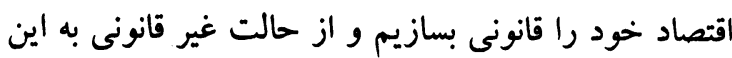
طرف بكشانيم و كدام قوانين را ما ايجاد كنيم .

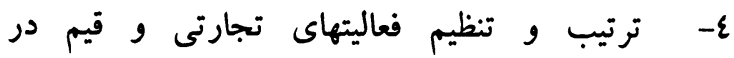

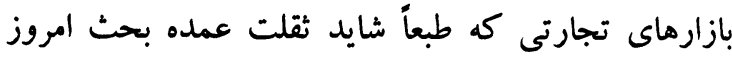

$$
\text { روى همين موضوع متمر كز شود . }
$$

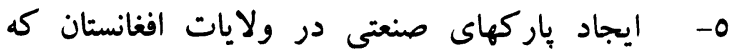

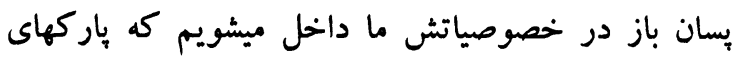
صنعتى در كجا احداث ميشود و به جه منظور آنس احداث

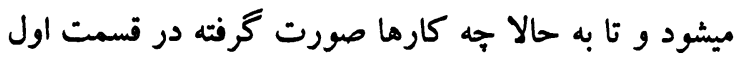

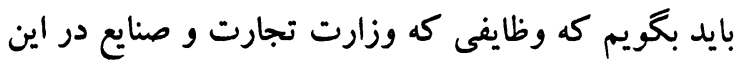

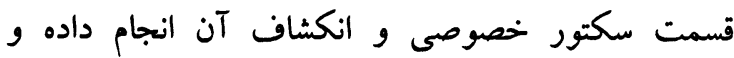

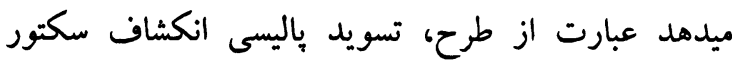

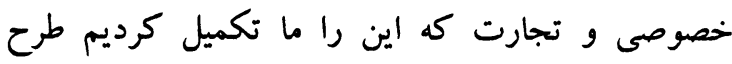
ستراتئى رسمى سازى اقتصاد افغانستان كه ما ما جطور

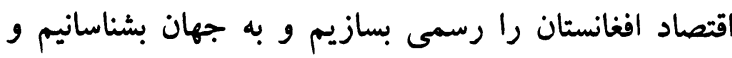

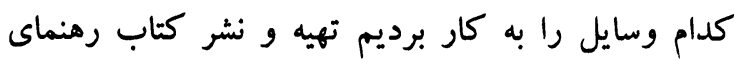
سرمايه گذارى خصوصى و تجارت در افغانستان كه اين

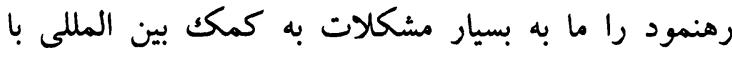

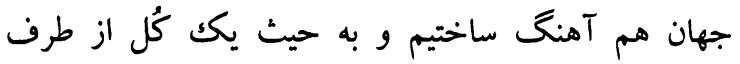

كه امروز مطرح خواهد شد و توسط وزير صاحب و

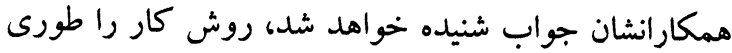
كرفتيم كه يكك سوال را وكيل صاحب ما مطرح ميسازد و بعد جواب توسط مهمانان ما شنيده ميشود، بعد ميرويم به ميه

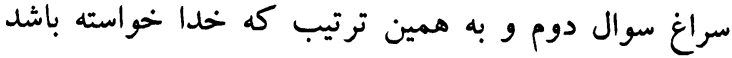
فرصت كافى هم براى سوال كننده و هم برائ ترائ جواب

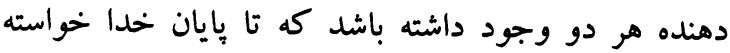

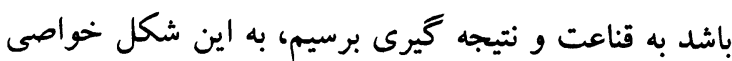

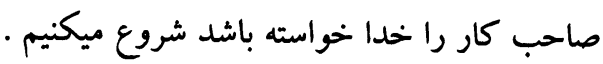
محمد امين فرمنگ ( وزير تجارت و صنايع افغانستان ) :

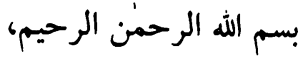
جناب رئيس صاحب! من ميخواستم خواهش كنم كه اتر امكان داشته باشد، اكر در آغاز براى من فرصت من دادئ ماده شود

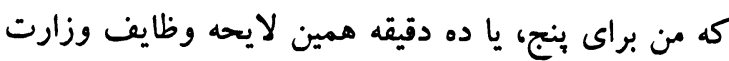

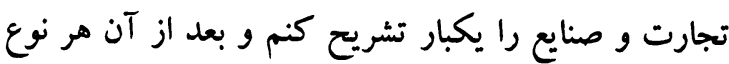
سوالى را كه وكلاى محترم داشته باشند در برتو همين

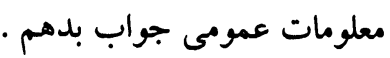
رئيس مجلس : درست است اول به وزير صاحب جانس ميدهيم كه صحبت خود را بكنند بعد شما سوالات خود را را ارائه كنيد ماته بفرمائيد وزير صاحب! محمد امين فرمنگ ( وزير تجارت و صنائ وزيع افغانستان ) :

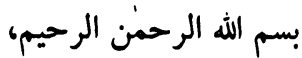
جناب جلالتمآب رئيس صاحب ولسى جرگه جمهورى الرحي

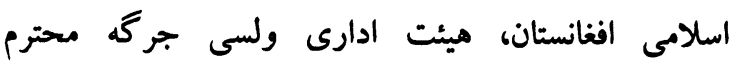

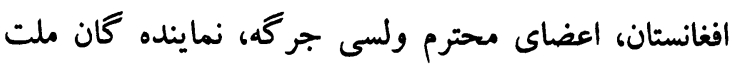

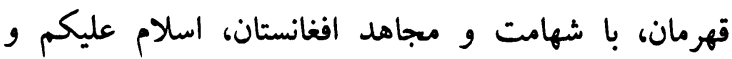

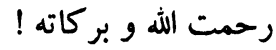
براى من امروز جاى بس افتخار است كه مطابق به درخواست و يا فيصله كه از طرف اين مجلس بن بزري

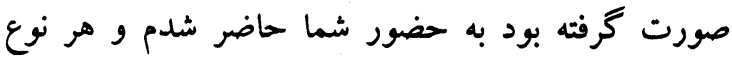
سوالاتى كه شما راجع به اوضاع اقتصادى افغانستان

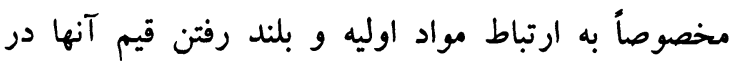

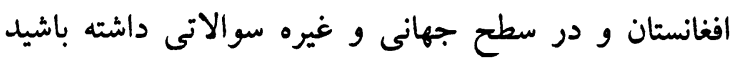

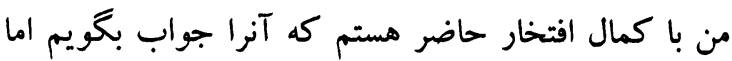


تاجكستان، موافقتنامه همكارى سه جانبه تجارتى و و

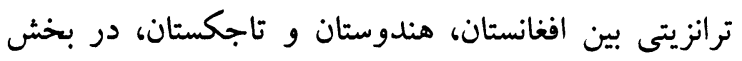

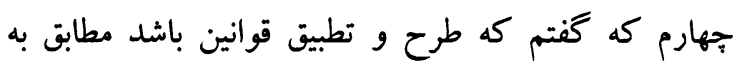

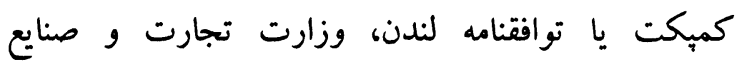

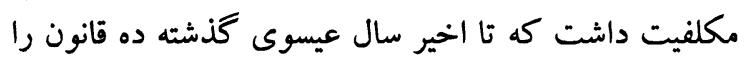
به غرض اينكه تجارت افغانستان تنظيم شود و بايد جامعه

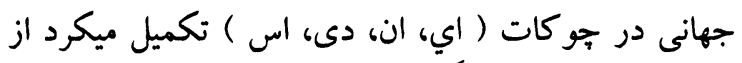

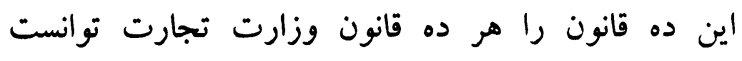

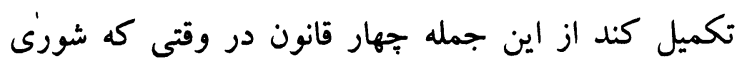

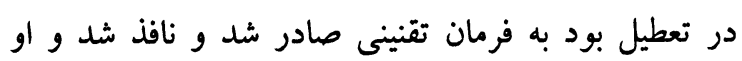

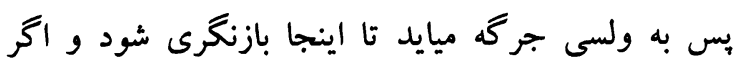

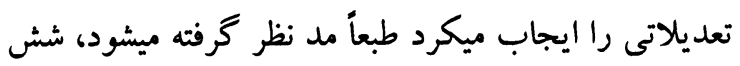

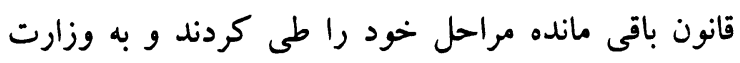

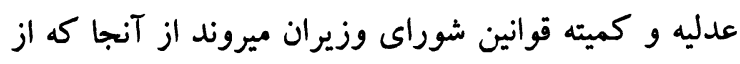

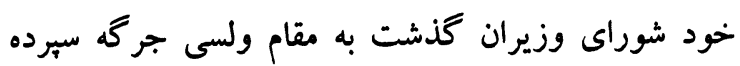

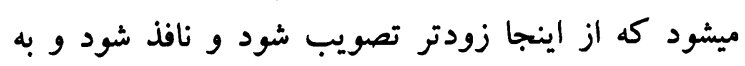

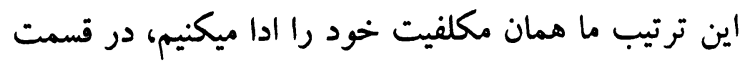
بنجم بر علاوه اين ده قانونى كه ما مكلفيت داشتيم نظر به به مانه

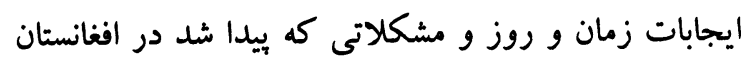
ما سه قانونى ديخر را هم روى دست گرفان وفيم كه تكميل شدند و مراحل خود را طى كردند قانونى كه بايد از

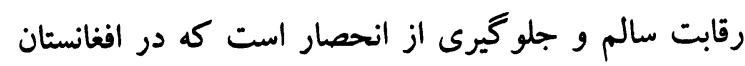

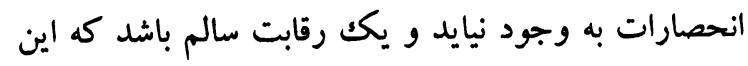
باعث انكشاف اقتصادى افغانستان شود، طرح تعديل قانون ونان ونان

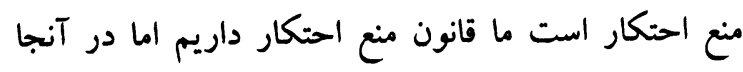
بعضى تعديلات را ايجاب ميكند كه احتكار صورت نغيرد

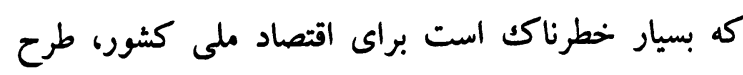
تعديل قانون سرمايه گذارى است كه جند سال قبل ساخته شده بود شرايط امروز تغير كرده اين را بايد با شرايط سلهاري

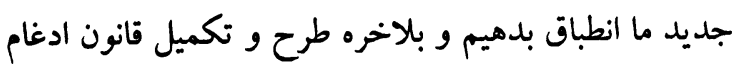

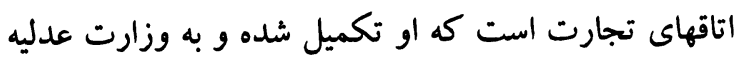

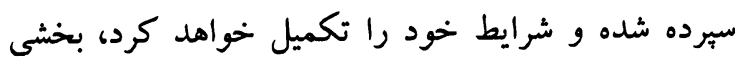

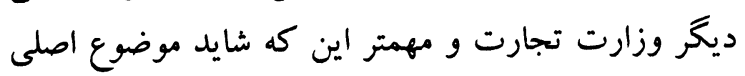
بحث امروز ما وشما هم همين موضوع باشد مسئله قيمتها
جامعه بين المللى به صورت اقتصاد رسمى افغانستان مورد

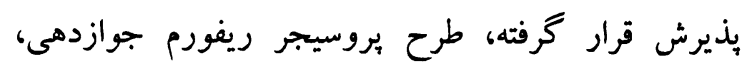

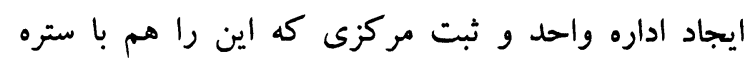

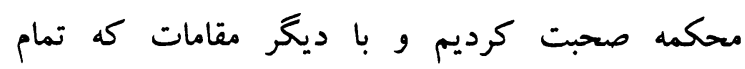

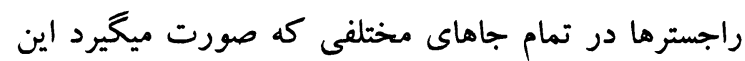

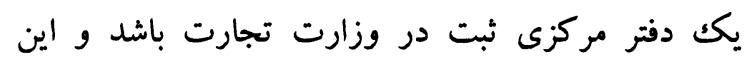

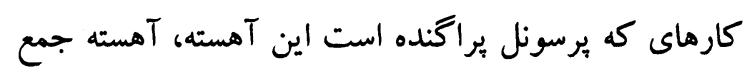

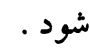

7- طرح و ارائه باليسى سكتورى در جو كات همين

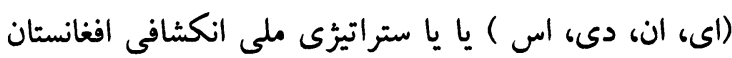

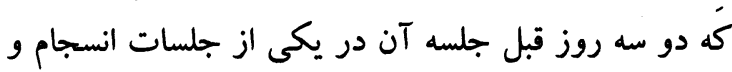

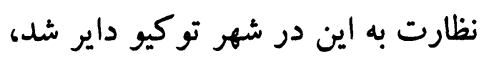

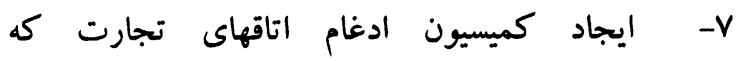

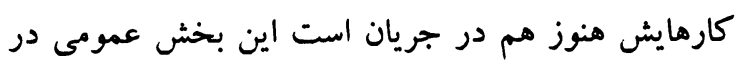

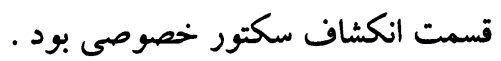
در قسمت شموليت افغانستان در بعضى سازمانهاى بين المللى و غير از اين همكاريهاى منطقوى افغانستان توانسته

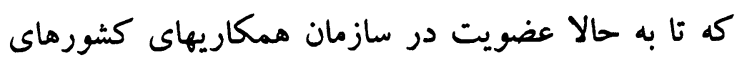

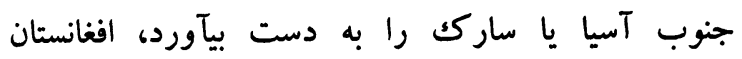
عضويت سازمان همكاريهاى منطقه ايكو را به به دست

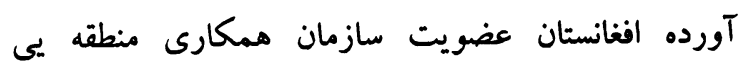

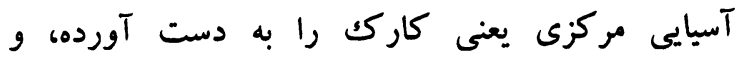

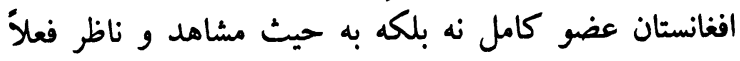
در سازمان تجارت بين المللى جهانى يا ( دبليو، تى، او )

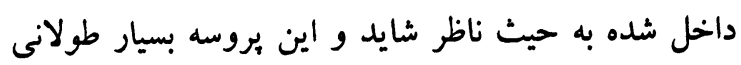

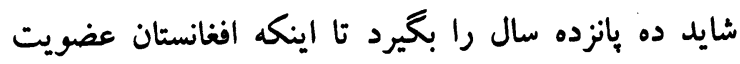

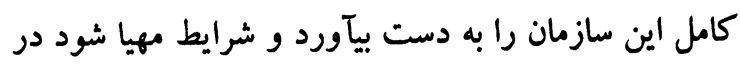

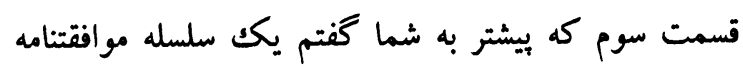

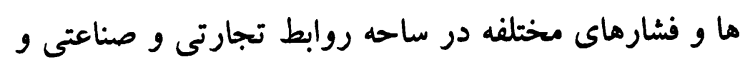

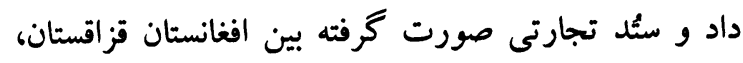

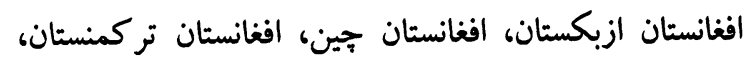

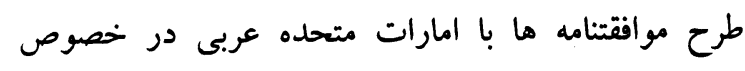

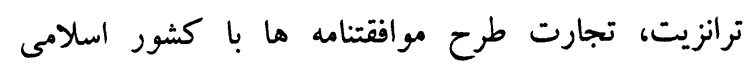

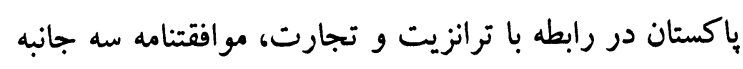

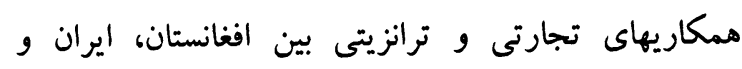


بائين بيايد همين حالا در بازارهاى افغانستان مواد اوليه و مواد نفتى ارزانترين قيمت است در تمام منطقه و اين را ما ما مان

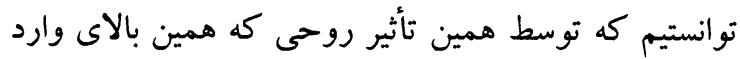

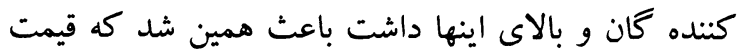
بائين بيايد در بهلوى آن ما به يكك سلسله مجالسى كه ونه

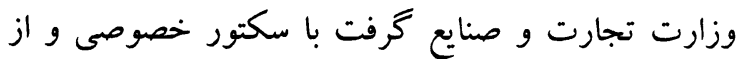
سكتور خصوصى بايد تشكر كنيم در اينجا كه با بسيار علاقمندى، وطندوستى و همكارى با مردم افغانستان قبول

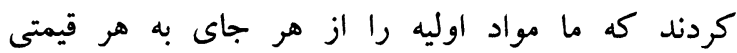

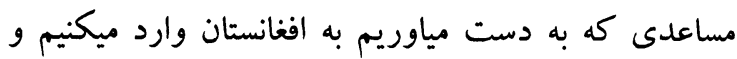
بلدون گرفتن مفاد اين را به هر جاى ميرسانيم و همين كار

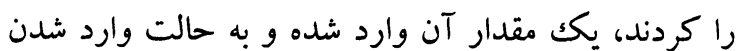
است و اين هم بالاى قيمتها تأثير انداخته كه شايد بسيار وند

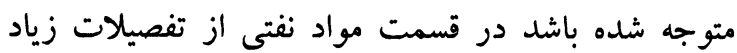
من صرف نظر ميكنم همان شش هفت ماه يِ بيش بحرانى

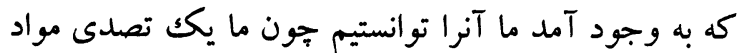

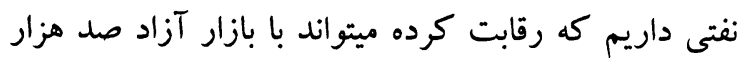
تن امرى كه رئيس صاحب جمهور افغانستان داد كه داد خريدارى شود و او در صورت نوبتى وارد افغانستان شد

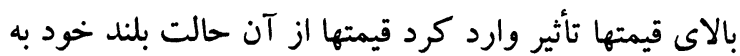
يائين آملد و امروز هم همان قيمت راير وا با نوسانات بسيار

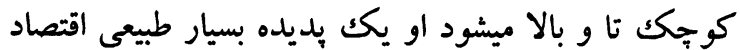

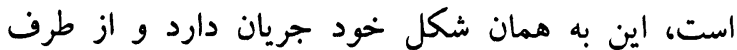
مردم كدام شكايتى نيست فقط در قسمت كاز ئك اند اندازه

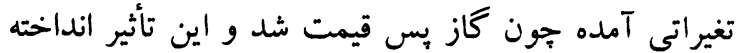
بالاى افغانستان و در قسمت كاز بين مراكزى كه كاز

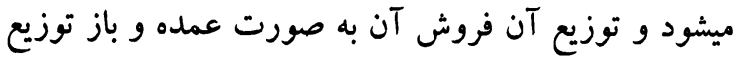
آن در دهات دور دست و جاهاى دور رفته اين طبعاً هم

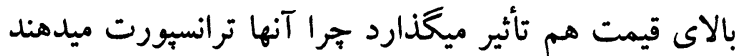
و ميخواهند يك جيزى مفاد كنند آنها هم مردم غريب

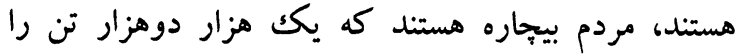

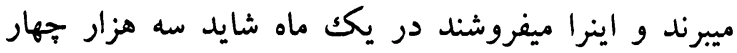

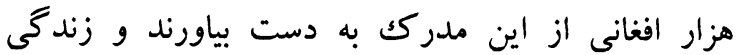
خويش را بيش بيرند و باز در قسمت قيمتهاى آنها اكر

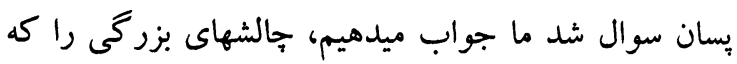

است تنظيم قيمتها و فعاليتهاى تجارتى كه در اين رابطه به حضور شما به عرض ميرسانم:

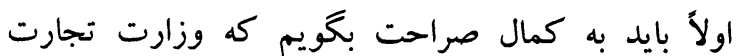
وزارت كنترول كننده قيمتها در بازار نيست، اين را داديت ورآغاز دورة مؤقت اين مسئله كنترول قيمتها و تعين و تثبيت

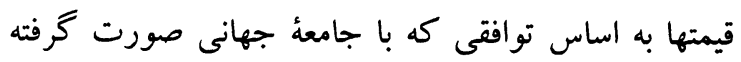
اين از بين رفته و اين صلاحيت را وزارت تجارت ندارد،

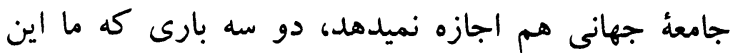

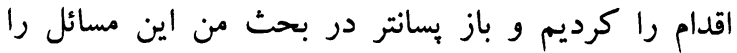

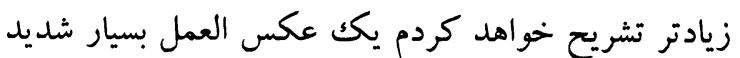

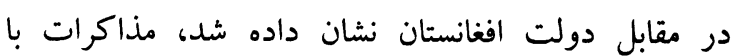

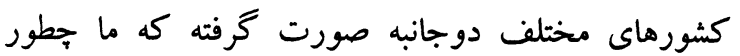

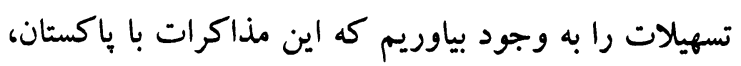

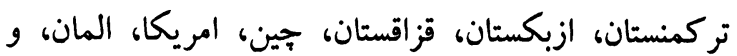

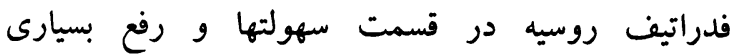

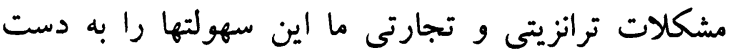
آورديم در بهلوى آن ما توانستيم كه در همين وقتى كه تهن تهن بحران مواد غذائى بود يكك سلسله كمكهاى بسيار عاجل

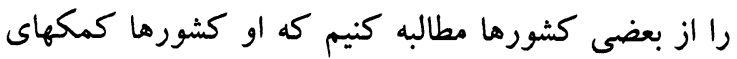

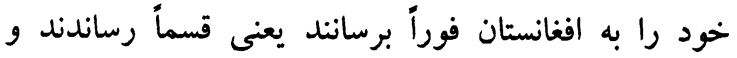

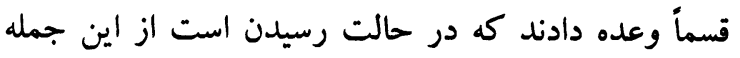
جمهورى تركمنستان آرد مقدار يكك هزار تن، تيل ديزل

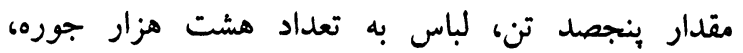

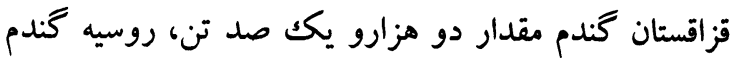

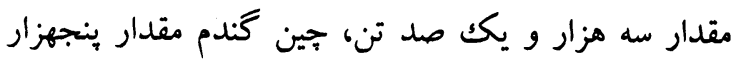

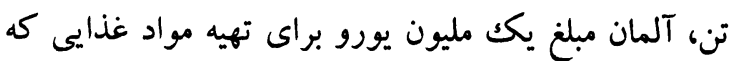

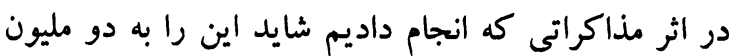

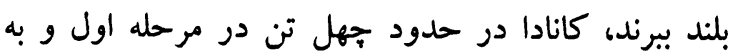
ادامه آن در مراحل مختلفه اضافه ميكند، كانادا كمكهاى

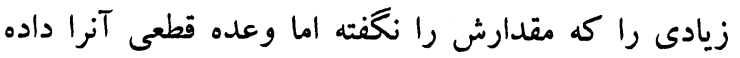

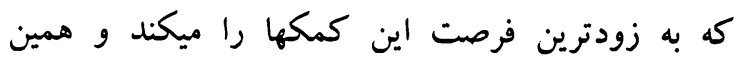

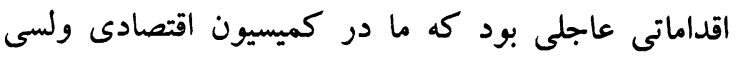
جر گه قبلاً گفته بوديم، كه ما انجام بود ميدهيم انجام دام داديم و و

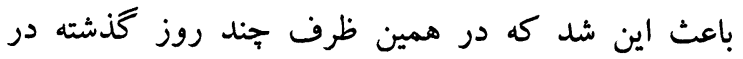

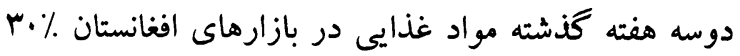


بازار جهانى بلند رفته و هيج اين بول رانه وزارت وارت ماليه

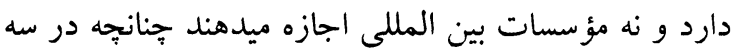
جهار روز بيش در كانفرانس تو كيو مؤسسه IMF تهد المديد

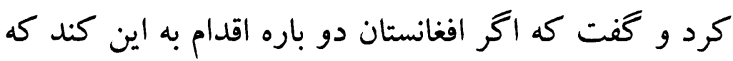

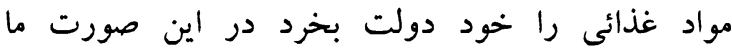

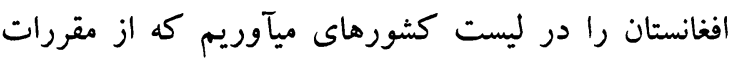
بين الملى تخطى كرده و كمكهاى بين المللى را بالاى

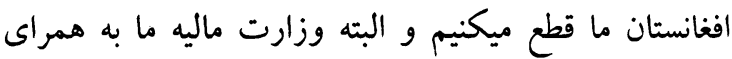

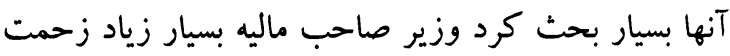

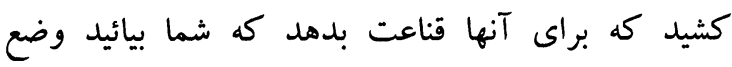

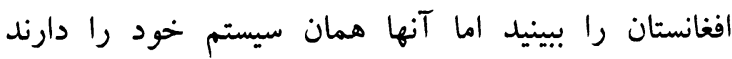
ميكويند بايد كه از كمكهاى بين المللى استفاده ميكنيد

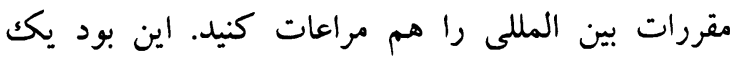

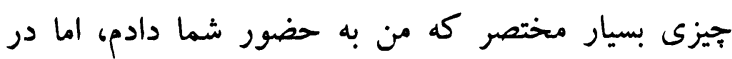

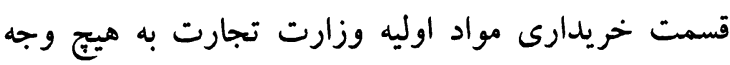

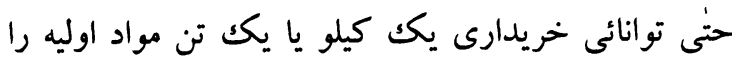
ندارد كه آنرا به بازار عرضه كند، به به به كلى ائى اين حسابات

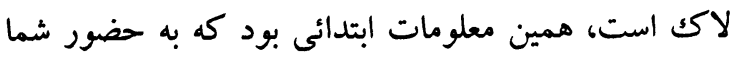

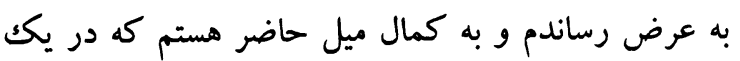
فضائى آرام با حفظ مجلس و وساندم و مخصوصاً بدون اينكه به ميه مئه يكك مناقشه ما اين را مبدل بسازيم هر نوع سوال كه باشد واشد

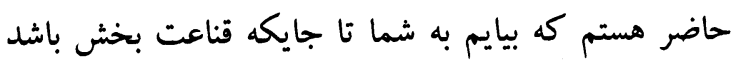

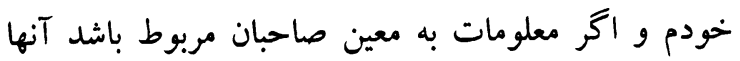

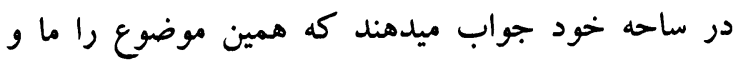

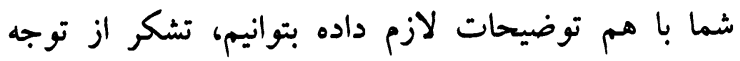

شما .

داكتر فضل الله مجددى :

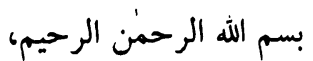

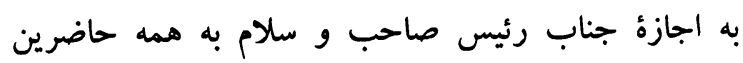

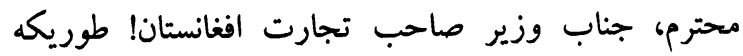

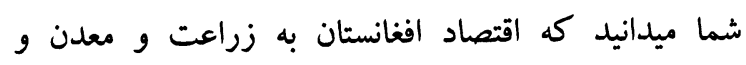

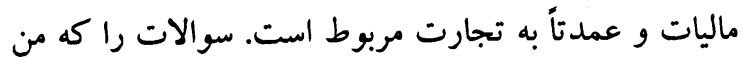

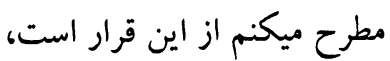
1- تجارت در حال حاضر جند فيصد عوايد ملى ما را را

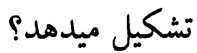

ما در مقابلش قرار داريم اولين مشكل ما مشكل با مؤسسه

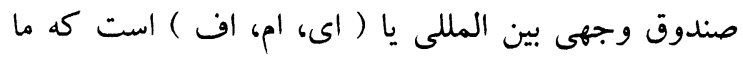

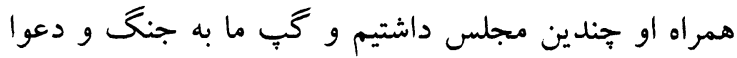
كشيد و آنها بالاى ما بسيار محدوديتها مجان را تحميل ميكردند

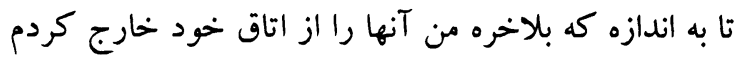

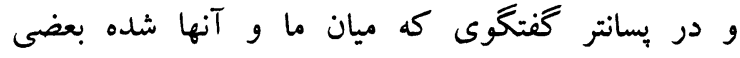

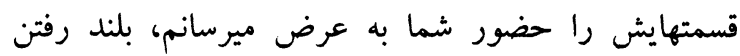

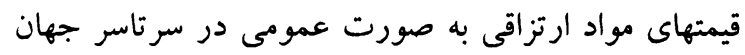

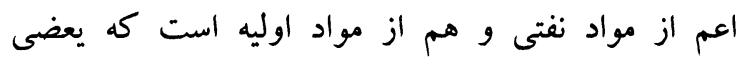

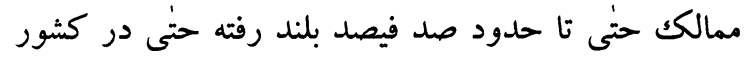

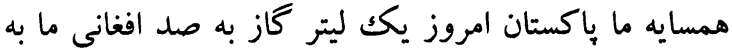

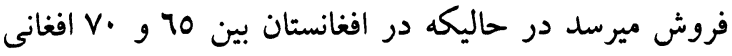
به فروش ميرسد يعنى تفاوت بين ما و بإكستان كه يكك دروس كشورى است كه راه بحرى دارد با تمام دنيا ارتباط ئل

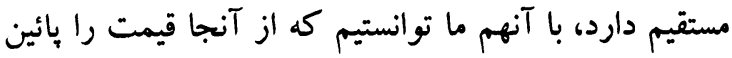
تر نگاه كنيم در قسمت مواد نفتى ما ميتوانيم در بازار

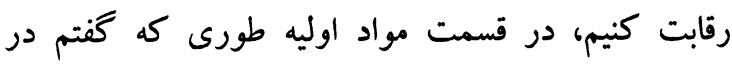

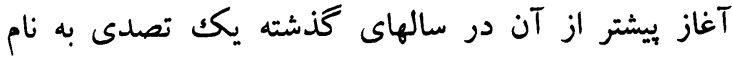

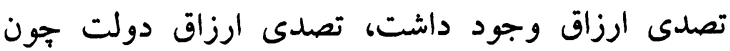
خودش از خود عوايد داشت همين تصدى ارزاق هميشه

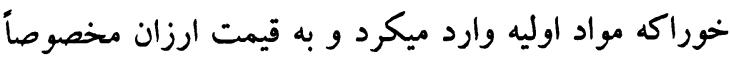
براى طبقه كه داراى عايدات ثابت هستند، مامورين دولت

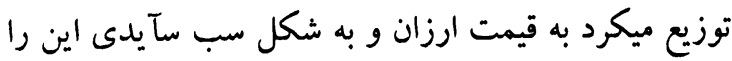

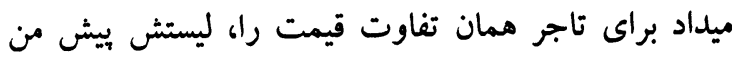

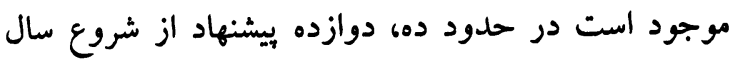

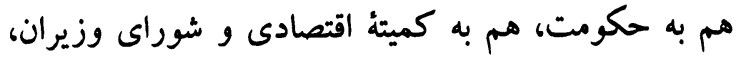
هم به كميته اقصادى ولسى جر گه و هم به ولسى جرگه كه ليستش ييش من موجود است بيشنهاد كردم كه از

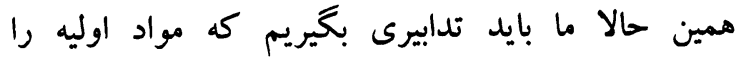

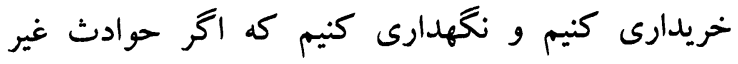

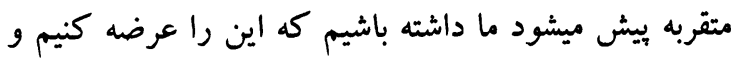

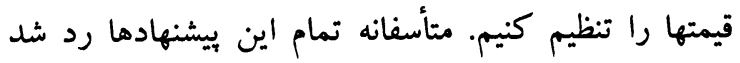

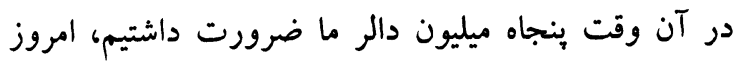
اكر اين را بخواهند دو باره فعال بسازند دو صد صد ميليون

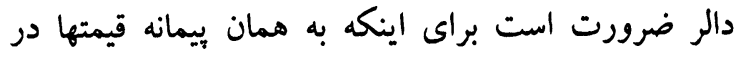


پاركهاى صنعتى و منسجم تجار متوسط كه در ولايات

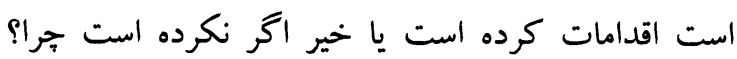
همين بود سوالات . وزير تجارت وصنايع : در اين هيج شكك نيست جناب مجددى صاحب كه وفه اقتصاد

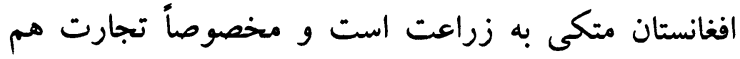

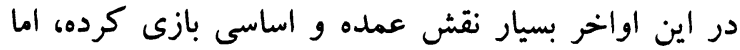

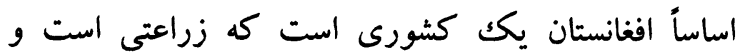

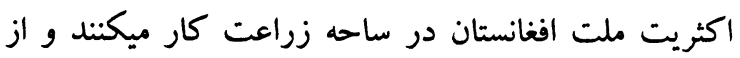
همين معيشت ميكنند. در طى حند سال اخير تا كدام اندازه

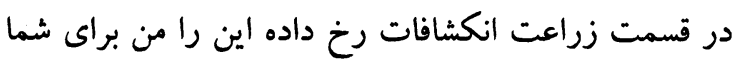

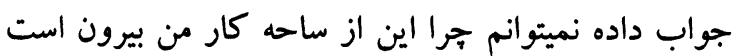
اين شايد وزير صاحب زراعت در اين قسمت جواب

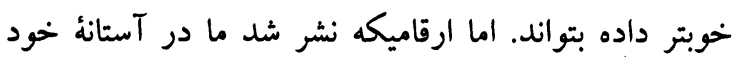

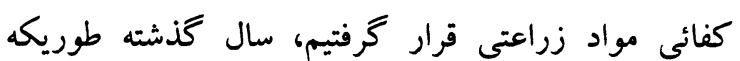

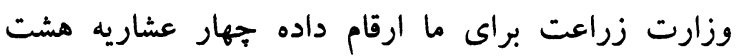
ميليون تن مواد غذائى زراعتى در افغانستان توليد شده

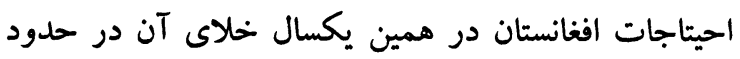

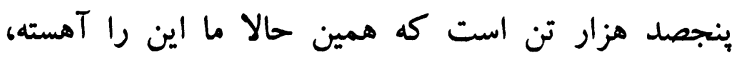

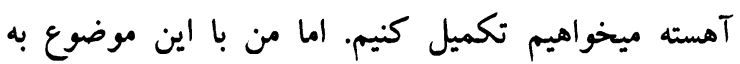

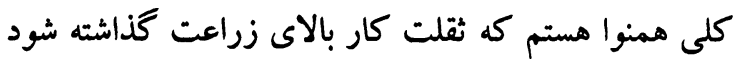
جرا زراعت نه تنها مواد غذائى، مواد اوليه براى مردم تهيه

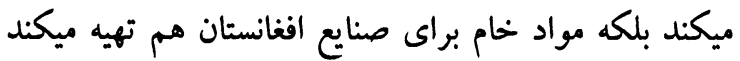

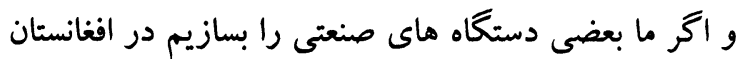
و مواد خام آنرا داخل توليد نكنيم و مواد خام و نيمه خام دام

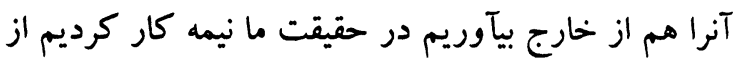
آن خاطر است كه يعنى انكشاف سكتور زئر زراعت بـان بسيار مهم است و همين حالا وزارت زراعت در بودجه جديد اسله

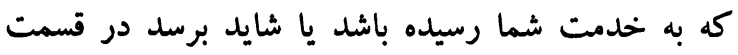

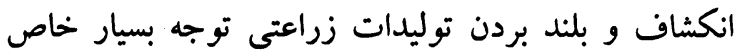

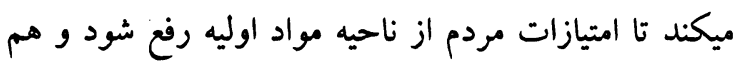

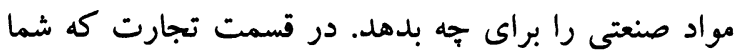

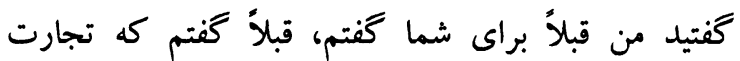

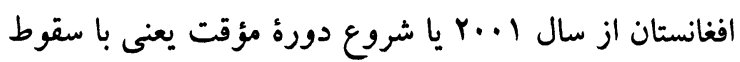

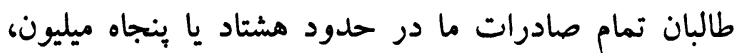

r- بيلانس بين صادرات و واردات به كدام تناسب | - 1ست؟

r- عوائد از ناحيه تجارت به مقايسه سال 19VA يعنى 

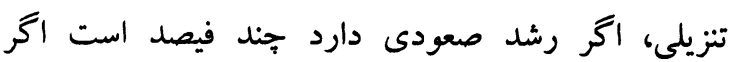
تنزيلى دارد جرا ؟ ع- بخاطر جلو گيرى از صعود قيم جه اقدامات مناسب

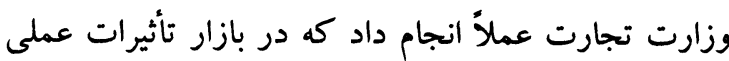
خود را بجا كذاشته باشد ؟ ورن 0- بخاطر رشد تجارت و صنعت آيا شما اقداماتى براى ايجاد واحدهاى ولايتى به خاطر ايجاد باركهاى صنعتى و منسجم كردن تجارها در ولايات انجام داده ايد يا خير؟ و السلام عليكم و رحمة|اله و بر كاته.

وزير تجارت و صنايع : شما گفتيد در قسمت زراعت، معادن و تجارت، ونهات مخصوصاً

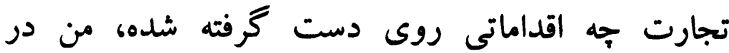
قسمت زراعت و معادن ... . داكتر فضل الله مجددى : جناب وزير صاحب! سوال من اين بود كه اقتصاد افغانستان

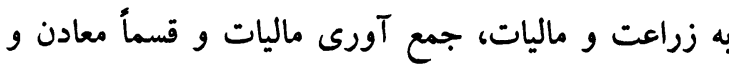

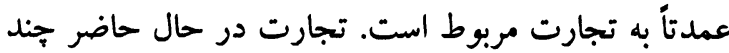

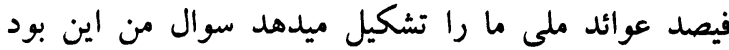

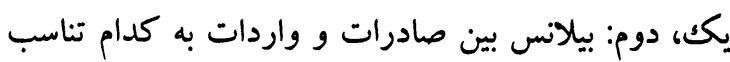
است در حال حاضر ؟ سوم: عوائد از ناحيه تجارت به مقايسه سال 19V^ يعنى

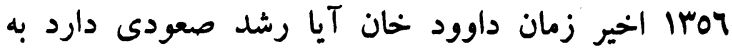

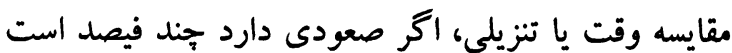
اخر تنزيلى دارد جرا؟

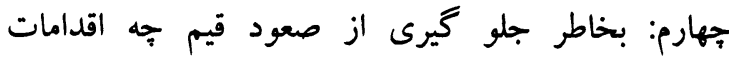
مناسب وزارت تجارت در اين اواخر انجام داده است كه هـ

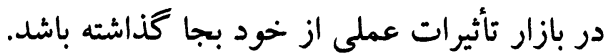
ينجم: بخاطر رشد تجارت و صنعت وزارت محترم تجارت لهارت آيا واحدهاى ادارى خود را در ولايات به خاطر نهار ايجاد 
يكك روش را كرفتيم گثنيم به همكارى يكديگر كار

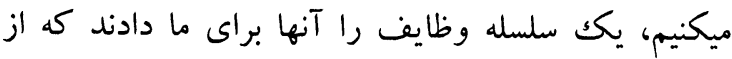

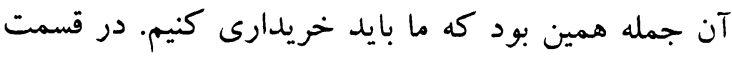

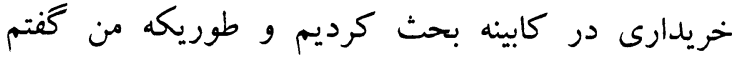

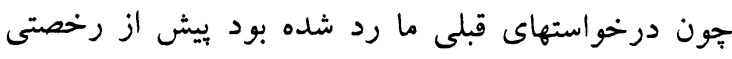

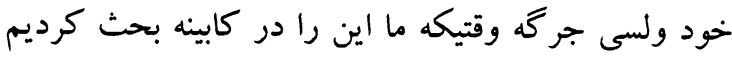
سنجشش شد صد ميليون دالر ضرورت بود كه بـ بايد دولت

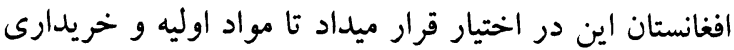

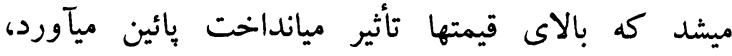
متأسفانه كه دولت افغانستان را نه IMF اجازه داد و

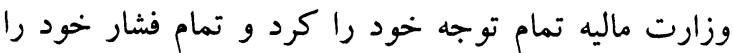

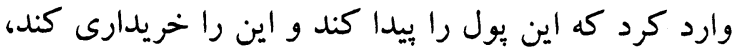

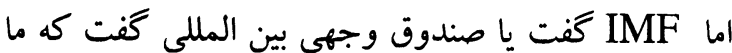

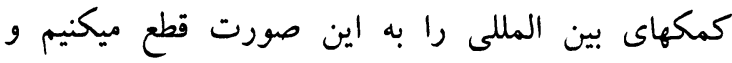

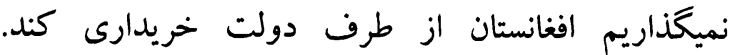

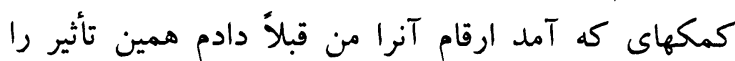

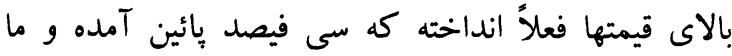
اميد ميكنيم كه با وارد شدن تدريجى اين كمكها كه دوام الدهام

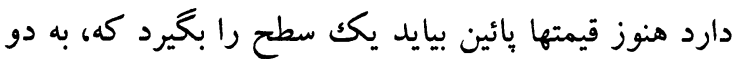

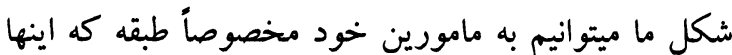

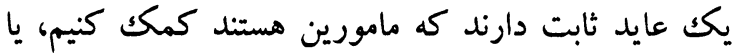

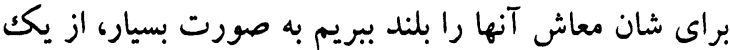

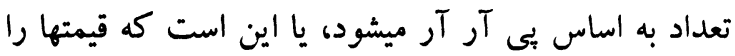

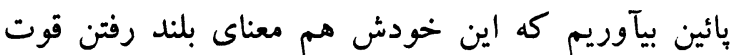

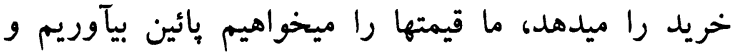

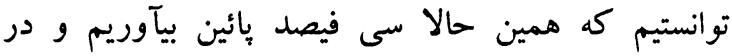
آينده انشا الله اين بلند ميرود. در قسمت ايجاد بادين باركهاى

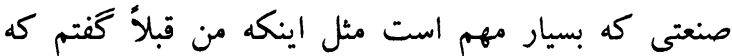

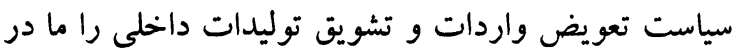

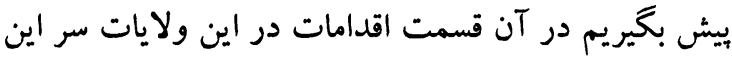
بار كها كار شده معين صاحب صنعتى ما كه مسئول همين مسئله هستند به شما مختصر توضيحات خود را را ارائه

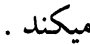

بين بنجاه تا هشتاد در نوسان بود. امروز ما توانستيم كه

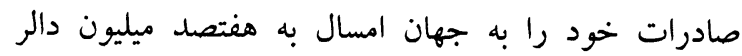

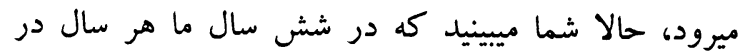

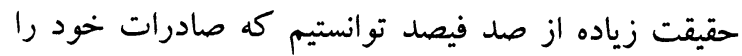

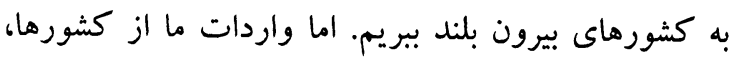

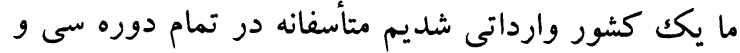
ينج سال جنگ و از بين رفتن تمام نهادهاى صنعتى و و وانى

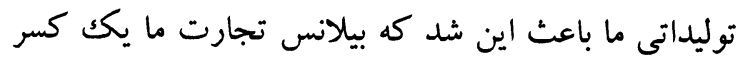

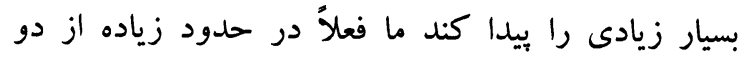

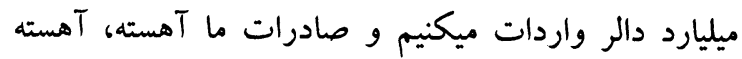

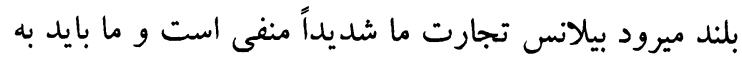
سرعت، (بعداً من اين را تشريح ميكنم به ارتباط ديخر

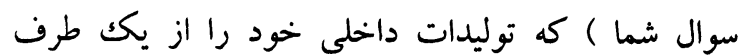
سياست تعويض واردات و ازدياد توليدات داخلى در در درد

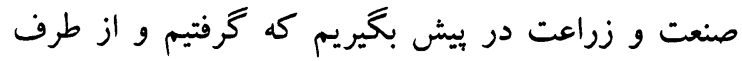
ديگر صنايع توليد كنيم جيزهاى را توليد كنيم كه بتوانيم

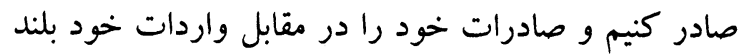

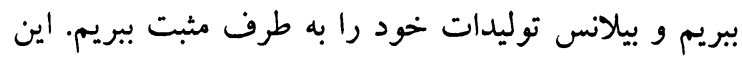

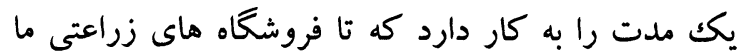

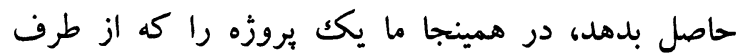

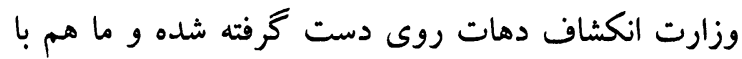

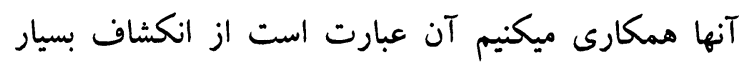
عاجل صنايع دستى در روستاهاى افغانستان است. كه اين

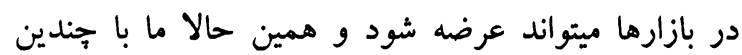

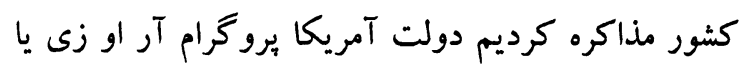
ايجاد مراكز توليد صنايع دستى و وزارت تجارت درد ايجاد

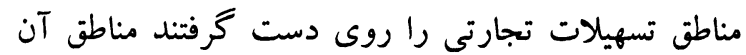
تعين شده كه در اينجا توليدات جمع شود و از از همانجا بدون مسئول گمركى به كشورهاى ماند آمريكا، آلمان،

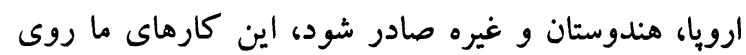

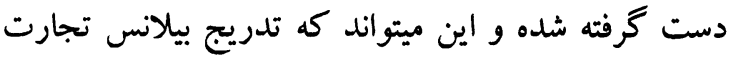

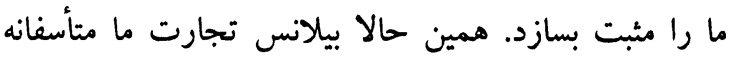

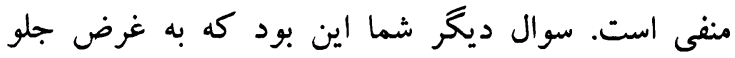
گيرى از صعود قيم شما جه كرديد؟ من قبو شبلاً براى شما

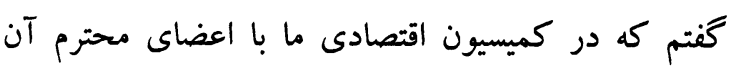


آمريتونه ايجاد كري دي خو زموبد بِلان دا دى خبي حيه

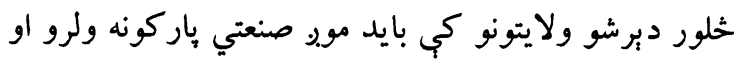

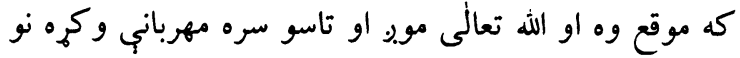

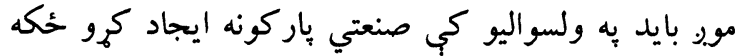

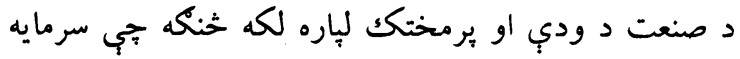

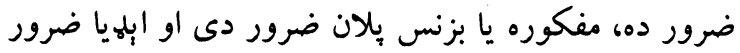

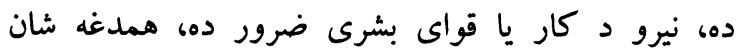

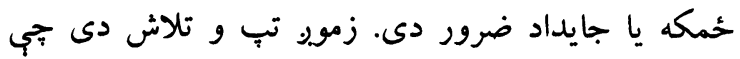

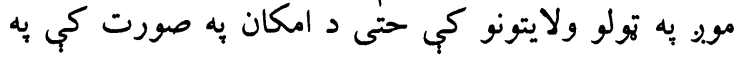

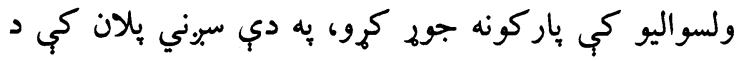

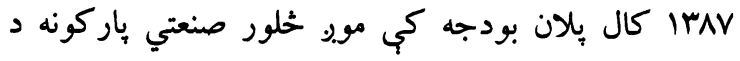

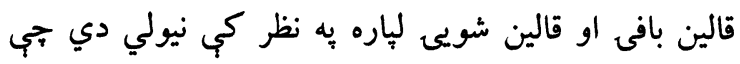

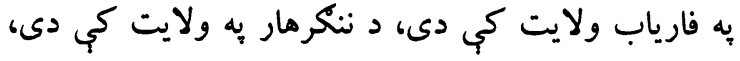

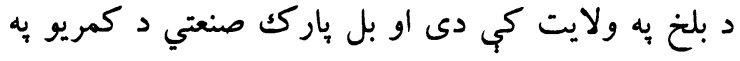

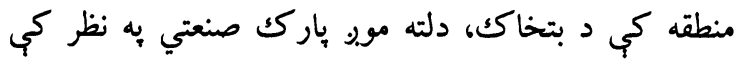

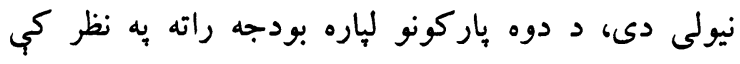

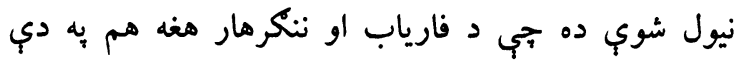

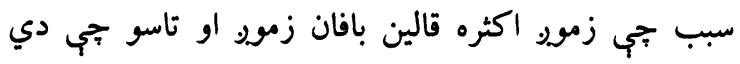

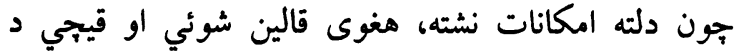

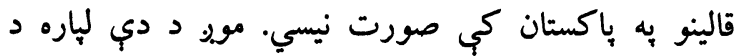

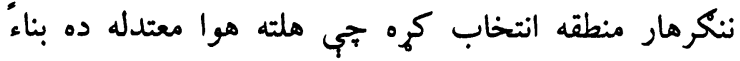

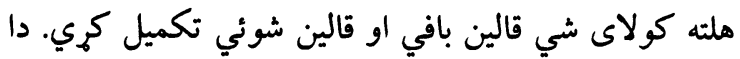

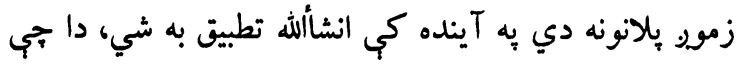

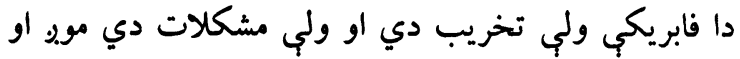

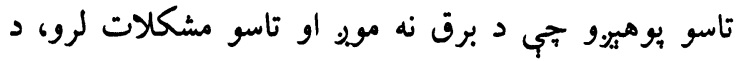
بودجب له وجي موب. ته تخصيص د صنعت به بخش كئ كي نه

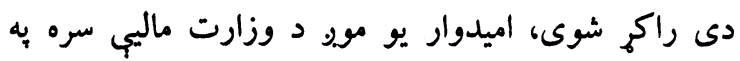

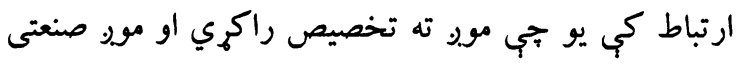

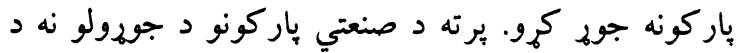

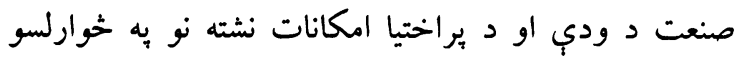

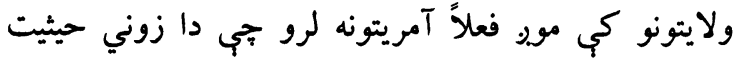

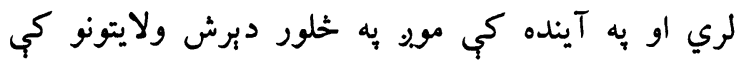

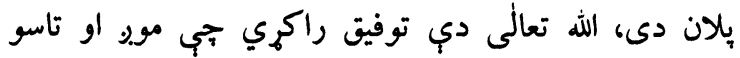
صنعتي بار كونه جوف كرو او هلته . ...
د سوداكرى او صنايعو وزارت صنعتي معين :

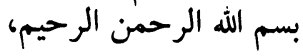
د خبل دروند او قدرمن مشر د ولسي جركي الرحب د بناغلي

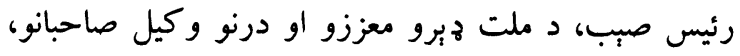

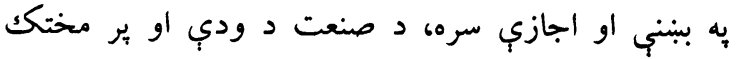

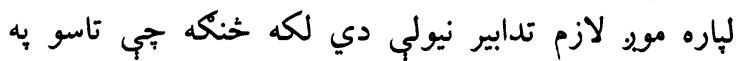

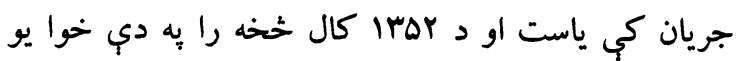

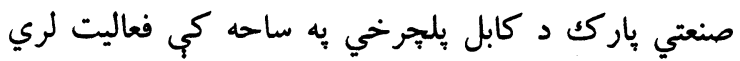

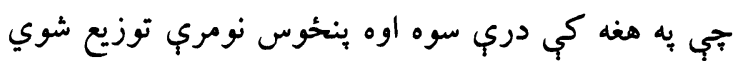

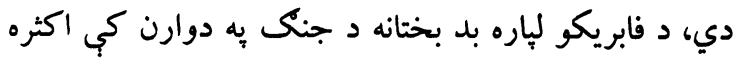

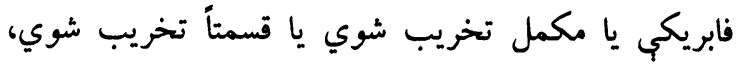
بعد د مؤقتي دوري نه د هغه به باز سازى اقدام وشو، فعلاً

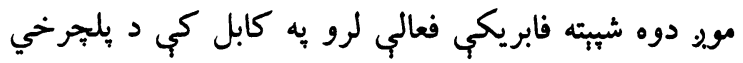

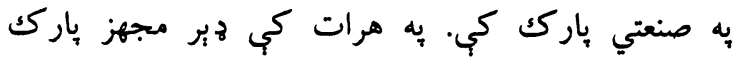

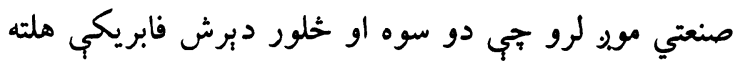

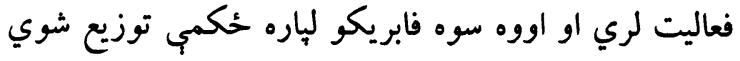
دي شايد وكيل صاحبان به جريان كي وي وي اميدوار يو هغه

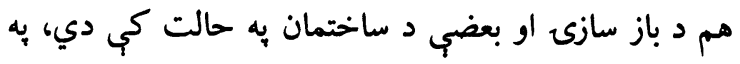

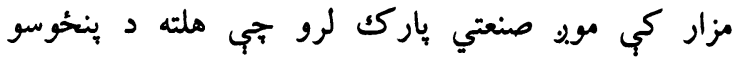

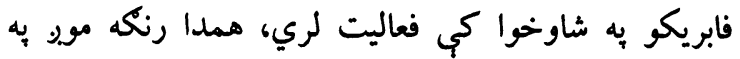

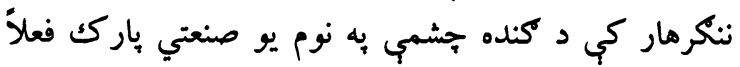

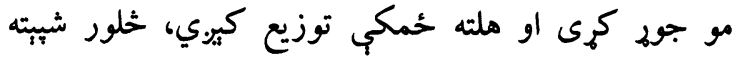

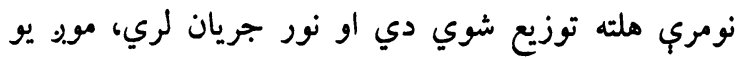

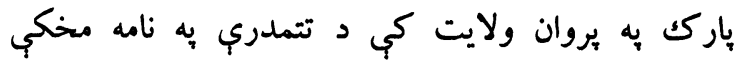
وخت كي نومري توزيع شوي هُبر كم دي، يو يو اتلس نومري توزيع شوي دي، ولبي د سنجددري يه نومي نوم يو لوري

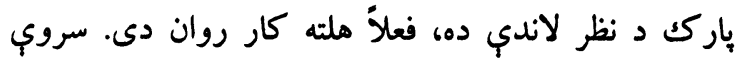

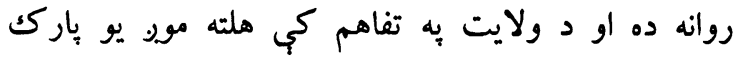

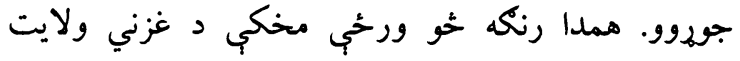

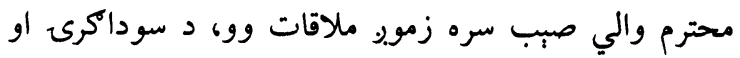

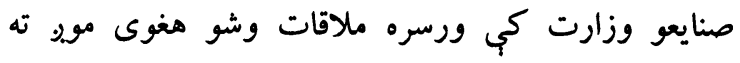

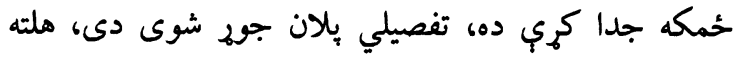

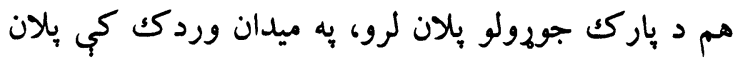

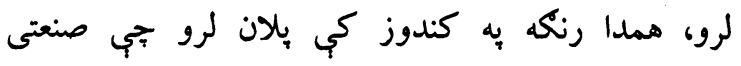

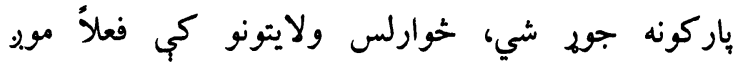


وزير صاحب كه شما تا كنون جند جواز نامه تجارتى اين شر كتهاى مافياى تجارتى را كه باعث بلند رفتن قيمتها و

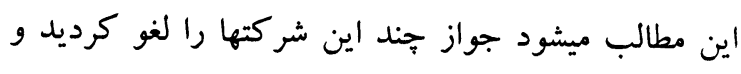

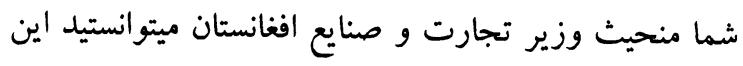

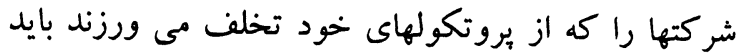

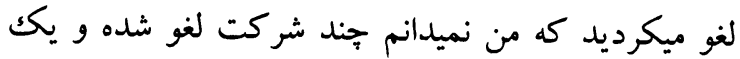

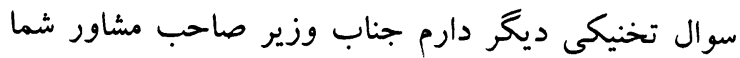

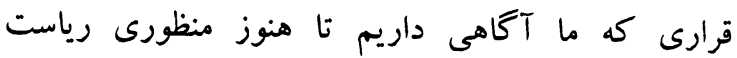

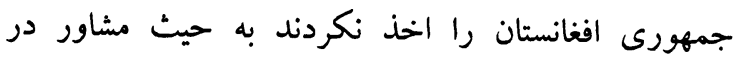

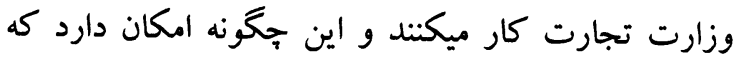
يك كسى منظورى مقام رياست جمهورى را نداشته باشد

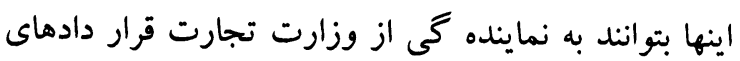

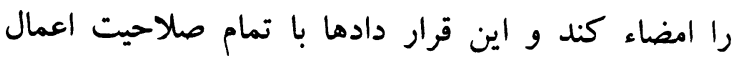
شود. سوال ديگر جناب وزير صاحب اين است قسميكه دوستان قبلى از سخنرانى قبلى هم ياد آورى كردند

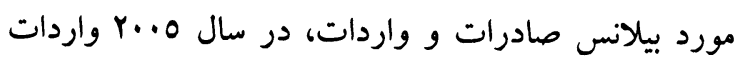

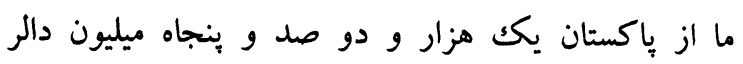

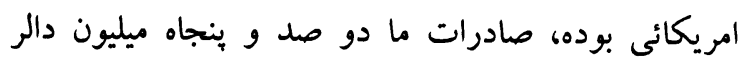

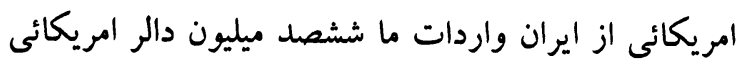
بوده و صادرات ما از دو تا ينج ميليون دالر امريكائى از ازئي

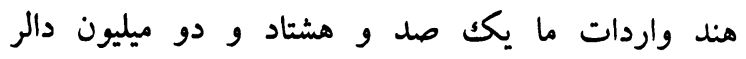

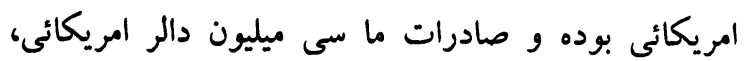

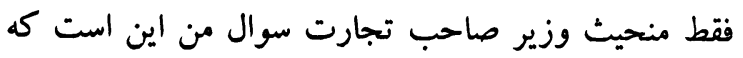

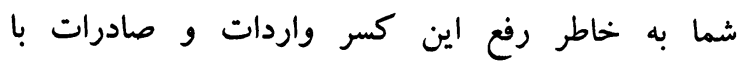

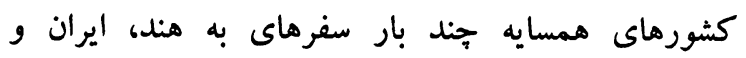

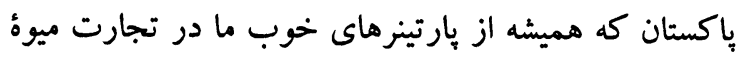

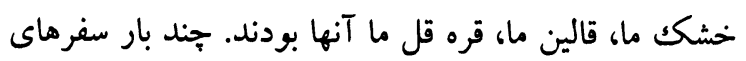
با اينها كرديد و جخگ كشور همسايه را بخاطر رفع كسر واردات و صادرات

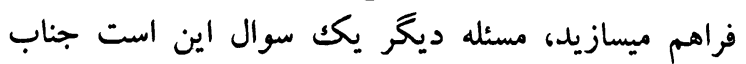
وزير صاحب كه سالانه در افغانستان بنام قالين دو ميليون دئن متر مربع قالين تولين ميشود از جمله دو ميليون متر مربع فقط تنها سه فيصد اين از افغانستان صادر ميشود و نود مئرد

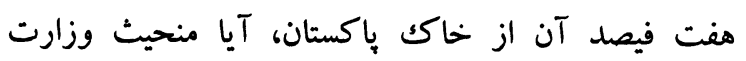

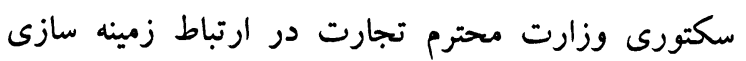

وزير تجارت و صنايع : يكك جيزى اكر اجازه باشد من افزود ميكنم آن عبارت آن از از

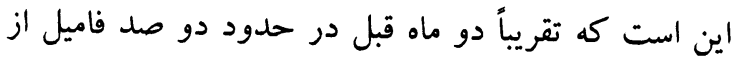
هموطنان تركمن ما كه در بإكستان قالين توليد ميكردند

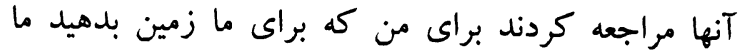

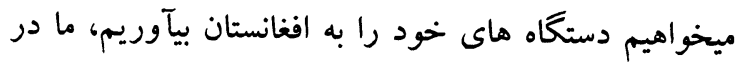

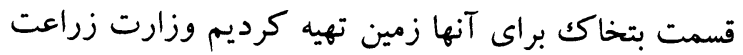

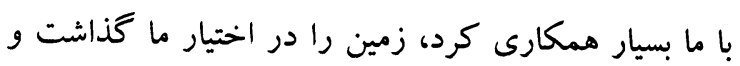

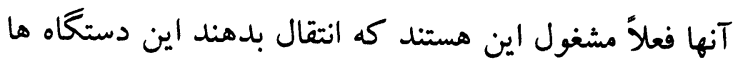

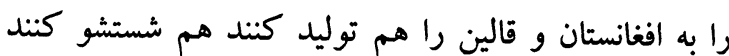
هم برش كنند هم به صادرات آماده بسازند و ما آنرا باز

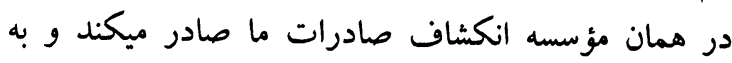

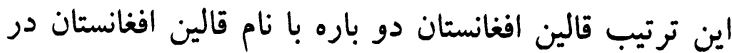

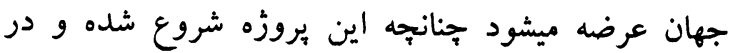

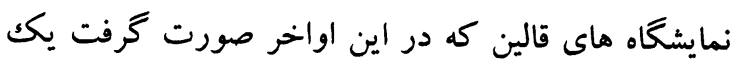
قالين افغانستان شما خبر داريد به نام باميان در جهان دان درجه إنه

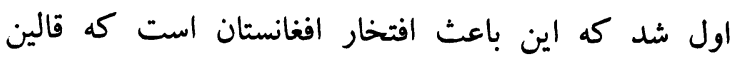

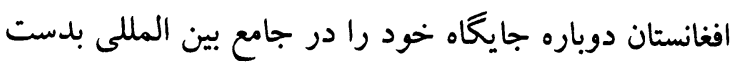

$$
\text { مير احمد جورينده : }
$$

جناب رئيس صاحب، وزير صاحب تجارت و و همراهان

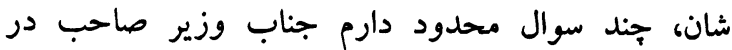

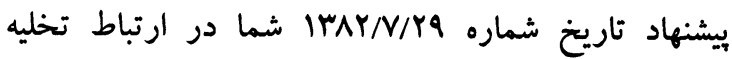
هفتاد و دو واگن تيل بى كفيت متعلقه ينج شركت توريدى طورى بيشنهاد شده به مقام رياست جمهورى كه كه

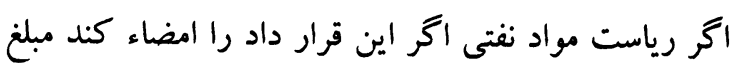

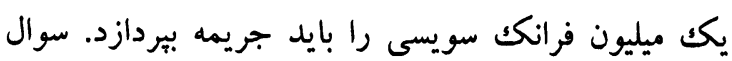
در اينجا است كه اين قرار داد را شركت مواد فراد نفتى نكرده و شركتهاى خصوصى كرده كه در اينجا نفع ميبردند، در

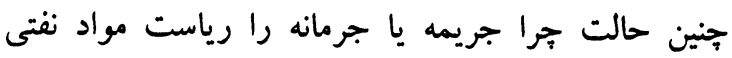
بيردازد، سوال من اين است جناب وزير صاحب و و سوال ديخر اين است جناب وزير صاحب شما هميشه شكايت داريد از مافياى تجارتى و هميشه ميگوئيد كه باعث بلند

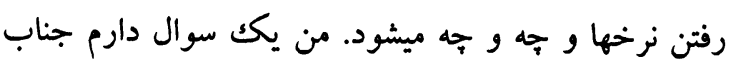


اين از بنج شش سال قبل بدينسو شروع شده و موجود

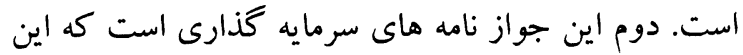

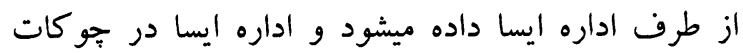

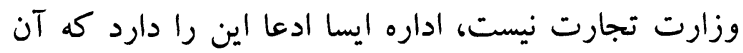
يكك اداره مستقل است خودش عوائد دارد، همين جواز

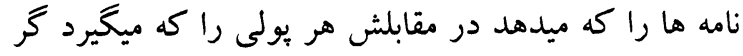

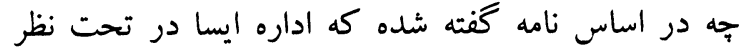
رئيس كميسيون عالى سرمايه گذارى خصوصى كار ميكند كه او رئيس كميسيون، وزير تجارت و صنايع نايع افغانستان است اما مكاتيش نزد ما موجود است، هر قدر كه ما به ونه ونه ايسا مراجعه كرديم كه اين را براى ما رايور بدهند رائ مايور

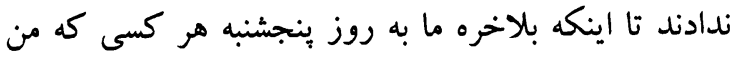

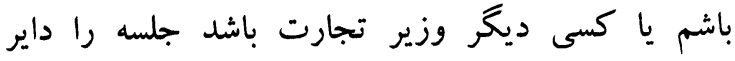
كرديم تا از ايسا مستقيماً ما سوال كنيم، كميسيون سوال كند كه كدام جوايز را دادند و كد كدام كسانيكه هنوز زمين

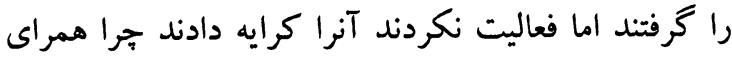

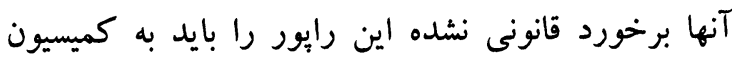

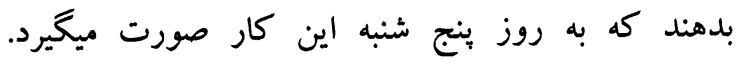

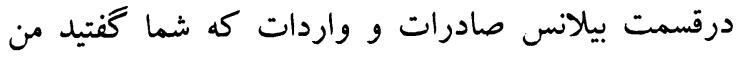
قبلاً در اين قسمت توضيحات دادم من نميخواهم كه آنرا

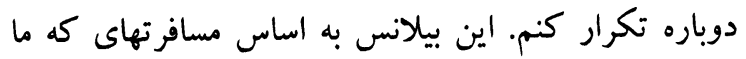

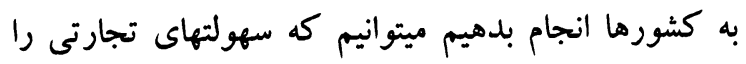

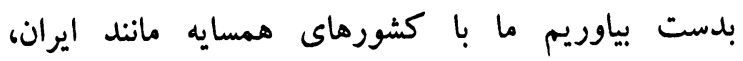

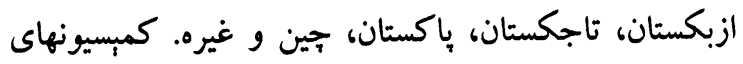
مشترك اقتصادى داريم، رؤساى كمبسيونهاى مشترك وكن اقتصادى وزير صاحب ماليه است، وزير صاحب اقتصاد

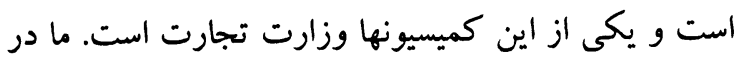
مسافرتهاى كه انجام ميدهيم با مقامات كشورهاى كه بـ بان

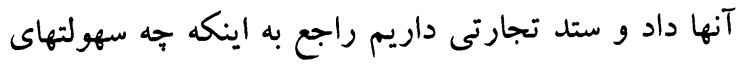

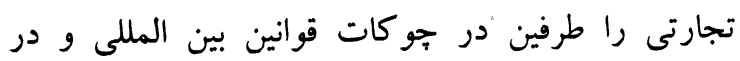
جو كات همكاريهاى منطقوى بايد صادرات و واردات

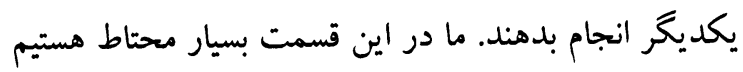

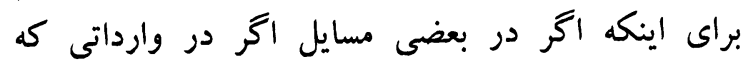
ميكنيم بسيار قيودات ما وضع كنيم آنها در مقابل صادرات

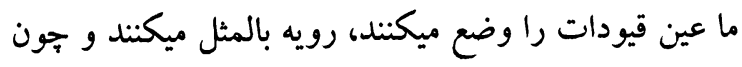

كار براى تاجران قالين اينكه شما قبلاً در صحبت خود از

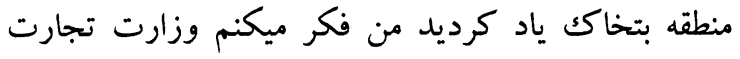

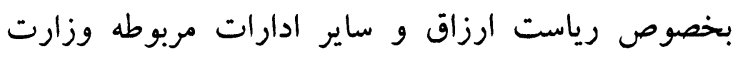

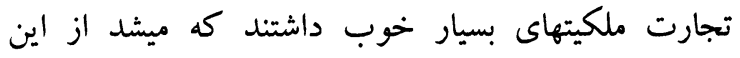

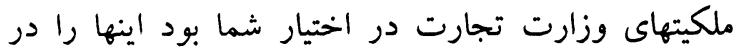

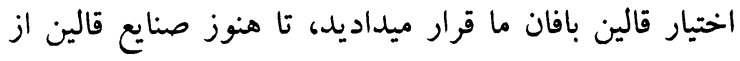

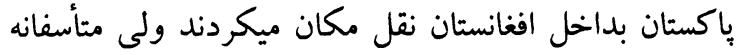

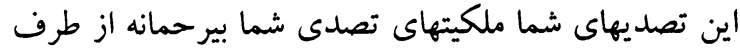

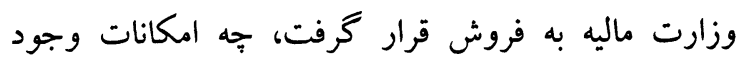

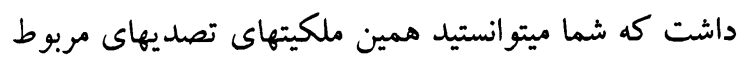

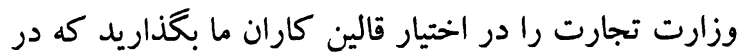
اين مورد كارهاى صورت ميخرفت و هميشه وزارت

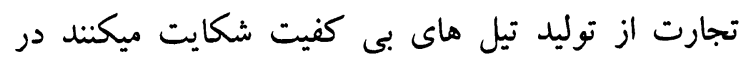

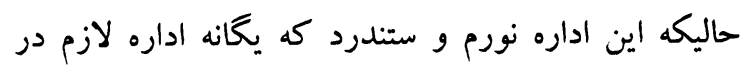

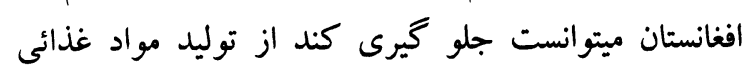

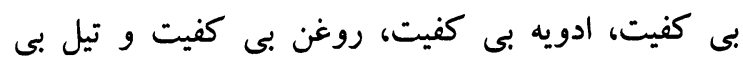

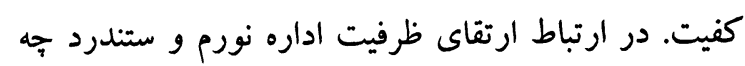

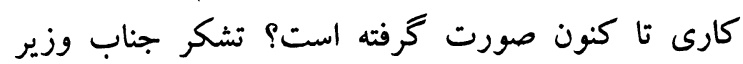
وزير تجارت و صنايع :

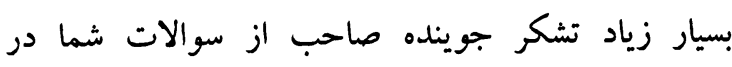

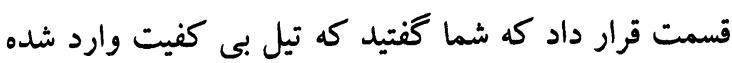

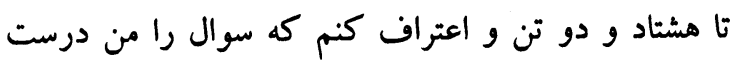

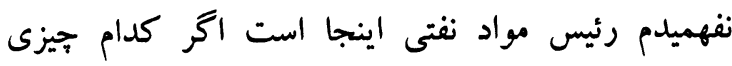

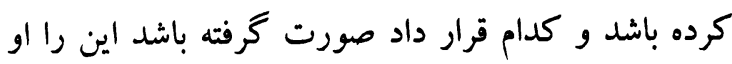
ميتواند تشريح كند. در قسمت ديخر سوالهاى شما من اولتر

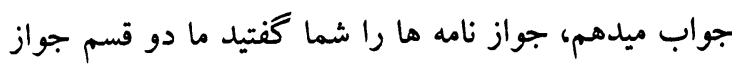

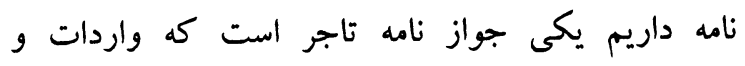

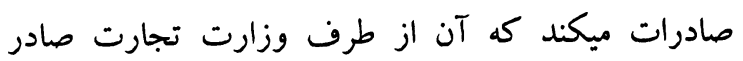

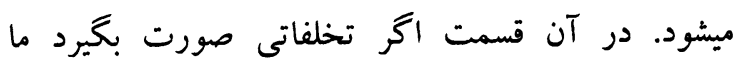

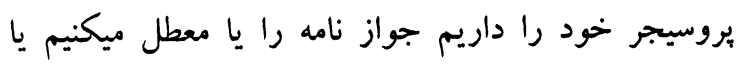
تاجر مربوطه را متوجه ميسازيم كه مطابق به جواز

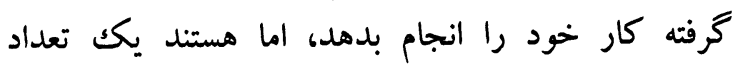

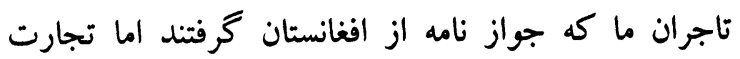

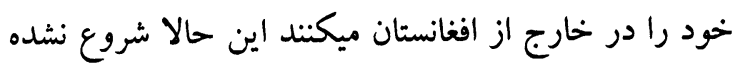


دوام ميدهيم متأسفانه هنوز يكك تعداد زياد كاركران قالين

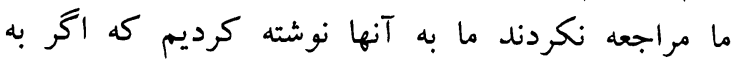

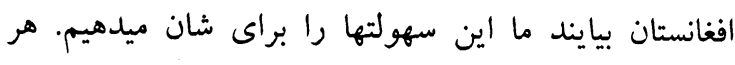

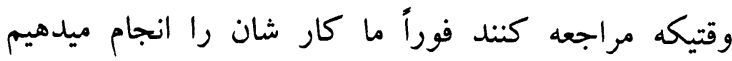

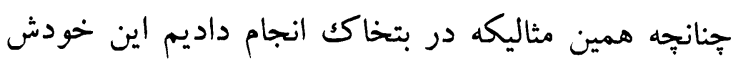

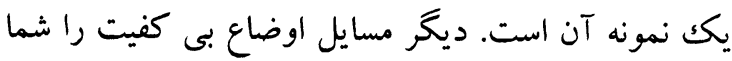

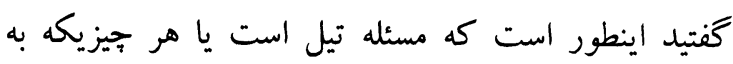
افغانستان وارد ميشود بايد كفيتش كنترول شود و و براى آن آن

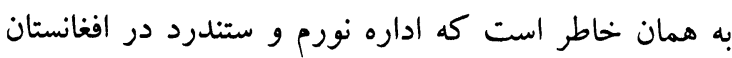

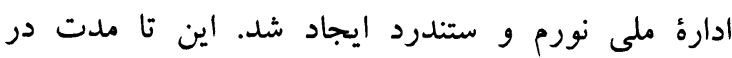

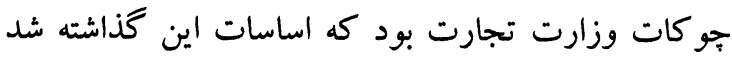

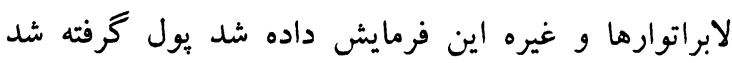
كمكك شد در بروسه

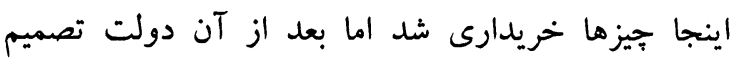

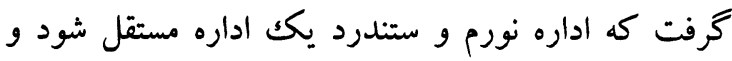

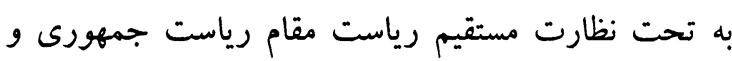
يا معاونيت اول رياست جمهورى قرار داده شود كه فعلاً

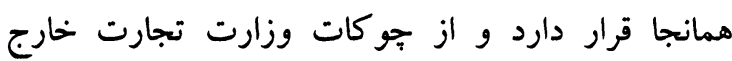
شده، وزارت با كار آن ديخر كار ندارد و تثبيت آنرا هم تهم

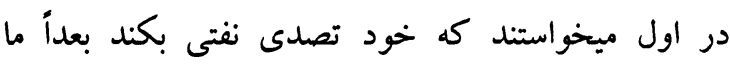

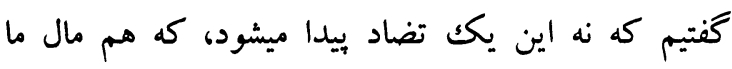

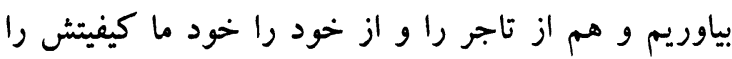

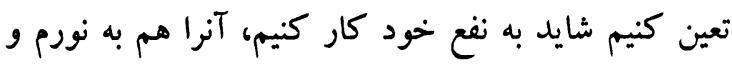

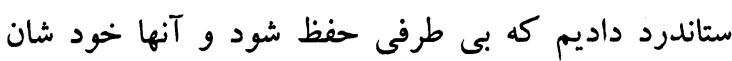

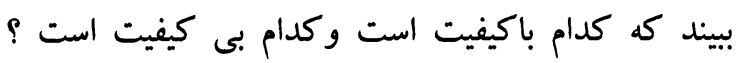

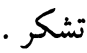

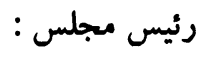
وكلاى محترم! براى از اينكه از وقت استفاده خوب شده

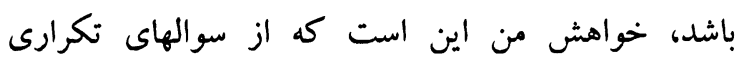

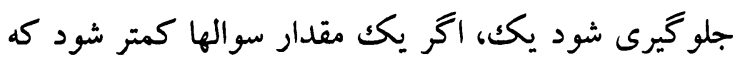

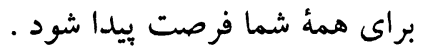

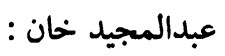
بسم الله الرحمن الرحيم، بهان

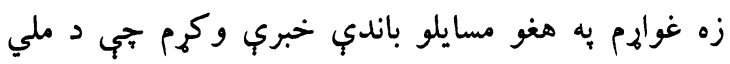
اقتصاد د كمبسيون او د ماليي وزارت، سوداكرى وزئ وزارت،
ما بسيار آسيب هذير هستيم اكر صادرات كمى هم داريم

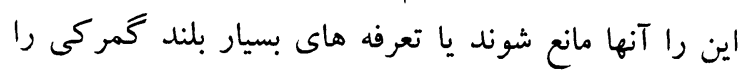

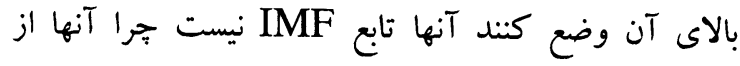

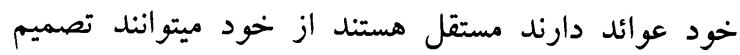

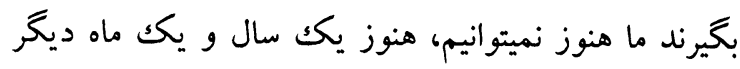

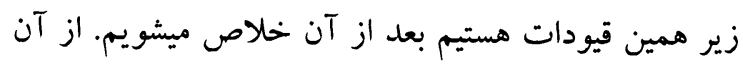
خاطر است كه ما همراى آنها كوشش ميكنيم كه راههاى

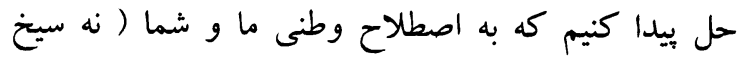

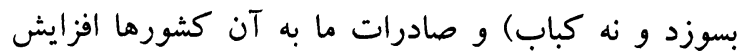

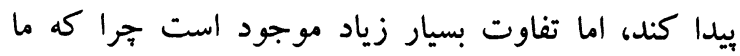

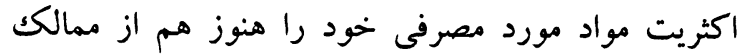

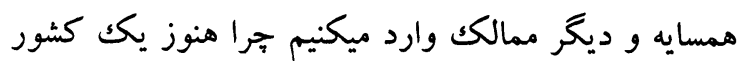

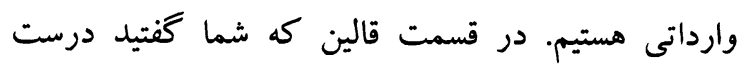

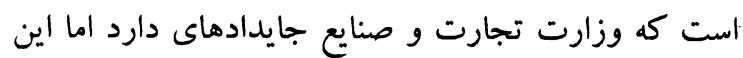

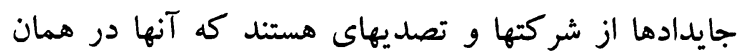

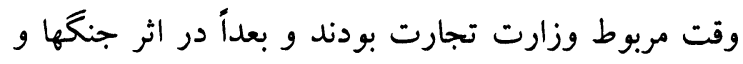

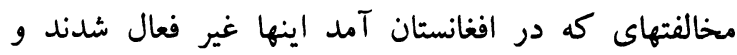

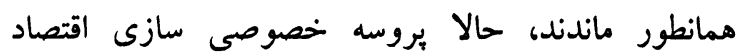

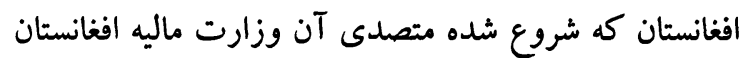

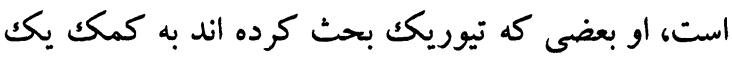

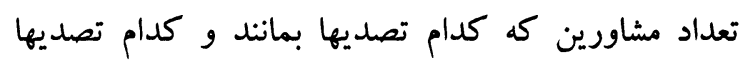
مبدل به شركتهاى خصوصى شوند يعنى به سكار سكتور

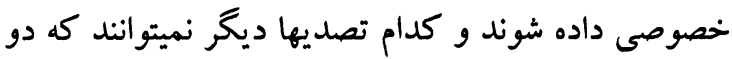

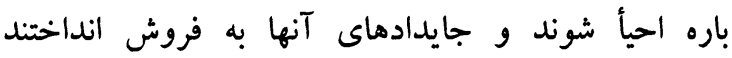

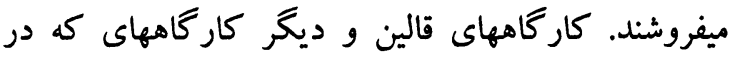

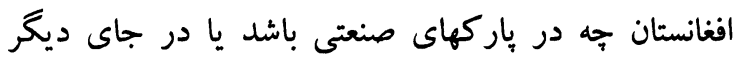

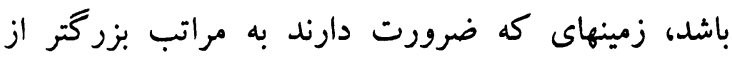

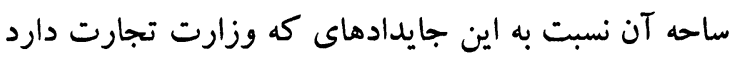

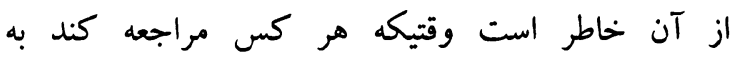

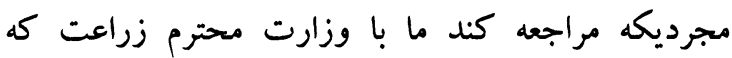

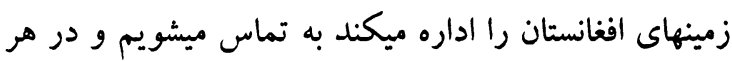

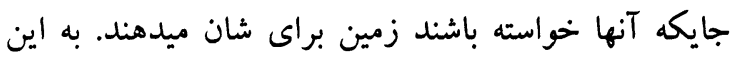
زمينهاى يكك جريب و دو جريب يا كمتر از آن، آنها

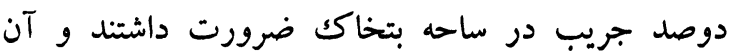
دوصد جريب را ما براى شان داديم و اين بروسه را ما دات 
AV كال نه شروع كيري به دي زموبر بحث ندى، زمور.

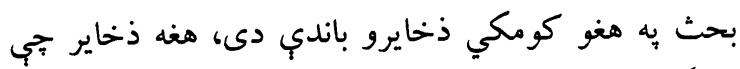

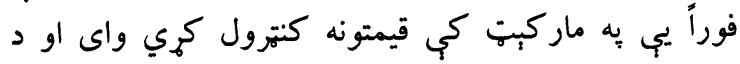

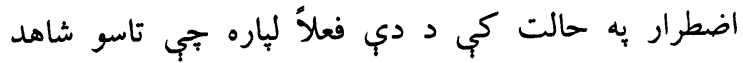

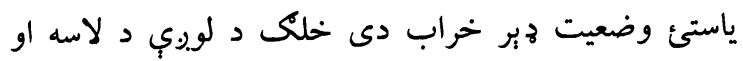

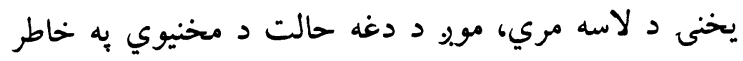

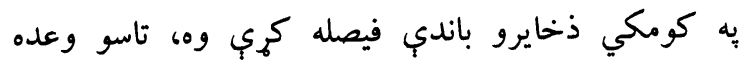

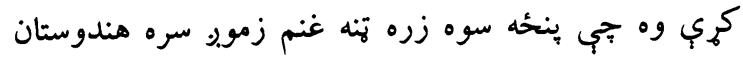

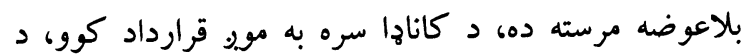

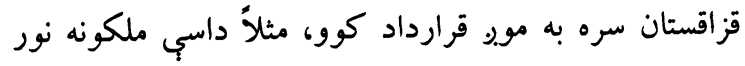

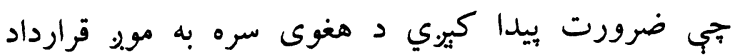

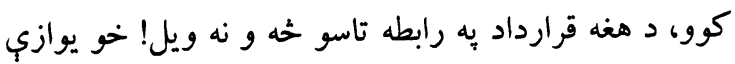

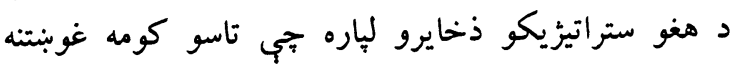

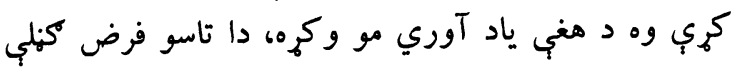

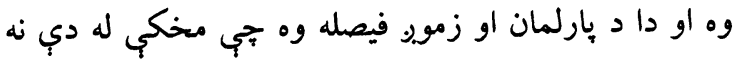

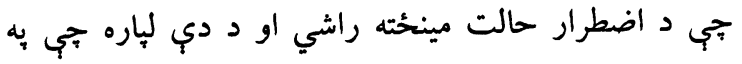

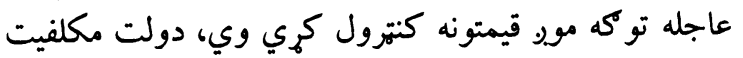

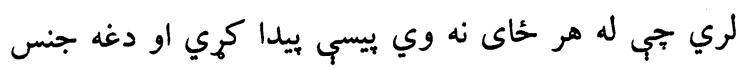

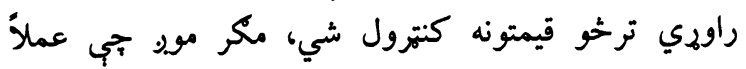
اوس كورو هغه كارونه يو هم ونشول، دا دي بله خبره، بله

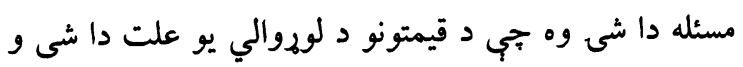

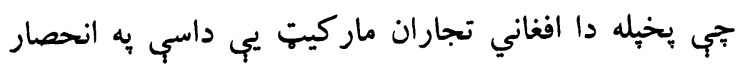

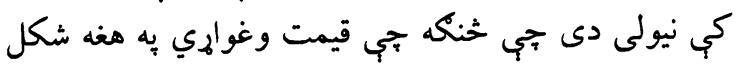

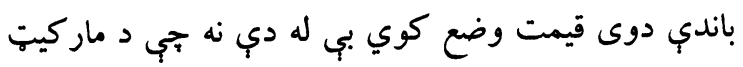

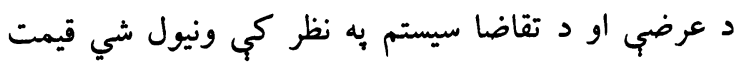

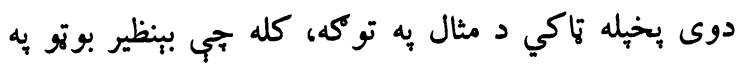

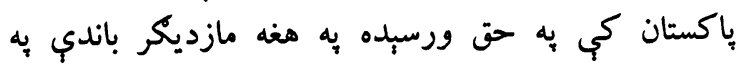

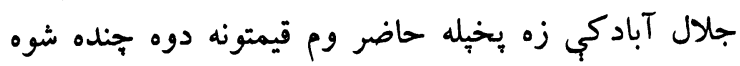

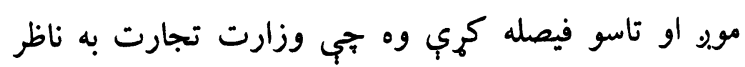

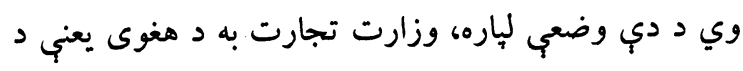
تجارانو د كتيو يه نظر كي وني نيولو سره حالات فوراً

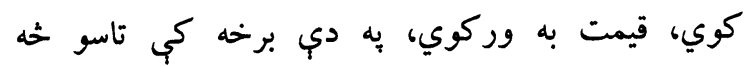

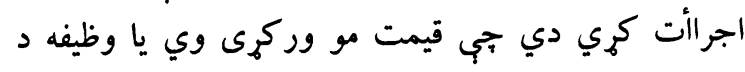

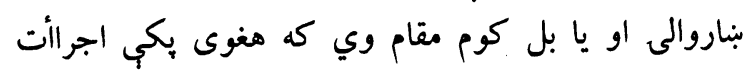

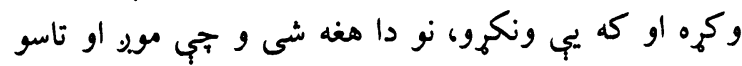

اقتصاد وزارت او د زراعت وزارت تر منحُ جبي كومب

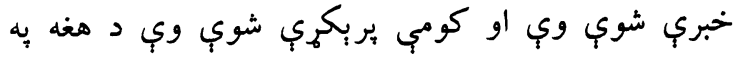
هكله زه د ملي اقتصاد د كمبسيون به به نمايند

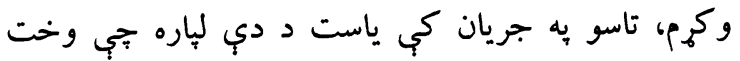
ة تر زيات و نه نيول شي به مفصله توكه يجي نه وايو زموي.

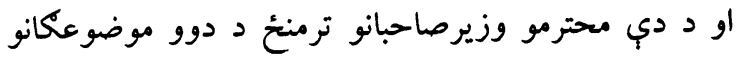

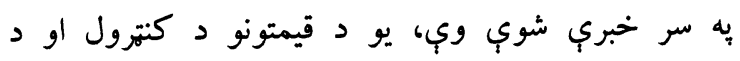

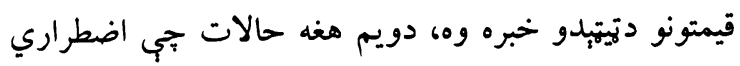

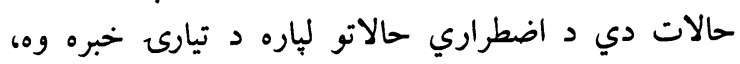

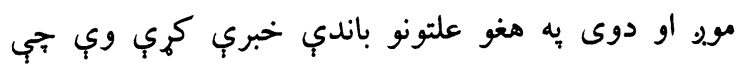

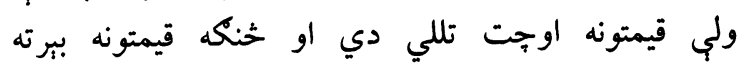

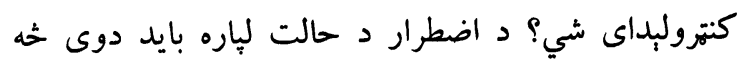

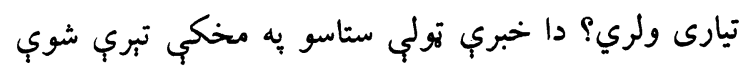

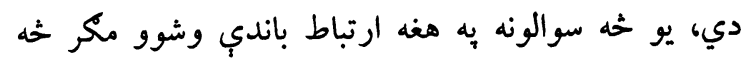

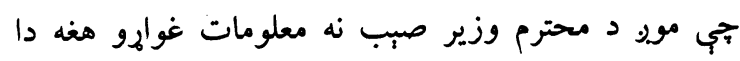

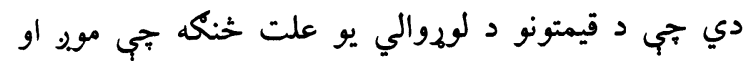

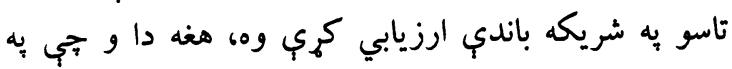

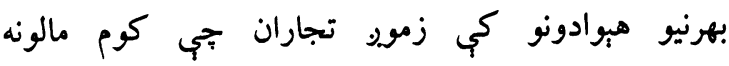

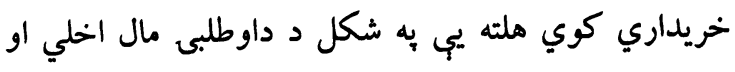

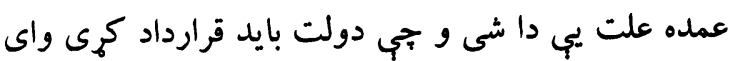

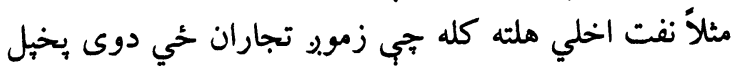

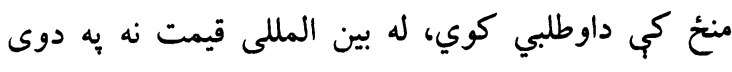

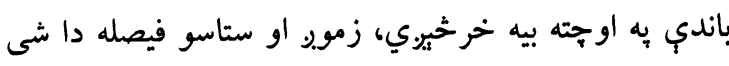

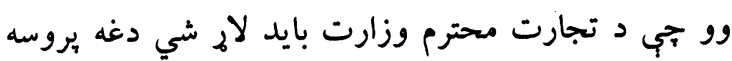

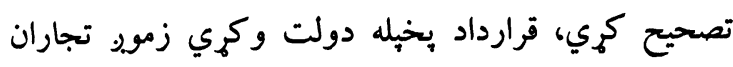

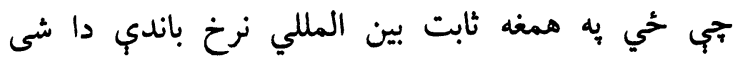

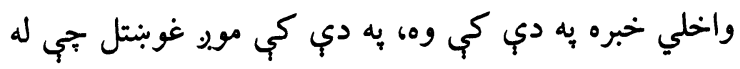

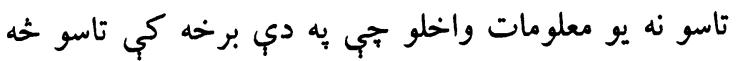

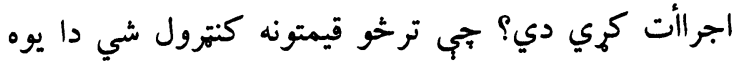

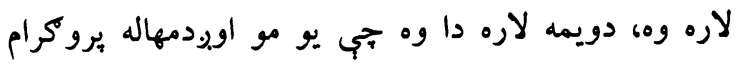

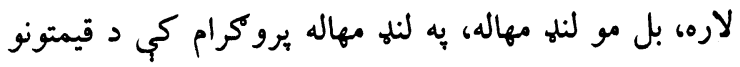

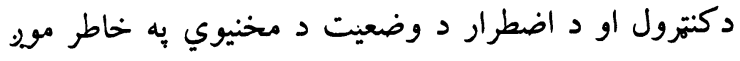

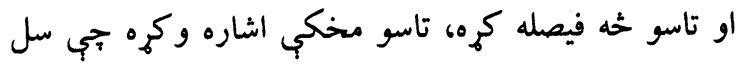

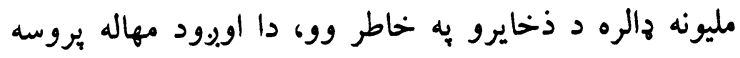
وه مورد او تاسو دي فيصلي ته رسبدلي وو جيجي هغه به له 
رئيس مجلس : انجنير صاحب ! خواهش من اين است كه بحَذاريد كه صحبت خود را بكند، باز به نوبت صحبت من كنيد النيد كه اخلال نشود . وزير تجارت و صنايع : شآيد اگر صحبت خود را ختم كنم شايد سوال شما حل

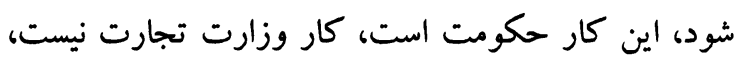
كارى است كه شما همراى حكومت بايد كه صهو صحبت كنيد

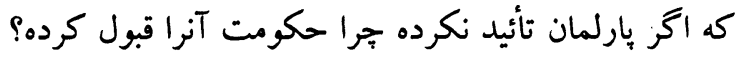

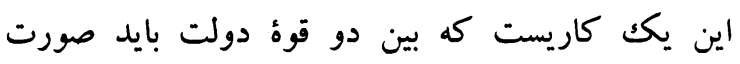

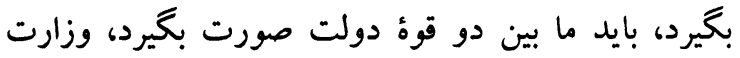

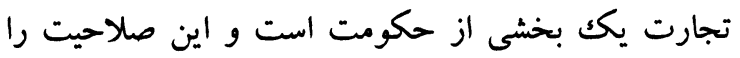

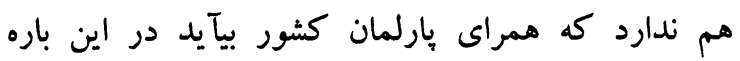

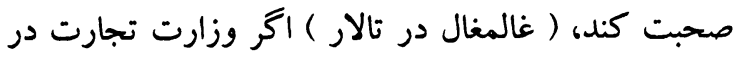

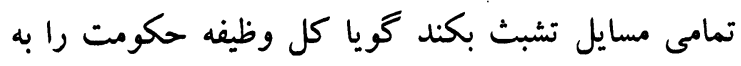

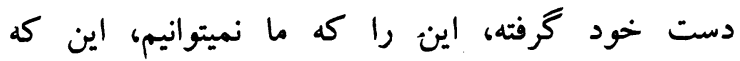
صلاحيت من نيست . روند رئيس مجلس : اجازه بدهيد وكيل صاحبان! وكيل صاحبان محترم خصوصاً انجنير صاحب خواهش من است كه به نوبيت

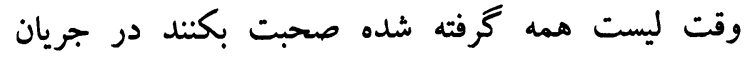
صحبت اخلال نسود كه به نتيجه برسيم، وزير صاحب لشه

بفرمائيد ! وزير تجارت و صنايع : از همان خاطراست كه ما از همين يولهاى كه كَتهم كه بيست فيصد اين تنها از راه كمكهاى بين المللى به إنه افغانستان آمده شرطى كه گذاشتند اين است كه كنترول قيمتها بايد از بين برود، دولت در امور اقتصادى مداخله

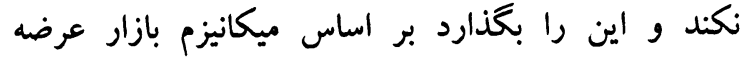

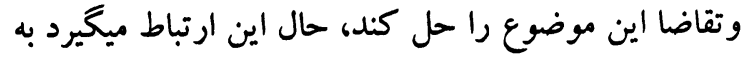

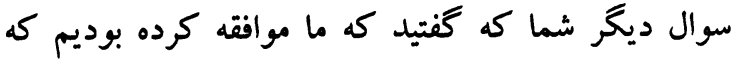
جطور همراى وارد كنند آنان وكسانيكه عرضه ميكنند

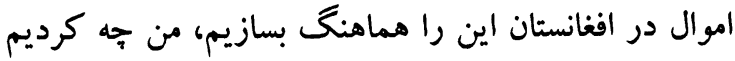

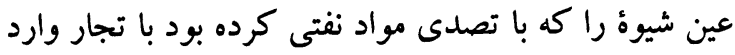

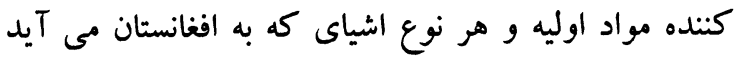

سره بهه دي باندي خبري كمّي وي به دي برخه كي تاسو

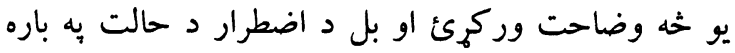

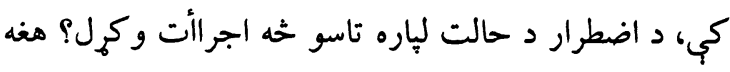
وعدي جبي تاسو كري وي هغه عملي يجي وبناياست، يوار دي

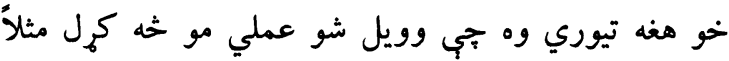

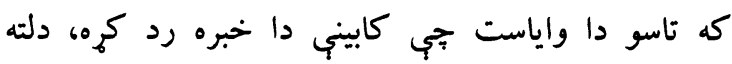

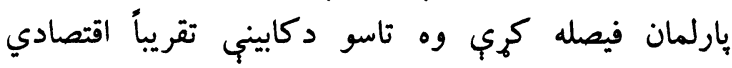

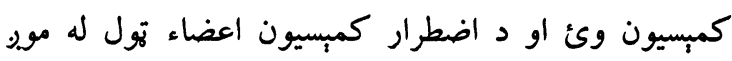

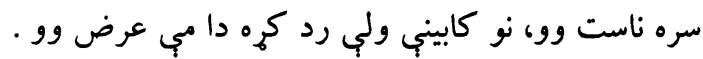
وزير تجارت و صنايع : در قسمت اول سوال شما كه گفتتى كه ما وظيفه كنترول

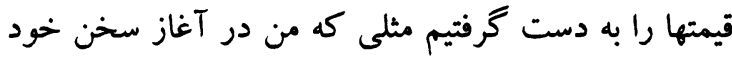

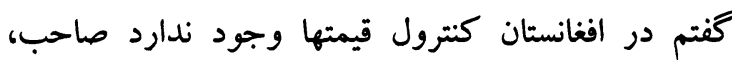
كنترول قيمتها از اين خاطر وجود ندارد كه بر اساس فيصله

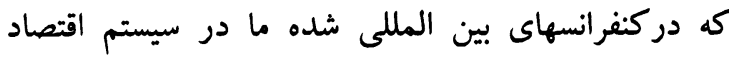

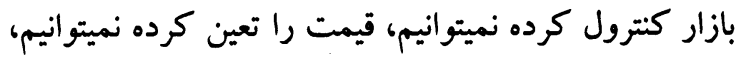
من اين را يبشتر بسيار مفصل تشريح كردم كه اين را بارها

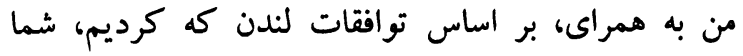

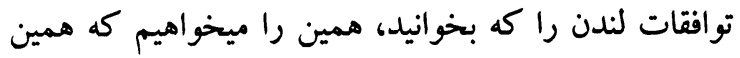

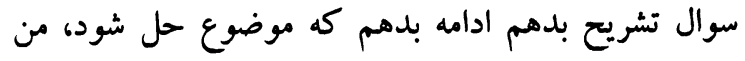
درقانون اساسى خود كفتيم كه به اقتصاد بازار قبول داريم

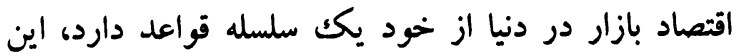

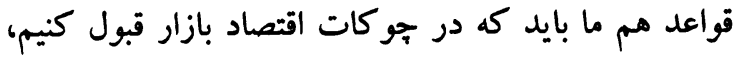

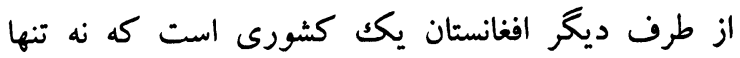

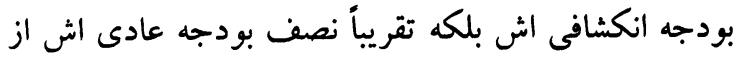

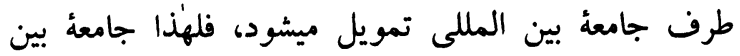

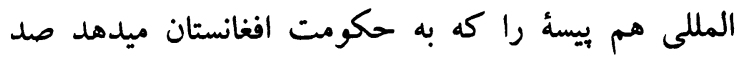

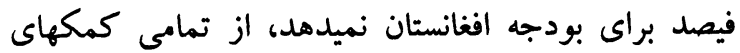

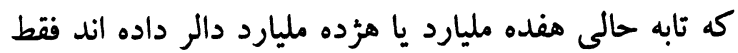
بيست فيصد اين از راه بودجئ افغانستان مصرف شدهدها

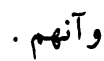

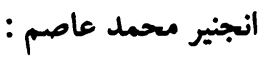
همين را ما تأئيد نكرديم، اين بايد به تائيد همين مجلس برسد. 
ديخًر بخيرد، حال بايد در هيمن مجلس در حقيقت همين

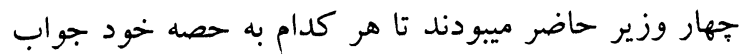

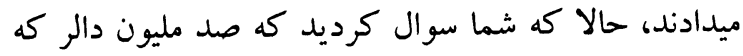

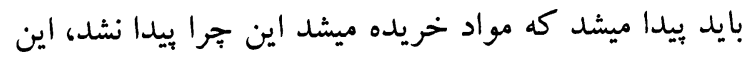
سوال را من جواب داده نميتوانم اين را وزير صاحب ماليه

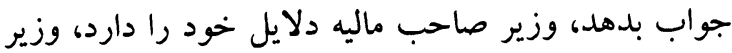

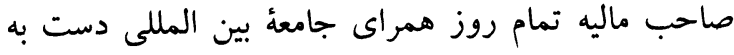

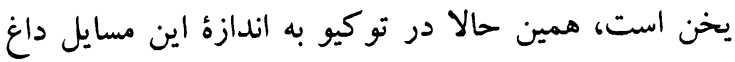

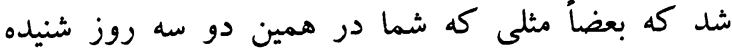

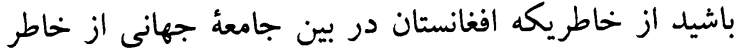
مسايل عسكرى مشكلات بيداشده به همان بيمانه شايد

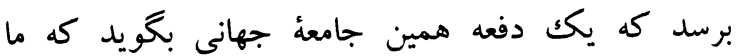

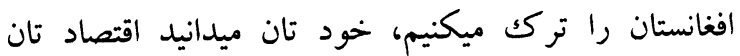

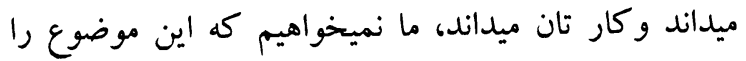

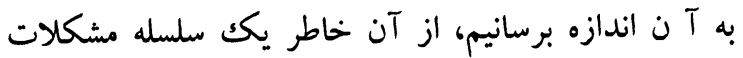
يبش ما است، خوب يبشتر از اينكه من به ادامه اين جوابها بروم، يكك سوال ديخر را ميخواستم جواب آقاى جوينده

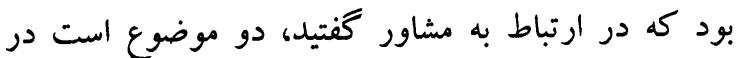

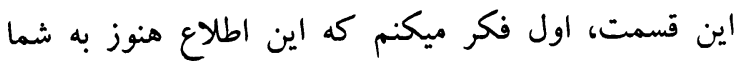

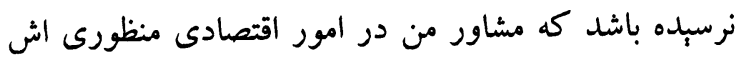

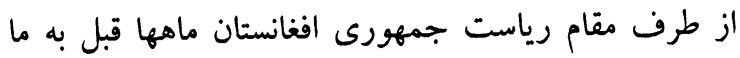

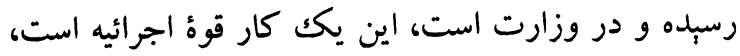

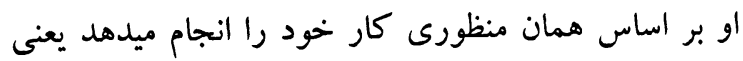

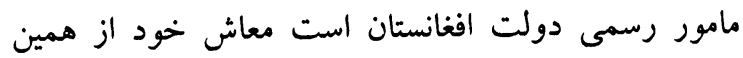

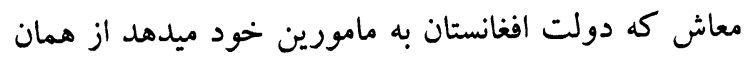
ميخيرد كدام معاش يا از كدام مؤسسه بين المللى نميخيرد اما فرمانش آمده موجود است، قسمت دومش كئ كه شما

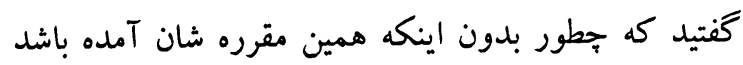

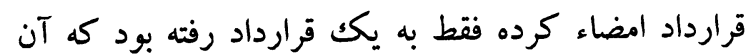

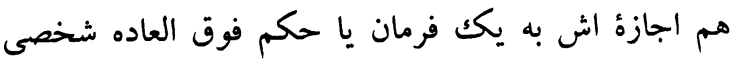

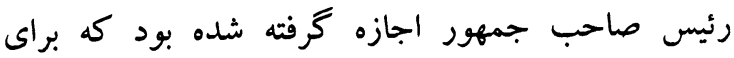

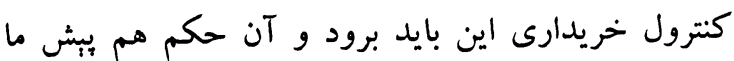

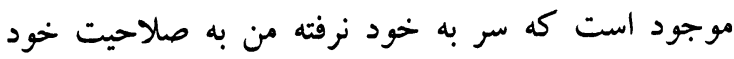

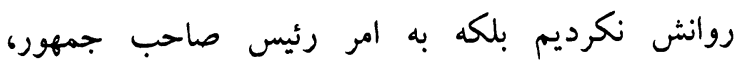
جمهورى اسلامى افغانستان روانش كرديم كه او خودش رئ رئس
نسُستيم و به همراى آنها گفتيم كه شما اين مال را بياوريد به اساس همان اساس خريدارى تان قيمت خريدارى تان جقدر است ؟ اينقدر مصارف تان است اينقدر مفاد تان است اين قيمت، قيمت تنظيم كننده قيمت عادلانه بازار

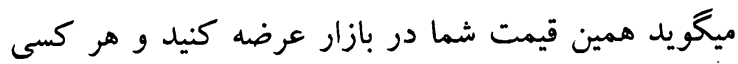

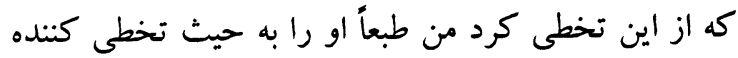

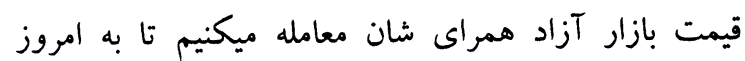

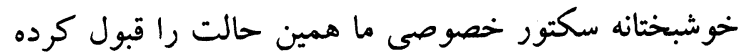

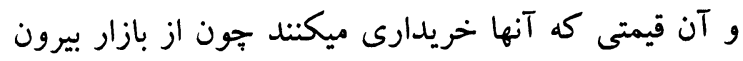

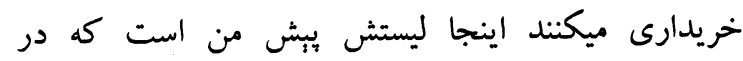

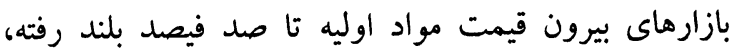

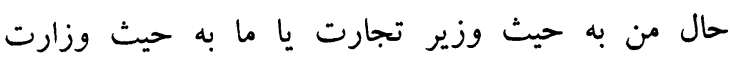

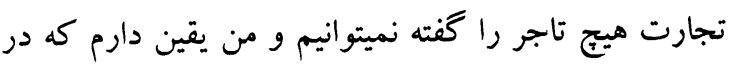

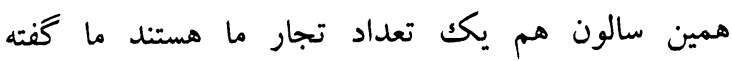
نميتوانيم كه شما يكك جنس را، يك مال مال را به قيمت بله بلند

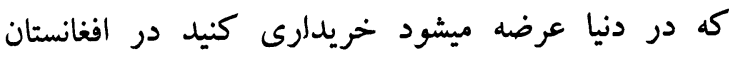

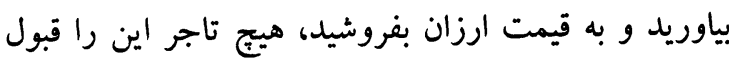

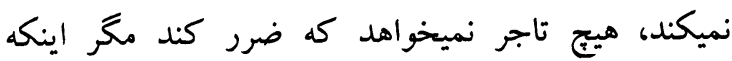

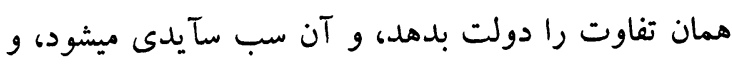
سب سآيدى را افغانستان به هيج صورت دون داده نميتواند اول

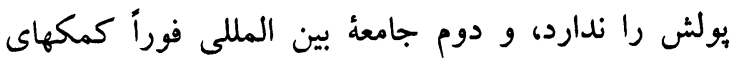
خود را قطع ميكند، در اين حال وقتيكه من در مقابل اين

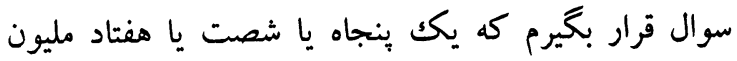

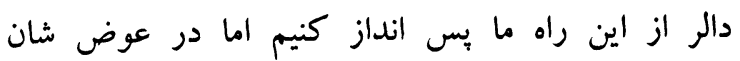
ملياردها دالر كمكهاى بين المللى را از دست بدهيم، كدام

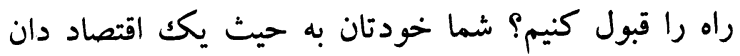

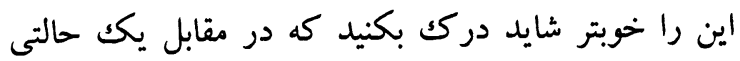

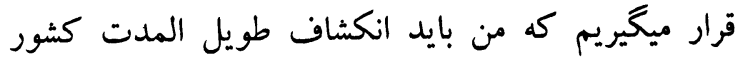

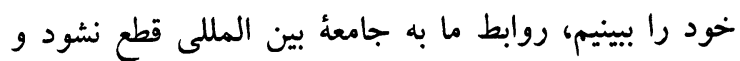

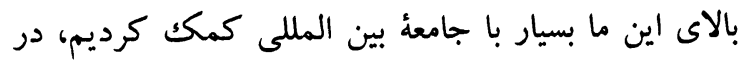

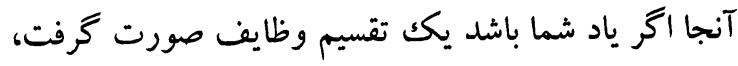

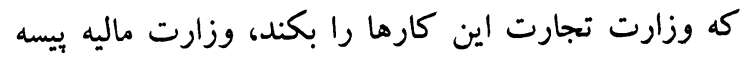

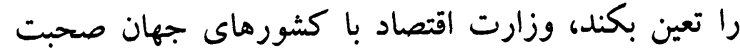

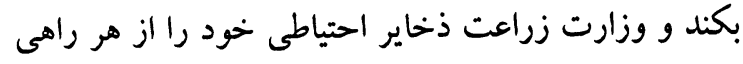

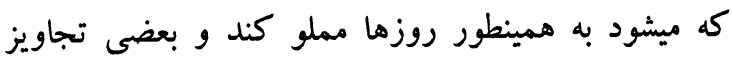


عهده خود گرفت و قسمت ديخرش ما يكك اييل يا يكك

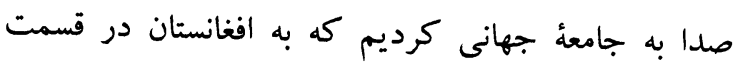

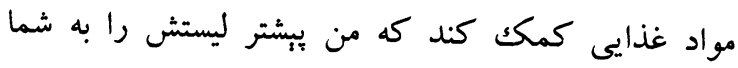

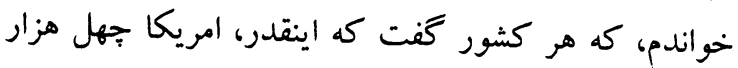

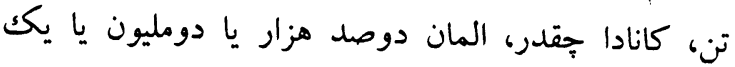

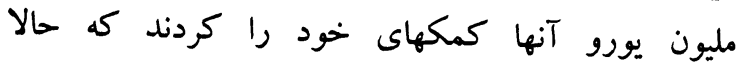

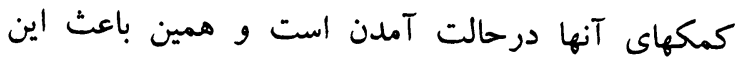

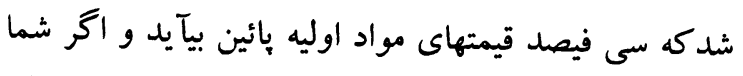

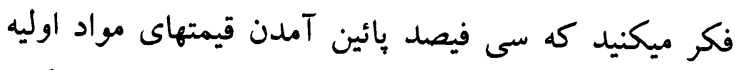

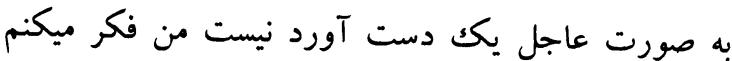
كه يك دست آورد است و اميد ميكنيم كه زمستان آهسته

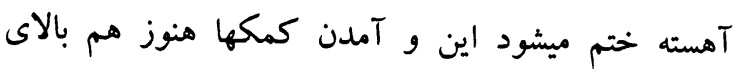

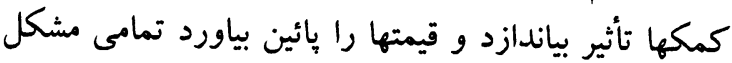

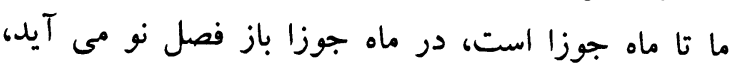

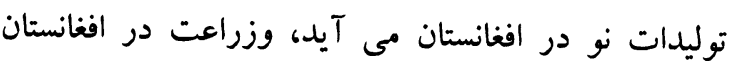

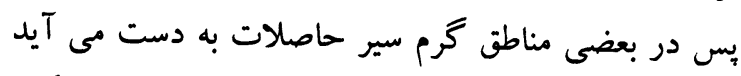

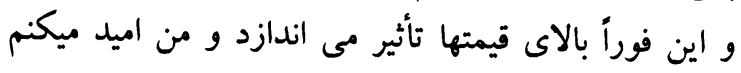

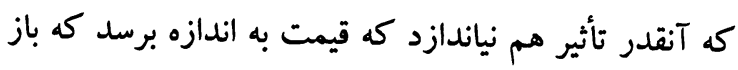

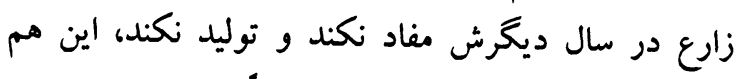

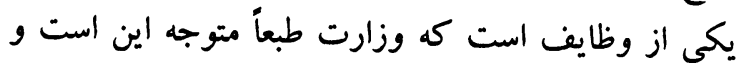

$$
\text { على اين را در نظر ميخيرد . }
$$

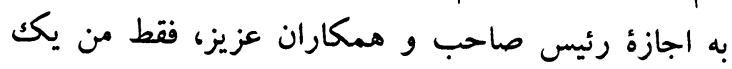

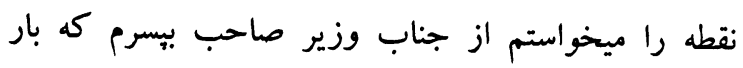

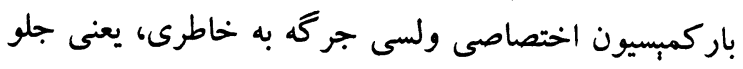

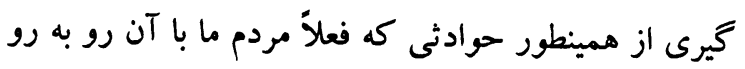

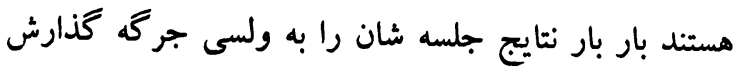

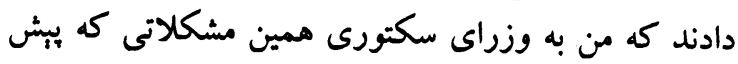

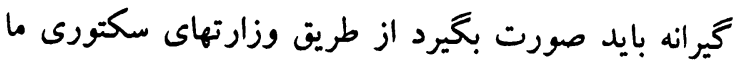
به ايشان كذاشتيم، فقط من همين را ميخواستيم كه همين

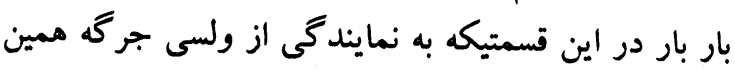

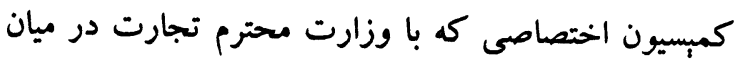

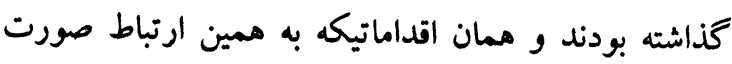

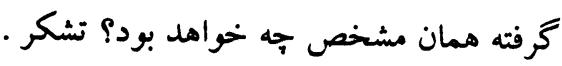

واجب الاحترام است بايد قبول شود اين سوال آقاى

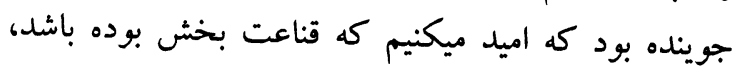

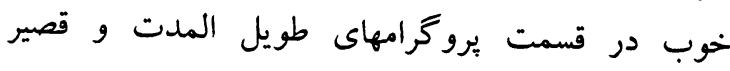

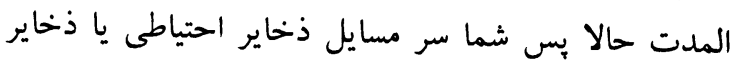

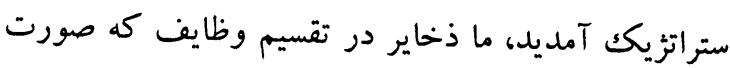

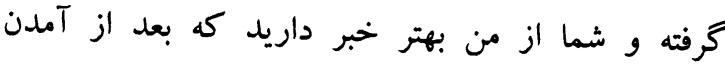

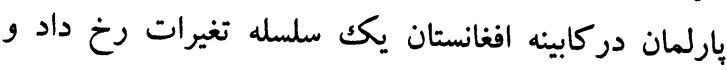

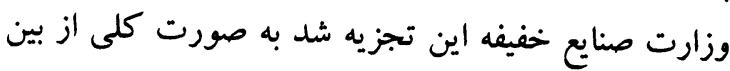

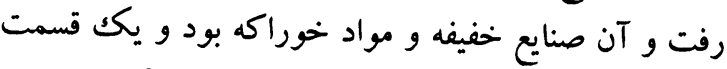

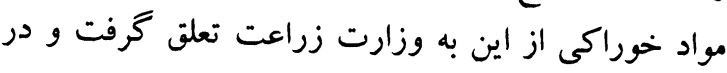

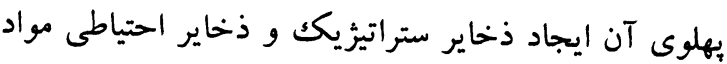

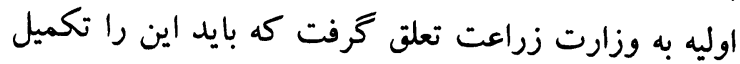

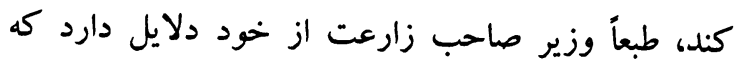

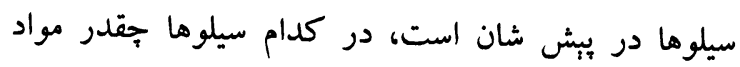

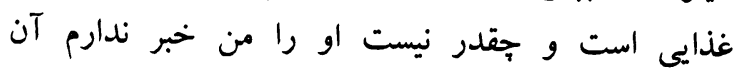

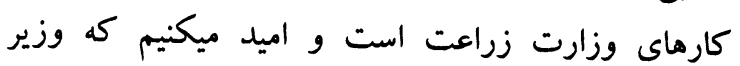

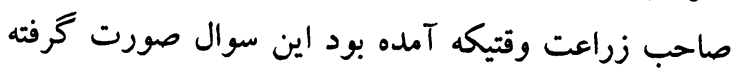

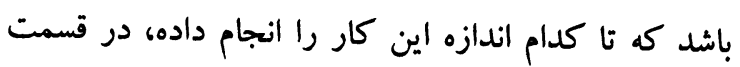

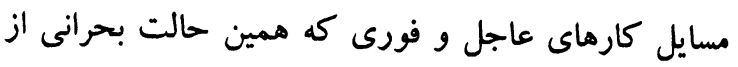

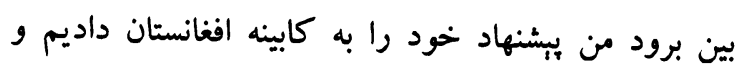

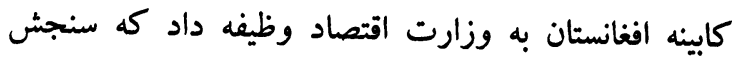

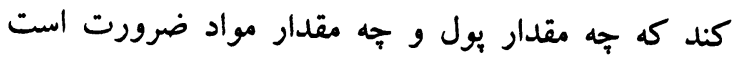

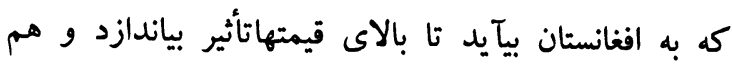

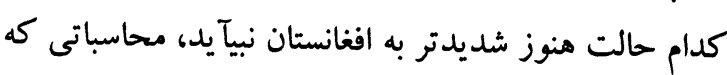

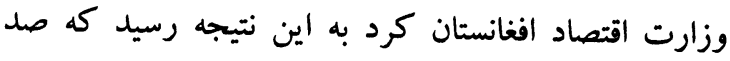

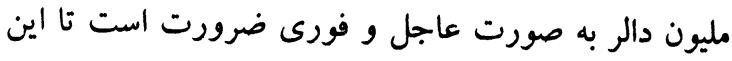

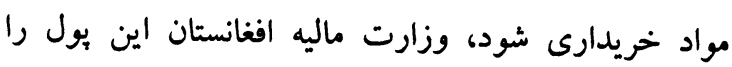

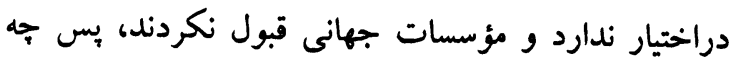

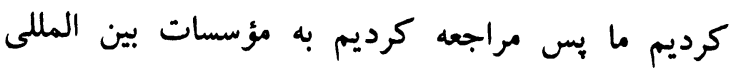

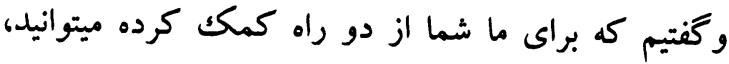

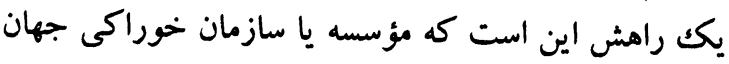

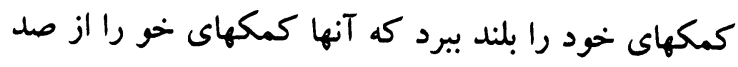

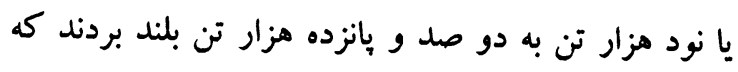

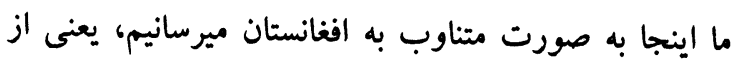

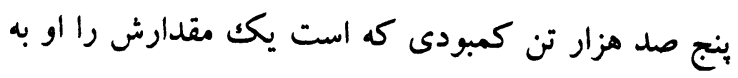


نه قوء مقننه به تنهايى خود اين مسايل را نميتواند تا

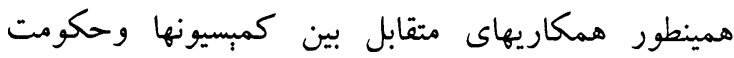

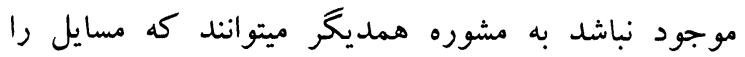
خوبتر حل كنند، تشكر . فئل فوزيه كوفى :

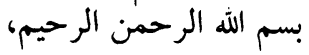
قبل از اينكه از وزير صاحب تجارت سوال الرحب، كنيم جناب رئيس صاحب من اكر دقيق به ياد داشته باشم در اجلاس آنس

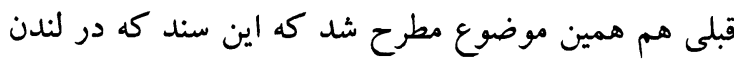

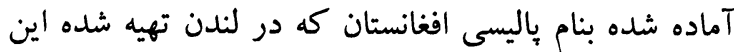

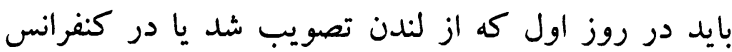
لندن تصويب شد در مجلس شورى هم تصويب ميشود، جون مطابق قانون اساسى از صلاحيتهاى اختصاصى شورى

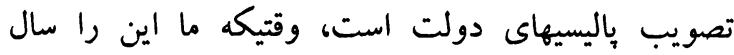

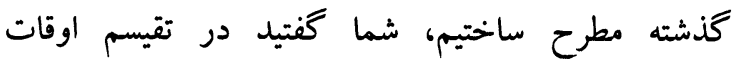
آجنداى كارى اجلاس كذشته است كه تا آخرين روزها متأسفانه نبودم اميدوار هستم كه اجلاسى حد اقل اين بار باشد به دليل اينكه ما و شما در كنفرانس تو كيو به شكل هئل ميان دوره يى اين را بحث كردند و دوباره مرور كردند

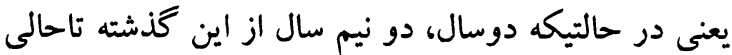
شورى در جريان نيست، و بسيارى موضوعاتيكه من

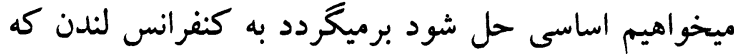

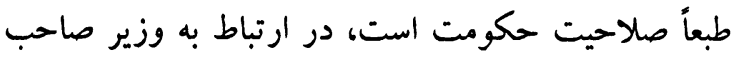
تجارت در بسيارى از مواردى كه وزير صاحب تجارت

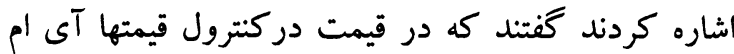
اف و بانكك جهانى با ما همكار نيستند يعنى اين مؤسسات

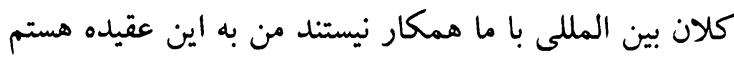

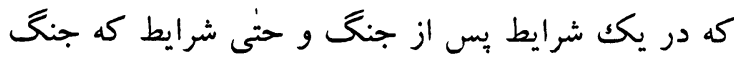

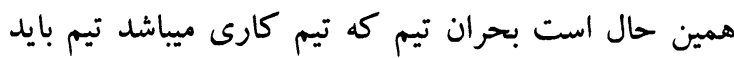

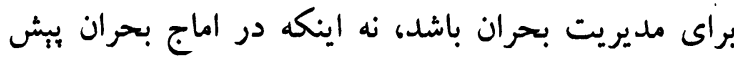

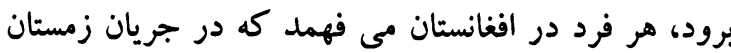

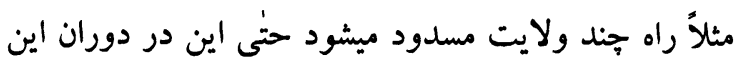
بحران در زمستان سخت امسال نه در سالهاى عادى هم در در درد افغانستان من مى فهمم كه كدام راههاى كدام ولايت مسدود ميشود ؟ و به همين مشكلات ديخر به فيه جه تعداد

$$
\text { وزير تجارت و صنايع : }
$$

ميخواستم بحضور جناب قاسمى صاحب به عرض برسانم كه يكك كمبسيون اختصاصى بين وزارت تجارت و و ولسى جر گه وجود ندارد، وزارت ما همراى ولسى جر گهه كدام

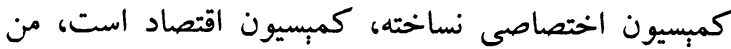

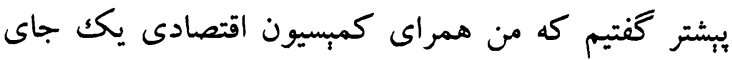
نشستيم وكفتيم كه تاديبات در تمامى مسايل با هم به به به

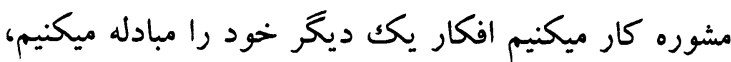
از نظريات يكك ديگر خود استفاده ميكنيم و به همان اساس بود كه همين تقسيم وظايف كه به ما داده شد كه

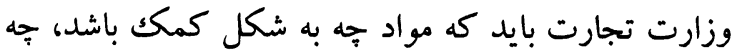

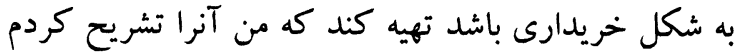

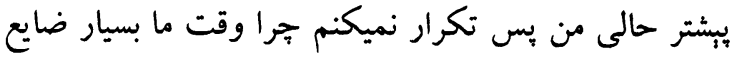

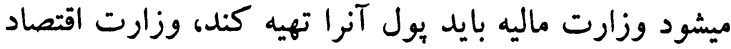
بايد كه مطالعه كند كه ما جقدر ضرورت وات ماريم، جقدر يول ضرورت داريم، بازارهاى ما به جقدر مدت مات كفايت

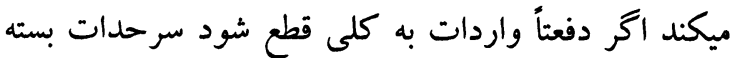

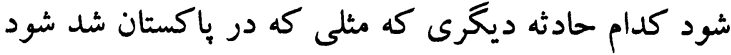

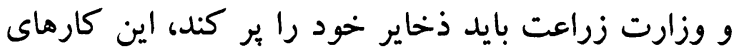

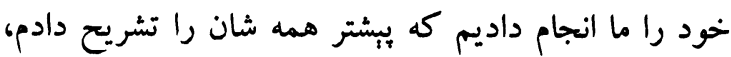

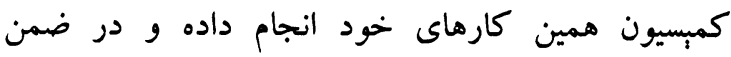

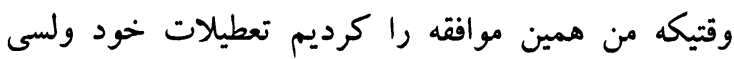

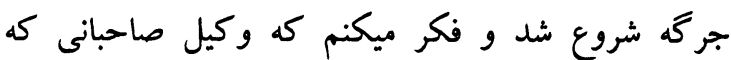

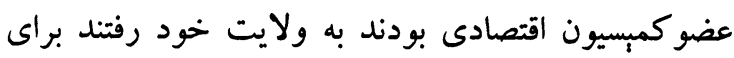

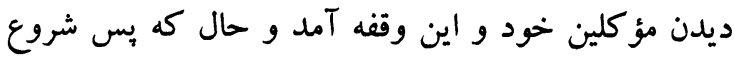

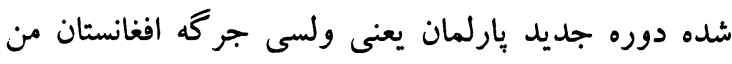

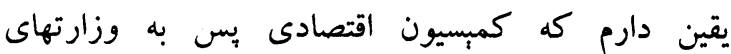
سكتورى كه كفتيم همين همكارى خود را دوا دوام ميدهند

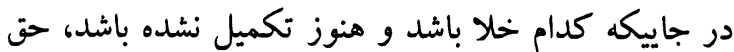

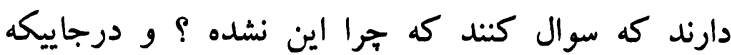
نظريات نو آمده باشد جرا شما مفهميد كه در همين مسايل اقتصادى هر يكك روز به ديخر روز تغير ميكند و وسايل

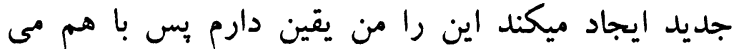

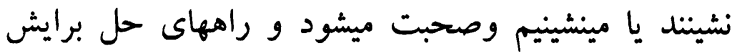

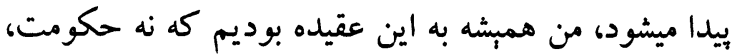


احتياج دارند به آنها بول زيادتر داده شود ـ اين يكك حالتى

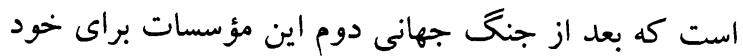

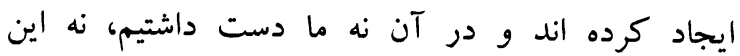
كشورهاى عقب مانده ديخردست داشتند، آنها خود شاد ان دان

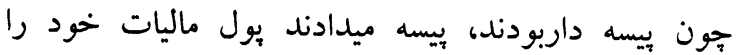
ميدادند به همين تصميم رسيدند كه اين كار را ما بايد

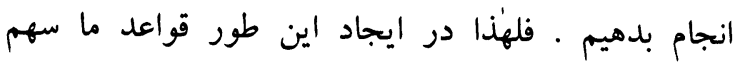

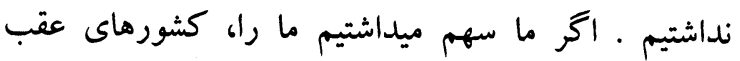
مانده را در سال هاى •0 عيسوى سهم ميدادند، يقين دارم كه زمامداران همان وقت كشورهاى عقب ماند مانده جدى لهى

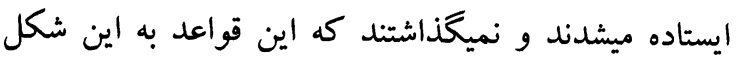

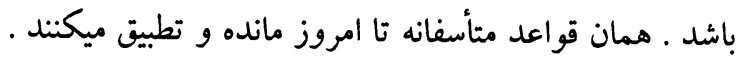

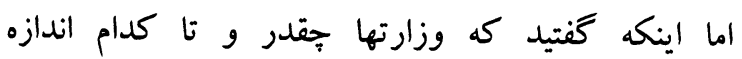
صلاحيت دارند، با وصف همين قواعد همراى وزيل آنها صحبت ميكنند، من گفتم كه هر وزارت در ساحه كارى هم

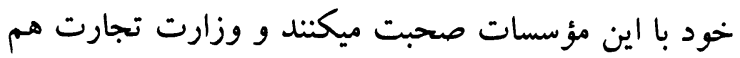

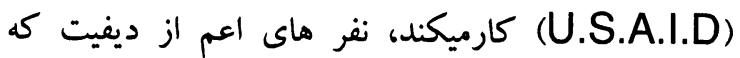
هندوستان است كارميكند و هم (G.T.Z) كه از آلمان

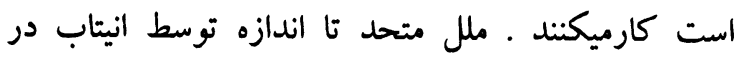
آنجا كار ميكند . من به ارتباط كارهاى كه مسأله مواد مل ماد

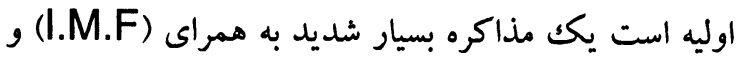

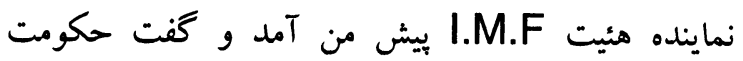
افغانستان كلانترين تخطى را انجام داده كه از ازئن رئيس

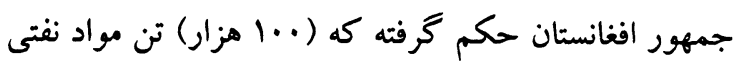

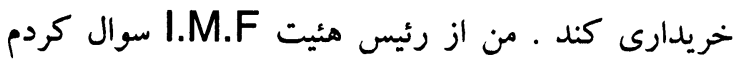

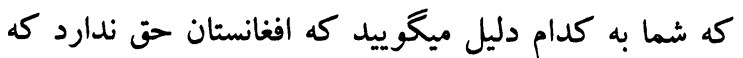
احتياجات خود را خودش رفع كند درحاليكه تصدى مواد

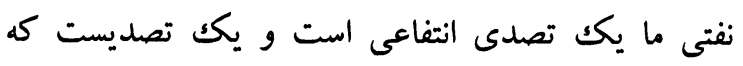

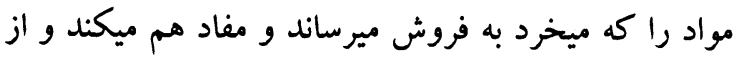

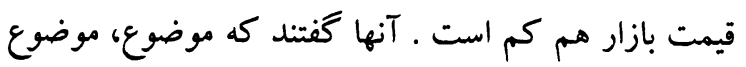

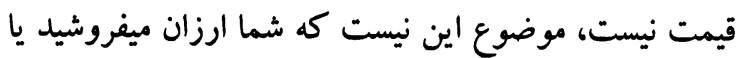

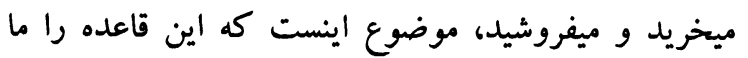

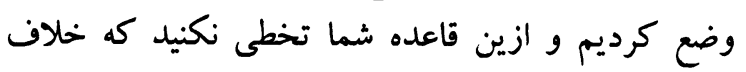

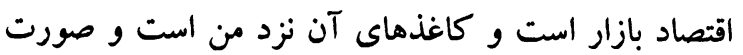
مذاكرات من موجود است . برايشان به صراحت لهان لهنه
مهاجرين بيرون از افغانستان هستند ما بايد برنامه ها

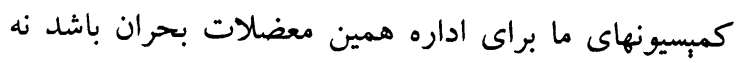

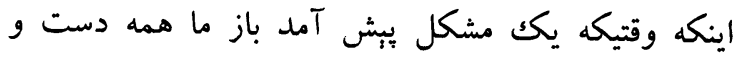

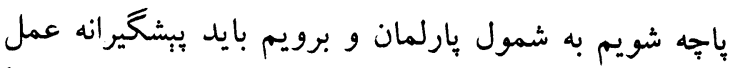
كنيم، من از وزير صاحب اين سوال را ميكنيم كه طبعاً اينها بسيار تأثير گذار هستند يعنى سازمانهاى ماحس كلان بين

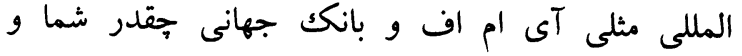
كمبسيونهاى مربوطه و وزارتخانه هاى مربوطه در المالي حالتيكه

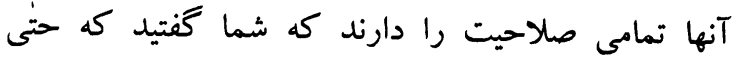
دركنفرانس تو كيو هم اى آيم ايف نبذيرفت دربسيارى از دارسي

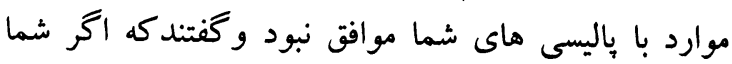
مثلاً سب سايدى وضع كنيد يا خلاف باليسى اقتصاد بازار

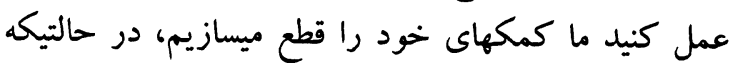

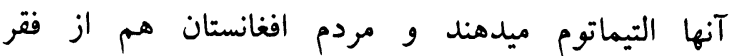

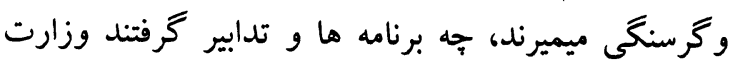
تجارت و ديخر وزارتخانه هاى كه با شما همكار هستئد

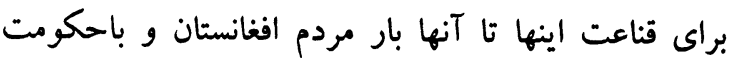

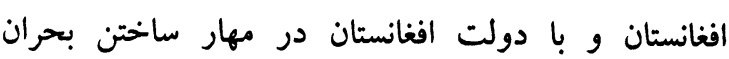
همكار باشند ؟ وزير تجارت صنايع : شما گفتيد كه (I.M.F)، بانكك جهانى و امثال آن همين

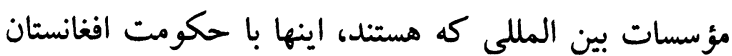
همكارى نميكنند، من نميگويم، ادعا نكردم كه آنها

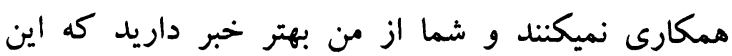

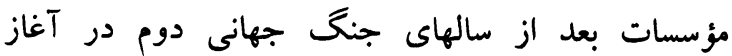
سالهاى 0.0 بوجود آمدند براى اينكه كمكهايى كهات كه كشورهاى بيشرفته به كشورهاى عقب مانده ميكنند، همين مؤسسات اين كمكها را تنظيم كنند و يكك سلسله قواعد و

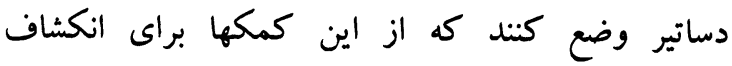

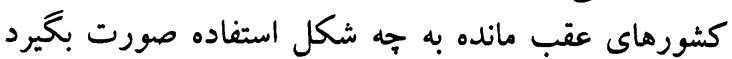

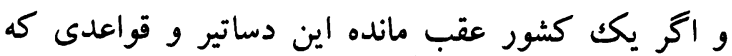
آنها وضع ميكنند، تخطى ميكنند بايد كه برايشان اخططار

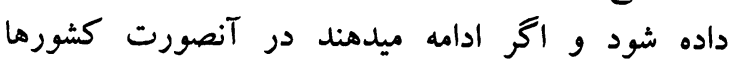

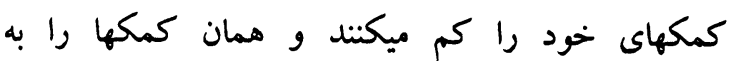
كشورهاى ديگرى كه اين قواعد را مراعات ميكنند و همان 
ديده ايم. اما با آنهم من براى شما به ايمان خود قسم ميخورم كه در مقابل همين مؤسسات بين المللى تا جاييكه

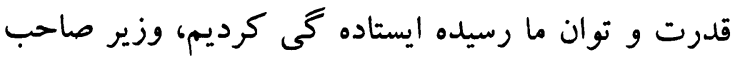

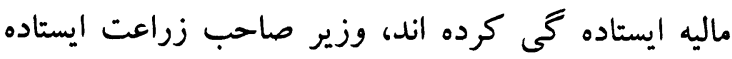
گى كرده اند، وزير صاحب اقتصاد، تمام كابينه، رئيس صاحب جمهور، شما خبر داريد همين بارلمان ما ايستاده كى كرده است، شما خبر داريد كه حتى به به بيمانهُ مناقشات

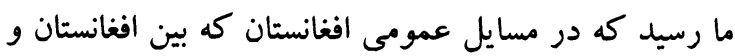
انخلستان كه امروز حضور دارد در افغانستان به تشنج كشانيده شد، شما خبر داريد كه نتيجه گيرى

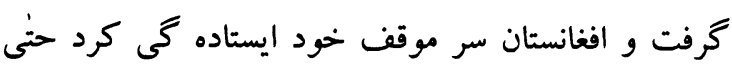

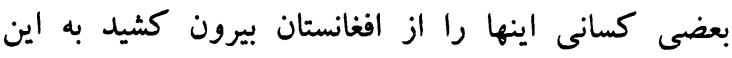

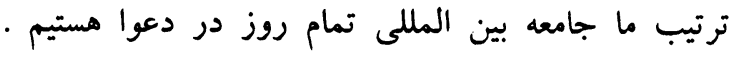

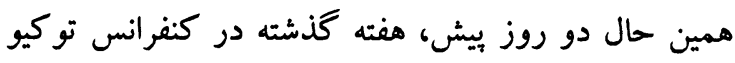
من با هئيت افغانى رفتم در آنجا سر همين مسايل به اندازه

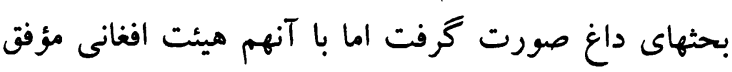
شد كه به جامعه جهانى همين قناعت را بدهد كه كمكهاى

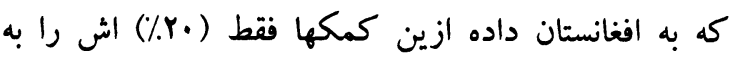

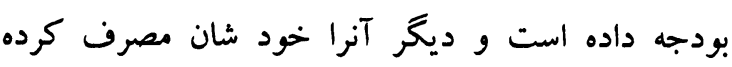

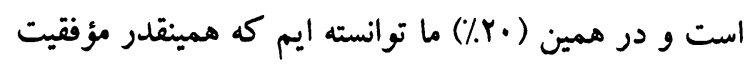

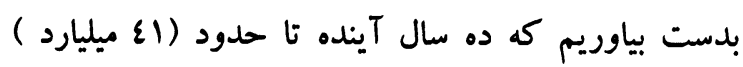

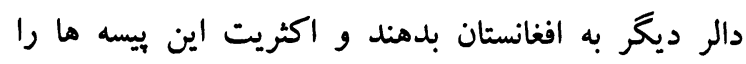

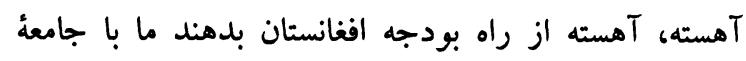
جهانى هميشه دست به گريبان هستيم و هميشه ممراى شان انه انهان جنگ ميكنيم، از اطاق خود ميكشيم و ديكر ميكنيم اما در

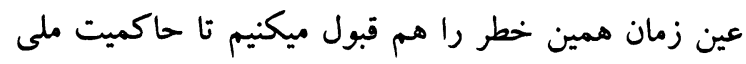

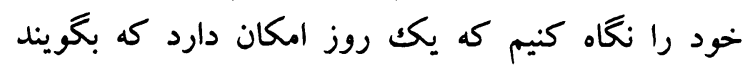

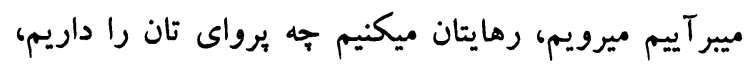

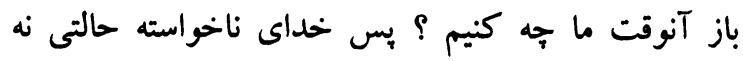

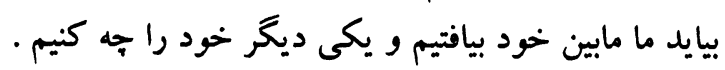

$$
\text { رئيس مجلس : }
$$

تشكر وزير صاحب تجارت ! وكيل صاحبان محترم بيش ميش از اينكه سوال ديخر وكيل صاحبان را بشنويم، بيوسته يك ونك يادداشت براى ما ميرسد كه اخر شما موافق باشيد كه مثلاً سه نفر ازين طرف يكجاى صحبت كنند، بعد وزير بردير
كفتم كه من تابع منافع عالى مردم افغانستان هستم و من

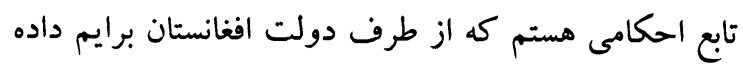

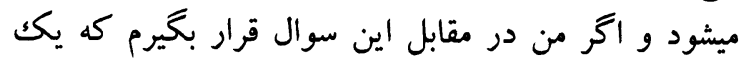

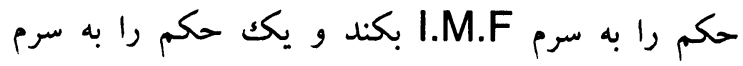

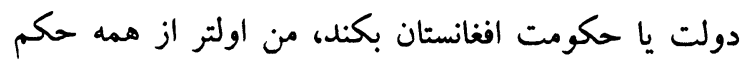

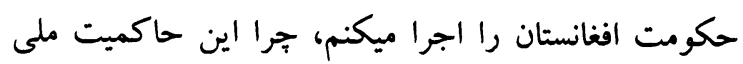

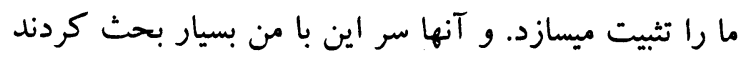

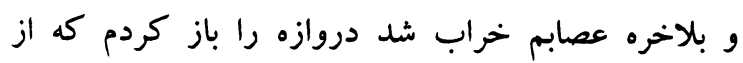

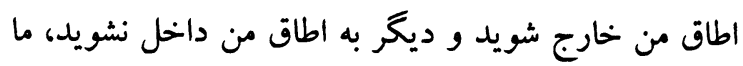

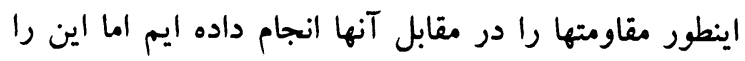

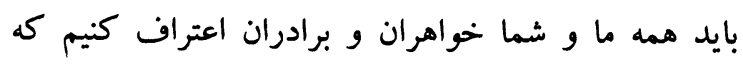

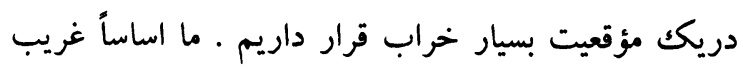

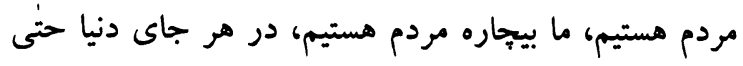

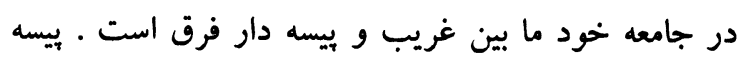

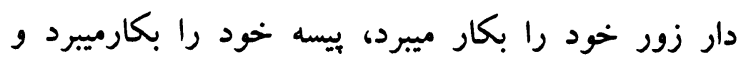
ميگويد كه اين كار را بكن، در جامعهُ جهانى هم همينطور

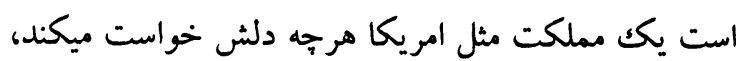
حال كى برايش بـَويد كه هر قدر بخوييم نكن ميخويد

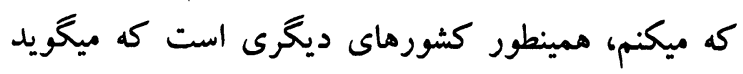
كه من ييسه ميدهم، از مردم خود ماليه ميگيرم و اين ماليه

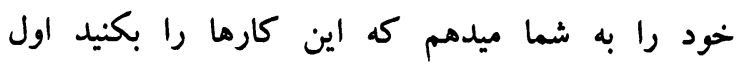

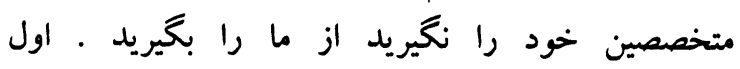

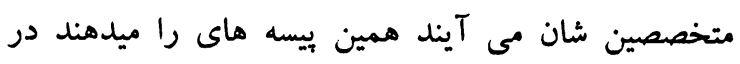

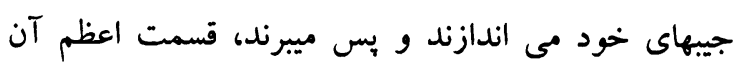
بس به مملكت خود شان ميرود دوم وقتيكه ما براى آنها

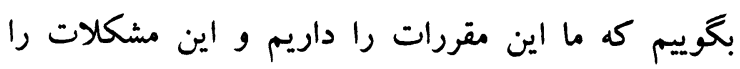

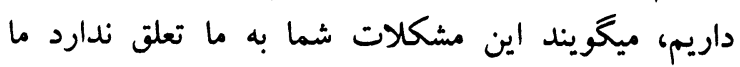

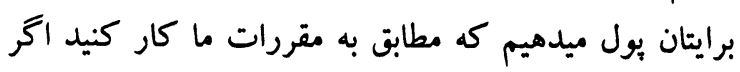

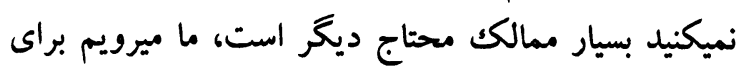

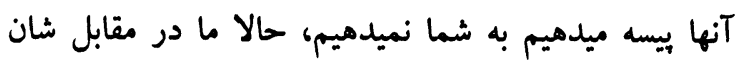
جه بخويم ؟ بخوييم نميخيريم، اكر بخوييم نميخيريم خود

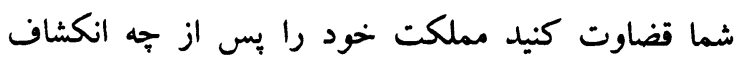
بدميم؟ ما توليد نداريم، ما خراب شديم، ما ما سى سال

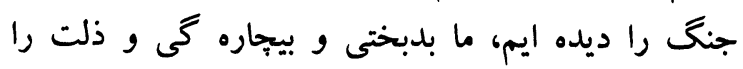

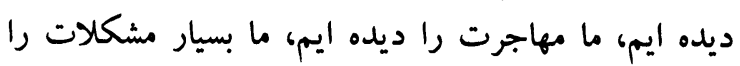


تضاوت ميكنيم و توقعات مردم هم در اينجا حتماً مدنظر

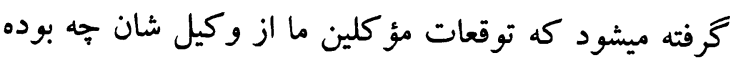

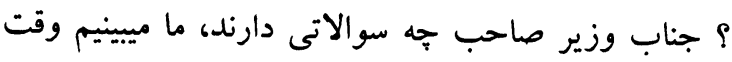

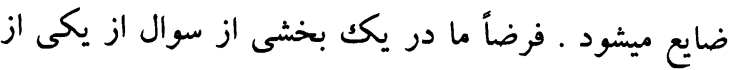

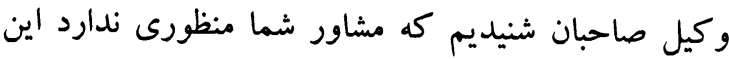

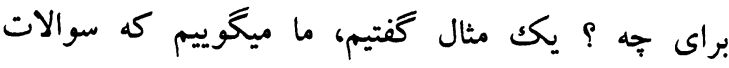

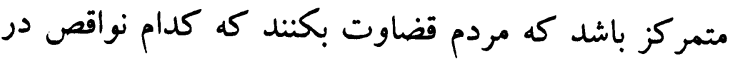

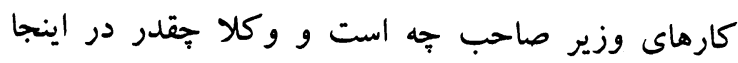
موضوع را جدى ميخيرند . رئيس مجلس : درست است بيشتر هم موضوع را مطرح كردم كه موضوع مشخص است، متمركز صحبت شود.

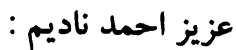

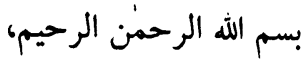
جلالتمآب رئيس، مهمانان كرامى، وكلاى نجيب ملت التران

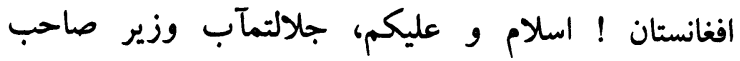

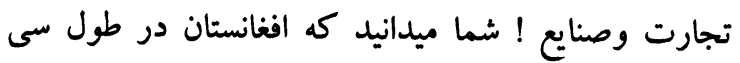

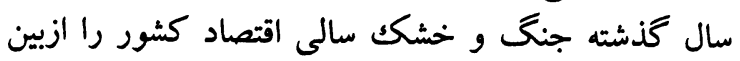
برده است ولى با نظام جديد و با حمايت جائ جامعة جهاني فرصتهاى زيادى براى رشد اقتصاد افغانستان ميسر شد كه ديا

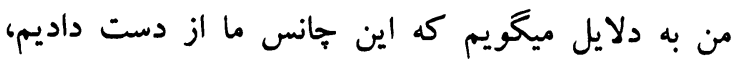

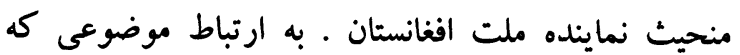

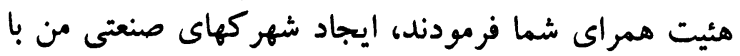
دلايل و اسناد براى شما ميكويم كه سرمايه كذاران دمان داخلى

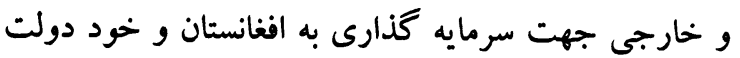

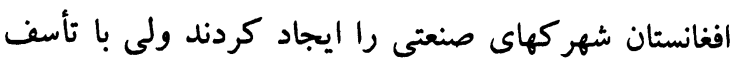

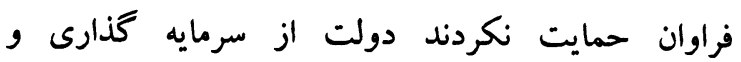

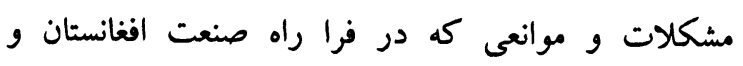

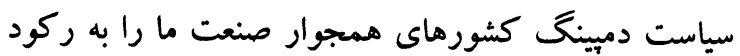

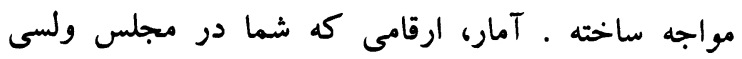

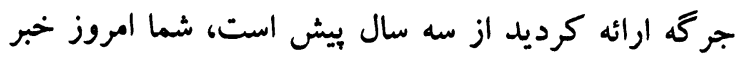

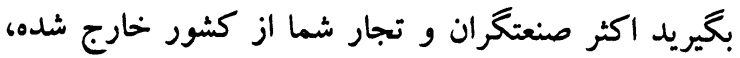
حتى در جمهورى اسلامى ايران شهرك صن صنعتى ايجاد شده

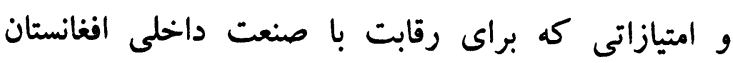
ميدهد در آنجا سرمايه كذارى كرده اند و آنها از افغانها
صاحب جواب بكويند و دو نفر از آنطرف بعد جواب

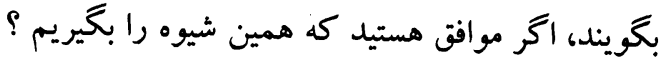
وزير تجارت و صنايع :

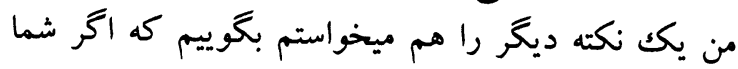

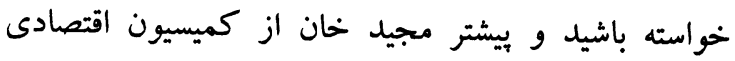

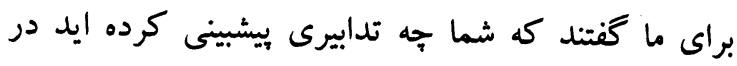

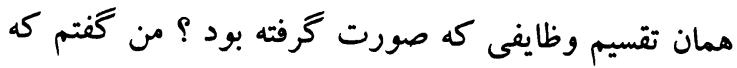

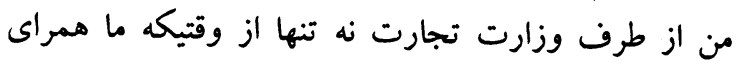
كميسيون اقتصادى يكجاى شديم صحبت ميكرديم، بلكه

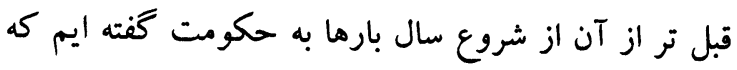

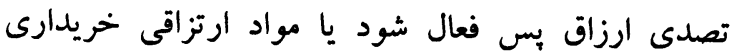

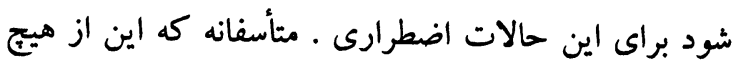
طرف قبول نشد و همان ليستش ييش من است، مكاتيب

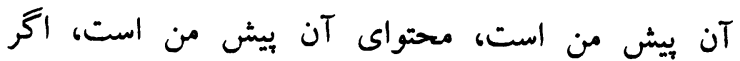

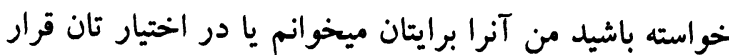

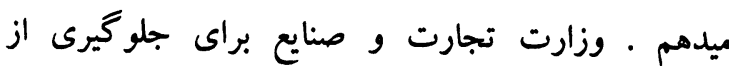
حالات بحرانى كار خود را از آغاز سال انجام داده است و ورات

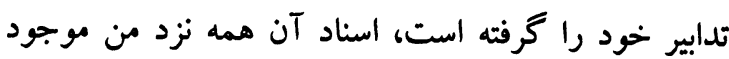

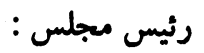
باز هم وكيل صاحبان براى اينكه مجلس استقامت بيدا

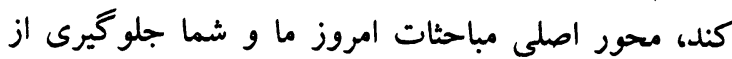

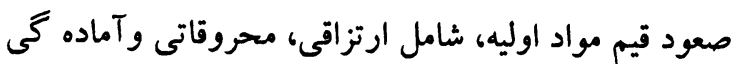

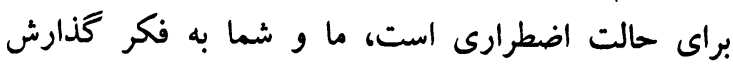

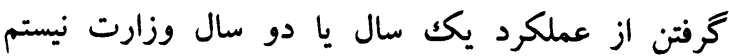

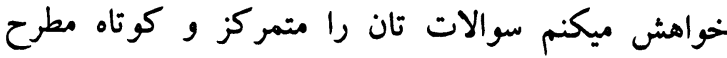

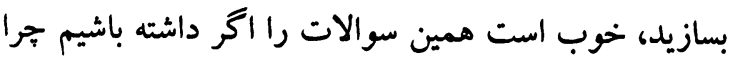
به نام اعتراض اخر نظر مطرح شود، اخر واقعاً اعتراض داض

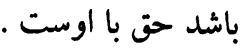
محمد اقبال صافى : بسم الله الرحمن الرحيم، وافئ جناب رئيس صاحب! امروز مجلس ما، مجلس استيضاح وزير صاحب است و مجلس استجواب نيست در مواردى

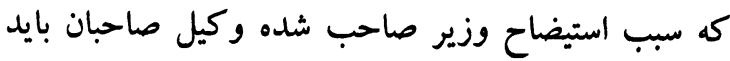
سوال بكنند، اينجا مطبوعات است، همه ما ميشنويم، 
ميشود، بطرول مخلوط است و نوشته اند كه جون واكنها

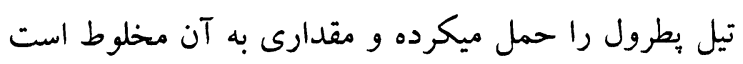

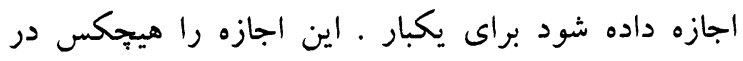

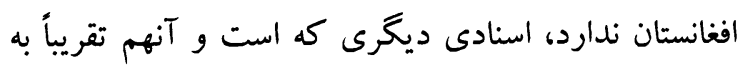

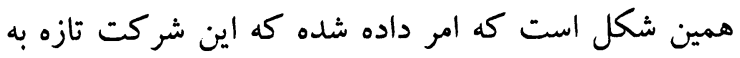

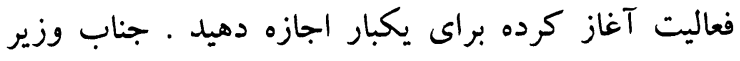

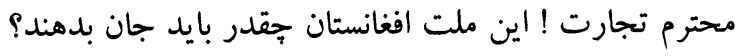

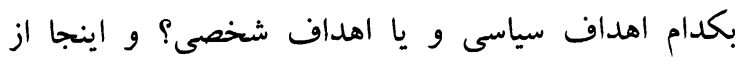

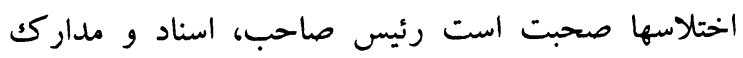

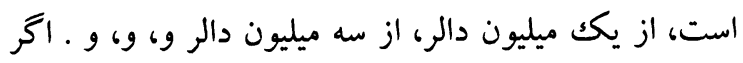

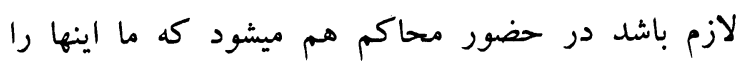

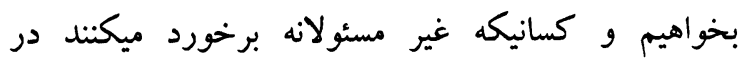

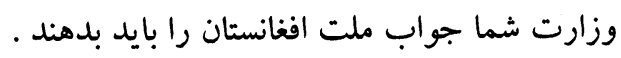
موضوع بعدى وزير صاحب به كميسيون فرمودند كه كندو

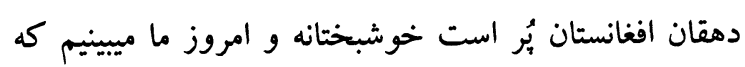

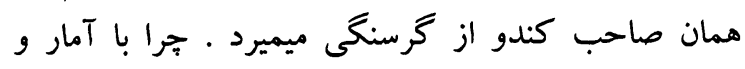

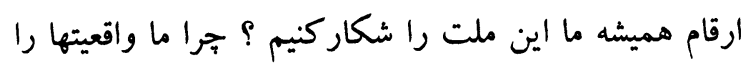

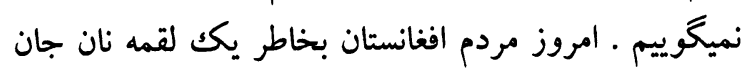

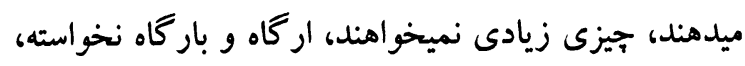
موتر نخواسته، فقط يكك لقمه نان خشكك ميخواهند، آيا

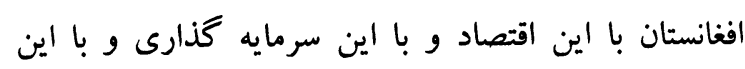

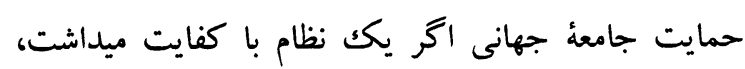

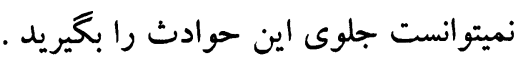

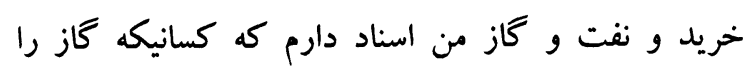

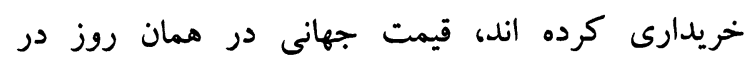
بيرزهاى كشورهاى صادر كننده مشخص است و جيز جيزيكه

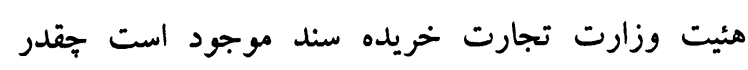

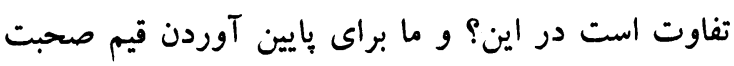

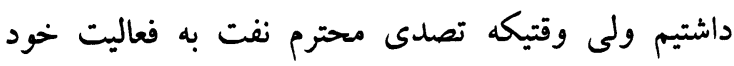

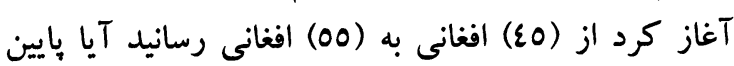

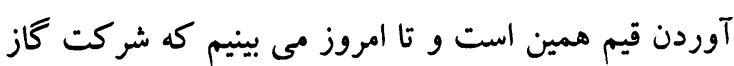

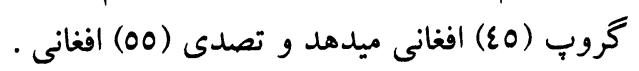

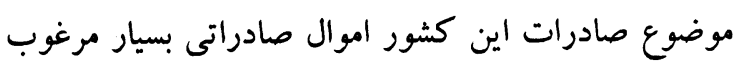

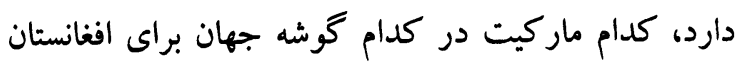

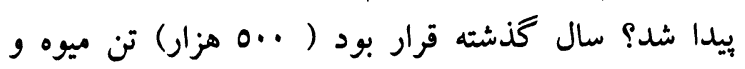

دعوت ميكنند جون هيج حمايتى صورت نگگرفته و در اين

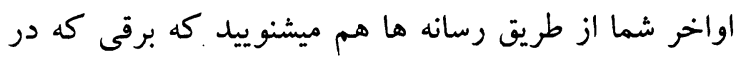

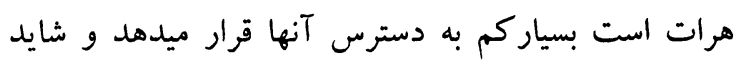
تر كمنستان و ايران اين را قطع بكنند و اين باعث تعطيل

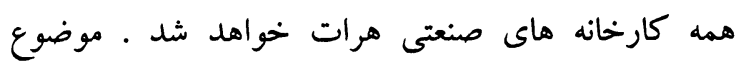

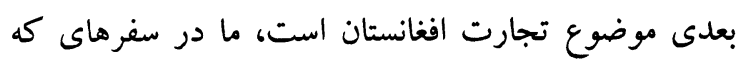

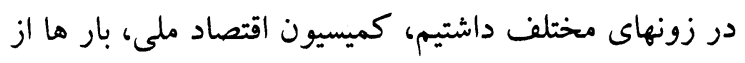

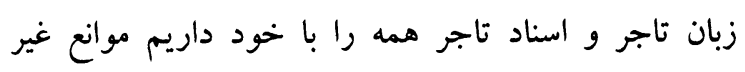

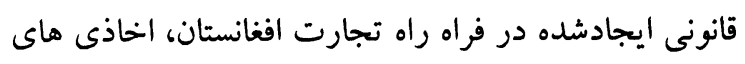
شاروالى ها، نيروهاى امنيتى، محصول و تكسهاى دوباره و

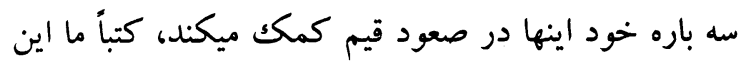
را به وزارت محترم تجارت ارسال داشتيم شما كدام

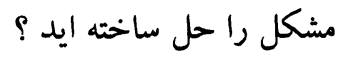

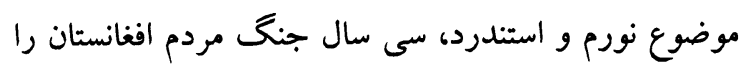
همه از لحاظ روانى و جسمى مريض ساخته است ولى نبود

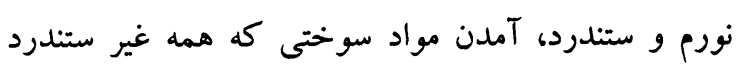
است، شما ميدانيد كه اينها فضاى افغانستان را آلوده ساخته

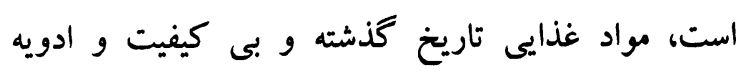
جات بى كيفيت تمام ملت ما را مريض ساخته است و واين

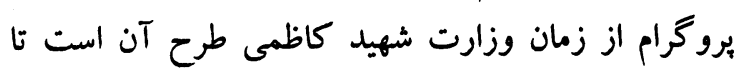

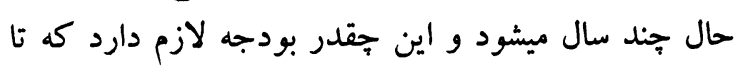

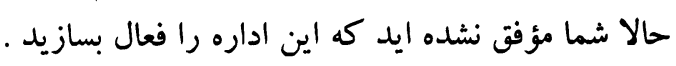
موضوع بعدى موضوع تصدى نفت است، كه شما بيشتر

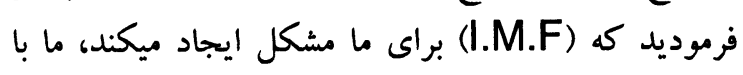

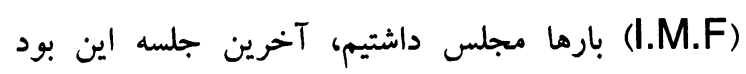

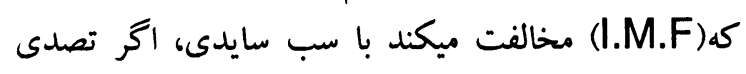

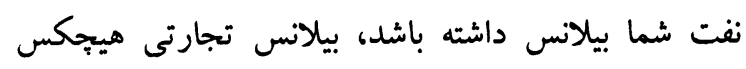

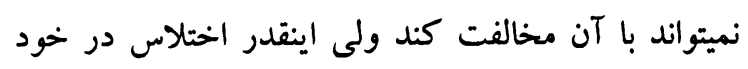
تصدى وجود دارد كه اسناد موجود است، بارها براى

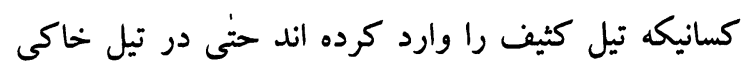

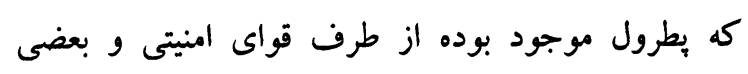

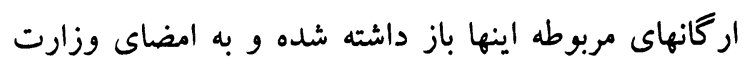
محترم اين خارج شده كه باعث آتش سوزيهاى فراوان

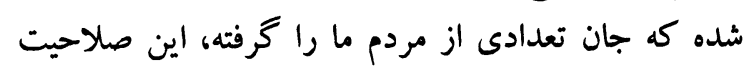

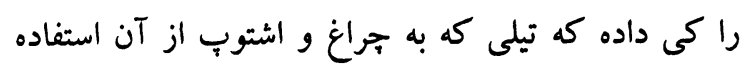




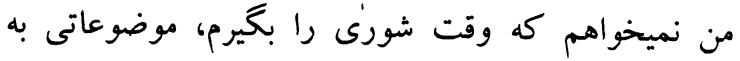

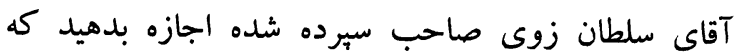

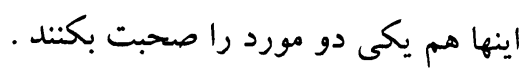

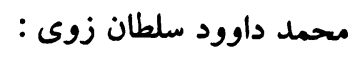

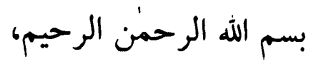

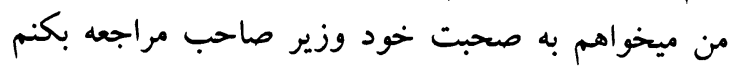

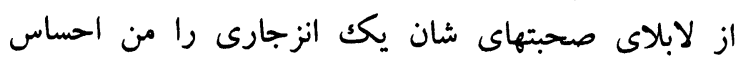

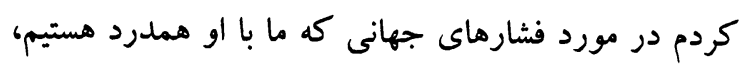

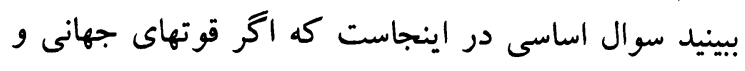

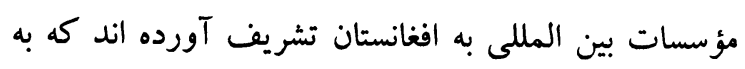

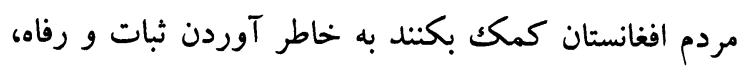

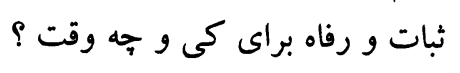

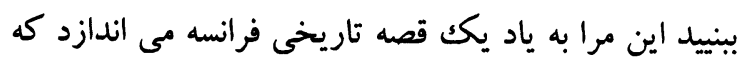

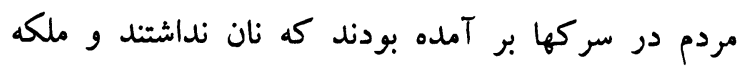

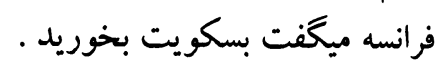

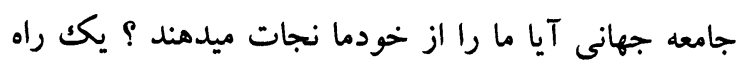

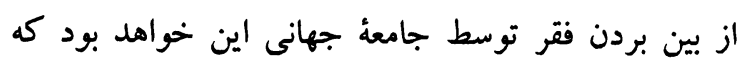

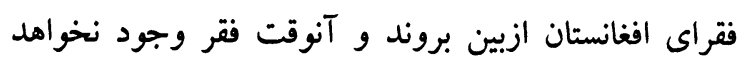

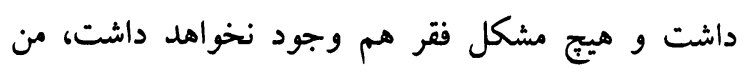

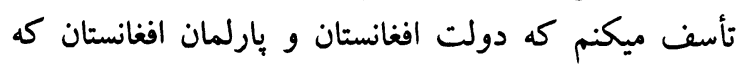

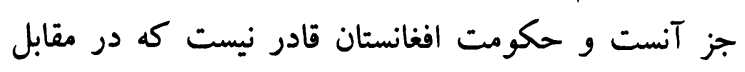

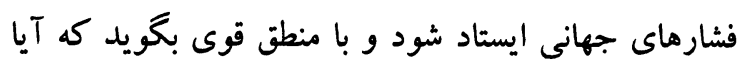

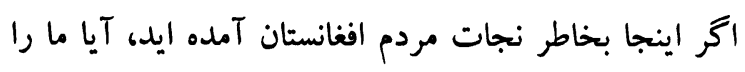

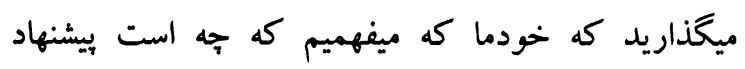

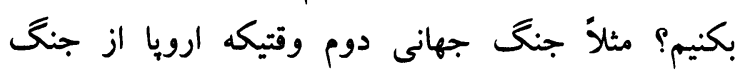

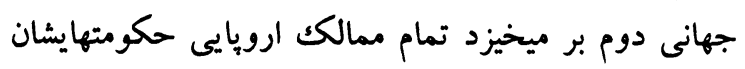

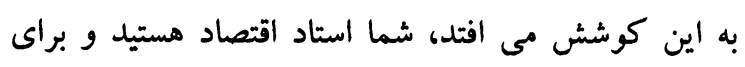

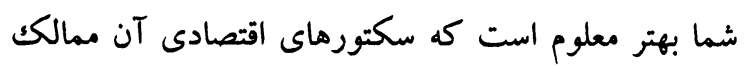

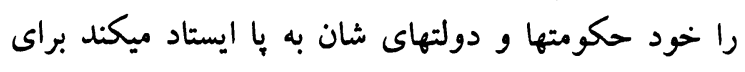

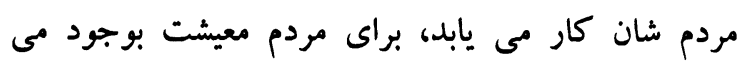

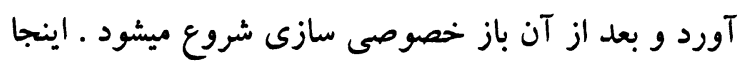

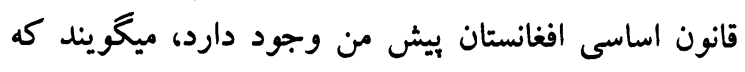

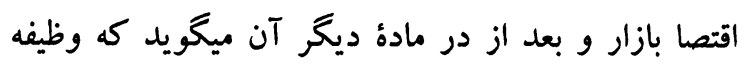

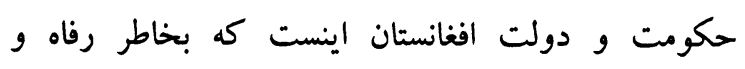
مصالح مردم تمام قوانين را عيار بسازد. ما به همين اساس بناس وراس
حتى انكور هرات كه بنام است صادر شود حتى يكك

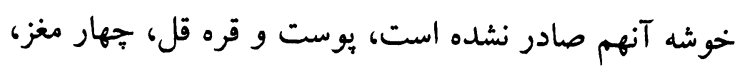

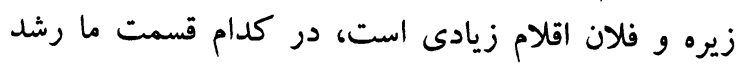

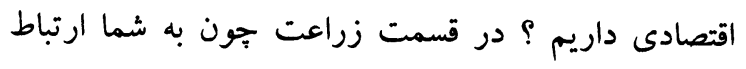

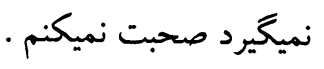

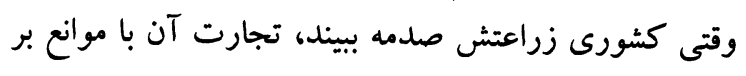

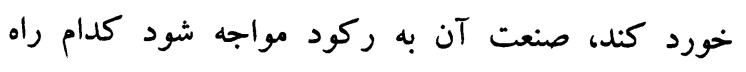

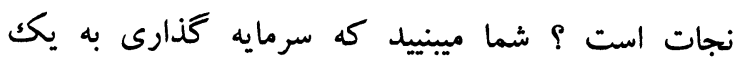

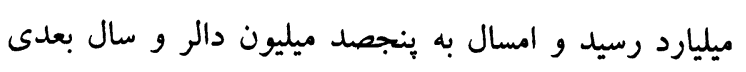

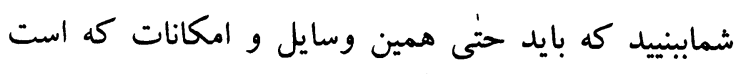

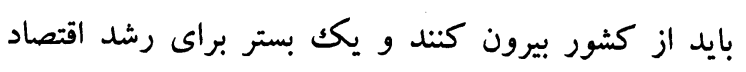

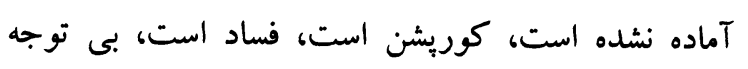

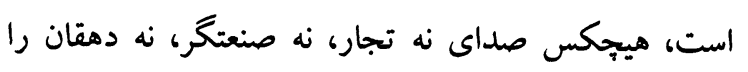

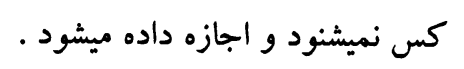

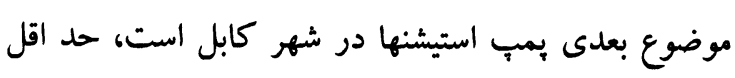

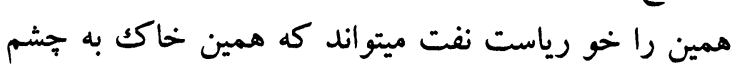

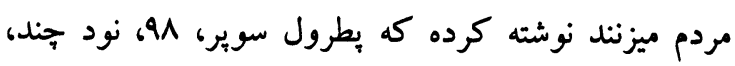

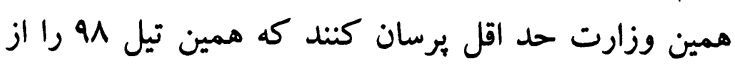

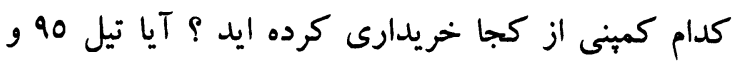

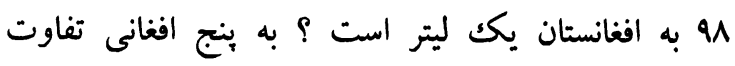

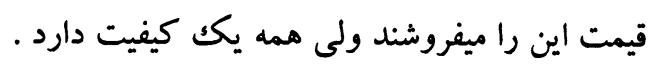

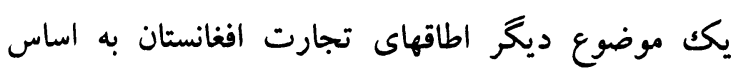

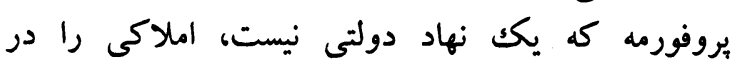

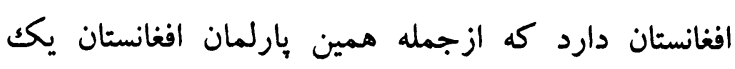

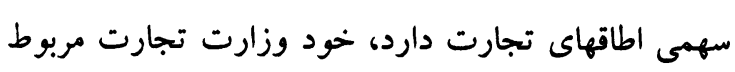

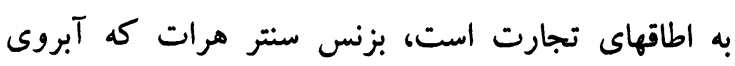

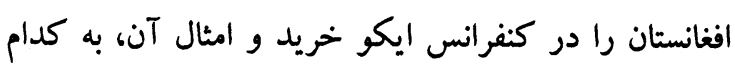

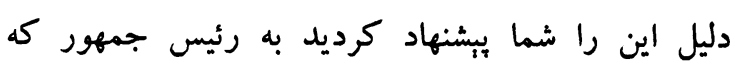

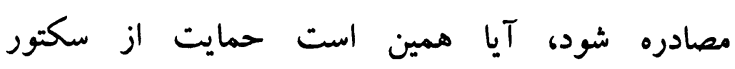

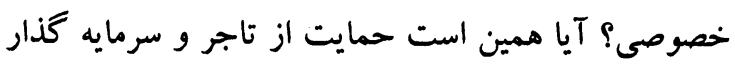

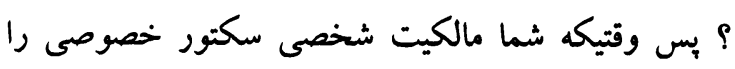

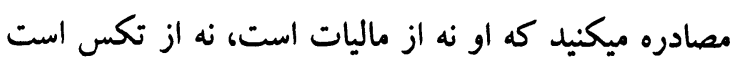

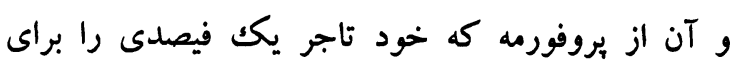

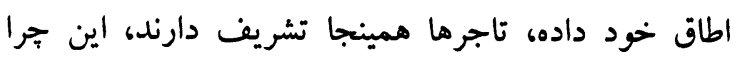
مصادره ميشود ؟ همين است حمايت ؟ موارد زياد است و 
وزير تجارت و صنايع : بسيار زياد تشكر ميكنم هم از جناب نادم صاحب وزب و و هم

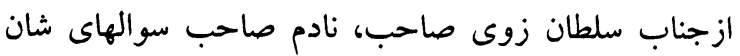

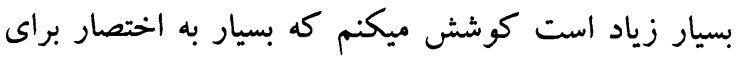

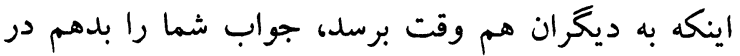

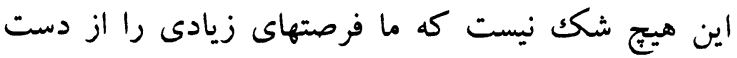
داديم، من با شما همنوا هستم، جامعة جهانى آمد باز آنرا

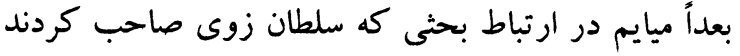

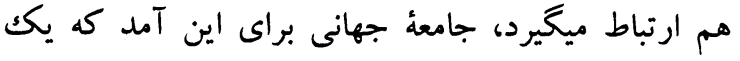

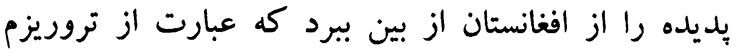

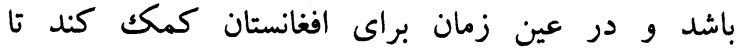
افغانستان بتواند به بِاى خود ايستاد شود، متأسفانه هم بران حكومت افغانستان و همجنان جامعة جهانى اشتباه كردند

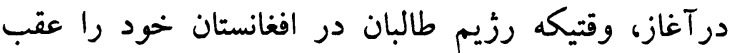
كشيد، جامعه جهانى و افغانستان سر اين فكر نكردند كه وردي

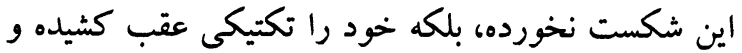

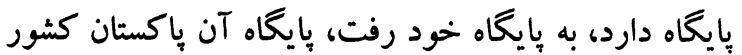

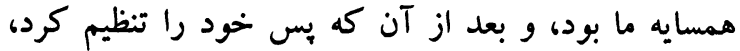

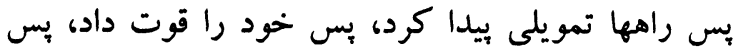

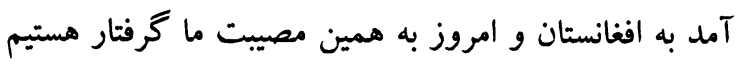

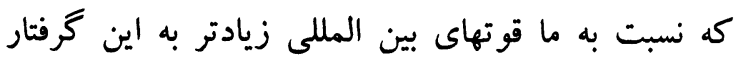

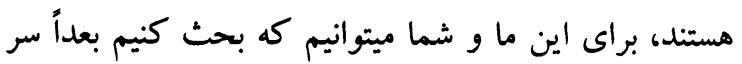

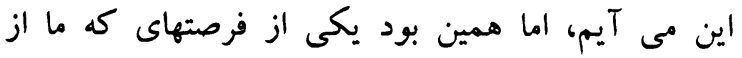

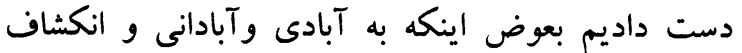
مملكت خود كار كنيم مجبور شديم كه همراى تروريزم

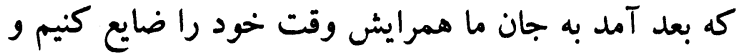

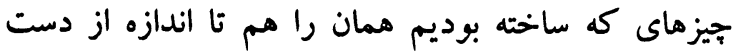

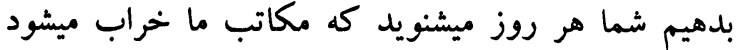

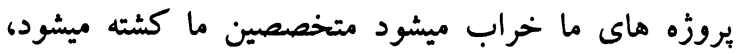

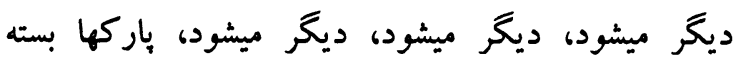

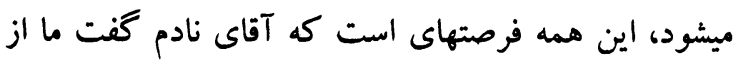

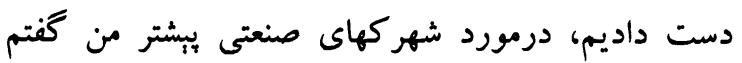
معين صاحب باز شايد به شما توضيحات بدهد جرا مسئول مهرد مسايل صنعتى است، آقاى نادم! ما توليدات صنعتى به به صنات خارج اگر نداريم توليدات زراعتى و صنايع دستى و
نماينده آى ام اف را در افغانستان و آمر عمومى بخش

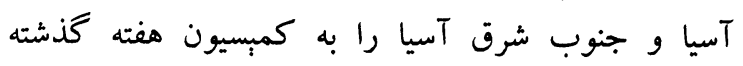

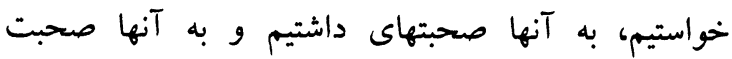

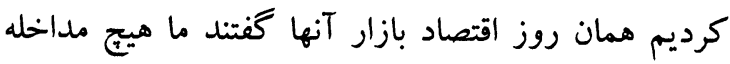
نميكنيم در اين فلسفه اقتصاد بازار شما كه شما روز امروز

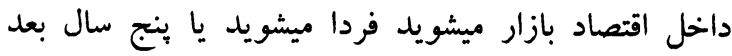

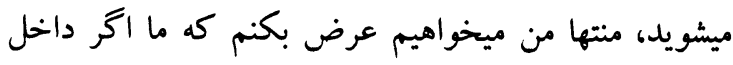

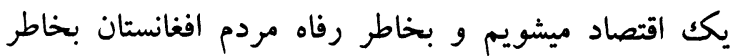

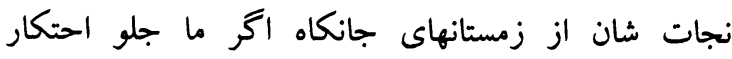
ميخيريم، جلو انحصار ميخيريم حكومت وظيفه دارد كه به نهان انهان

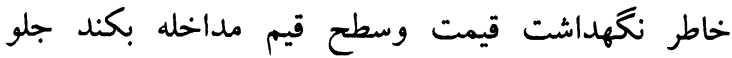

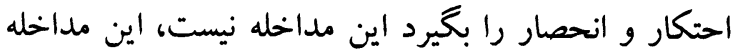

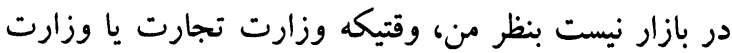

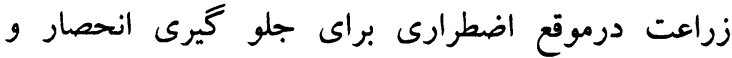
احتكار مداخله ميكند اين مداخله در بازار شمرده نميشود درد

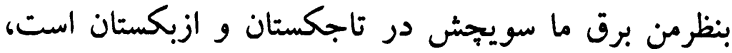
غله ما در پإكستان و هندوستان وقتيكه سرفه ميكند اينجا قيمت غله بلند ميرود امنيت مارا اردوهاى خارجى ميخيرد ودئه ما جه هستيم ؟ اين سوال فلسفى است كه ما متوجه وزير وزير صاحب زراعت، وزير صاحب نجارت نيست، ما منحيث لهر

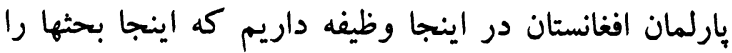

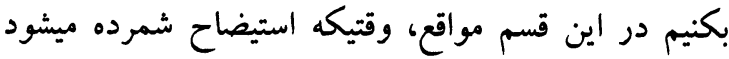

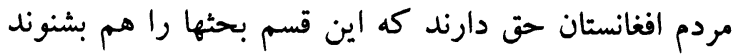
كه Tيا ما يكك ملت هستيم و دولت هستيم جه وظيفه داريم

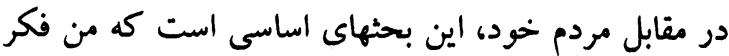

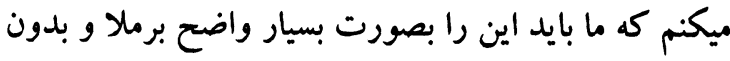

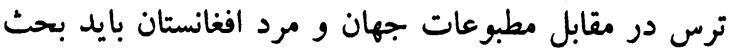

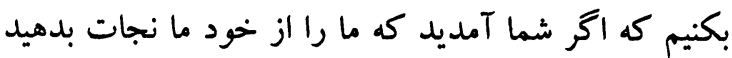
فقر ما از بين ببريد فقر از بين رفته، اين هم يك امد راهش اهد

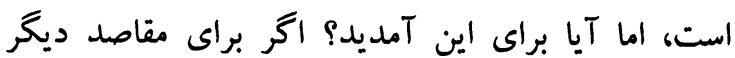

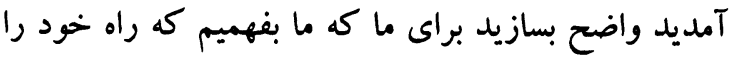

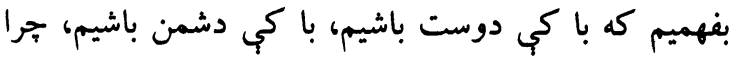

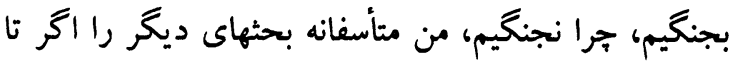

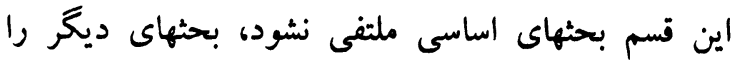

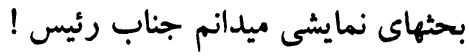


اين اخاذى را از بين ببرد اما من كَب شما را تأئيد ميكنم

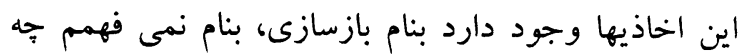

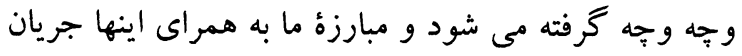
دارد اين به ذات خود يكك فساد ادارى است ـ ـ حال ما مثلاًا

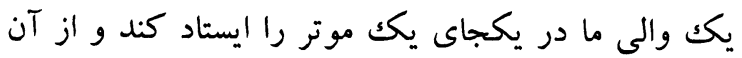

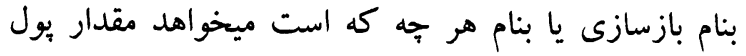
بحيرد و ما همين قوت عسكرى را نداشته باشيم وزارت

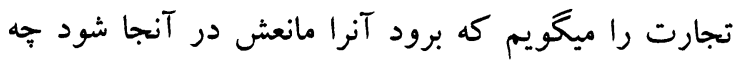

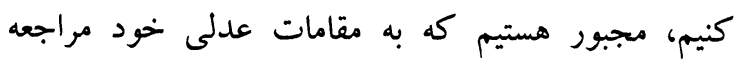
كنيم به مقامات امنيتى خود مراجعه كنيم و از آنها بخوئيم

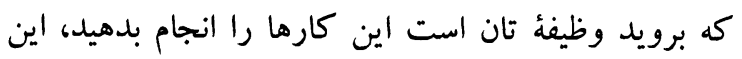

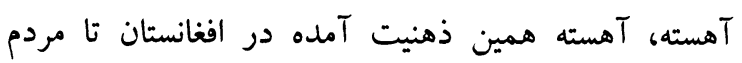

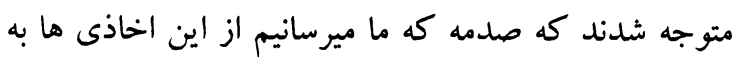
تاجر در حقيقت نهادش صدمه به خود ميرسانيم اين به مند ماند تدريج مردم آهسته، آهسته ذهنيتهاى شان اصلاح ميشود،

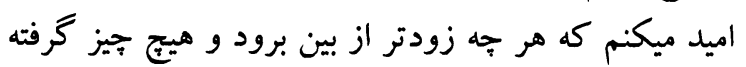
نشود اما در عين زمان تاجر مكلف است كر كه تهو تمام

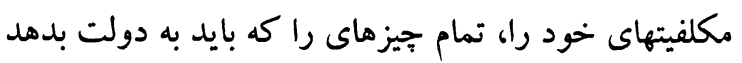

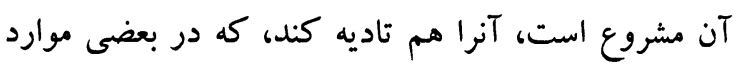
در اين قسمت هم كوتاهى وجود دارد كه اين صورت

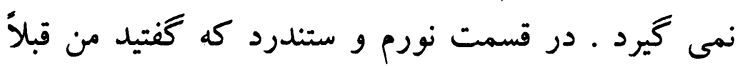
تشريح كردم حاجت بهه اين نيست كه باز هم بيان كنم

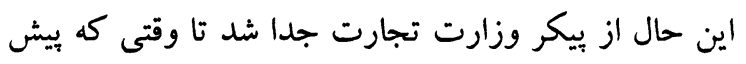

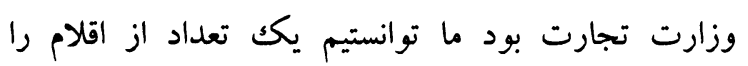

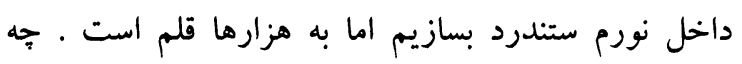
وارد ميشود و جه صادر ميشود كه بايد است درين جو كات داخل شود به اساسى معيارهاى بين المللى تيار

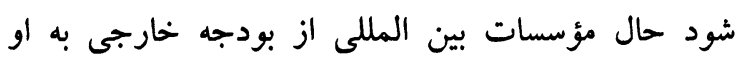

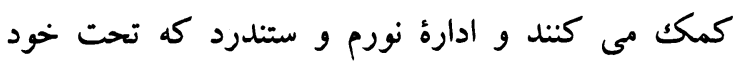

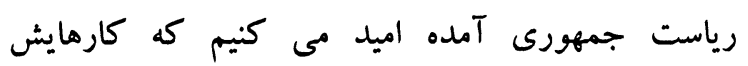
سرعت بيدا كند و يول خود را بلدست بيآورد و اين كارها را زود انجام بدهد اين كار بسيا ر مشكل است، كشورهاى

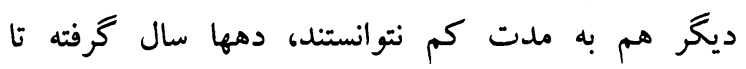

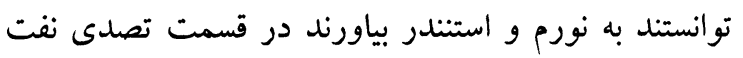

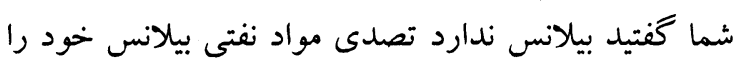

نباتات طبى زياد داريم، من ارقامى را كه گفتم شما آنرا مربوط به سالهاى بِّ دانس دانستيد اينطور نيست، ما ما امسال

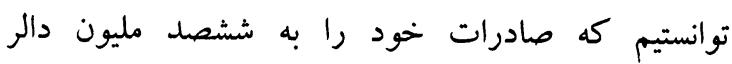
برسانيم، تنها صادرات همين مواد خود را، بار كهاى صناد صنتى

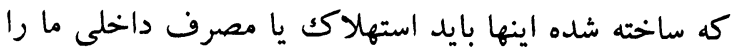

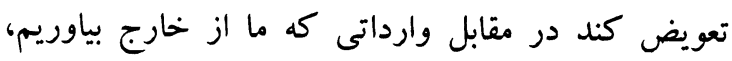
يعنى عوض اينكه يكك بطرى موتر را ما از خارج بياوريم

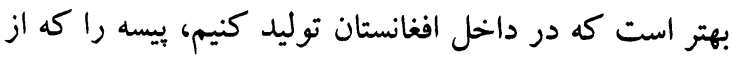

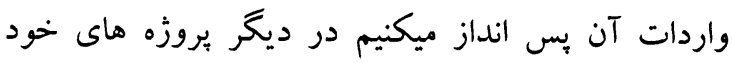

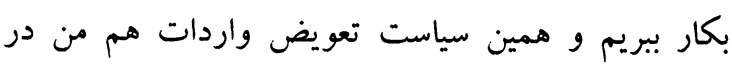

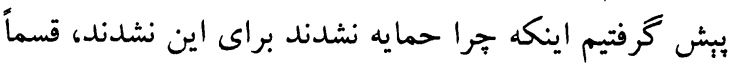

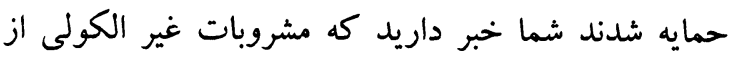
بست فيصد به جهل فيصد بلند رفت، در بعضى مسايل

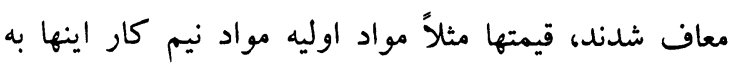

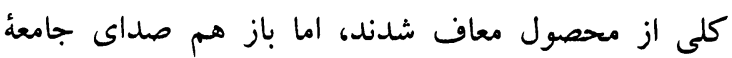
جهانى به ما بر آمد، همين حالى در در تو كيو براى اخطار دادند كه اخر شما بس مشروبات غير الكولى رانى را همين محصولش را بس به همان بيست فيصد نه بياوريد ما در

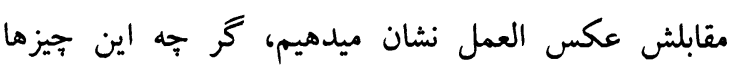

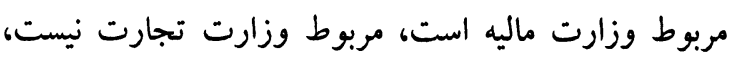

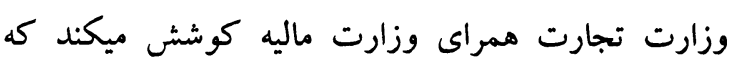

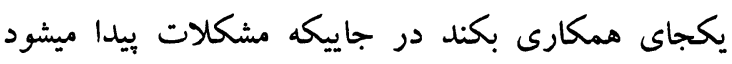

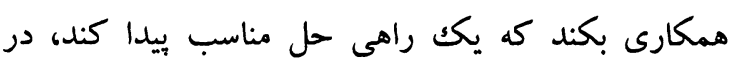

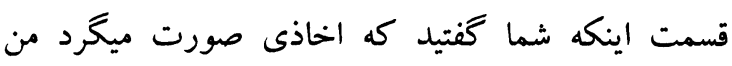

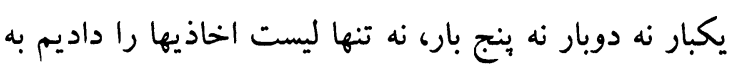

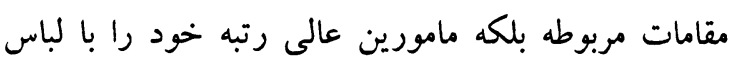

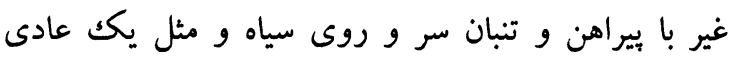

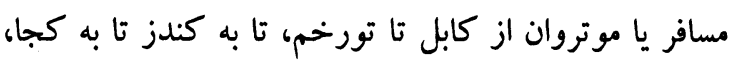

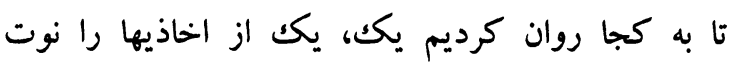

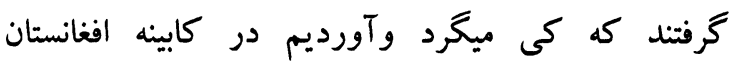

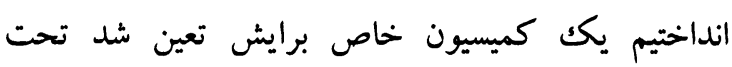
رياست معاون دوم رياست جمهورى كه اينها را ازبين

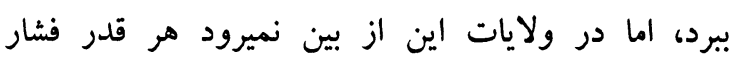

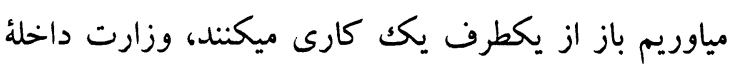

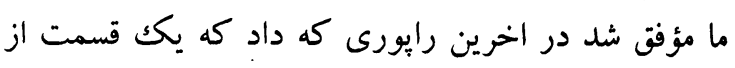


ميكنند با يكك تيل ديخر مخلوط ميكنند دو جند و سه جند

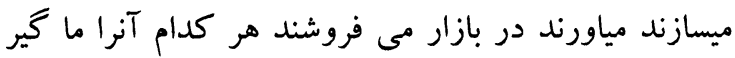

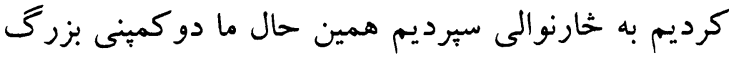

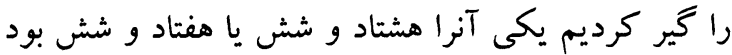

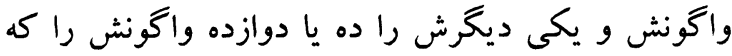

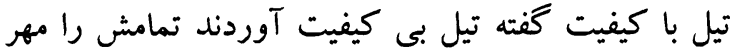

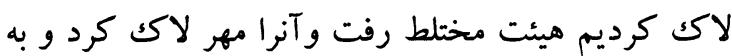

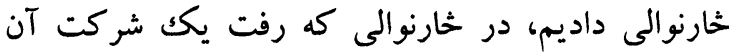

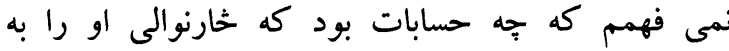
محكمه ارجاع كرد، محكمه اولى حكم برائتش را داد ماد ما واله

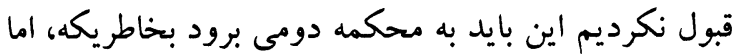

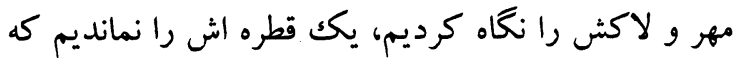
بس شود، كمينى ديخرش برد يكقدار تيل را در كابل،

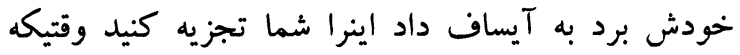

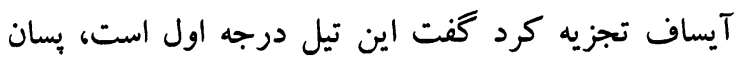

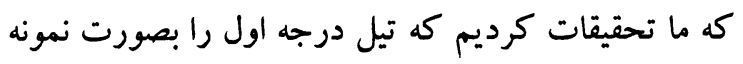
برده نه از ذخاير خود كه مهر و لاكت شده و و تصديق

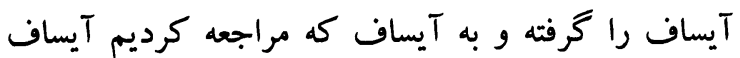

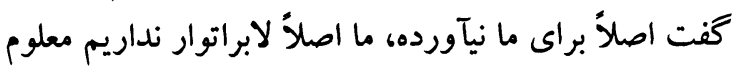

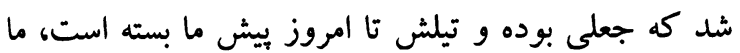

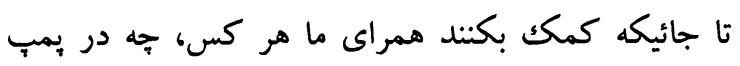

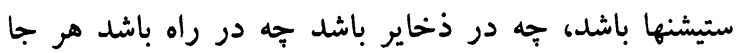

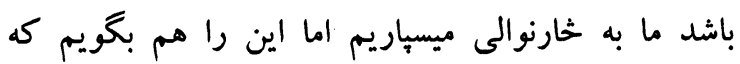

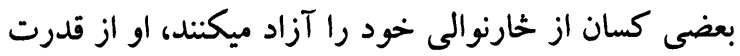
ما بيرون است، ما در آنجا مداخله كرده نميتوانيم اينكه

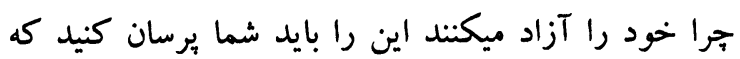

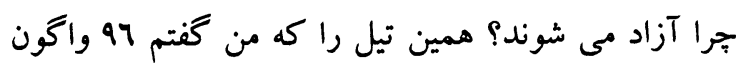

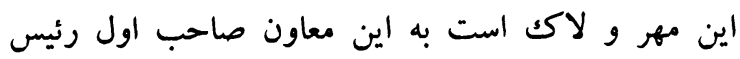

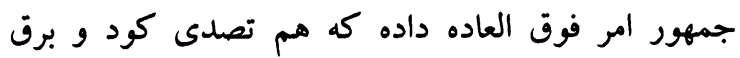
شمال اكر تيل برايش نرسد سقوط ميكند ايستاد ميشود و

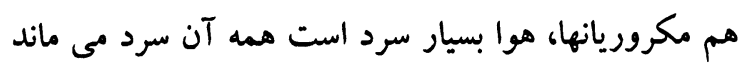
يكك امر فوق العاده دادند كه تحت رياست يكار يكت هيئت مختلط باز شود و به همين دو منبع داده شود و مقدارش

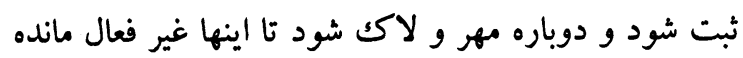
نشود و يول آن در يك حساب خاص مانده شُود تارد
داده بيلانسهايش را من ديده ام اما يكك كارى كه ما

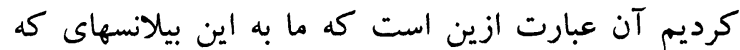

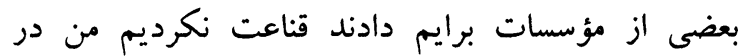
بهلوى آن مؤسسات بين الملى يكى شؤس شهرت جهات بهاتى دارند

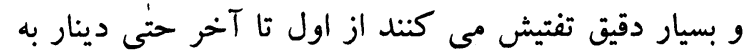

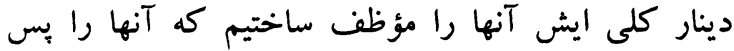

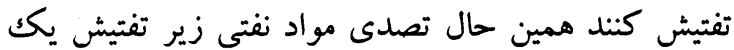
مؤسسه بين المللى بنام دولايد است كه تفتيش مئ كئ كند

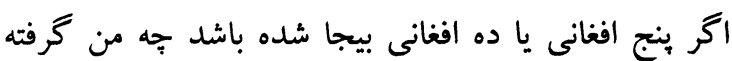

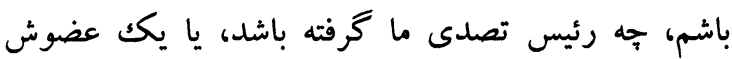

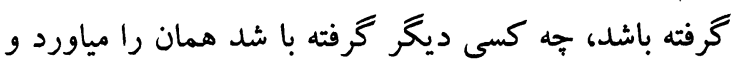

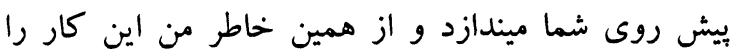
كردم هم او را گفتم كه تفتيش كند، هم اطاقهاى تجارت را كه تفتيش كنند، هم آيسا را كه تفتيش كنتد كل كل كنيش آنها از

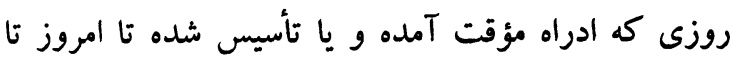

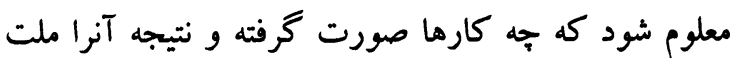

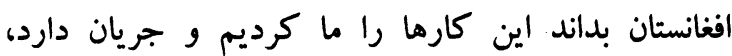

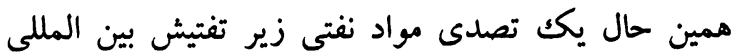

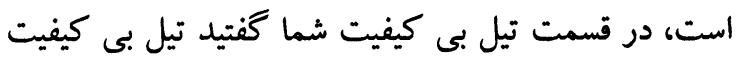

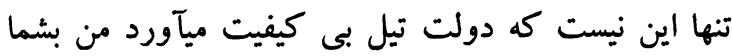

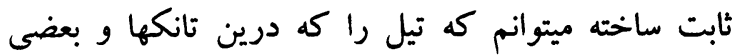

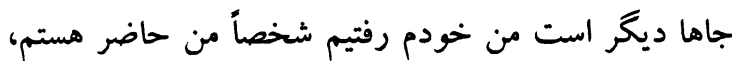

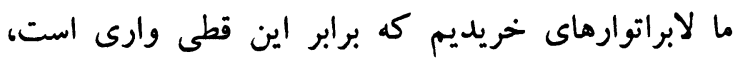
ديجيتل، من حاضر هستم كه در بين همين اطاق بزرى

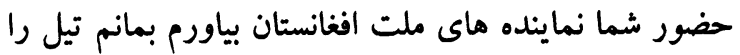

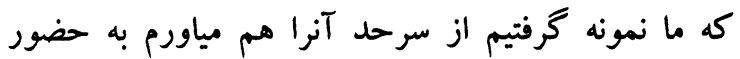

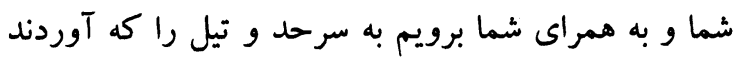

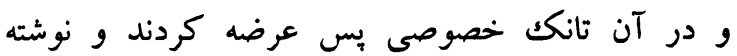

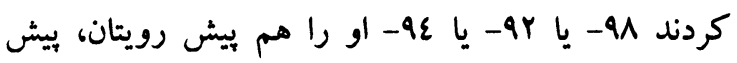
روى رئيس صاحب مجلس يا بيشروى شما مى مانم جند

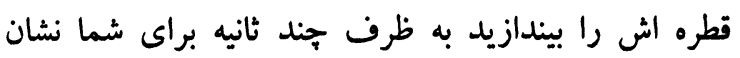

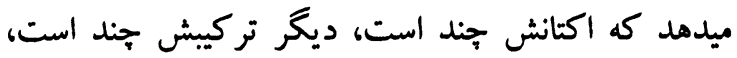

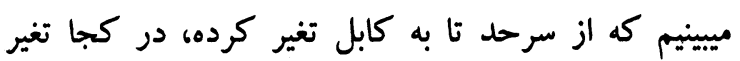

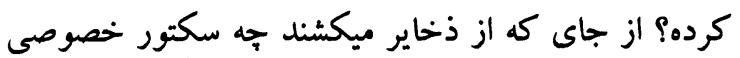

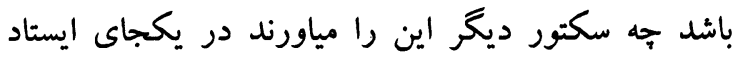


اينكه از يك كشور ييشرفته آمده و خودش يكك انجينر

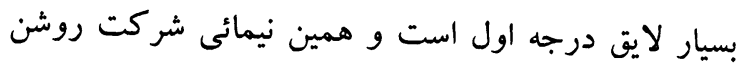

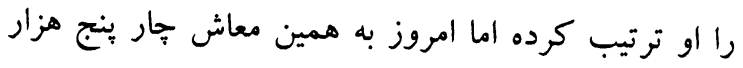

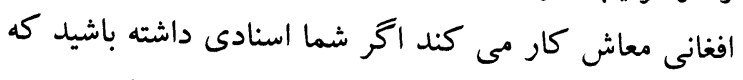

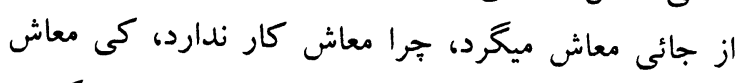

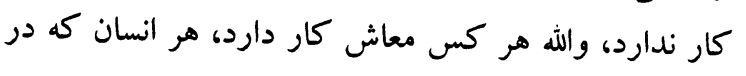

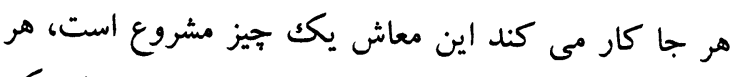

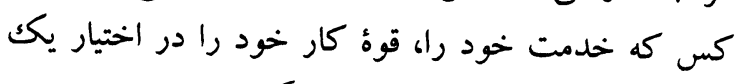

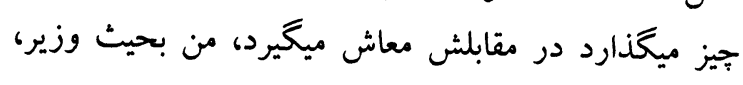

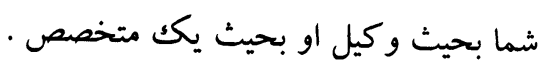
رئيس مجلس :

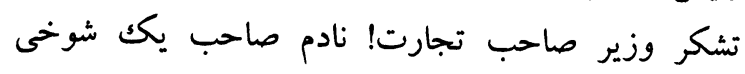

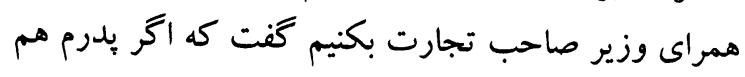

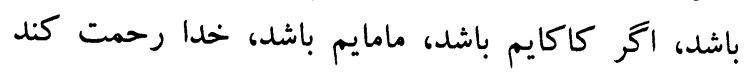

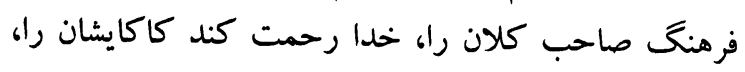

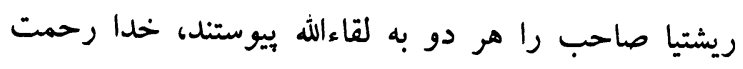
شان كند، كاكا و ماماى شان را رانمى فهمب، شوخى كرديم

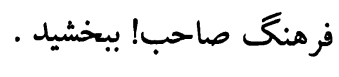
شكريه باركزى :

من يكت اعتراض دارم و او اعتراض من امروز سر نقض المان

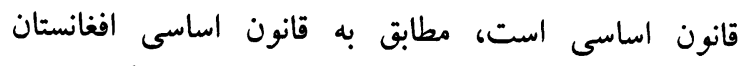

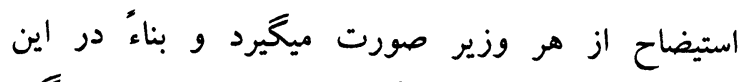

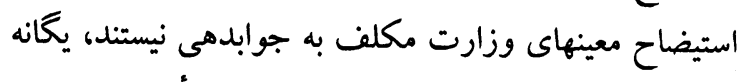
كسى كه مكلف است به خاطرى كه در رأس اداره خود بهان

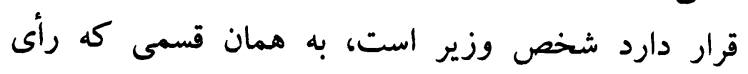

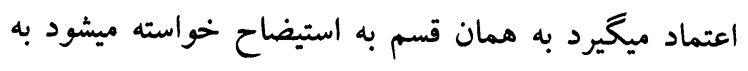

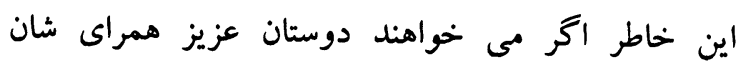

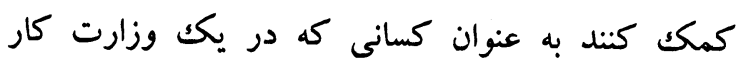

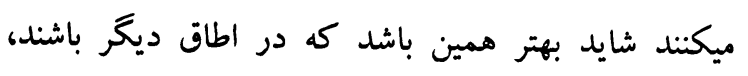

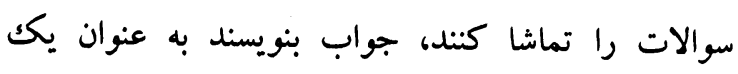

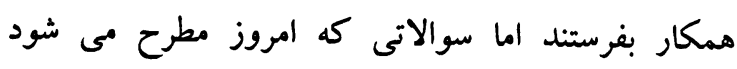

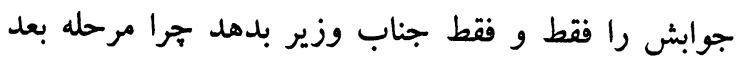

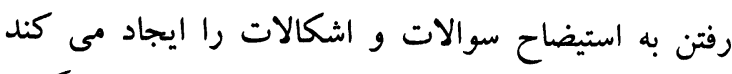

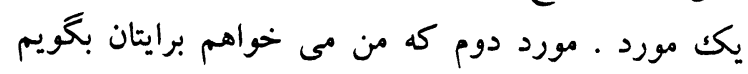

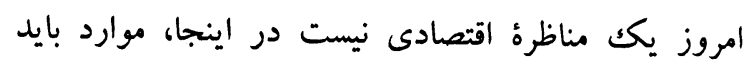

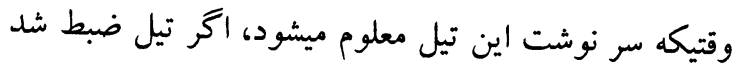

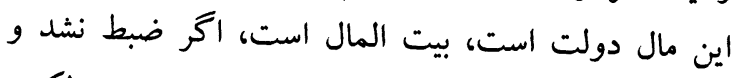

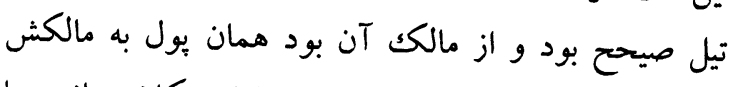

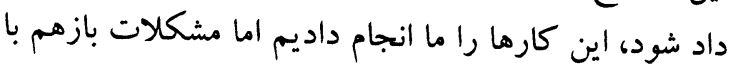

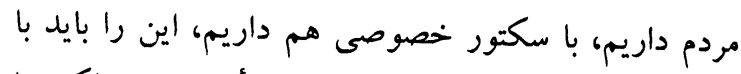

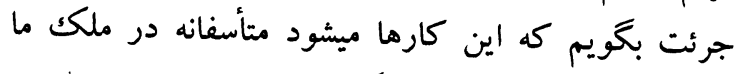

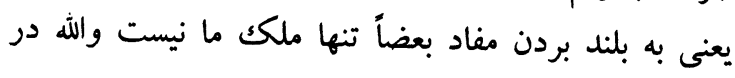

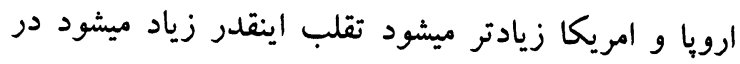

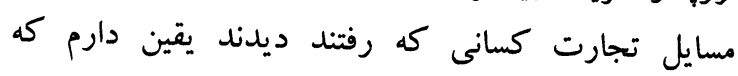

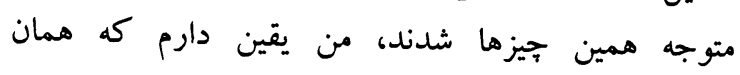

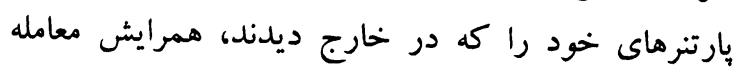

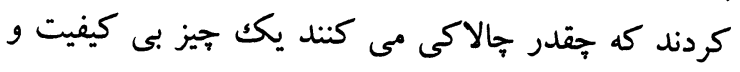

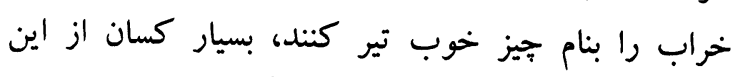

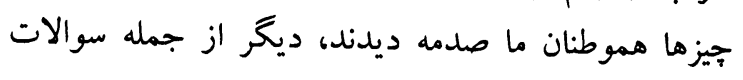

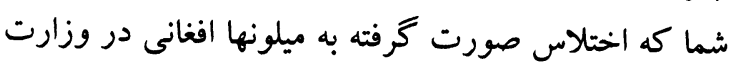

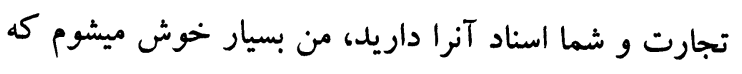

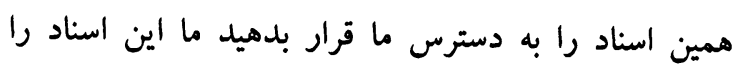

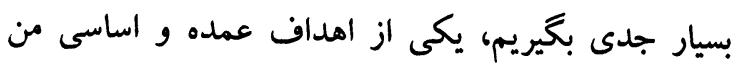

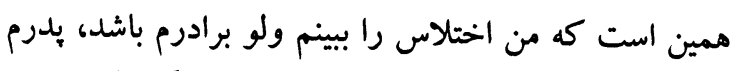

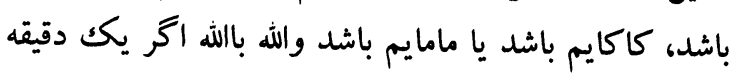

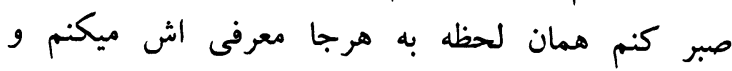

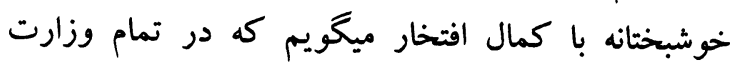

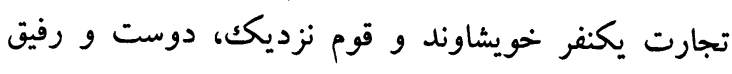

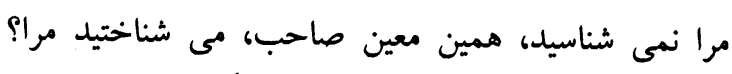

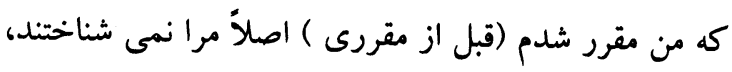

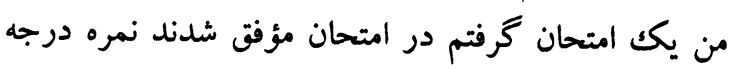

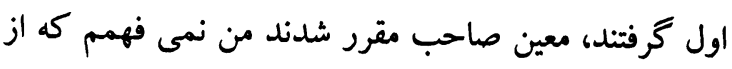

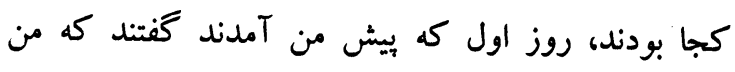

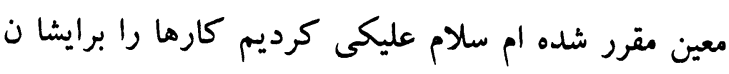

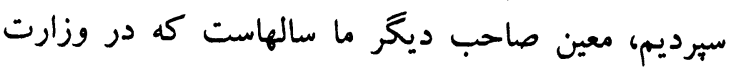

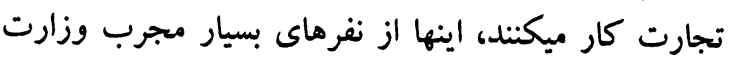

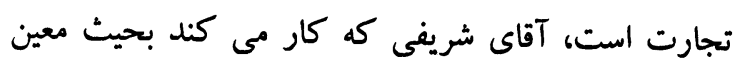

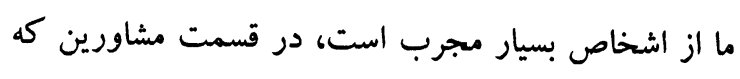

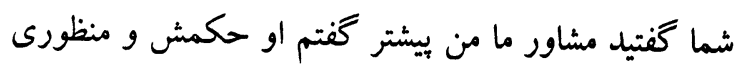

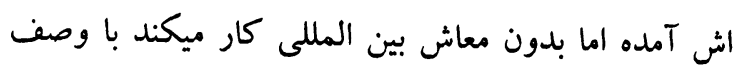




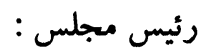

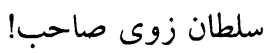

محمد داؤد سلطان زوى : ماحب

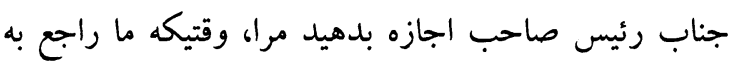

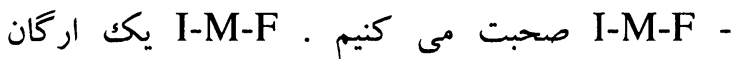
دسيلينى است بالاى حكومت افغانستان مثل سايه هر دقيقه

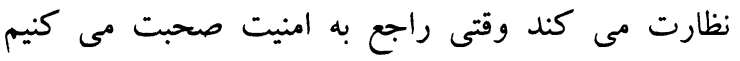
مجبور هستيم كه راجع به اين موضوعات صحبت كنيت كنيم جناب رئيس صاحب إن إن

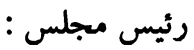
سلطان زوى صاحب! حق داريدكه شما سوالات خود را مطرح كنيد اما برداشت من اينست كه استيضاح امروز

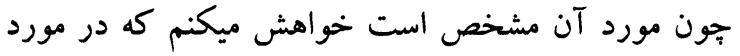
اصلى صحبت كنيد . محمد داؤد سلطان زوى : ماندي : مان در همان مورد صحبت ميشود رئيس صاحب حال كال كه

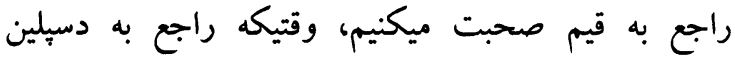

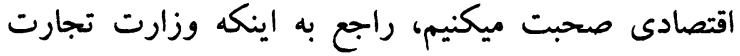

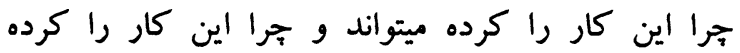

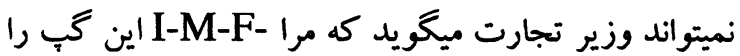

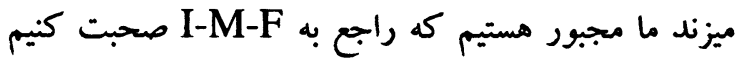

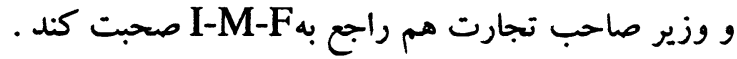

\section{جاكتر فضل الله مجددي :}

يكت اعتراض من بالاى همكارانم است بدون ائن اينكه از

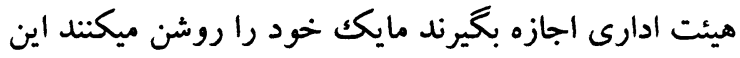

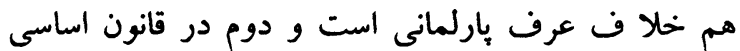

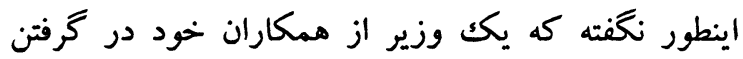

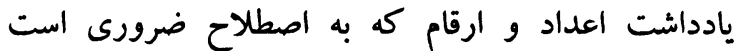

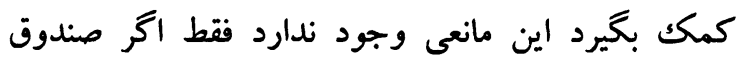

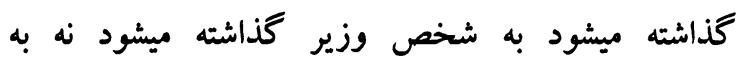
معاونينش از نظر قانون اساسى اين اعتراض وارد نبود و و من

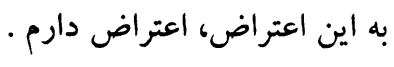

مطرح شود كه واقعاً جرا وزير صاحب محترم به استيضاح

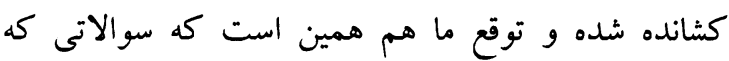

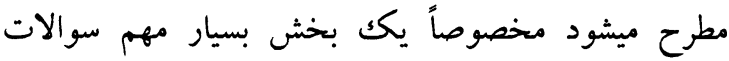

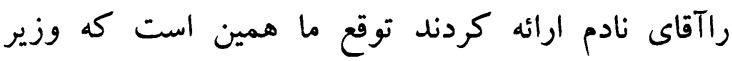

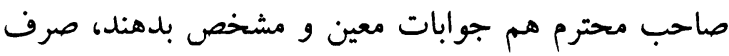

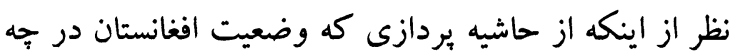

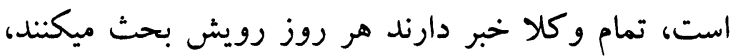

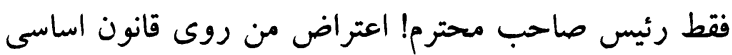

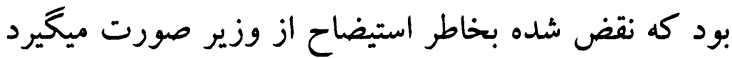

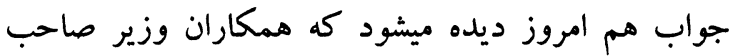

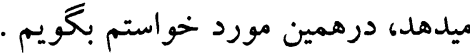

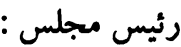

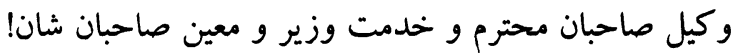

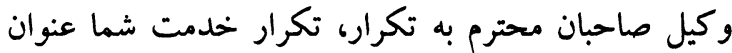

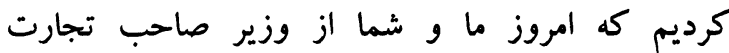

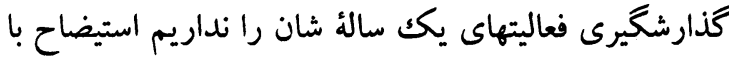

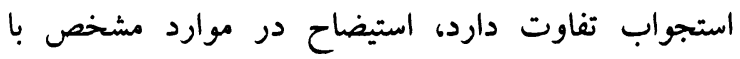
سوالات مشخص، با اسناد مشخص مطرح ميشود، شما ماردا

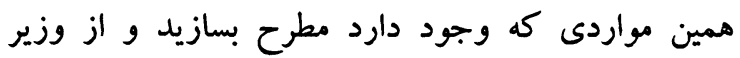

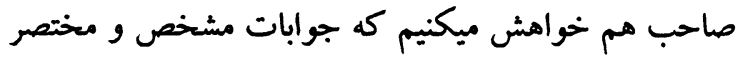

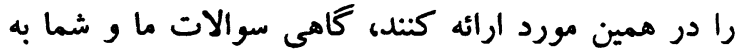
حدى بيرون ميرود كه او از حالت استيضاح بيرون ميشود، مشخص هدف اساسى كه خواستيد دوستان كه ثبت نام نام كرده اند همين بود كه مواد ارتزاقى، مواد نفتى، مواد اوليه

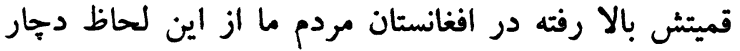

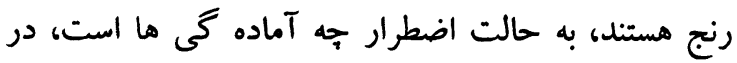

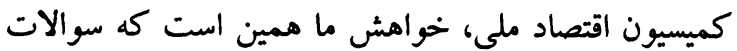

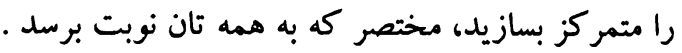

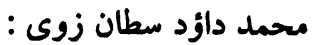
جناب رئيس صاحب! وقتيكه در شرايط فعلى افغانستان

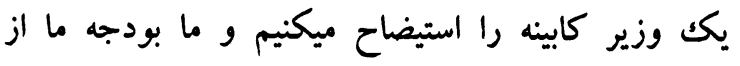

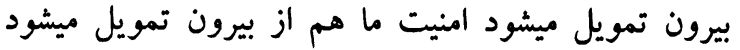

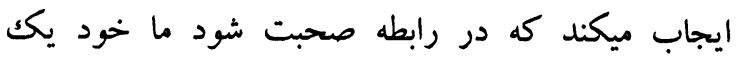
مملكت عادى نيستيم در حالت جنگ هستيم. 
افغانستان است كه كشت بِنبه حال فعلاً به اساس قرار دادى

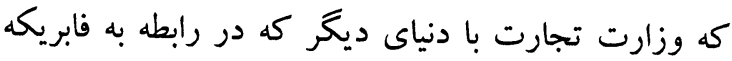

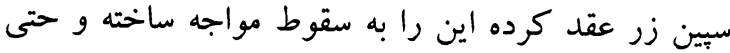

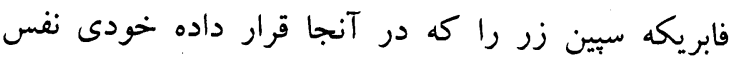

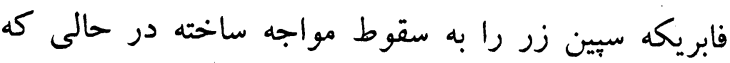

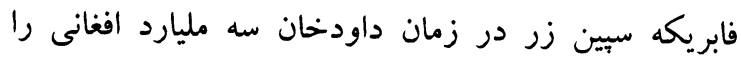
طور سب سايدى به مصرف ميرساند اما متأسفانه امروز

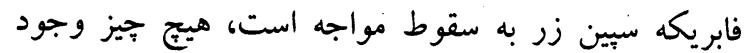

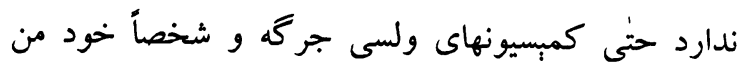

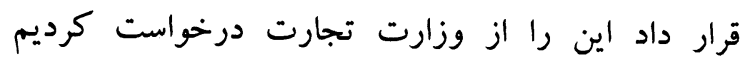

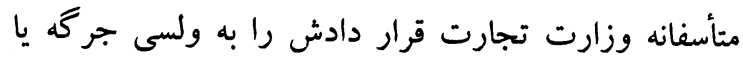
به كميسيون مربوطه يا به شخص من كه نماينده مردم

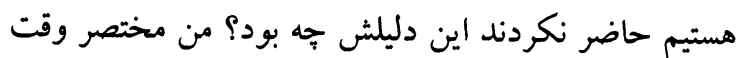

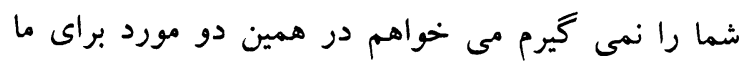

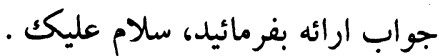

$$
\text { وزير تجارت و صنايع : }
$$
در قسمت I-M-F به حضور شما مختصر عرض ميكنم

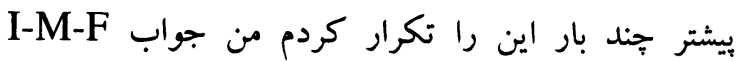

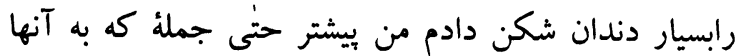

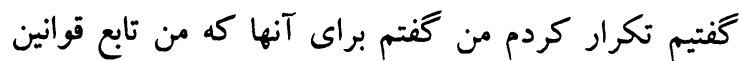
كشور خود هستم، تابع قوانين كشور شما نيستم يا مؤسسه منه

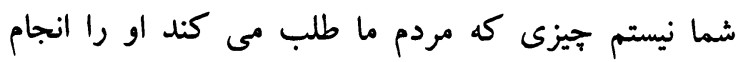

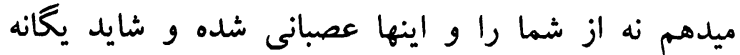
وزيرى باشم كه دروازه اطاق خود را باز كردم يكك هشت أنه

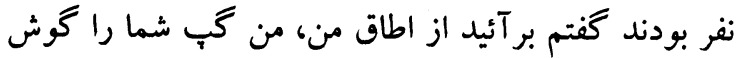

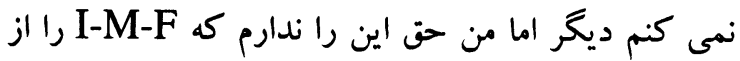

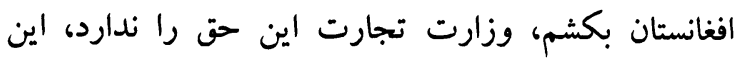

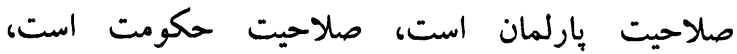
درآخرين ملاقاتيكه با مؤسسات بين المللى و رئيس

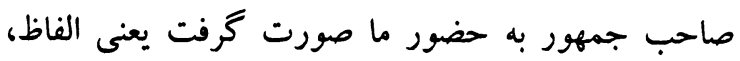
كلمات و جملات را كه رئيس صاحب جمهور به ماحور در مقابل مؤسسات بين المللى و سوء استفادة آنها در افغانستان اجرا كرد هر كشور ديخرى كه ميبود ممين مؤسسات ميرفتند

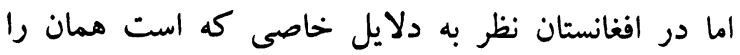

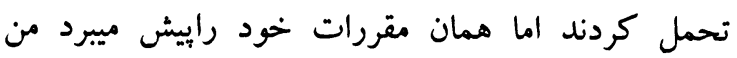

قارى رحمت الله :

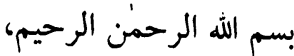
به اجازة جناب رئيس و العضاى مجلس، الرحنب، جناب وزير

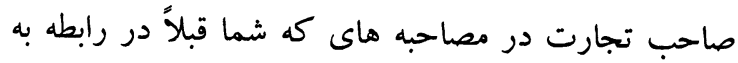

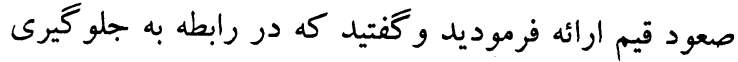

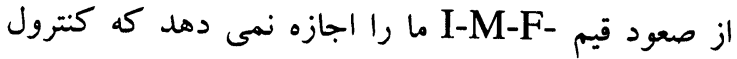
قيم را بوجود بياوريم در حالى كه شما مكلفيت تان در در دان

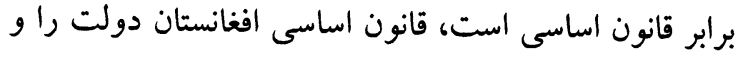

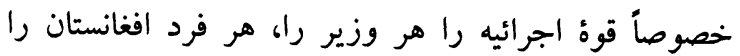

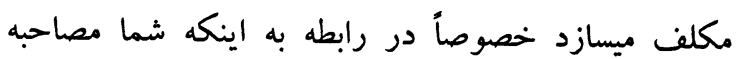

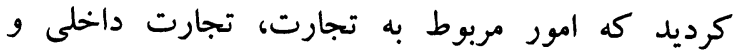

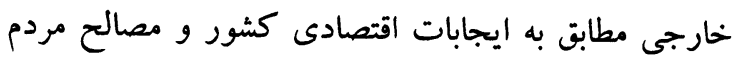

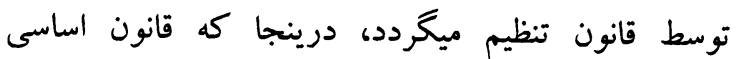
افغانستان كه از جمله سه مادة اول قانون اساسى افغنانستان

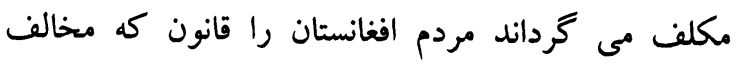

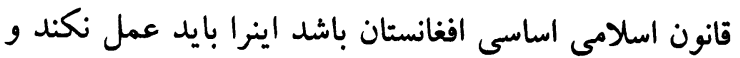

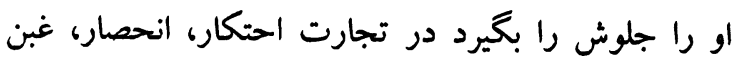

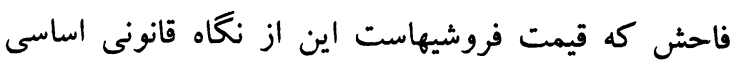

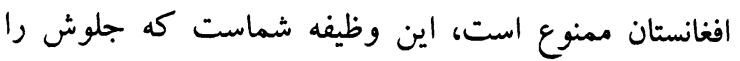
ميگرفتيد همان قسمى كه ملت افغانستان در برابر مجامع ومان

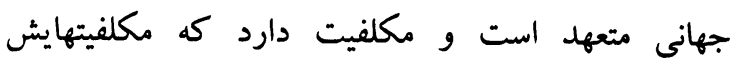

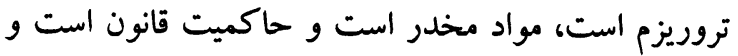

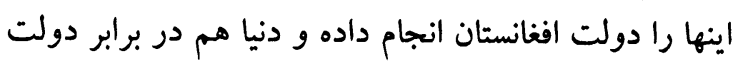

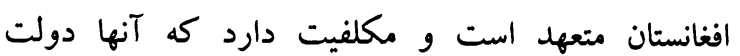

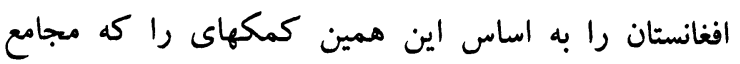
جهانى از قبل كرده حال هم ميكند بايد انجام بدهد، شما ونها

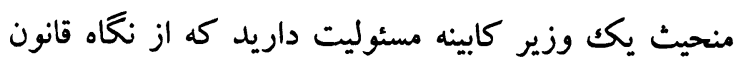
اساسى بايد شما اين جواب را به مردم افغانستان نمى كفتيد

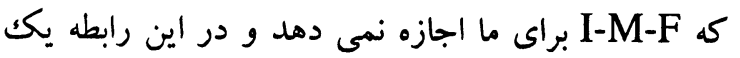
موضوع كه اين بايد واضح شود كه شما به كدام مسئوليت

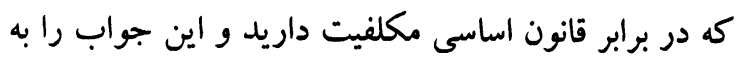

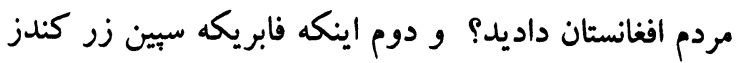

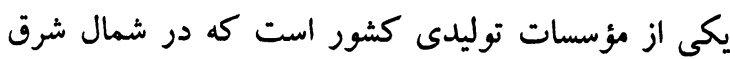
يكى از محصولات زراعتى افغانستان كه در توليد كشت إن

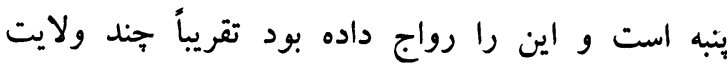


وكمي، ولبي د محترمب كوفي صبب د خبري پِه تائيد كله

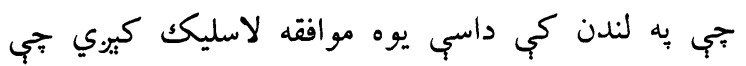

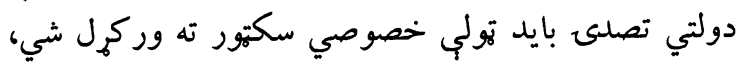

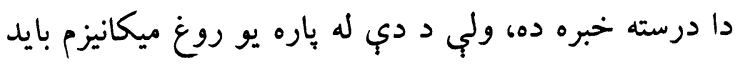

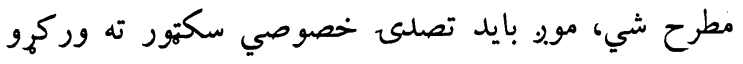

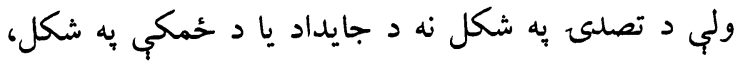

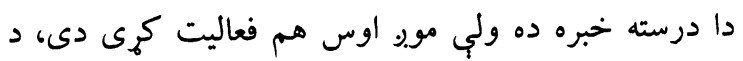

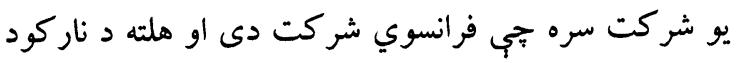

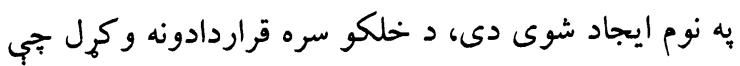

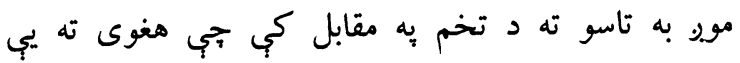

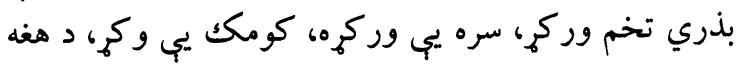

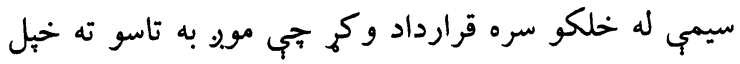
حاصلات ببرته همدي شركت ته دروهو او شركت بـ بيا به به

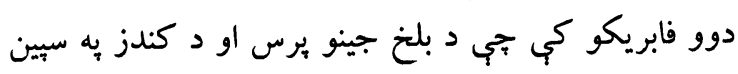

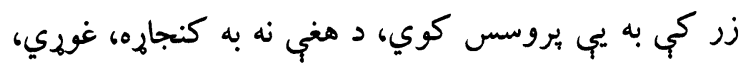

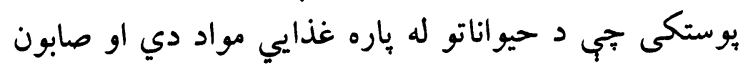

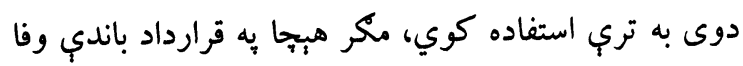

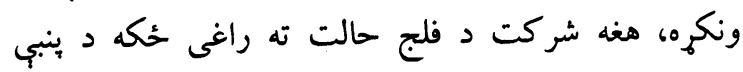

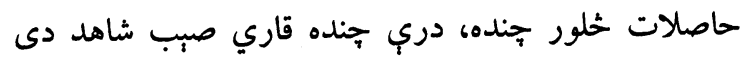

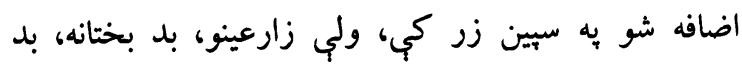

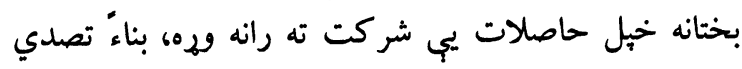

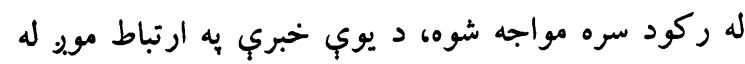

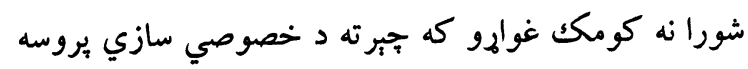

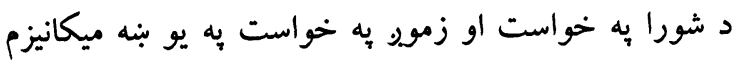

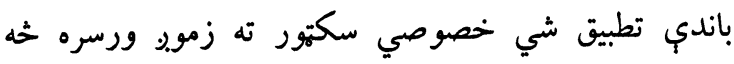

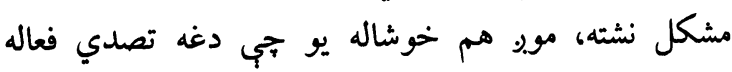

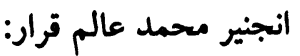

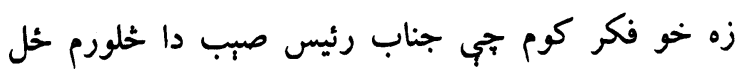

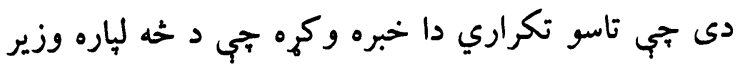

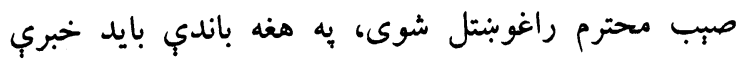

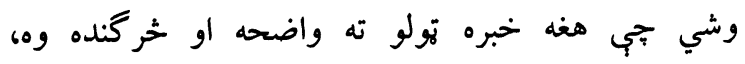
بشردوست صبب هم ناست ده او ينخُوسو كسو دلته امضاء

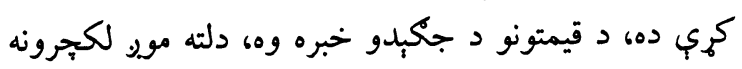

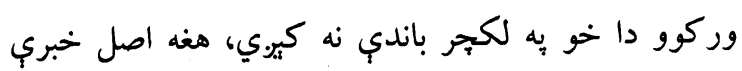

بحث وزير تجارت را حضور شما ميكويم كه آنها را از

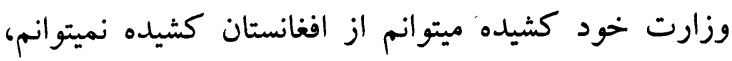

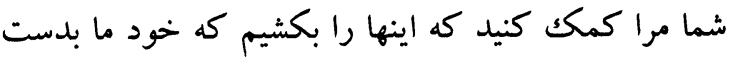

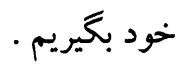
رئيس مجلس : اينك وكيل صاحبان بيشنهاد وزير صاحب تجارت رات را

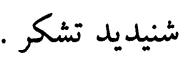
وزير تجارت و صنايع :

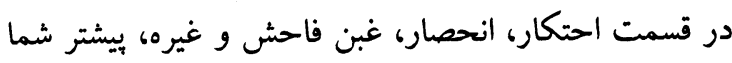

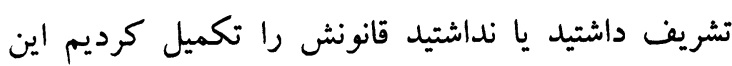

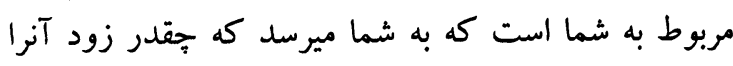

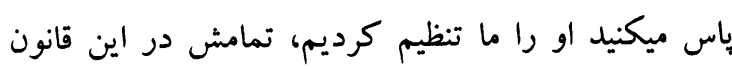

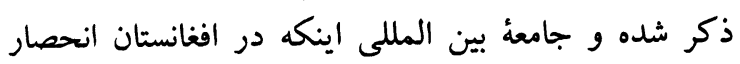

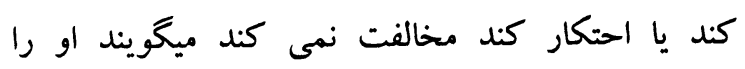

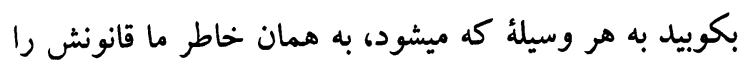

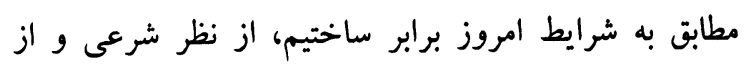

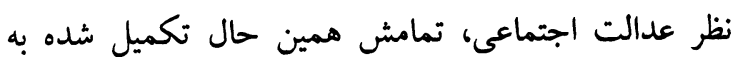

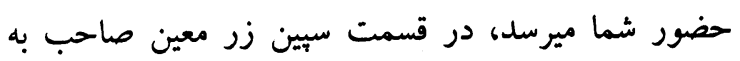

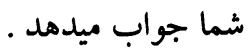
د سوداكرى او صنايعو وزارت معين :

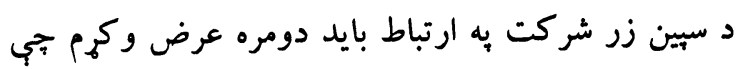

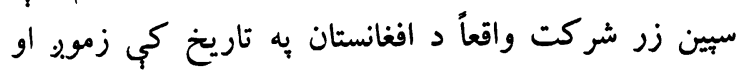

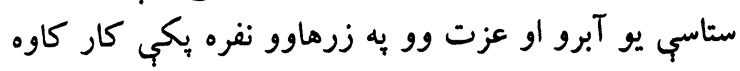

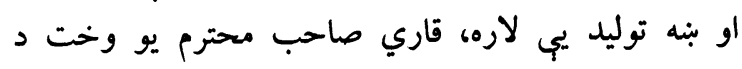

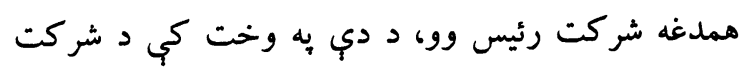

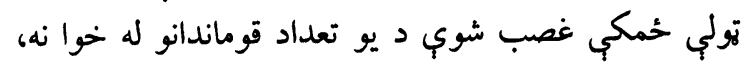

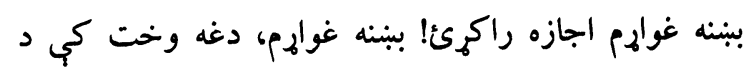

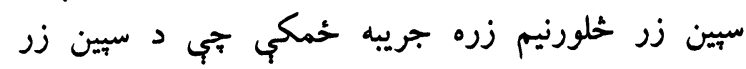

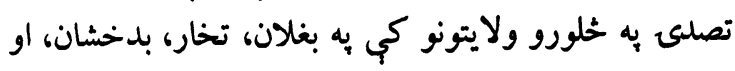

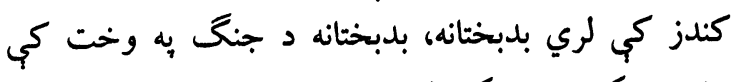

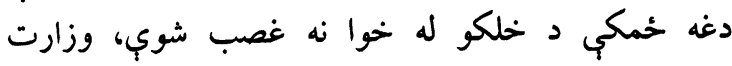

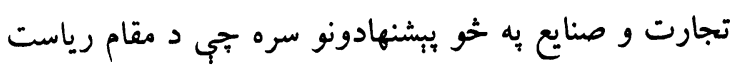

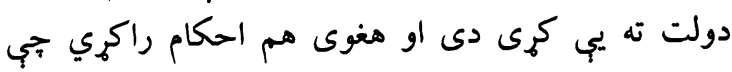

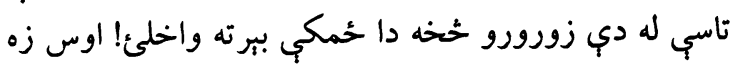

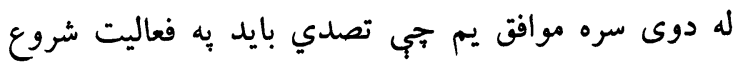


بخواهيم يكجاى نمايندة I-M-F را در بين كميسيون و

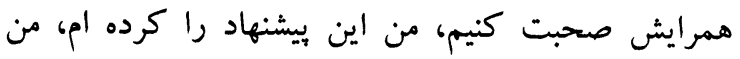

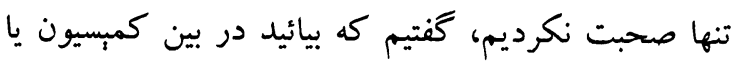

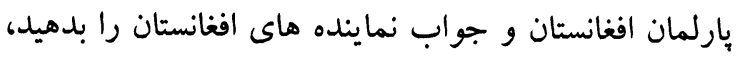

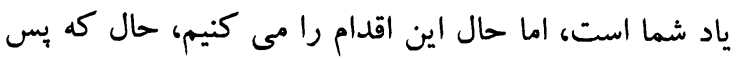

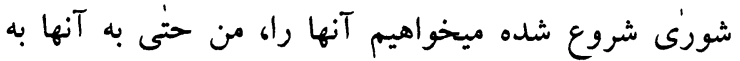

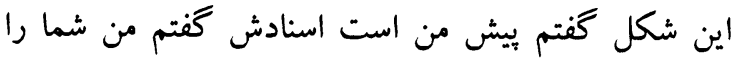

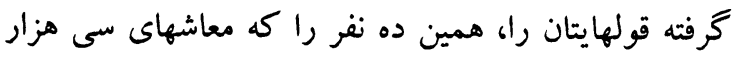

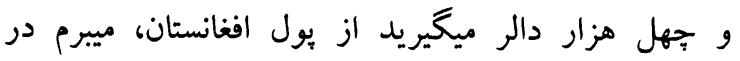

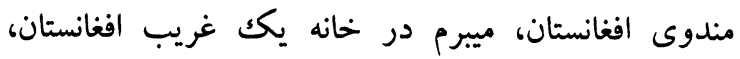

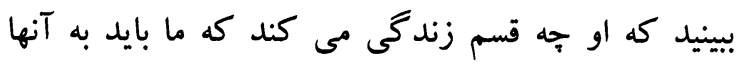

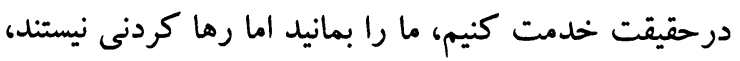
اما آنها را به حضور شما مياورم، اين را تعهد ميكنم مياورم

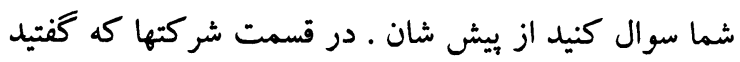
اكر خلاف قانون نباشد و اين خلاف كدام مقردة خدأ خود

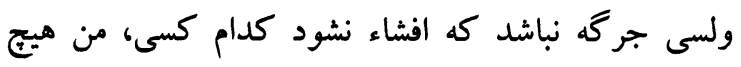

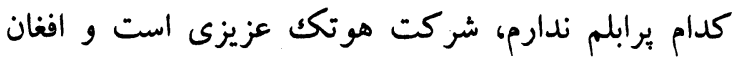
نشنل يطروليم هر دوى اينها تيلهاى بى كيفيت را آورده و

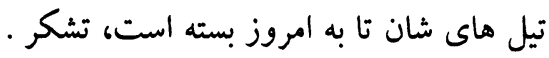

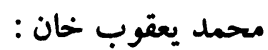

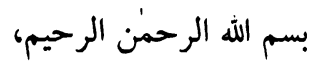

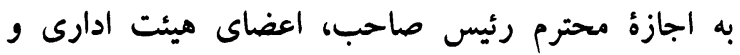

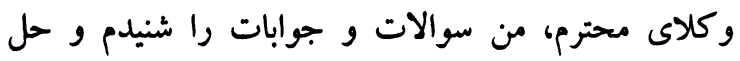

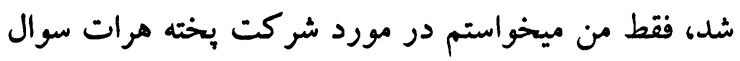
بكنم كه شركت بخته هرات يكك وقتى يكى از شر كتهاى

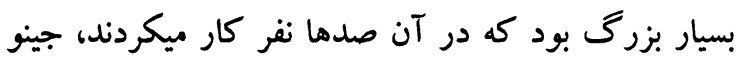
يرس ولسوالى مرغاب كه بخته آنرا در يكسال كسى انتقال

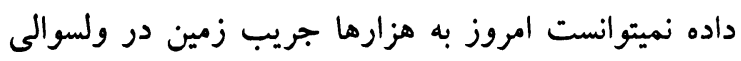

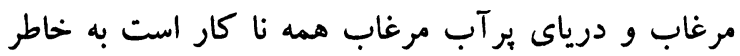
اينكه بازارى براى خريدن بخته وجود ندارد آيا كدام بر مرئ

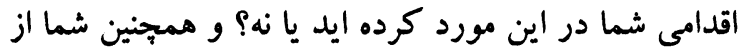

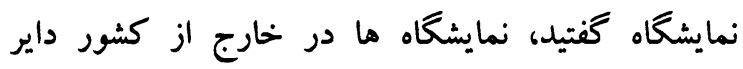
ميشود آيا شما در آينده در افغانستان در مركز كه كابل هاه

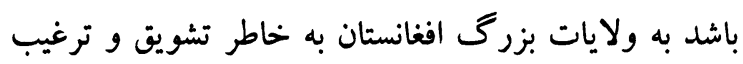

ته سهى بايد راشي او يوبنته ترب وكري جبي وزير صبب

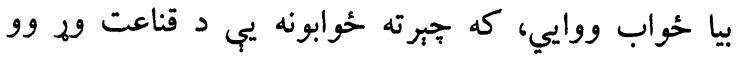
هغه ده كه نه وي نو د سلب اعتماد خبره بيا رامينح ته

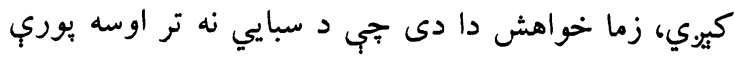

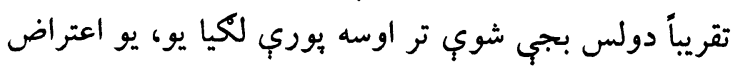

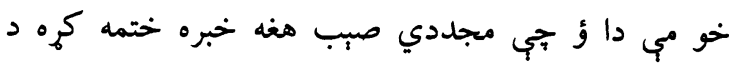

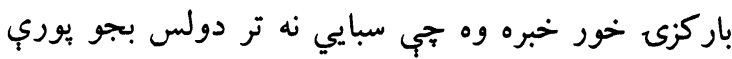

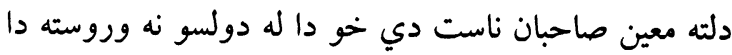

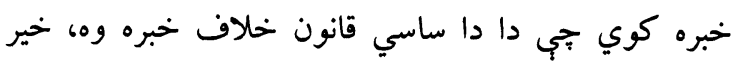

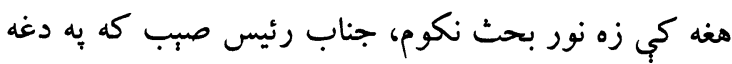

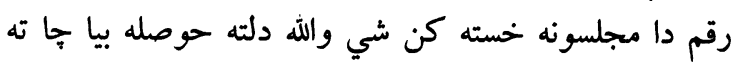

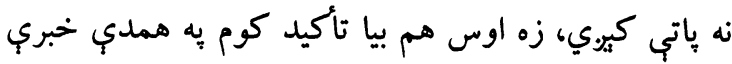

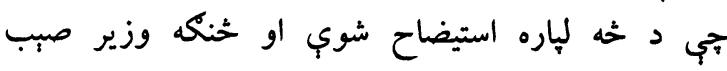

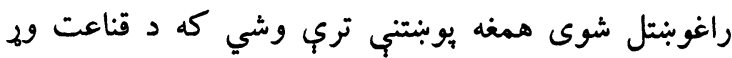

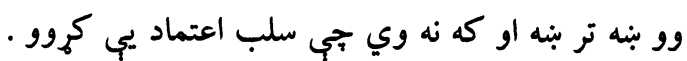

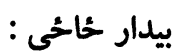

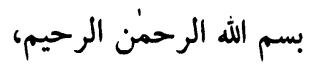

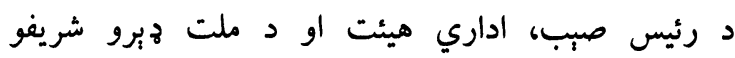

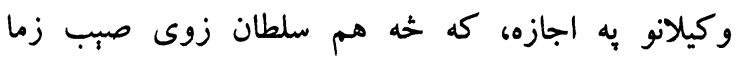

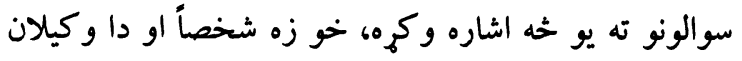

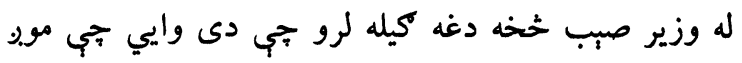

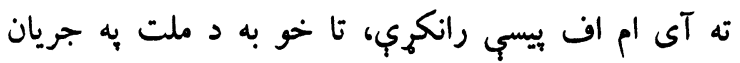

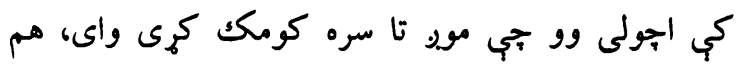

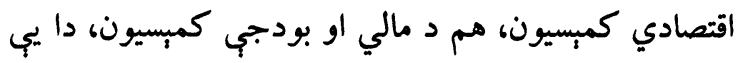

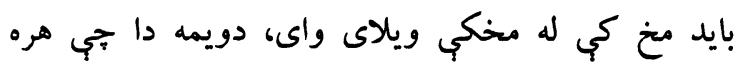

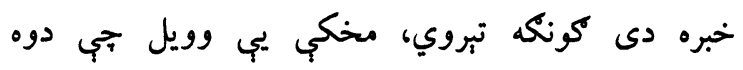

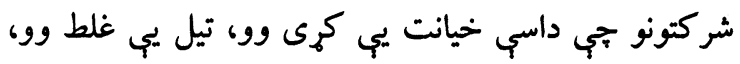

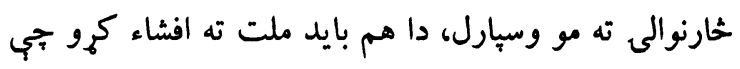

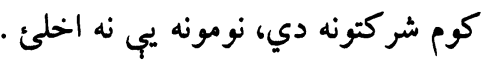

وزير تجارت و صنايع : حاحى صاحب بسيار سوالات بجاست تشكر، من كميسيون

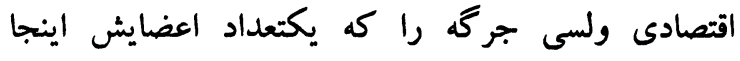

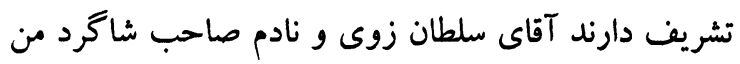
بود در فاكولته اقتصاد، خود شان اقتصاد دان هستند ما به ونه

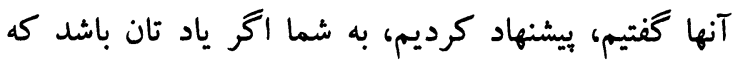


اسلام د اصولو سره مخالفت ولري مويد هغه نشو منلى، بهـ

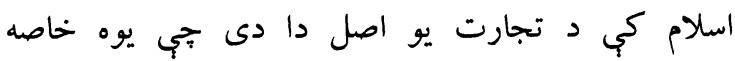

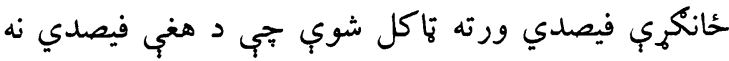

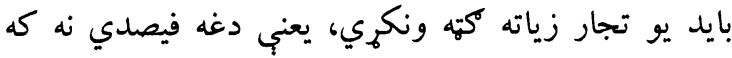

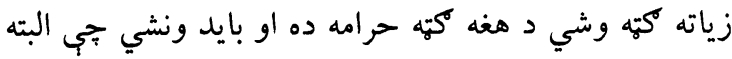

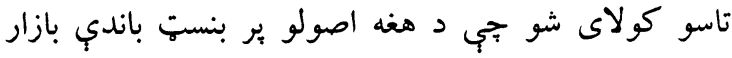

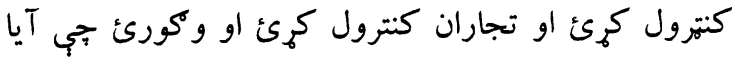

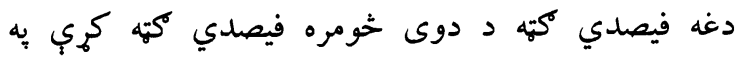

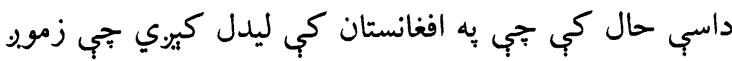

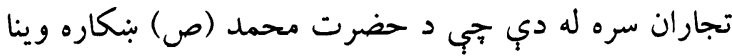

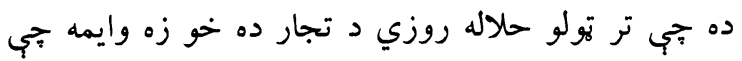

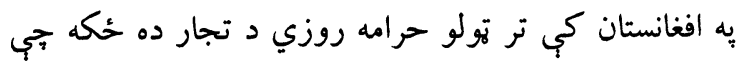

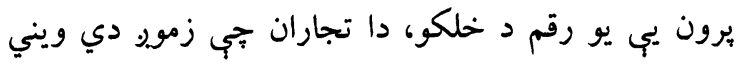

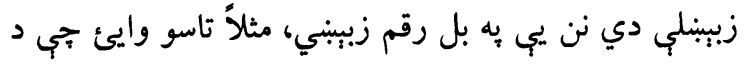

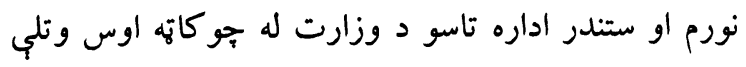

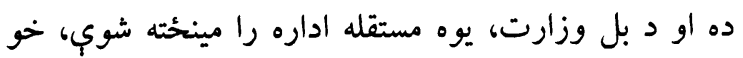

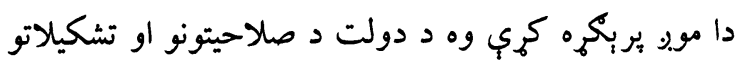

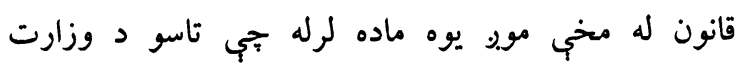

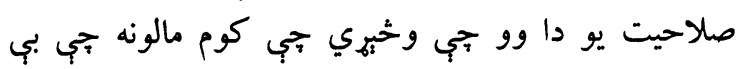

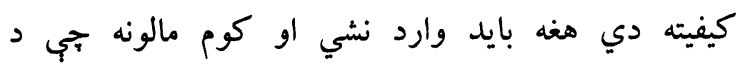

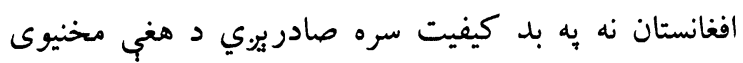
هم بايد ستاسو وزارت له خوا نه وشي جي يوه يوه تر توله

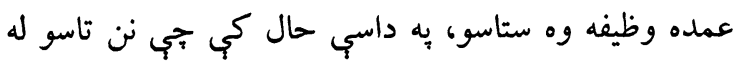

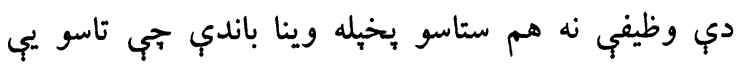

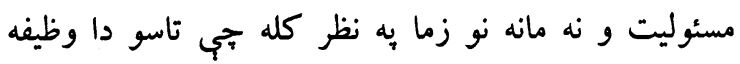
هم د لاسه وركمي ده كله تجي تاسو بازار هم د اسلامي لهي نهي اصولو به بنست باندي نه كنترولوئ او كله جي دي دا آوازاه

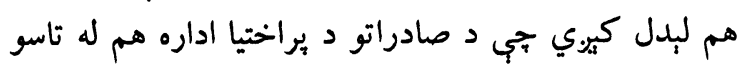

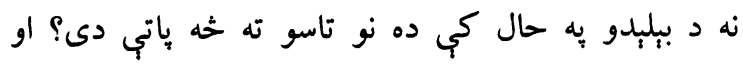

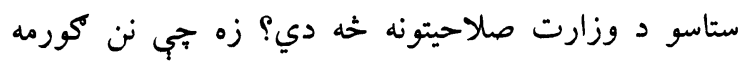
تاسو بخيله ويلي جب بمب ستبشنونه جبي د تيلو دي تاسو

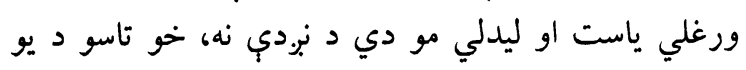

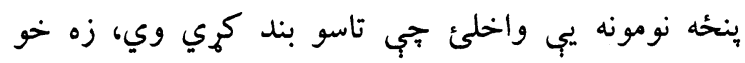

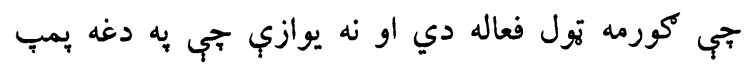
ستشنونو كبي خراب تيل، بب كيفيته تيل خرحيوي، ستاسو
مردم همين نمايشگاه قالين و صنعتهاى دستى افغانستان را

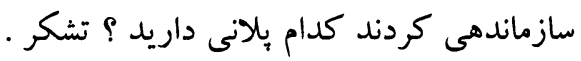
وزير تجارت و صنايع :

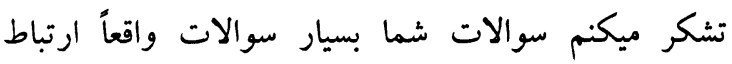

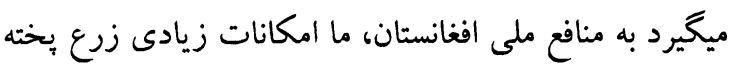

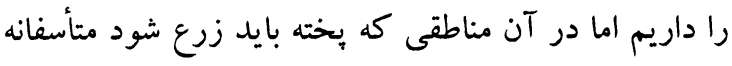

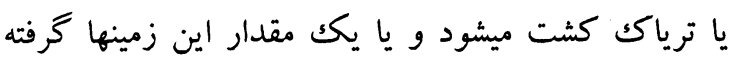

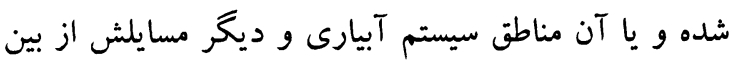

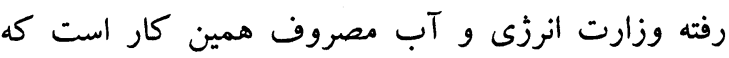

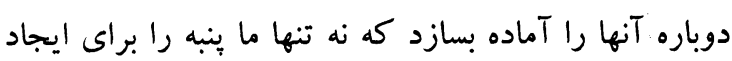
فابريكات نساجى كه يكك وقتى در افغانستان بسيار بيشرفته

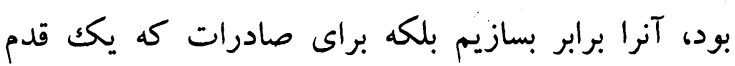

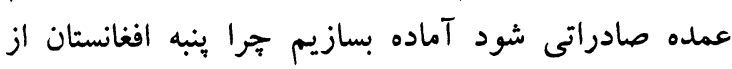

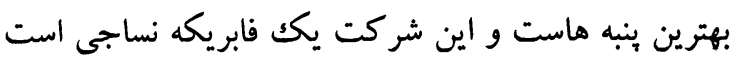

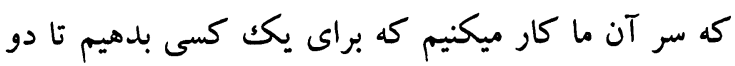

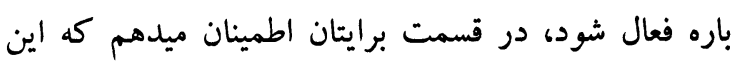

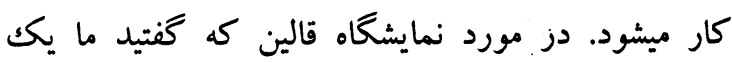
نمايشگاه قالين در تابستان امسال در شهر كابل داير دورد كرديم به شكل بين الملى كه وزير تجارت امريكا هم آمده بود و و

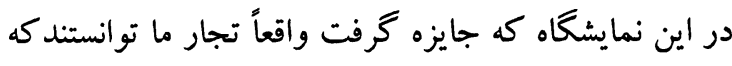

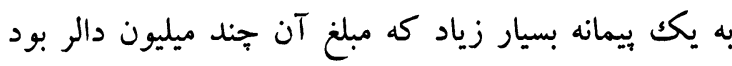
فراموش كرديم فرمايش بحيرند، كه قالين بافهاى ما آنرا

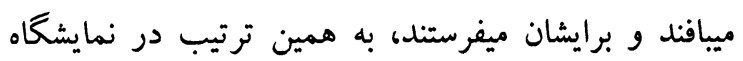

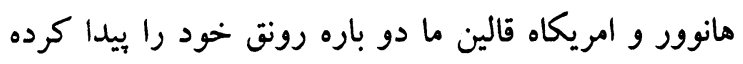

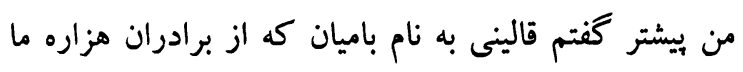

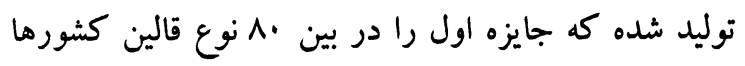

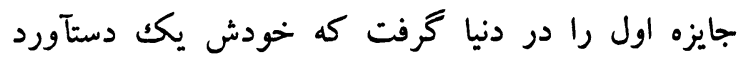
بسيار كلان است در افغانستان .

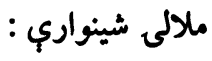

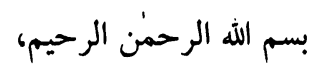

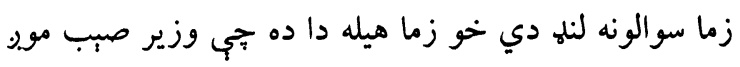

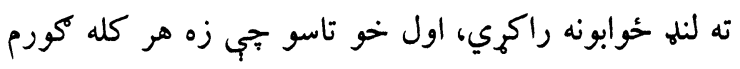

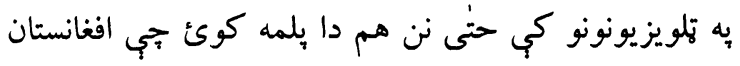

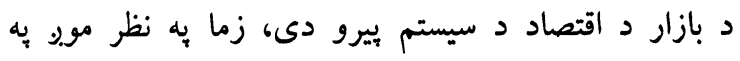

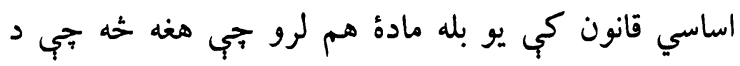


ته زمينه برابره شوي او نوي تجاران لا اوسه يوري ورته

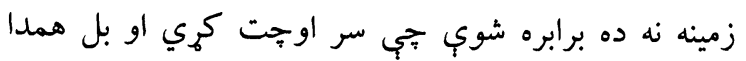
جب تاسو خبل صلاحيتونه وويل جي خئيني صلاحيتونه د

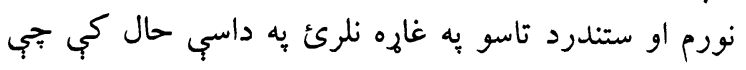

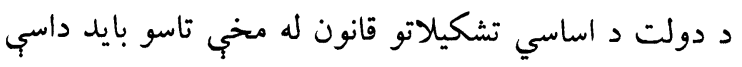
يو صلاحيت ولرئ جب مواد كنترول كرئ، كله تجي داني داني

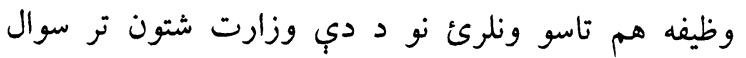

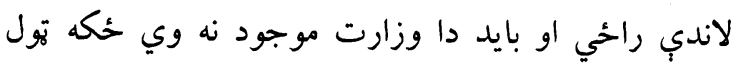

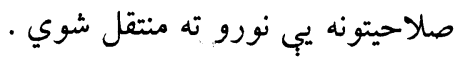

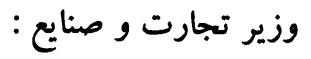

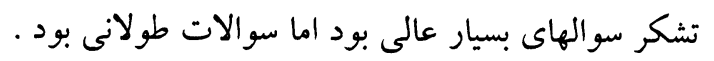
محمد داوود كلكانى :

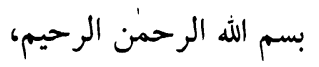

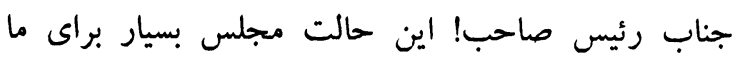

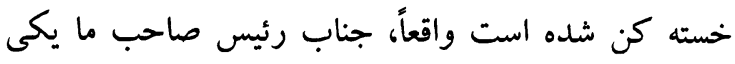

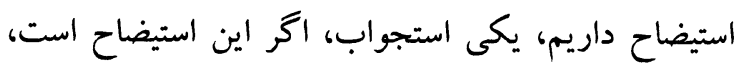

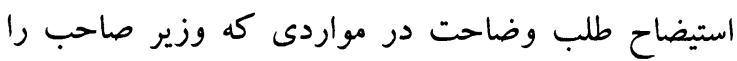

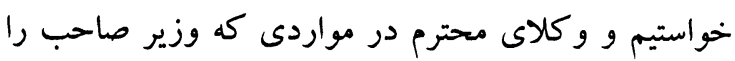

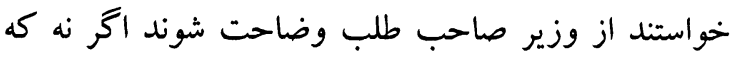

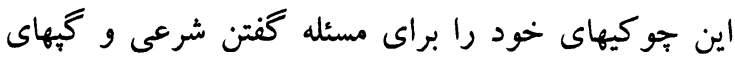

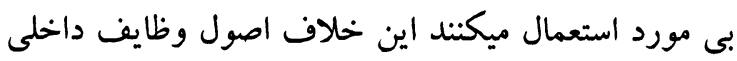

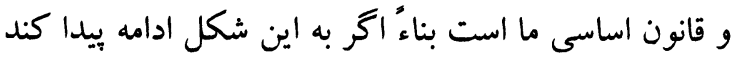

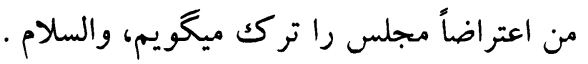
رئيس مجلس : نئ تشكر كلكانى صاحب ! و كلاى محترم! گبّ آقاى كلكانى

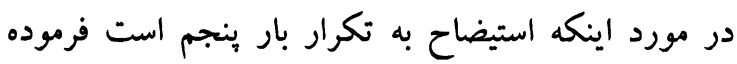
انجنير صاحب قرار، وكلاى محترم وقت هم تقريباً ختم است به تكرار خواهش دارم كه بلى استيضاح و استجواب فرق دارد اكرنميخواهيد كه استيضاح داشته باشيم به به بهن استجواب باز يكك هفته ديگر را تغير بدهيم · وزيل وزير تجارت و صنايع : بسيار ببخشيد والله صاحب من بخويم كه من بين دو سنگ

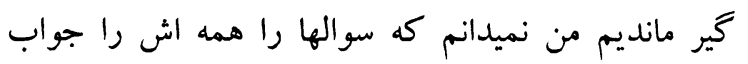

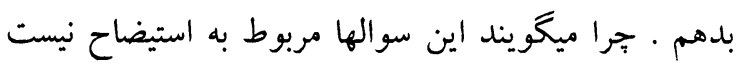
يكك تعداد ميگويند و يكك تعداد ميكويد كه نه جواب ابن
له خوا نه ستاسو د مواد نفتي رياست له خوا نه جي كوم

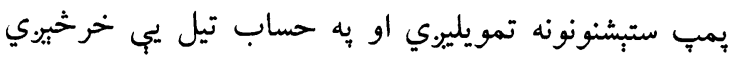

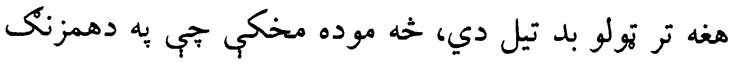

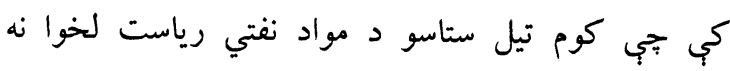

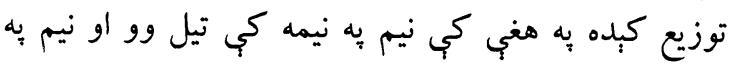

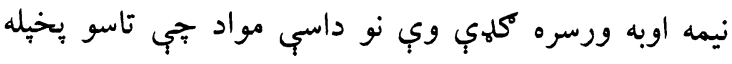

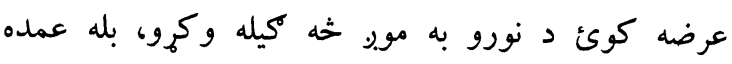

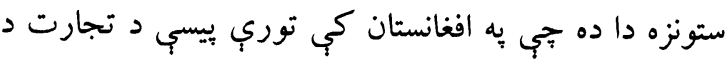

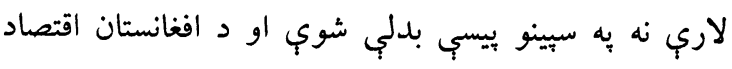

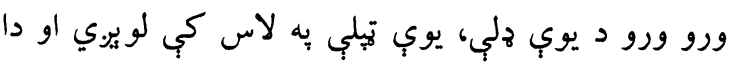

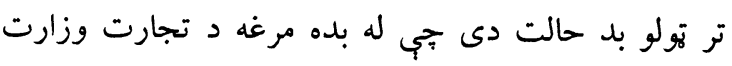

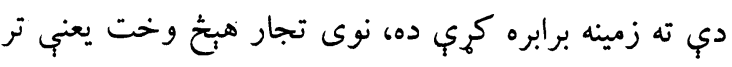

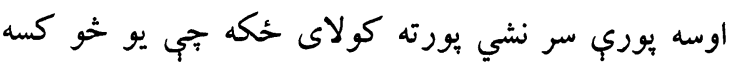

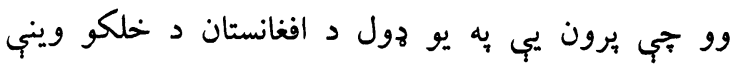

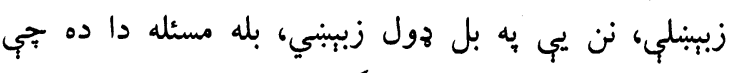

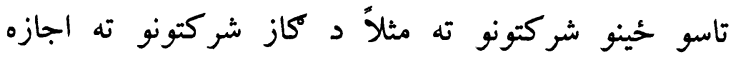

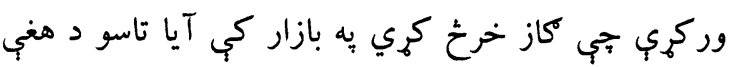

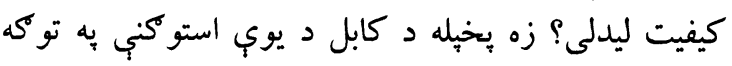

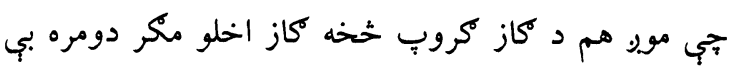

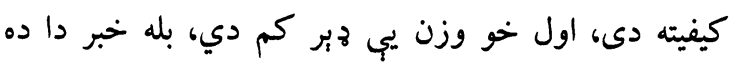

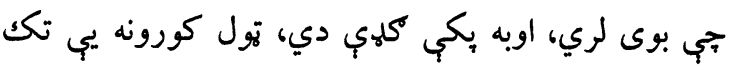

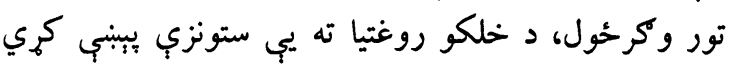

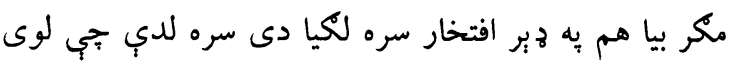

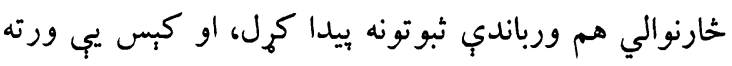

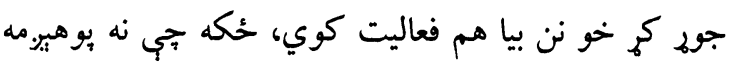

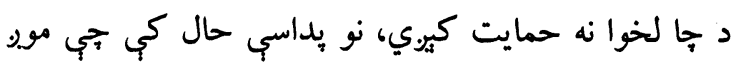

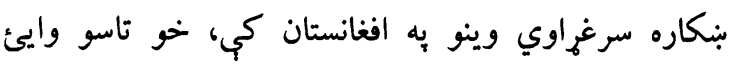

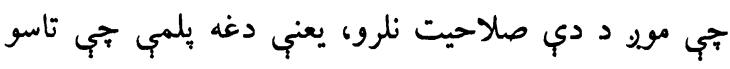

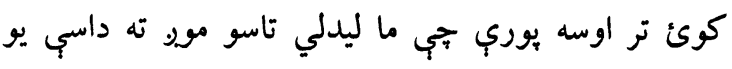

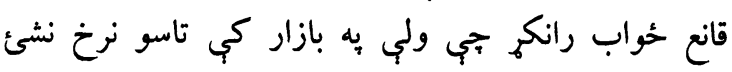

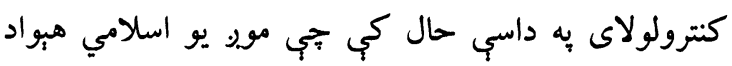

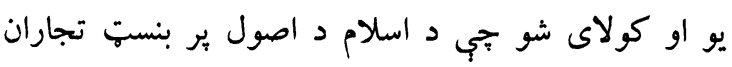

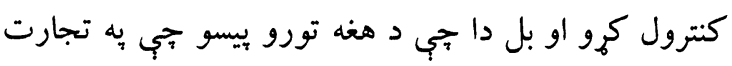

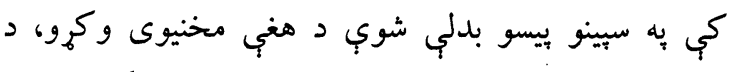

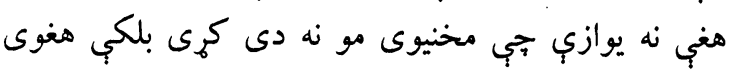


جدا كنيم · راجع به گاز گروب گفتيد گاز گروب قيمت

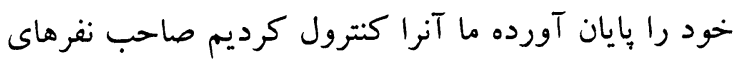

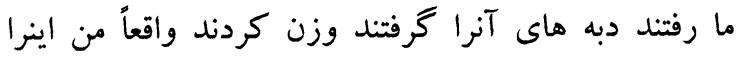

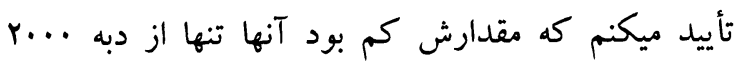
افغانى ميگيرند بالاى اين اعتراض كرديم بلاخره اينها

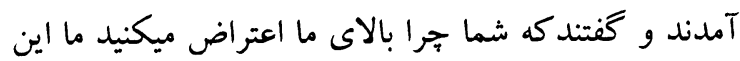

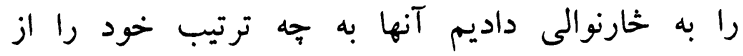
خارنوالى خلاص كردند اين را من كفته نميتوانم اينجا كيهاى است كه متأسفانه همه ما وشما ميدانيم • ديخر اينكه

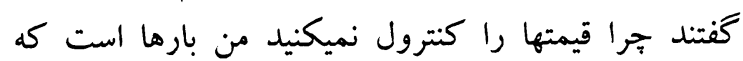
ميكويم كنترول قيمتها از بين رفته در افغانستان، كنترول

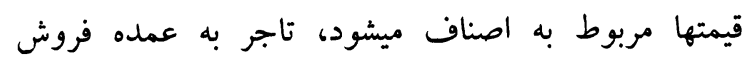

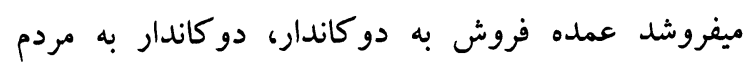

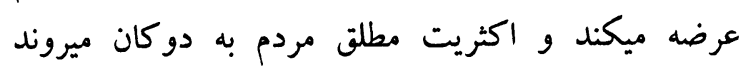

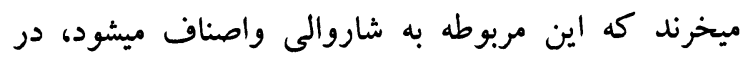
شاروالى يكك رياست تفتيش و كنترول بود كه بر به آنرا

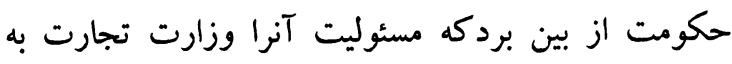

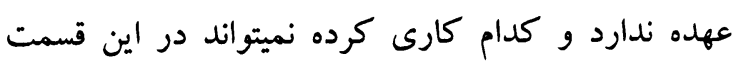

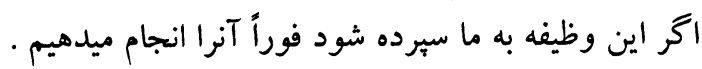

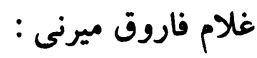

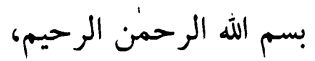

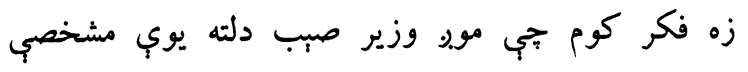

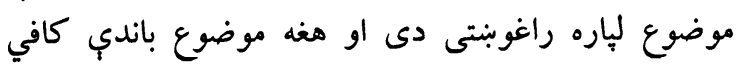

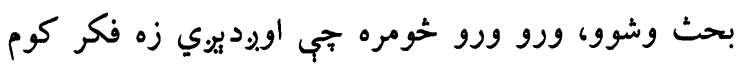

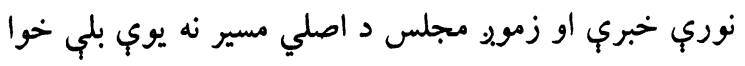

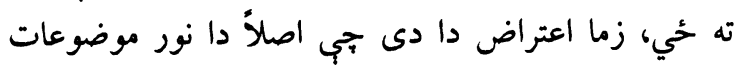
اضافي دي، خبري كافي شوي دي اوس خبره دافي دا دا ده تجي

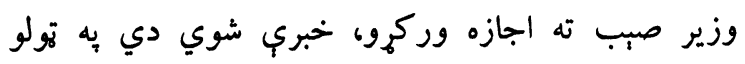

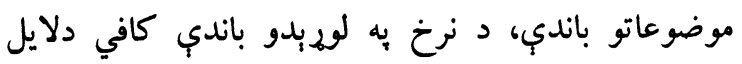

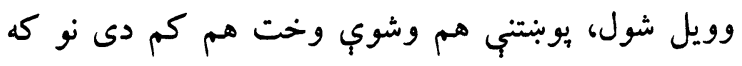

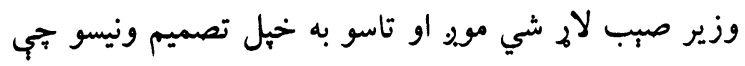
خحه كوو، خيكه دا د استيضاح موضوع ده، نور كومه مسئله نده ياتي جبي دوام وركوو.
بدهيد اما من تصميم گرفته ام جواب ميدهم و اكر تا شام هم دوام كرد من حاضر هستم كه جواب بدمئ بدهم اينكه

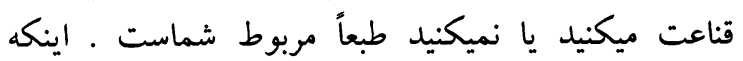

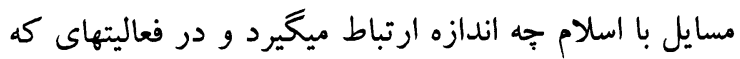

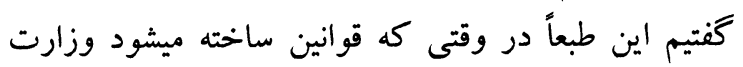

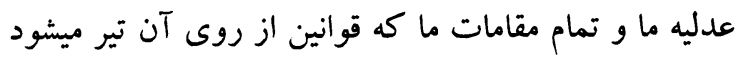

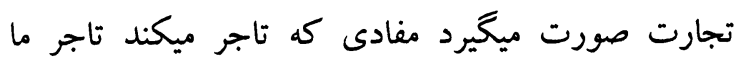

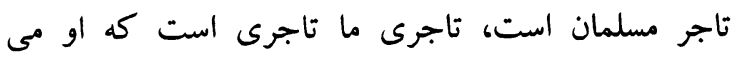
سنجد، طبعاً در هر جامعه و هر جايى منجمله در افغانستان

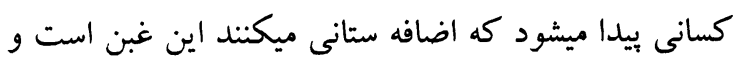

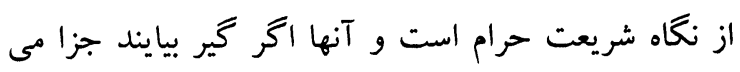

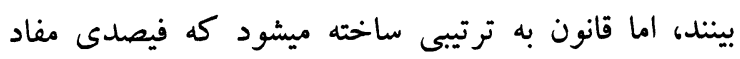
طورى باشدكه دين مقدس اسلام آنرا اجازه ميدهد اينرا

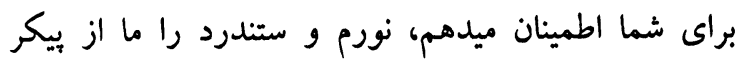
خود جدا نكرديم نورم و ستندرد را كابينه از وزارت

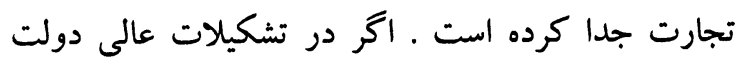

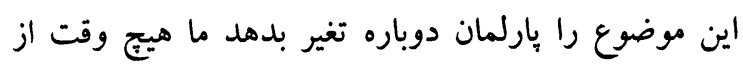

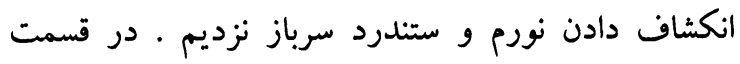

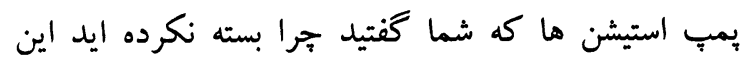

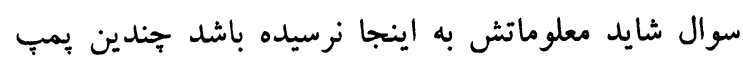

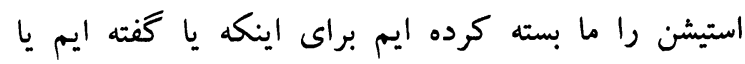

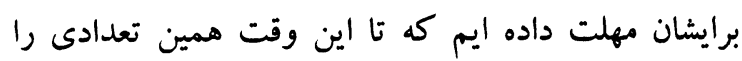

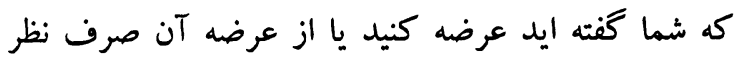

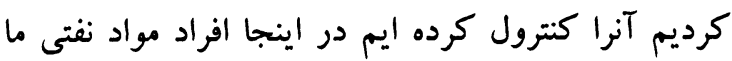

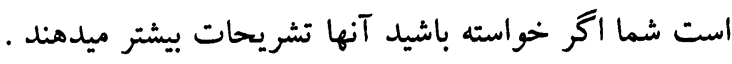

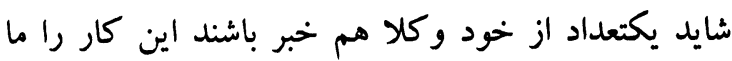

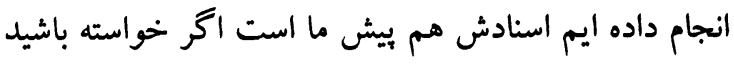

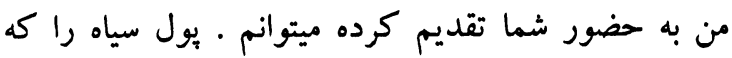

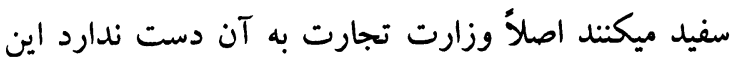

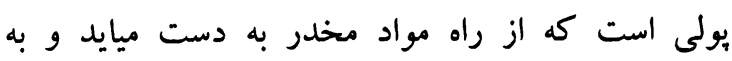

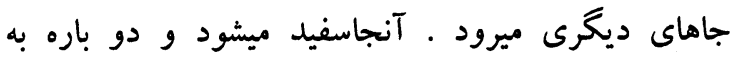

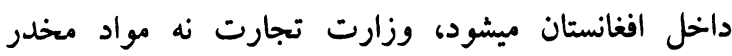

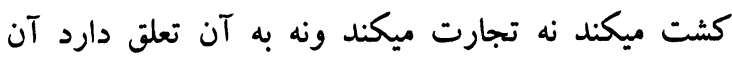
كسانى كه اين كار را ميكنند آنها تاجر نيستند آنها قاجاقبر

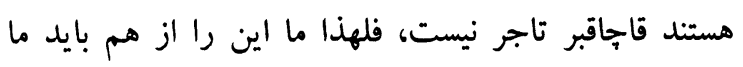




$$
\text { وزير تجارت و صنايع : }
$$

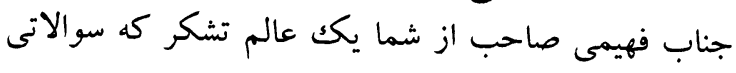

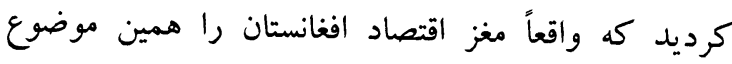
تشكيل ميدهد از شما تشكر ميكنم، در قسمت صنائ صنايع

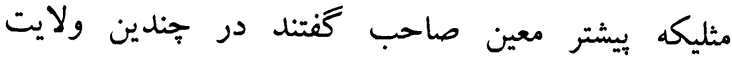

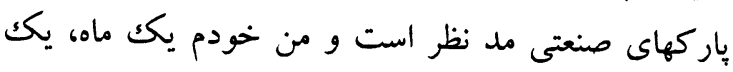

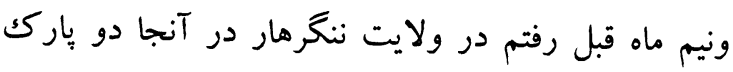

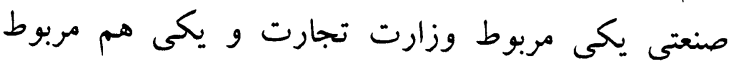

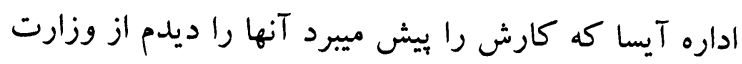

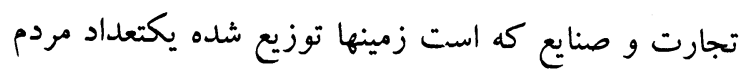

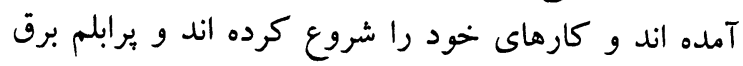

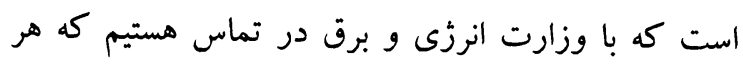

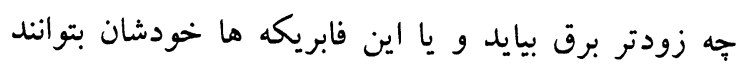

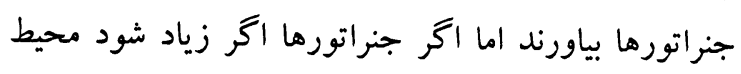

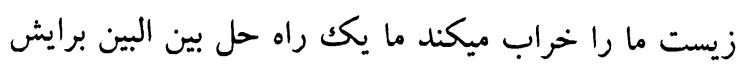

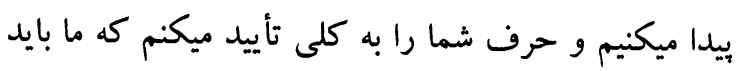
است واردات خود را كم كنيم صادرات خود را زياد كنيم و صادرات خود را يروسس شده زياد كنيم، به جواب سوال دوم شما ميايم كه وزارت تجارت و و صنايع 9 حوزه

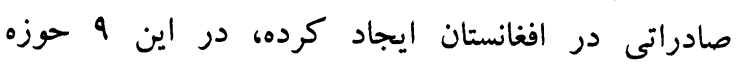

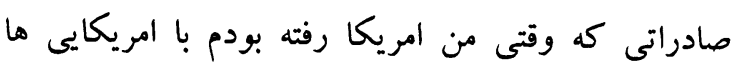

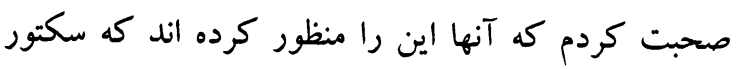
خصوصى بيايد سرمايه كذارى كند ذخاير بسازد، سردخانه و فابريكه هاى تيروسس بسازد و ميوه تا جايى به شكل ميوه با خارج برود كه مردم تازه ميخورند و ديكر خراب

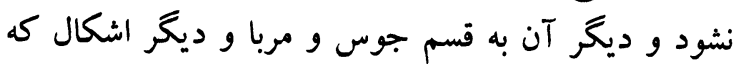

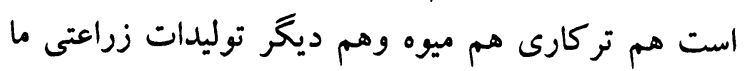

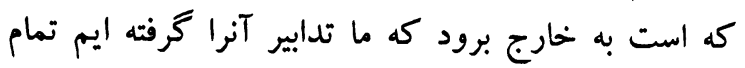
هِلانهايش تكميل است به همراى وزارت انكشاف بهاف دهات

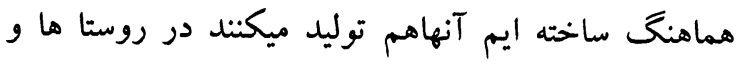

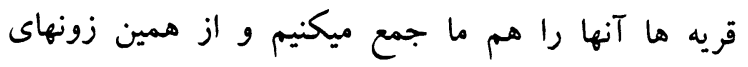
سهولتهاى تجارتى كه با كشور امريكا آلمان، هندوستان،

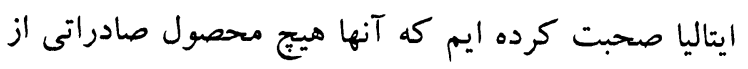
ما نميكيرند آنجا صادر ميكنيم و در هر يكك از اين زونها

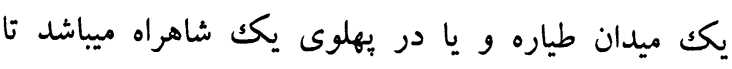

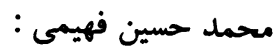

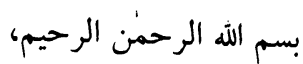

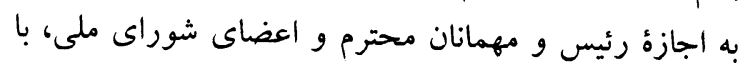

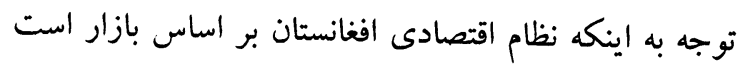

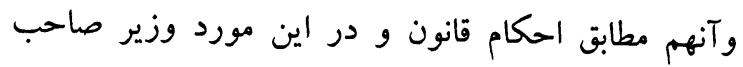

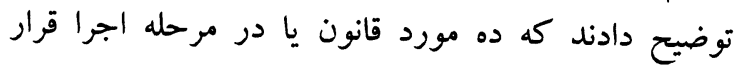

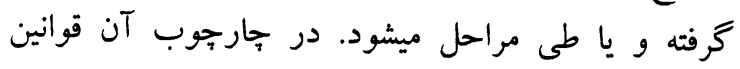

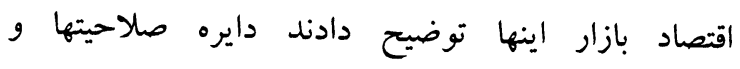

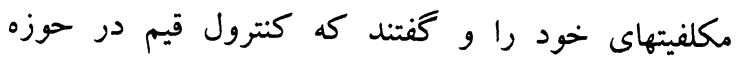
صلاحيت وزير تجارت نيست و به اساس اين قوانينى كه

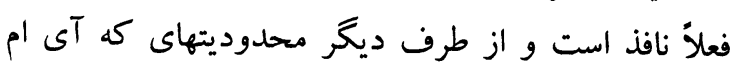

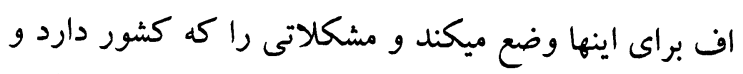
از طرفى هم وضع اقتصادى كشور هم متأثر از عملكرد انهاد

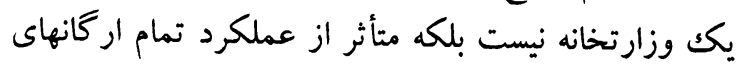

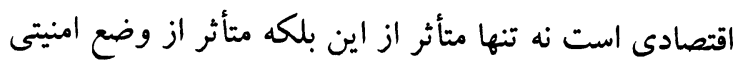
كشور، وضعيت سياسى كشور و وضعيت منطقه ئى است . باتوجه به اين موضوعات من يكك سوال بسيار كوتاه كه

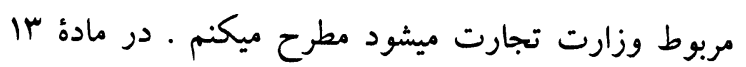
قانون اساسى وزارت صنايع و تجارت مكلف است كهارت مهيث

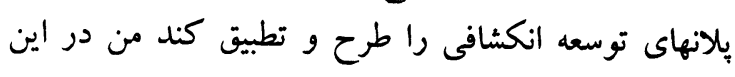

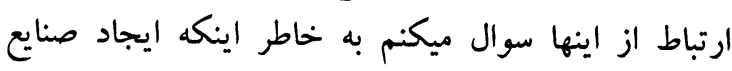

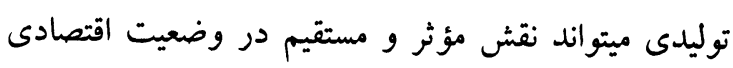

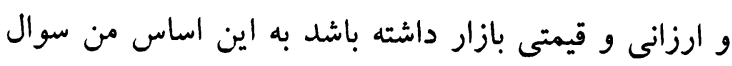

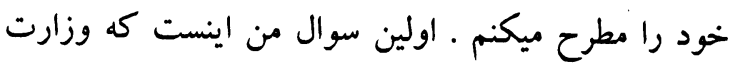

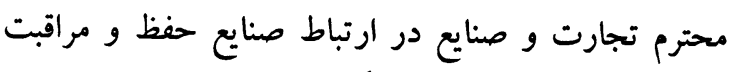

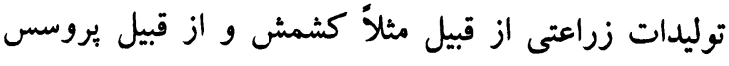

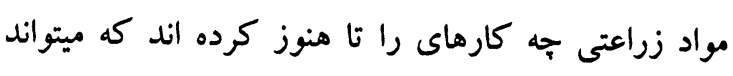

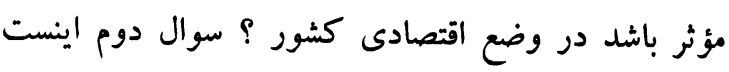

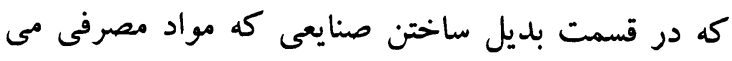

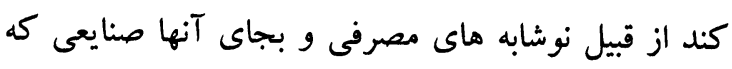

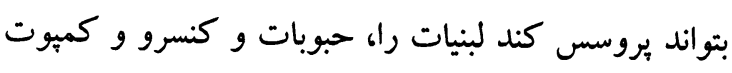
و غيره درست كند و براى مردم افغانستان بسيار مؤثر

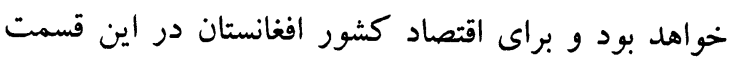

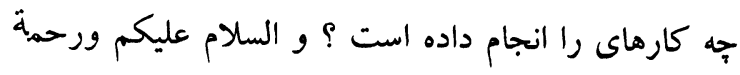

الها 
كاملاً ناكام است ـ دليل اول فساد گسترده كه در وزارت تجارت وجود دارد، فساد تنها رشوت و اختلاس نيست،

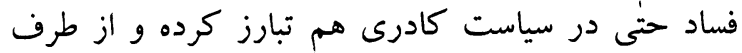

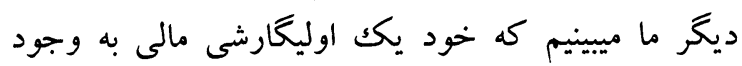

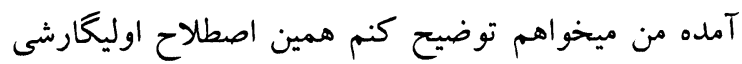

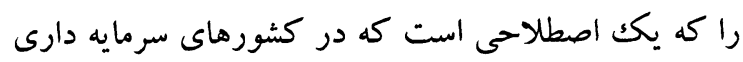

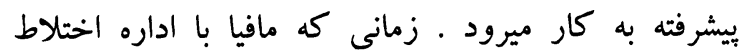

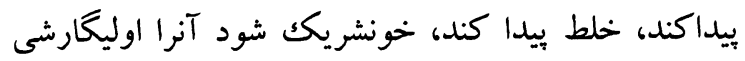

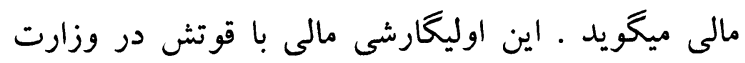

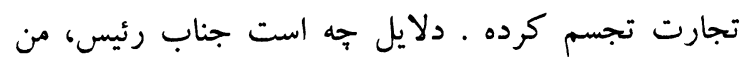

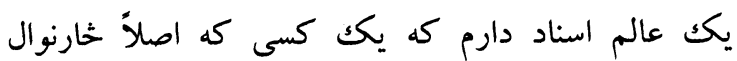

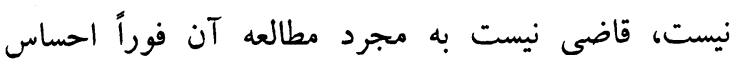

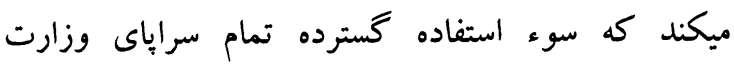

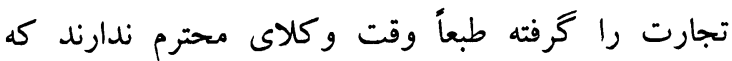

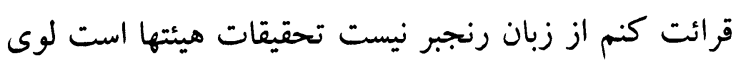

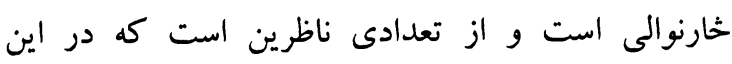

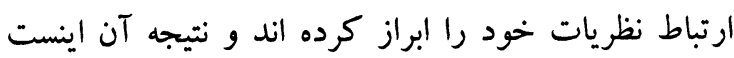

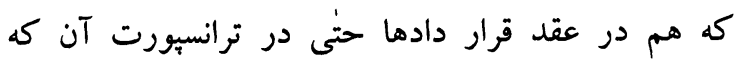

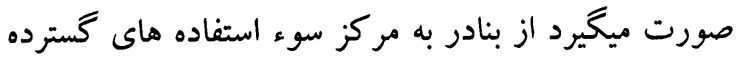

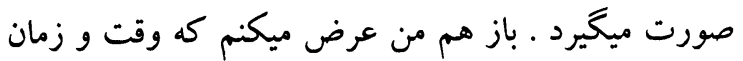

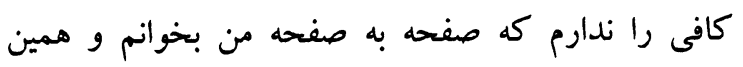

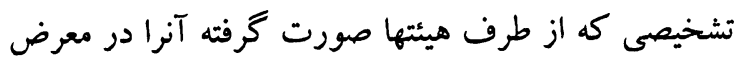

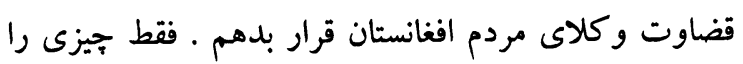

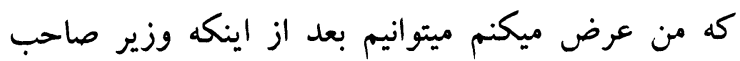
تجارت را اجازه ميدهيم كه برايد ما وقت كافى ميكم بايد داشته باشيم كه همين دلايل رابه جناب رئيس جمهور ارائه كنيم كه همين دلايل مقنع وجود داشت به خاطر سلب اعتماد از

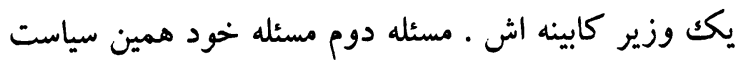

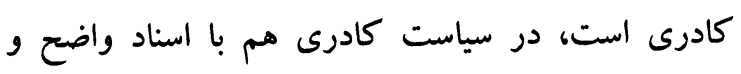
دقيق و بسيار مستند داريم كه اصلاً هيج نوع قوريت دوانين ومقررات حاكم در افغانستان مراعات نشده وزارت تجارئ مدارت

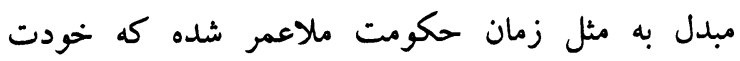

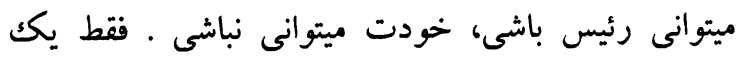

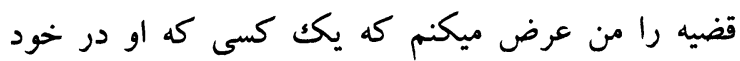

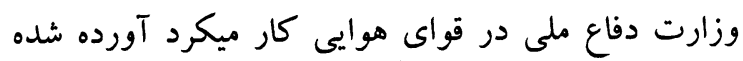

مسئله انتقال آن سهولت بيدا كند ويا توسط كارگً برود به

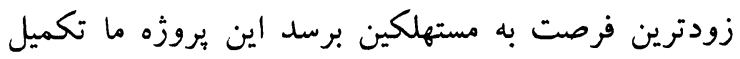

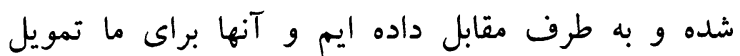
ميكنند تشكر ! واكه

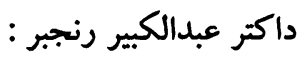

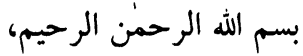
جلالتمآب رئيس، نماينده هاى محترم مردم افغانستان ! من الرين

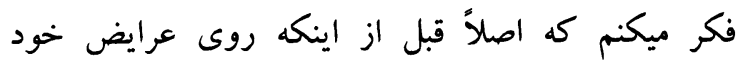

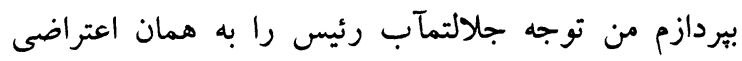
كه از طرف خانم شكريه باركزى شد من من جلب جلب ميكنم

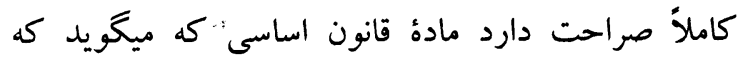

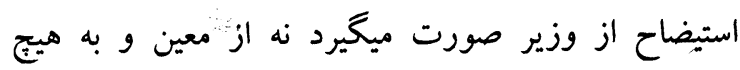

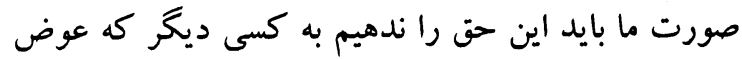
وزير صحبت كند در همين جلسه استيضاح يكى دوم موضوعى را كه من عرض ميكنم همين جلسه ما مبدل به هميه

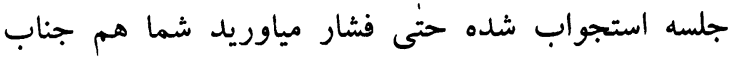

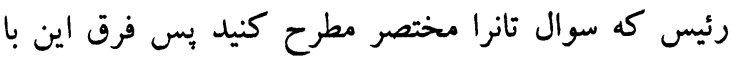

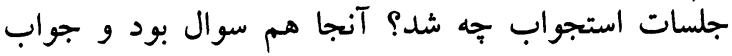
ميداد خود وزير · عرض من اينست ما تجربه كافى نداريم

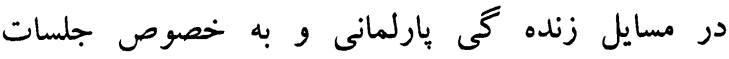

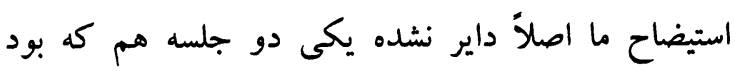

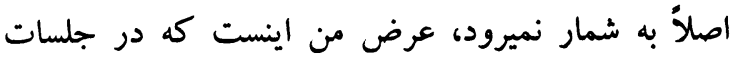
استيضاح وكلا و نماينده هاى مردم استدلال خود رات را ارائه

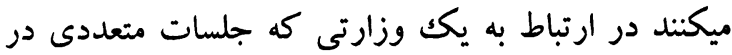

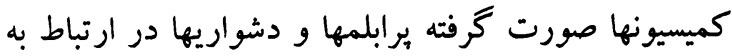
آن وزارت وجود دارد، سوالهاى مطرح شده در كميسيونها

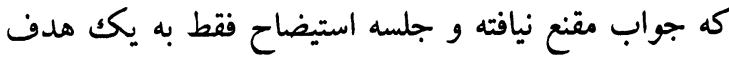

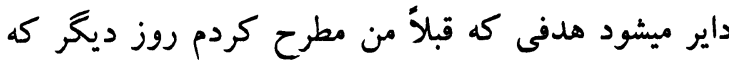

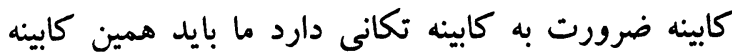

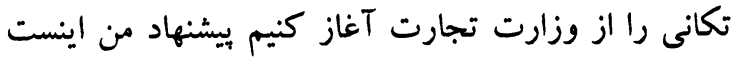
حالا آيا ما دلايل موجه آيا داريم كه باز رئيس دولت دولت

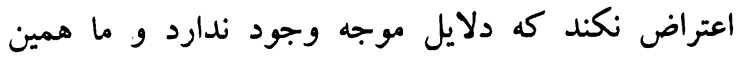

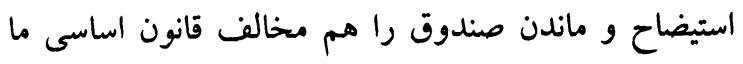
ارزيابى ميكنيم · فقط مختصر عرض ميكنم سه دليل بسيار قوى وجود دارد كه وزارت تجارت متأسفانه در كار خود مدئه 
مورد را من قرائت ميكنم خود رئيس مواد نفتى بيشنهاد

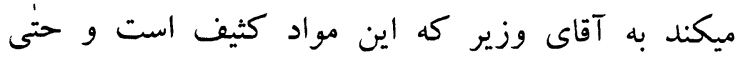

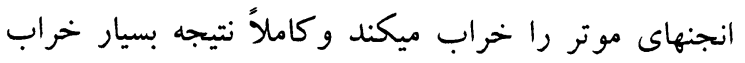
بار ميآورد و بسيار مضر است بينيد جقدر ماندر ماهرانه مطرح ميشود از طرف رئيس خودش اينها امر ميكنند كه اكيداً

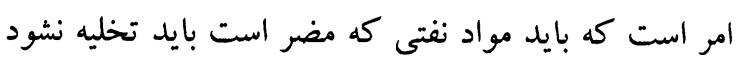

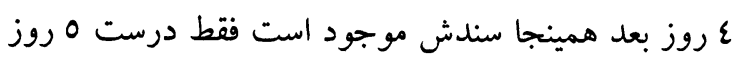

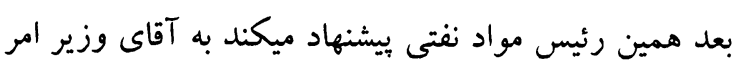

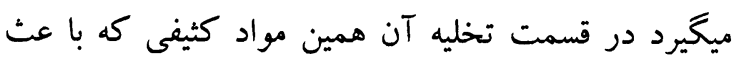
هلاكت مردم شده در شهر كابل از قسم نمونه ها بسيار

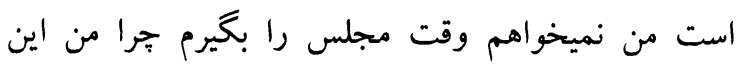

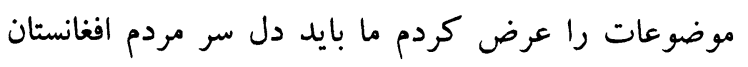

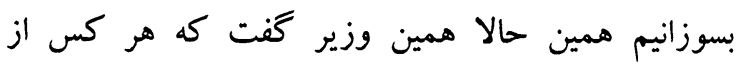

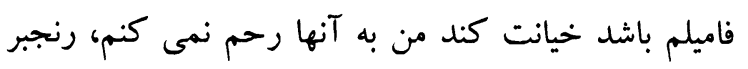
هم همه اعضاى جلسه هم همين قسم يكك موضيع كيرى

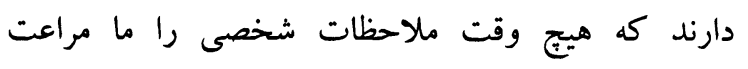

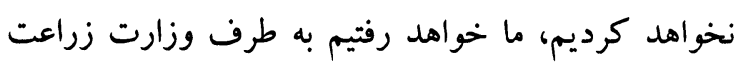
به وزارتهاى ديخر و همين كابينه تكانى را عملى خواهد ماهد

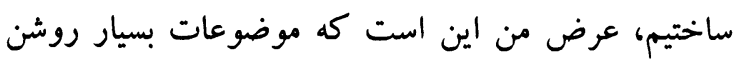
است، فوق العاده روشن است اكر من ما هر قدر سر اين فكر

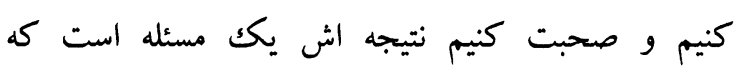

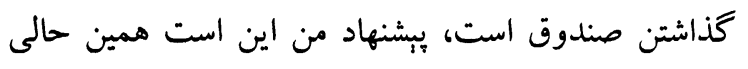

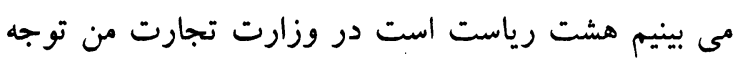

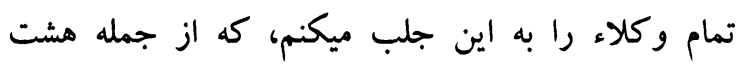
رياست هفت رياستش معاش ميخيرد اطاقها دارند، دفاتر

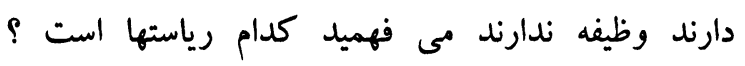
ميخواهيد من ميخوانم آن رياستهاى است كه در مريعه سابق همين مواد مورد ضرورت اوليه مردم افغانستان را تهيه

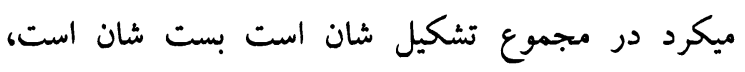
معاش شان را ميدهد آقاى وزير، كار از يبش شان مان نميخيرد

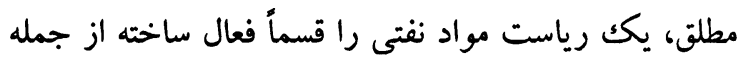

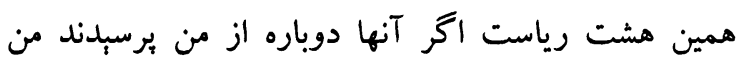

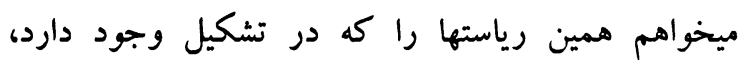
ميخوانم افسوتر است، ستراس است، افغان كارت كارت است،

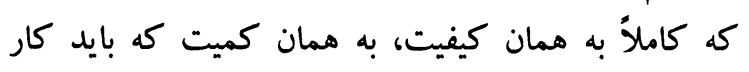

نصب شده در وزارت تجارت در بست رتبه يك يكى از

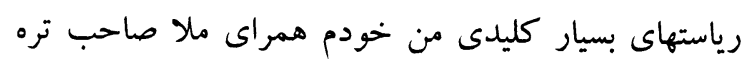

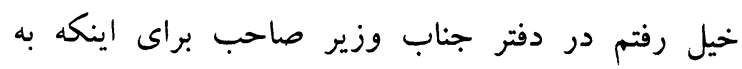

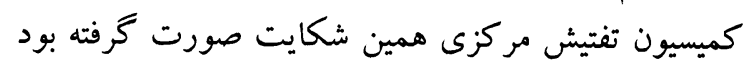

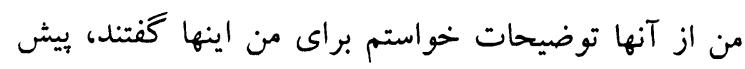
روى من هستند كه خير است فرق نميكند جالا شده آنجا

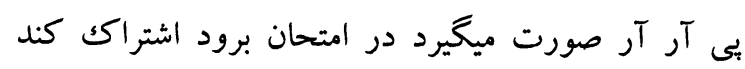

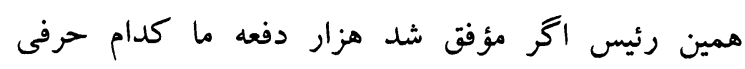

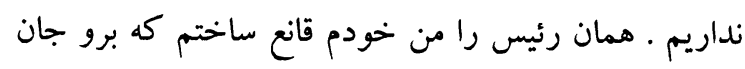

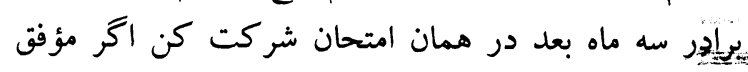

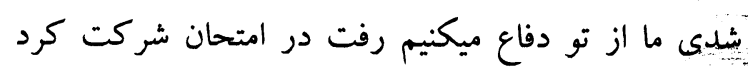

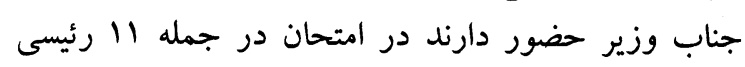

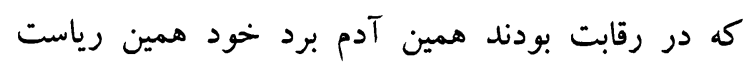

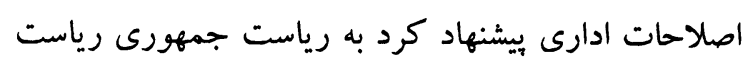

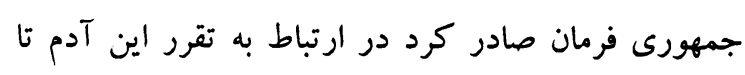

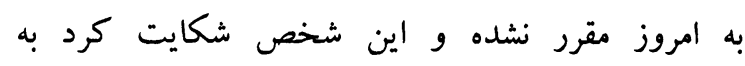
كميسيون ارتشا و فساد ادارى سند اين كميسيون وجود دارد آقاى وطندوست خوب گكته اند كه بايد آنها را هم

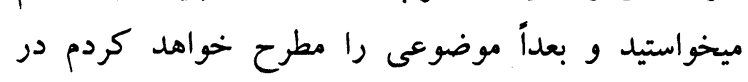

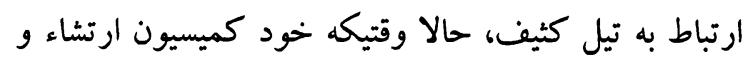

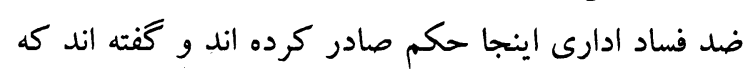
مخالف قانون عمل شده نقص حقوق بشر شده اصلاً

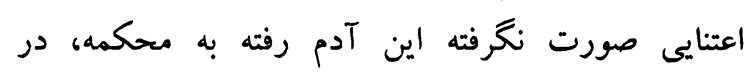

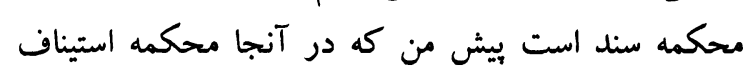
يكك تعداد قضات بسيار بزرگ و و عاليرتبه حكم صنم صادر

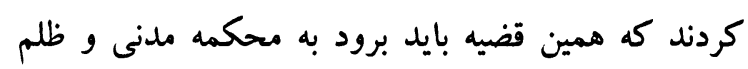

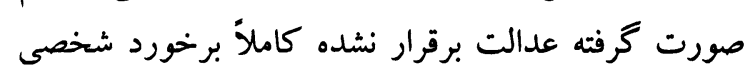

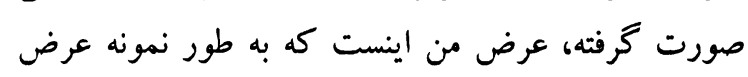
كردم دهها مثال ديخر من دارم در ارتباط به خود اينه اختيلاس

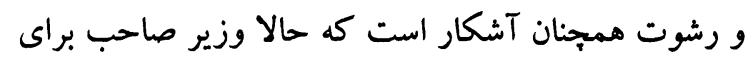

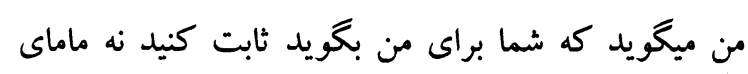

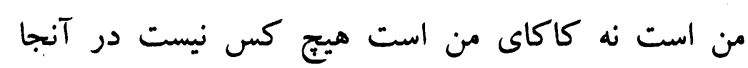

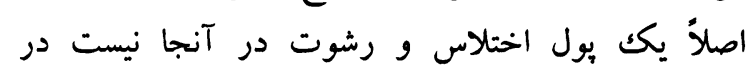

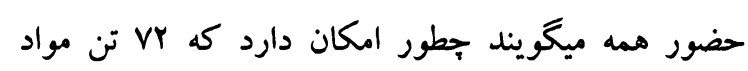

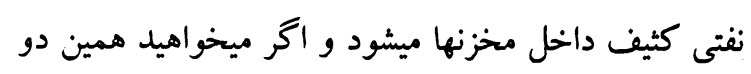


هبخ داسب يوه خه زه نه وينم جب زما زهـ ورباندي بنه

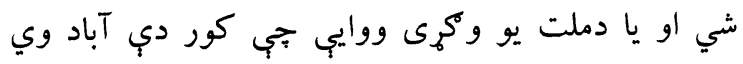

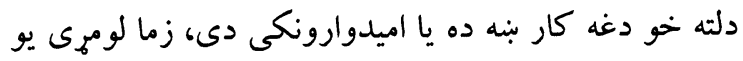

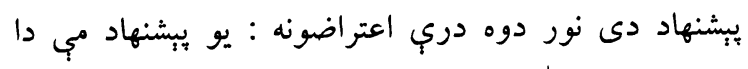

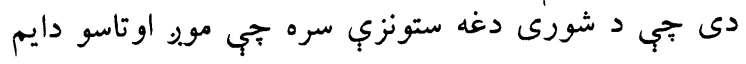

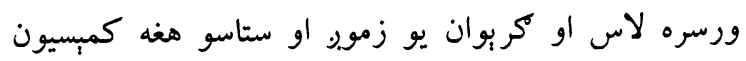

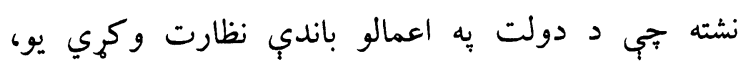

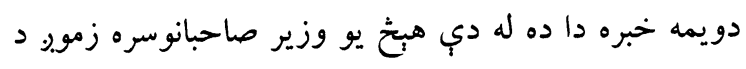

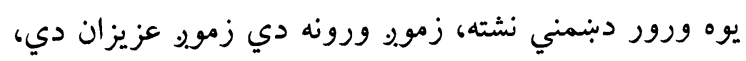

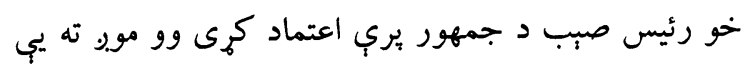

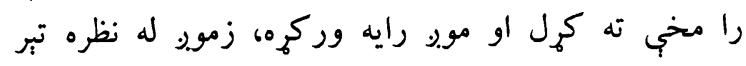

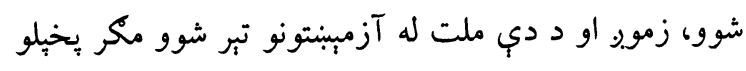

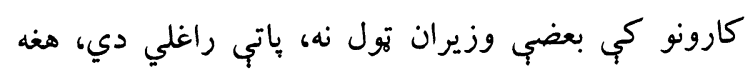

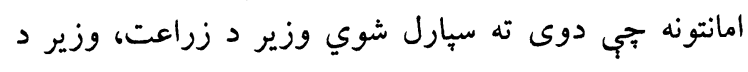

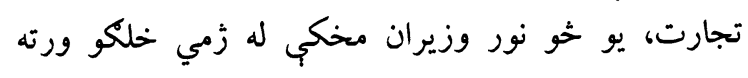

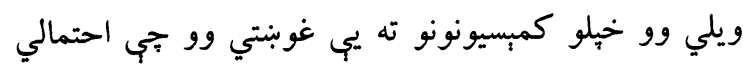

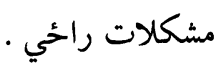
رئيس مجلس : اعتراض دي خُه شى دى علم كل خل خانه دا خو نظر دى .

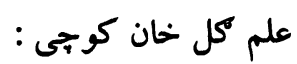
اعتراض مب دا دى دوى د دي ملت لياره اساسي تدابير نه

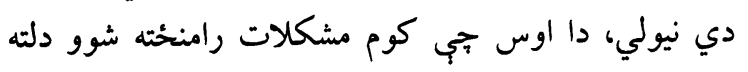

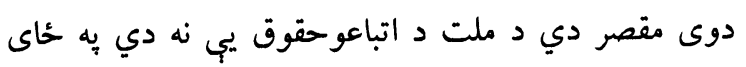
كمي، زما اعتراض ورباندي دا دى دوى دوى خيل اصلي قاني دانوني

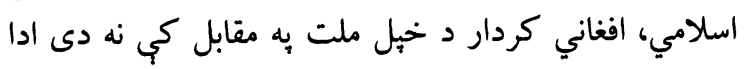

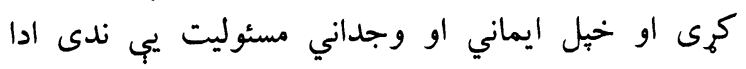

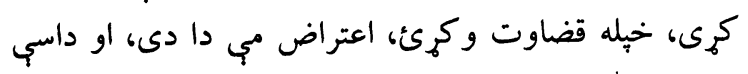

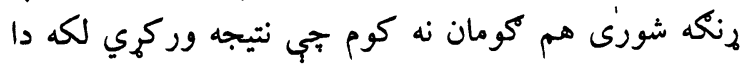

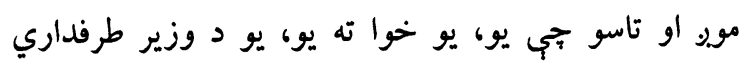

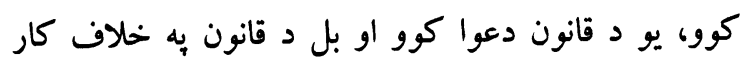

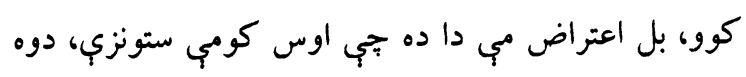

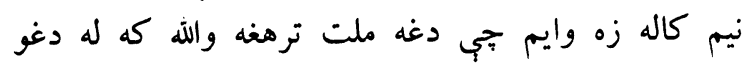
ستونزو خلاص شي تجب ترخو موي. خهيل خان، خيل اسلام، خبل ملت او اصلي رسالت و نه يُّرنو والسلام .
ميكرد نه تنها كار نميكند اصلاً در هيج هستند، مواد نفتى وكاز مايع است كه فقط دوسال است كه آنها قسماً فعال شدند كه آن هم به فشار مردم ذهنيت عامه، افغان تور

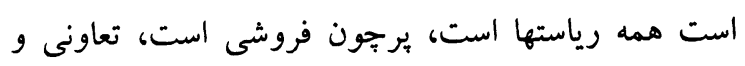

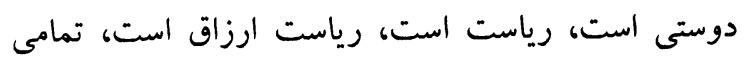

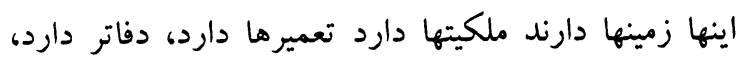

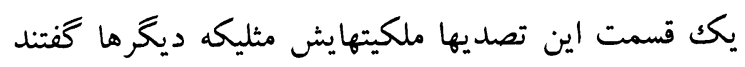

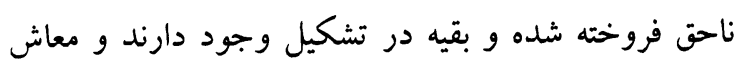

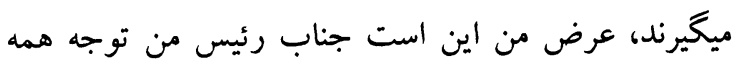

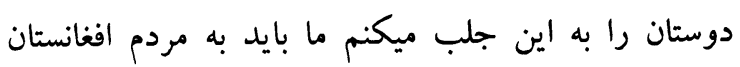

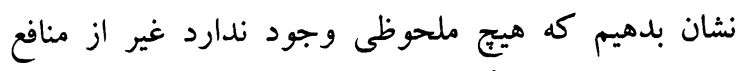

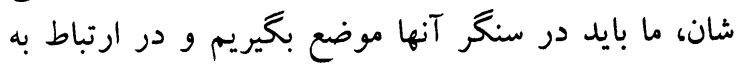

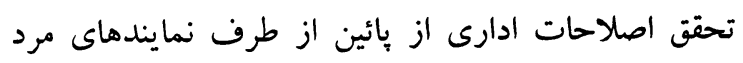

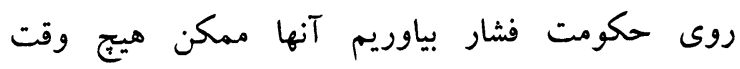

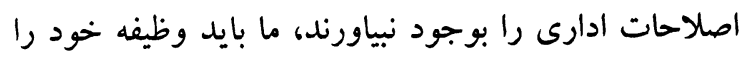

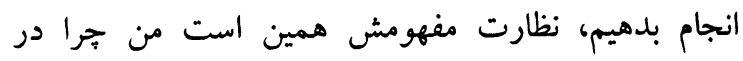

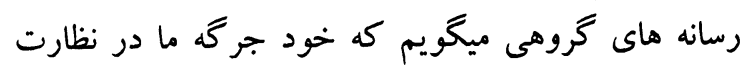

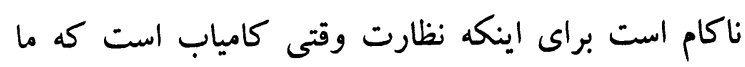

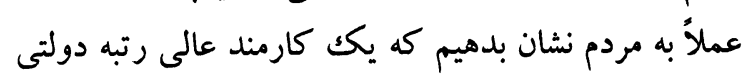

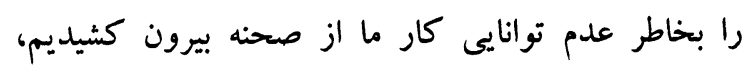
تشكر . رأح

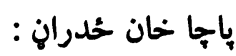

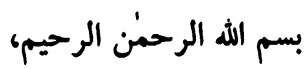

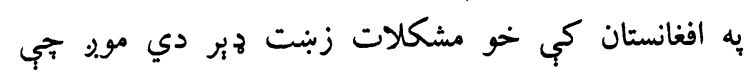

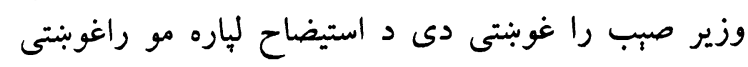

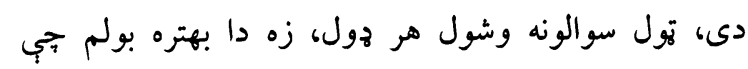

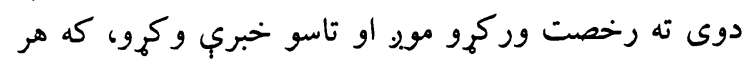

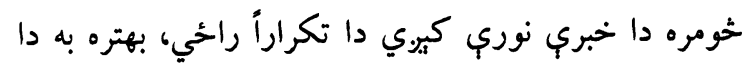
وي جي دوى ته رخصت وركيو، وخت نا وخته دى له له

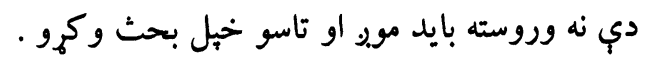

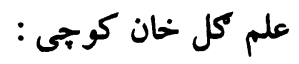

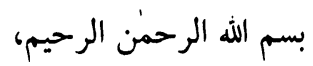

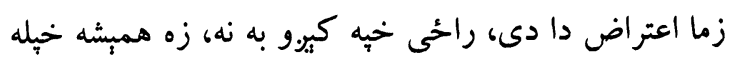

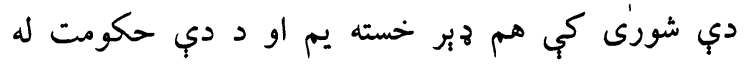

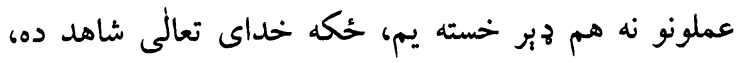


ببرم، اينطور اسناد بسيار زياد آدم تهيه كرده ميتواند،

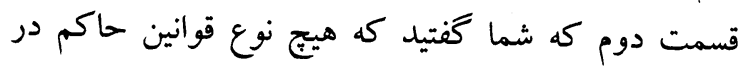
وزارت تجارت موجود نيست، وزارت تجارت به اساس

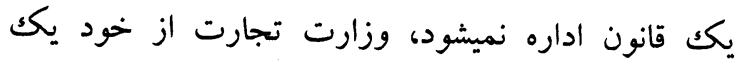

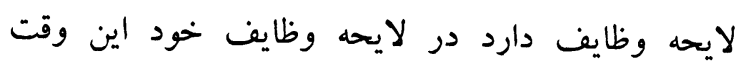
ساخته شده در اين لايحه وظايف وظايف شان تثبيت شده وظايف خود را انجام داده و وظايف خود رائ را اينجا هم تشريح كرده و وزارت تجارت تمامى وظايفى را كه در در ورد

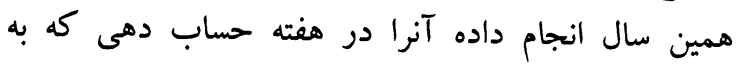

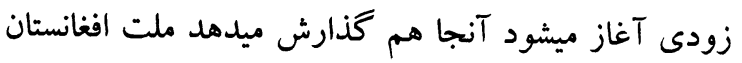

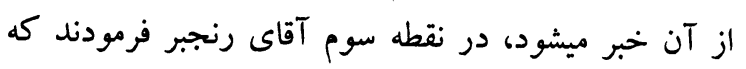
راجع به يكك شخص معين صحبت كردند گفتند، مرا مثال

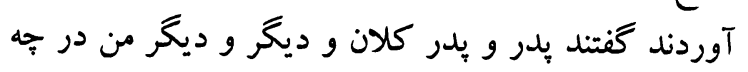

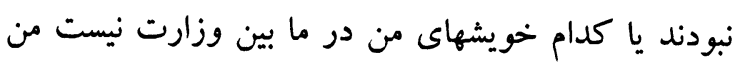

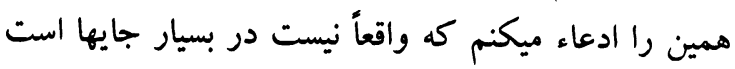

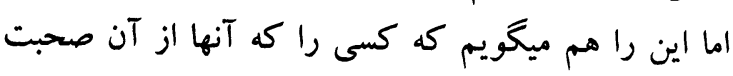

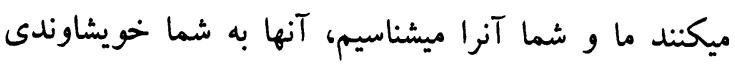

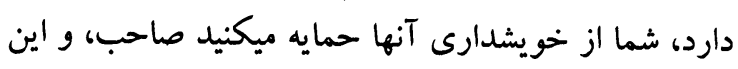

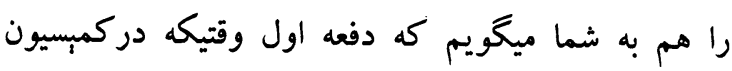

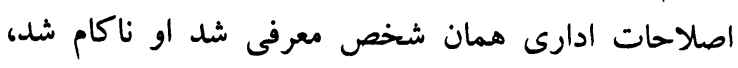

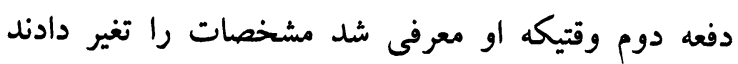

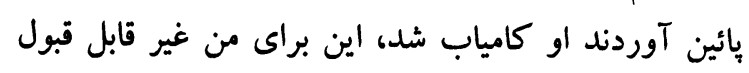
است كه از خاطر يكك شخص مشخصات بائين بيآيد،

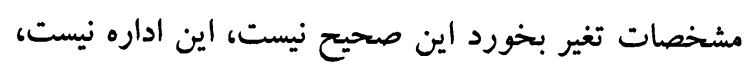
اداره بايد مشخصات خود هيج وقت تغير ندهد، همان شخصى را كه همين مشخصات ميخواهد، وسوم از همه

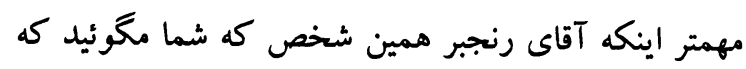
جه گر فته من بارها برايش وظيفه تعين كرديم كفتيم كه آنه

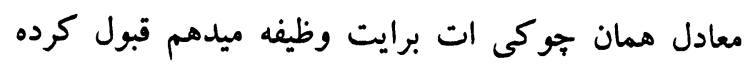

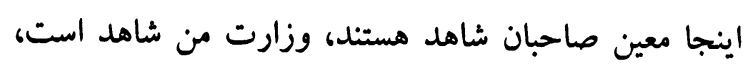

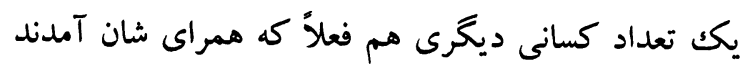

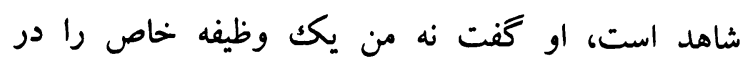
وزارت تجارت ميخواهم و وظيفه خاص يكت وظيفه بوده اهن

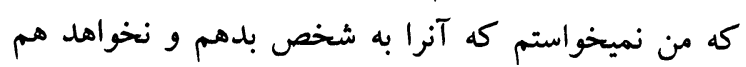

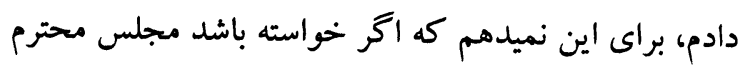

نجيب الله كابلى :

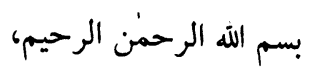

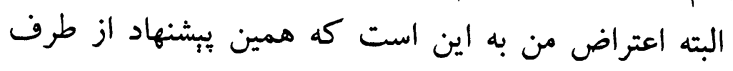

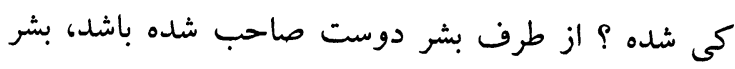

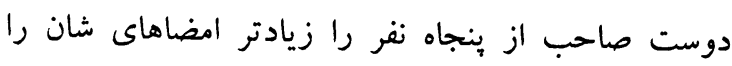

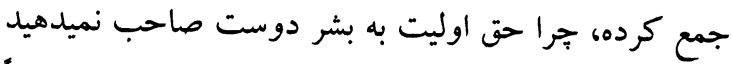
كه صحبت كند، اول بايد بشر دوست صحربت إن ميكرد فعلاً

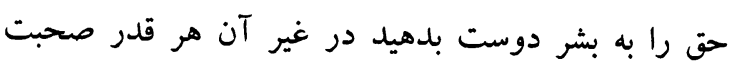
ميكنيد جيزى نيست . نائب دوم مجلس : عرض من اين است جناب رئيس صاحب كه بشر دوست

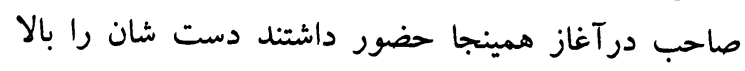

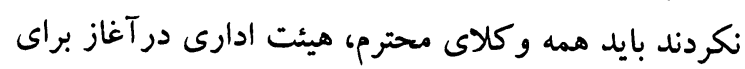

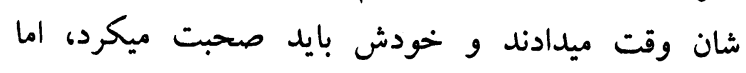

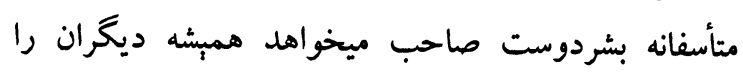

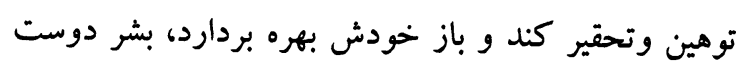
صاحب در ليست ما است براى شان وقت ميدهيم قبل از

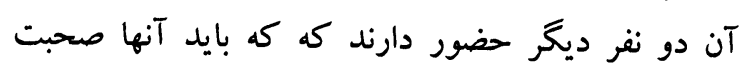
كنند، تشكر .

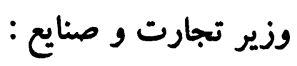
من به ارتباط سوالات آقاى رنجبر ميخواستم، آنها سه وذه ونه موضوع را مطرح كردند گفتند فساد ادارى بسيار گسترده رنه در وزارت تجارت وجود دارد در آنجا يكك مافيا بوجود

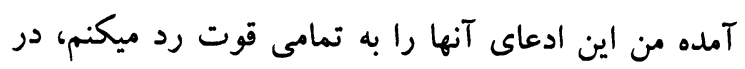

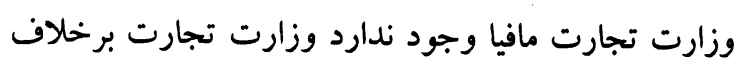
آهسته اهسته تصفيه ميشود اين را شما ميتوانيد از رسانه ها

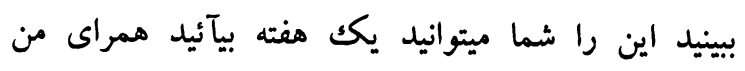
بنشيند كار كنيد و بينيد، اين را شما ميتوانيد كه از تجار

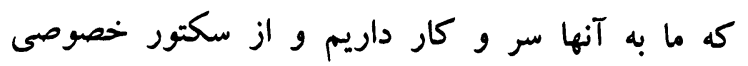

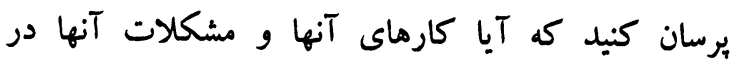

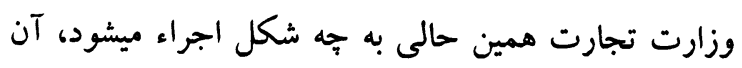

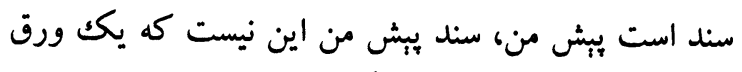

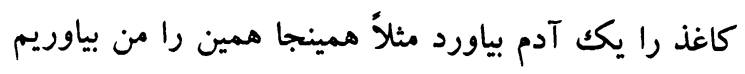
اينجا امضاء معاون صاحب دوم هم است اين را هند جين جيز با هم يكك جاى كنم باز بحيرم زيرش يك امث امضاء كنم 
كار وانخلو، هيخ آسماني بريبنتي نشته دي تجي مورو او

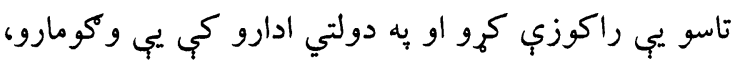

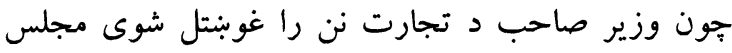

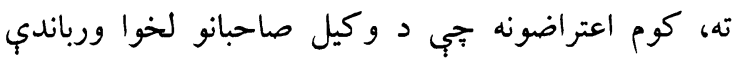

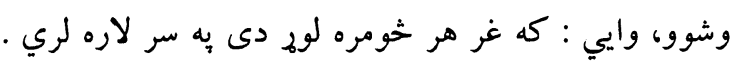

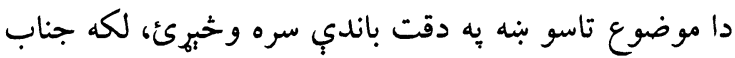

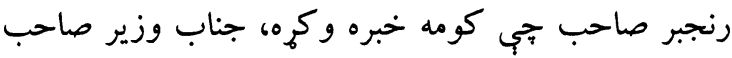

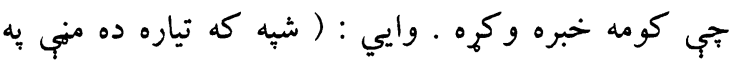

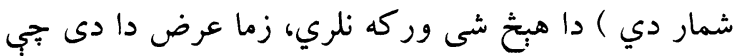

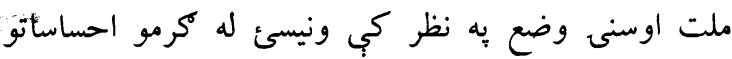

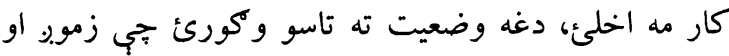

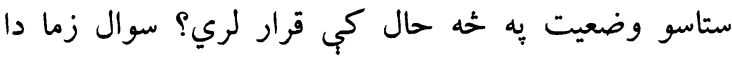

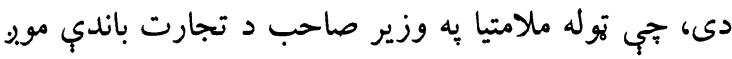

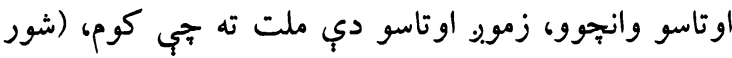
او زوبه به تالار كي ) .

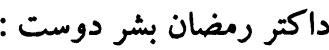

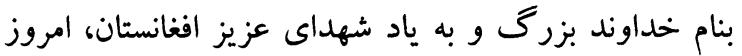

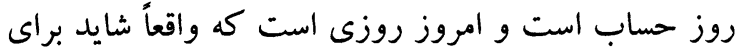

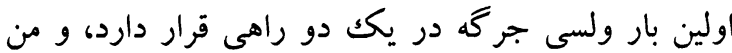

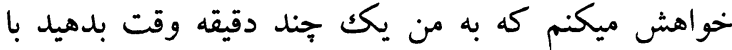
وجوديكه وقت نان است گرسنه هستيد اما سرنوشت ملت منت مطرح است، مسئل شخصى هيجكدام مطرح نيست، امروز

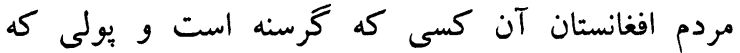
داشت به آن روغن خريده نميشود، به آن نان خريده

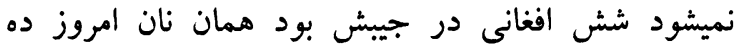

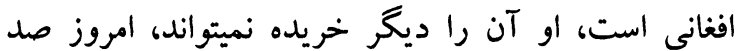

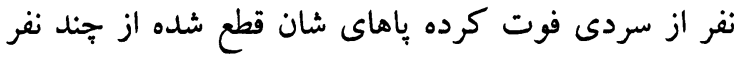

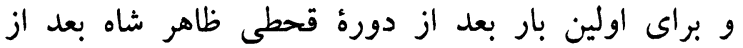

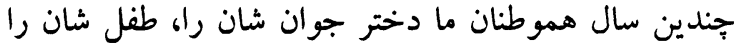
فروختند ! امشب او در اخبار ميشنود كه ولسى جرئن

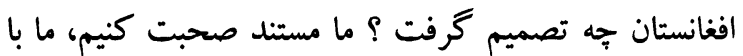
دليل صحبت كنيم، ما مسئلة شخصى، قومى، تنظيمى همه

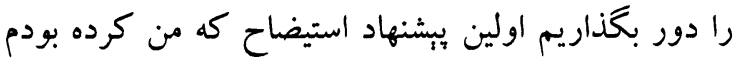

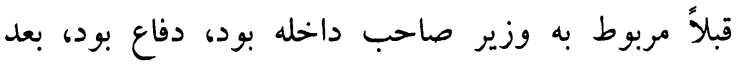

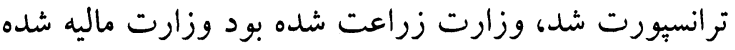

از تمامى اسناد من مى آورم كه در همان اداره كه قبلاً در

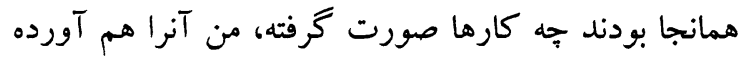

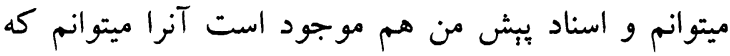
اينجا بمانم و شما قضاوت كنيد، اسناد ديغر ران را هم بينينيد،

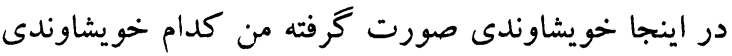

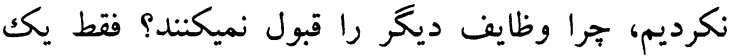

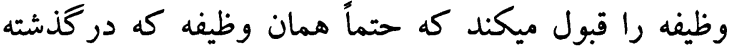
بود همان باز به دست بيآيد، درقسمت اينكه شما كفتيد كه دئه

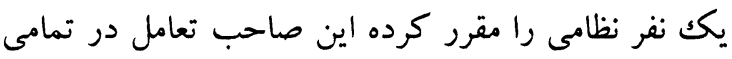

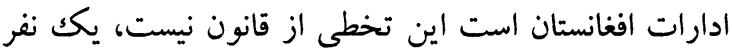

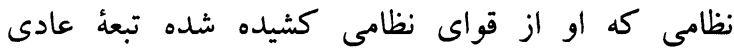

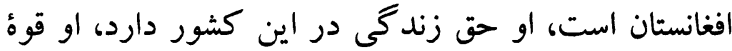

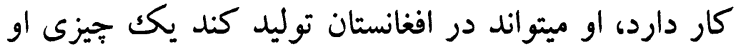

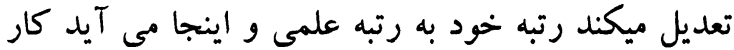

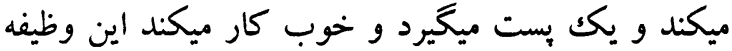

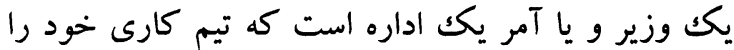

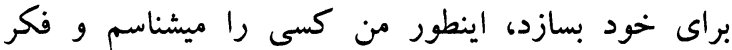

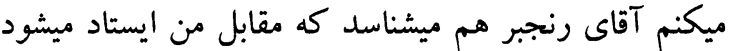

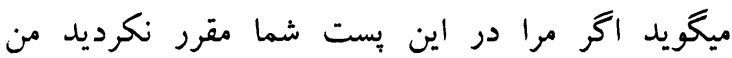

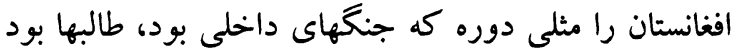

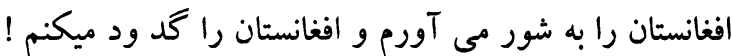

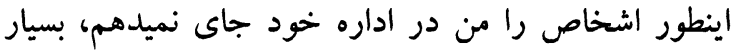
معذرت ميخواهم صاحب (غالمغال در تالار ) ).

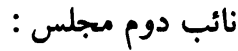
اجازه بدهيد اين كار هيئت ادارى است، هيئت ادارى مى مي

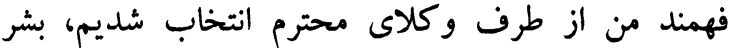

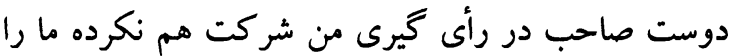

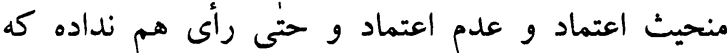

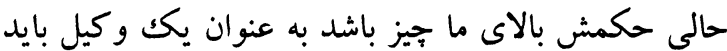

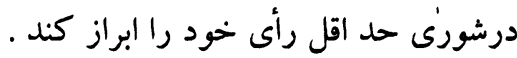
ملا تره خبل كوجى :

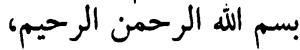

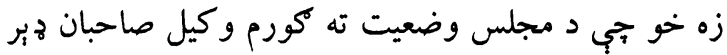

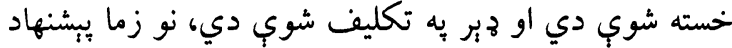

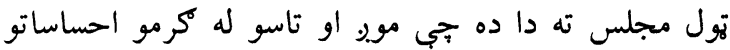


وزير تجارت آن قيمتها را كه مردم امروز شكر ميكنند

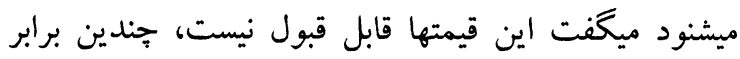

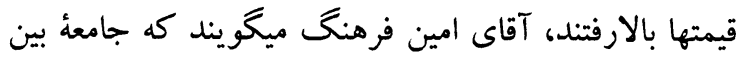

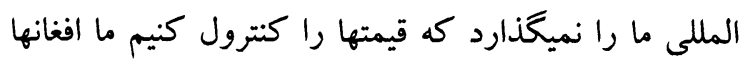
متأسفانه هر زز وقتى از خواب صبح بيدار شويم، دير بيدار

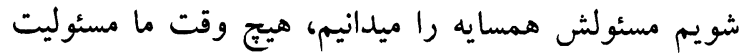

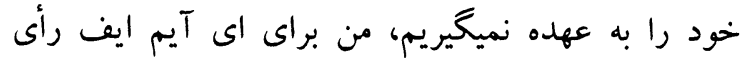

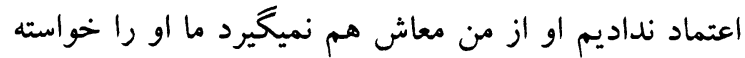

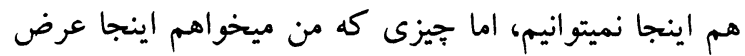
كنم اين است كه طبق كفته هاى خود آنها هر وقتيكه انها دولت افغانستان يكك موضوع را گُفته جدى است ما آنرا

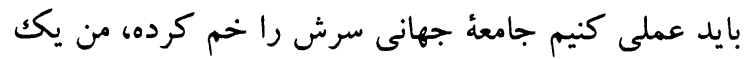

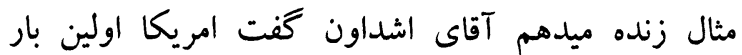
كفت كه به من بيشنهاد كرد كه اين ماموريت در افغانستان

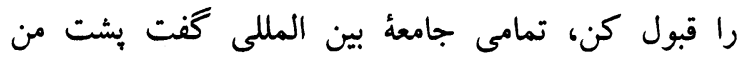

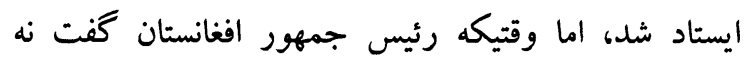

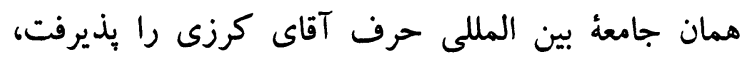

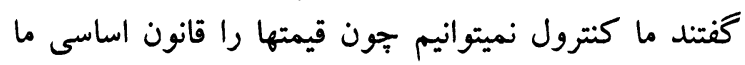

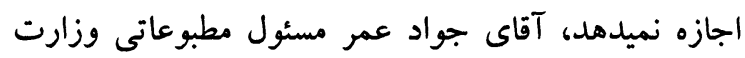

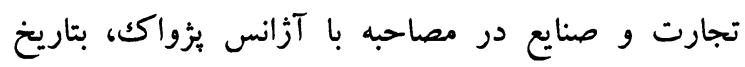
بيست و شش، شش هشتاد و شش كه در روزنامه منتشر

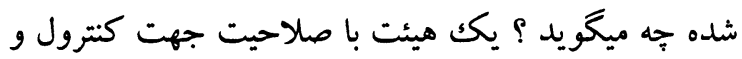
بررسى قيمت تيل بطرول وكاز مايع در شهر كابل مأل روز

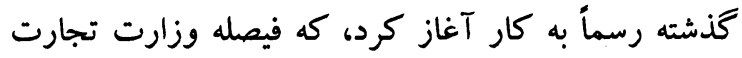
را تطبيق كند، فيصله وزارت تجارت كه اعلان شد اين بود كار كارد

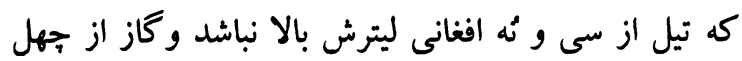

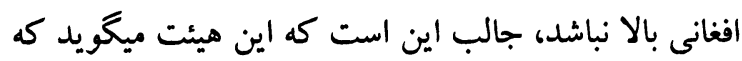

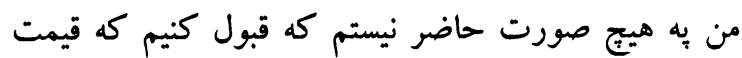

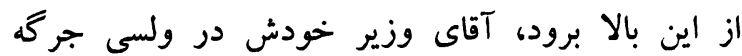

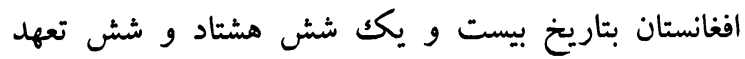

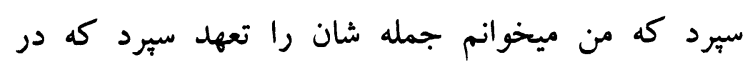
زمستان قيمت يكك ليتر تيل و يكك كيلو كاز كمتر از جهان ميل

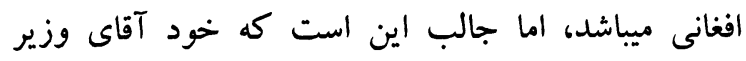
قيمت را كه تعين ميكند خودش دوباره آنرا تغير ميدهد آنا بدون اينكه تغيرات در شرايط جهانى بوجود آمده باشد، تئل
بود، كه آنها به تدريج ممكن است بعداً شود يعنى كه اينجا مسئله شخصى مطرح نيست با هيج كس، من به به دور

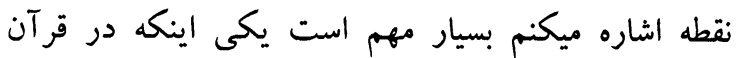

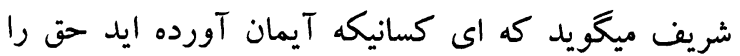
بكوئيد، و بعد در زمان خليفه دوم مسلمانها، براى خلي خليفه

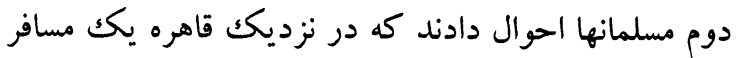

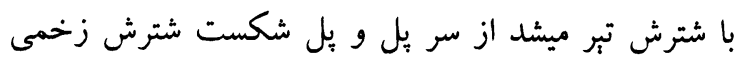

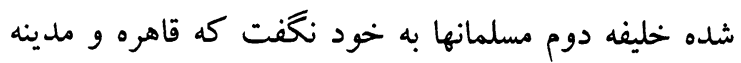
جندين فرسخ راه است، هزاران دليل ديخر ميتوانست او به دونه

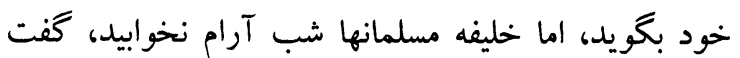
بخاطرى كه يل در قلمرو من شكسته آن محكم و درست آخت

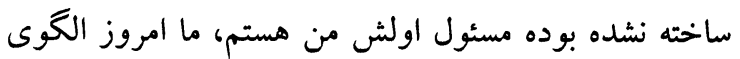

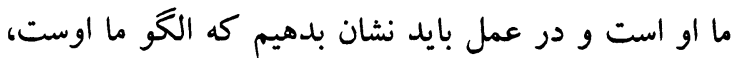

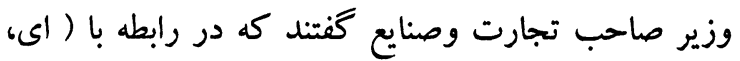

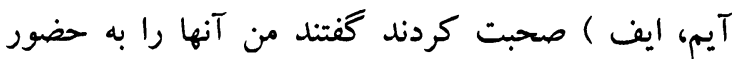

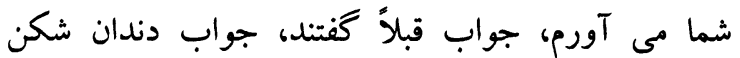
دادم، من از وزير صاحب محترم ميخواهيم كه يكك جند

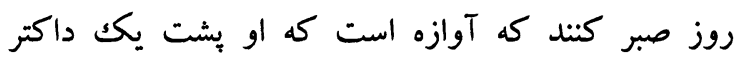

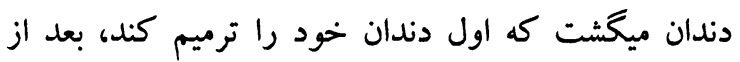
آن اكر خواستيم او بيايد . رئيس مجلس : أفأ آقاى بشر دوست! شما سوالهاى مشخص مبل تان را مطرح كنيد، سوالت را مطرح بساز . داكتر رمضان بشر دوست : دو مسئله بسيار مهم مطرح است يكي فئ قيمتها، بتاريخ بيست

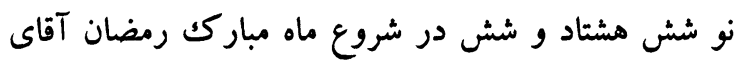

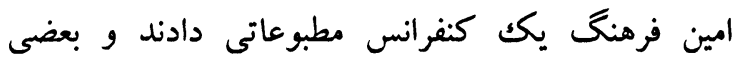
قيمتها را آنجا ذكر كردند كه من ميخوانم، سندش اينجا

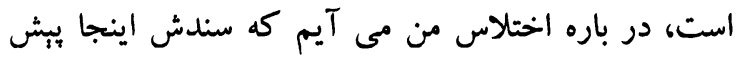

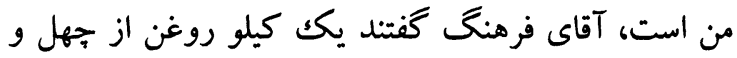

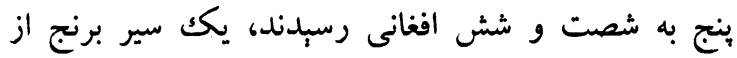

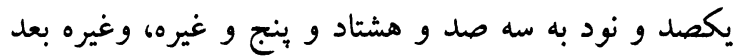

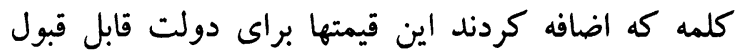
نيست، امروز تاريخ يازده است اين قيمت سه برابر، جهار

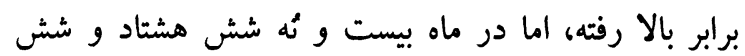


ضد رقابت سالم هنوز نداشته، و انها دو سال است كه هنوز

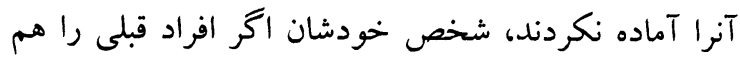

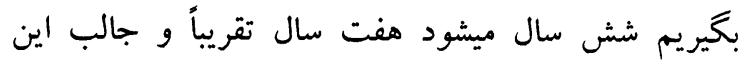

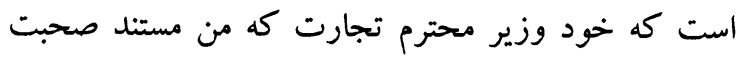

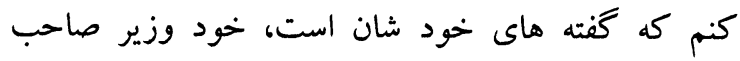
محترم تجارت باز دركمبسيون در ولسى جركه بتاريخ بيست و يكك ينج هشتاد و شش اعتراف ميكند كه احتكار

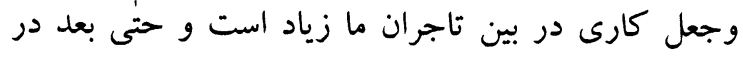

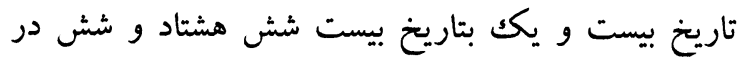

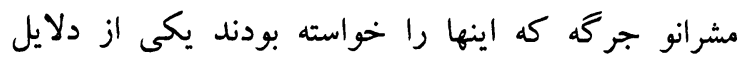
افزايش قيمت را كارشكنى بعضى شر كتهاى خصو انو انهى

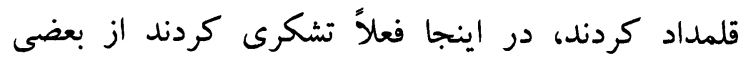

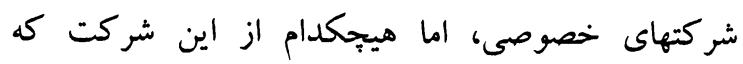

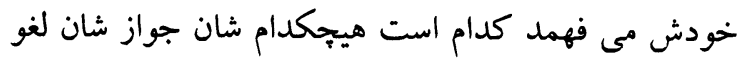

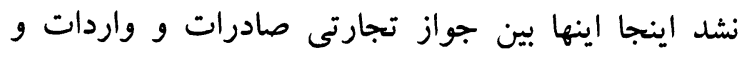
جواز سرمايه گذارى ميخواهند اختلاط بوجود بياورند ديند درد ذهن مردم افغانستان، جواز تجارت مربوط به وزيه وزارت تجارت است، و هيج ربط به كمبسيون حمايت از سرمايه كذارى ندارد و حتى خود شان اعتراف ميكند كه با وجود وند

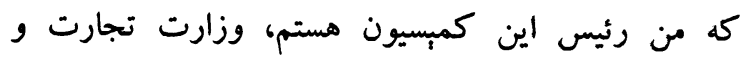

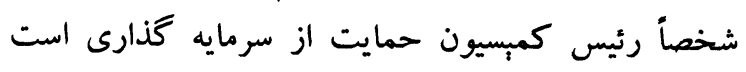

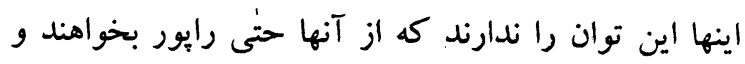

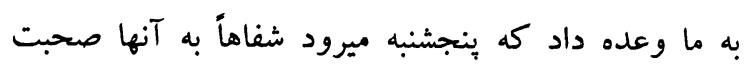

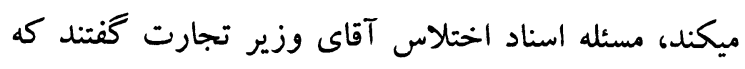

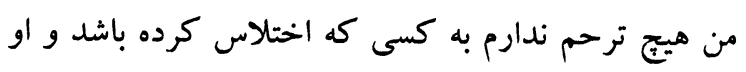

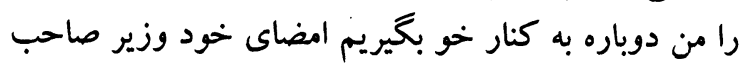

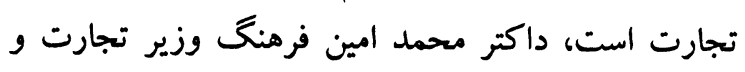
صنايع شماره مكتوب دو صدو شصت و دو تاريخش بنج

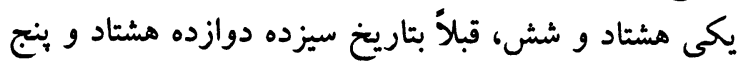

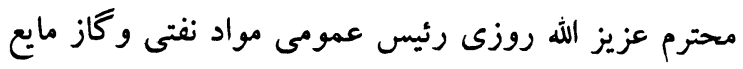

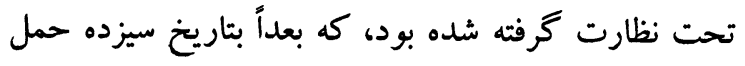

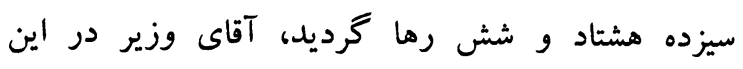

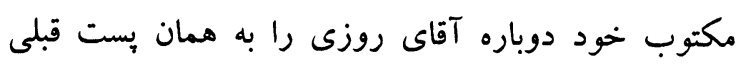

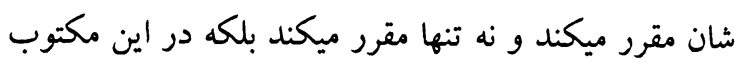

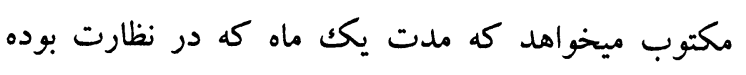

بتاريخ بيست و سه شش هشتاد و شش فيصله وزارت

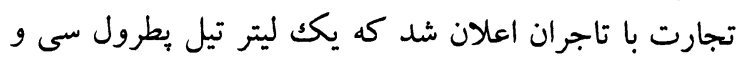

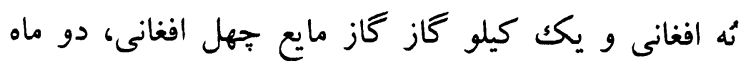

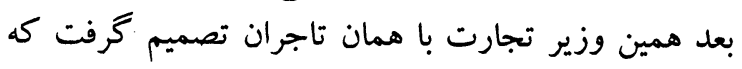

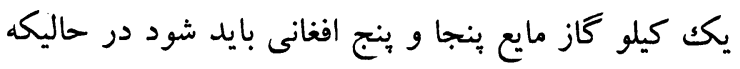

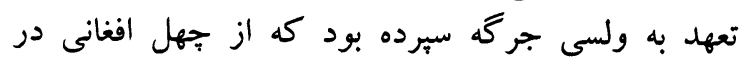

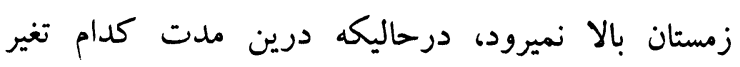
عمومى در سطح بازار بوجود نيامد، مسئله ديخر، بارها اينها

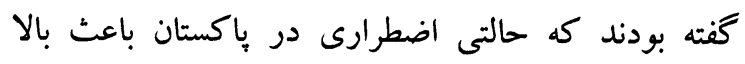

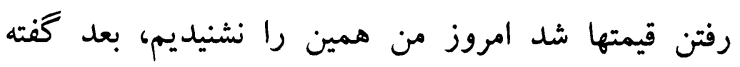

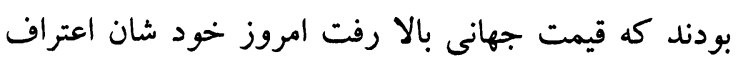

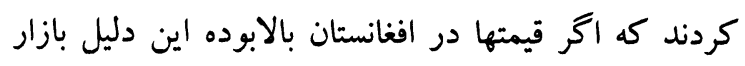

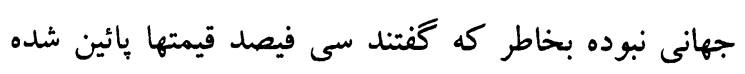
در افغانستان در حاليكه در جامعه جهانى قيمتها نه نهائه تنها

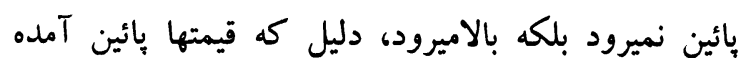
كفتند كه من كمكك از جامعه بين المللى خواستيم و آن بائ

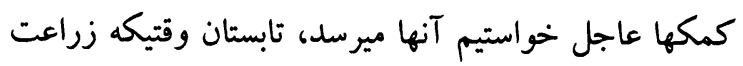

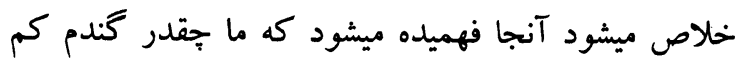

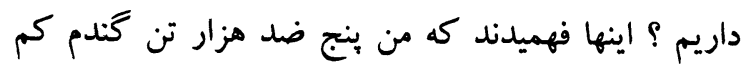
داريم، شش ماه بيش آنها مى نشينتد تا افراد اين كشور

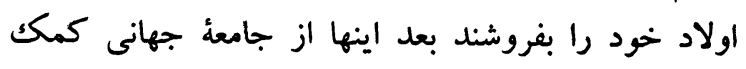

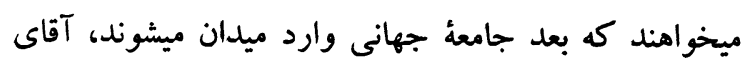
رئيس جمهور ما فقط هفته كذشته با رئيس جمهور امريكا

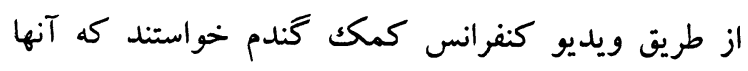

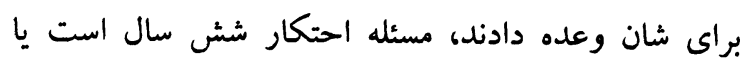

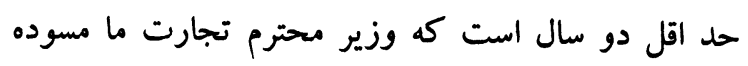

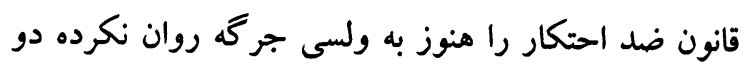

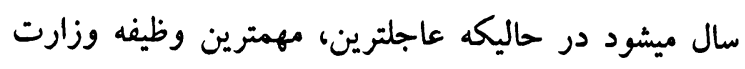
تجارت در حاليكه به كفته خودش به ماله سوى مون سكتور

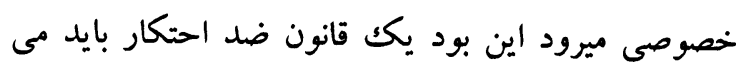

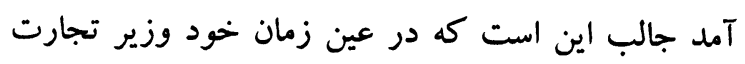

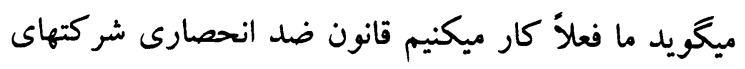
خصوصى و رقابت سالم تهيه كنيد، يعنى اين به اين مفهوم

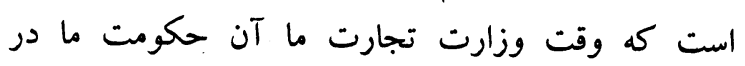
مجموع سكتورهاى دولتى ما را به خصوصى سبرد قانون 
ملى خود را درك كنيم اكر اين از اين قتلخاه سياسى زنده

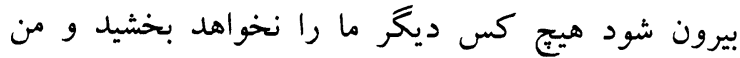

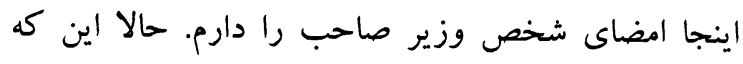
يبمان صاحب كمى زخمى است كه ما رأى نداديم منتها متأسفانه ما در همين جدال براى جو كى وقى وقتى يكى هزاره

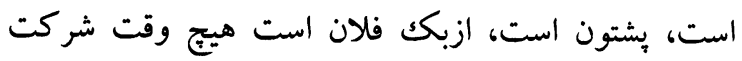
نميكنيم كه احساس نكند كه همين ممكن است به قوم

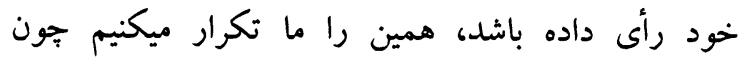
موهبت او هم دارد ما هم داريم جاى ترديد نيست، با اسناد با امضاى وزير صاحب محترم كه اينجا نشسته، رئيس مواد

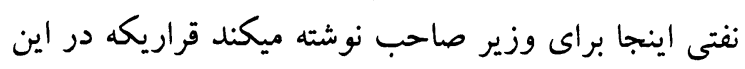

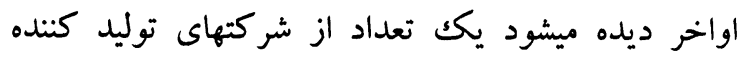
كان مواد نفتى بطرولهاى صورت بائين كه تحت تصفيه

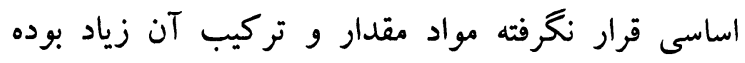

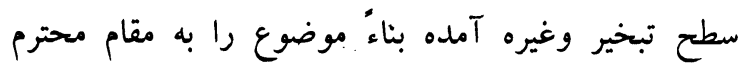
ييشنهاد در زمينه طالب هدايت ميباشد. اين را رئيس عمومى مواد نفتى و گاز براى وزير صاحب نوشته، وزير مائه

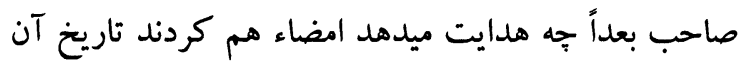

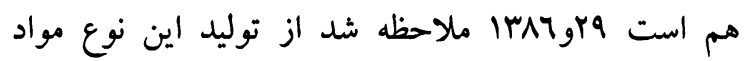
نفتى بى كفيت اكيداً ممانعت به عمل آيد، خانه شان آباد تشكر اما حند روز بعد خود وزير صاحب نشئ نشسته همان رئيس عمومى برايش ويشنهاد ميكند، رئيس عمومى آن

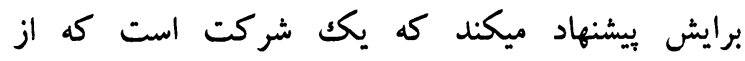

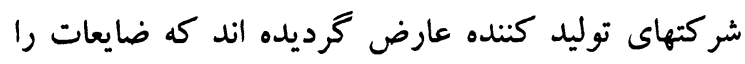
خود شر كت محترم متقبل ميشوند و خواستند كه همين

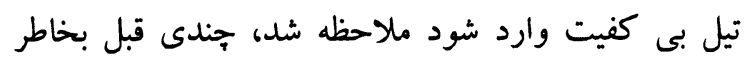

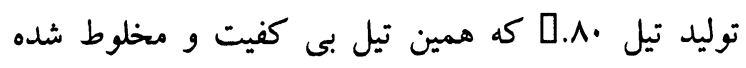

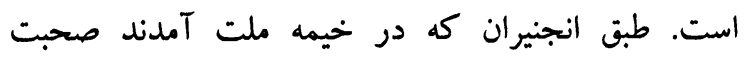
كرديم و اينجا اسنادش هست، سبكى كه ضايعات زياد دارد تصويب گرديده بود كه تيل متذكره توريد نكردئ

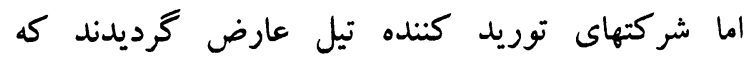
ضايعات را خود شركتهاى محترم متقبل ميشوند، بناء

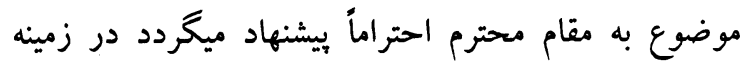

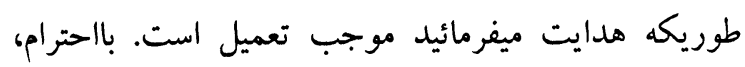

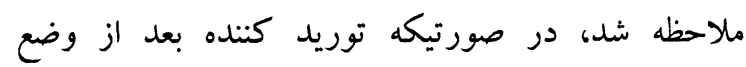

همين معاش و امتيازاتش هم اجراء شود، جرا آزاد شده ؟

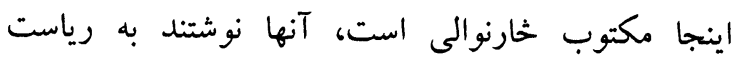

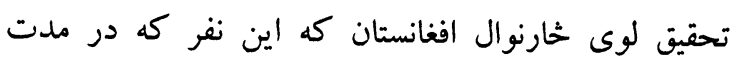

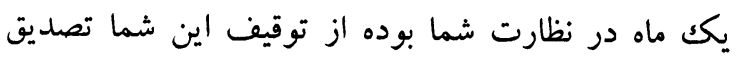

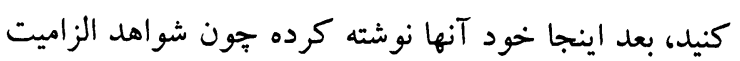
وجود نداشت بتاريخ سيزده حمل سيزده هشتاد و شش رها رها

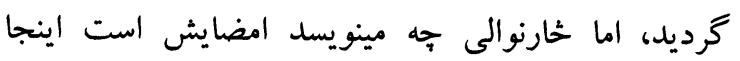
بيش من وجود دارد، خارنوالى نوشته كرده كه به ملاحظه الها

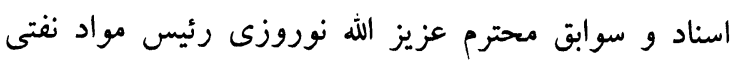

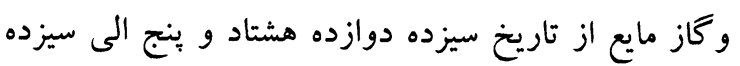

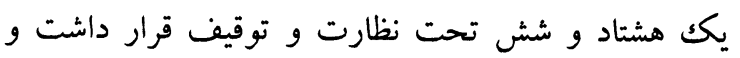

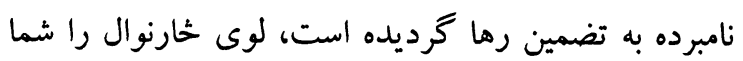

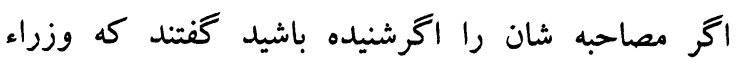

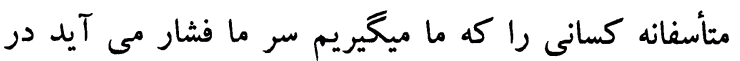

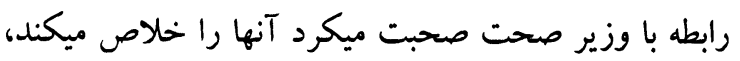

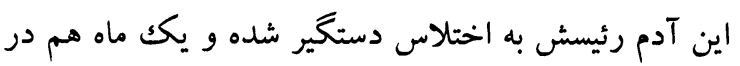

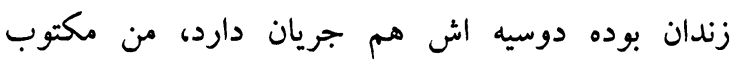

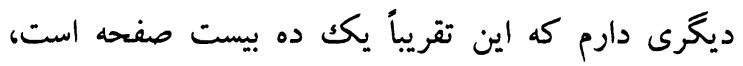
تاريخ بيست و هشت دوازده سيزده هشتاد و بنج قرار احاله قضيه اختلاس مواد نفتى مطابق مادة سى وهفت قانون

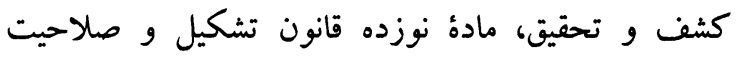
حخارنوالى، محترم رياست عمومى خحارنوالى امنيت، در اين

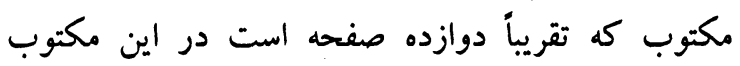

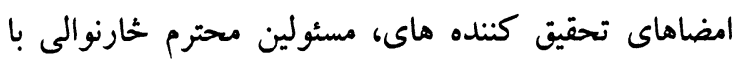

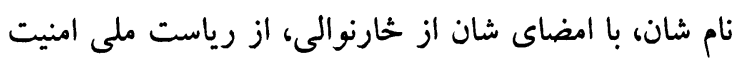
ملى وجود دارد در اين دوازده صفحه آنها به صورت

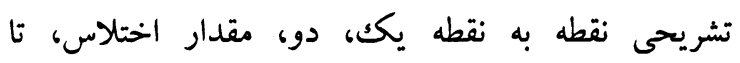
همينطور ادامه دارد، مقدار اختلاس و تمام جزئيات نوشته نهاته

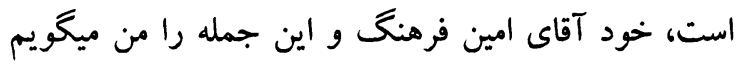

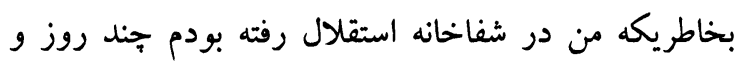

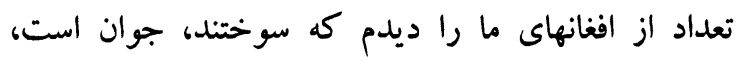
دختر است، بجه است در حال جان دادن هستند. دليلش

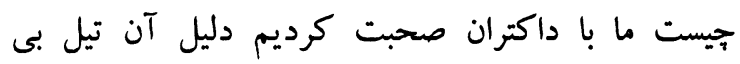
كفيت و وزير شخصاً به امضاى خود دستور وارد شدن تيل

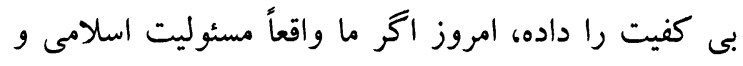


كاه كه است وقتيكه شركت خصوصى خودش ذخيره نداشته باشد از ذخيره دولتى كار ميخيرد، از آن استفاده ميكند و طبق فرمان رئيس جمهور كه من اينجا دارم سه

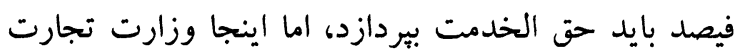

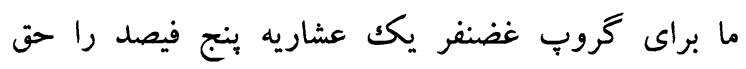

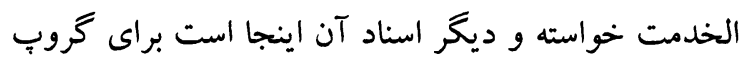

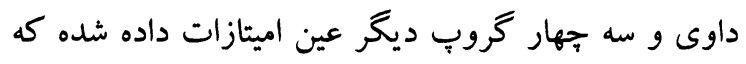

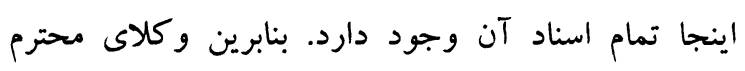

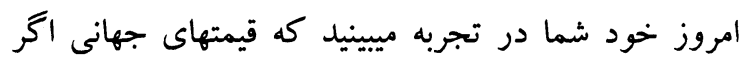
باعث افزايش قيمتها در افغانستان ميبود اين قيمتها بايد به

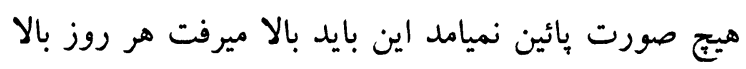

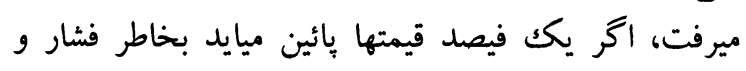

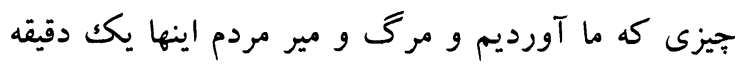

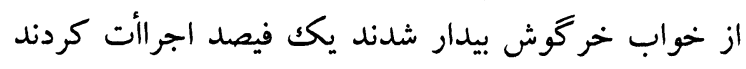

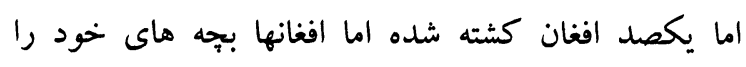

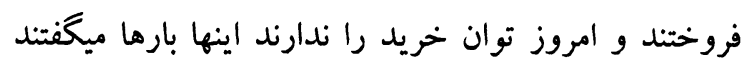

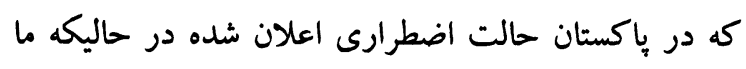
شاهد هستيم كه قيمتها همانطور كه من تاريخ آنرا كفتم اضئ

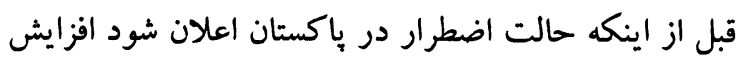

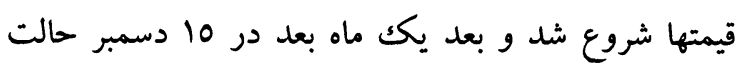

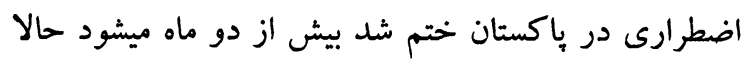

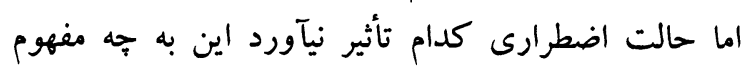

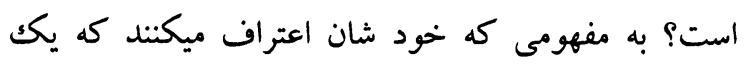

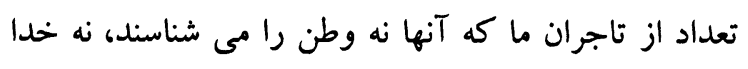

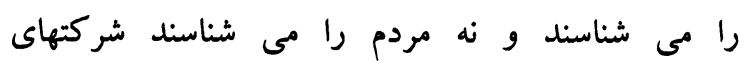

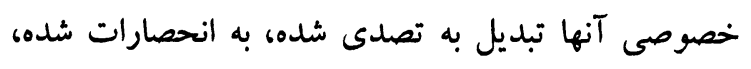
رقابت سالم را آنها به رسميت نمى شناسند. آنها احتكار

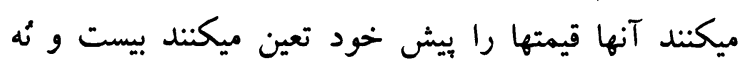

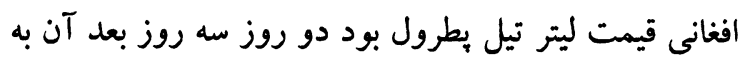
ينجاه و سه افغانى در تمام تانكهاى تيل رسيد، بنابر اين خواهش من از شما اين است اختلاس، بى كلى كفايتى، عدم احساس مسئوليت و دلسوزى به مردم نه تنها در كار وزير إني

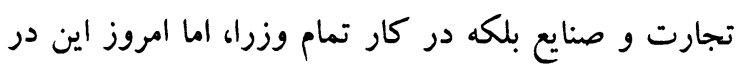
گير ما است همينجا است و من ميترسم كه كدام معامله

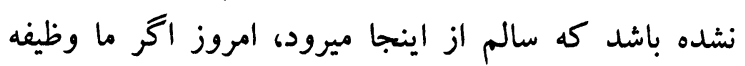

لابراتوار ضايعات را متقبل شود مواد مذكور تخليه گُردد

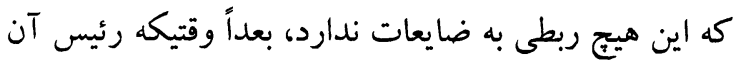

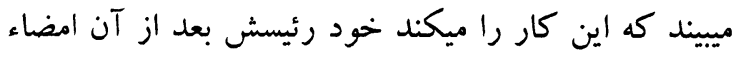
ميكند و هيج نزد وزير نميبرد كه من اينجا دارم، اينجا مكتوب ديخر . ميكن و مئر نائب دوم مجلس : جناب بشر دوست صاحب! كافى صحبت كرديد يك مجك

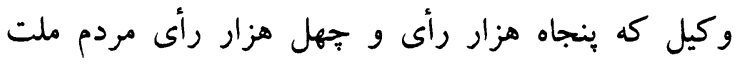

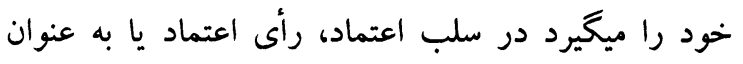

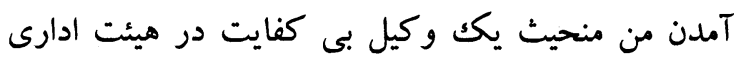

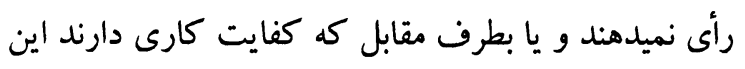

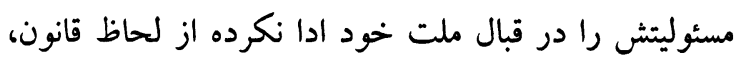
بناء" نوبت به ديخر وكيل صاحبان است، ديخر وركيل وريل

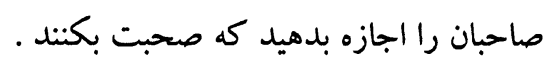
رئيس مجلس : ييمان صاحب ! يكك دقيقة ديكر هم اجازه بدهيد برايش .

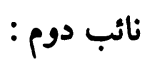
اجازه است؟ بفرمايد بشر دوست صاحب! · لـ دقيقه ديخر هم اجازه است گتهاى شما را ميشنويم اما شما مسئوليت

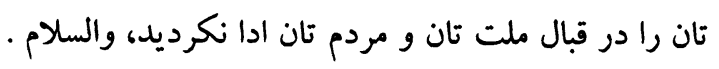
داكتر رمضان بشر دوست :

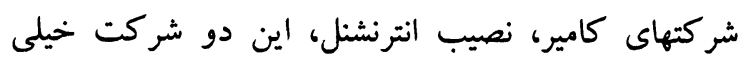
تيل بى كفيت و مخلوط را وارد كردند رياست لابراتوار

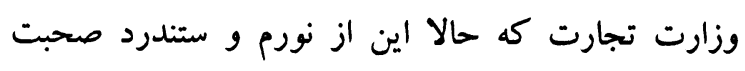
كرد اما در خود وزارت تجارت تجارت يك يك رياست لابراتوار

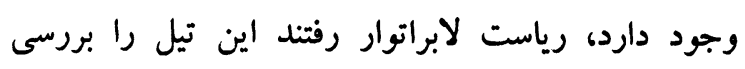

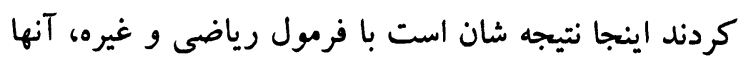

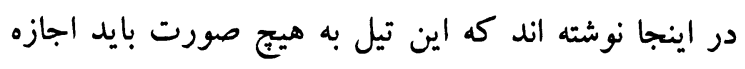

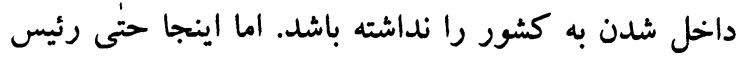
مواد نفتى نوشته اند كه خير است يكبار اجازه داده شود

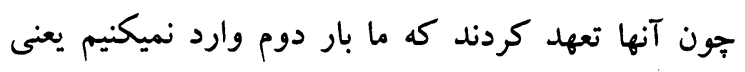

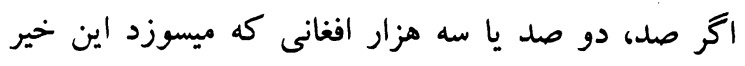

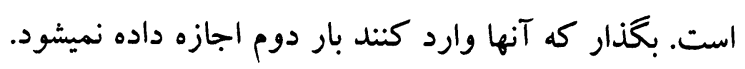

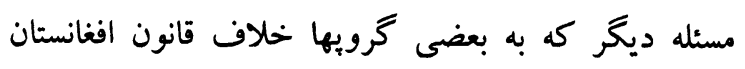

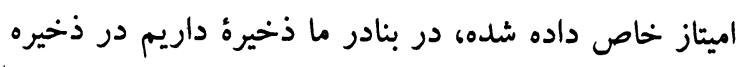


روز ما حدر و سوالات مختصر از وزير صاحب سوال شود

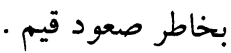
وزير تجارت و صنايع : من اول بكويم از همكار سابقه خود و ونعلاً كه وكيل

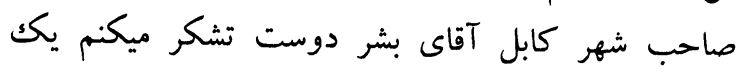

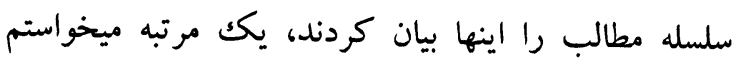

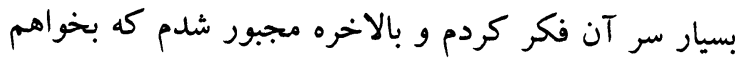

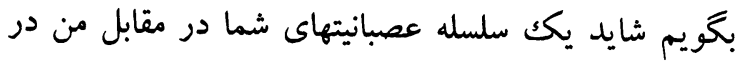

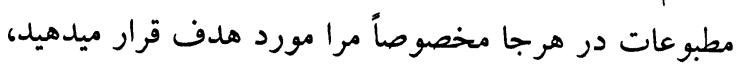

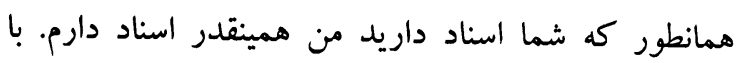

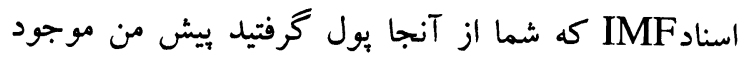

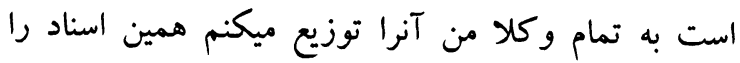

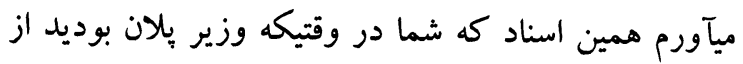

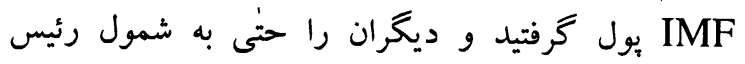

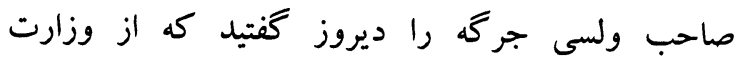

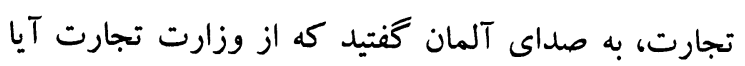

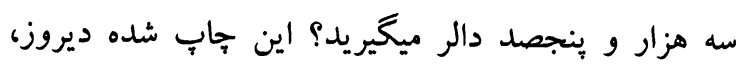

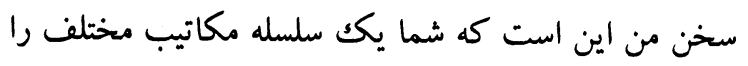

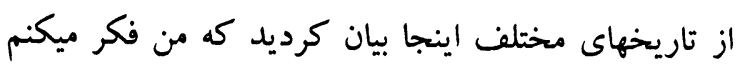

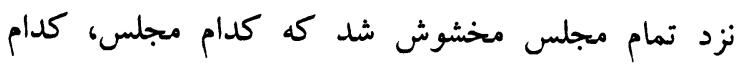

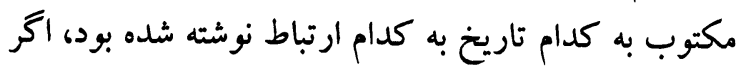

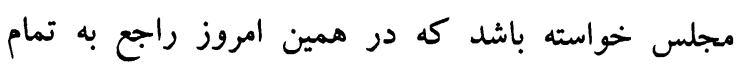

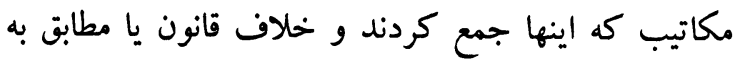

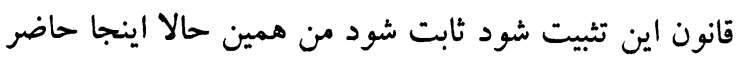

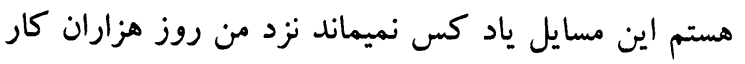

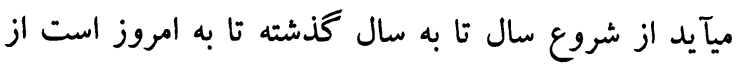

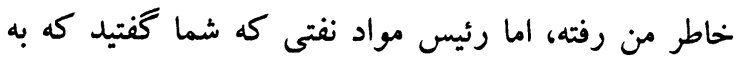

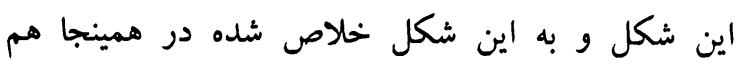

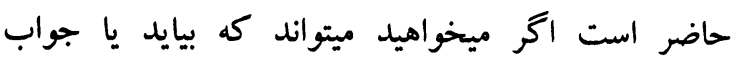
قناعت بخش براى شما ميدهد يا اين است كه مسئول

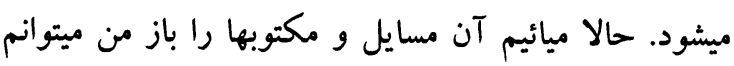

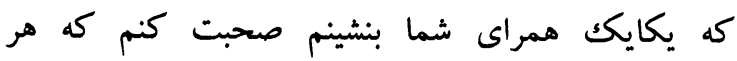

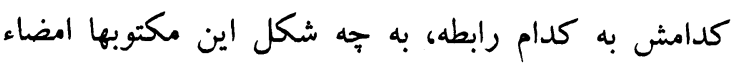

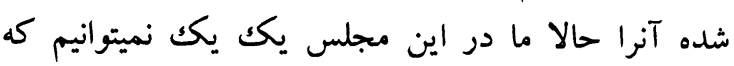

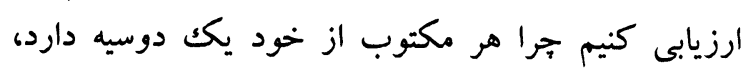

خود را انجام ندهيم ييش خدا و بيش خلق مار ما مسئوليت

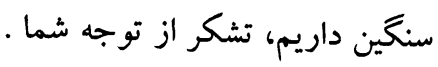

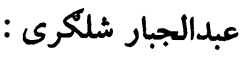

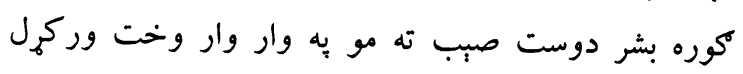

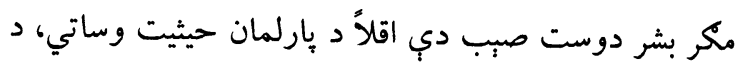

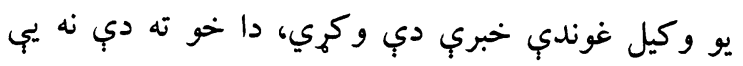

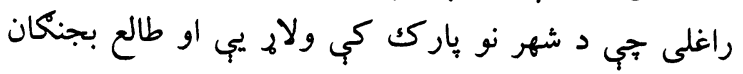
كوي . مئ.

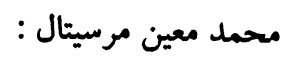
بسم الله الرحمن الرحيم، معنبال

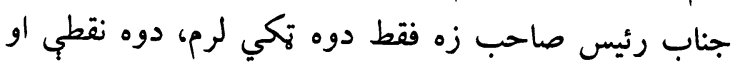

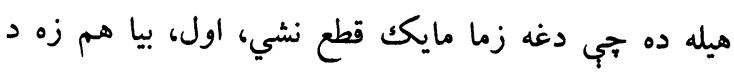

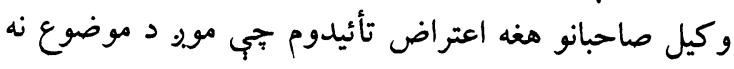

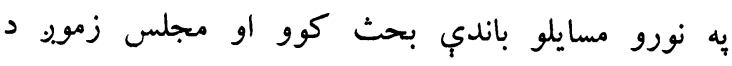

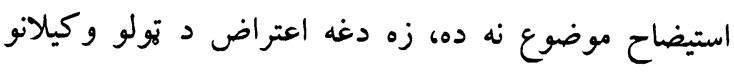

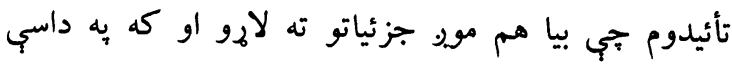

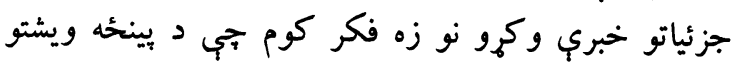

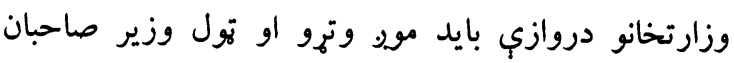

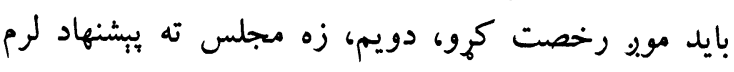

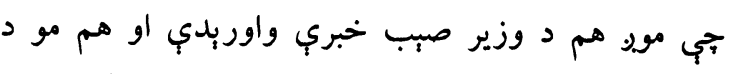

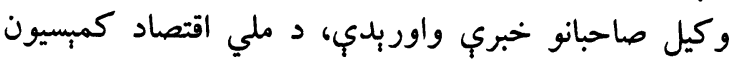

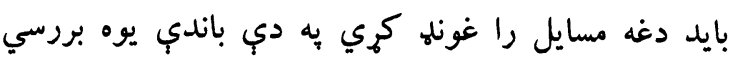

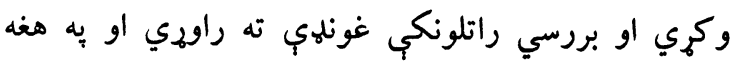

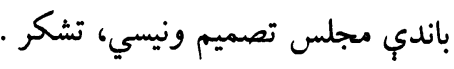
سيد داوود هاشمى:

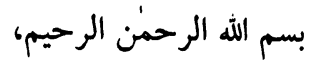

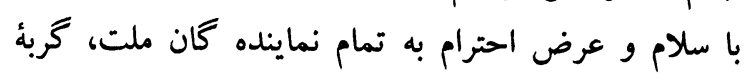

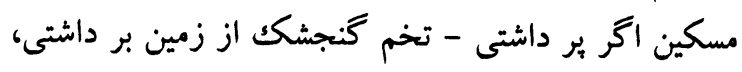

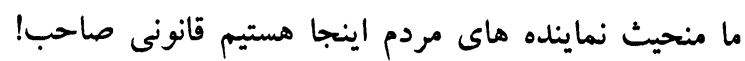

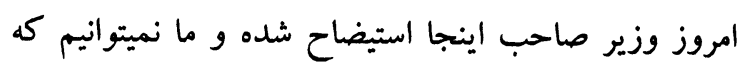

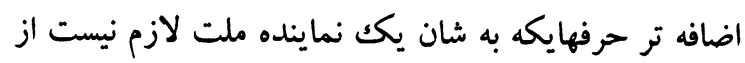

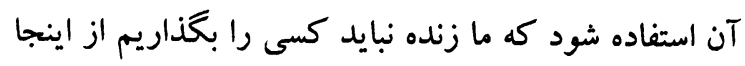

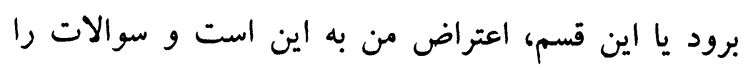

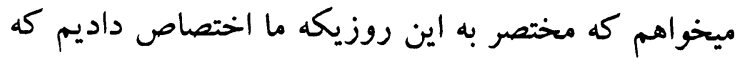


برادرشان معين وزارت تجارت باشد، معين ادارى كه بعد

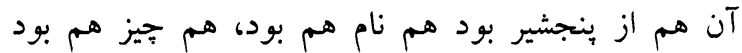
خوب من در اين زمينه تحقيق بيشتر نكرده بودم، مسئله

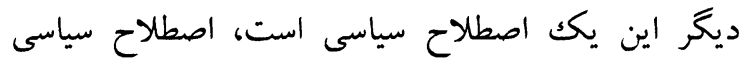

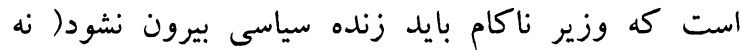

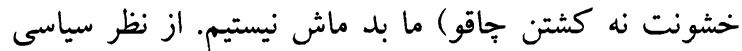
بايد از اينجا زنده بيرون نشود وزير بـى كفئ كفايت، مسئله

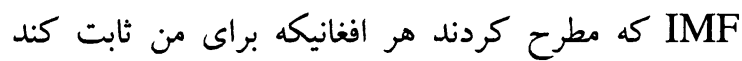

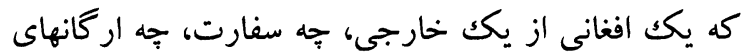

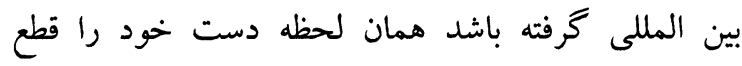
ميكنم. كسيكه معاش خود را، كسى كه تمام دارائى خود را براى مردم خود ميداد و كسيكه هيج امتياز نخرفت

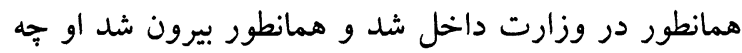

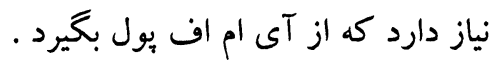
رئيس مجلس:

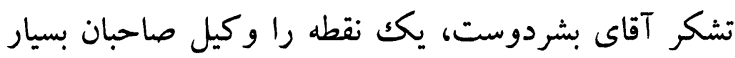

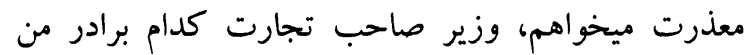

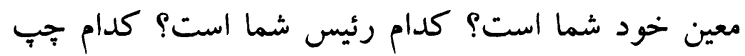

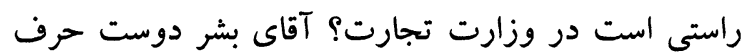
خود را بس كرفتيد شما؟ تشكر. نياز محمد اميرى : لئ

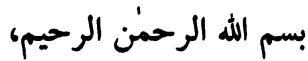

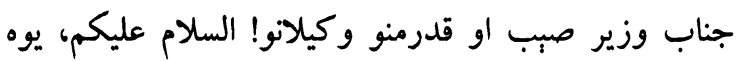

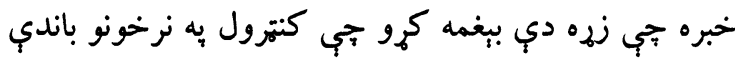

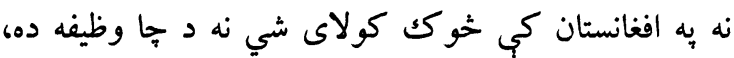

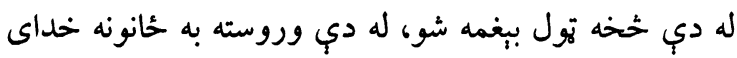

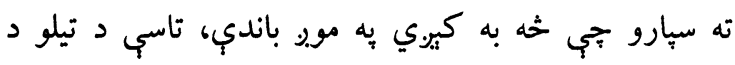

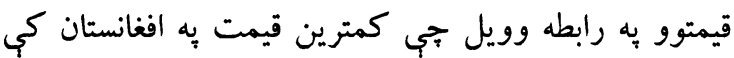

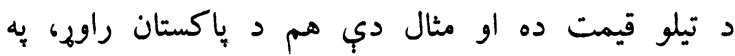

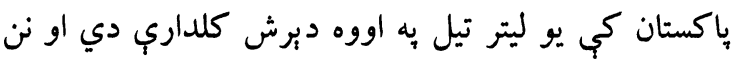

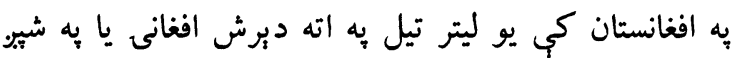

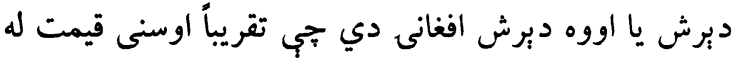

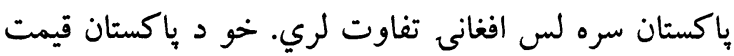

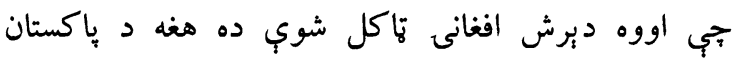

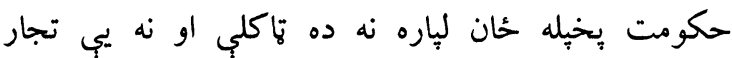

اين دوسيه دارد اين دوسيه بايد مطالعه شود، از آن خاطر

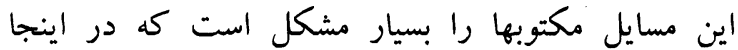
جواب داده بتوانيم. اما من هم در مجلس حاضر هستم

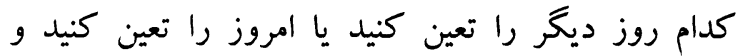
همراى خود بشر دوست صاحب هم حاضر هستم كه يك ديك رون

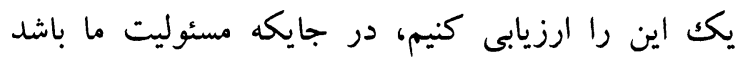

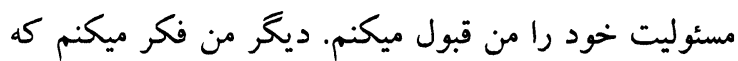

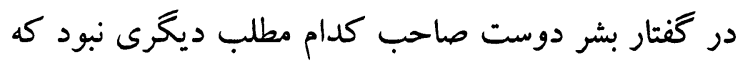

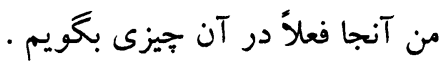
رئيس مجلس : وكيل صاحبان محترم اكر اجازه بدهيد كه جمع بندى

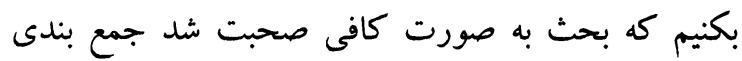
شود درست است؟ به به به حاجى احمد فريد :

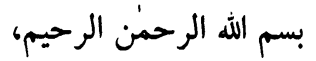
جناب رئيس صاحب من سر اين بحث ندارم كه وزير الرحبم،

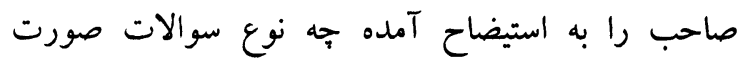

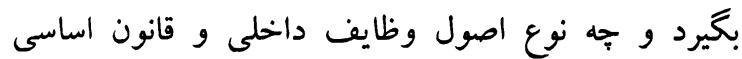

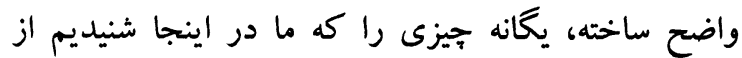

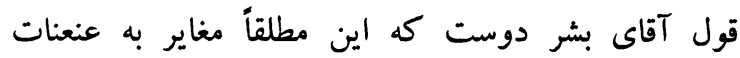

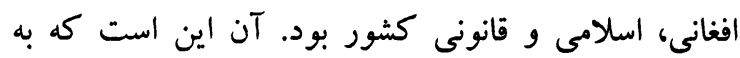
خانئ ملت نسبت قتلكاه سياسى كرد، مانى ما اينجا قاتلهاى

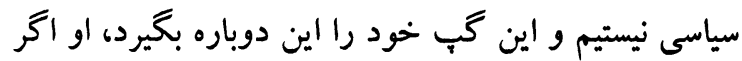

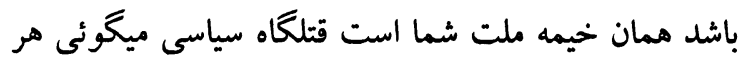

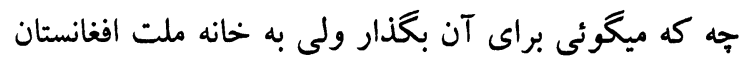

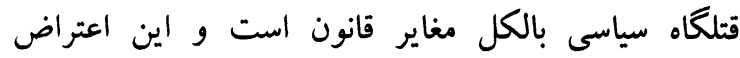

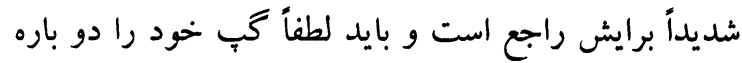
بحيرد، تشكر .

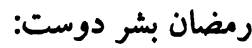

ميخويند آفتاب با دو انگشت دونهان ينهان نميشود بعضى كسان

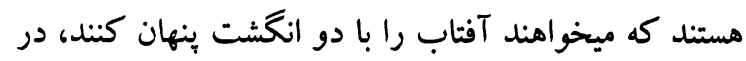

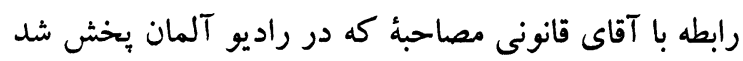

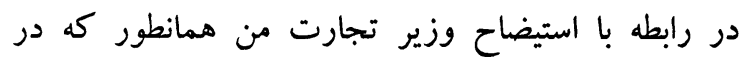

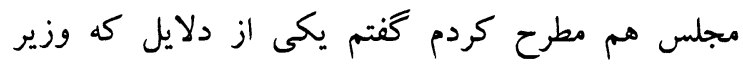

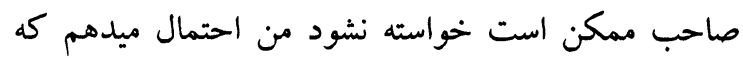


افغانستان خلكو ته يبي خدمت كرى به عاميانه او به ساده

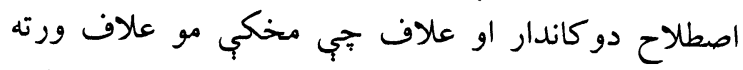

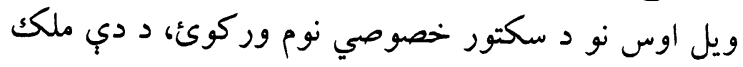

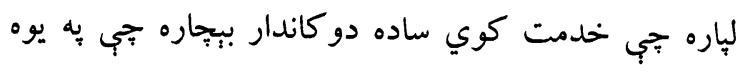

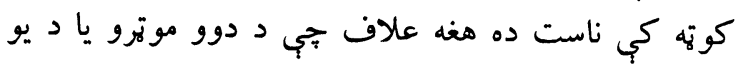
نيم موتر غنمو د اخيستو قدرت لري. هغه خحوك ده د سكتور

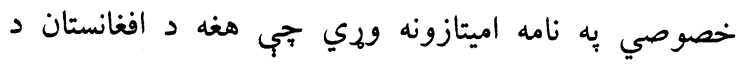

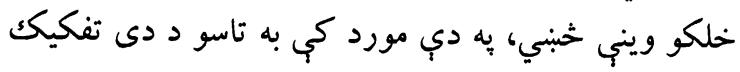

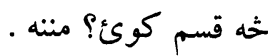
وزير تجارت و صنايع : در قسمت تيل و مقايسه افغانستان و پِاكستان كه شما كفتيد

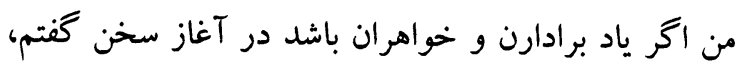
از تيل صحبت نكردم از گاز صحبت كردم من قيمت گاز

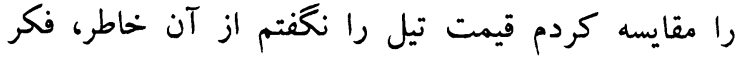
ميكنم يكك سوء تفاهم شده. در قسمت ذخاير كه شما

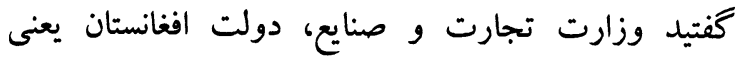

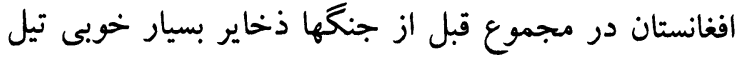

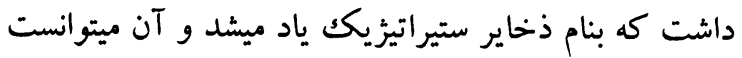

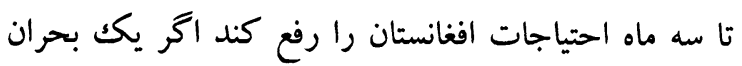

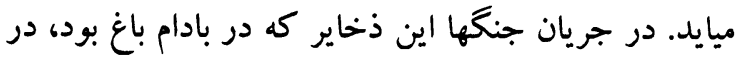

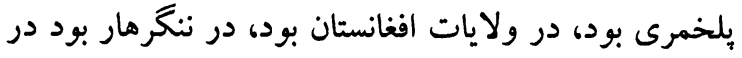
كجا و اينها به كلى تخريب شدند. در شُ دالئ ساليه وزارت

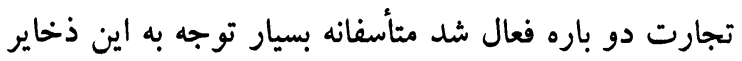

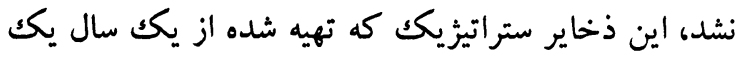

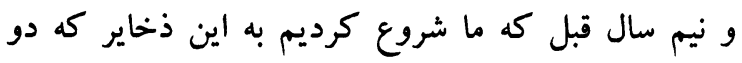

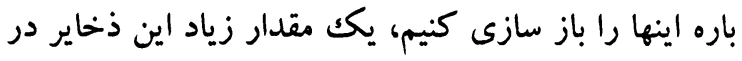

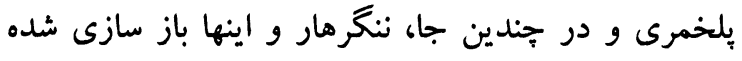

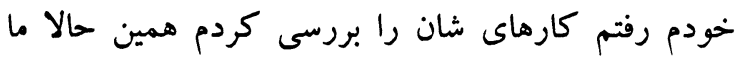
كنجايش اين را داريم، در خود ردم حيرتان بسيار ذخاير بزرى است كه اين تيل همين حالا همانجا ذخيره نغًاه كنيم، در بهلوى آن سكتور خصوصى هر شركت براى خود ذخاير ساختند و تيل كه مياورند بعد از آن كه كفيت آن ديده شد در همان ذخاير خود مياندازند وقتيكه ميكشند كفيت آن هم ديده ميشود كه همان كفيت باشد وقتيكه به ديه

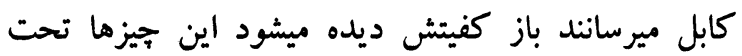

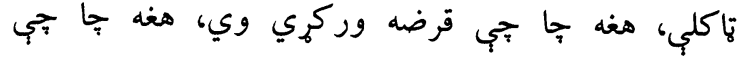

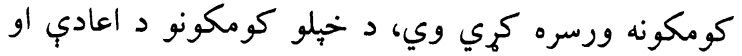

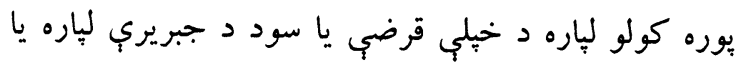

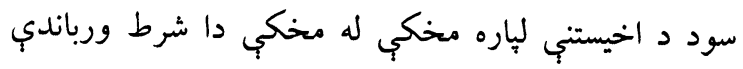

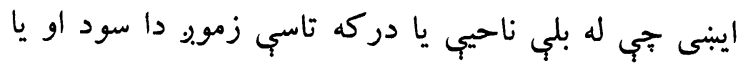

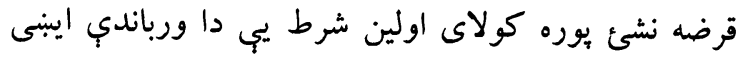

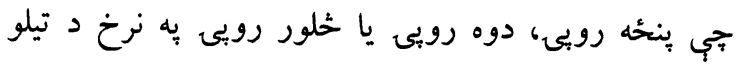

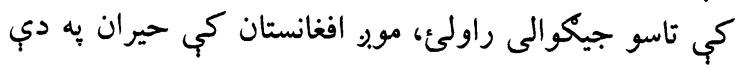

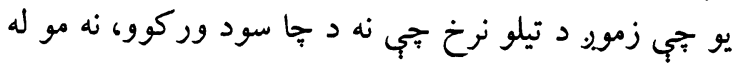

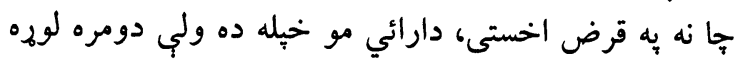

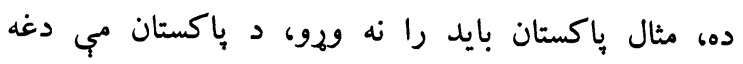

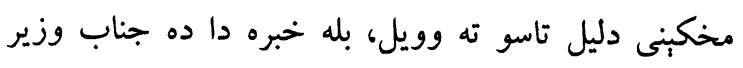

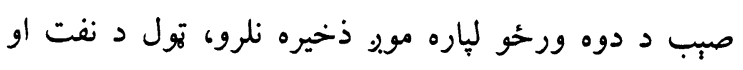

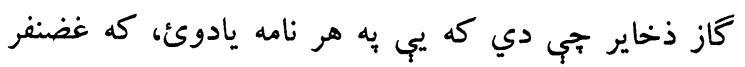

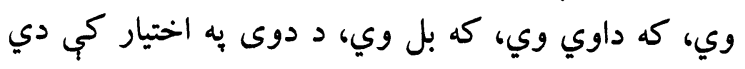

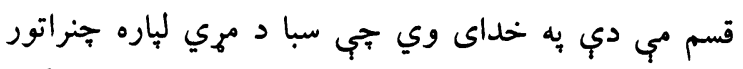

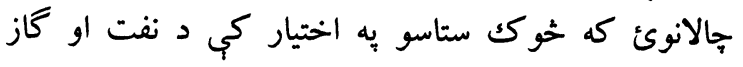
ذخيري دركي

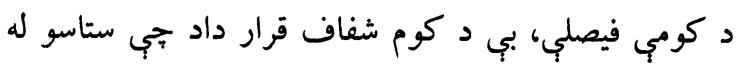

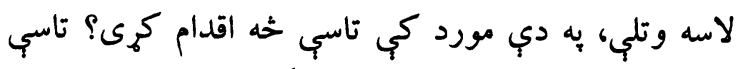
د تجارت وزير يه صفت جي واقعاً موير تا ته اميد درلود

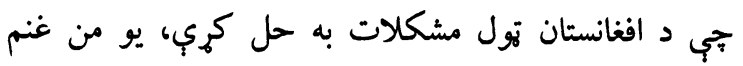

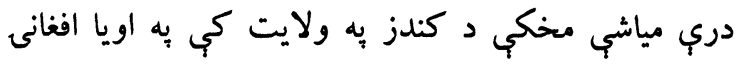

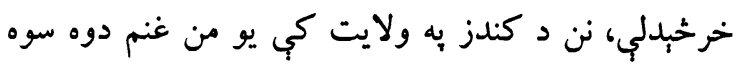

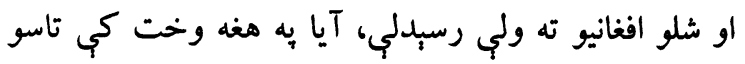

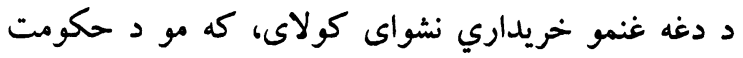

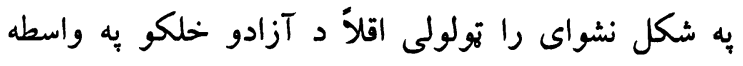

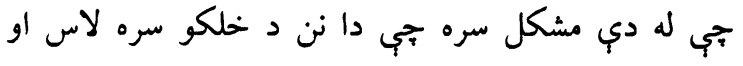
كريوان ياست خحان مو نشو خلاصولاى، بله خبره د سكتور

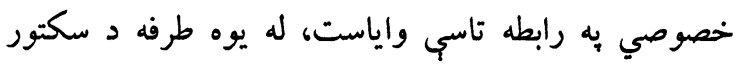
خصوصي نوم اخلئ ترجيح هغه خصوصي نهي سكتور ته

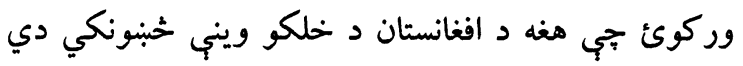

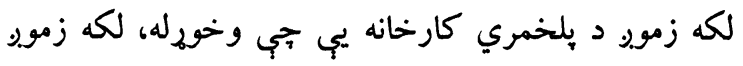

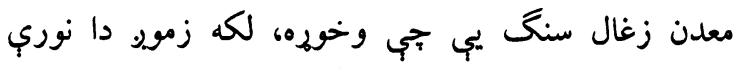

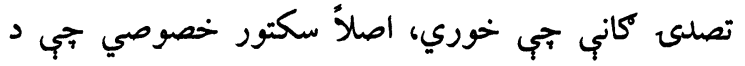




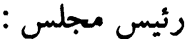

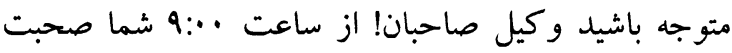

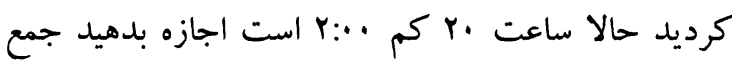

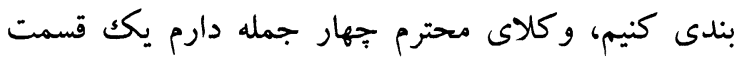

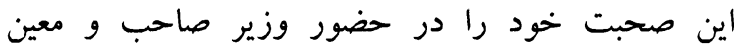
صاحبان آن ميخواهم مطرح كنم يكك قسمت ديخًر آنرا باز اينها تشريف ببرند ما و شما براى دو يا سه دوقيقه مئه ديخر

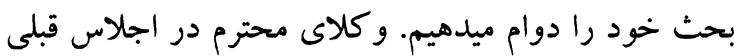

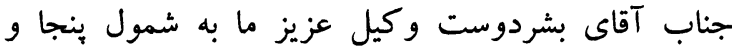

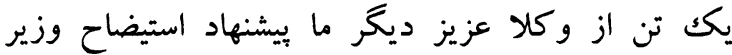
تجارت افغانستان را ارائه كردند، اين تقاضاى اينها مطابق

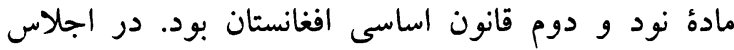
قبلى در مورد تعداد امضاء هاى كه ترتيب شده بود كه آيا نامهاى شان مشخص است يا نيست بين وكلاى ما شكك

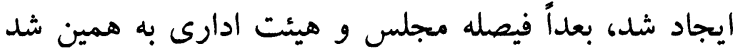

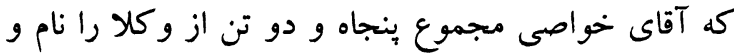
امضاء هاى شان را تثبيت و تشخيص كنند اينها اين كار را

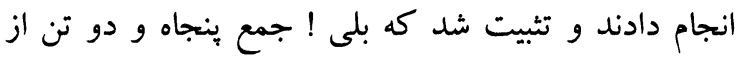
و كلا به شمول آقاى بشردوست امضاءهاى شان دقيق است و تقاضاى استيضاح وزير صاحب تجارت را كردند. اما جون ختم دوره اجلاس قبلى ما بود شامل آجندا كارى مجلس نشد ماند به اين اجلاس در اين اجلاس باز هم تكرار ميخواهم كه بحويم تقاضاى آقاى بشردوست و ينجاه و يكك تن از و كلاى عزيز ما جون باد با ماده دوم قانون

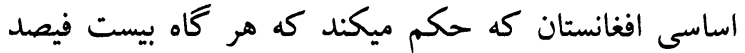

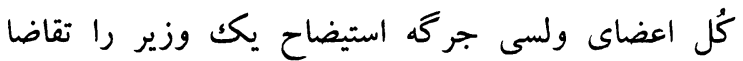
كنند ولسى جر گه ميتواند اسيتضاح بكند اين مسئله به شما و كلاى محترم مطرح شد و فيصله شد كه جون اين تقاضا مطابقت دارد با قانون اساسى و اصول وظايف داخلى ما وزير صاحب تجارت به استيضاح خواسته شود. سفر

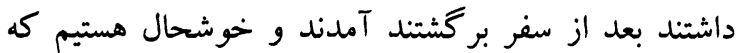

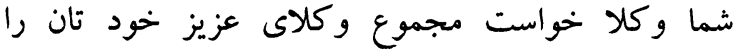

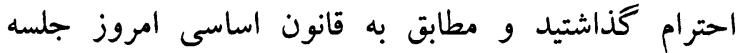

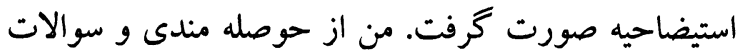
را كه شما وكلاى عزيز مطرح ساختيد يا به صورت
كنترول است، اما ذخاير خود را ما توسعه داده ميرويم و

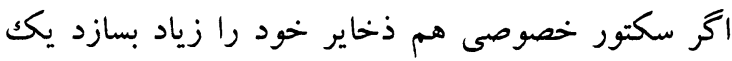

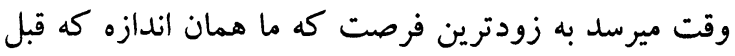
از جنگ از براى سه ماه ميتوانستيم از ذخاير استفاده كنيم اكر يك حالت اضطرارى غير قابل بيش بينى ميامد انشالله

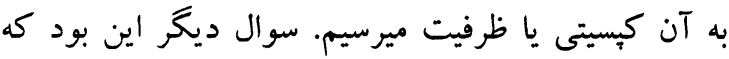

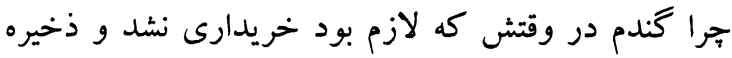

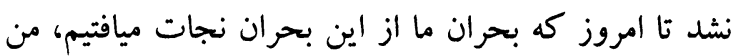

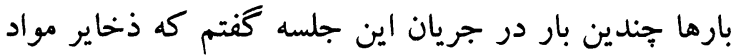

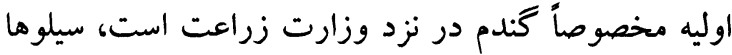
در نزد وزارت تجارت است. وزارت زراعت ماتد دالا درد

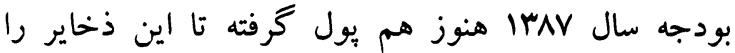

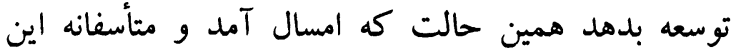

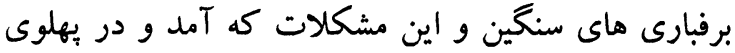
آن كه در كشورهاى همسايه و حتى امريكا و ديخر و ديخر صد فيصد قيمت مواد غذائى بلند رفت كه وارد

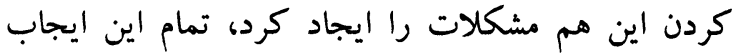

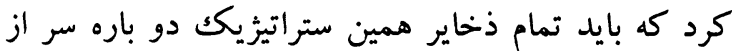

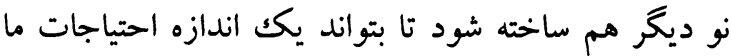

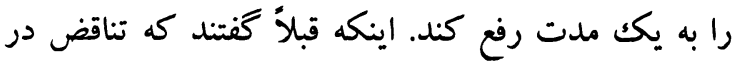
كفتار من بوده كه از يكك سو گفتتم كه قيمت در جهان بسيار بلند رفته اما درافغانستان بائين است، علت آن آن اينست كه تناقض نيست اين يكك سنجش اقتصادى است آقاى

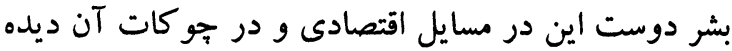
شود. در افغانستان در همين سه جهار هفته اخير عرضه مواد

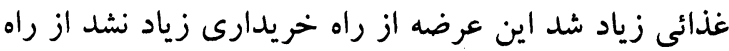

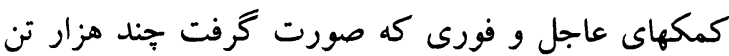
آمد به بازار اين داخل شد و قيمتها را سى فيصد بائين آورد و اين تسلسل دارد، همين حالا كشورها براى ما تعهد كردند كه تا فصل جديد ميرسد كه وزارت زراعت بيش بينى كرده كه انشااله ما خود كفا ميشويم اين را بصورت

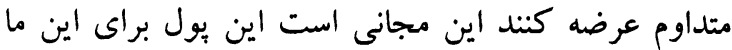
يول نداديم از آن خاطر اين بالاى قيمتهاى داخلى الخلى تأثير انداخت كه قيمتها يائين بيايد. من فكر ميكنم اين سوال شما را جواب داده ام لمابه 
مجلس هستند نصاب تكميل است تصميمى را كه شما

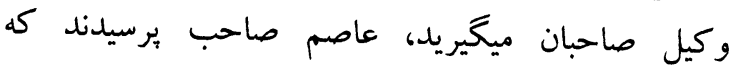
سوالاتى كه باقى مانده جوابهايش كه باقى مانده متعلق به ماند

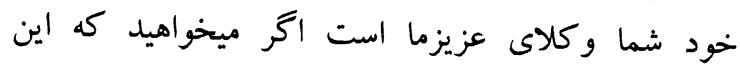

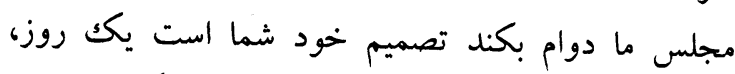
يكك ساعت دو ساعت شما دوام ميدهيد ، طبعاً اتر تصميم بحيريد باز براى فردا ميشود، امروز ديخر همه به اندازه كافى صحبت كردند اكر ميگوئيد كه نه دوام صحبتها فئرون

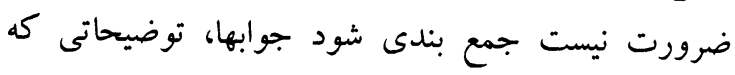

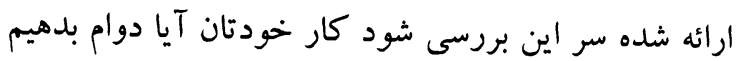

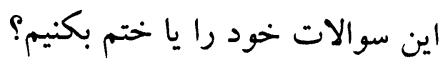

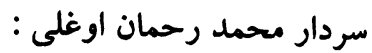

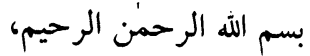
جناب رئيس صاحب! من همان كوزه بر سر و فرق من الرحن

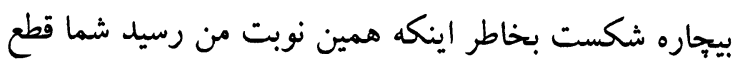

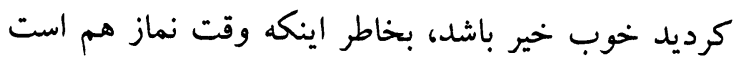

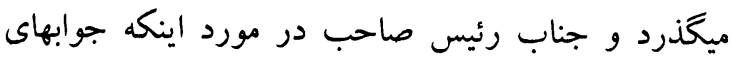

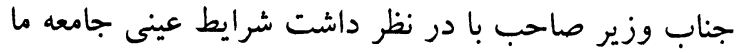
جقدر قناعت بخش است و يا جقدر قناعت بخش نيست بايد يك بحث جدى صورت بخيرد حد اقل سه نفر

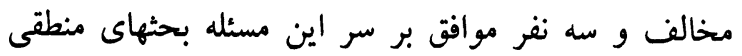

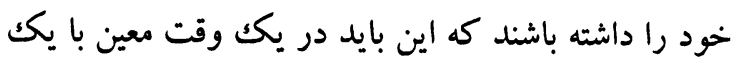
حوصله معين صورت بخيرد بنابرين من ييشنهاد ميكنم كه

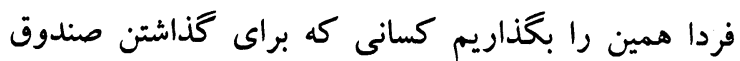

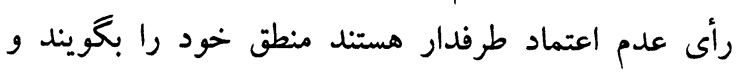

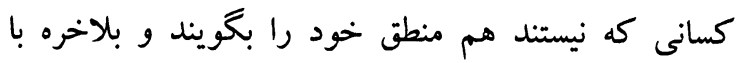

يك رأى به طرف آنجيزى كه مورد قبول است برويم. احمد بهزاد :

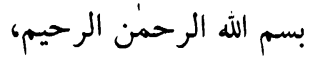

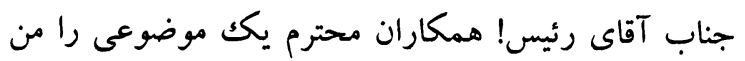

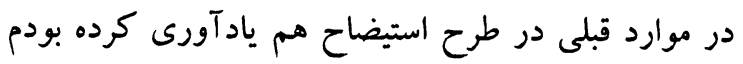
امروز هم ما با همان معضل دست به گر ميبان شديم بيينيد

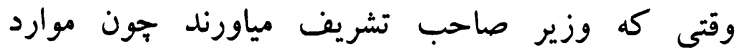
استيضاح از قبل كتبى وجود ندارد سوالات بسيار يراگنده

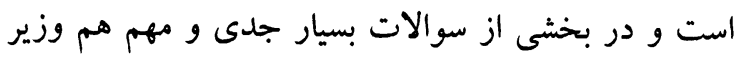

مشخص يا به صورت كلى و همجنان از حوصله مندى و

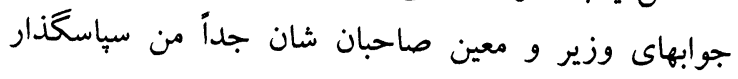

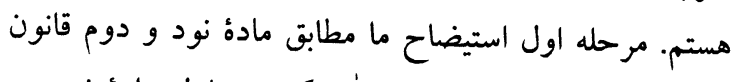

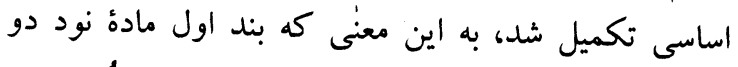

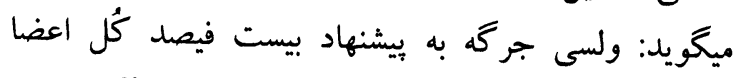

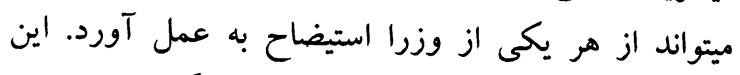

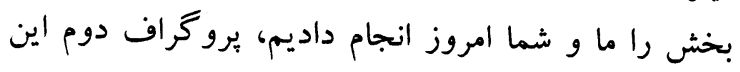

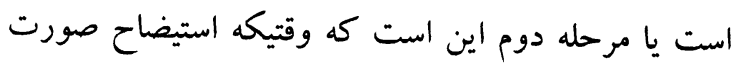

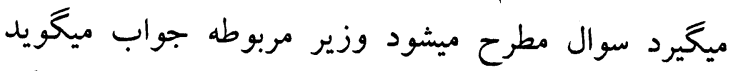

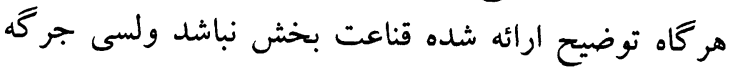

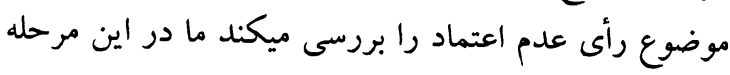

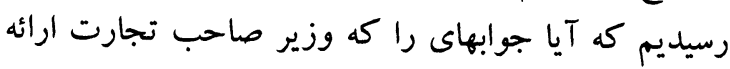

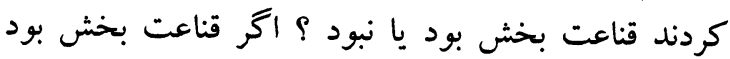

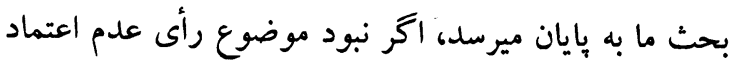
بررسى ميشود بعد اگر وقتى كه رأى عدم اعتماد بررسى مانى

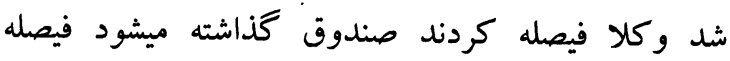

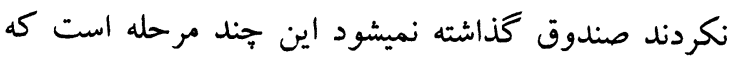
در عمل وجود دارد ما فعلاً در مرحله اين رسيديم كه آيا

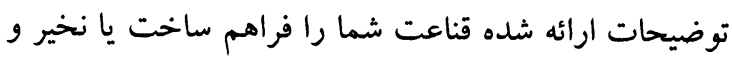

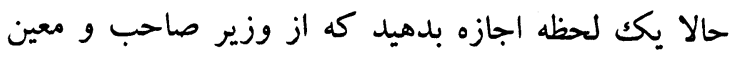

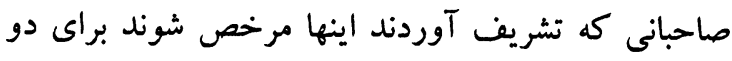

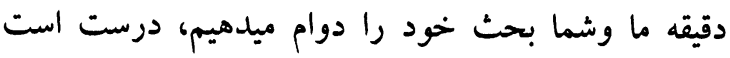
وكيل صاحبان؟ وزير صاحب معين صاحبان محترم از شما

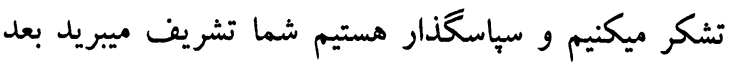

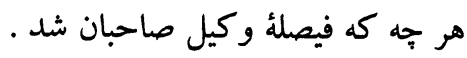
وزير تجارت و صنايع : جناب رئيس صاحب يكك سوال تحريرى آمده كه بايد به

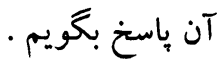
رئيس مجلس : باشد خير است وزير صاحب به روزهاى آينده اين سوال

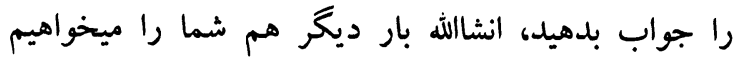
تشكر وزير صاحب آقاى نصرت وزير صاحب و ومالد معين صاحبان را همراهى كنيد تشكر ميكنيم از شما، وكلاى

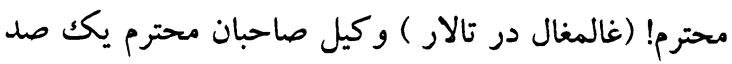

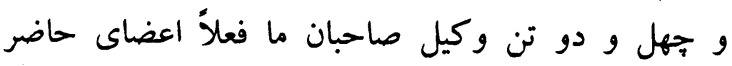


رئيس مجلس :

تشكر بهزاد صاحب! به تائيد فرموده آقاى بهزاد من همين

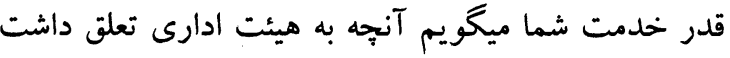

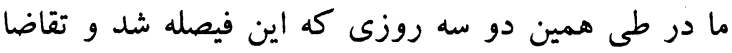

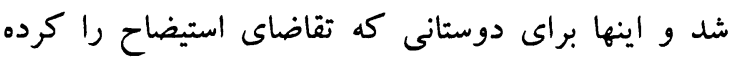

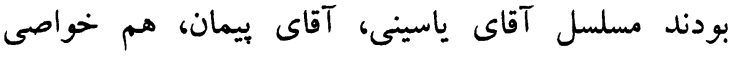
صاحب كفتيم خدمت شان كه دوستان در استيضاح سوال

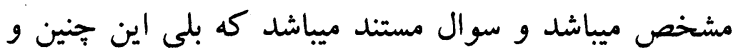

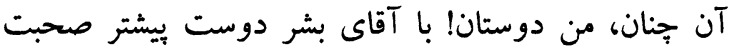

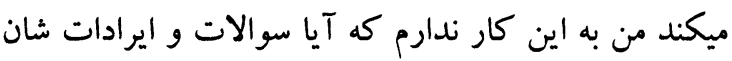

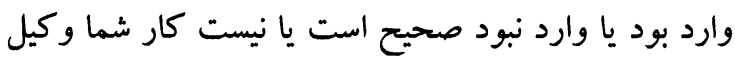
صاحبان است اما يك حيز را ميخواهم بخويم خدمت شما

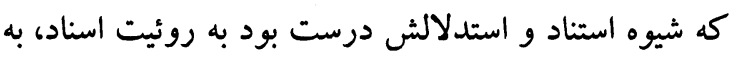

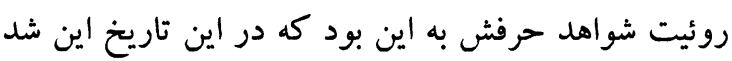
و آن شد كفتم من قضاوت در نتيجه اش ندارم كار كار شما

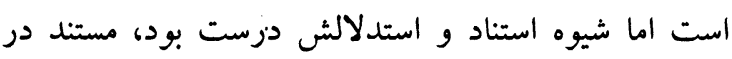

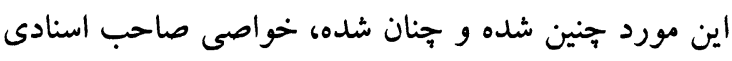
كه در دست آقاى بشر دوست است و همجنان آقاى

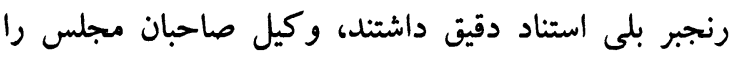

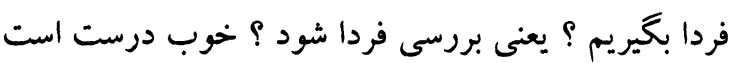
فردا بررسى و نتيجه گيرى ميكنيم • فردي فردا

وآخر الدعوانا ان الحمدلله رب العالمين

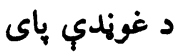

صاحب ميخويند كه من آمادگى ندارم فعلاً يعنى اينكه از

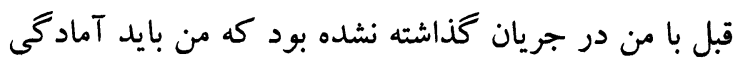

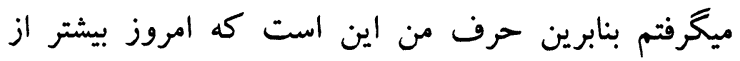
سوالهاى كه مطرح شد اصلاً جنبه استيضاحى نداشت است حتى استى

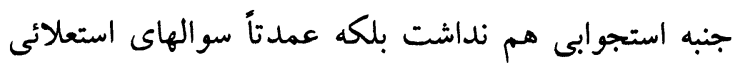

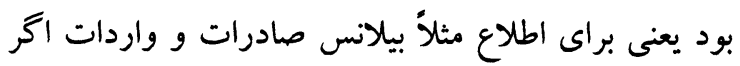

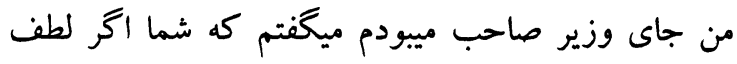
كنيد به يكك سايت خبرى مانند سايت بى بى سى سى مراجعه مئه

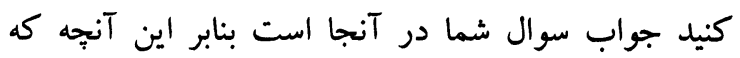

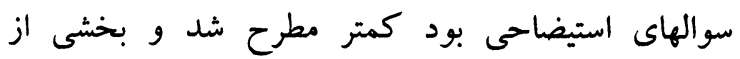
سوالات استيضاحى هم كه مطرح شد جناب وزير صاحب مبرد

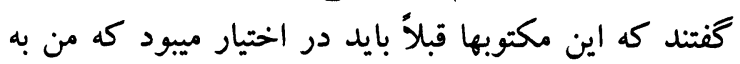
صورت شفاف، درست و اصولى جواب ميدادم بنابرين

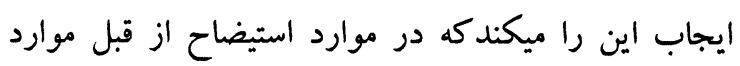

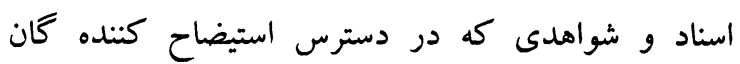

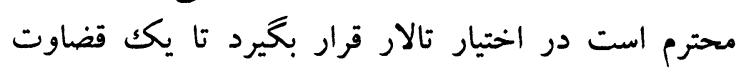

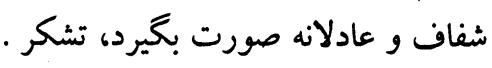

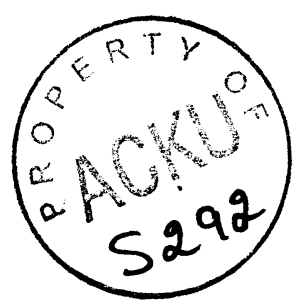




$$
\text { دو دوبيم تقنيني كال دوسي رسمي خيرونه }
$$

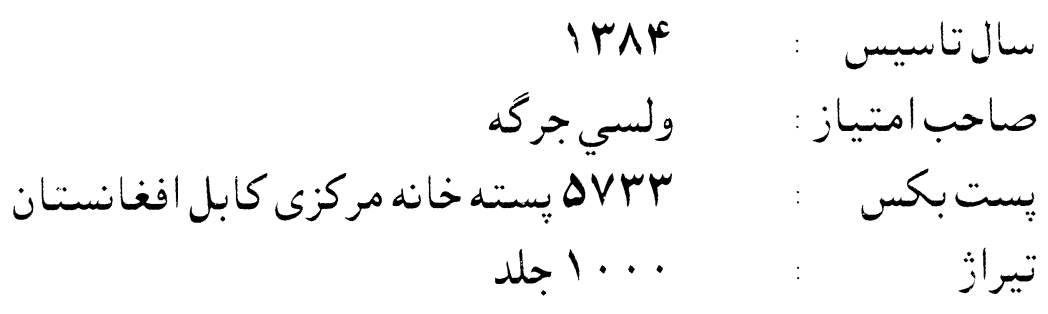

جلونكي : د ثبت عمومي مديريت wj.records@yahoo.com wj.records@hotmail.com http://www.parliament.af . . qTVO Y. rETTV . . वrVOr. वr rq9 
